\title{
WEST VALLEY DEMONSTRATION PROJECT ANNUAL SITE ENVIRONMENTAL REPORT CALENDAR YEAR 2005
}

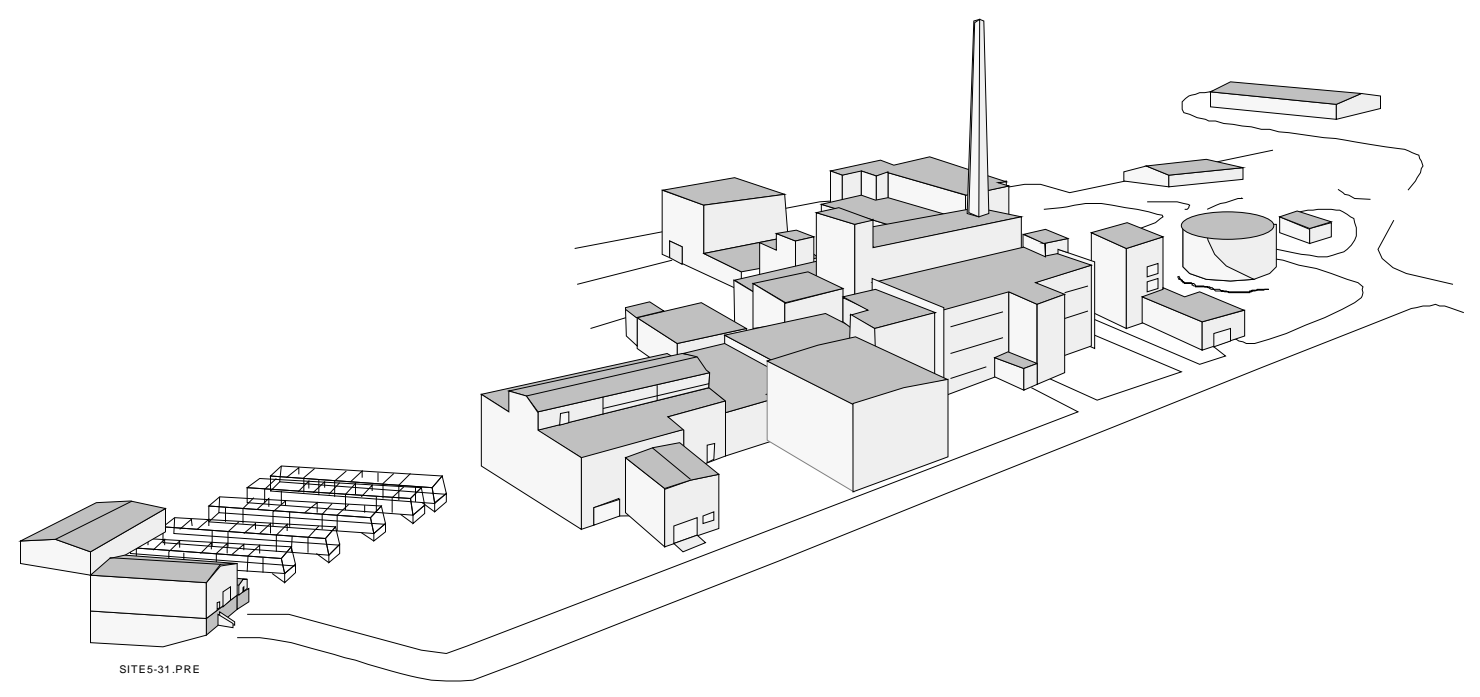

\section{WEST VALLEY NUCLEAR SERVICES COMPANY \\ AND \\ URS GROUP, INC.}
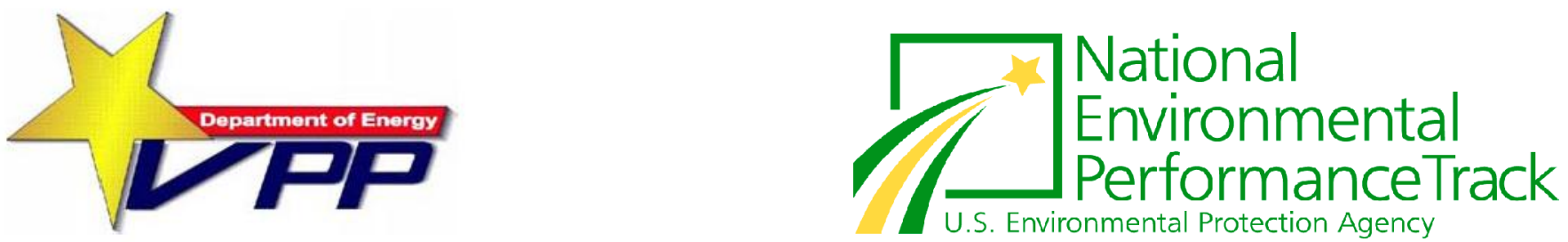

Prepared by: West Valley Nuclear Services Co. and URS Group, Inc.

Prepared for: U.S. Department of Energy

DOE-WVDP

September 2006

10282 Rock Springs Road

Under: Contract DE-AC24-81NE44139

West Valley, New York 14171-9799 



\section{Department of Energy}

West Valley Demonstration Project

10282 Rock Springs Road

West Valley, NY 14171-9799

To the Reader:

This report, prepared by the U.S. Department of Energy (DOE) West Valley Demonstration Project (WVDP), summarizes the environmental protection program at the WVDP for calendar year 2005.

Monitoring and surveillance of the WVDP facilities are conducted to verify that public health and safety and the environment are protected. The quality assurance requirements applied to the environmental monitoring program by the DOE ensure the validity and accuracy of the monitoring data.

At the WVDP, radiological air emissions are controlled and permitted by the U.S. Environmental Protection Agency (EPA) under National Emission Standards for Hazardous Air Pollutants, Subpart H, regulations. Nonradiological liquid effluent discharges are controlled and permitted through the New York State Pollutant Discharge Elimination System.

Air, surface water, groundwater, storm water, drinking water, soil, sediment, and biological samples are collected and analyzed for radiological and nonradiological constituents. The resulting data are evaluated to assess effects of activities at the WVDP. Monitoring of treated water effluents and facility ventilation system emissions verified that the dose received by off-site residents continues to be minimal.

Calculated doses to the hypothetical maximally exposed off-site individual from airborne radiological releases in 2005 were less than one-tenth of one percent of the EPA limit. Combined airborne and waterborne radiological releases in 2005 to the same individual were less than one-tenth of one percent of the DOE limit.

The Project's continuing commitment to safety was reaffirmed in 2005 when it was recommended for recertification as a DOE-Voluntary Protection Program (VPP) STAR site and continued membership in the EPA's National Environmental Performance Track. The WVDP is one of the few DOE sites to be awarded both the VPP STAR and National Environmental Performance Track membership. By the close of 2005, WVDP employees achieved 3.7 million safe work hours and three years without a lost time work accident. In recognition of this safety record, the WVDP was awarded the Washington Group President's Award for Safety for the third consecutive year.

If you have any questions or comments about the information in this report, please contact the WVNSCO Communications Department at (716) 942-2152 or complete and return the enclosed survey.

Sincerely,

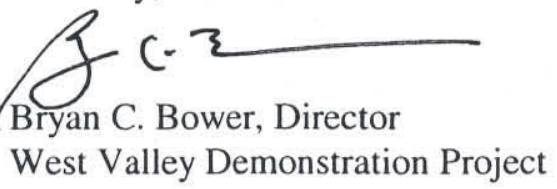





\section{Can We Make This Report More Useful to You?}

We want to make the WVDP Annual Site Environmental Report more useful to its readers. Please take a few minutes to let us know if the report meets your needs. Then fold and tape this page so the mailing address is visible and place it in the mail.

1. How do you use the WVDP Annual Site Environmental Report?
To learn general information about the WVDP
To learn about doses received for the current year
To learn about site compliance information
To gather effluent or environmental surveillance data
Other:

2. What part(s) of this report do you use the most?
Summary
Main report
Data tables
Section

3. Which part of the report do you find easier to use?

Printed report

Compact disk

Comments:

4. Does the WVDP Annual Site Environmental Report contain enough:
a. Useful illustrations and graphs? $\square$ Yes
b. Project background information? $\square$ Yes
c. Scientific background information? $\square$ Yes
$\square$ No
$\square$ No
$\square$ No
Comments:

5. Is this report: (please check one)

$\square$ About right technically?

Too technical?

Not technical enough?

For example:

For example:

6. If you could change this report to make it more readable and useful to you, what would you change?

7. What is your affiliation?
U.S. DOE
NYSERDA
Other government office/agency
Public interest group
Elected official
Media
Other group:
Other individual:

8. To help us identify our audience, please indicate your educational background.
$\square$ G
$\square$ U
$\square$ Exp
$\square$ Litll
Graduate degree:
Undergraduate degree:
Scientific
$\square$ Nonscientific
Experience with science outside college setting
Little or no scientific background

If you wish to be added to the WVDP Annual Site Environmental Report mailing list, please call the WVDP Communications Department at (716) 942-2152, or send an e-mail message to sonja.allen@wvnsco.com. 
Fold on this line.

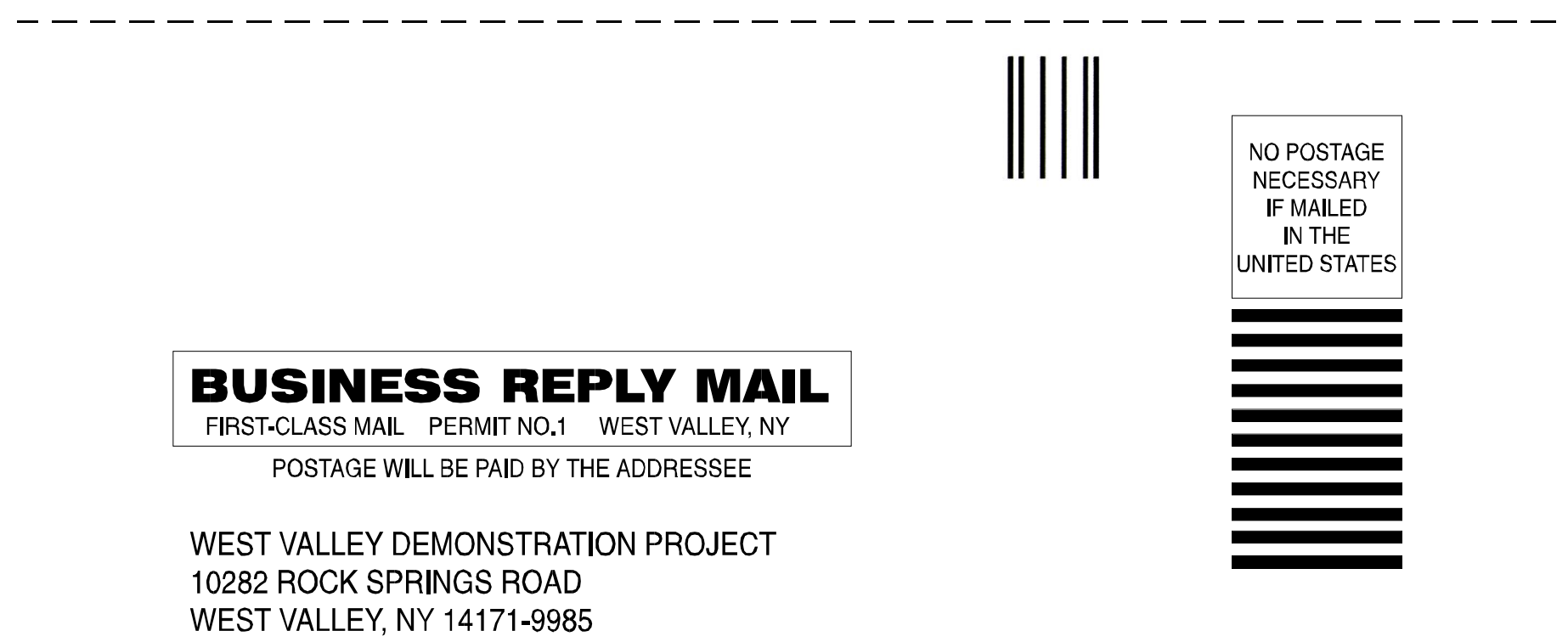

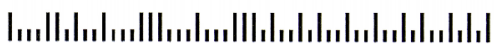

Fold on this line, then seal with tape.

Please do not staple. 


\section{SUMMARY OF CHANGES TO THE 2005 WVDP ANNUAL SITE ENVIRONMENTAL REPORT FROM THE 2004 ANNUAL SITE ENVIRONMENTAL REPORT}

This report, prepared by the U.S. Department of Energy (DOE) West Valley Demonstration Project (WVDP) office, summarizes the environmental protection program at the WVDP for calendar year (CY) 2005. Monitoring and surveillance of the facilities used by the DOE for the WVDP are conducted in order to protect public health and safety and the environment. The quality assurance protocols applied to the environmental monitoring program by the DOE ensure the validity and accuracy of the monitoring data.

Changes in content for the 2005 Annual Site Environmental Report (ASER) are summarized below.

\section{REVISIONS AND ADDITIONS}

- $\quad$ The Environmental Compliance Summary was updated for CY 2005 to describe continued implementation of the WVDP environmental management system. A new "Compliance Status Summary" table was incorporated to summarize and highlight the compliance status of the WVDP with applicable environmental statutes, executive orders, and DOE directives.

- A "Summary of Waste Management Achievements" table was incorporated into the Environmental Compliance Summary in an effort to consolidate and streamline information. Environmental permits effective during CY 2005 were updated.

- Data formerly discussed in Chapters 1 and 2 were consolidated into new figures and/or tables.

- $\quad$ Numerous modifications to the environmental monitoring program were implemented in early 2005. These changes, summarized in Appendix B, resulted from a comprehensive, systematic evaluation of the existing program. The evaluation included comparison of monitoring locations, analytical parameters, sample types, and sampling frequencies with those at other DOE and commercial sites. These changes, which took into consideration the reduction of radiological risk as site cleanup progresses, were incorporated to maximize the program's efficiency and cost effectiveness.

- $\quad$ Data and text were updated throughout to reflect results from the CY 2005 environmental monitoring program. Tables, graphs, maps, supplemental information sections, and references were updated.

- $\quad$ A modified State Pollution Discharge Elimination System (SPDES) permit received in 2005 included requirements for monitoring 20 new storm water outfalls. Storm water monitoring locations are presented on maps in Appendix A, analytical requirements are outlined in Appendix B, and the data tables are presented in Appendix C-3.

- A brief discussion was added about the "Memorandum of Understanding" (MOU) between the Environmental Protection Agency and the Nuclear Regulatory Commission (NRC) pertaining to decommissioning and decontamination of contaminated NRC-licensed sites. This MOU specified "triggers" (i.e., radiological concentration thresholds) for residential and commercial/industrial soil contamination that would trigger consultation between the agencies. A data table presenting the trigger levels was added to Appendix G-1.

The meteorological wind frequency roses were removed from Appendix I.

New York State Energy Research and Development Authority (NYSERDA) groundwater monitoring data for the State-Licensed Disposal Area were removed from the ASER, and all text discussions regarding NYSERDA operations were referred to the NYSERDA website at www.nyserda.org. 


\section{SPECIAL ISSUES IN CY 2005}

- $\quad$ By the close of CY 2005, the employees at the WVDP achieved more than 3 years and 3.7 million cumulative work hours without a lost-time work accident.

- $\quad$ The challenging dismantlement and removal of major pieces of equipment from the vitrification cell was completed in July 2005, making the WVDP the first site in the nation to design, construct, operate, shut down, and dismantle a full-scale radioactive vitrification system.

- $\quad$ Remote mixed waste processing continued in the remote-handled waste facility, which handled 39 containers holding approximately 3,250 cubic feet of waste in 2005, including four boxes of historical waste from the chemical process cell waste storage area.

- $\quad$ A record volume of more than 300,000 cubic feet of low-level waste (LLW) was shipped off site, by truck and rail, for disposal.

- $\quad$ The site's infrastructure capacity was reduced dramatically, as employees were relocated off site to the Ashford Office Complex or to a few consolidated areas on site, and the equivalent of 115 office trailer units were emptied and removed from service.

- $\quad$ Portable ventilation units were again used in 2005 in an expanded role to protect workers during waste processing activities.

- The DOE published its record of decision for the WVDP Waste Management Final Environmental Impact Statement in June 2005. The decision was to implement Alternative A for management of WVDP LLW and mixed LLW that are either currently in storage at the site or will be generated at the site over the next 10 years. A decision on transuranic waste will be deferred, contingent upon a determination by the DOE that the waste meets all statutory and regulatory requirements for disposal at the Waste Isolation Pilot Plant near Carlsbad, New Mexico. The high-level waste canisters will remain in storage on site until they can be shipped directly to a repository.

- Under the Resource Conservation and Recovery Act \$3008(h) Administrative Order on Consent, the New York State Department of Environmental Conservation (NYSDEC) reviewed the "WVDP Solid Waste Management Unit (SWMU) Assessment and Description of Current Conditions Report." As a result of this review, NYSDEC requested that corrective measures studies (CMSs) be performed for select SWMUs at the WVDP. Draft CMSs for six of the units are scheduled to be submitted to NYSDEC in mid-2006. Closure of two SWMUs was deferred to closure under SPDES requirements.

In November 2005, the DOE approved the downgrade of the WVDP to a Category 3 nuclear facility, making it the first time in the site's history that it has been assigned the least of the three DOE nuclear facility designations. 


\title{
West Valley Demonstration Project Annual Site Environmental Report \\ for
}

\section{Calendar Year 2005}

Prepared for the U.S. Department of Energy

West Valley Demonstration Project Office

under contract DE-AC24-81NE44139

\author{
September 2006 \\ West Valley Nuclear Services Company and URS Group, Inc. \\ 10282 Rock Springs Road \\ West Valley, New York 14171-9799
}


This page intentionally left blank 


\section{Preface}

Environmental monitoring at the West Valley Demonstration Project (WVDP) is conducted by the West Valley Nuclear Services Company (WVNSCO), under contract to the U.S. Department of Energy. The data collected provide a historical record of radionuclide and radiation levels and chemical data from natural and man-made sources in the survey area. The data also document the chemical and radiological quality of the groundwater on and around the WVDP and of the air and water released by the WVDP. Meteorological data are also presented.

It is the policy at the WVDP to conduct all activities, including design, construction, testing, start-up, commissioning, operation, maintenance, and decontamination and decommissioning, in a manner that is appropriate to the nature, scale, and environmental effects of these activities. The WVDP management is committed to full compliance with applicable federal and New York State laws and regulations for the protection of the environment, to continual improvement, to the prevention and/or minimization of pollution, and to public outreach, including stakeholder involvement.

This report represents a single, comprehensive source of on-site and off-site environmental monitoring data collected during 2005 by environmental monitoring personnel. The environmental monitoring program and results are discussed in the body of this report. Additional monitoring information is presented in the appendices. Appendix A contains maps of on-site and off-site sampling locations. Appendices $B$ through $K$ can be found in electronic format on the compact disk (as indicated by the $\mathbf{G D}$ icon) located inside the back cover. Appendix $B$ is a summary of the site environmental monitoring schedule. Appendices $C$ through $J$ contain summaries of data obtained during 2005 and are intended for those readers interested in more detail than is provided in the main body of the report. Appendix $K$ lists laws and regulations pertaining to the WVDP.

Requests for additional copies of the 2005 Annual Site Environmental Report and questions regarding the report should be referred to the WVDP Communications Department, 10282 Rock Springs Road, West Valley, New York 14171 (telephone: 716-942-2152). Additional Project information, including WVDP site environmental reports, is available on the internet at http://www.wv.doe.gov. 
This page intentionally left blank

$i v$ 


\section{Table of Contents}

PREFACE

iii

EXECUTIVE SUMMARY

EXE-1

Purpose of This Report

EXE-1

Major Site Programs

EXE-1

Operation of the Remote-Handled Waste Facility

EXE-1

Vitrification Facility Dismantlement Project

EXE-1

Waste Management

EXE-2

Infrastructure Reduction

EXE-2

Reduction of Risks Associated With Radioactive Materials

EXE-2

Waste Management Environmental Impact Statement

EXE-2

Key Initiatives

EXE-2

Environmental Performance Indicators

EXE-2

Pollution Prevention/Waste Minimization Goals

EXE-2

Environmental Management System

EXE-3

Recognition and Awards

EXE-3

Compliance

EXE-3

Environmental Monitoring

EXE-3

Groundwater Monitoring

EXE-4

Quality Assurance

EXE-4

Conclusion

EXE-5

INTRODUCTION

INT-1

Site Location

INT-1

General Environmental Setting

INT-1

Site Mission

INT-3

Primary Operations and Activities

INT-3

Relevant Demographics

INT-4 


\section{Table of Contents}

ENVIRONMENTAL COMPLIANCE SUMMARY ECS-1

Compliance Program ECS-1

Compliance Status ECS-1

Environmental Protection Program (DOE Order 450.1) ECS-1

Radiation Protection of the Public and the Environment (DOE Order 5400.5) ECS-7

Radioactive Waste Management (DOE Order 435.1) ECS-7

Resource Conservation and Recovery Act ECS-8

Clean Air Act ECS-12

Emergency Planning and Community Right-to-Know Act ECS-13

Clean Water Act ECS-14

Safe Drinking Water Act ECS-17

Toxic Substances Control Act ECS-18

National Environmental Policy Act ECS-18

Federal Insecticide, Fungicide, and Rodenticide Act ECS-20

Environmental Conservation Law - Structures Impounding Waters and Structures in Waters ECS-20

Current Achievements and Program Highlights ECS-20

Vitrification Facility Dismantlement Project ECS-20

Infrastructure Reduction ECS-20

Star Status ECS-21

EPA National Environmental Performance Track ECS-21

Environmental Issues and Actions ECS-21

Construction and Demolition Debris Landfill ECS-21

NRC-Licensed Disposal Area ECS-21

Unplanned Releases ECS-21

Coalition Files Suit Over WVDP EIS Process ECS-21 Project Assessment Activities in 2005

Introduction 1-1

Completion of Vitrification $1-1$

Environmental Management System

Integrated Safety Management System Implementation $1-5$

Occupational Safety and Environmental Training

Self-Assessments $1-6$

Voluntary Protection Program Star Status $1-6$ 


\section{Table of Contents}

Chapter 1 (concluded)

Environmental Monitoring Program Overview ___ 1-6

Environmental Management of Aqueous Radioactive Waste ___ 1-7

North Plateau Groundwater Recovery System ____ 1-8

Nuclear Regulatory Commission-Licensed Disposal Area Interceptor Trench and

Pretreatment System ___ 1-8

Environmental Management of Airborne Radioactive Emissions ___ 1-8

Environmental Management of Radiological Exposure ___ _ 1-9

Changes in the 2005 Environmental Monitoring Program ___ 1-9

2005 Activities at the WVDP ___ 1-9

Vitrification Cell Dismantlement____ 1-9

Remote-Handled Waste Facility Operation ___ 1-9

Reduction of Infrastructure Footprint ___ 1-10

Low-Level Radioactive Waste Shipping Program ___ 1-10

Reduction of Risks Associated With Radioactive Materials ___ 1-10

Performance Measures ___ 1-10

Radiation Doses to the Maximally Exposed Off-Site Individual_____ 1-10

SPDES Permit Limit Exceptions ___ 1-10

Waste Minimization and Pollution Prevention ___ 1-12

Spills and Releases ___ 1-13

CHAPTER 2. ENVIRONMENTAL RADIOLOGICAL PROTECTION PROGRAM AND

DOSE ASSESSMENT _ _ 2-1

RADIATION IN THE ENVIRONMENT ___ 2-1

Sources of Radiation ___ 2-1

Exposure Pathways ____ 2-1

Land Use Survey ___ 2-3

Dose to the Public ___ 2-3

vii 


\section{Table of Contents}

Chapter 2 (continued)

ROUTINE MONITORING PROGRAM ___ 2-5

Radiological Sampling Program Overview ___ $2-5$

Overview of Water Effluent and Ambient Surface Water Monitoring ___ 2-6

Low-Level Waste Treatment Facility Effluent ____ 2-6

Northeast Swamp and North Swamp Drainage____ 2-6

Other North Plateau Surface Waters and Water Effluent ___ 2-8

South Plateau Surface Water and Nuclear Regulatory Commission-Licensed Disposal Area

Interceptor Trench ___ 2-9

Off-Site Surface Water ___ 2-10

Overview of Drinking Water Monitoring ____ 2-11

On-Site Tap Water ___ 2-11

Off-Site Drinking Water Wells ___ 2-11

Overview of Sediment Monitoring ___ 2-11

On-Site Sediments ___ 2-11

Off-Site Sediments ___ 2-11

Overview of Air Emission and Ambient Air Monitoring ____ 2-12

Ventilation and Emission Systems ___ 2-13

Perimeter and Remote Ambient Air Monitoring ____ 2-14

Atmospheric Deposition and Soil Monitoring ___ 2-15

Fallout Pots ___ 2-15

Off-Site Surface Soil ___ 2-15

Overview of Food Chain Monitoring ___ 2-15

Direct Environmental Radiation Monitoring ___ 2-15

On-Site Radiation Monitoring ____ 2-15

Perimeter and Off-Site Radiation Monitoring_____ 2-15

Confirmation of Results ___ 2-15

Meteorological Monitoring ___ 2-16

Special Monitoring ___ 2-17

RADIOLOGICAL EFFLUENTS AND DOSE___ 2-18

Dose Assessment Methodology ____ 2-18

Measurement of Radionuclide Concentrations in Liquid and Air Releases ___ 2-18

Measurement of Radionuclide Concentrations in Food ___ 2-18

Predicted Dose From Airborne Emissions ___ 2-20

Maximum Dose to an Off-Site Individual ___ 2-20

Collective Population Dose____ 2-20

Iodine Emissions From the Main Stack ___ 2-20

viii 


\section{Table of Contents}

Chapter 2 (concluded)

Predicted Dose From Waterborne Releases ___ 2-22

Maximum Dose to an Off-Site Individual___ 2-24

Collective Dose to the Population____ 2-25

Calculated Dose From Local Foodstuff Tests ___ 2-25

Predicted Dose From All Pathways ___ 2-25

Risk Assessment ___ 2-26

Release of Materials Containing Residual Radioactivity ___ 2-26

Dose to Biota: Aquatic and Terrestrial Wildlife____ 2-27

Summary ___ 2-28

CHAPTER 3. ENVIRONMENTAL NONRADIOLOGICAL PROGRAM INFORMATION___ 3-1

Overview of New York State Water Classifications, Water Quality Standards, and Water Effluent Limits ___ 3-1

Surface Water, Subsurface Drainage Water, and Water Effluent Monitoring ___ 3-2

SPDES Permit-Required Monitoring ___ 3-2

Mercury Analytical Method Study ____ 3-3

Storm Water Discharge Monitoring ___ 3-3

South Plateau Surface and Subsurface Water Monitoring ____ 3-4

Other On-Site and Off-Site Surface Water Monitoring ___ 3-4

Drinking Water Monitoring ___ 3-5

Soil and Sediment Monitoring ___ 3-5

Lag Storage Area \#2 Hardstand ___ 3-6

Air Emission Monitoring ___ ___ 3-6 ___ _ _ _ _ _ _ _ _ _ _ _ _ _

CHAPTER 4. GROUNDWATER PROTECTION PROGRAM ___ $4-1$

Groundwater Monitoring Program Overview ___ 4-1

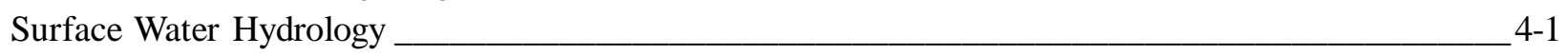

Geology ___ ___ 4-2

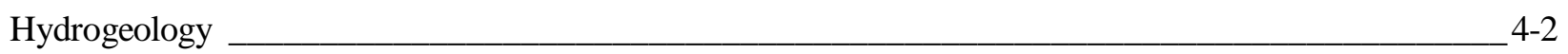

Kent Recessional Sequence ___ 4-2

Lavery Till ___ 4-2

Sand and Gravel and Till-Sand Units _____

ix 


\section{Table of Contents}

Chapter 4 (concluded)

Routine Groundwater Monitoring Program ___ 4-4

Monitoring Well Network ___ 4-4

Groundwater Elevation Monitoring ___ _ _ _ _ _ _ _ _ _ _ _ _

Analytical Trigger Level Evaluation ___ 4-7

Groundwater Monitoring Program Highlights 1982 Through $2005 \_$4-7

Results of Routine Groundwater Monitoring____ 4-8

Sand and Gravel Unit on the North Plateau ___ 4-8

Long-Term Trends of Gross Beta and Tritium at Selected Groundwater Monitoring Locations __ 4-8

North Plateau Seeps ____ 4-9

Results for Volatile and Semivolatile Organic Compounds___ 4-9

Special Groundwater Activities ___ _ _ 4-11

Gross Beta Plume on the North Plateau ___ 4-11

North Plateau Groundwater Recovery System ___ 4-12

Permeable Treatment Wall____ 4-12

Northeast Swamp Drainage Monitoring ____ 4-12

South Plateau Weathered Lavery Till Monitoring at the NDA___ 4-12

Additional Monitoring and Investigations ___ 4-13

Results of Radioisotopic Sampling ___ 4-13

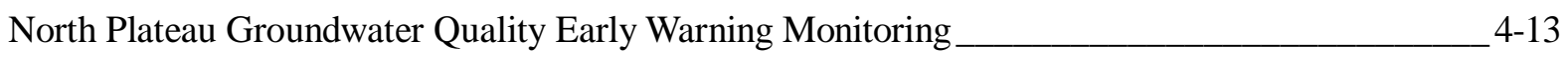

Investigation of Chromium and Nickel in the Sand and Gravel Unit and Evaluation of Corrosion in Groundwater Monitoring Wells ___ 4-14

Fuel Receiving and Storage Pool Water Infiltration ___ 4-14

Off-Site Groundwater Monitoring ___ 4-14

CHAPTER 5. QUALITY ASSURANCE ___ 5-1

Quality Assurance Program ____ 5-1

Responsibility ___ 5-1

Planning ___ _ _ 5-1

Training ____ 5-1

Control of Design, Procedures, Items, and Documents ___ 5-2

Corrective Action ___ 5-2

Documentation ___ _ 5-2

Audits and Assessments____ 5-2 


\section{Table of Contents}

Chapter 5 (concluded)

Quality Control ___ 5-2

Field QC ___ 5-2

Laboratory QC ___ _ _ 5-3

Independent Comparisons and Crosschecks ___ 5-3

Data Management ___ 5-4

Data Verification and Validation ___ 5-5

Data Assessment and Reporting ___ 5-5

Audits, Appraisals, and Self-Assessments ___ 5-5

Lessons Learned___ 5-6

Conclusion ___ 5-6

USEFUL INFORMATION ____ UI-1

Radiation and Radioactivity ___ UI-1

Measurement of Radioactivity ____ UI-2

Background Radiation ___ UI-3

Measurement of Dose ___ UI-3

Derived Concentration Guides____ UI-3

Data Reporting ___ UI-4

Units of Measure___ UI-6

Unit Prefixes ___ UI-6

Scientific Notation ___ UI-7

Conversion Chart____ UI-7

GLOSSARY ___ GLO-1

ACRONYMS AND ABBREVIATIONS ___ A\&A-1

REFERENCES AND BIBLIOGRAPHY ___ R\&B-1

DISTRIBUTION ___ DST-1

APPENDIX A. ENVIRONMENTAL MONITORING PROGRAM MAPS ___ A-i

$x i$ 


\section{Table of Contents}

\section{List of Figures}

INT-1. Location of the Western New York Nuclear Service Center

INT-2

ECS-1. WVDP SPDES Effluent Limit Exceptions

ECS-15

1-1. Annual Effective Dose Equivalent to the Maximally Exposed Off-Site Individual

1-2. Annual SPDES Effluent Limit Exceptions

$1-11$

1-3. Percentage of Waste-Reduction-Exceeding Goals

1-4. Number of Immediately Reportable Spills or Releases $1-13$

2-1. Comparison of Doses From Natural and Man-Made Sources to the Dose From 2005 WVDP Effluents

2-2. Ten-Year Trends of Gross Alpha, Gross Beta, and Tritium Concentrations at Sampling Location WFFELBR

2-3. Ten-Year Average Cesium-137 Concentrations in Sediment From Cattaraugus Creek Downstream of the WVDP (SFCCSED) Compared With Upstream Concentrations (SFBISED)

2-4. Ten-Year Trends of Gross Alpha and Gross Beta Concentrations in Air at Rock Springs Road (AFRSPRD)

2-5. Ten-Year Trends of Environmental Radiation Levels at Perimeter TLDs

2-6. Air Emissions From Point Sources: Dose Percent by Radionuclide in CY 2005

2-7. Water Effluents: Dose Percent by Radionuclide in CY 2005

2-8. All Sources: Dose Percent by Radionuclide in CY 2005

2-9. Effective Dose Equivalent From Liquid and Airborne Effluents to a Maximally Exposed Individual Residing Near the WVDP

2-10. Collective Effective Dose Equivalent From Liquid and Airborne Effluents to the Population Residing Within 50 Miles $(80 \mathrm{~km})$ of the WVDP 


\section{Table of Contents}

List of Figures (concluded)

4-1. Geologic Cross Section Through the North Plateau __ 4-3

4-2. Geologic Cross Section Through the South Plateau __ 4-3

4-3. North Plateau Gross Beta Plume Area: Fourth-Quarter 2005 Results ___ 4-10

4-4. Average Annual Gross Beta Concentrations at Locations Closer to the Source of the North Plateau Plume 4-15

4-5. Average Annual Gross Beta Concentrations at Locations Closer to the Leading Edges of the North Plateau Plume____ 4-15

4-6. Average Annual Gross Beta Concentrations at Locations Near Former Lagoon 1 __ _ _ _ _ _ _ _ _

4-7. Average Annual Tritium Concentrations at Selected Locations in the Sand and Gravel Unit 4-16

4-8. Concentrations of 1,2-DCE-t, 1,1,1-TCA, 1,1-DCA, and DCDFMeth at Well 8612 in the Sand and Gravel Unit

4-9. Concentrations of Tributyl Phosphate at Selected Locations in the Sand and Gravel Unit 4-17

4-10. Annualized Average Strontium-90 Concentrations at WNSWAMP 4-18

A-1. West Valley Demonstration Project Base Map A-1

A-2. On-Site Surface Water and Soil/Sediment Sampling Locations ___ A-2

A-3. On-Site Storm Water Outfalls A-3

A-4. Rail Spur Storm Water Outfalls____ A-4

A-5. Off-Site Surface Water and Soil/Sediment Sampling Locations ___ A-5

A-6. On-Site Air Monitoring and Sampling Locations _____ A-6

A-7. Off-Site Air and Fallout Sampling Locations ____ A-7

A-8. Active WVDP Groundwater Monitoring Locations ___ A-8

A-9. North Plateau Groundwater Monitoring Network______ A-9

A-10. South Plateau Groundwater Monitoring Network ___ A-10

A-11. Near-Site Drinking Water and Biological Sampling Locations ___ A-11

A-12. Location of On-Site Thermoluminescent Dosimeters (TLDs) ___ A-12

A-13. Location of Off-Site Thermoluminescent Dosimeters (TLDs) Within 5 Kilometers of the WVDP _ A-13

A-14. Environmental Sampling Locations Between 5 and 10 Kilometers From the WVDP ___ A-14

A-15. Environmental Sampling Locations More Than 10 Kilometers From the WVDP____ A-15

A-16. Population by Sector Within 80 Kilometers of the WVDP (2002 Estimate) ____ A-16 


\section{Table of Contents}

\section{List of Tables}

Compliance Tables:

ECS-1. Compliance Status Summary for the WVDP in 2005

ECS-2

ECS-2. WVDP Environmental Permits ECS-23

ECS-3. Summary of Waste Management Achievements at the WVDP in 2005 ECS-25

ECS-4. WVDP 2005 Air Quality Noncompliance Episodes ECS-27

ECS-5. Status of EPCRA (SARA Title III) Reporting at the WVDP in 2005 ECS-27

ECS-6. Reportable Chemicals Above EPCRA 312 Threshold Planning Quantities Stored at the WVDP in 2005

ECS-7. WVDP 2005 NPDES/SPDES Permit Noncompliance Episodes ECS-28

ECS-8. WVDP Migratory Bird Nest Depredation Episodes in 2005 ECS-28

1-1. Elements of the Environmental Management System at the WVDP $1-2$

1-2. 2005 Radioactivity Releases Versus 10-Year Averages

2-1. Potential Local Off-Site Exposure Pathways Under Existing WVDP Conditions $2-4$

2-2. 2005 Comparison of Radiological Results With Backgrounds and DOE DCGs $2-7$

2-3. Summary of Annual Effective Dose Equivalents to an Individual and Population From WVDP Releases in 2005 $2-21$

2-4. Release of Property Containing Residual Radioactive Material $2-29$

2-5. 2005 Evaluation of Dose to Aquatic and Terrestrial Biota 2-30

2-6. WVDP Radiological Dose and Release Summary $2-31$

4-1. Groundwater Monitoring Overview by Geographic Area: Monitoring Year 2005 4-5

4-2. Groundwater Monitoring Overview by Monitoring Purpose: Monitoring Year 2005 4-5

4-3. WVDP RCRA SSWMUs and Constituent SWMUs 4-6

xiv 


\section{Table of Contents}

\section{List of Figures \\ (Available only on CD, as indicated by the $\mathrm{GD}$ icon.)}

H-1. 2005 Average Annual Gamma Exposure Rates Around the WVDP ___ H-6

H-2. 2005 Average Annual Gamma Exposure Rates on the WVDP ___ H-6

I-1. Calendar Year 2005 Weekly Precipitation____ I-3

I-2. Calendar Year 2005 Cumulative Precipitation____ I-3 


\section{Table of Contents}

\section{List of Tables \\ (Available only on CD, as indicated by the $\mathrm{GD}$ icon.)}

APPENDIX B. 2005 ENVIRONMENTAL MONITORING PROGRAM B-i

APPENDIX C-1. SUMMARY OF WATER LIMITS, GUIDELINES, AND STANDARDS C-1

C-1A. West Valley Demonstration Project State Pollutant Discharge Elimination System Sampling Program C-3

C-1B. New York State Water Quality Standards and Guidelines C-5

C-1C. New York State Department of Health/U.S. Environmental Protection Agency MCLs, MCLGs, and Raw Water Standards

C-1D. U.S. Department of Energy Derived Concentration Guides C-8

APPENDIX C-2. PROCESS EFFLUENT DATA C-9

C-2A. Total Radioactivity of Liquid Effluents Released From Lagoon 3 (WNSP001) in 2005 C-11

C-2B. Comparison of 2005 Lagoon 3 (WNSP001) Liquid Effluent Radioactivity Concentrations With U.S. Department of Energy Guidelines

C-2C. 2005 SPDES Results for Outfall 001 (WNSP001): Water Quality C-13

C-2D. 2005 SPDES Results for Outfall 001 (WNSP001): Metals C-15

C-2E. 2005 SPDES Results for Outfall 007 (WNSP007): Water Quality and Iron $\mathrm{C}-17$

C-2F. 2005 SPDES Results for Sums of Outfalls 001, 007, 008, and 116: Water Quality C-18

C-2G. 2005 Quarterly/Semiannual/Annual SPDES Results for Outfall 001 (WNSP001): Water Quality, Metals, and Organics C-19 C-2H. 2005 Annual SPDES Results for Outfall 007 (WNSP007): Water Quality C-20 C-2I. 2005 Annual SPDES Results for Outfall 01B (WNSP01B): Water Quality $\mathrm{C}-20$

C-2J. 2005 SPDES Results for Outfall 008 (WNSP008): Water Quality C-20

C-2K. 2005 Radioactivity at Sewage Treatment Outfall (WNSP007) C-21

APPENDIX C-3. SPDES-PERMITTED STORM WATER OUTFALL DISCHARGE DATA C-23

C-3A. 2005 Storm Water Discharge Monitoring Data for Outfall Group 1: Storm Water Outfall S04 _ C-25

C-3B. 2005 Storm Water Discharge Monitoring Data for Outfall Group 2: Storm Water Outfall S06 __ C-26 2005 Storm Water Discharge Monitoring Data for Outfall Group 2: Storm Water Outfall S33 __ C-27

C-3C. 2005 Storm Water Discharge Monitoring Data for Outfall Group 3: Storm Water Outfall S09 __ C-28 2005 Storm Water Discharge Monitoring Data for Outfall Group 3: Storm Water Outfall S12 _ C-29

$x v i$ 


\section{Table of Contents}

List of Tables (continued)

C-3D. 2005 Storm Water Discharge Monitoring Data for Outfall Group 4: Storm Water Outfall S34 __ C-30

C-3E. 2005 Storm Water Discharge Monitoring Data for Outfall Group 5: Storm Water Outfall S17 __ C-32

C-3F. 2005 Storm Water Discharge Monitoring Data for Outfall Group 6: Storm Water Outfall S36 __ C-33

C-3G. 2005 Storm Water Discharge Monitoring Data for Outfall Group 7: Storm Water Outfall S20 __ C-34

C-3H. 2005 Storm Water Discharge Monitoring Data for Outfall Group 8: Storm Water Outfall S27 __ C-36 2005 Storm Water Discharge Monitoring Data for Outfall Group 8: Storm Water Outfall S35 _ C-37

APPENDIX C-4. SITE SURFACE DRAINAGE, SUBSURFACE DRAINAGE, AND

CONTAINED WATER DATA C-39

C-4A. 2005 Radioactivity and pH in Surface Water at Facility Yard Drainage (WNSP005) C-41

C-4B. 2005 Radioactivity in Surface Water at French Drain (WNSP008) ___ C-41

C-4C. 2005 Water Quality of Surface Water at the North Swamp (WNSW74A) __ C-42

C-4D. 2005 Water Quality of Surface Water at the Northeast Swamp (WNSWAMP) ___ C-45

C-4E. 2005 Indicator Results at Storage and Disposal Area Drainage (WNNDADR) ___ C _ _ _ _ _

C-4F. 2005 Indicator Results in Subsurface Water at the NDA Interceptor Trench

(WNNDATR) ___ C-48

C-4G. 2005 Indicator Results at SDA Drainage (WNSDADR) __ _ C-49

C-4H. 2005 Indicator Results in Surface Water at Cooling Tower Basin (WNCOOLW) ___ C-49

APPENDIX C-5. AMBIENT SURFACE WATER DATA ___ C-51

C-5A. 2005 Radioactivity and pH in Surface Water Downstream of the WVDP in Cattaraugus

Creek at Felton Bridge (WFFELBR) ___ C-53

C-5B. 2005 Water Quality of Surface Water Downstream of the WVDP in Buttermilk Creek at

Thomas Corners Bridge (WFBCTCB) ___ C-54

C-5C. 2005 Water Quality of Surface Water Downstream of the WVDP at Frank's Creek

(WNSP006) _ C-57

C-5D. 2005 Total Dissolved Solids From Outfall WNSP116 ___ C-60

C-5E. 2005 Indicator Results in Surface Water at Erdman Brook (WNERB53)___ C-60

C-5F. 2005 Indicator Results in Surface Water at Frank's Creek East of the SDA (WNFRC67) __ C-61

C-5G. 2005 Indicator Results in Surface Water at Drum Cell Drainage (WNDCELD) ____ C-61

C-5H. 2005 Water Quality of Surface Water at the Standing Water Location (WNSTAW9) ___ C-62 


\section{Table of Contents}

List of Tables (continued)

APPENDIX C-6. POTABLE WATER (DRINKING WATER) DATA C-63

C-6A. 2005 Indicator Results in Background Potable Well Water C-65

C-6B. 2005 Indicator Results in Main Plant Potable Water (WNDNKMP); 2005 Indicator Results in Environmental Laboratory Potable Water (WNDNKEL); and 2005 Indicator Results in Maintenance Shop Potable Water (WNDNKMS) C-66

C-6C. 2005 Water Quality Results in Utility Room Potable Water (WNDNKUR) C-67

C-6D. 2005 Water Quality Results in Utility Room Raw (Untreated) Water (WNURRAW) __ _ C-67

C-6E. 2005 Biological and Chlorine Results From Various Site Tap Water Locations ___ C-68

C-6F. 2005 Tap Water Nitrate Results From WVDP Restroom Sink ____ C-68

C-6G. 2005 Copper and Lead Results From On-Site Tap Water Locations at the WVDP____ C-68

APPENDIX D. SUMMARY OF AIR MONITORING DATA D-1

D-1. 2005 Effluent Airborne Radioactivity at Main Stack (ANSTACK)___ D-3

D-2. 2005 Effluent Airborne Radioactivity at Vitrification System HVAC (ANVITSK) ___ D-4

D-3. 2005 Effluent Airborne Radioactivity at 01-14 Building (ANCSSTK) ___ D-5

D-4. 2005 Effluent Airborne Radioactivity at Contact Size-Reduction Facility (ANCSRFK) ___ _ D-6

D-5. 2005 Effluent Airborne Radioactivity at Supernatant Treatment System (ANSTSTK) ___ D-7

D-6. 2005 Effluent Airborne Radioactivity at Container Sorting and Packaging Facility (ANCSPFK)

D-7. 2005 Effluent Airborne Radioactivity at Outdoor Ventilation Enclosures/Portable Ventilation Units

D-8. 2005 Effluent Airborne Radioactivity at Remote-Handled Waste Facility Stack (ANRHWFK) D-10

D-9. 2005 Ambient Airborne Radioactivity at Lag Storage (ANLAGAM) D-11

D-10. 2005 Ambient Airborne Radioactivity at the NDA (ANNDAAM) D-12

D-11. 2005 Ambient Airborne Radioactivity at SDA Trench 9 (ANSDAT9) D-12

D-12. 2005 Ambient Airborne Radioactivity at Rock Springs Road (AFRSPRD) D-13

D-13. 2005 Ambient Airborne Radioactivity at Dutch Hill Road (AFBOEHN) D-14

D-14. 2005 Ambient Airborne Radioactivity at Fox Valley Road (AFFXVRD) D-14

D-15. 2005 Ambient Airborne Radioactivity at the Bulk Storage Warehouse (AFBLKST) D-15

D-16. 2005 Ambient Airborne Radioactivity at Route 240 (AFRT240) D-15

D-17. 2005 Ambient Airborne Radioactivity at Thomas Corners Road (AFTCORD) D-16

D-18. 2005 Ambient Airborne Radioactivity at West Valley (AFWEVAL) D-16

D-19. 2005 Ambient Airborne Radioactivity at Springville (AFSPRVL) D-17 


\section{Table of Contents}

List of Tables (continued)

D-20. 2005 Radioactivity in Fallout: Dutch Hill (AFDHFOP)

D-18

D-21. 2005 Radioactivity in Fallout: Rain Gauge (ANRGFOP)

D-18

D-22. 2005 Radioactivity in Fallout: Route 240 (AF24FOP)

D-18

D-23. 2005 Radioactivity in Fallout: Thomas Corners (AFTCFOP)

D-19

D-24. 2005 Radioactivity in Fallout: Fox Valley Road (AFFXFOP)

D-19

APPENDIX E. SUMMARY OF GROUNDWATER MONITORING DATA

Groundwater Sampling Methodology

2005 Groundwater Sampling and Analysis Agenda

E-3

E-1. Groundwater Monitoring Network Sorted by Geologic Unit E-4

E-2. 2005 Indicator Results From the Sand and Gravel Unit

E-3. 2005 Indicator Results From the Lavery Till-Sand Unit E-10

E-4. 2005 Indicator Results From the Weathered Lavery Till Unit

E-11

E-5. 2005 Indicator Results From the Unweathered Lavery Till Unit E-12

E-6. 2005 Indicator Results From the Kent Recessional Sequence E-13

E-7. 2005 Metals Results for Early Warning Monitoring Wells E-13

E-8. 2005 Volatile Organic Compound Results at Selected Groundwater Monitoring Locations E-14

E-9. 2005 Tributyl Phosphate Results at Selected Groundwater Monitoring Locations E-14

E-10. 2005 Results for Metals in Groundwater E-15

E-11. 2005 Radioactivity in Groundwater From Selected Monitoring Locations E-17

E-12. Practical Quantitation Limits E-21

APPENDIX F. SUMMARY OF BIOLOGICAL DATA F-1

F-1. 2005 Radioactivity Concentrations in Milk F-3

F-2. 2005 Radioactivity Concentrations in Venison F-4

F-3. 2005 Radioactivity Concentrations in Food Crops F-5

F-4. 2005 Radioactivity Concentrations in Edible Portions of Fish From Cattaraugus Creek F-6 


\section{Table of Contents}

List of Tables (continued)

APPENDIX G-1. SUMMARY OF SOIL AND AQUATIC SEDIMENT GUIDELINES AND

STANDARDS G-1

G-1A. Eastern U.S. Background Concentrations for Elements in Soils G-3

G-1B. Screening Concentrations for Elements in Contaminated Sediments G-4

G-1C. Consultation Triggers for Residential and Commercial/Industrial Soil Contamination G-5

APPENDIX G-2. SOIL AND SEDIMENT DATA G-7

G-2A. 2005 Contaminants in On-Site Soils Downstream of the WVDP at Frank's Creek (SNSP006) G-9

G-2B. 2005 Contaminants in On-Site Soils From North Swamp (SNSW74A) G-11

G-2C. 2005 Contaminants in On-Site Soils From Northeast Swamp (SNSWAMP) G-13

G-2D. 2005 Radioactivity in Surface Soils Collected at Air Stations Around the WVDP G-14

G-2E. 2005 Radioactivity in Stream Sediments Around the WVDP G-15

G-2F. Metals and Organics From the Lag Storage Area \#2 Truck Staging Area Shallow Soil Characterization G-16

APPENDIX H. SUMMARY OF DIRECT RADIATION MONITORING DATA H-1

H-1. Summary of 2005 Quarterly Averages of Off-Site TLD Measurements $\mathrm{H}-3$

H-2. Summary of 2005 Quarterly Averages of On-Site TLD Measurements $\mathrm{H}-4$

H-3. Third-Quarter 2005 TLD Results and Instantaneous Exposure Rate Readings With a HighPressure Ion Chamber at Each Monitoring Location H-5

APPENDIX I. SUMMARY OF METEOROLOGICAL DATA I-1

I-1. 2005 Site Precipitation Collection Data I-4

APPENDIX J. SUMMARY OF QUALITY ASSURANCE CROSSCHECK ANALYSES $\mathrm{J}-1$

J-1. Crosscheck Sample Comparisons From the DOE Mixed Analyte Performance Evaluation Program; May 2005 $\mathrm{J}-3$

J-2. Crosscheck Sample Comparisons From the DOE Mixed Analyte Performance Evaluation Program; November 2005 J-6 


\section{Table of Contents}

List of Tables (concluded)

J-3. Comparisons of Results From Crosscheck Samples Analyzed for Water Quality

Parameters as Part of the EPA's 2005 Discharge Monitoring Report - Quality Assurance

Study 25 for the National Pollutant Discharge Elimination System

APPENDIX K. ENVIRONMENTAL LAWS, REGULATIONS, STANDARDS, AND

ORDERS

K-1

K-1. U.S. Department of Energy Radiation Protection Standards and Derived Concentration Guides K-3

K-2. Environmental Laws, Regulations, Standards, and Orders ___ K-4

K-3. West Valley Demonstration Project Act K-7

$x x i$ 
This page intentionally left blank

xxii 


\section{EXECUTIVE SUMMARY}

\section{Purpose of This Report}

The Annual Site Environmental Report for the West Valley Demonstration Project (WVDP or Project) is published to provide information about environmental conditions at the WVDP to members of the public living near the site and to other interested stakeholders. The WVDP is located in western New York State, about 30 miles (50 kilometers [km]) south of Buffalo, within the New York State-owned Western New York Nuclear Service Center. In accordance with United States (U.S.) Department of Energy (DOE) Order 231.1A, "Environment, Safety, and Health Reporting," this report summarizes calendar year (CY) 2005 environmental monitoring data so as to describe the performance of the WVDP's environmental management system (EMS), confirm compliance with standards and regulations, and highlight important programs. Activities at the WVDP are being conducted in conjunction with the New York State Energy Research and Development Authority.

\section{Major Site Programs}

The WVDP is located on the site of a former commercial nuclear fuel reprocessing plant, which was shut down in 1976. In 1980, Public Law 96-368 (the WVDP Act) was passed. This Act authorized the DOE to demonstrate a method for so- lidifying 600,000 gallons (2.3 million liters) of liquid high-level radioactive waste (HLW) that remained at the West Valley site. Vitrification of the HLW, begun in 1996, was completed in September 2002. Activities for decontaminating the vitrification and support facilities and for managing and disposing of wastes were then initiated and continued through CY 2005. Major activities that occurred in 2005 are described below.

Operation of the Remote-Handled Waste Facility (RHWF). Construction of the RHWF, a facility used to prepare higher-activity wastes for shipment and disposal, was completed in June 2004, and processing of radioactive waste was then initiated. In 2005, approximately 3,250 cubic feet ( 92 cubic meters) of waste were processed, including four boxes of historical waste from the chemical process cell waste storage area.

Vitrification Facility Dismantlement Project. Dismantlement of the major pieces of equipment in the vitrification cell was completed in July 2005 , making the WVDP the first site in the nation to

$A$ reader opinion survey has been inserted in this report. If it is missing, please contact the WVDP Communications Department at (716) 942-2152. Additional Project information is available on the internet at http://www.wv.doe.gov. 
design, construct, operate, shut down, and dismantle a full-scale radioactive vitrification system.

Waste Management. Management of HLW, transuranic waste, mixed waste (i.e., waste that is both hazardous and radioactive), low-level radioactive waste (LLW), hazardous waste, and nonhazardous regulated waste continued to be a priority at the WVDP in 2005.

Upgrades were made to facilities and areas on site to support increased preparation of LLW for off-site shipment. More than 300,000 cubic feet (8,500 cubic meters) of LLW were shipped in 2005. About 573 pounds ( 260 kilograms) of hazardous waste was shipped. No mixed waste was shipped in 2005.

Approximately 280 tons ( 250 metric tons) of nonradioactive, nonhazardous material were sent off site in 2005, much of which was recycled. Also, about 840 tons (760 metric tons) of digested sludge was shipped from the WVDP's sanitary and industrial wastewater treatment facility to the Buffalo Sewer Authority for disposal.

Infrastructure Reduction. In 2005, the equivalent of 115 temporary office trailer units were removed from service and dismantled or moved off site. Employees were relocated to the Ashford Office Complex or to a few consolidated areas on site.

\section{Reduction of Risks Associated With Radio-} active Materials. In November 2005, the DOE approved the downgrade of the WVDP to a Category 3 nuclear facility, marking the first time in the site's history that it has been assigned the least of three DOE nuclear facility designations. The categorization is based upon the amounts, types, and configuration of nuclear materials at the site and their potential risks.
Waste Management Environmental Impact Statement. In June 2005, the DOE issued the Record of Decision (ROD) on the Waste Management Environmental Impact Statement (EIS). This ROD defined management of WVDP LLW and mixed LLW, deferred the decision on management of transuranic wastes, and specified that canisters of vitrified HLW will remain in storage on site until they can be shipped directly to a repository. In 2005, preparation of the Decommissioning and/or Long-Term Stewardship EIS continued.

\section{Key Initiatives}

Environmental Performance Indicators. In 2005, management at the WVDP continued efforts to meet goals established for the U.S. Environmental Protection Agency's (EPA) National Environmental Performance Track program for the three-year period of CY 2004-2006. The three goals are: (1) elimination of Halon 1301 from firesuppression systems on site, (2) a 10\% reduction in total energy usage, and (3) a 10\% reduction in total radiological curies discharged in wastewater. The first commitment was completed in 2004 and no Halon 1301 remains on site. The second goal was met in 2004 and again in 2005, when energy usage was reduced by about $19 \%$. The third commitment, although met in 2004, was not met in 2005, when curies released in wastewater discharges exceeded the goal by more than $50 \%$. Corrective measures implemented in the latter part of 2005 improved performance. Additional corrective measures are being developed to further assist in meeting this commitment during 2006.

Pollution Prevention/Waste Minimization Goals. In 2005, as part of the site's EMS, a longterm waste minimization and pollution prevention program to promote affirmative procurement and minimize the generation of LLW, mixed waste, hazardous waste, industrial waste, and sanitary 
waste continued at the WVDP. The program emphasized good business practices, source reduction, and recycling. Waste minimization goals for generation of waste in three of the five categories (LLW, mixed, and hazardous) were met or exceeded in 2005. Target reduction goals for generation of both industrial waste and sanitary waste (e.g., paper, glass, plastic, wood, and scrap metal) were not met. Activities supporting the site milestones and infrastructure reduction resulted in the generation of quantities of waste that exceeded target goals.

\section{Environmental Management System}

The WVDP EMS satisfies the requirements of DOE Order 450.1, "Environmental Protection Program." The WVDP EMS is an integral part of the WVDP Integrated Safety Management System (ISMS). In 2005, WVDP employees continued to demonstrate their commitment to an all-inclusive approach to safety, coordinating the EMS with other safety management and work planning processes through the integrated environmental, health, and safety management program.

Recognition and Awards. In 2005, the WVDP reaffirmed its commitment to the DOE's Voluntary Protection Program (VPP) and was examined as part of the annual ISMS review. VPP Star status is granted in recognition of excellent worker safety and health programs. The DOE recommended recertification of the WVDP as a DOEVPP Star site in 2005.

By year-end 2005, WVDP employees reached 3.7 million safe work hours and three years without a lost-time work accident. In recognition of this safety record, the WVDP was awarded the Washington Group President's Award for Safety for the third consecutive year.
Compliance. Management at the WVDP continued to provide strong support for environmental compliance in 2005. Requirements and guidance from applicable state and federal statutes, executive orders, DOE orders, and standards are integrated into the Project's compliance program. In CY 2005:

- no notices of violation or inspection findings from any environmental regulatory agencies were received by the WVDP.

- inspections by the New York State Department of Environmental Conservation and the local department of health verified Project compliance with the applicable environmental and health regulations.

- waste management areas at the site were monitored in compliance with the Resource Conservation and Recovery Act $\$ 3008(\mathrm{~h})$ Administrative Order on Consent.

- Project representatives met requirements of the Emergency Planning and Community Right-toKnow Act by collecting information about hazardous materials used at the Project and making this information available to the local community.

- no exceedances to State Pollutant Discharge Elimination System (SPDES) permit limits or to the EPA's National Emission Standards for Hazardous Air Pollutants (NESHAP) dose standard were noted in 2005 .

Environmental Monitoring. As part of the EMS, environmental monitoring was continued on and near the site to detect and evaluate changes in the environment resulting from Project (or pre-Project) activities and to assess the effect of any such changes on the environment or human population. Within the environmental monitoring program, airborne and waterborne effluents were sampled and 
environmental surveillance of the site and nearby areas was conducted.

Radiological Releases. In 2005, the WVDP maintained six NESHAP permits for release of airborne emissions. The primary source of airborne radionuclide emissions was the main stack of the process building.

Waterborne releases were from two primary sources: lagoon 3, from which treated water is released in batches, and from a well-characterized seepage on the north plateau of the WVDP that is contaminated with strontium-90 from preWVDP operations. Seven batches totaling approximately 13.6 million gallons ( 51.4 million liters) were discharged from lagoon 3 in 2005. Radiological concentrations and flow from north plateau seepage were closely monitored.

Estimated Dose. In 2005, the estimated dose to a maximally exposed off-site individual (MEOSI) from airborne emissions at the WVDP was $0.0012 \mathrm{mrem}(0.000012 \mathrm{mSv})$, about $0.01 \%$ of the 10 mrem NESHAP standard. Estimated dose from waterborne sources in 2005 was about 0.046 mrem $(0.00046 \mathrm{mSv})$, with $0.011 \mathrm{mrem}$ attributable to liquid effluent releases and 0.035 mrem attributable to the north plateau drainage.

Total estimated dose to the MEOSI from both airborne and waterborne sources in 2005 was $0.047 \mathrm{mrem}(0.00047 \mathrm{mSv})$, about $0.05 \%$ of the annual 100 mrem DOE standard. In comparison, the typical dose to a member of the public from natural background sources is 295 mrem per year.

Estimated dose to the population within a 50-mile $(80-\mathrm{km})$ radius of the WVDP from DOE activities in 2005 was 0.2 person-rem (0.002 person$\mathrm{Sv})$. This same population would have received approximately 453,000 person-rem from natural background radiation in 2005 .
Dose to Biota. An evaluation of dose to biota for CY 2005, as part of the WVDP environmental monitoring program, resulted in the conclusion that populations of aquatic and terrestrial biota (both plants and animals) are not being exposed to doses in excess of the existing DOE dose standard for aquatic animals and the recommended standards for terrestrial biota.

Nonradiological Releases. Nonradiological releases from Project wastewater were measured under the site's SPDES permit. An updated permit, which added 20 storm water monitoring points to the five existing effluent points, took effect on January 1, 2005. In 2005, no exceedances of any permit limits were noted.

Changes to the Environmental Monitoring Program. An extensive replanning of the monitoring program was conducted in 2005. As a result, numerous modifications were made to maximize the program's efficiency and cost-effectiveness.

Groundwater Monitoring. Monitoring of groundwater at the WVDP continued in 2005, including monitoring of strontium-90 activity in and around the groundwater plume on the north plateau.

Quality Assurance. In 2005, implementation of a quality assurance program for activities supporting the environmental monitoring and groundwater monitoring programs continued at the WVDP. As part of this ongoing effort, on-site and subcontract laboratories that analyze WVDP environmental samples participated in independent radiological and nonradiological constituent performance evaluation studies. In these studies, test environmental samples with concentrations known by the testing agency, but unknown by the laboratory, were analyzed. Of almost 200 performance evaluation analyses conducted by or for the WVDP, more than $97 \%$ fell within acceptance limits. 
Several inspections, audits, and assessments of components of the environmental monitoring program were conducted in 2005. Although actions were recommended to improve the program, nothing was found that would compromise the data quality in this report or the environmental monitoring program in general.

\section{Conclusion}

In addition to demonstrating compliance with environmental regulations and directives, evaluation of data collected in 2005 continued to indicate that WVDP activities pose no threat to public health or safety, or to the environment. 
This page intentionally left blank

EXE - 6 


\section{INTRODUCTION}

\section{Site Location}

The West Valley Demonstration Project (WVDP or Project) is located in western New York State, about 30 miles (50 kilometers [km]) south of Buffalo, New York (Fig. INT-1). The WVDP facilities occupy a security-fenced area of about 167 acres (68 hectares [ha]) within the 3,338-acre (1,351 ha) Western New York Nuclear Service Center (WNYNSC) located primarily in the town of Ashford in northern Cattaraugus County. The security-fenced area is referred to as the Project premises.

\section{General Environmental Setting}

Climate. Although extremes of $98.6^{\circ} \mathrm{F}\left(37^{\circ} \mathrm{C}\right)$ and $-43.6^{\circ} \mathrm{F}\left(-42^{\circ} \mathrm{C}\right)$ have been recorded in western New York, the climate is moderate, with an average annual temperature (1971-2000) of $48^{\circ} \mathrm{F}$ $\left(8.9^{\circ} \mathrm{C}\right)$. Precipitation is markedly influenced by Lake Erie to the west and, to a lesser extent, by Lake Ontario to the north. Regional winds are generally from the west and south at about 9 miles per hour (mph) (4 meters/second [m/sec]).

Ecology. The WNYNSC lies within the northern deciduous forest biome, and the diversity of its vegetation is typical of the region. Equally divided between forest and open land, the site provides a habitat especially attractive to white-tailed deer and various indigenous migratory birds, reptiles, and small mammals. No species on the federal endangered species list are known to reside on the WNYNSC.

Geology and Hydrology. The Project lies on New York State's Allegheny Plateau at an average elevation of about 1,300 feet (400 meters [m]). The underlying geology includes a sequence of glacial sediments above shale bedrock. The Project is drained by several small streams and is divided by a stream valley into two general areas: the north plateau and the south plateau.

Frank's Creek, which enters the site from the south and flows northward, receives drainage from the south plateau. As Frank's Creek progresses northward, it is joined by tributaries Erdman Brook (between the south and north plateaus) and Quarry Creek (north of the Project's fenceline). Frank's Creek continues northward across the WNYNSC and flows into Buttermilk Creek, which leaves the WNYNSC and enters Cattaraugus Creek. (See Figs. A-1 and A-5.) Cattaraugus Creek ultimately drains into Lake Erie, to the northwest.

INT - 1 


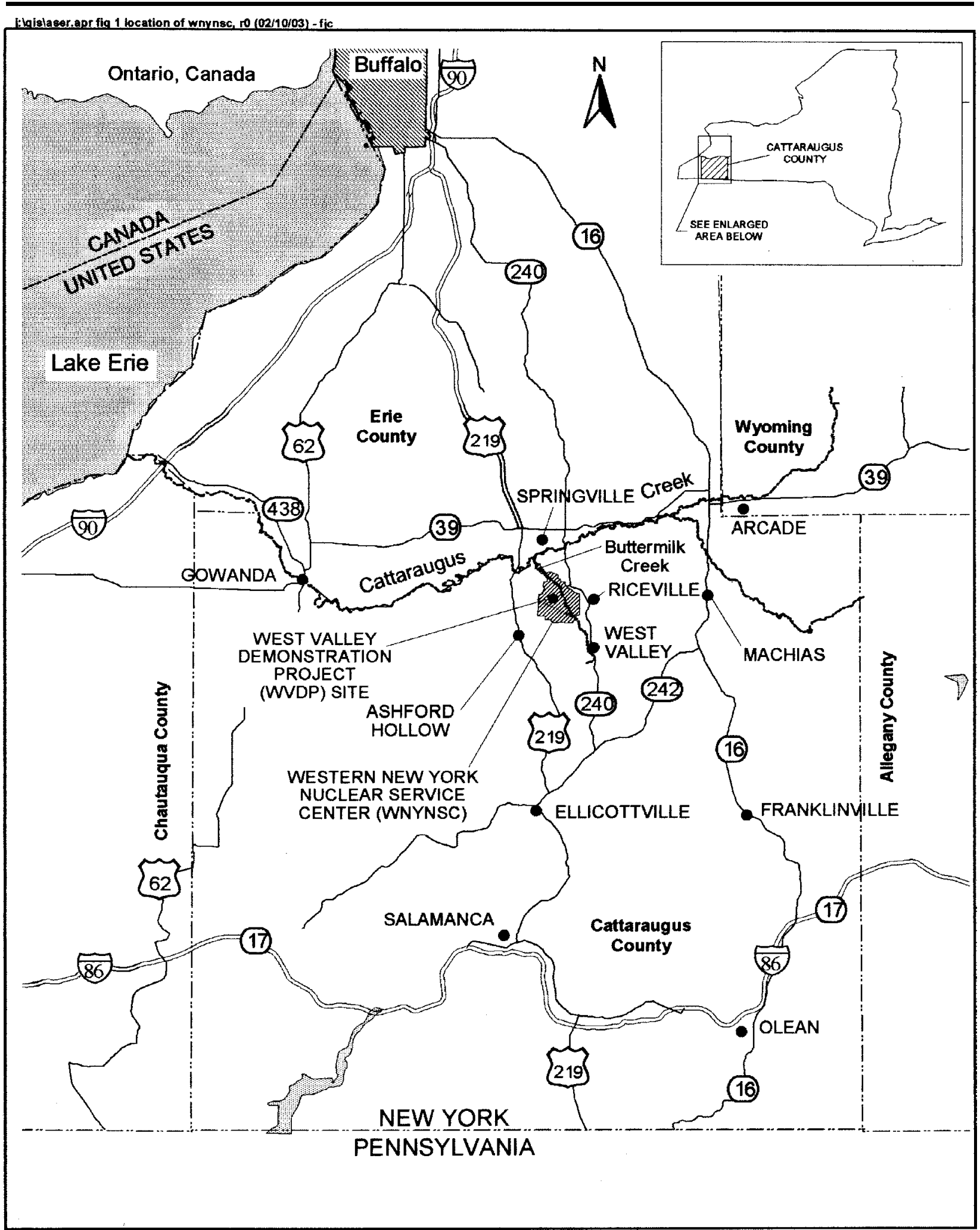

Figure INT-1. Location of the Western New York Nuclear Service Center

INT - 2 


\section{Site Mission}

The facility that later became the WVDP was the site of a commercial nuclear fuel reprocessing plant run by Nuclear Fuel Services, Inc. (NFS) from 1966 until 1972. Uranium and plutonium were recovered from spent nuclear fuel for reuse. In 1972, the reprocessing facility closed for expansion, but in 1976 NFS notified the New York State Energy Research and Development Authority that it was no longer economically feasible to continue in the fuel-reprocessing business and the plant was shut down. In 1980, Public Law 96-368 (the West Valley Demonstration Project Act) was passed. This Act authorized the United States Department of Energy to demonstrate a method for solidifying 600,000 gallons (2.3 million liters) of liquid highlevel radioactive waste (HLW) that remained at the West Valley site. (For a detailed history of the site, see the Introduction of the 2003 Annual Site Environmental Report. See Table K-3 ${ }^{\text {Go }}$ for the complete text of the WVDPAct.)

The purposes of the WVDP Act were to carry out the following activities: solidify the HLW that was left at the site from the original nuclear fuel reprocessing activities; develop suitable containers for holding and transporting the solidified waste; transport, in accordance with applicable provisions of law, the waste solidified at the WNYNSC to an appropriate Federal repository for permanent disposal; dispose of any low-level and transuranic radioactive waste resulting from the solidification of HLW; and decontaminate and decommission Project facilities used for solidification of radioactive waste.

Vitrification of the HLW, begun in 1996, was completed in September 2002. Activities for decontaminating the vitrification and support facilities and for disposing of wastes were then initiated and continue through the present.

\section{Primary Operations and Activities}

The following projects were initiated, continued, or completed in 2005 :

Vitrification Facility Dismantlement Project. In 2005 , the remainder of the equipment in the vitrification cell was dismantled and removed. Completion of this effort made the WVDP the first site in the nation to design, construct, operate, shut down, and dismantle a full-scale radioactive vitrification system.

Remote-Handled Waste Facility (RHWF). The new RHWF, which began processing radioactive waste in June 2004, was used throughout 2005 to prepare higher-activity wastes for shipment and disposal. Four boxes of mixed waste from the chemical process cell waste storage area were removed and processed in the RHWF in 2005.

Waste Characterization, Packaging, and Shipping. Upgrades were made to several facilities and areas on site to support new or increased activities to prepare Class Alow-level waste (LLW) for off-site shipment. Characterization of the waste streams (wastes that came from the same point of origin or that had similar physical characteristics) continued throughout 2005, and shipments of waste off site took place by truck and rail. In 2005 , more than 300,000 cubic feet $(8,500$ cubic meters) of LLW were shipped.

Infrastructure Reduction. Office personnel were relocated to new offices on and off the WVDP. Temporary office trailers, connecting hallways, and ancillary structures, 115 units in all, were removed from the site. Excess office components and furnishings were removed and dispositioned through the government excess process by a combination of surplus sales, transfers of property, and donations. 
Environmental Monitoring. The primary focus of the WVDP's environmental monitoring program is to detect and evaluate changes in the environment resulting from Project (or pre-Project) activities and to assess the effect of any such changes on the human population.

Among the factors considered in designing the environmental monitoring program were the types of wastes and other by-products resulting from the processing of HLW; possible pathways for movement of contaminants into the environment; geologic, hydrologic, and meteorologic site conditions; quality assurance standards for monitoring and sampling procedures and analyses; and the limits and standards set by federal and state governments and agencies. (For more information on the design of the environmental monitoring program, see "Environmental Monitoring Program" and "Exposure Pathway Monitoring" in the Introduction of the 2003 Annual Site Environmental Report.) Results of the 2005 monitoring program are discussed in Chapters 2, 3, and 4 of this report.

\section{Relevant Demographics}

Although several roads and a railway approach or pass through the WNYNSC, the public does not have access to the Project grounds. Deer hunting may be allowed (a year-to-year decision), but fishing and human habitation on the WNYNSC are prohibited.

Land near the WNYNSC is used primarily for agriculture and arboriculture. Downstream of the WNYNSC, Cattaraugus Creek is used locally for swimming, canoeing, and fishing. Although some water is taken from the creek to irrigate nearby golf course greens and tree farms, no public drinking water is drawn from the creek before it flows into Lake Erie. Water from Lake Erie is used as a public drinking water supply.
The communities of West Valley, Riceville, Ashford Hollow, and the village of Springville are located within approximately 5 miles $(8 \mathrm{~km})$ of the Project. The nearby population, approximately 9,200 residents within 6.2 miles $(10 \mathrm{~km})$ of the Project, relies largely on an agricultural economy. No major industries are located within this area. The WVDP is one of the largest employers in Cattaraugus County. 


\section{ENVIRONMENTAL COMPLIANCE SUMMARY \\ Calendar Year 2005}

\section{Compliance Program}

The United States (U.S.) Department of Energy (DOE) is currently focusing on several goals at the West Valley Demonstration Project (WVDP or Project) in support of completion of the WVDP Act. (See Appendix $\mathrm{K}^{\mathbf{6 D}}$.) Activities during 2005 included increased processing and packaging of low-level radioactive waste (LLW) inventories for off-site shipment and disposal, dismantling the former vitrification waste processing cell and removing the radioactive waste, continued operation of the remote-handled waste facility, reducing infrastructure, and continued treatment of radioactively contaminated groundwater.

Activities at the WVDP are regulated by various federal and state public, worker, and environmental protection laws. These laws are administered primarily by the U.S. Environmental Protection Agency (EPA), the U.S. Fish and Wildlife Service, the U.S. Army Corps of Engineers (ACOE), the New York State Department of Environmental Conservation (NYSDEC), and the New York State Department of Health (NYSDOH) through programs and regulatory requirements for permitting, reporting, inspecting, self-monitoring, and audits. Table ECS-1 summarizes the WVDP's compliance status with applicable environmental statutes, DOE directives, and executive orders.
Because release of radiological and nonradiological materials from an active facility cannot be completely prevented, the EPA, NYSDEC, and DOE have established standards for effluents that are intended to protect human health, safety, and the environment. The DOE applies to the EPA for permits to release limited amounts of radiological constituents to the air and applies to NYSDEC for permits to release limited amounts of nonradiological constituents to the air and water in concentrations determined to be safe for humans and the environment. In general, the permits describe release points, specify management and reporting requirements, list discharge limits on those pollutants likely to be present, and define the sampling and analysis regimen. A summary of permits may be found in Table ECS-2. No releases above allowable permit or regulatory limits occurred in 2005.

\section{Compliance Status}

The following summary describes WVDP compliance with DOE Orders 450.1, 5400.5, and 435.1 and federal and state laws and regulations applicable to the Project.

Environmental Protection Program (DOE Order 450.1). DOE Order 450.1, issued in January 2003, required that DOE sites implement an 


\section{Table ECS-1}

Compliance Status Summary for the WVDP in 2005

\begin{tabular}{|c|c|c|c|}
\hline Citation & $\begin{array}{c}\text { Environmental Statute, } \\
\text { DOE Directive, Executive Order }\end{array}$ & $\begin{array}{l}\text { WVDP Compliance } \\
\text { Status }\end{array}$ & $\begin{array}{l}\text { Location in } \\
2005 \text { ASER }\end{array}$ \\
\hline $\begin{array}{l}42 \text { United } \\
\text { States Code } \\
\text { (USC) §2011 } \\
\text { et seq. }\end{array}$ & $\begin{array}{l}\text { The Atomic Energy Act (AEA) of } 1954 \text { was } \\
\text { enacted to assure the proper management of } \\
\text { source, special nuclear, and by-product material. } \\
\text { The AEA and the statutes that amended it } \\
\text { delegate the control of nuclear energy primarily } \\
\text { to the DOE, the Nuclear Regulatory } \\
\text { Commission (NRC), and the EPA. }\end{array}$ & $\begin{array}{l}\text { See discussions of the WVDP Act and of } \\
\text { DOE Orders 435.1, 450.1, and 5400.5. }\end{array}$ & $\begin{array}{l}\text { Environmental } \\
\text { Compliance } \\
\text { Summary }\end{array}$ \\
\hline $\begin{array}{l}\text { Public Law } \\
96-368\end{array}$ & $\begin{array}{l}\text { The West Valley Demonstration Project Act } \\
\text { of } 1980 \text { (WVDP Act) authorized the DOE to } \\
\text { carry out a high-level liquid nuclear waste } \\
\text { demonstration project at the Western New York } \\
\text { Service Center in West Valley, New York. }\end{array}$ & $\begin{array}{l}\text { The DOE is focusing on goals that will } \\
\text { lead to completion of activities listed in } \\
\text { the WVDP Act. }\end{array}$ & $\begin{array}{l}\text { Executive } \\
\text { Summary; } \\
\text { Introduction; } \\
\text { Appendix K }\end{array}$ \\
\hline $\begin{array}{l}\text { DOE Order } \\
450.1\end{array}$ & $\begin{array}{l}\text { DOE O 450.1, Environmental Protection } \\
\text { Program, required implementation of an EMS } \\
\text { for conducting work at DOE sites to protect the } \\
\text { air, water, land, and other natural and cultural } \\
\text { resources impacted by DOE operations. }\end{array}$ & $\begin{array}{l}\text { The WVDP EMS is integrated with other } \\
\text { site safety management and work } \\
\text { planning processes. }\end{array}$ & $\begin{array}{l}\text { Environmental } \\
\text { Compliance } \\
\text { Summary; } \\
\text { Chapter } 1\end{array}$ \\
\hline $\begin{array}{l}\text { DOE Order } \\
5400.5\end{array}$ & $\begin{array}{l}\text { DOE Order 5400.5, Radiation Protection of } \\
\text { the Public and the Environment, established } \\
\text { standards and requirements for operations of the } \\
\text { DOE and DOE contractors with respect to } \\
\text { protecting members of the public and the } \\
\text { environment against undue risk from radiation. }\end{array}$ & $\begin{array}{l}\text { Estimated doses from airborne and } \\
\text { waterborne releases to the maximally } \\
\text { exposed off-site individual in } 2005 \text { were } \\
0.05 \% \text { of the } 100 \text { mrem standard, and } \\
\text { about } 0.02 \% \text { of natural background } \\
\text { radiation. }\end{array}$ & 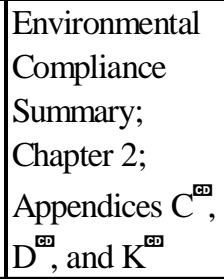 \\
\hline $\begin{array}{l}\text { DOE Order } \\
231.1 \mathrm{~A}\end{array}$ & $\begin{array}{l}\text { DOE O 231.1A, Environment, Safety, and } \\
\text { Health Reporting, was issued to ensure timely } \\
\text { collection, reporting, analysis, and } \\
\text { dissemination of information on environment, } \\
\text { safety, and health issues as required by law or } \\
\text { regulations or as needed to ensure that the DOE } \\
\text { and National Nuclear Security Administration } \\
\text { are kept fully informed on a timely basis about } \\
\text { events that could adversely affect the health and } \\
\text { safety of the public or the workers, the } \\
\text { environment, the intended purpose of DOE } \\
\text { facilities, or the credibility of the DOE. } \\
\end{array}$ & $\begin{array}{l}\text { This WVDP Annual Site Environmental } \\
\text { Report (ASER) is prepared and } \\
\text { submitted annually in compliance with } \\
\text { DOE O 231.1A. }\end{array}$ & \begin{tabular}{|l} 
Entire 2005 \\
WVDP ASER
\end{tabular} \\
\hline $\begin{array}{l}\text { DOE Order } \\
435.1\end{array}$ & $\begin{array}{l}\text { DOE O 435.1, Radioactive Waste } \\
\text { Management, was issued to ensure that all } \\
\text { DOE radioactive waste is managed in a manner } \\
\text { that is protective of worker and public health } \\
\text { and safety, and the environment. }\end{array}$ & $\begin{array}{l}\text { Management of radioactive waste at the } \\
\text { WVDP is conducted in accordance with } \\
\text { written site policies, procedures, and } \\
\text { manuals. }\end{array}$ & $\begin{array}{l}\text { Environmental } \\
\text { Compliance } \\
\text { Summary; } \\
\text { Chapter } 1\end{array}$ \\
\hline
\end{tabular}

\section{ECS - 2}


Table ECS-1 (continued)

Compliance Status Summary for the WVDP in 2005

\begin{tabular}{|c|c|c|c|}
\hline Citation & $\begin{array}{c}\text { Environmental Statute, } \\
\text { DOE Directive, Executive Order }\end{array}$ & $\begin{array}{l}\text { WVDP Compliance } \\
\text { Status }\end{array}$ & $\begin{array}{l}\text { Location in } \\
2005 \text { ASER }\end{array}$ \\
\hline $\begin{array}{l}42 \text { USC } \$ 6901 \\
\text { et seq. New } \\
\text { York State } \\
\text { (NYS) } \\
\text { Environmental } \\
\text { Conservation } \\
\text { Law (ECL) }\end{array}$ & $\begin{array}{l}\text { The Resource Conservation and Recovery } \\
\text { Act (RCRA) of } 1976 \text { and the New York State } \\
\text { Solid Waste Disposal Act (NYS ECL Article } \\
27 \text { [Title 9]) govern the generation, storage, } \\
\text { handling, and disposal of hazardous wastes and } \\
\text { closure of tank systems that handle these wastes } \\
\text { RCRA was enacted to ensure that hazardous } \\
\text { wastes are managed in a way that protects } \\
\text { human health, safety, and the environment. }\end{array}$ & $\begin{array}{l}\text { Generation, storage, handling, and } \\
\text { disposal of hazardous waste, and closure } \\
\text { of tank systems that handle hazardous } \\
\text { waste at the WVDP, are conducted in } \\
\text { accordance with the RCRA Part A } \\
\text { Permit Application and interim status } \\
\text { regulatory requirements, as well as the } \\
\text { RCRA §3008(h) Administrative Order } \\
\text { on Consent. Activities are compliant } \\
\text { with written site procedures. Compliance } \\
\text { was verified by inspections in } 2005 .\end{array}$ & $\begin{array}{l}\text { Environmental } \\
\text { Compliance } \\
\text { Summary; } \\
\text { Chapter } 4\end{array}$ \\
\hline $\begin{array}{l}\text { Amendment to } \\
42 \text { USC } \$ 6961\end{array}$ & $\begin{array}{l}\text { The Federal Facilities Compliance Act } \\
\text { (FFCA) of } 1992 \text { (an amendment to RCRA) } \\
\text { clarified provisions concerning the application } \\
\text { of certain requirements and sanctions to federal } \\
\text { facilities. }\end{array}$ & $\begin{array}{l}\text { An Order of Consent, negotiated under } \\
\text { the FFCA, was executed between } \\
\text { NYSDEC and DOE in 1996. The order } \\
\text { establishes commitments regarding } \\
\text { compliance with the Site Treatment Plan } \\
\text { (STP) for mixed waste inventories at the } \\
\text { WVDP. }\end{array}$ & $\begin{array}{l}\text { Environmental } \\
\text { Compliance } \\
\text { Summary }\end{array}$ \\
\hline $\begin{array}{l}\text { NYS } \\
\text { Navigation } \\
\text { Law and ECL }\end{array}$ & $\begin{array}{l}\text { NYS Navigation Law, Article 12, et seq.; NYS } \\
\text { ECL, Article } 17 \text { (Titles } 10 \text { and 17); and Article } \\
\text { 40. These articles regulate design, operation, } \\
\text { inspection, maintenance, and closure of } \\
\text { aboveground bulk petroleum and bulk chemical } \\
\text { storage tanks. They also regulate spill reporting } \\
\text { and cleanup. }\end{array}$ & $\begin{array}{l}\text { There are } 10 \text { registered bulk storage } \\
\text { tanks that are periodically inspected and } \\
\text { maintained. Spills are reported and } \\
\text { cleaned up in accordance with written } \\
\text { policies and procedures. In } 2005, \text { there } \\
\text { were no spills in excess of the reportable } \\
\text { quantities. }\end{array}$ & $\begin{array}{l}\text { Environmental } \\
\text { Compliance } \\
\text { Summary; } \\
\text { Chapter 1 }\end{array}$ \\
\hline $\begin{array}{l}\text { Executive } \\
\text { Orders (E.O.) } \\
13101 \text { and } \\
13148\end{array}$ & $\begin{array}{l}\text { E.O. 13101, Greening the Government } \\
\text { Through Waste Prevention, Recycling, and } \\
\text { Federal Acquisition, promotes the use of } \\
\text { recycled and environmentally preferable } \\
\text { products and services by federal agencies. E.O. } \\
\text { 13148, Greening the Government Through } \\
\text { Leadership in Environmental Management, } \\
\text { specifies that heads of federal agencies are } \\
\text { responsible for integrating environmental } \\
\text { accountability into agency day-to-day decision- } \\
\text { making and long-term planning processes. }\end{array}$ & $\begin{array}{l}\text { Waste minimization, pollution } \\
\text { prevention, recycling, and affirmative } \\
\text { procurement objectives are achieved in } \\
\text { accordance with written site policies and } \\
\text { procedures. }\end{array}$ & $\begin{array}{l}\text { Environmental } \\
\text { Compliance } \\
\text { Summary; } \\
\text { Chapter 1 }\end{array}$ \\
\hline
\end{tabular}

ECS - 3 
Table ECS-1 (continued)

Compliance Status Summary for the WVDP in 2005

\begin{tabular}{|c|c|c|c|}
\hline Citation & $\begin{array}{c}\text { Environmental Statute, } \\
\text { DOE Directive, Executive Order }\end{array}$ & $\begin{array}{c}\text { WVDP Compliance } \\
\text { Status }\end{array}$ & $\begin{array}{l}\text { Location in } \\
2005 \mathrm{ASER}\end{array}$ \\
\hline $\begin{array}{l}42 \text { USC } \$ 7401 \\
\text { et seq.; Title } \\
40 \text { of the Code } \\
\text { of Federal } \\
\text { Regulations } \\
\text { (CFR) } 61 \text {, } \\
\text { Subpart H }\end{array}$ & $\begin{array}{l}\text { The Clean Air Act of } 1970 \text { (CAA) and the NYS } \\
\text { ECL regulate the release of air pollutants } \\
\text { through permits and air quality limits. Emissions } \\
\text { of radionuclides are regulated by the EPA via } \\
\text { the National Emission Standards for } \\
\text { Hazardous Air Pollutants (NESHAP) } \\
\text { regulations. }\end{array}$ & \begin{tabular}{|l|} 
In 2005, the DOE maintained one Air \\
Facility Registration Certificate for \\
nonradiological emissions and six \\
NESHAP permits for radiological \\
emissions for the WVDP. Estimated dose \\
from radiological air emissions to the \\
maximally exposed off-site individual in \\
2005 was $0.01 \%$ of the 10 millirem \\
Subpart H standard. Nonradiological \\
emissions of nitrogren oxides and sulfur \\
oxides were less than $10 \%$ of the \\
standard for maintaining the registration \\
certificate.
\end{tabular} & $\begin{array}{l}\text { Environmental } \\
\text { Compliance } \\
\text { Summary; } \\
\text { Chapters } 2 \text { and } 3 \\
\text { Appendix D }\end{array}$ \\
\hline $\begin{array}{l}42 \text { USC } \\
\$ 11001 \text { et seq. }\end{array}$ & $\begin{array}{l}\text { The Emergency Planning and Community } \\
\text { Right-to-Know Act of } 1986 \text { (EPCRA) was } \\
\text { designated to help local communities protect } \\
\text { public health, safety, and the environment from } \\
\text { chemical hazards. }\end{array}$ & $\begin{array}{l}\text { The WVDP's chemical inventory was } \\
\text { reported in } 2005 . \text { No further reporting } \\
\text { was required. }\end{array}$ & $\begin{array}{l}\text { Environmental } \\
\text { Compliance } \\
\text { Summary }\end{array}$ \\
\hline $\begin{array}{l}33 \text { USC } \$ 1251 \\
\text { et seq. }\end{array}$ & \begin{tabular}{|l|} 
The Federal Water Pollution Control Act \\
(Clean Water Act [CWA]) and NYS ECL seek \\
to improve surface water quality by establishing \\
standards and a system of permits. Wastewater \\
and storm water discharges are regulated by \\
NYSDEC permits through the State Pollutant \\
Discharge Elimination System (SPDES). \\
Discharges of fill material are regulated through \\
permits issued by the ACOE and water quality \\
certifications issued by NYSDEC.
\end{tabular} & $\begin{array}{l}\text { In } 2005 \text {, no SPDES exceedences were } \\
\text { noted. Monitoring of storm water under } \\
\text { the SPDES permit was added in } 2005 \text {. } \\
\text { Compliance with permit requirements } \\
\text { was confirmed by inspections in } 2005 \text {. A } \\
\text { fill discharge permit from the ACOE } \\
\text { expired in } 2005 \text { as the work was } \\
\text { completed. }\end{array}$ & $\begin{array}{l}\text { Environmental } \\
\text { Compliance } \\
\text { Summary; } \\
\text { Chapter 3; } \\
\text { Appendix C }\end{array}$ \\
\hline $\begin{array}{l}\text { NYS ECL, } \\
\text { Article 15, } \\
\text { Title 5, et seq. }\end{array}$ & $\begin{array}{l}\text { NYS ECL, Title 5, Protection of Water } \\
\text { regulates the safety of dams and other surface } \\
\text { water impounding structures, including } \\
\text { construction, inspection, operation, maintenance } \\
\text { and modification of these structures. }\end{array}$ & $\begin{array}{l}\text { The two surface water impounding dam } \\
\text { structures on the Western New York } \\
\text { Nuclear Services Center (WNYNSC) } \\
\text { have been periodically inspected and } \\
\text { properly maintained. }\end{array}$ & $\begin{array}{l}\text { Environmental } \\
\text { Compliance } \\
\text { Summary }\end{array}$ \\
\hline E.O. 11990 & $\begin{array}{l}\text { E.O. 11990, Protection of Wetlands, directs } \\
\text { federal agencies to avoid, where possible, } \\
\text { impacts (e.g., destruction, modification, or new } \\
\text { construction) that would adversely effect } \\
\text { wetlands wherever there is a practical } \\
\text { alternative. Activities in wetlands are regulated } \\
\text { by the ACOE and NYSDEC permits. }\end{array}$ & $\begin{array}{l}\text { Wetlands on the WVDP have been } \\
\text { identified, delineated, and mapped. In } \\
\text { 2005, NYSDEC approved the wetland } \\
\text { delineation report and the ACOE } \\
\text { performed a field verification wetland } \\
\text { assessment. }\end{array}$ & $\begin{array}{l}\text { Environmental } \\
\text { Compliance } \\
\text { Summary }\end{array}$ \\
\hline
\end{tabular}

ECS - 4 
Table ECS-1 (continued)

Compliance Status Summary for the WVDP in 2005

\begin{tabular}{|c|c|c|c|}
\hline Citation & $\begin{array}{c}\text { Environmental Statute, } \\
\text { DOE Directive, Executive Order }\end{array}$ & $\begin{array}{l}\text { WVDP Compliance } \\
\text { Status }\end{array}$ & $\begin{array}{l}\text { Location in } \\
2005 \text { ASER }\end{array}$ \\
\hline $\begin{array}{l}42 \text { USC §300f } \\
\text { et seq. }\end{array}$ & $\begin{array}{l}\text { The Safe Drinking Water Act of } 1974 \\
\text { (SDWA) requires that each federal agency } \\
\text { operating or maintaining a public water system } \\
\text { must comply with all federal, state, and local } \\
\text { requirements regarding safe drinking water. } \\
\text { Compliance in New York is overseen by } \\
\text { NYSDOH through the NYS Public Health Law } \\
\text { and county health departments. }\end{array}$ & $\begin{array}{l}\text { CY } 2005 \text { results from analyses of } \\
\text { drinking water were reported to the } \\
\text { Cattaraugus County Health Department } \\
\text { (CCHD). All test results were within } \\
\text { drinking water limits. }\end{array}$ & $\begin{array}{l}\text { Environmental } \\
\text { Compliance } \\
\text { Summary; } \\
\text { Chapter 2; } \\
\text { Chapter 3; } \\
\text { Appendix C } C^{\text {ex }}\end{array}$ \\
\hline $\begin{array}{l}15 \text { USC } \$ 2601 \\
\text { et seq. }\end{array}$ & $\begin{array}{l}\text { The Toxic Substances Control Act of } 1976 \\
\text { (TSCA) was enacted to give the EPA the ability } \\
\text { to track industrial chemicals produced or } \\
\text { imported into the U.S. }\end{array}$ & $\begin{array}{l}\text { Asbestos-containing materials and } \\
\text { polychlorinated biphenyls (PCBs) are } \\
\text { managed in accordance with written site } \\
\text { policies and procedures. }\end{array}$ & $\begin{array}{l}\text { Environmental } \\
\text { Compliance } \\
\text { Summary }\end{array}$ \\
\hline $\begin{array}{l}42 \text { USC } \$ 4321 \\
\text { et seq. }\end{array}$ & $\begin{array}{l}\text { The National Environmental Policy Act of } \\
1969 \text { (NEPA) established a national policy to } \\
\text { ensure that protection of the environment is } \\
\text { included in federal planning and decision- } \\
\text { making. }\end{array}$ & $\begin{array}{l}\text { Alternatives for management of WVDP } \\
\text { LLW, mixed waste, high-level waste } \\
\text { (HLW), and transuranic (TRU) wastes } \\
\text { were evaluated in a Waste Management } \\
\text { Environmental Impact Statement (EIS). } \\
\text { In } 2005 \text { the Record of Decision (ROD) } \\
\text { was issued. }\end{array}$ & $\begin{array}{l}\text { Environmental } \\
\text { Compliance } \\
\text { Summary }\end{array}$ \\
\hline $\begin{array}{l}16 \text { USC } \$ 703 \\
\text { et seq. }\end{array}$ & $\begin{array}{l}\text { The Migratory Bird Treaty Act of } 1918 \\
\text { implements various treaties and conventions } \\
\text { between the U.S. and foreign countries for the } \\
\text { protection of migratory birds. Under the Act, } \\
\text { taking, killing, or possessing migratory birds is } \\
\text { unlawful. }\end{array}$ & $\begin{array}{l}\text { The DOE maintains, and complies with, } \\
\text { a NYS Division of Fish and Wildlife } \\
\text { Bird Depredation License and a U.S. } \\
\text { Fish and Wildlife Bird Depredation } \\
\text { Permit for the WVDP. }\end{array}$ & $\begin{array}{l}\text { Environmental } \\
\text { Compliance } \\
\text { Summary }\end{array}$ \\
\hline $\begin{array}{l}16 \text { USC } \S 1531 \\
\text { et seq. }\end{array}$ & $\begin{array}{l}\text { The Endangered Species Act of } 1973 \text { provides } \\
\text { for the conservation of endangered and } \\
\text { threatened species of fish, wildlife, and plants. }\end{array}$ & $\begin{array}{l}\text { Several ecological surveys of the WVDP } \\
\text { premises have been conducted. Except } \\
\text { for "occasional transient individuals," no } \\
\text { plant or animal species protected under } \\
\text { this Act are known to exist at the WVDP. }\end{array}$ & $\begin{array}{l}\text { Environmental } \\
\text { Compliance } \\
\text { Summary }\end{array}$ \\
\hline $\begin{array}{l}7 \text { USC \$136 et } \\
\text { seq. }\end{array}$ & $\begin{array}{l}\text { The Federal Insecticide, Fungicide, and } \\
\text { Rodenticide Act of } 1996 \text { (FIFRA) and NYS } \\
\text { ECL provide for EPA and NYSDEC control of } \\
\text { pesticide distribution, sale, and use. }\end{array}$ & $\begin{array}{l}\text { Chemical pesticides are applied at the } \\
\text { WVDP only after alternative methods are } \\
\text { evaluated by trained and NYSDEC- } \\
\text { certified professionals and determined to } \\
\text { be unfeasible. }\end{array}$ & $\begin{array}{l}\text { Environmental } \\
\text { Compliance } \\
\text { Summary }\end{array}$ \\
\hline
\end{tabular}

ECS - 5 


\section{Table ECS-1 (concluded)}

Compliance Status Summary for the WVDP in 2005

\begin{tabular}{|c|c|c|c|}
\hline Citation & $\begin{array}{c}\text { Environmental Statute, } \\
\text { DOE Directive, Executive Order }\end{array}$ & $\begin{array}{c}\text { WVDP Compliance } \\
\text { Status } \\
\end{array}$ & $\begin{array}{l}\text { Location in } \\
2005 \text { ASER }\end{array}$ \\
\hline 16 USC $\$ 470$ & $\begin{array}{l}\text { The National Historic Preservation Act of } \\
1966 \text { established a program for the preservation } \\
\text { of historic properties throughout the nation. }\end{array}$ & $\begin{array}{l}\text { Surveys have been conducted of the } \\
\text { WNYNSC for historic and } \\
\text { archaeological sites. }\end{array}$ & $\begin{array}{l}\text { Results are } \\
\text { summarized in } \\
\text { EIS documents } \\
\text { and are not } \\
\text { reported in the } \\
\text { ASER. }\end{array}$ \\
\hline $\begin{array}{l}42 \text { USC } \$ 9601 \\
\text { et seq. }\end{array}$ & $\begin{array}{l}\text { The Comprehensive Environmental } \\
\text { Response, Compensation, and Liability Act } \\
\text { of } 1980 \text { (CERCLA, including the Superfund } \\
\text { Amendments and Reauthorization Act of } \\
1986 \text { [SARA]) provides the regulatory } \\
\text { framework for remediation of releases of } \\
\text { hazardous substances and remediation of } \\
\text { inactive hazardous waste disposal sites. }\end{array}$ & $\begin{array}{l}\text { Based on the results of a Preliminary } \\
\text { Assessment Report prepared for the } \\
\text { DOE, it was determined that the WVDP } \\
\text { did not qualify for listing on the National } \\
\text { Priorities List. Therefore, no further } \\
\text { investigation pursuant to CERCLA was } \\
\text { warranted. However, if a spill exceeds a } \\
\text { reportable quantity, CERCLA reporting } \\
\text { requirements may be triggered. The } \\
\text { WVDP annually reports chemical } \\
\text { inventories under EPCRA (also known as } \\
\text { SARA Title III) as appropriate. }\end{array}$ & $\begin{array}{l}\text { Environmental } \\
\text { Compliance } \\
\text { Summary }\end{array}$ \\
\hline E.O. 11988 & $\begin{array}{l}\text { E.O. 11988, Floodplain Management, was } \\
\text { issued to avoid adverse impacts associated with } \\
\text { the occupancy and modification of floodplains } \\
\text { and to avoid direct or indirect support of } \\
\text { floodplain development wherever there is a } \\
\text { practicable alternative. }\end{array}$ & $\begin{array}{l}\text { No activities were performed at the site } \\
\text { that would impact the } 100 \text {-year flood } \\
\text { plain within the WVDP premises. }\end{array}$ & $\begin{array}{l}\text { Environmental } \\
\text { Compliance } \\
\text { Summary }\end{array}$ \\
\hline
\end{tabular}

environmental management system (EMS) by December 31, 2005. An EMS is a continuing cycle of systematic planning, implementing, evaluating, and improving processes and actions undertaken to achieve environmental goals.

Environmental Management System. Since 1999, the WVDP has implemented an EMS via policies and procedures that provide for accomplishing work through proactive management, environmental stewardship, and integration of appropriate technologies across all Project functions. The West Valley Nuclear Services Co. (WVNSCO) EMS satisfies the requirements of both the "Code of
Environmental Management Principles" for federal agencies and the International Organization for Standardization 14001, "Environmental Management Systems: Specifications for Guidance and Use." Elements of the WVDP EMS are discussed in Chapter 1 and summarized in Table 1-1.

Integrated Safety Management System (ISMS). TheEMS is an important part of the WVDP ISMS. Sitewide management continues to demonstrate commitment to an all-inclusive approach to safety through ongoing efforts to strengthen its integrated safety management program and by encouraging worker involvement.

$E C S-6$ 
In November 2005, a self-assessment was conducted to confirm that the WVDP's integrated environmental, safety, and health management system continues to be effectively implemented. Results from the self-assessment were verified in the DOE's annual review, completed in December 2005, when the DOE-WVDP Ohio Field Office submitted a report to DOE Headquarters declaring that the WVDP meets the EMS requirements specified in DOE Order 450.1.

\section{Radiation Protection of the Public and the En- vironment (DOE Order 5400.5). Objectives of DOE Order 5400.5 are to ensure that (1) opera- tions are conducted so that radiation exposures to members of the public are maintained within the limits established in the Order, (2) potential expo- sures to members of the public are as far below the limits as is reasonably achievable, (3) routine and nonroutine releases are monitored and dose to the public is assessed, and (4) the environment is protected from radioactive contamination to the extent practicable.}

This ASER summarizes radiological releases from the WVDP in 2005, presents estimates of dose to the public and the environment, and compares these values with release and dose standards established by DOE Order 5400.5. (See Appendix $\mathrm{K}^{\mathbf{6 0}}$ and Chapter 2.) In 2005, both releases and estimates of dose to the public were well within applicable limits.

\section{Radioactive Waste Management (DOE Or-} der 435.1). Radioactive wastes at the WVDP are managed in accordance with a defined radioactive waste acceptance program supported by approved site procedures. The formal site program, updated in August 2005, defines how radioactive waste - including HLW, TRU waste, LLW, and the radioactive component of mixed waste - is managed at the WVDP to (1) protect the public from exposure to radioactive materials, (2) pro- tect the environment, (3) protect workers, and (4) comply with applicable federal, state, and local laws and regulations, as well as applicable Executive Orders and other DOE directives.

Nationwide Management of Waste. In May 1997, DOE Headquarters issued the Final Waste Management Programmatic EIS to evaluate nationwide management and siting alternatives for treatment, storage, and disposal of five types of radioactive and hazardous waste. The alternatives addressed waste generated, stored, or buried over the next 20 years at 54 sites in the DOE complex.

The Final Waste Management Programmatic EIS was issued with the intent of developing and issuing separate RODs for each type of waste analyzed. In 1998, the DOE issued RODs for TRU and nonwastewater hazardous waste. In 1999, the DOE issued the ROD for HLW. This decision specified that WVDP-vitrified HLW will remain in on-site storage until it is accepted for disposal at a geologic repository.

On February 25, 2000, the DOE issued its ROD for the management of LLW and mixed LLW, including West Valley's wastes. Hanford and the Nevada Test Site (NTS) were identified as designated national DOE disposal sites for these waste types (Volume 65, Federal Register [FR], p. 10061 [65 FR 10061]). In 2001, West Valley successfully completed the program approval process for access to the NTS, and on July 17, 2001 received approval to ship waste. LLW shipments from the WVDP have been ongoing since then.

Waste Characterization, Packaging, and Shipping. In 2005, upgrades were made to several facilities and areas on site to support new or increased activities to prepare Class ALLW for off-site shipment. Characterization of waste streams (wastes that came from the same point of origin or that had similar physical characteristics) continued through-

ECS - 7 
out 2005, and shipments of waste took place by truck and by rail. Details pertaining to the LLW shipments in 2005 are included in Table ECS-3.

Resource Conservation and Recovery Act. RCRA and its implementing regulations govern the life cycle of hazardous waste from "cradle-tograve" and mandate that generators take responsibility for ensuring the proper treatment, storage, and ultimate disposal of their wastes.

The EPA is responsible for issuing guidelines and regulations for the proper management of solid and hazardous waste (including mixed [radioactive and hazardous] waste). In New York, the EPA has delegated the authority to issue permits and enforce these regulations to NYSDEC. In addition, the U.S. Department of Transportation is responsible for issuing guidelines and regulations for labeling, packaging, and spill-reporting for hazardous and mixed wastes while in transit.

A hazardous waste permit is required for facilities that treat or store large quantities of hazardous waste for more than 90 days or dispose of hazardous waste at the facility. New York State facilities in existence on the date that hazardous waste regulations impacting their operations took effect were required to apply for interim status from NYSDEC by submitting a RCRA Part A Permit Application in accordance with Title 6 of the Official Compilation of Codes, Rules, and Regulations of the State of New York (6 NYCRR) Part 373-3. Facility operations during interim status are limited to those described in the Part A Permit Application and must comply with the Interim Status Standards regulations.

In 1984, the DOE notified the EPA of hazardous waste activities at the WVDP and identified the WVDP as a generator of hazardous waste. After New York initially received final EPA authorization to implement its base hazardous waste management program effective in May 1986, hazardous waste permitting authority was delegated to NYSDEC. In June 1990, the effective date of the New York State regulations governing treatment, storage, and disposal of mixed (i.e., RCRA hazardous and Atomic Energy Commission radioactive) waste, a RCRA Part A Permit Application for the WVDP was filed with NYSDEC for storage and treatment of hazardous and mixed wastes, and the WVDP has operated under interim status ever since.

The RCRA Part A Permit Application is revised as changes to the site's interim status waste-management operations occur. The last update of the RCRA Part A Permit Application was submitted to NYSDEC on March 6, 2001. On November 13, 2001, NYSDEC responded that the RCRA Part A Permit modifications met the requirements for changes to interim status treatment and storage operations at the WVDP.

In a July 16, 2003 letter to the DOE, NYSDEC made an official request for the submittal of a Part 373-2 Permit Application for the WVDP. The complete Part 373-2 Permit Application (i.e., Part B) was transmitted to NYSDEC on December 23, 2004. This includes RCRA closure plans for all interim status units that continue to be managed in accordance with 6 NYCRR Part 373-3 until a final determination by NYSDEC on the Part 373-2 Permit Application is made and a 6 NYCRR Part 373-2 permit is issued.

In December 2002, the WVDP previously submitted an interim status closure plan for the HLW tanks 8D-1 and 8D-2 and the Supernatant Treatment System to NYSDEC. NYSDEC responded that the closure plan did not properly address RCRA clean closure requirements. Three additional closure plans (for the vitrification facility, the lag storage addition \#1 [LSA\#1] and LSA\#2 hardstand, and the interim waste storage facility) were submitted in December 2004, prior to the

ECS - 8 
date by which the WVDP expected these units to receive their final volume of hazardous waste, as required by 6 NYCRR Part 373-3. NYSDEC's response is pending for these closure plans.

In April 2005, the DOE transmitted nine additional RCRA hazardous waste closure plans. These nine closure plans are associated with interim status hazardous waste units, which are also SWMUs. The closure plans were transmitted in anticipation of implementing interim status unit closure activities in 2006 for one or more of the permitted units. NYSDEC's response is expected in 2006.

RCRA $\$ 3008(h)$ Administrative Order on Consent. The DOE and the New York State Energy Research and Development Authority (NYSERDA) entered into a RCRA §3008(h) Administrative Order on Consent (the Consent Order) with NYSDEC and the EPA in March 1992. The Consent Order required NYSERDA and the DOE's WVDP office to conduct RCRAfacility investigations (RFIs) at on-site solid waste management units (SWMUs) to determine if there had been a release or if there is a potential for release of RCRA-regulated hazardous constituents from SWMUs. The final RFI reports were submitted in 1997, completing the investigative activities associated with the Consent Order. No corrective actions were required at that time as a result of the RFIs. Groundwater monitoring, as recommended in the RFI reports and approved by the EPA and NYSDEC, continued during 2005 in compliance with the requirements of the Consent Order. Groundwater monitoring results are presented in Appendix $E^{\text {GD }}$ and discussed in Chapter 4.

On February 17, 2005, the DOE transmitted a summary report to NYSDEC and the EPA for one SWMU (Breach in Laundry Wastewater Line) identified and reported in 2003. Following review of this summary evaluation of soil sampling re- sults, the Division of Solid \& Hazardous Materials of NYSDEC and the EPA communicated in a May 2005 correspondence that no further action is needed at this time. (See "Process Sewer Integrity Evaluation" later in this chapter for additional detail.)

Pursuant to a request from NYSDEC in a January 2004 correspondence, a report entitled "West Valley Demonstration Project Solid Waste Management Unit Assessment and Current Conditions Report" was submitted to NYSDEC in November 2004. This report summarized the historic activities at individual SWMUs and provided current environmental monitoring data and information on site activities performed since the completion of the RFI reports.

As a result of its review, NYSDEC determined that corrective measures studies (CMSs) pursuant to the Consent Order were required. Therefore, in an April 2005 correspondence, NYSDEC requested that CMSs be performed for select SWMUs at the WVDP. The DOE and NYSDEC met in June 2005 to discuss NYSDEC's request and the scope of subsequent CMS activities. As a result of this meeting, the DOE submitted to NYSDEC a draft "Corrective Measures Study Work Plan for the West Valley Demonstration Project" in August 2005 to address CMS requirements for six SWMUs. Closure of two SWMUs was deferred to closure under SPDES requirements. NYSDEC transmitted comments to the DOE in November and the DOE subsequently transmitted a revised draft CMS Work Plan to NYSDEC in January 2006 addressing NYSDEC comments. NYSDEC is expected to approve this work plan in 2006. Concurrently, the DOE began preparing draft CMS reports for the six SWMUs agreed upon by NYSDEC in the June 2005 meeting. The draft CMS reports are scheduled to be submitted to NYSDEC for review in mid-2006. 
Hazardous Waste Management Program. Hazardous wastes at the WVDP are managed in accordance with 6 NYCRR Parts 370-374 and 376. Hazardous and mixed waste activities are reported to NYSDEC annually by submitting the WVDP's Annual Hazardous Waste Report. This report summarizes the hazardous waste activities for the previous year, specifies the waste quantities generated, treated, and/or disposed of, and identifies the treatment, storage, and disposal facilities used. The Annual Hazardous Waste Report for 2005 was submitted to NYSDEC in February 2006. Quantities of hazardous waste generated and disposed of in 2005 are summarized in Table ECS-3.

A hazardous waste reduction plan documenting efforts to minimize hazardous waste generation is prepared annually and submitted to NYSDEC per regulations. The most recent "Annual Status Report for the Hazardous Waste Reduction Program" was submitted to NYSDEC in 2005. In addition, an update of the biennial hazardous waste reduction plan is prepared. This update was last performed in 2005.

An annual inspection to assess compliance with hazardous waste regulations was conducted by NYSDEC on March 15, 2005. No deficiencies were noted.

Mixed Waste Management Program. Mixed waste contains both a radioactive component, regulated under the AEA, and a hazardous component, regulated under RCRA.

The FFCA of 1992, an amendment to RCRA, requires DOE facilities to prepare a Site Treatment Plan (STP) for treating mixed waste inventories to meet land disposal restrictions and to update the plan annually to account for development of treatment technologies, capacities, and changes in mixed waste inventories. Each plan is approved by the respective state agency or the EPA after consultation with other affected states and after consideration of public comments.

The WVDP STP is comprised of two volumes: the Background Volume (that provides information on each mixed waste stream and its preferred treatment method) and the Plan Volume (that includes schedules for treating the mixed waste to meet RCRA land disposal restriction requirements).

The DOE entered into a Consent Order with NYSDEC for the WVDP on August 27, 1996 that requires completing milestones identified in the Plan Volume. The Plan is updated annually to bring waste stream, inventory, and treatment information current through September 30, the end of the DOE fiscal year (FY). The one milestone proposed in the FY 2004 STP Annual Update was completed in the fourth quarter of FY 2005.

No mixed waste was shipped from the WVDP in 2005. (See Table ECS-3.)

Nonhazardous, Regulated Waste Management Program. Nonradioactive, nonhazardous material was shipped off site to solid waste management facilities in 2005. Certain components of this waste (e.g., lead-acid batteries and spent lamps [universal wastes]) were reclaimed or recycled at off-site, authorized reclamation and recycling facilities. Digested sludge and treated wastewater from the site sanitary and industrial wastewater treatment facility were shipped to the Buffalo Sewer Authority for disposal. Quantities of nonhazardous wastes handled in 2005 are listed in Table ECS-3.

Waste Minimization and Pollution Prevention. In 2005, WVNSCO continued a long-term program to minimize the generation of LLW, mixed waste, hazardous waste, industrial waste, and sanitary waste, and to promote affirmative procurement as directed by Executive Orders 13101 and 
13148. The Affirmative Procurement Program specifies responsibilities and direction for federal agencies in acquiring recycled and environmentally preferable products and services as designated by the EPA in 40 CFR Part 247, "Comprehensive Procurement Guideline for Products Containing Recovered Material.”WVNSCO annually reports challenges and successes associated with the purchase and use of these materials and services to the DOE. See Table ECS-3 for waste quantities generated in 2005 as compared with target quantities. See "Performance Measures" in Chapter 1 for a trend plot of waste minimization goals achieved over the last 10 years.

\section{Underground Storage Tanks Program. RCRA} regulations cover the use and management of underground tanks for storage of petroleum and hazardous substances and establish minimum design requirements to protect groundwater resources from releases. The regulations, specified in $40 \mathrm{CFR}$ Part 280, require underground storage tanks to be equipped with overfill protection, spill prevention, corrosion protection, and leak detection systems. New tanks must comply with regulations at the time of installation. In addition, 40 CFR 112 addresses the requirements of a spill prevention control and countermeasure (SPCC) plan for the management of oil discharged from tanks, lines, and associated transfer activities.

New York State also regulates underground storage tanks through two programs - petroleum bulk storage (6 NYCRR Parts 612-614) and chemical bulk storage (6 NYCRR Parts 595-599). State registration and minimum design requirements are similar to those of the federal program, except that petroleum tank fill ports must be color coded using American Petroleum Institute standards to indicate the product being stored.

A 550-gallon, double-walled, steel underground storage tank, upgraded in 1998 to bring it into com- pliance with the most recent EPA requirements (40 CFR Part 280.21), is used to store diesel fuel for the supernatant treatment system/permanent ventilation system standby power unit. This tank is equipped with aboveground piping, an upgraded interstitial leak-detection system, and a high-level warning device, and therefore meets the state requirements of 6 NYCRR Parts 612-614. This is the only underground petroleum storage tank currently in use at the WVDP. (There are no underground chemical bulk storage tanks at the WVDP.)

A former underground petroleum storage tank, closed in place before the New York State underground storage tank program closure requirements were implemented in 1985, was removed in 1997. In accordance with a stipulation agreement with NYSDEC, a soil bioventing system was installed in August 1999 to remediate localized petroleumcontaminated soils in the vicinity of the tank. The system stimulated natural in-situ biodegradation of petroleum hydrocarbons in the soil by providing an abundant oxygen supply to existing soil microorganisms within the contaminated soil zone. Soil and groundwater samples were collected in 2002 to evaluate the level of remediation achieved. Based on the sample results, NYSDEC determined that no further remediation was required. Final disposition is pending the Decommissioning and/ or Long-Term Stewardship EIS.

New York State-Regulated Aboveground Storage Tanks. New York State regulates aboveground petroleum and chemical bulk storage tanks under 6 NYCRR Parts 612-614, and Parts 595-599, respectively. These regulations require secondary containment, external gauges to indicate the content levels, monthly visual inspections of petroleum tanks, and documented daily, annual, and five-year inspections of chemical tanks. Documentation relating to these periodic inspections is maintained at the WVDP and is available for regulatory agencies to review. Pe-

ECS -11 
troleum tank fill ports also must be color-coded, and chemical tanks must be labeled to indicate the product stored. Petroleum bulk storage is also addressed through the WVDP's SPCC plan prepared in accordance with 40 CFR 112.

Tank registration for the WVDP at the end of 2005 included nine aboveground petroleum tanks (three containing No. 2 fuel oil, one containing unleaded gasoline, and the others containing diesel fuel).

One aboveground hazardous bulk chemical storage tank containing a nitric acid mixture was on the WVDP registration at the end of 2005. This tank is located inside the vitrification test facility. Plans were made in 2005 to permanently close this tank in early 2006.

Seven aboveground chemical storage tanks, used as needed to contain nitric acid or nitric acid mixtures, were emptied in the fall of 2002 and were permanently closed near the end of 2004. The required submittals were made to NYSDEC to remove these seven tanks from the registration and a new registration certificate reflecting these closures was received by the DOE in February 2005.

The most current inspections by NYSDEC confirmed that the petroleum and chemical bulk storage tanks were in compliance with NYS regulations.

Medical Waste Tracking. Contact with medical waste can potentially expose humans to infectious diseases and pathogens from bodily fluids. Medical evaluations, inoculations, and laboratory work at the on-site Health Services office regularly generate potentially infectious medical wastes that must be tracked in accordance with NYSDEC requirements (6 NYCRR Part 364.9). The DOE has retained the services of a permitted waste hauler and disposal firm to manage these medical wastes. Medical wastes such as dressings, pro- tective clothing (e.g., rubber gloves), needles, and syringes are sterilized with an autoclave by the disposal firm before disposal. The quantity of medical waste generated and disposed of in 2005 is listed in Table ECS-3.

Clean Air Act. The CAA establishes a framework for the EPA to regulate air emissions from both stationary and mobile sources. Amendments to the CAA mandate that each state establish a program to permit operation of sources of air pollution. In New York State, NYSDEC implements the requirements of the EPACAA Title V permitting process through 6 NYCRR Parts 200, 201, 231, and 621. A listing of air permits in effect at the WVDP can be found in Table ECS-2. As shown in Table ECS-4, no air quality noncompliances were noted in 2005.

Radiological Emissions. Emissions of airborne radionuclides are regulated by the EPA under NESHAP (40 CFR Part 61, Subpart H). The DOE currently holds permits for six point sources of radionuclide emissions at the WVDP. In 2005, stack systems in use for potential major emission points were inspected in accordance with $40 \mathrm{CFR}$ 61, Appendix B, Method 114. Visual inspections, leak checks, and cleaning were carried out, as appropriate.

Monitoring results from sampling of permitted and nonpermitted air emission points (e.g., those points that, due to the low potential for release of radionuclides, do not require permitting), are presented in Appendix $\mathrm{D}^{\mathrm{GD}}$ and discussed in Chapter 2.

Results from sampling of airborne releases, estimates of releases from sources that do not require sampling, and estimates of releases from diffuse sources (such as the lagoon system) are used to estimate dose from the WVDP to the maximally exposed individual. Estimated doses are summarized in annual NESHAP reports that are

ECS - 12 
submitted to the EPA by June $30^{\text {th }}$ of the following calendar year.

Estimated CY 2005 dose from the WVDP was approximately 0.0012 millirem (mrem), $0.01 \%$ of the 10 mrem NESHAP standard. (See Tables 2-3 and 2-6 for additional information regarding airborne radiological releases and estimated dose from WVDP air emissions.)

Nonradiological Emissions. Nonradiological point sources of air emissions are regulated by NYSDEC. NYSDEC issues permits for stationary sources (e.g., stacks, ducts, vents) that emit regulated hazardous air pollutants if quantities released are above a predetermined threshold. Major source facilities are required by 6 NYCRR Part 201 to file a Title V Permit Application unless emissions are capped below operating limits. The DOE submitted and received NYSDEC's approval of a plan for capping WVDP annual airborne releases of oxides of nitrogen $\left(\mathrm{NO}_{\mathrm{x}}\right)$ and sulfur dioxide $\left(\mathrm{SO}_{2}\right)$ at 99 tons each. Releases in 2005 were about $4.1 \%$ and $0.01 \%$, respectively, of the capping limits for each. Therefore, there were no air permit regulatory exceedances in 2005 .

Two boilers are the remaining Project site contributors of $\mathrm{NO}_{\mathrm{x}}$ and $\mathrm{SO}_{2}$. These sources are operated and monitored as required by the NYSDEC Air Facility Registration Certificate, as modified on March 22, 2005.

Emergency Planning and Community Rightto-Know Act. EPCRA was designed to create a working partnership between industry, business, state and local governments, public health and emergency response representatives, and interested citizens. EPCRA is intended to address concerns about the effects of chemicals used, stored, and released in local communities.
E.O. 13148 requires all federal agencies to comply with the following EPCRA provisions if certain thresholds are exceeded: planning notification (Sections 302-303), extremely hazardous substance (EHS) release notification (Section 304), material safety data sheet (MSDS)/chemical inventory (Sections 311-312), and toxic release inventory (TRI) reporting (Section 313). Compliance with these provisions continued at the WVDP in 2005, as summarized in Table ECS-5.

- WVDP representatives participated in semiannual meetings of the Cattaraugus County Local Emergency Planning Committee (EPCRA Sections 302-303). WVDP representatives also attended meetings held by the Cattaraugus and Erie County Emergency Management Services concerning WVDP and other local emergency planning activities. Area hospitals and the West Valley Volunteer Hose Company continued to participate in on-site briefings, emergency response exercises, and information exchanges concerning hazardous-substance management at the WVDP. The WVDP representatives continue to interface with off-site organizations with which Memoranda of Understanding or Letters of Agreement exist. These organizations are annually provided an opportunity to participate in a site tour and update to better understand on-site hazards for emergency response.

In July 2005, the triennial emergency response exercise, which involved a simulated rail transportation accident and injury, was held at the WVDP. The exercise enabled emergency response organizations to test the skills of on- and off-site emergency responders in the event of a real transportation accident. Participating teams were the on-site Transportation Emergency Management Organization, Radiological Assistance Program Team, and off-site agencies such as the West Valley Volunteer Hose Company, Cattaraugus County HazMat Team, and Bertrand Chaffee Hospital.

ECS - 13 
- There were no releases of EHS at the WVDP in 2005 that triggered the release notification requirements of EPCRA Section 304.

- Under EPCRA Section 311, WVDP personnel are required to review information about reportable chemicals every quarter. If a hazardous chemical not previously reported is present on site in an amount exceeding the threshold planning quantity, an MSDS and an updated hazardous chemical list are submitted to the state and local emergency response groups. This supplemental reporting ensures that the public and emergency responders have current information about hazardous chemicals at the WVDP. No new chemicals were added to the hazardous chemicals list in 2005 and no additional EPCRA Section 311 notifications were required.

- Under EPCRA Section 312 regulations, annual reports are submitted to state and local emergency response organizations and fire departments specifying the quantity, location, and hazards associated with chemicals stored at the WVDP. In 2005, nine reportable chemicals were stored at the WVDP above threshold planning quantities. These chemicals are listed in Table ECS-6.

- Under EPCRA Section 313, information must be provided about releases to all environmental media (e.g., air, water) of EPA-listed TRI chemicals used at or above specified regulatory thresholds at the WVDP. In 2005, no chemical exceeded the reporting threshold for the EPCRA Section 313 report.

Clean Water Act. Section 404 of the CWA regulates the development of areas in and adjacent to the waters of the United States. Supreme Court interpretations of Section 404 have affirmed the inclusion of certain nonisolated wetlands in the regulatory definition of waters of the United States. Section 404 regulates the disposal of solids, in the form of dredged or fill material, into these areas by granting the $\mathrm{ACOE}$ the authority to designate disposal areas and issue permits for these activities. E.O. 11990 directs federal agencies to "avoid to the extent possible the longand short-term adverse impacts that destroy or modify wetlands." Article 24 of the NYS ECLalso contains requirements for the protection of freshwater wetlands and adjacent buffer areas.

Section 401 of the CWA requires applicants for a federal permit (required by Section 404) to obtain certification from the host state that the proposed discharge complies with effluent- and water-quality-related limitations, guidelines, and national standards of performance, identified under Sections 301-303, 306-307, and 511(c) of the CWA. The EPA delegated administration of this program to NYS for activities within New York.

Section 402 of the CWA regulates process, sanitary, certain storm water, and other effluent discharges to surface waters. Regulated storm water discharges include those that receive runoff from areas where industrial, construction, or demolition activities are performed. Administration of Section 402 in New York is delegated to NYSDEC, which, under NYS ECL, also regulates disharges to groundwater.

Wetlands. Jurisdictional wetlands are defined in Section 404 of the CWA as those satisfying specific technical criteria related to vegetation, soils, and hydrologic conditions. The DOE notifies the ACOE and NYSDEC of proposed actions that could affect wetland units not specifically exempted from regulation or notification.

Wetland field assessments are periodically performed and wetland maps revised accordingly, with the most recent assessment and mapping completed in 2004. This assessment identified the presence of 68 jurisdictional wetlands that range in size from 0.01 acres to 7.3 acres and cover approximately 36.5 acres within the WVDP and adjacent premises. In December 2005, NYSDEC 
approved this wetland delineation report. Field verification wetland assessment was performed by the ACOE in 2005, with final written approval from the ACOE expected in 2006.

SPDES Permit. New York State is delegated by the EPA to administer the National Pollutant Discharge Elimination System (NPDES) under an equivalent state program. At the WVDP, NYSDEC regulates point-source liquid effluent discharges to surface waters of NYS under the SPDES permit.

New and modified SPDES permit requirements for the WVDP, which went into effect on January 1, 2005, included (1) reduced sampling and analysis of discharges at outfall 001 (monitoring point WNSP001), (2) reduced reporting frequency for the mercury analytical method study, (3) new requirements for monitoring and reporting usage of water treatment chemicals, (4) additional water discharge sampling and analysis where herbicides are applied, and (5) a new requirement to prepare and implement a Storm Water Pollution Prevention Plan.
In addition to five existing permitted monitoring points, the permit added authorization, monitoring requirements, and release limits for discharges at 20 storm water outfalls. These outfalls receive storm water runoff from inactive waste disposal areas, areas where materials or wastes are stored or handled, and areas where construction or structure dismantlement or other soil disturbance activities may be performed.

The compliance points for monitoring discharges to Buttermilk Creek tributaries, including Erdman Brook, Frank's Creek, and Quarry Creek, may be found on Figures A-2, A-3, and A-4. The routine monitoring points and the new storm water monitoring points are described in Appendix $\mathrm{B}^{\mathrm{CD}}$. Monitoring results for 2005 are presented in Appendix $\mathrm{C}^{\mathrm{GD}}$ and discussed in Chapter 3.

As shown on Figure ECS-1, the annual number of effluent limit exceptions to requirements in the site's SPDES permit has been substantially reduced over time, especially when compared to the peak of 35 exceptions noted in 1986. As indicated on this fig-

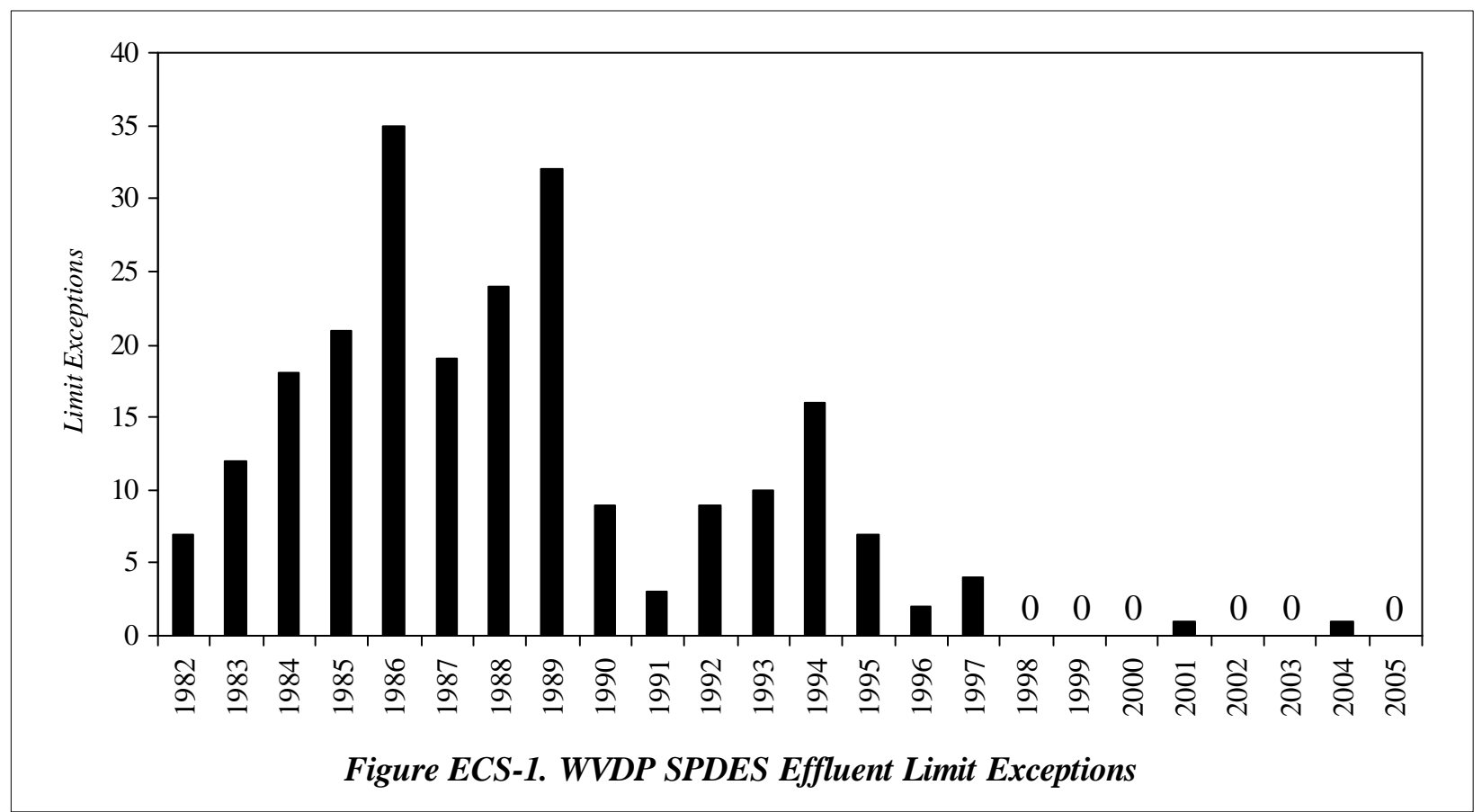


ure, there were no permit effluent limit exceptions recorded during 2005. (See Table ECS-7.)

In September 2005, NYSDEC issued for public comment a draft modification to the WVDP SPDES permit. This modification reflects the new NYSDEC policy for regulating mercury in water discharges from the WVDP and addresses requests from the DOE to eliminate $\mathrm{pH}$ limits for site storm water discharges and to reduce monitoring for 17 analytical parameters at outfall 001 . The finalized permit modification is expected in 2006.

Storm Water Discharge Monitoring. The NPDES Permit Application Regulations for Storm Water Discharges, Final Rule (40 CFR Parts 122, 123 , and 124, as amended), and as expressed in Section 403(p) of the CWA, require that specified facilities acquire NPDES permits for storm water discharge associated with industrial activities. Permitted or interim status RCRA hazardous waste treatment, storage, and disposal facilities are specifically defined as associated with industrial activity in the regulations (40 CFR Part 122.26[a][14][iv]).

Since the WVDP is an interim status RCRA facility, storm water discharges from the WVDP qualify as being associated with industrial activity. Six other groups of activities at the WVDP are also subject to storm water permitting: 1) aboveground container storage; 2) aboveground and underground tank storage; 3 ) belowground waste burial; 4) haul roads and railway lines; 5) liquid waste treatment facilities; and 6) construction activities.

As discussed above, the WVDP SPDES permit (as modified in 2005) included new requirements for storm water monitoring. To meet the new requirements in the modified permit, the monitoring plan for storm water discharges at the WVDP was revised and implemented in 2005.
NYSDEC SPDES Inspection. On March 23 and August 23, 2005, NYSDEC completed its inspections of the WVDP facilities through observation of the SPDES outfalls, the site sanitary and industrial wastewater treatment facility (WWTF) operation, storm water discharge control practices, effluent-holding lagoon embankment conditions, flow monitoring devices, and discharge monitoring records. No deficiencies were identified.

Process Sewer Integrity Evaluation. Video inspection of camera-accessible process sewer lines was initiated in 2003. During this inspection, a hole was discovered in a tributary line where laundry wastewater was discharging to subsurface soil. The breached line was removed from service and laundry wastewater was diverted to another line with known integrity. Reports of this discovery were filed with NYSDEC in 2003. Video inspection of process sewer lines was completed and the final report was submitted to NYSDEC in the fall of 2004. In 2005, NYSDEC, the DOE, and the NYS-licensed Professional Engineer responsible for sewer integrity evaluation met to review and discuss the final report and the video recordings. The Division of Solid \& Hazardous Materials Department of NYSDEC evaluated the soil sampling results from this investigation and concluded that no further action was needed at this time. The NYS-licensed Professional Engineer from the NYSDEC Division of Water, after additional review and evaluation, identified a future action to include periodic video inspection of the lines to be completed by 2010 .

North Plateau Groundwater Activities. In November 1995, a groundwater recovery system was installed at the WVDP to mitigate a portion of the strontium-90 groundwater plume and reduce groundwater seepage northeast of the process building. In 1999, a pilot-scale permeable treatment wall was installed to test in-situ passive technology for treating contaminated groundwater.

ECS - 16 
Detailed descriptions of these two treatment processes and activities in 2005 are presented in Chapter 4 .

Petroleum- and Chemical-Product Spill Reporting. The objective of the spill notification and reporting policy for the WVDP is to ensure that all spills are properly managed, documented, and remediated in accordance with applicable regulations. This policy identifies departmental responsibilities for spill management and proper spill-control procedures and stresses the responsibility of each employee to notify the plant systems operations shift supervisor when a spill is discovered. This first-line reporting requirement helps to ensure that spills are properly evaluated and managed.

Under a 1996 agreement with NYSDEC, the DOE is not required to report a spill of petroleum products onto an impervious surface if the spill is less than 5 gallons (19 liters) and is cleaned up within two hours of discovery. Any spill of 5 gallons or less onto the ground is entered into a petroleum spill log that used to be submitted monthly to NYSDEC. In 2005, this agreement was modified to reduce reporting frequency from monthly to quarterly.

A spill of more than 5 gallons on any surface must also be logged and reported within two hours to the NYSDEC hotline. A spill of any amount that enters state waters must be reported to the NYSDEC hotline within two hours of discovery and, if it has reached navigable state waters, also reported to the National Response Center. No reportable spills of over 5 gallons of petroleum products to an impervious surface, or to the ground or waters of the state, occurred at the WVDP in 2005.

The WVDP operators are also required to report spills or releases of hazardous substances in accordance with reporting requirements of RCRA,
CERCLA (if a reportable quantity has been exceeded), and the CAA, EPCRA, CWA, and TSCA. No chemical spills or releases exceeded reportable quantities and, thus, no reporting during CY 2005 was required.

Safe Drinking Water Act. Drinking water for the WVDP is obtained from surface water reservoirs on the WNYNSC. The WVDP system is considered a nontransient, noncommunity public water supply. The WVDP's drinking water treatment facility purifies the water by clarification, filtration, and chlorination before it is distributed on site.

Monitoring and Reporting. Samples from the WVDP drinking water system are periodically collected and tested for various water quality parameters. (See Appendix $B^{\text {Go }}$ for a description of sampling frequency and analytical constituents and Appendix C- $6^{\text {GD }}$ for a listing of 2005 test results.) Test results are reported monthly to the CCHD, which also independently collects and analyzes a monthly sample of WVDP tap water to determine bacterial and residual chlorine content, and an annual tap water sample for nitrate (as nitrogen). All test results were within drinking water limits in 2005.

Cross-Connection Control. The SDWA requires that public water suppliers prevent cross-connections between the potable water supply and systems containing hazardous or infectious substances. Cross-connection control devices, such as double check valves and reduced-pressure zone valves, must be installed, inspected, and maintained at strategic locations at facilities where hazardous materials are used in a manner that could result in their introduction into the potable water distribution system under low pressure conditions. The WVDP has a total of 13 backflow prevention devices, all of which were tested and repaired as necessary by a NYSDOH-licensed tester in 2005 to ensure that all devices were functioning properly.

ECS - 17 
Toxic Substances Control Act. TSCA regulates the manufacture, processing, distribution, and use of chemicals, including asbestos-containing material (ACM) and PCBs.

Asbestos-Containing Material. In 2005, continued compliance was maintained with all TSCA requirements pertaining to asbestos by managing ACM in accordance with the site "Asbestos Management Plan." This plan includes requirements for limiting worker exposure to ACM and for asbestos-abatement projects, maintenance activities, and periodic surveillance inspections (at least once every three years). This plan also identifies the inventory and status of on-site ACM.

Activities in 2005 included the repair or abatement of damaged/friable ACM, removal/cutting of nonfriable ACM from roof systems to support trailer removal activities, and maintenance of signs and labels to warn workers of ACM. All activities associated with ACM are completed by personnel who are certified by the New York State Department of Labor (NYSDOL). WVNSCO maintains an asbestos-handling license issued by NYSDOL.

Polychlorinated Biphenyls. Because PCBs are regulated as a hazardous waste in NYS, the DOE continued in 2005 to manage radioactively contaminated PCB waste as mixed waste and nonradioactive PCB waste as hazardous waste. Details concerning PCB-contaminated radioactive waste management, including a description of the waste, proposed treatment technologies, and schedules, can be found in the "Site Treatment Plan, Fiscal Year 2005 Update."

To comply with TSCA and PCB regulations, all operations associated with PCBs comply with the "PCB and PCB-Contaminated Material Management Plan." The WVDP operators maintain an annual document log that details PCB use, appro- priate on-site storage, and any changes in storage or disposal status. The WVDP also complies with regulations for disposal of PCBs, which conditionally allow radioactive and nonradioactive $\mathrm{PCBs}$ to be stored for more than one year (40 CFR Parts 750 and 761).

National Environmental Policy Act. Under NEPA, the DOE is required to consider the overall environmental effects of its proposed actions. The President's Council on Environmental Quality established a screening system of analyses and documentation that requires each proposed action to be categorized according to the extent of its potential environmental effect. The levels of documentation include categorical exclusions (CXs), environmental assessments (EAs), and EISs.

CXs document actions that will not have a significant effect on the environment. EAs are used to evaluate the extent to which the proposed action will affect the environment. If a proposed action has the potential for significant effects, an EIS is prepared that describes proposed alternatives to an action and explains the effects of each.

Facility maintenance, decontamination activities, and minor projects that supported HLW vitrification were documented and submitted for approval as CXs. Based on preliminary review of proposed activities for building removal, as part of infrastructure reduction at the WVDP, an EA is being developed to evaluate potential effects on the environment.

In December 1988, the DOE published a Notice of Intent (NOI) with NYSERDA to prepare an EIS for the completion of the WVDPAct and closure of the facilities at the WNYNSC.

The draft EIS, which describes the potential environmental effects associated with Project completion and various site closure alternatives, was 


\section{West Valley Citizen Task Force}

In addition to the public comment process required by the National Environmental Policy Act, NYSERDA, with participation from the DOE, formed the West Valley Citizen Task Force in January 1997. The mission of the Task Force is to provide advice on the completion of the WVDP Act and cleanup, closure, and/or long-term management of the facilities at the site. The Task Force process has helped illuminate the various interests and concerns of the community, increased the two-way flow of information between the site managers and the community, and provided an effective way for the Task Force members to establish mutually-agreed-upon recommendations for the site managers to consider in their decision-making process.

completed in 1996 and released without a preferred alternative for a six-month public review and comment period. Having met throughout 1997 and 1998 to review alternatives presented in the draft EIS, the West Valley Citizen Task Force (CTF; see inset) issued the West Valley Citizen Task Force Final Report (July 29, 1998). This report provided recommendations and advice on the development of a preferred alternative. Throughout 2005, the CTF continued to meet and discuss issues relating to Project completion and site closure decision-making.

In 2001, the DOE formally initiated a plan to split the scope of the 1996 draft EIS into two phases one for near-term waste management decisionmaking and one for final decommissioning and/or long-term stewardship decision-making. Each phase would be covered by a separate EIS.

The DOE published an NOI on March 26, 2001 (66 FR 16447) formally announcing its rescoping plan and preparation of the waste management
EIS. The DOE also published an Advance NOI on November 6, 2001 (66 FR 56090) announcing in advance its commitment to begin work, in cooperation with NYSERDA, on the EIS for decommissioning and/or long-term stewardship.

Waste Management EIS. On May 16, 2003, the DOE issued the draft Waste Management EIS (68 FR 26587) for public comment. The Waste Management EIS presented alternatives for the management of WVDP LLW, mixed LLW, TRU waste, and HLW. The DOE addressed public comments and issued the final Waste Management EIS in January 2004.

The DOE published its decision in the Federal Register (70 FR 35073) on June 16, 2005. The DOE has decided to implement Alternative A, the preferred alternative, for the management of WVDP LLW and mixed LLW that are either currently in storage at the site or will be generated at the site over the next ten years. Adecision on TRU wastes will be deferred, contingent upon a determination by the DOE that the waste meets all statutory and regulatory requirements for disposal at the Waste Isolation Pilot Plant near Carlsbad, New Mexico. The HLW canisters will remain in storage on site until they can be shipped directly to a repository.

Decommissioning and/or Long-Term Stewardship at the WVDP and WNYNSC. The NRC is authorized by the WVDP Act to prescribe decommissioning criteria for the WVDP. From 1998 until early 2002 the NRC worked to develop decommissioning criteria through a series of draft policy papers and public meetings. On February 1, 2002, the NRC issued its "Decommissioning Criteria for the West Valley Demonstration Project (M-32) at the West Valley Site; Final Policy Statement" in the Federal Register (67 FR 5003). The Final Policy Statement applies the NRC's License Termination Rule (10 CFR Part 20, Subpart E) as

ECS - 19 
the decommissioning criteria for the WVDP and as the decommissioning goal for the entire WNYNSC.

The DOE published an NOI on March 13, 2003 (68 FR 12044) announcing its intent to prepare, in cooperation with NYSERDA, the Decommissioning and/or Long-Term Stewardship EIS. The DOE and NYSERDA are joint lead agencies on this EIS and the EPA, NRC, and NYSDEC are cooperating agencies. This work continued with the issuance of an internal, multi-agency predecisioned draft in September 2005.

In 2005, an impasse continued between the DOE and NYSERDA pertaining to agency responsibilities for decommissioning and/or long-term stewardship at the WVDP and the WNYNSC. In mid-2005, proposed legislation dealing with the long-term responsibility for the WVDP was introduced into the U.S. House of Representatives by Congressmen Kuhl, Boehlert, Reynolds, and Higgins, and a companion bill was introduced into the U.S. Senate by Senators Schumer and Clinton. The bill, entitled "West Valley Remediation Act of 2005," includes provisions for federal (DOE) takeover of the responsibility for the WVDP and the entire WNYNSC from the current owner, the State of New York. The legislation directs the DOE to complete and issue a draft of the site's decommissioning and long-term stewardship EIS within two years of the law's enactment. The bill also includes a provision for minimum funding levels and prohibits any new waste from being transported to West Valley.

The future progress of this legislation is uncertain as of early 2006. As a result, the NYSERDA Board voted to authorize legal action against the DOE over issues relating to ongoing cleanup responsibilities at the WVDP. However, this legal action is still pending.
Federal Insecticide, Fungicide, and Rodenticide Act. In 2005, approximately 350 pounds (160 kilograms) of a NYSDEC-registered biocide were applied by NYSDEC-licensed commercial pesticide applicators to control algae and waterborne pathogens in the site cooling water tower system. Control of the organisms is necessary to minimize the potential for cooling system damage due to fouling from algae buildup and minimize the potential for worker exposure to waterborne pathogens such as Legionella.

Environmental Conservation Law - Structures Impounding Waters and Structures in Waters. Under the ECL, two site earthen dams, which form the site water supply, must be inspected and maintained to minimize the potential for uncontrolled releases of the impounded water. The dams, including the grass cover, have been periodically inspected and properly maintained in accordance with NYSDEC regulations and guidelines to prevent soil exposure to erosive forces of storm water runoff and other methods of structural failure.

\section{Current Achievements and Program Highlights}

Vitrification Facility Dismantlement Project. In 2005, the remaining major pieces of equipment in the vitrification cell were dismantled and removed. Completion of this effort made the WVDP the first site in the nation to design, construct, operate, shut down, and dismantle a full-scale radioactive vitrification system.

Infrastructure Reduction. Office personnel were relocated to new offices on and off the site. Temporary office trailers, connecting hallways, and ancillary structures, 115 units in all, were removed from the site. Excess office components and furnishings were removed and dispositioned through the government excess process by a com-

ECS - 20 
bination of surplus sales, transfers of property, and donations. All structures and equipment that were released had not been exposed to radioactive contamination and, therefore, did not contain residual radioactive materials.

Star Status. By the end of 2005, the WVDP's employees were responsible for achieving more than three years and 3.7 million cumulative manhours worked without a lost-time work accident.

The WVDP's Star status in DOE's Voluntary Protection Program underwent DOE review in 2005. During a week-long visit, an independent DOE team reviewed the Project's safety program and evaluated it against DOE's criteria for designation as a Star site. Based on the review, the team recommended continued Star status for the WVDP.

\section{EPA National Environmental Performance} Track. The WVDP was recognized as a top environmental leader in 2000 and was accepted into the EPA's National Environmental Performance Track. The WVDP was awarded Charter Member status as part of the first group of applicants.

To qualify for the award, the WVDP had to demonstrate that it voluntarily had adopted and implemented an EMS, had attained previously specified environmental objectives, had made a commitment to achieve four future goals, had a public outreach program, and had a sustained record of environmental compliance.

A WVDP renewal request, proposing three new environmental commitments, was accepted by the EPA in December 2004. Progress toward achieving these commitments is summarized in Table ECS-3. In 2005, the WVDP employees continued to monitor, and take necessary actions toward, successfully achieving these goals.

\section{Environmental Issues and Actions}

Construction and Demolition Debris Landcompleted in August 1986. The solid waste landfill area was closed in accordance with NYSDEC standards for this type of landfill, following NYSDEC approval (Mitrey, 1986) of the closure plan (Standish, 1985). To meet routine post-closure requirements, the CDDL cover was inspected twice in 2005 and found to be in generally good condition. The grass cover on the clay and soil cap is routinely maintained and cut, and drainage is maintained to ensure that no obvious ponding or soil erosion occurs.

NRC-Licensed Disposal Area (NDA). As mentioned earlier in this chapter, a draft "Corrective Measures Study Work Plan for the West Valley Demonstration Project" was submitted to NYSDEC in 2005 for review. After reviewing the CMS work plan for the NDA, NYSDEC requested in November 2005 that DOE demonstrate that the depth of the existing cover over the burial ground is continuous and as deep (4 $\mathrm{ft}[1.2 \mathrm{~m}])$ as required by the NRC license. In response to this request, the DOE is evaluating investigation activities that would provide surface and subsurface control data related to cap thickness and extent. The DOE is also evaluating additional capping options in response to NYSDEC's request.

Unplanned Releases. No unplanned releases of pollutants or hazardous substances, radiological or nonradiological, from the WVDP occurred in 2005.

Coalition Files Suit Over WVDP EIS Process. On August 26, 2005, the Coalition on West Valley Nuclear Wastes (a citizen's group) filed a complaint in the U.S. District Court, Western District of New York, against the DOE regarding work at the WVDP.

ECS - 21 
In its complaint, the Coalition contended that the March 26, 2001 DOE announcement that revised the approach to the EIS for completion of the WVDP Act violated NEPA and the Stipulation of Compromise Settlement between the DOE and the Coalition. The EIS, which had been initiated in 1988, was revised into two separate studies - one on facility decontamination and waste management and a second on site closure or long-term stewardship. (See "National Environmental Policy Act" earlier in this chapter.)

Reaching a ROD on the Waste Management EIS in June 2005 enabled the DOE to evaluate off-site shipment and waste disposal, which helped accelerate the shipping of LLW being stored at the site and being generated by routine Project activities.

Through the complaint, the Coalition seeks to prevent the DOE from taking any actions as a result of the Waste Management EIS. It also requests that the DOE be ordered to complete the EIS process as outlined in 1988, requests a declaration that separating the EIS into two EISs violates NEPA, and seeks a declaration that the DOE is not empowered to reclassify waste at the West Valley site using the "waste incidential to reprocessing" determination process.

\section{Project Assessment Activities in 2005}

As the primary contractor for the DOE in CY 2005 at the WVDP, WVNSCO maintained a comprehensive review program for proposed and ongoing operations. Assessments were conducted through formal surveillances and informal programs. Formal surveillances monitored compliance with regulations, directives, and DOE Orders. The informal program was used to identify issues or potential problems that could be corrected immediately.
The local DOE Project office and other agencies with responsibilities for the WVDP also independently reviewed various aspects of the environmental and waste management programs, as discussed in preceding sections. In 2005, overall results reflected continuing, well-managed environmental programs at the WVDP.

ECS - 22 


\section{Compliance Tables}

DOE Headquarters uses environmental compliance summary information from sites across the DOE complex to compile national environmental summary reports. The tables on the following pages were prepared to assist in this compilation.

\section{Table ECS-2 \\ WVDP Environmental Permits}

\begin{tabular}{|c|c|c|c|c|}
\hline $\begin{array}{c}\text { Permit Name and } \\
\text { Number }\end{array}$ & $\begin{array}{c}\text { Agency/Permit } \\
\text { Type }\end{array}$ & Description & 2005 Changes & Status \\
\hline $\begin{array}{l}\text { West Valley } \\
\text { Demonstration Project } \\
\text { RCRA Part A Permit } \\
\text { Application }\end{array}$ & $\begin{array}{l}\text { NYSDEC/Hazardous } \\
\text { Waste }\end{array}$ & $\begin{array}{l}\text { Provides interim status } \\
\text { under RCRA for treatment } \\
\text { and storage of hazardous } \\
\text { waste }\end{array}$ & No changes to Part A. & $\begin{array}{l}\text { No expiration date. A } \\
\text { RCRA Part B Permit } \\
\text { Application was submitted } \\
\text { on December 23, } 2004 .\end{array}$ \\
\hline $\begin{array}{l}\text { Air Facility Registration } \\
\text { Certificate } \\
(9-0422-00005 / 00099)\end{array}$ & NYSDEC/Air Emissions & $\begin{array}{l}\text { Sitewide permit includes: } \\
-2 \text { boilers }\end{array}$ & $\begin{array}{l}\text { The existing Air Facility } \\
\text { Registration Certificate was } \\
\text { modified. }\end{array}$ & $\begin{array}{l}\text { Revised 3/22/05. No } \\
\text { expiration date. }\end{array}$ \\
\hline $\begin{array}{l}\text { Slurry-fed ceramic melter } \\
\text { (modification to WVDP- } \\
\text { 687-01) process building } \\
\text { ventilation }\end{array}$ & EPA/NESHAP & \begin{tabular}{|l|} 
Slurry-fed ceramic melter \\
radionuclide emissions - \\
main plant stack modified \\
2/18/97
\end{tabular} & None & $\begin{array}{l}\text { Permit approved 2/18/97. } \\
\text { No expiration date. Request } \\
\text { to modify submitted to the } \\
\text { EPA } 8 / 99 \text {. }\end{array}$ \\
\hline $\begin{array}{l}\text { Vitrification Facility } \\
\text { Heating, Ventilation, and } \\
\text { Air-Conditioning } \\
\text { (HVAC) System } \\
\end{array}$ & EPA/NESHAP & $\begin{array}{l}\text { Vitrification facility HVAC } \\
\text { system for radionuclide } \\
\text { emissions }\end{array}$ & None & $\begin{array}{l}\text { Permit approved 2/18/97. } \\
\text { No expiration date. }\end{array}$ \\
\hline \begin{tabular}{|l|} 
01-14 Building \\
Ventilation System \\
(WVDP-187-01)
\end{tabular} & EPA/NESHAP & $\begin{array}{l}\text { Liquid waste treatment } \\
\text { system ventilation of } \\
\text { radionuclide emissions in } \\
\text { the } 01-14 \text { building }\end{array}$ & None & $\begin{array}{l}\text { Issued 10/5/87. Modified } \\
5 / 25 / 89 \text {. No expiration } \\
\text { date. }\end{array}$ \\
\hline $\begin{array}{l}\text { Contact Size-Reduction } \\
\text { Facility (WVDP-287-01) }\end{array}$ & EPA/NESHAP & $\begin{array}{l}\text { Contact size-reduction and } \\
\text { decontamination facility } \\
\text { radionuclide emissions }\end{array}$ & None & $\begin{array}{l}\text { Issued 10/5/87. No } \\
\text { expiration date. }\end{array}$ \\
\hline $\begin{array}{l}\text { Supernatant Treatment } \\
\text { System/Permanent } \\
\text { Ventilation System } \\
\text { (WVDP-387-01) }\end{array}$ & EPA/NESHAP & $\begin{array}{l}\text { Supernatant treatment } \\
\text { system ventilation for } \\
\text { radionuclide emissions }\end{array}$ & None & $\begin{array}{l}\text { Revised 1/1/97. No } \\
\text { expiration date. }\end{array}$ \\
\hline $\begin{array}{l}\text { Outdoor Ventilated } \\
\text { Enclosures } \\
\text { (WVDP-587-01) }\end{array}$ & EPA/NESHAP & $\begin{array}{l}\text { Ten portable ventilation } \\
\text { units for removal of } \\
\text { radionuclides }\end{array}$ & None & $\begin{array}{l}\text { Issued 12/22/87. No } \\
\text { expiration date. }\end{array}$ \\
\hline \begin{tabular}{|l|} 
State Pollutant Discharge \\
Elimination System \\
(NY0000973)
\end{tabular} & NYSDEC/Water & $\begin{array}{l}\text { Covers discharges to surface } \\
\text { waters from various on-site } \\
\text { sources }\end{array}$ & None & $\begin{array}{l}\text { An amended permit } \\
\text { addressing storm water } \\
\text { discharges, monitoring } \\
\text { modifications, and other } \\
\text { items went into effect on } \\
\text { 1/1/05. Expires } 2 / 1 / 09 \text {. }\end{array}$ \\
\hline
\end{tabular}

\section{ECS - 23}




\section{Table ECS-2 (concluded) WVDP Environmental Permits}

\begin{tabular}{|c|c|c|c|c|}
\hline $\begin{array}{c}\text { Permit Name and } \\
\text { Number }\end{array}$ & $\begin{array}{c}\text { Agency/Permit } \\
\text { Type }\end{array}$ & Description & 2005 Changes & Status \\
\hline $\begin{array}{l}\text { Buffalo Pollutant } \\
\text { Discharge Elimination } \\
\text { System (05-05-TR096) }\end{array}$ & $\begin{array}{l}\text { Buffalo Sewer } \\
\text { Authority/sanitary sewage } \\
\text { and sewage sludge disposal }\end{array}$ & $\begin{array}{l}\text { Permit issued to hauler of } \\
\text { waste from the wastewater } \\
\text { treatment facility }\end{array}$ & Renewed 6/05. & $\begin{array}{l}\text { Hauler must renew permit } \\
\text { by } 6 / 30 / 06 \text {. }\end{array}$ \\
\hline $\begin{array}{l}\text { Chemical Bulk Storage } \\
(9-000158)\end{array}$ & $\begin{array}{l}\text { NYSDEC/chemical bulk } \\
\text { storage tank }\end{array}$ & $\begin{array}{l}\text { Registration of bulk storage } \\
\text { tanks used for listed } \\
\text { hazardous chemicals }\end{array}$ & $\begin{array}{l}\text { Cold chemical tanks 65D05 } \\
\text { and 65D06 were } \\
\text { permanently closed and } \\
\text { deleted from the registration } \\
\text { on 2/20/04. Cold chemical } \\
\text { tanks 65D02,65D03, } \\
65 \mathrm{D} 04,65 \mathrm{D} 07,65 \mathrm{D} 08, \\
65 \mathrm{D} 09, \text { and } 63-\mathrm{V}-048 \text { were } \\
\text { permanently closed on } \\
11 / 10 / 04 . \\
\text { A new registration certificate } \\
\text { reflecting these closures was } \\
\text { received by the WVDP in } \\
\text { February } 2005 .\end{array}$ & Registration expires 7/5/07. \\
\hline $\begin{array}{l}\text { Petroleum Bulk Storage } \\
(9-008885)\end{array}$ & $\begin{array}{l}\text { NYSDEC/petroleum bulk } \\
\text { storage tank registration }\end{array}$ & $\begin{array}{l}\text { Registration of bulk storage } \\
\text { tanks used for petroleum }\end{array}$ & None & $\begin{array}{l}\text { Registration expires 9/2/06. } \\
\text { Will be renewed before } \\
\text { expiration. }\end{array}$ \\
\hline $\begin{array}{l}\text { Bird Depredation License } \\
\text { (32) }\end{array}$ & $\begin{array}{l}\text { New York State Division } \\
\text { of Fish and Wildlife }\end{array}$ & $\begin{array}{l}\text { State license for the removal } \\
\text { of all nests of migratory } \\
\text { birds }\end{array}$ & $\begin{array}{l}\text { License amended and } \\
\text { renewed on 8/15/05. }\end{array}$ & $\begin{array}{l}\text { NYS license expires } \\
6 / 30 / 06\end{array}$ \\
\hline $\begin{array}{l}\text { Bird Depredation Permit } \\
(\mathrm{MB} 747595-0)\end{array}$ & $\begin{array}{l}\text { U.S. Fish and Wildlife } \\
\text { Service }\end{array}$ & $\begin{array}{l}\text { Federal permit for the } \\
\text { limited taking of migratory } \\
\text { birds and active bird nests }\end{array}$ & $\begin{array}{l}\text { Permit renewed and } \\
\text { modified on 7/22/05. }\end{array}$ & Permit expires 6/30/06. \\
\hline
\end{tabular}

ECS - 24 


\section{Table ECS-3}

Summary of Waste Management Achievements at the WVDP in 2005

\begin{tabular}{|c|c|c|c|c|}
\hline Description & $\begin{array}{l}2005 \text { Expected } \\
\text { Result or Goal }\end{array}$ & 2005 Achievement & Discussion & $\begin{array}{l}\text { ASER } \\
\text { Section }\end{array}$ \\
\hline \multicolumn{5}{|c|}{ WVDP Pollution Prevention (P2)/Waste Reduction Goals ${ }^{a}$} \\
\hline $\begin{array}{l}\text { Low-level waste } \\
\text { generation }\end{array}$ & $\begin{array}{l}80 \% \text { Reduction } \\
\left(10,125 \mathrm{ft}^{3}\right. \\
\left.\left[287 \mathrm{~m}^{3}\right]\right) \\
\end{array}$ & $89 \%$ Reduction & Exceeded the reduction goal by $9 \%$ & ECS, Chapter 1 \\
\hline $\begin{array}{l}\text { Mixed waste } \\
\text { generation }\end{array}$ & $\begin{array}{l}80 \% \text { Reduction } \\
(1,160 \mathrm{lb}[524 \mathrm{~kg}])\end{array}$ & $98 \%$ Reduction & Exceeded the reduction goal by $18 \%$ & ECS, Chapter 1 \\
\hline $\begin{array}{l}\text { Hazardous waste } \\
\text { generation }\end{array}$ & $\begin{array}{l}75 \% \text { Reduction } \\
(2,500 \mathrm{lb} \\
[1,136 \mathrm{~kg}]) \\
\end{array}$ & $96 \%$ Reduction & Exceeded the reduction goal by $21 \%$ & ECS, Chapter 1 \\
\hline $\begin{array}{l}\text { Industrial waste } \\
\text { generation }\end{array}$ & $\begin{array}{l}60 \% \text { Reduction } \\
(19,600 \mathrm{lb} \\
[8,889 \mathrm{~kg}])\end{array}$ & $\begin{array}{l}\text { Waste generation } \\
\text { increased }(138.72 \text { tons } \\
[125,845 \mathrm{~kg}]) ; \text { the goal } \\
\text { was not met. }\end{array}$ & $\begin{array}{l}\text { Increased waste generation was due to } \\
\text { activities supporting site milestones } \\
\text { for CY } 2005 \text { and infrastructure } \\
\text { reduction. }\end{array}$ & ECS, Chapter 1 \\
\hline $\begin{array}{l}\text { Sanitary waste } \\
\text { generation }\end{array}$ & $\begin{array}{l}75 \% \text { Reduction } \\
(290 \text { tons } \\
[260 \text { metric tons }])\end{array}$ & $\begin{array}{l}45 \% \text { Reduction (See } \\
\text { paper, scrap metal and } \\
\text { other below) }\end{array}$ & $\begin{array}{l}\text { Below the goal by } 30 \% \text {. Increased } \\
\text { waste generation was due to } \\
\text { infrastructure reduction of the } \\
\text { equivalent of } 115 \text { site trailers. Most } \\
\text { offered for sale, resulting in cost } \\
\text { avoidance of more than } \$ 300 \mathrm{~K} \text {. }\end{array}$ & ECS, Chapter 1 \\
\hline \multicolumn{5}{|c|}{ WVDP EPA National Performance Track Objectives ${ }^{b}$} \\
\hline $\begin{array}{l}\text { Halon } 1301 \text { in fire } \\
\text { suppression systems }\end{array}$ & $\begin{array}{l}\text { Eliminate usage } \\
\text { 2004-2006 }\end{array}$ & $\begin{array}{l}\text { Eliminated during } \\
2004 \text { (0 lbs.) }\end{array}$ & No Halon 1301 remains on site. & ECS, Chapter 1 \\
\hline Energy usage & $\begin{array}{l}2004-2006 ; \text { Reduce } \\
\text { total energy usage } \\
\text { by } 10 \%\end{array}$ & $\begin{array}{l}\text { Reduced usage by } \\
18.8 \%\end{array}$ & On track to meet the 2006 goal. & ECS, Chapter 1 \\
\hline $\begin{array}{l}\text { Radiological } \\
\text { wastewater from the } \\
\text { low-level waste } \\
\text { treatment facility } \\
\text { (LLWTF } \\
\text { [WNSP001]) }\end{array}$ & $\begin{array}{l}\text { By the end of } 2006 ; \\
\text { reduce radiological } \\
\text { curies in wastewater } \\
\text { discharges by } 10 \%\end{array}$ & $\begin{array}{l}\text { Commitment not met } \\
\text { in } 2005 \text {, increased } \\
\text { curies by } \\
\text { approximately } 58 \% \text {. } \\
\text { About } 13.6 \text { million } \\
\text { gallons ( } 51.4 \text { million } \\
\text { liters) of wastewater } \\
\text { was discharged. }\end{array}$ & $\begin{array}{l}\text { Corrective measures implemented in } \\
\text { the latter part of } 2005 \text {, which } \\
\text { improved performance in later } \\
\text { discharges. Additional corrective } \\
\text { measures are being developed to } \\
\text { further assist in meeting this } \\
\text { commitment. }\end{array}$ & $\begin{array}{l}\text { ECS, Chapters } \\
\text { 1and } 2\end{array}$ \\
\hline
\end{tabular}

${ }^{a}$ Pollution prevention/waste-reduction goals, applicable to routine wastes, were established in 1999 on the basis of 1993 quantities.

${ }^{b}$ Established commitments per WVDP EPA National Environmental Performance Track membership requirements.

ECS - 25 


\section{Table ECS-3 (continued)}

Summary of Waste Management Achievements at the WVDP in 2005

\begin{tabular}{|c|c|c|c|c|}
\hline $\begin{array}{c}\text { Waste } \\
\text { Description }\end{array}$ & Type of Project & $\begin{array}{c}2005 \text { Weight or } \\
\text { Volume }\end{array}$ & Discussion & $\begin{array}{l}\text { ASER } \\
\text { Section }\end{array}$ \\
\hline \multicolumn{5}{|c|}{ Other Site Waste Minimization Efforts/Processing/Shipping } \\
\hline $\begin{array}{l}\text { Remote-handled } \\
\text { waste facility } \\
\text { operations }\end{array}$ & $\begin{array}{l}\text { Waste processing } \\
\text { and packaging }\end{array}$ & $\begin{array}{l}39 \text { containers; } \\
3,250 \mathrm{ft}^{3}\left(92 \mathrm{~m}^{3}\right)\end{array}$ & $\begin{array}{l}\text { Containers were characterized, sorted, } \\
\text { processed as necessary, and packaged } \\
\text { to meet regulatory requirements for } \\
\text { transportation. }\end{array}$ & ECS, Chapter 1 \\
\hline Low-level waste & Waste shipping & $\begin{array}{l}\text { More than } 300,000 \mathrm{ft}^{3} \\
\left(8,500 \mathrm{~m}^{3}\right)\end{array}$ & 280 truck and 3 rail shipments off site & ECS, Chapter 1 \\
\hline Hazardous waste & Waste shipping & $573 \mathrm{lbs}(260 \mathrm{~kg})$ & Shipped to an EPA-approved facility. & ECS, Chapter 1 \\
\hline Mixed waste & Waste shipping & None & No mixed waste was shipped in 2005. & ECS, Chapter 1 \\
\hline $\begin{array}{l}\text { Paper and paper } \\
\text { products }\end{array}$ & Waste reduction & $\begin{array}{l}117 \text { tons } \\
(106 \text { metric tons })\end{array}$ & $\begin{array}{l}\text { Waste recycling, affirmative } \\
\text { procurement, } \mathrm{P} 2 \text { program }\end{array}$ & ECS, Chapter 1 \\
\hline Scrap metals & Waste reduction & $\begin{array}{l}147 \text { tons } \\
\text { (133 metric tons) }\end{array}$ & $\begin{array}{l}\text { Waste recycling, affirmative } \\
\text { procurement, } \mathrm{P} 2 \text { program }\end{array}$ & ECS, Chapter 1 \\
\hline Other materials & Waste reduction & $\begin{array}{l}11.6 \text { tons } \\
(10.5 \text { metric tons })\end{array}$ & $\begin{array}{l}\text { Waste recycling, affirmative } \\
\text { procurement, } \mathrm{P} 2 \text { program }\end{array}$ & ECS, Chapter 1 \\
\hline $\begin{array}{l}\text { Nonradioactive, } \\
\text { nonhazardous, } \\
\text { regulated waste }\end{array}$ & Waste shipping & $\begin{array}{l}6.24 \text { tons ( } 5.66 \text { metric } \\
\text { tons) (See lead acid } \\
\text { batteries below) }\end{array}$ & Waste minimization effort & ECS, Chapter 1 \\
\hline $\begin{array}{l}\text { Lead-acid batteries } \\
\text { and spent lamps } \\
\text { (universal waste) }\end{array}$ & Waste recycling & $\begin{array}{l}5.19 \text { tons } \\
(4.71 \text { metric tons }) \text { of } \\
\text { the above }\end{array}$ & $\begin{array}{l}\text { This volume of the above regulated } \\
\text { waste was reclaimed or recycled at off- } \\
\text { site, authorized reclamation and } \\
\text { recycling facilities. }\end{array}$ & ECS, Chapter 1 \\
\hline $\begin{array}{l}\text { Wastewater internal } \\
\text { mercury pre- } \\
\text { treatment process } \\
\text { compliance point at } \\
\text { WNSP01B }\end{array}$ & $\begin{array}{l}\text { Pre-treatment for } \\
\text { mercury }\end{array}$ & $\begin{array}{l}42,000 \text { gallons } \\
(160,000 \text { liters })\end{array}$ & $\begin{array}{l}\text { The liquid waste treatment system pre- } \\
\text { treats residual radioactive wastewater. } \\
\text { Effluent is sampled to determine } \\
\text { compliance with Federal Great Lakes } \\
\text { Initiative and SPDES permit } \\
\text { requirements for total mercury. }\end{array}$ & $\begin{array}{l}\text { ECS, Chapters } 1 \\
\text { and } 3\end{array}$ \\
\hline $\begin{array}{l}\text { Treated sewage and } \\
\text { industrial } \\
\text { wastewaters } \\
\text { (WNSP007) } \\
\end{array}$ & $\begin{array}{l}\text { Wastewater } \\
\text { processing, } \\
\text { discharge }\end{array}$ & $\begin{array}{l}6.74 \text { million gallons } \\
(25.5 \text { million liters })\end{array}$ & $\begin{array}{l}\text { The WWTF treats sewage and various } \\
\text { industrial wastewaters that are } \\
\text { discharged through WNSP007. }\end{array}$ & $\begin{array}{l}\text { ECS, Chapters } \\
1,2, \text { and } 3\end{array}$ \\
\hline $\begin{array}{l}\text { North plateau } \\
\text { groundwater } \\
\text { recovery system } \\
\text { (NPGRS) }\end{array}$ & $\begin{array}{l}\text { Pump and treat } \\
\text { strontium-90 } \\
\text { (Sr-90) } \\
\text { contaminated } \\
\text { groundwater }\end{array}$ & $\begin{array}{l}4.1 \text { million gallons } \\
(16 \text { million liters })\end{array}$ & $\begin{array}{l}\text { The NPGRS operates to recover } \\
\text { groundwater from an area near the } \\
\text { leading edge of the Sr- } 90 \text { plume on the } \\
\text { north plateau. Water is treated by ion } \\
\text { exchange to remove Sr-90, then } \\
\text { transferred to the lagoon system. }\end{array}$ & $\begin{array}{l}\text { Chapters 1,2, } \\
\text { and } 4\end{array}$ \\
\hline
\end{tabular}

ECS - 26 


\section{Table ECS-3 (concluded)}

Summary of Waste Management Achievements at the WVDP in 2005

\begin{tabular}{|l|l|l|l|l|}
\hline \multicolumn{1}{|c|}{$\begin{array}{c}\text { Waste } \\
\text { Description }\end{array}$} & Type of Project & $\begin{array}{c}\text { 2005 Weight or } \\
\text { Volume }\end{array}$ & \multicolumn{1}{c|}{$\begin{array}{c}\text { ASER } \\
\text { Section }\end{array}$} \\
\hline $\begin{array}{l}\text { NRC-licensed } \\
\text { disposal area } \\
\text { groundwater } \\
\text { interceptor trench } \\
\text { (WNNDATR) }\end{array}$ & $\begin{array}{l}\text { Interceptor trench } \\
\text { and groundwater pre } \\
\text { treatment }\end{array}$ & $\begin{array}{l}401,000 \text { gallons } \\
(1,520,000 \text { liters })\end{array}$ & $\begin{array}{l}\text { lroundwater is pumped and } \\
\text { transferred to the LLWTF; no n- } \\
\text { dodecane or tributyl phosphate were } \\
\text { encountered in 2005. Therefore no pre- } \\
\text { treatment was necessary. }\end{array}$ & $\begin{array}{l}\text { Chapters 1,2,3, } \\
\text { and } 4\end{array}$ \\
\hline $\begin{array}{l}\text { Digested sanitary } \\
\text { sludge }\end{array}$ & Waste shipping & $\begin{array}{l}840 \text { tons } \\
(762 \text { metric tons })\end{array}$ & $\begin{array}{l}\text { Digested sludge from the site sanitary } \\
\text { and industrial wastewater facility is } \\
\text { shipped to the Buffalo Sewer } \\
\text { Authority for disposal. }\end{array}$ & ECS \\
\hline Medical wastes & Waste shipping & 15 lbs (6.8 kg) & $\begin{array}{l}\text { The services of a permitted waste } \\
\text { hauler and disposal firm is retained to } \\
\text { manage medical wastes. }\end{array}$ & ECS \\
\hline
\end{tabular}

\section{Table ECS-4}

WVDP 2005 Air Quality Noncompliance Episodes

\begin{tabular}{|ccccc|}
\hline Permit Type & Facility & Parameter & Date(s) Exceeded & Description/Solutions \\
EPANESHAP & All & All & None & None \\
NYSDEC Air & All & All & None & None \\
& & There were no episodes of noncompliance in 2005. & \\
\hline
\end{tabular}

\section{Table ECS-5}

Status of EPCRA (SARA Title III) Reporting at the WVDP in 2005

\begin{tabular}{|c|c|c|c|}
\hline & EPCRASection & Description of Reporting & Status* \\
\hline & EPCRA 302-303 & Planning Notification & Not Required \\
\hline & EPCRA 304 & $\begin{array}{l}\text { Extremely Hazardous Substance } \\
\text { Release Notification }\end{array}$ & Not Required \\
\hline & EPCRA 311 & Material Safety Data Sheet & Not Required \\
\hline & EPCRA 312 & Chemical Inventory & Yes \\
\hline & EPCRA 313 & Toxic Release Inventory Reporting & Not Required \\
\hline \multicolumn{4}{|c|}{$\begin{array}{c}* \\
\text { * } \\
\\
\end{array}$} \\
\hline
\end{tabular}

\section{ECS - 27}




\section{ENVIRONMENTAL MANAGEMENT SYSTEM}

\section{Introduction}

The vitrified high-level radioactive waste (HLW) presently stored at the Western New York Nuclear Service Center (WNYNSC) on the West Valley Demonstration Project (WVDP or Project) premises is the by-product of the reprocessing of spent nuclear fuel during the late 1960s and early 1970s. At that time, the WNYNSC was leased by Nuclear Fuel Services, Inc. (NFS) for a commercial nuclear fuel reprocessing facility.

As the WNYNSC is no longer an active nuclear fuel reprocessing facility, the environmental monitoring program at the WVDP focuses on measuring radioactivity and chemical constituents associated with the residual by-products of the former NFS operations, the Project's former HLW treatment operations, and the Project's operations for management of HLW, transuranic waste, and low-level radioactive waste (LLW).

\section{Completion of Vitrification}

HLW from NFS operations was originally stored in two of four underground tanks (tanks 8D-2 and 8D-4). Contents in the tanks were pretreated to remove sodium salts and sulfates and most of the radioactive cesium, and resulting wastes were fixed into about 20,000 drums of cemented LLW be- tween 1988 and 1990. Vitrification of the HLW began in 1996 and continued through September 2002. (See the 2002 WVDP Annual Site Environmental Report [ASER] [West Valley Nuclear Services Company (WVNSCO) and URS, 2003] for a complete description of the vitrification process.)

Over the course of vitrification, more than 12.2 million cesium/strontium curies were transferred to the vitrification facility and 275 canisters were filled. Two additional waste canisters were generated when the melter was evacuated. Canisters are in temporary storage in a shielded cell, the former chemical processing cell, in the main plant and are being maintained until a disposal facility becomes available.

\section{Environmental Management System}

The Project's "Environmental Management System" (EMS) provides the basic policy and direction for work at the WVDP through procedures that support proactive management, environmental stewardship, and the integration of appropriate technologies throughout all aspects of work. The environmental monitoring program is an important component of the EMS and the accomplishment of its mission. EMS implementation is summarized in Table 1-1. 


\section{Table 1-1}

Elements of the Environmental Management System at the WVDP

\section{Environmental Policy}

\section{Environmental Aspects and Impacts}

\section{Legal and Other Requirements}

The environmental policy for the WVDP is to conduct all activities, including design, construction, testing, startup, commissioning, operation, maintenance, and decontamination and decommissioning in a manner appropriate to the nature, scale, and environmental impacts of these activities. The WVDP management is committed to full compliance with applicable federal and New York State (NYS) laws and regulations for the protection of the environment, continual improvement, the prevention and/or minimization of pollution, and public outreach, including stakeholder involvement.

When operations have an environmental aspect, WVNSCO implements the EMS to minimize or eliminate any adverse potential impact. The EMS is a prerequisite for the United States (U.S.) Environmental Protection Agency (EPA) National Environmental Performance Track awarded by the EPA to the WVDP. Using the EMS, WVDP employees evaluate operations, identify the aspects of operations that can impact the environment, and determine those impacts that are significant. The following operational aspects have been determined to have the potential to affect the environment:

- Waste generation and management

- Atmospheric emissions

- Liquid effluents

- Storage or use of chemicals and radioactive materials

- Natural resource usage - power and water consumption

- Noise

- Soil disturbance

- Disturbances to endangered species/protected habitats

- Contamination areas from historical operations

- Facility operations, maintenance, and decontamination activities

- Other facility-specific compliance aspects.

WVNSCO has implemented an environmental regulatory review and assessment process to deliver WVDP-level requirements and guidance to all staff. New or revised requirements (e.g., new regulations) are analyzed to determine their applicability to the WVDP and to identify whether actions are required to achieve compliance. This may involve developing or revising WVDP documents or operating procedures, implementing administrative controls, providing training, installing engineered controls, or increasing monitoring.

$$
1-2
$$


Table 1-1 (continued)

Elements of the Environmental Management System at the WVDP

Objectives and Targets

Environmental Management Program

Structure and

Responsibility

Training, Awareness and Competence

Communication and Community Involvement

EMS Documentation

Document Control
The performance-based management system is designed to develop, align, balance, and implement the strategic objectives for the WVDP, including environmental objectives. Objectives and targets are developed by calendar year (CY). For the three-year period of CY 2004-2006, WVNSCO refined three commitments under the EPA National Environmental Performance Track. These commitments, and progress toward achieving the objectives, are presented in Table ECS-3.

A pollution prevention program to conserve resources and minimize waste generation is implemented at the WVDP. The budgeting system is designed to ensure that priorities are balanced and that resources essential to the implementation and control of the EMS are provided.

All employees at the WVDP have specific roles and responsibilities in key areas, including environmental protection. Environmental and waste management technical support personnel assist the line organization with their environmental responsibilities.

Training on EMS requirements has been provided to staff whose responsibilities include environmental protection. The training program includes general environmental awareness for all employees, regulatory compliance training for select staff, and specific courses for managers, internal assessors, EMS implementation teams, and operations personnel whose work can impact the environment.

The WVDP representatives continue to improve processes for internal and external communications on environmental issues.

Communications with the local community include monthly meetings with the local Citizen Task Force and meetings with the general public on a quarterly basis. (See "National Environmental Policy

Act" in the Environmental Compliance Summary.) Notable community involvement activities by the WVDP personnel in 2005 included the Annual Food Drive, participation in the United Way Day of Caring, and the mentoring program with local schools.

Comprehensive, up-to-date environmental policies are written to describe the EMS. These procedures and manuals inform staff how to control processes and perform work at the WVDP in a manner that protects the environment.

A comprehensive electronic document control system to ensure the effective management of procedural documents is maintained. When facilities require additional procedures to control their work, documentcontrol protocols are implemented to ensure that workers have access to the current version of procedures.

$$
1-3
$$


Table 1-1 (concluded)

Elements of the Environmental Management System at the WVDP

Operational Control

Emergency Preparedness and Response

Monitoring and Measurement

Nonconformance and Corrective and Preventive Actions

Records

EMSAudit

Management Review
Operations are evaluated for the adequacy of current controls to prevent impacts to the environment. As needed, additional administrative or engineered controls are identified and plans for upgrades and improvements are developed and implemented.

An emergency preparedness and response program with specialized staff provides timely response to hazardous material releases or other environmental emergencies. This program includes procedures for preventing, as well as responding to, emergencies.

Liquid effluent and air-emission monitoring helps ensure the effectiveness of controls, adherence to regulatory requirements, and timely identification and implementation of corrective measures. A comprehensive, sitewide environmental monitoring program is in place at the WVDP. Results are reported to regulatory agencies and summarized in this ASER. In addition, monitoring data are assessed for adverse trends to determine site performance, impacts from site conditions, and the need for proactive or corrective measures.

The WVDP employees continue to implement processes that identify and correct problems. This includes a lessons learned program to prevent recurrences, robust self-assessment and environmental assessment programs, and an electronic action tracking system.

EMS-related records, including audit and training records, are maintained to ensure integrity, facilitate retrieval, and protect from loss.

To periodically verify that the EMS is operating as intended, assessments are conducted by the U.S. Department of Energy (DOE) and its contractors. These assessments are designed to ensure that nonconformances are identified and addressed. In addition, compliance with regulatory requirements is verified through routine inspections, operational evaluations, and periodic assessments and self-assessments.

In addition to audits, a management review process has been established to involve top management in the overall assessment of environmental performance, the EMS, and progress toward achieving environmental goals. This review also identifies, as necessary, the need for changes to and continual improvement of the EMS. 
The WVDP EMS satisfies the requirements of DOEOrder 450.1, "Environmental Protection Program." (See the discussion of DOE Order 450.1 in the "Environmental Compliance Summary.") The EMS is also in compliance with the "Code of Environmental Management Principles" (CEMP) for federal agencies and International Organization for Standardization 14001, Environmental Management Systems: "Specification for Guidance and Use," which is being implemented worldwide. Following the principles and performance objectives of the CEMP helps to ensure that a federal facility's environmental performance is proactive, flexible, cost-effective, and sustainable. The WVDP has been renewed for membership in the EPA's National Environmental Performance Track program for implementation of this EMS. The most recent objectives were developed for the threeyear period of 2004-2006. (See National Environmental Performance Track inset in this chapter.)

\section{Integrated Safety Management System} (ISMS) Implementation. A plan to integrate environmental, safety, and health (ES\&H) management programs at the WVDP was developed and initiated in 1998. During this development, the EMS was identified as an integral part of the ISMS. Environmental subject matter experts participate in a sitewide work review group to review work plans, identify ES\&H concerns, and specify practices that ensure work is performed safely.

Implementation of an ISMS at the WVDP, including the EMS, was verified by the DOE Ohio Field Office in November 1998. The most recent selfassessment by WVNSCO, performed in November 2005, verified that the ISMS continues to be effectively implemented at the WVDP. An annual ISMS review by the DOE occurred in December 2005. The DOE specifically evaluated the integration of the EMS into the ISMS and confirmed results of the WVNSCO self-assessment.

\section{National Environmental PerformanceTrack \\ U.S. Environmental Protection Agency}

Performance Track is a partnership that recognizes top environmental performance among participating U.S. facilities of all types, sizes, and complexity, public and private. Program partners are providing leadership in many areas, including preventing pollution at its source. Currently, the program has about 400 members and welcomes all qualifying facilities. Applications are accepted twice a year: April 1May 31 and September 1-October 31.

The logo identifies those facilities that qualify for Achievement Track membership. Achievement Track facilities can participate in a peer exchange network to share experience, benchmark each other's performance, share information on successful practices and strategies, and receive recognition for their work at state and local levels. The WVDP was approved for renewal for a three-year membership in this program for 2004-2006.

\section{Occupational Safety and Environmental} Training. The safety of personnel who are involved in industrial operations under DOE cognizance is protected by standards mandated by DOE Order 440.1A, "Worker Protection Management for DOE Federal and Contractor Employees," which directs compliance with specific Occupational Safety and Health Act requirements. This act governs diverse occupational hazards. 
Any person working at the WVDP who has a personal photo badge receives general employee training that covers health and safety, emergency response, and environmental compliance issues. All visitors to the WVDP receive a site-specific briefing on safety and emergency procedures before being admitted to the site.

Hazardous waste operations and emergency response regulations require that employees at treatment, storage, and disposal facilities receive training appropriate to their job function and responsibilities. The WVDP environmental, health, and safety training matrix identifies the specific training requirements for such employees.

Training programs at the WVDP include, but are not limited to:

-24-hour/40-hour hazardous waste operations

- emergency spill-response training

- decontamination techniques

- waste minimization and pollution prevention

- the WVDP environmental management program

- radiation hazards and warnings

- dosimetry and respiratory protection

- medical emergency response training

- electrical safety and fire protection

Training programs have evolved into a comprehensive curriculum of knowledge and skills necessary to maintain the health and safety of employees and ensure the continued compliance of the WVDP with applicable regulations and requirements.
Self-Assessments. Self-assessments continued to be conducted in 2005 to review the management and effectiveness of the WVDP environmental protection and monitoring programs. Results of these self-assessments are evaluated and corrective actions are tracked through to completion. Overall self-assessments confirmed that the WVDP employees continued to implement quality requirements and, in some cases, improve the quality of the environmental protection and monitoring program. (See the "Environmental Compliance Summary" and Chapter 5, "Quality Assurance.”)

Voluntary Protection Program (VPP) Star Status. On May 5, 2000 the WVDP received VPP Star status. This prestigious award was granted in recognition of excellent worker safety and health programs at the WVDP. (See also the "Environmental Compliance Summary.”)

The WVDP has reaffirmed its commitment to DOE's VPP and was reviewed as part of the annual ISMS review. The DOE recommended recertification of the WVDP as a DOE-VPP Star site in 2005.

Employees of the WVDP reached 3.7 million safe work hours and three years without a lost-time work accident by the end of 2005. In recognition of this safety record, the WVDP was awarded the Washington Group President's Award for Safety for the third consecutive year.

\section{Environmental Monitoring Program Overview}

Human beings are exposed to radioactivity from site activities primarily through air, water, and food. All three pathways are monitored at the WVDP, but air and surface water pathways are the two primary means by which radioactive material can move off site. (For detailed information about ra- 
diation and radioactivity, measurement of radioactivity, measurement of dose, and reporting of radiological data, see the "Useful Information" section later in this report.)

Site geology (types of soil and bedrock), hydrology (location and flow of surface water and groundwater), and meteorology (wind speed, patterns, and direction) are all considered when evaluating potential exposure through the major pathways.

The on-site and off-site monitoring program at the WVDP includes measuring the concentration of alpha and beta radioactivity, conventionally referred to as "gross alpha" and "gross beta," in air and water effluents. Measuring the total alpha and beta radioactivity from key locations produces a comprehensive picture of on-site and off-site levels of radioactivity from all sources. For a DOE site such as the WVDP, frequent updating and tracking of the overall radioactivity levels in effluents is an important tool in maintaining acceptable operations.

More-detailed measurements are also made for specific radionuclides. Strontium-90 and cesium137 are measured because they have been previously detected in WVDP waste materials. Radiation from other important radionuclides, such as tritium or iodine-129, is not sufficiently energetic to be detected by gross measurement techniques, so these must be analyzed separately using methods with greater sensitivity. Heavy elements, such as uranium, plutonium, and americium, require special analysis because they exist in such small concentrations in the WVDP environs.

The radionuclides monitored at the Project are those that might produce relatively higher doses or that are most abundant in air and water effluents. Because man-made sources of radiation at the Project have been decaying for more than 30 years, the monitoring program does not routinely include short-lived radionuclides, that is, isotopes with a half-life of less than two years, which would be present at less than $1 / 1,000$ of the original radioactivity levels. (See Appendix $B^{\mathrm{GD}}$ for the schedule of samples and radionuclides measured and Appendix $\mathrm{K}^{\mathbf{6 0}}$ for a listing of the half-lives of radionuclides measured in WVDP samples and related DOE protection standards, such as the derived concentration guides [DCGs]. See also the discussion of DCGs in the "Useful Information" section, later in this report.)

The WVDP monitoring program includes nonradiological wastewater discharge and storm water monitoring for water quality and chemical constituents. Permit discharge limits, water quality standards, guidelines, maximum contaminant level goals, and soil cleanup criteria reference values are provided, where available, for comparison purposes. (See Appendix $\mathrm{B}^{\mathbf{6 D}}$ for the schedule of sample locations and analytical requirements, Chapter 3 for a discussion of nonradiological program information, and Appendices $\mathrm{C}^{\mathrm{ED}}$ through $\mathrm{G}^{\mathrm{ED}}$ for data presentations.)

Environmental Management of Aqueous Radioactive Waste. Water containing radioactive material from site process operations is collected and treated in the low-level waste treatment facility (LLWTF), which includes the LLW treatment building and associated holding lagoons. (Water from the sanitary system, which does not contain added radioactive material, is managed in a separate system.)

The treated process water is held, sampled, and analyzed before its release through a New York State Pollutant Discharge Elimination System (SPDES)-permitted outfall. In 2005, about 13.6 million gallons (51.4 million liters) of water were treated in the LLWTF system and discharged through outfall 001, the lagoon 3 weir. The total 
2005 discharge waters contained the following estimated releases of radioactivity as compared to the previous 10-year average. (See "Overview of Water Effluent and Ambient Surface Water Monitoring" in Chapter 2.)

Table 1-2. 2005 Radioactivity Releases Versus 10-Year Averages

\begin{tabular}{|l|c|c|c|}
\hline Radionuclide & $\begin{array}{c}\text { 10-Year } \\
\text { Average } \\
\text { Curies }\end{array}$ & $\begin{array}{c}\text { 2005 } \\
\text { Curies }\end{array}$ & $\begin{array}{c}\text { \% of } \\
\text { 10-Year } \\
\text { Average }\end{array}$ \\
\hline Tritium & 0.36 & 0.063 & $17 \%$ \\
\hline $\begin{array}{l}\text { Gross Alpha } \\
\text { and Beta }\end{array}$ & 0.018 & 0.023 & $130 \%$ \\
\hline \multicolumn{4}{|c|}{ Airborne Discharge ANSTACK } \\
\hline \multicolumn{4}{|c|}{ Gaseous } \\
\hline Tritium & 0.038 & 0.0011 & $2.8 \%$ \\
\hline Iodine-129 & 0.0018 & 0.000027 & $1.5 \%$ \\
\hline \multicolumn{4}{|c|}{ Particulate } \\
\hline $\begin{array}{l}\text { Gross Alpha } \\
\text { and Beta }\end{array}$ & 0.00028 & 0.000041 & $14.5 \%$ \\
\hline
\end{tabular}

Note that although the 10-year average was exceeded by $30 \%$ at the LLWTF, the waterborne dose from all sources decreased slightly from 0.047 mrem in 2004 to 0.046 mrem in 2005 as shown in the 2004 ASER and in Chapter 2.

North Plateau Groundwater Recovery System (NPGRS). The NPGRS operated throughout 2005, recovering groundwater from an area near the leading edge of the strontium-90 plume on the north plateau. Approximately 4.1 million gallons (16 million liters) were recovered during 2005. For a more-detailed discussion of the plume and the NPGRS, see "Northeast Swamp and North Swamp Drainage" in Chapter 2 and "Sand and Gravel Unit on the North Plateau" and "Special Groundwater Activities" in Chapter 4.
Nuclear Regulatory Commission-Licensed Disposal Area (NDA) Interceptor Trench and Pretreatment System. Radioactively-contaminated n-dodecane, in combination with tributyl phosphate (TBP), was discovered at the northern boundary of the NDA in 1983, shortly after the DOE assumed control of the WVDP. To contain subsurface migration of this radioactive organic mixture, an interceptor trench and liquid pretreatment system (LPS) were installed.

As in previous years, $n$-dodecane/TBP contamination was not detected in the trench water; therefore no water was pre-treated by the LPS in 2005. Approximately 401,000 gallons (1,520,000 liters) of radiologically-contaminated water were transferred from the interceptor trench to the LLWTF during the year. Results of surface and groundwater monitoring in the vicinity of the trench are discussed in Chapter 2 under "South Plateau Surface Water and NDA Interceptor Trench" and in Chapter 4 under "Results of Monitoring at the NDA."

Environmental Management of Airborne Radioactive Emissions. Ventilated air from the various WVDP facilities is continuously sampled during operations for particulate matter and for gaseous radioactivity. In addition to monitors that alarm if particulate matter radioactivity increases above preset levels, the sample media are analyzed in the laboratory for the specific radionuclides that are present in the radioactive materials being handled.

Air used to ventilate the facilities undergoing radioactive material cleanup is passed through filtration devices before being emitted to the atmosphere. These filtration devices are generally more effective for particulate matter than for gaseous radioactivity. For this reason, facility air treatment tends to remove a lesser percentage of gaseous radioactivity (e.g., tritium [as hydrogen tritium oxide] and iodine-129) than radioactivity associated with particulate matter (e.g., strontium- 
90 and cesium-137). However, gaseous radionuclide emissions still remain so far below the most restrictive regulatory limit for public safety that additional treatment technologies beyond those already provided are not necessary.

Table 1-2 shows the gaseous and particulate matter radioactivity emissions from the main plant in 2005 compared to the previous 10-year averages. (See Chapter 2 for a discussion of iodine-129 emissions from the main plant stack.) As expected, these 2005 values are quite low in comparison with the 10-year average, which includes the entire duration of the vitrification system operation.

\section{Environmental Management of Radiological}

Exposure. Environmental radiation is measured with thermoluminescent dosimeters (TLDs) at onsite and off-site locations. (See Figs. A-12 through A-15 for the locations of on-site and off-site TLD monitoring points.) Although exposure rates at most on-site locations were elevated with respect to background, results from perimeter TLDs that would be more representative of exposure to the public were statistically indistinguishable from background results. (See "Direct Environmental Radiation Monitoring" in Chapter 2.)

Changes in the 2005 Environmental Monitoring Program. As a result of a comprehensive, systematic evaluation, which included comparison of monitoring locations and parameter sampling durations and frequencies with those at other DOE and commercial sites and consideration for radiological risk reduction as site cleanup progresses, numerous modifications to the environmental monitoring program were made in 2005. Changes to analytical parameters, sample collection frequencies, and sampling locations were incorporated to maximize the program's efficiency and cost-effectiveness. In a few instances, sample collection frequency was reduced to biennial or triennial and therefore no data are available for 2005. These reductions include the nine off-site residential wells which will be sampled and analyzed biennially for indicator parameters. Also, the soil samples collected near the six off-site air sampling stations will be collected once every three years for radioisotopic analyses. In January 2005, the SPDES permit was modified by the New York State Department of Environmental Conservation (NYSDEC) to include requirements for monitoring storm water discharges. (See Appendix $B^{\text {GD }}$ for a detailed summary of the program changes and the sample points and parameters measured in 2005.)

\section{Activities at the WVDP}

Significant components, initiatives, and accomplishments at the WVDP in 2005 are summarized below.

Vitrification Cell Dismantlement. Decontamination of the equipment in the vitrification cell began in 2004 and dismantlement activities were completed on July 31,2005 . This, the nation's first dismantlement of a vitrification system, was completed using totally remote equipment and methods to remove approximately 25,000 cubic feet of waste, package 240 containers with dismantled equipment and debris, and package and remove oversized equipment, including the 54-ton melter.

\section{Remote-Handled Waste Facility (RHWF)} Operation. Construction of the RHWF was completed in 2004, with the DOE authorizing the startup of radioactive processing in June 2004. In the RHWF, wastes were characterized, sorted, processed as necessary, and packaged to meet regulatory requirements for transportation off site for disposal. Remote mixed waste processing in the facility continued in 2005. A total of 39 containers holding approximately 3,250 cubic feet (92 cubic meters) of waste materials were processed by the end of the year, including four legacy waste boxes removed from the chemical process cell waste storage area. 
Reduction of Infrastructure Footprint. Infrastructure reduction activities began in 2004 with the removal of several office and storage trailers. During 2005, the site's infrastructure capacity was significantly reduced, as employees were relocated to the Ashford Office Complex and a few consolidated areas on site. The equivalent of 115 trailer units were removed from service and dismantled or moved off site.

\section{Low-Level Radioactive Waste Shipping Pro-} gram. In 1997, the LLW shipping program was initiated to reduce the inventory of legacy and newly-generated waste stored on site. Most waste was sent to commercial disposal facilities until July 2001, when the WVDP was approved to ship LLW to the Nevada Test Site, a DOE facility. During calendar year (CY) 2005, 280 truck shipments and three rail shipments containing more than 300,000 cubic feet $(8,500$ cubic meters) were safely shipped for off-site disposal. LLW shipping will continue during 2006.

Reduction of Risks Associated With Radioactive Materials. In November 2005, the DOE approved the downgrade of the WVDP to a Category 3 nuclear facility, marking the first time in the site's history that it has been assigned the least of the three DOE nuclear facility designations. The categorization is based on the amounts, types, and configuration of nuclear materials at the site and their potential risks.

Criticality Control Zones (CCZs) were eliminated in September 2005 for all waste storage areas. The purpose of CCZs was to ensure that fissile materials were not stored in a configuration that could cause a potential criticality incident. A Nuclear Criticality Safety Evaluation was performed on 1,300 waste containers. Results of this evaluation demonstrated that the stringent storage requirements associated with CCZs were not necessary for the materials being stored.

\section{Performance Measures}

Performance measures can be used to evaluate effectiveness, efficiency, quality, timeliness, productivity, safety, or other areas that reflect achievements related to organization or process goals, and can be used as a tool to identify the need to institute changes.

The performance measures applicable to operations conducted at the WVDP reflect process performance related to (1) the potential radiological dose received by the maximally exposed off-site individual(MEOSI), (2) wastewater treatment in the LLWTF, (3) the reduction in waste generation, and (4) the identification of spills and releases.

Radiation Doses to the Maximally Exposed Off-Site Individual. One of the most important pieces of information derived from environmental monitoring program data is the potential radiological dose to an off-site individual from on-site activities. As an overall assessment of Project activities and the effectiveness of the as-low-asreasonably-achievable concept, the potential radiological dose to the MEOSI is an indicator of well-managed radiological operations. The effective dose equivalents for air effluent emissions, liquid effluent discharges, and other liquid releases (such as swamp drainage) from 1996 through 2005 are graphed on Figure 1-1. Note that the sum of these values is well below the DOE standard of 100 mrem per year. The consistently low effluent results indicate that radiological activities at the site are well-controlled. (See also Table 2-3 in Chapter 2, "Environmental Radiological Protection Program and Dose Assessment.")

SPDES Permit Limit Exceptions. Effective operation of the site wastewater treatment facilities is indicated by compliance with the applicable discharge permit limits. Approximately 60 chemical and water quality constituents are monitored regu- 


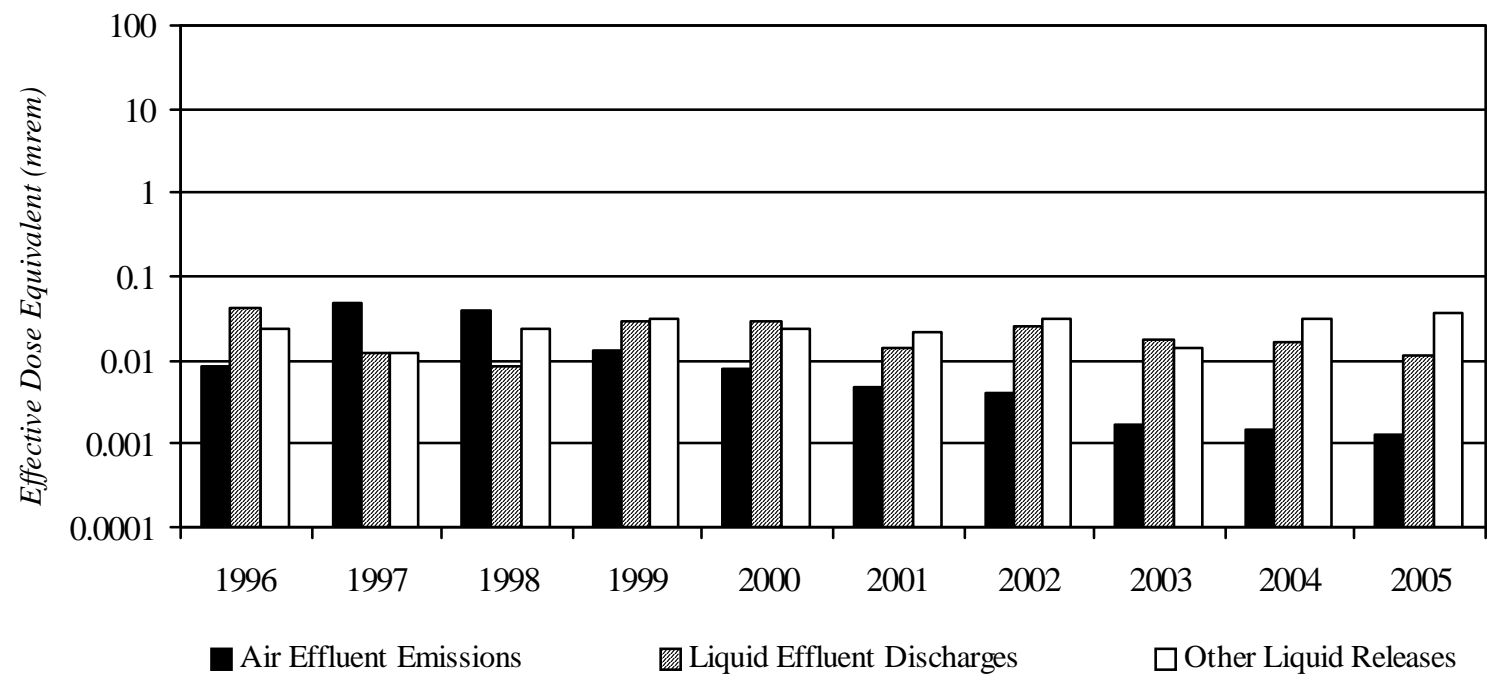

Figure 1-1. Annual Effective Dose Equivalent to the Maximally Exposed Off-Site Individual

larly as part of the SPDES permit requirements. The analytical results are reported to NYSDEC via Discharge Monitoring Reports, required under the SPDES program.

Although the goal of the LLWTF and wastewater treatment facility operations is to maintain effluent water quality consistently within the permit requirements, occasionally SPDES permit limit exceptions do occur. A Water Task Team, composed of WVDP personnel with expertise in wastewater engineering, treatment plant operations and process monitoring, and National Pollutant Discharge Elimination System/ SPDES permitting and compliance, was formed in 1995 to address the causes of these exceptions. All SPDES permit limit exceptions are evaluated to determine their cause and to identify corrective measures.

There were no SPDES-effluent limit exceptions during 2005. (See Fig. 1-
2.) Historical limit exceptions are discussed in previous ASERs.

Although exceptions are not always related to operating deficiencies, corrective actions may include improved operation or treatment techniques. In 1997, the DOE notified NYSDEC of the presence of mercury in the influent wastewater to the LLWTF and of its likely presence at outfall 001 at concentrations below the detectable level of 0.2

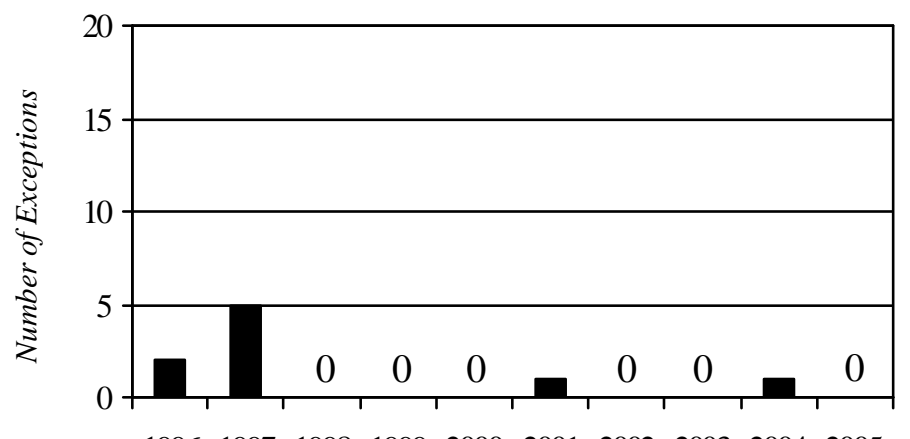

1996199719981999200020012002200320042005

Figure 1-2. Annual SPDES Effluent Limit Exceptions

$1-11$ 
micrograms per liter ( $\mu \mathrm{g} / \mathrm{L})$. In 2002, a modification to the SPDES permit required that samples being collected for measurement of mercury be analyzed in duplicate by EPAMethod 245.1 (with a method detection level of $0.2 \mu \mathrm{g} / \mathrm{L}$ ) and by newer, more-sensitive EPAMethod 1631E. Results of the comparison are reported to NYSDEC on a semiannual basis. Results from EPA Method 1631E in CY 2005 were consistent with those from EPA Method 245.1. (See "Mercury Analytical Method Study," in Chapter 3 for a discussion of this study.)

\section{Waste Minimization and Pollution Preven-} tion. The WVDP formalized a waste minimization program in 1991 to reduce the generation of LLW, mixed waste, hazardous waste, and industrial and sanitary waste (e.g., paper, plastic, wood, and scrap metal). This program is a comprehensive and continual effort to prevent or minimize pollution, with the overall goals of reducing health and safety risks, protecting the environment, and complying with all federal and state regulations. This is done by placing emphasis on good business practices, source reduction, and recycling. (See also the "Waste Minimization and Pollution
Prevention" section in the "Environmental Compliance Summary.”)

Hazardous waste and industrial waste volumes have been tracked separately for vitrification-related and nonvitrification-related waste streams since vitrification began in 1996. In 1999, the WVDP set cumulative waste-reduction goals for fiscal year (FY) 2000 and beyond, using quantities of routine waste generated in 1993 as a baseline. Since 2002, all WVDP pollution prevention goals are in alignment with the DOE's pollution prevention goals, which are based on the federal FY.

In 2005, WVNSCO continued its program of reducing and eliminating the amount of waste generated from site activities. The cumulative nonvitrification waste-reduction goals for FY 2005 are presented in Table ECS-3 in the "Environmental Compliance Summary." To demonstrate effectiveness of the waste minimization program, a graph of the percentage of waste reduction achieved above or below the annual goal for each category is presented on Figure 1-3 for CYs 1996 through 2005 .

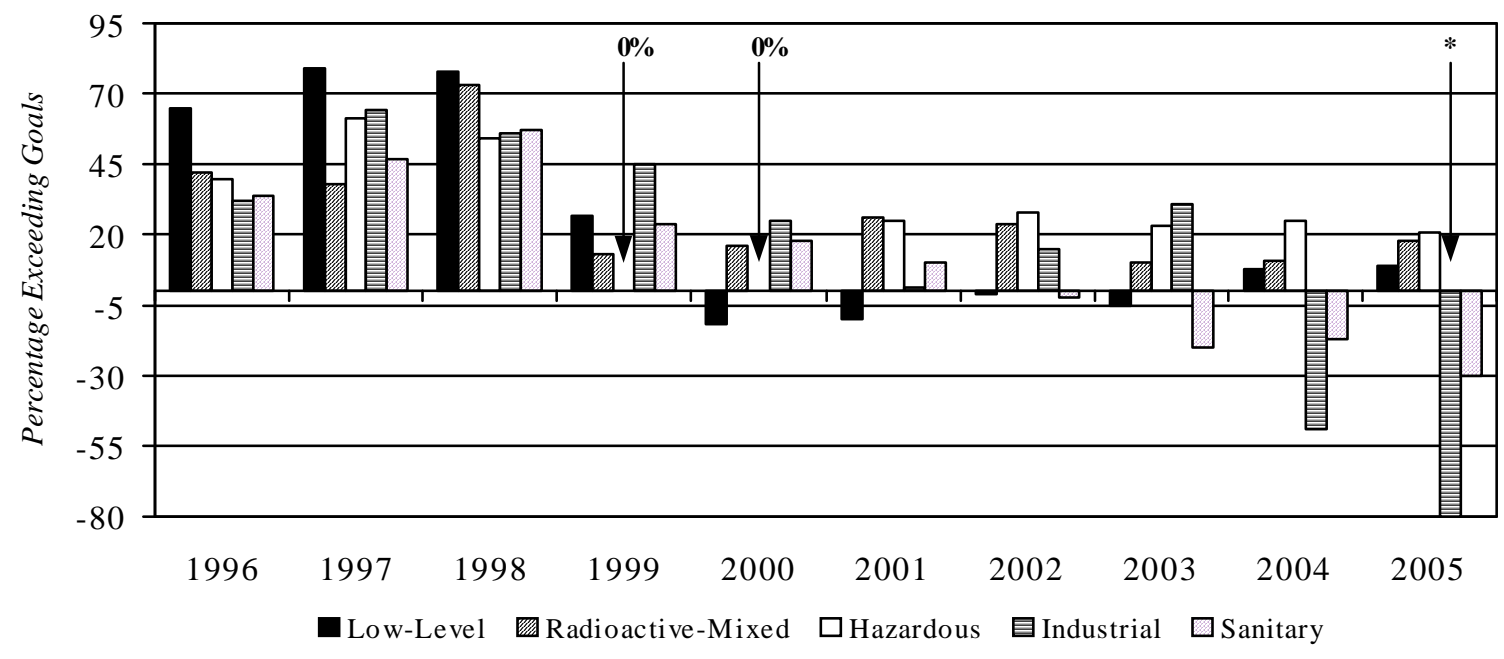

Figure 1-3. Percentage of Waste-Reduction-Exceeding Goals

* Increased industrial and sanitary waste generation was due to activities supporting site milestones for CY 2005 and infrastructure reduction. 
All but two of the waste-reduction goals were exceeded in FY 2005. The generation of industrial and sanitary wastes (e.g., paper, glass, plastic, and wood) did not meet the goal due to activities in support of site closure milestones such as the infrastructure reduction activities, relocation of office employees, and efforts to eliminate unnecessary paper. (See Table ECS-3 for specifics of waste management at the WVDP.)

Pollution Prevention Awareness Program. The WVDP's Pollution Prevention (P2) Awareness Program is a significant part of the Project's waste minimization program. The goal of the program is to make all employees aware of the importance of pollution prevention both at work and at home.

A component of the P2 Awareness Program at the WVDP is the Pollution Prevention Coordinators group. This group communicates, shares, and publicizes prevention, reduction, reuse, and recycling information to all departments at the WVDP. The P2 Coordinators identify and facilitate the implementation of effective source reduction, reuse, recycling, and procurement of recycled products. The WVDP employs an incentive-based program (the Bright Ideas Program) to encourage waste stream reduction/elimination, energy savings, and affirmative procurement.
Spills and Releases. Chemical spills greater than the applicable reportable quantity must be reported immediately to NYSDEC, the National Response Center, and other agencies as required. There were no reportable chemical spills during 2005.

Petroleum spills greater than five gallons - or of any amount that travel to waters of the state - must be reported immediately to the NYSDEC spill hotline and entered in the WVDP's quarterly log. There were no reportable petroleum spills in 2005. Figure 1-4 shows immediately reportable spills from 1996 to 2005 .

Prevention is the best means of protection against oil, chemical, and hazardous substance spills or releases. WVDP employees are trained in applicable standard operating procedures for equipment that they use, and best management practices have been developed that identify potential spill sources and preventive measures that will reduce the likelihood of releases. Spill training, notification, and reporting policies have also been developed to emphasize the responsibility of each employee to report spills immediately upon discovery. This first-line reporting helps to ensure that spills will be properly documented and mitigated in accordance with applicable regulations.

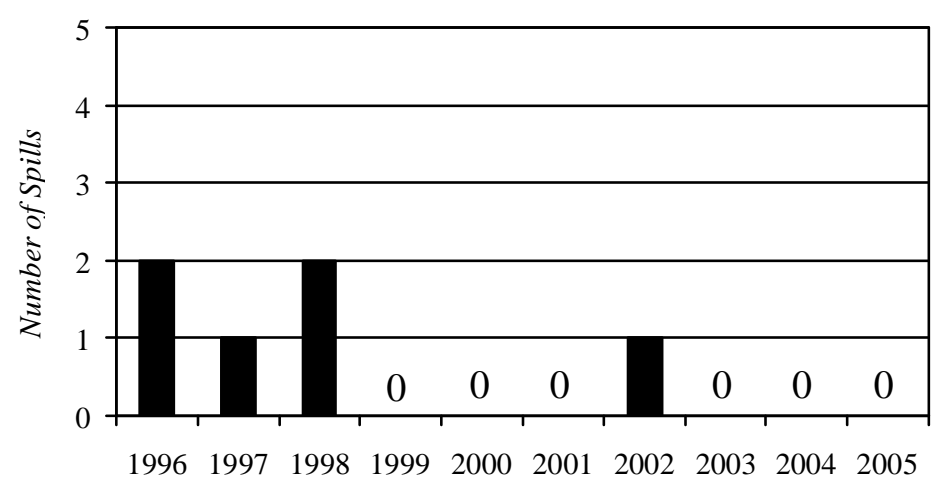

Figure 1-4. Number of Immediately Reportable Spills or Releases

$$
1-13
$$


This page intentionally left blank

$$
1-14
$$




\section{ENVIRONMENTAL RADIOLOGICAL PROTECTION PROGRAM AND DOSE ASSESSMENT}

\section{Radiation in the Environment}

\section{Sources of Radiation}

Members of the public are routinely exposed to ionizing radiation from both natural and man-made sources. (See the inset on the next page for a discussion of ionizing radiation.) An individual living in the United States (U.S.) is estimated to receive an average annual effective dose equivalent of about 360 millirem (mrem) (3.6 millisieverts [mSv]) (National Council on Radiation Protection and Measurements Report 93, 1987).

While most of the radiation dose received by the public is from natural background sources, manmade sources of radiation also contribute. Manmade sources include diagnostic and therapeutic $\mathrm{x}$-rays, nuclear medicine, fallout from nuclear weapons tests, effluents from nuclear facilities, and consumer products such as smoke detectors and cigarettes (Fig. 2-1).

Routine activities at the West Valley Demonstration Project (WVDP or Project) have the potential to release radioactive or hazardous substances that could affect the environment.

\section{Exposure Pathways}

The radionuclides at the WVDP are residues from the reprocessing of commercial nuclear fuel during the 1960s and early 1970 s by a previous site operator. A very small fraction of these radionuclides is released off site each year through ventilation systems and liquid discharges. WVDP releases contribute a negligible amount of radiation dose to the surrounding population through several exposure pathways.

An exposure pathway consists of a route for contamination or radiation to be transported by environmental media from a source to a receptor where exposure may occur. For example, a member of the public could be exposed to low concentrations of radioactive particles carried by prevailing winds.

The potential pathways of exposure from Project emissions are inhalation of gases and particulates, ingestion of locally-grown food products and game, and exposure to external penetrating radiation emitted from contaminated materials. Table 2-1 summarizes the potential exposure pathways for the local off-site population and describes the rationale for including or excluding each pathway 


\section{Ionizing Radiation}

Radiation can be damaging if, in colliding with matter, the alpha or beta particles or gamma rays knock electrons loose from the absorber atoms. This process is called ionization, and the radiation that produces it is referred to as ionizing radiation. Ionization changes an electrically neutral atom, in which the positively charged protons and the negatively charged electrons balance each other, into a charged atom called an ion. An ion can be either positively or negatively charged. The degree of damage depends upon the type of ionizing radiation.

\section{Potential Effects of Radiation}

Biological effects of radiation can be either somatic or genetic. Somatic effects of radiation exposure are limited to the exposed individual. For example, sufficiently high exposure to radiation can cause clouding of the lens of the eye or a decrease in the number of white blood cells.

Radiation can also cause chromosomes to break or rearrange themselves or to join incorrectly with other chromosomes. These changes may produce genetic effects and may show up in future generations. Radiation-produced genetic defects and mutations in the offspring of an exposed parent, while not positively identified in humans, have been observed in some animal studies.

The effect of radiation depends on the amount absorbed within a given exposure time. The only observable effect of an instantaneous whole-body dose of $50 \mathrm{rem}(0.5 \mathrm{~Sv})$ might be a temporary reduction in white blood cell count. An instantaneous dose of 100-200 rem (1-2 Sv) might cause additional temporary effects, such as vomiting, but usually would have no long-lasting side effects. Assessing biological damage from low-level radiation is difficult because other factors can cause the same symptoms as radiation exposure. Moreover, the body is able to repair damage caused by low-level radiation. There have been no documented effects from exposures of less than 10 rem.

The effect most often associated with exposure to relatively high levels of radiation appears to be an increased risk of cancer. However, scientists have not been able to demonstrate with certainty that exposure to low-level radiation causes an increase in injurious biological effects, nor have they been able to determine if there is a level of radiation exposure below which there are no adverse biological effects.

\section{Health Effects of Low-Level Radiation}

Radionuclides entering the body through air, water, or food are distributed in different organs of the body. For example, isotopes of iodine concentrate in the thyroid. Strontium, plutonium, and americium isotopes concentrate in the skeleton. When inhaled, particulate uranium and plutonium isotopes may remain in the lungs for a long period of time. Some radionuclides such as tritium, carbon-14, or cesium-137 are distributed uniformly throughout the body. Thus, depending on the radionuclide, some organs may receive quite different doses. Moreover, at the same dose levels, certain organs (such as the breast) are more prone to developing a fatal cancer than other organs (such as the thyroid).

Because of the uncertainty and difficulty in measuring the incidence of increased cancer resulting from exposure to ionizing radiation, to be conservative, a linear model is used to predict health risks from low levels of radiation. This model assumes that there is a risk associated with all dose levels even though the body may effectively repair damage incurred from low levels of alpha, beta, and gamma radiations.

$2-2$ 
when calculating dose from the WVDP. For instance, drinking water is not considered a pathway for exposure from the WVDP because surveys determined that local residents do not use Cattaraugus Creek as a source of drinking water.

\section{Land Use Survey}

Periodic surveys of local residents provide information about local family sizes, sources of food, and gardening practices. In early 2003 , census information was updated from calendar year (CY) 2000. Information from the most recent land use survey, conducted in early 2002, was used to confirm the locations of the nearest residences. This information is required when using computer models for the annual dose assessments. (See the discussion of "Dose Assessment Methodology" later in this chapter for more information on calculation of dose to the public.)

\section{Dose to the Public}

Each year the potential radiological dose to the public that is attributable to operations and effluents from the WVDP is assessed to verify that no individual could have received a dose exceeding the limits established by the regulatory agencies.

Estimated doses are compared directly with current radiation standards established by the U.S. Department of Energy (DOE) and the U.S. Environmental Protection Agency (EPA) for protection of the public. These values are also compared with the annual dose an average U.S. resident receives from natural background radiation and to doses reported in previous years for the Project. Figure 2-1 shows the relative contribution to the annual dose in mrem from natural and man-made sources in comparison with the estimated CY 2005 maximum individual dose from the WVDP. (Units of dose measurement are explained in detail later in this chapter.)

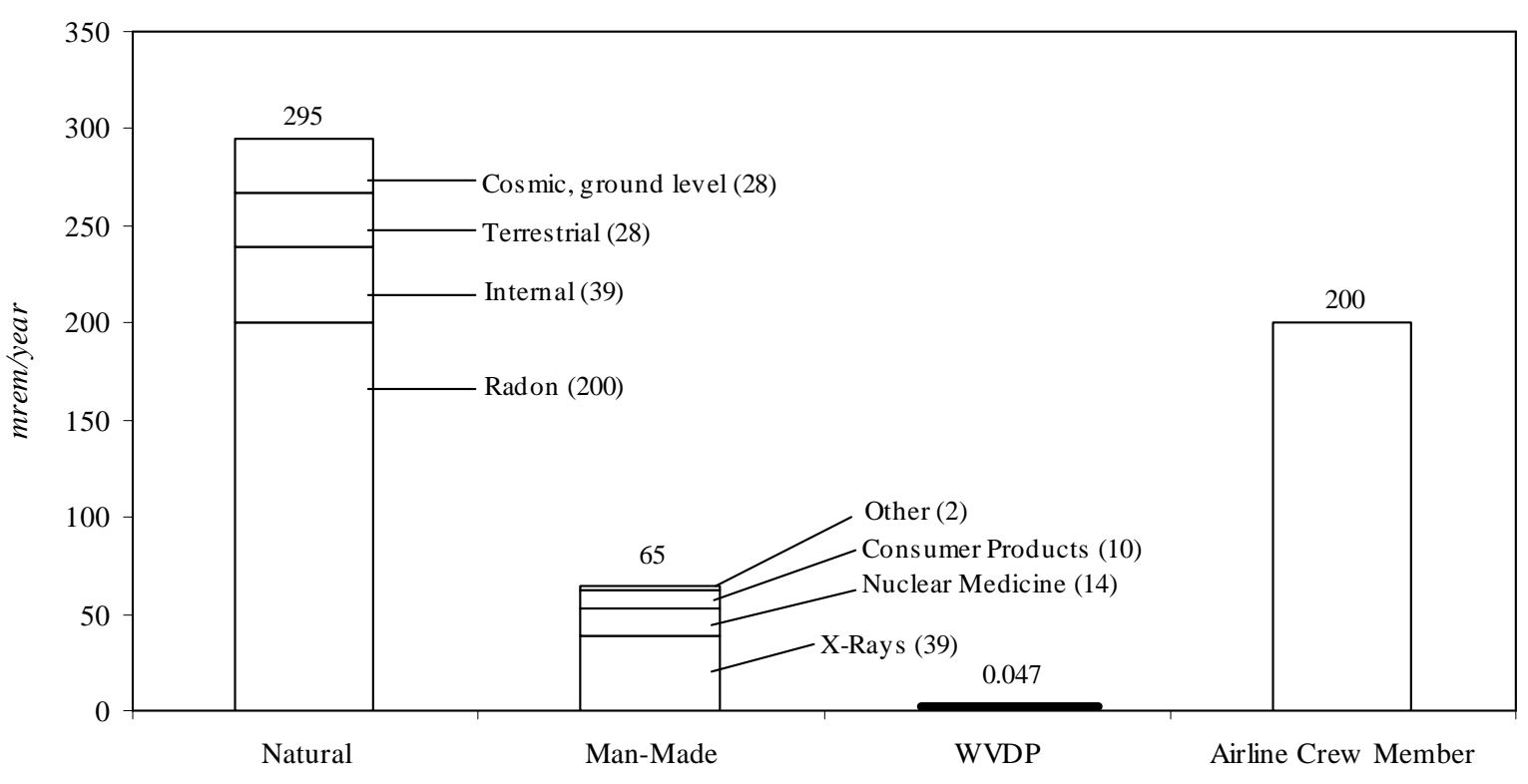

Figure 2-1. Comparison of Doses From Natural and Man-Made Sources to the Dose From 2005 WVDP Effluents

$2-3$ 
As can be seen in Figure 2-1, natural sources of radiation contribute $295 \mathrm{mrem}(2.95 \mathrm{mSv})$ and man-made sources contribute $65 \mathrm{mrem}(0.65 \mathrm{mSv})$ of the total annual U.S. average dose of $360 \mathrm{mrem}$ ( $3.60 \mathrm{mSv})$. In 2005, the WVDP contributed a very small amount $(0.047 \mathrm{mrem}[0.00047 \mathrm{mSv}])$ of the total annual man-made radiation dose to the maximally exposed off-site individual residing near the WVDP. This is much less than the average dose received from using consumer products and is insignificant compared to the federal standard of 100 mrem allowed from any DOE site operation in a calendar year and the $295 \mathrm{mrem}(2.95 \mathrm{mSv})$ received annually from natural sources.
The results of these conservative dose calculations demonstrate that the potential maximum dose to an off-site resident is well below permissible standards and is consistent with the as-low-asreasonably-achievable philosophy of radiation protection.

The following sections describe the monitoring program used to measure radiation in the environment near the WVDP and the methods used and the results of dose assessments using these measurements.

Table 2-1

\section{Potential Local Off-Site Exposure Pathways Under Existing WVDP Conditions}

\section{Exposure Pathway and Transporting Medium}

Inhalation: gases and particulates in air (included)

Ingestion: cultivated crops

(included)

Ingestion: surface and groundwater (excluded)

Ingestion: meat, milk, and vegetables (included)

External exposure: radiation from particulates and gases directly from air or surface water or indirectly from surface deposition (included)

\section{Reason for Inclusion/Exclusion}

Off-site transport of contaminants from WVDP stacks or resuspended particulates from soils or water

Local agricultural products irrigated with potentially contaminated surface or groundwater; foliar deposition and uptake of deposited airborne contaminants

No documented use of local surface water or downgradient groundwater wells as drinking water by local residents

Fish exposed to contaminants in water or sediments may be consumed; vegetables, venison, and milk may be consumed following deposition of transported airborne and surface water contaminants

Transport of air particulates and gases to offsite receptors; transport of contaminants in surface water and direct exposure during stream use and swimming

\section{$2-4$}




\section{Routine Monitoring Program}

\section{Radiological Sampling Program Overview}

In 2002, the WVDP completed the vitrification of high-level waste. The focus of site activities has since shifted to decontaminating and dismantling facilities and packaging and shipping waste. Consequently, the types and quantities of emissions and effluents that could be released to the environment have changed. In 2005, the WVDP environmental monitoring program was comprehensively re-evaluated and revised. New sampling points and matrices were added, and sampling was reduced or discontinued at many other locations. (See Appendix $\mathrm{B}^{\mathrm{GD}}$ for a complete listing of specific changes to the monitoring program in 2005.)

Overall, the goal of the environmental monitoring program, to ensure that public health and safety and the environment continue to be protected with respect to potential releases from current site activities, has remained the same.

As part of the environmental monitoring program, samples from environmental media are collected each year and measured for radioactivity. Environmental sampling locations are shown on maps in Appendix A and the complete environmental monitoring schedule is summarized in Appendix $\mathrm{B}^{\mathrm{GD}}$. This schedule provides information on monitoring and reporting requirements and the types and extent of sampling and monitoring at each location. An explanation of the codes that identify the sample medium and the specific sampling or monitoring location is also found in Appendix $\mathrm{B}^{\mathbf{C D}}$. For example, a location code such as AFGRVAL indicates an air sample (A), collected off-site (F), at the Great Valley (GRVAL) sampling station. The codes are used throughout this report for ease of reference and to be consistent with the data reported in the appendices.

The food pathway is monitored by collecting samples of milk and produce at near-site and remote locations, samples of fish upstream and downstream of the site, and samples of venison from deer collected near the site and at background locations. Stream sediments are sampled upstream and downstream of the WVDP, and both on-site groundwater and off-site drinking water are routinely sampled. Direct radiation is monitored on site, at the perimeter of the site, in communities near the site, and at a background location.

The primary focus of the monitoring program, however, is on surface water and air pathways, as these are the principal means of transport of radionuclides from the WVDP.

Liquid and air effluents are monitored on site by collecting samples at locations where radioactivity is released or might be released. Release points include water effluent outfalls and plant ventilation stacks.

Surface water samples are collected within the Project area from ponds, swamps, seeps, and drainage channels that flow through the Western New York Nuclear Service Center (WNYNSC) and then off site into Cattaraugus Creek.

Both surface water and air samples are collected at perimeter locations where the highest off-site concentrations of transported radionuclides might be expected. Samples are also collected at remote locations to provide background concentration data for comparison with data from on-site and nearsite samples. Table 2-2 summarizes statistical com- 
parisons of results from monitoring locations with results from background locations. As in the past, although results from many on-site or downstream monitoring points exceeded background concentrations, few results from near-site locations did.

\section{Overview of Water Effluent and Ambient Surface Water Monitoring}

The Project is drained by several small streams. Frank's Creek flows along, and receives drainage from, the south plateau. As Frank's Creek flows northward, it is joined by a tributary, Erdman Brook, which receives effluent from the low-level waste treatment facility (LLWTF). On the north plateau, beyond the Project fence line, the north and northeast swamp areas and Quarry Creek drain into Frank's Creek. Frank's Creek continues across the WNYNSC and flows into Buttermilk Creek, which leaves the WNYNSC and enters Cattaraugus Creek (Figs. A-2 and A-5).

Three locations (the LLWTF and the two natural drainages from the northeast and north swamps) are the primary discharge sources that contribute to dose via the liquid pathway. See "Predicted Dose From Waterborne Releases" later in this chapter for an estimate of the dose attributable to these sources.

Low-Level Waste Treatment Facility Effluent. The discharge from the LLWTF through the lagoon 3 weir at outfall 001 (WNSP001 on Fig. A-2) into Erdman Brook is the primary controlled point source of radioactivity released to surface waters from the Project. Seven batch releases totaling about 13.6 million gallons (gal) (51.4 million liters [L]) were discharged from WNSP001 in 2005.

The total amounts of radioactivity from specific radionuclides in the lagoon 3 effluent are listed in
Appendix C-2 ${ }^{\mathrm{GD}}$. The annual average concentration of each radionuclide is divided by its corresponding DOE derived concentration guide (DCG) to determine what percentage of the DCG was released. (DCGs are discussed in Chapter 1. DOE DCGs for radionuclides of interest at the WVDP are listed in Appendix $\mathrm{K}^{\mathbf{6 D}}$.) As a DOE policy, the sum of the percentages calculated for all radionuclides released should not exceed $100 \%$. The combined annual average of radionuclide concentrations from lagoon 3 effluent in 2005 was approximately $28.1 \%$ of the DCGs.

The LLWTF was designed to efficiently remove strontium-90 and cesium-137, the more prevalent of the long-lived fission products in WVDP wastewaters. Other radionuclides, such as uranium isotopes, are also removed to a lesser extent. Uranium isotopes are found in WVDP liquid waste because they were present in the nuclear fuel that was once reprocessed at the site. Uranium-232, a major contributor to the combined DCG in lagoon 3 effluent, averaged about $6 \%$ of its DCG in 2005. Variations in liquid effluent radionuclide ratios continue to reflect the dynamic nature of the waste streams being processed through the LLWTF.

Outfall WNSP001 and other selected discharge points are also monitored for nonradiological parameters under the New York State Pollutant Discharge Elimination System program. See Chapter 3, "Environmental Nonradiological Program Information."

\section{Northeast Swamp and North Swamp Drain-} age. These two drainages conduct surface water and emergent groundwater off site. The northeast swamp (WNSWAMP) is sampled to monitor surface water drainage from the northeastern portion of the site's north plateau. The north swamp (WNSW74A) is sampled to monitor drainage to Quarry Creek from the northern portion of the plateau (Fig. A-2). 
Table 2-2

\section{Comparison of Radiological Results With Backgrounds and DOE DCGs}

\begin{tabular}{|c|c|c|c|c|}
\hline Sample Type & $\begin{array}{l}\text { Number of } \\
\text { Sampling } \\
\text { Locations }\end{array}$ & $\begin{array}{l}\text { Locations with } \\
\text { Results Greater } \\
\text { than DOE DCGs }\end{array}$ & $\begin{array}{l}\text { Number with } \\
\text { Results Greater } \\
\text { than Background }\end{array}$ & $\begin{array}{l}\text { Locations with Results Statistically } \\
\text { Greater than Background } \\
\text { (Constituent) }\end{array}$ \\
\hline \multicolumn{5}{|c|}{ Air ( 1 background location; units of $\mu \mathrm{Ci} / \mathrm{mL}$ ) } \\
\hline On-site air emission points & 7 & 0 & 4 & $\begin{array}{l}\text { ANSTACK (tritium, strontium-90, } \\
\text { iodine-129, cesium-137, plutonium-238, } \\
\text { plutonium-239/240, americium-241); } \\
\text { ANSTSTK (iodine-129); ANCSRFK } \\
\text { (uranium-233/234, uranium-238); } \\
\text { ANCSPFK (iodine-129) }\end{array}$ \\
\hline On-site ambient air points & 3 & 0 & 1 & ANSDAT9 (tritium) \\
\hline Off-site ambient air points & 8 & 0 & 0 & None \\
\hline \multicolumn{5}{|c|}{ Surface water ( 2 background locations; units of $\mu \mathrm{Ci} / \mathrm{mL}$ ) } \\
\hline On-site controlled effluents & 2 & 0 & 2 & $\begin{array}{l}\text { WNSP001 (gross alpha, gross beta, } \\
\text { tritium, strontium-90, technetium-99, } \\
\text { cesium-137, uranium-232, uranium- } \\
\text { 233/234, uranium-235/236, uranium- } \\
\text { 238); WNSP007 (gross beta, strontium- } \\
\text { 90) }\end{array}$ \\
\hline On-site surface waters & 11 & $\begin{array}{l}\text { WNSWAMP } \\
\text { (strontium-90) }\end{array}$ & 8 & $\begin{array}{l}\text { WNSP006 (gross beta, strontium-90, } \\
\text { uranium-232, uranium-233/234, uranium- } \\
\text { 238); WNSP005 (gross beta, strontium- } \\
\text { 90); WNSWAMP (gross beta, tritium, } \\
\text { strontium-90); WNSW74A (gross beta, } \\
\text { strontium-90); WNNDADR (gross alpha, } \\
\text { gross beta, tritium, strontium-90); } \\
\text { WNNDATR (gross beta, tritium, } \\
\text { strontium-90); WNSDADR (gross alpha, } \\
\text { tritium); WNERB53 (gross beta, } \\
\text { strontium-90) }\end{array}$ \\
\hline Off-site surface waters & 2 & 0 & 2 & $\begin{array}{l}\text { WFBCTCB (gross beta, strontium-90); } \\
\text { WFFELBR (gross beta) }\end{array}$ \\
\hline \multicolumn{5}{|c|}{ Drinking water ( 2 background locations; units of $\mu \mathrm{Ci} / \mathrm{mL}$ ) } \\
\hline On-site drinking water & 3 & NA & 0 & None \\
\hline Off-site drinking water & 9 & NA & NS & $\begin{array}{l}\text { Not sampled in 2005; next sampling in } \\
2006\end{array}$ \\
\hline \multicolumn{5}{|c|}{ Soil ( 1 background location; units of $\mu \mathrm{Ci} / g$ [dry]) } \\
\hline Off-site soils & 5 & NA & NS & $\begin{array}{l}\text { Not sampled in 2005; next sampling in } \\
2007\end{array}$ \\
\hline
\end{tabular}

Note: Results from air emission points, liquid effluent points, downstream water sampling points, and on-site sampling points for all matrices may be expected to be greater than background.

NA - DOE DCGs are not applicable for these matrices

NS - Not sampled in CY 2005

$$
2-7
$$




\section{Table 2-2 (concluded)}

\section{Comparison of Radiological Results With Backgrounds and DOE DCGs}

\begin{tabular}{|c|c|c|c|c|}
\hline Sample Type & $\begin{array}{l}\text { Number of } \\
\text { Sampling } \\
\text { Locations }\end{array}$ & $\begin{array}{l}\text { Locations with } \\
\text { Results Greater } \\
\text { than DOE DCGs }\end{array}$ & $\begin{array}{l}\text { Number with } \\
\text { Results Greater } \\
\text { than Background }\end{array}$ & $\begin{array}{l}\text { Locations with Results Statistically } \\
\text { Greater than Background } \\
\text { (Constituent) }\end{array}$ \\
\hline \multicolumn{5}{|c|}{ Sediments ( 2 background locations; units of $\mu \mathrm{Ci} / \mathrm{g}$ [dry]) } \\
\hline On-site sediments/soils & 3 & NA & 3 & $\begin{array}{l}\text { SNSP006 (gross beta, strontium-90, } \\
\text { cesium-137); SNSWAMP (gross alpha, } \\
\text { gross beta, strontium-90, cesium-137, } \\
\text { uranium-235/236, plutonium-238, } \\
\text { plutonium-239/240, americium-241); } \\
\text { SNSW74A (gross beta, cesium-137, } \\
\text { uranium-235/236) }\end{array}$ \\
\hline Off-site sediments & 3 & NA & 2 & $\begin{array}{l}\text { SFTCSED (cesium-137); SFCCSED } \\
\text { (cesium-137) }\end{array}$ \\
\hline \multicolumn{5}{|c|}{ Biologicals ( 3 background deer; 1 background per matrix for remainder; units of $\mu \mathrm{Ci} / \mathrm{g}$ [dry] or $\mu \mathrm{Ci} / \mathrm{mL}$ [free moisture]) } \\
\hline Fish & 2 & NA & 1 & BFFCATC (strontium-90) \\
\hline Milk & 4 & NA & 0 & None \\
\hline Deer & 3 & NA & 0 & None \\
\hline Vegetables/fruits & 3 & NA & 1 & BFVNEAB (strontium-90) \\
\hline \multicolumn{5}{|c|}{ Environmental dosimetry ( 1 background; units of mR/quarter) } \\
\hline On-site, near facilities & 20 & NA & 12 & $\begin{array}{l}\text { DNTLDs \# 18, 24, 32, 33, 34, 35, 36, } \\
38,39,40,42,43\end{array}$ \\
\hline Perimeter & 17 & NA & 0 & None \\
\hline Communities & 2 & NA & 0 & None \\
\hline
\end{tabular}

Note: Results from air emission points, liquid effluent points, downstream water sampling points, and on-site sampling points for all matrices may be expected to be greater than background.

NA - DOE DCGs are not applicable for these matrices

Data summaries from these two locations are found in Appendix C- $4^{\text {[D. }}$. Elevated gross beta concentrations at WNSWAMP, first noted in 1993, continued to be observed through 2005. Gross beta activity at this location is largely attributable to strontium-90. When results from effluent monitoring points were compared with DOE DCGs, WNSWAMP was the only point at which the DCGs had been exceeded. (See Chapter 4 for a graph of annualized average strontium-90 concentrations at WNSWAMP in 2005.)

Even though waters with elevated strontium-90 concentrations drain from WNSWAMP into Frank's Creek and ultimately into Cattaraugus
Creek, concentrations in waters collected from Cattaraugus Creek downstream at the first point of access by the general public (WFFELBR) were not significantly higher than those at background location WFBIGBR.

Other North Plateau Surface Waters and Water Effluent. Discharges from WNSP001 and WNSP007 (the sewage treatment outfall) leave the site through point WNSP006. Radiological results of analyses from WNSP006 and WNSP007 are summarized in Appendices C- $5{ }^{\text {GD }}$ and C- $2{ }^{\text {GD }}$, respectively. 
Many of the constituents detected in effluent from WNSP001 were not detectable a short distance downstream at location WNSP006. WNSP006 is located more than 2.5 miles (mi) (4.0 kilometers $[\mathrm{km}])$ upstream from Thomas Corners Road, the last monitoring point before Buttermilk Creek leaves the WNYNSC and before the public has access to the creek waters.

Sampling point WNSP005 monitors overland drainage and groundwater seepage on the east side of the main plant and WNCOOLW monitors coolant water from a contained basin within the facility. Summaries of radiological data for WNSP005 and WNCOOLW are found in Appendix C- $4{ }^{\mathrm{GD}}$.

All results from these locations were far below DOE DCGs in CY 2005.

\section{South Plateau Surface Water and Nuclear Regulatory Commission (NRC)-Licensed Disposal Area (NDA) Interceptor Trench.} Two inactive underground radioactive waste disposal areas, the NDA and the New York StateLicensed Disposal Area (SDA), lie on the south plateau of the site. The SDA is managed by the New York State Energy Research and Development Authority (NYSERDA) and the NDA is managed by DOE. Also located on the south plateau is the drum cell, an aboveground structure used at the WVDP to store approximately 20,000 drums of processed low-level radioactive waste. Surface waters, which flow from the south to the north, are routinely monitored at several points around these areas (Fig. A-2). In addition to routine samples collected by the WVDP, samples are collected and analyzed by the New York State Department of Health (NYSDOH) at the two stream sampling points that receive drainage from the south plateau, WNFRC67 and WNERB53.

NRC-Licensed Disposal Area. Sampling point WNNDATR is a sump at the lowest point in the collection trench system that intercepts groundwater from the northeastern and northwestern sides of the NDA. Water collected underground at this location is pumped to the LLWTF for treatment prior to discharge at outfall WNSP001. (See Chapter 1 and Chapter 4 for additional detail on the NDA Interceptor Trench and Pretreatment System.) If contamination were to migrate through the NDA, it would most likely be first detected in samples from WNNDATR.

Surface water drainage downstream of the NDA is monitored at WNNDADR. Further downstream, water from sampling point WNERB53 in Erdman Brook, which represents surface waters from the NDA before they join with drainage from the main plant and lagoon areas, is also monitored. Some drainage from western and northwestern portions of the SDA also passes through sampling points WNNDADR and WNERB53. (See Appendices $\mathrm{C}-4^{\mathrm{GD}}$ and $\mathrm{C}-5^{\mathrm{co}}$, respectively.)

Annual concentrations from WNNDATR are listed in Appendix C- $4{ }^{\text {GD }}$ and quarterly results are listed under "NDATR" in Appendix $\mathrm{E}^{\text {GD }}$.

Although strontium-90 and associated gross beta results at all three locations were elevated with respect to background (WFBCBKG), all were far below the strontium-90 DCG. Residual soil contamination from past waste burial activities is thought to be the source of the strontium-90 activity. The NDA is thought to be the predominant source of gross beta activity observed at WNNDATR.

Tritium concentrations have generally decreased over time at both WNNDATR and WNNDADR. Since the half-life of tritium is slightly longer than 12 years, decreasing tritium concentrations may be partially attributable to radioactive decay.

New York State-Licensed Disposal Area. Point WNSDADR is sampled to monitor drainage from 
trench covers on the southwestern area of the SDA. Immediately south of the SDA, and upstream of WNSDADR, point WNDCELD is sampled to monitor surface drainage from the area around the drum cell (Fig. A-2). To the north, sampling point WNFRC67, in Frank's Creek, is sampled to monitor drainage downstream of the drum cell and the eastern and southern borders of the SDA. Summaries of results from WNSDADR, WNDCELD, and WNFRC67 are found in Appendices $\mathrm{C}-4{ }^{\mathrm{GD}}$ and $\mathrm{C}-5^{\mathrm{ED}}$.

Off-Site Surface Water. Surface water samples are collected at four off-site locations, two on Buttermilk Creek and two on Cattaraugus Creek. Offsite sampling locations are shown on Fig. A-5. Results are presented in Appendix C $-5^{\text {[D. }}$.

Fox Valley Road and Thomas Corners Bridge Sampling Locations. Buttermilk Creek is the major surface drainage from the WNYNSC. One monitoring station is located upstream of the WVDP at Fox Valley Road (WFBCBKG) and one is located downstream at Thomas Corners Bridge (WFBCTCB). The Thomas Corners Bridge sampling location is upstream of Buttermilk Creek's confluence with Cattaraugus Creek.

Cattaraugus Creek at Felton Bridge and Bigelow Bridge Sampling Locations. Radiological data are taken from samples collected at Felton Bridge (WFFELBR), downstream of the point where Buttermilk Creek enters Cattaraugus Creek, and at Bigelow Bridge (WFBIGBR), upstream of this point.

As noted in Table 2-2, average gross beta concentrations at Felton Bridge (WFFELBR) were greater than background concentrations, however, they were detected at less than $1 \%$ of the DOE DCG for strontium-90. These elevated concentrations may be attributed to small amounts of radioactivity moving from the site via Frank's Creek. Figure 2-2 shows gross alpha, gross beta, and tritium results over the past ten years at Felton Bridge. For the most part, tritium concentrations

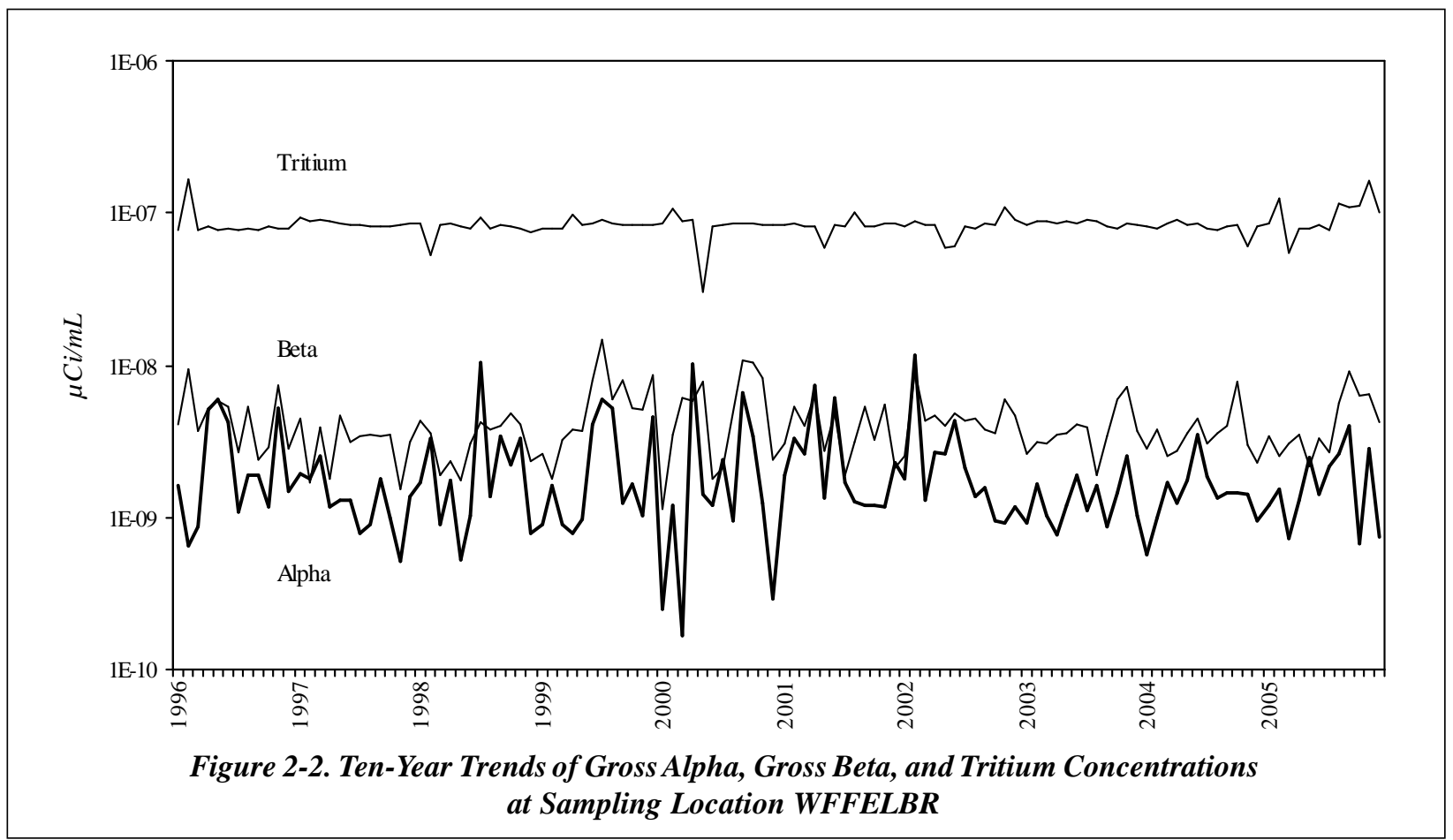


represent detection limits and not detected radioactivity. Taking into account seasonal fluctuations, gross beta activity has remained relatively constant at this location over the last decade.

\section{Overview of Drinking Water Monitoring}

Drinking water (potable water) is sampled both off site (near the WVDP) and on site. Off-site drinking water samples are taken from wells that represent the nearest unrestricted use of groundwater near the Project; none of these wells draw from groundwater units underlying the site. Drinking water and utility water for the Project are drawn from two on-site surface water reservoirs.

On-Site Tap Water. On-site drinking water sources were monitored for radionuclides at four locations: the entry point at the utility room (WNDNKUR), the Environmental Laboratory (WNDNKEL), the maintenance shop (WNDNKMS), and the main plant (WNDNKMP). Data tables may be found in Appendix C- $6{ }^{\text {CDD }}$. In addition, a standing water pond (WNSTAW9) near the site's drinking water reservoirs was monitored. Results are listed inAppendix C $-5^{\text {Go }}$.

Off-Site Drinking Water Wells. Nine off-site private residential groundwater wells near the site and a tenth background well south of the site are sampled. Sampling locations are shown on Figures A-11, A-14, and A-15. Only the background well was sampled in 2005. Results are presented in Appendix C- 6 . The remainder of the wells will be sampled again in 2006 .

\section{Overview of Sediment Monitoring}

Particulate matter in streams can adsorb radiological constituents in liquid effluents, settle on the bottom of the stream as sediment, and subsequently be eroded or resuspended, especially during periods of high stream flow. The resuspended sediments may provide a pathway for radiological constituents to reach humans either directly via exposure or indirectly through the food pathway.

On-Site Sediments. Sediments are collected at three on-site surface water sampling points where liquid effluents leaving the site are most likely to be radiologically contaminated: Frank's Creek where it leaves the security fence (SNSP006), the north swamp drainage swale (SNSW74A), and the northeast swamp drainage swale (SNSWAMP) (Fig. A-2). (Note that these sediment samples may be partially composed of soils.)

The NRC and the EPA, in a 2002 memorandum of understanding (MOU) pertaining to decommissioning and decontamination of contaminated sites, agreed upon concentrations of residual radioactivity in soil that would trigger consultation between these two agencies. Consultation "trigger" levels for contamination in both residential and industrial soil are listed in Table G-1C ${ }^{\text {ED }}$ for radionuclides found at the WVDP. Because the on-site sediment samples may be partially composed of soils (depending on annual rainfall and stream flow patterns), the MOU "trigger" levels are compared with analytical results from on-site soil/sediment samples in Appendix G-2 ${ }^{\text {Go }}$. The results at SNSP006 indicate that cesium-137 exceeds the industrial/commercial concentration threshold. Elevated cesium-137 at this location is largely attributable to site historical releases that occurred prior to DOE assuming operational control in 1982.

Off-Site Sediments. Sediments are collected off site at three locations downstream of the WVDP: Buttermilk Creek at Thomas Corners Road (SFTCSED), Cattaraugus Creek at Felton Bridge (SFCCSED), and Cattaraugus Creek at the Springville dam (SFSDSED). The first two points are at water sampling locations. The third is be- 
hind the Springville dam where significant sediments accumulate, including sediments that may have adsorbed radionuclides from the site. Sediments are also collected at one location upstream of waters receiving effluents from the WVDP, Buttermilk Creek at Fox Valley Road (SFBCSED). The upstream location provides background data for comparison with data from downstream points (Fig. A-5). See Appendix G- $2^{\text {[Do }}$ for results from off-site sediments.

A plot of annual average cesium-137 concentrations over 10 years at downstream sampling location SFCCSED is illustrated on Figure 2-3. As the figure indicates, although relatively stable, cesium137 concentrations at SFCCSED are consistently higher than those at the former background location (SFBISED). Cesium-137 activity historically is elevated in downstream Cattaraugus Creek sediments relative to upstream sediments. Even so, the levels are far lower at these downstream locations than those of naturally occurring gamma emitters, such as potassium- 40 .

\section{Overview of Air Emission and Ambient Air Monitoring}

Permits obtained from the EPA allow air containing small amounts of radioactivity to be released from plant ventilation stacks during normal operations. The air released must meet criteria specified in the National Emission Standards for Hazardous Air Pollutants (NESHAP) regulations to ensure that the environment and the public's health and safety are protected.

Unlike NESHAP dose criteria, the DOE DCGs are expressed in units of microcuries per milliliter $(\mu \mathrm{Ci} / \mathrm{mL})$ and can be directly compared with concentrations of radionuclides in WVDP air emissions. (Although the DOE DCGs are applicable where the public may breathe air containing radionuclides, the DCGs are also used at the WVDP as a reference screening tool for evaluating airborne emissions.) DOE standards and DCGs for radionuclides of interest at the WVDP are found in Appendix $\mathrm{K}^{\mathrm{GD}}$. When isotopic data are not avail-

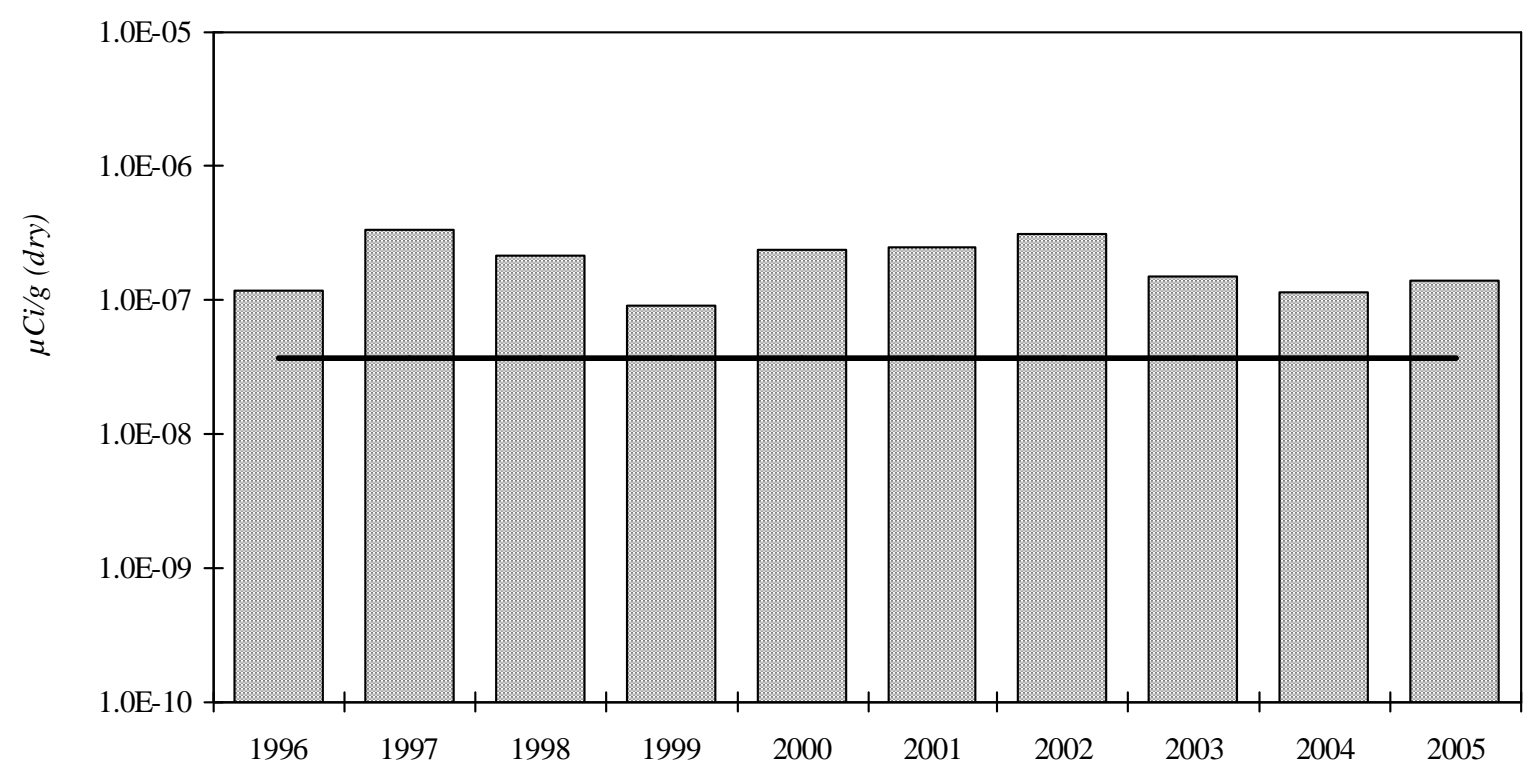

Figure 2-3. Ten-Year Average Cesium-137 Concentrations in Sediment From Cattaraugus Creek Downstream of the WVDP (SFCCSED) Compared With Upstream Concentrations (SFBISED [solid line]) 
able, gross alpha and beta measurements are assumed to come from americium-241 and strontium-90, respectively, because the DCGs for these radionuclides are the most limiting for major particulate emissions at the WVDP.

Ventilation and Emission Systems. The exhaust from eachEPA-permitted ventilation system on site is continuously filtered and the permanent systems are monitored as air is released to the atmosphere. Because radionuclide concentrations in air emissions are quite low, a large volume of air must be sampled at each point to measure the quantity of specific radionuclides released from the facility. Emissions are sampled for radioactivity in both particulate forms (e.g., strontium-90 and americium-241) and gaseous forms (e.g., tritium and iodine-129). The total release of each radionuclide (in curies) varies from year to year in response to changing site activities. For instance, releases of iodine-129 decreased after vitrification was completed. Calculated dose has consistently remained a small fraction of the standard. (See "Predicted Dose From Airborne Emissions" later in this chapter.)

The Main Plant Ventilation Stack. The main plant ventilation stack (ANSTACK) is the primary source of airborne releases at the WVDP. This stack, which vents to the atmosphere at a height of approximately 200 feet (ft) (more than 60 meters $[\mathrm{m}]$ ), releases ventilation exhaust from several facilities, including the liquid waste treatment system, the analytical laboratories, and off-gas from the former vitrification system.

Total curies released from the main stack in 2005 are listed in Appendix $D^{\text {GD }}$, together with annual averages, maxima, and a comparison of average isotopic concentrations with the applicable DCGs. As in previous years, the 2005 average radioactivity levels at the stack discharge point were already far below concentration guidelines for airborne radioactivity in an unrestricted environ- ment. Airborne concentrations from the stack to the site boundary are further reduced significantly by dispersion. Results from air samples taken just outside the site boundary confirm that WVDP operations had no discernible effect on off-site air quality. (See "Perimeter and Remote Ambient Air Monitoring," later in this chapter.)

Other On-Site Air Sampling Systems. Sampling systems similar to those of the main stack monitor airborne effluents from the former vitrification heating, ventilation, and air-conditioning system (ANVITSK), the 01-14 building ventilation stack (ANCSSTK), the contact size-reduction facility ventilation stack (ANCSRFK), the supernatant treatment system ventilation stack (ANSTSTK), the container sorting and packaging facility ventilation stack (ANCSPFK), and the remote-handled waste facility (ANRHWFK) (Fig. A-6).

Appendix $D^{\text {Go }}$ presents total radioactivity released for specific radionuclides (as available) at each of these sampling locations. Samples occasionally show detectable concentrations of gross radioactivity, as well as specific beta- and alpha-emitting radionuclides, but all results were below DOE effluent limitations.

Permitted portable outdoor ventilation enclosures (OVEs) are used to provide the ventilation necessary for the safety of personnel working with radioactive materials in areas outside permanently ventilated facilities or in areas where permanent ventilation needs to be augmented. Air samples from OVEs are collected continuously while emission points are discharging, and data from these portable ventilation units are included in annual evaluations of airborne emissions. Discharge concentrations from OVEs are far lower than DOE guidelines.

Three air samplers continued operating in 2005 to monitor ambient air near three on-site waste storage units - the lag storage area (ANLAGAM), 
the NDA (ANNDAAM), and the SDA (ANSDAT9) (Fig. A-6). These samplers were put in place to monitor potential diffuse releases of radioactivity. Data from these locations are presented in Appendix D ${ }^{\text {GD }}$.

Perimeter and Remote Ambient Air Monitoring. In 2005, samples for radionuclides in air were collected at six locations around the perimeter of the site and at three remote locations. Maps of the sampling locations are found on Figures A-7, A-14, and A-15.

The perimeter locations on Fox Valley Road (AFFXVRD), Rock Springs Road (AFRSPRD), Route 240 (AFRT240), Thomas Corners Road (AFTCORD), DutchHill Road (AFBOEHN), and at the site's bulk storage warehouse (AFBLKST) were chosen because they provide historical continuity (as former Nuclear Fuel Services, Inc. sampling locations) or because they represent the most likely locations for detecting off-site airborne concentrations of radioactivity.
The remote locations provide data from nearby communities (West Valley [AFWEVAL] and Springville [AFSPRVL]) and from a more distant background area (Great Valley [AFGRVAL], 18 miles [29 km] south of the site), which is considered representative of regional background air. Data from these locations are presented in A ppendix $D^{\text {GD }}$.

Ten-year gross alpha and gross beta concentrations at the Rock Springs Road location are shown on Figure 2-4. Within a range of seasonal and weekly fluctuations, the concentrations have been relatively constant over the past ten years.

Radioisotopic results from samples taken at the two near-site communities and from the site perimeter were statistically indistinguishable from results from the background samples, suggesting that there is no adverse site influence on the air quality at these near-site locations.

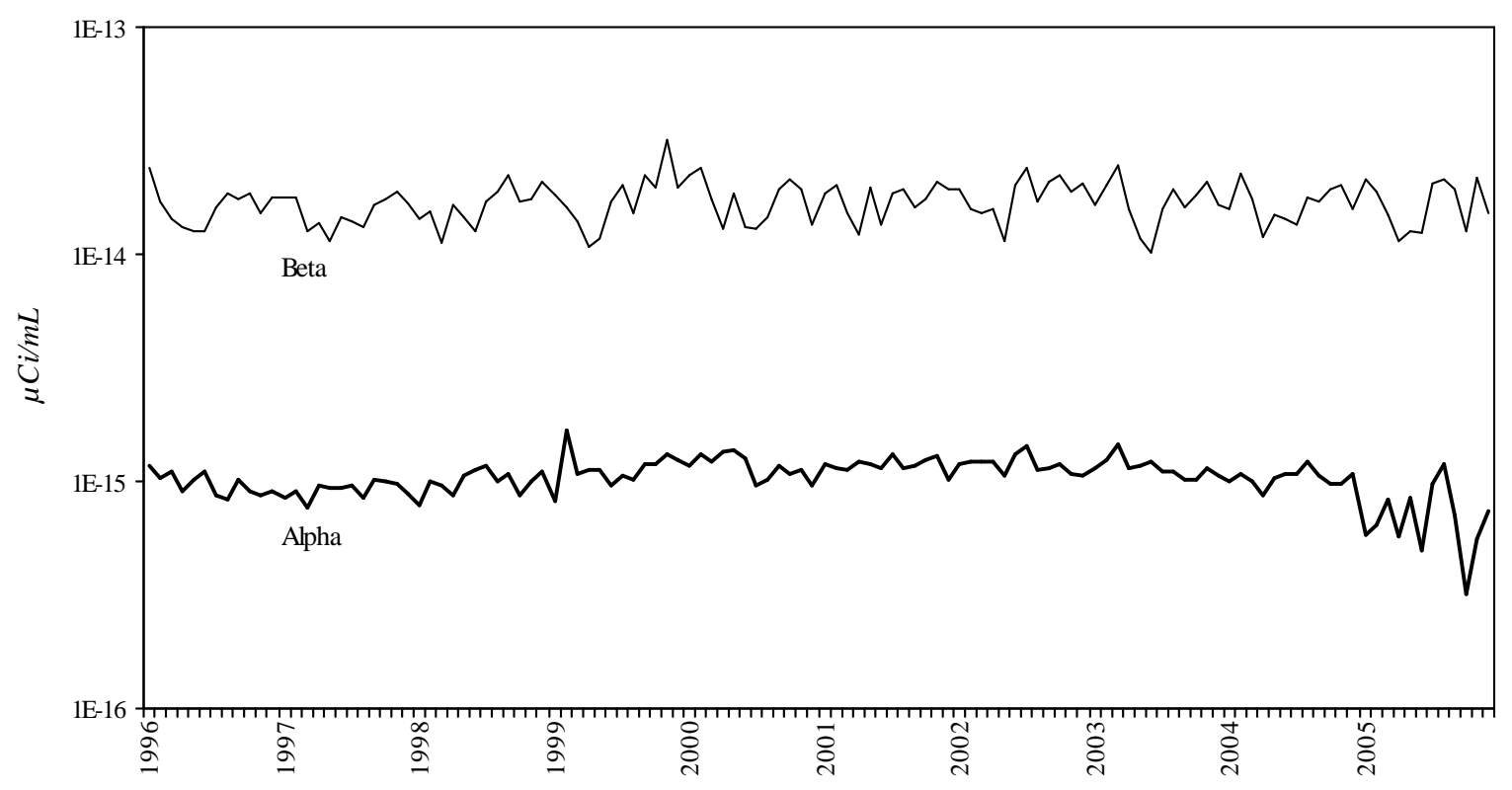

Figure 2-4. Ten-Year Trends of Gross Alpha and Gross Beta Concentrations in Air at Rock Springs Road (AFRSPRD) 


\section{Atmospheric Deposition and Soil Monitoring}

Fallout Pots. Fallout samples were collected in 2005 to monitor short-term deposition of radionuclides at four of the perimeter air sampler locations and at one on-site location near the rain gauge outside of the Environmental Laboratory (Figs. A6 and A-7). The data from precipitation analyses are presented in Appendix $\mathrm{D}^{\mathrm{GD}}$. The low levels of radioactivity released in main stack emissions did not measurably affect on-site or perimeter fallout pot samples in 2005.

Off-Site Surface Soil. Surface soil near the offsite air samplers is collected to assess long-term deposition of radionuclides. Maps of the off-site surface soil sampling locations are on Figures A-5, A-14, and A-15. In 2005, the frequency of collecting off-site soil samples was reduced from annually to every three years and no samples were collected in 2005. The next collection will be in 2007.

\section{Overview of Food Chain Monitoring}

Each year food samples are collected from locations near the site (Fig. A-11) and from remote locations (Figs. A-14 and A-15). Fish and deer are collected during periods when they would normally be taken by sportsmen for consumption. Corn, apples, and beans are collected annually at the time of harvest. Edible portions are analyzed for radionuclides. (See "Measurement of Radionuclide Concentrations in Food," later in this chapter, for a discussion of estimating doses from foodstuffs.) Results are listed in Appendix $\mathrm{F}^{\mathbf{G D}}$. Comparisons of results with background results are summarized in Table 2-2. Data have consistently demonstrated that the Project has little or no effect on local foodstuffs.

\section{Direct Environmental Radiation Monitoring}

Monitoring points are located on site at the waste management units, at the site security fence, around the WNYNSC perimeter and the access road, and at a background location remote from the WVDP (Figs. A-12 through A-15). Quarterly and annual averages of thermoluminescent dosimeter (TLD) measurements at off-site and on-site locations are noted in Appendix $\mathrm{H}^{\mathbf{c D}}$. The results of measurements in 2005 show typical seasonal variations and are similar to results from previous years.

On-Site Radiation Monitoring. As in past years, the on-site monitoring point with the highest dose readings was location DNTLD24, nearby which sealed containers of radioactive components and debris from the plant decontamination work are stored. Exposure rates at this location have been generally decreasing over time because the radioactivity in the materials stored nearby is decaying.

As expected, results from TLDs located near onsite facilities are generally higher than background results; however, these locations are well within the WNYNSC boundary and are not accessible by the public.

\section{Perimeter and Off-Site Radiation Monitoring.} The perimeter TLDs (TLDs \#1-16 and \#20) are distributed in the 16 compass sectors around the facility near the WNYNSC boundary. Results from the perimeter and community TLDs were statistically the same as results from the background TLD. The perimeter TLD quarterly averages shown on Figure 2-5 indicate seasonal fluctuations but no long-term trends.

Confirmation of Results. Performance of the environmental TLDs is confirmed periodically using a portable high-pressure ion chamber (HPIC) 
detection system. The TLD results include the entire third quarter of 2005; the HPIC results were each collected over a period of less than 30 minutes.

Since these measurements are made with different systems and over differing periods of time, they are not directly comparable. The average relative percent difference between the two sets of measurements was about $14 \%$, indicating general agreement between these two different measurement methods. (Guidance in American National Standards Institute N545-1975, the standard for environmental dosimetry, uses measurement agreement within $30 \%$ total uncertainty as a performance specification for TLD measurements.)

\section{Meteorological Monitoring}

Meteorological monitoring at the WVDP provides representative and verifiable data that characterize the local and regional climatology. These data are used primarily to assess potential effects of routine and nonroutine releases of airborne radioactive materials and to develop dispersion models used to calculate the effective dose equivalent to off-site residents. Since dispersive capabilities of the atmosphere are dependent upon wind speed, wind direction, and atmospheric stability (which includes a function of the difference in temperature between two elevations), these parameters are closely monitored and are available to the emergency response organization at the WVDP.

The on-site 197-ft (60-m) meteorological tower (Fig. A-1) continuously monitors wind speed, wind direction, and temperature at both the 197-ft (60$\mathrm{m})$ and 33-ft (10-m) elevations. In addition, an independent, remote $33-\mathrm{ft}(10-\mathrm{m})$ meteorological station, located approximately $5 \mathrm{mi}(8 \mathrm{~km})$ south of the site on a hillcrest on Dutch Hill Road (Fig. A-14), continuously monitors wind speed and wind direction. Dewpoint, precipitation, and barometric pressure are also monitored on site.

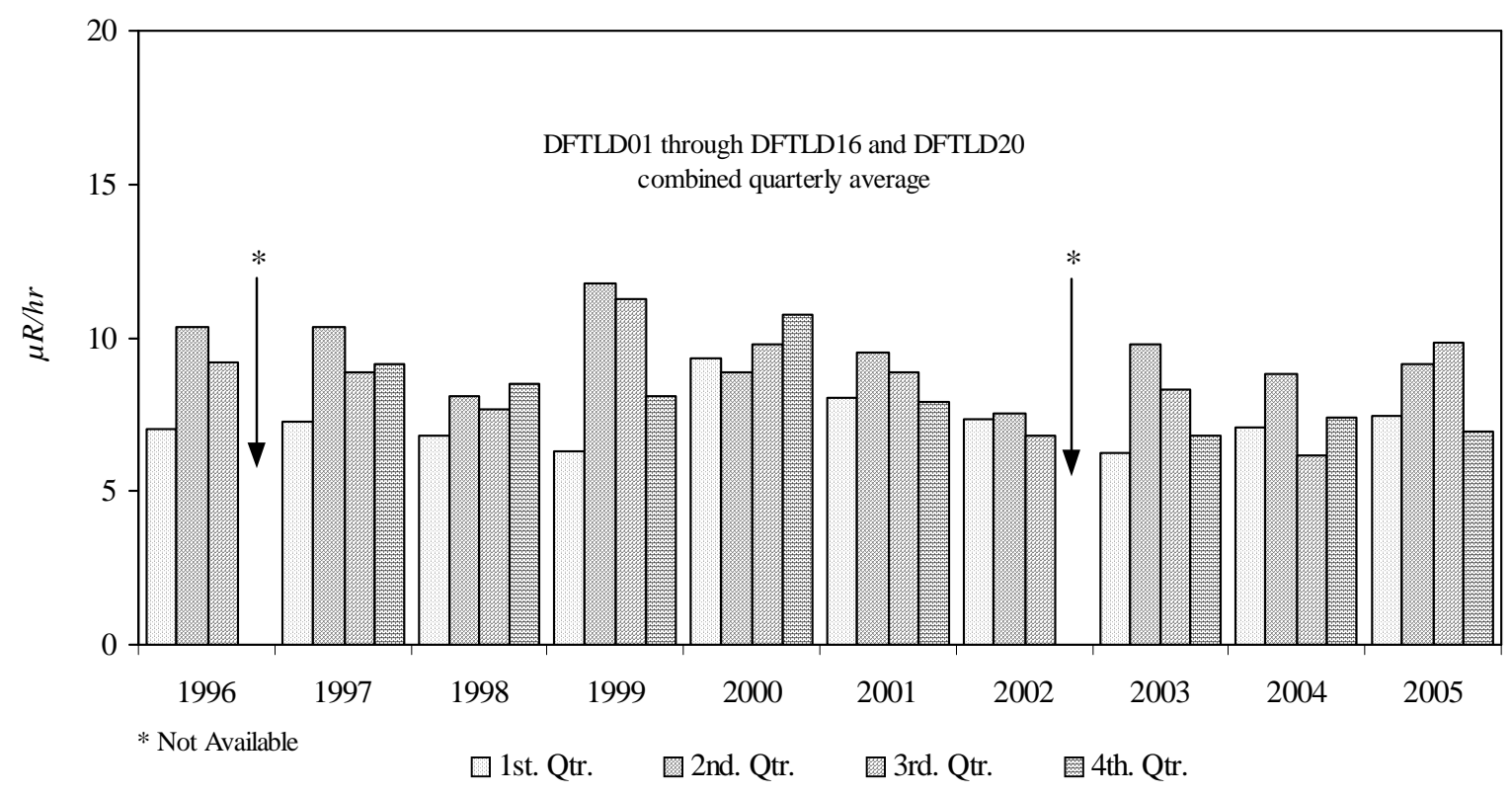

Figure 2-5. Ten-Year Trends of Environmental Radiation Levels at Perimeter TLDs 
The two meteorological locations supply data to the primary digital and analog data acquisition systems located within the Environmental Laboratory. Onsite systems are provided with either uninterruptible or standby power backup in case of site power failures. In 2005, the on-site system data recovery rate (the time valid data were logged versus the total elapsed time) was approximately $93.8 \%$.

Weekly and cumulative total precipitation data are presented in Appendix I ${ }^{\mathrm{GD}}$. Precipitation in 2005 was approximately 38.5 inches $(97.8$ centimeters [cm]), about $6 \%$ less than the long-term annual average (41.0 inches [104 cm]). Note that 4.13 inches $(10.5 \mathrm{~cm})$, more than $10 \%$ of the total rainfall in this drier-than-normal year, were received on two days at the end of August as the remnants of hurricane Katrina passed through Western New York.

Documentation, such as meteorological system calibration records, site log books, and analog strip charts, is stored in protected archives. Meteorological towers and instruments are examined three times per week for proper function and are calibrated semiannually and/or whenever instrument maintenance might affect calibration.

\section{Special Monitoring}

Special monitoring comprises sampling and analyses not covered by the routine environmental monitoring program but that address items of environmental interest. Special monitoring programs are used to verify and/or track these items. Some special environmental monitoring carried out in 2005 was associated with seepage of groundwater into a drained pool that was formerly used to store spent nuclear fuel rods. No hazards to employees or to the public were identified. (See "Additional Monitoring and Investigations" in Chapter 4.)

\section{$2-17$}




\section{Radiological Effluents and Dose}

\section{Dose Assessment Methodology}

The potential radiation dose to the general public from WVDP activities is evaluated by using a twopart methodology applied in a manner consistent with the requirements of DOE Order 5400.5. The first part uses the measurements of radionuclide concentrations in liquid and air released from the Project to determine the annual total effect using computer model calculations. The second part uses measurements of radioactivity in food from locations near the Project boundaries to corroborate the modeled impact of the annual total release.

Radiological dose is evaluated using methods that consider contributions from all major exposure pathways, including external irradiation, inhalation, and ingestion of local food products. The dose contributions from each radionuclide and pathway combination are then combined to obtain the total dose estimates reported in Table 2-3.

\section{Measurement of Radionuclide Concentra- tions in Liquid and Air Releases. Because it is difficult to distinguish by direct measurement the small amount of radioactivity originating from the Project or from naturally occurring radiation in the environment, computer codes are used to model the environmental dispersion of radionuclides that originate from on-site monitored ventilation stacks and liquid discharge points.}

Actual data from air and water release-monitoring samples are collected, together with annual weather measurements and the most recent demographic information. (See Appendices A, $C^{\text {G0 }}$, $\mathrm{D}^{\mathrm{GD}}$, and $\mathrm{I}^{\mathrm{GD}}$.) The effective dose equivalent (EDE) to the maximally exposed off-site individual
(MEOSI) and the collective EDE to the population within a 50-mile $(80-\mathrm{km})$ radius are then calculated using conservative DOE- and EPA-approved models to demonstrate compliance with radiation standards. (See the inset on "Radiation Dose" and "Units of Dose Measurement.")

Measurement of Radionuclide Concentrations in Food. The second part of the dose assessment is based on actual radioactivity measurements in samples of foodstuffs grown in the vicinity of the WVDP and the comparison of these values with measurements of samples collected from locations well beyond the potential influence of site effluents.

If any of the near-site food samples contain radionuclide concentrations that are statistically higher than the concentrations in control samples, separate dose calculations are performed to verify that the calculated foodstuff dose is within the dose range estimated by computer modeling. (See "Calculated Dose From Local Foodstuff Tests," later in this chapter.)

These estimates show that the concentrations of radioactivity, whether from sites near or distant from the WVDP, are small - usually near the analytical detection limits - thereby providing additional assurance that operations at the WVDP are not adversely affecting the public.

These calculated doses are used as an independent confirmation of (not added to) the computermodeled estimates (Table 2-3) because the models already include contributions from all environmental pathways. 


\section{Radiation Dose}

The energy released from a radionuclide is eventually deposited in matter encountered along the path of the radiation. The radiation energy absorbed by a unit mass of material is referred to as the absorbed dose. The absorbing material can be either inanimate matter or living tissue.

Alpha particles leave a dense track of ionization as they travel through tissue and thus deliver the most dose per unit path-length. However, alpha particles are not penetrating and must be taken into the body by inhalation or ingestion to cause harm. Beta and gamma radiation can penetrate the protective dead skin layer of the body from the outside, resulting in exposure of the internal organs to radiation.

Because beta and gamma radiations deposit much less energy in tissue per unit path-length relative to alpha radiation, they produce fewer biological effects for the same absorbed dose. To allow for the different biological effects of different kinds of radiation, the absorbed dose is multiplied by a quality factor to yield a unit called the dose equivalent. A radiation dose expressed as a dose equivalent, rather than as an absorbed dose, permits the risks from different types of radiation exposure to be compared with each other (e.g., exposure to alpha radiation compared with exposure to gamma radiation). For this reason, regulatory agencies limit the dose to individuals in terms of total dose equivalent.

\section{Units of Dose Measurement}

The unit for dose equivalent in common use in the U.S. is the rem, which stands for roentgen equivalent man. The international unit of dose equivalent is the sievert (Sv), which is equal to 100 rem. The millirem (mrem) and millisievert $(\mathrm{mSv})$, used more frequently to report the low dose equivalents encountered in environmental exposures, are equal to one-thousandth of a rem or sievert, respectively. Other radioactivity unit conversions are found on p. UI-5 at the back of this report.

The effective dose equivalent (EDE), also expressed in units of rem or sievert, provides a means of combining unequal organ and tissue doses into a single "effective" whole body dose that represents a comparable risk probability. The probability that a given dose will result in the induction of a fatal cancer is referred to as the risk associated with that dose. The EDE is calculated by multiplying the organ dose equivalent by the organ-weighting factors developed by the International Commission on Radiological Protection (ICRP) in Publications 26 (1977) and 30 (1979). The weighting factor is a ratio of the risk from a specific organ or tissue dose to the total risk resulting from an equal whole body dose. All organ-weighted dose equivalents are then summed to obtain the EDE.

The dose from internally deposited radionuclides calculated for a fifty-year period following intake is called the fifty-year committed effective dose equivalent (CEDE). The CEDE sums the dose to an individual over fifty years to account for the biological retention of radionuclides in the body. The total EDE for one year of exposure to radioactivity is calculated by adding the CEDE to the dose equivalent from external, penetrating radiation received during the year. Unless otherwise specified, all doses discussed here are total EDE values, which include the CEDE for internal emitters.

A collective population dose is expressed in units of person-rem or person-sievert because the individual doses are summed over the entire potentially exposed population. The average individual dose can therefore be estimated by dividing the collective dose by the population.

\section{$2-19$}




\section{Predicted Dose From Airborne Emissions}

Airborne emissions of radionuclides are regulated by the EPA under the Clean Air Act and its implementing regulations. DOE facilities are subject to Title 40 of the Code of Federal Regulations (CFR) 61, Subpart H, NESHAP. Subpart H contains the national emission standards for radionuclides other than radon from DOE facilities. The applicable standard for radionuclides is a maximum of 10 mrem $(0.1 \mathrm{mSv})$ effective dose equivalent to any member of the public in any year.

Releases of airborne radioactive materials in 2005 from nominal ground-level stacks (1 to $24 \mathrm{~m}$ high) and from the main 60-meter-high stack were modeled using the EPA-approved CAP88-PC computer code (Parks, June 1997). This air dispersion code estimates effective dose equivalents for the ingestion, inhalation, air immersion, and ground surface pathways.

Site-specific data for CY 2005 nonradon radionuclide releases in curies per year are listed in Appendix $\mathrm{D}^{\mathrm{GD}}$. Applicable information from these tables was used as input to the CAP88-PC code, as were wind data collected from the on-site meteorological tower during 2005 and the most recent local population distribution information.

Resulting output from the CAP88-PC code was then used to determine the total EDE from air emissions to a maximally exposed individual and the collective dose to the population within a 50mi $(80-\mathrm{km})$ radius of the WVDP.

Maximum Dose to an Off-Site Individual. Based on the nonradon airborne radioactivity released from all sources at the site during 2005 (i.e., permitted stacks, stacks that do not require permits, and nonpoint sources), it was estimated that a person living in the vicinity of the WVDP could have received a total EDE of 0.0012 mrem $(0.000012$ $\mathrm{mSv}$ ) from airborne releases. The computer model estimated that this MEOSI was located $1.2 \mathrm{mi}$ (1.9 $\mathrm{km})$ north-northwest of the site and was assumed to eat only locally-produced foods. About $90 \%$ of the estimated airborne dose was from iodine- 129.

When considering permitted stacks only, the maximum total EDE of $0.00041 \mathrm{mrem}(0.0000041 \mathrm{mSv})$ is far below levels that could be directly measured at the exposed individual's residence. This dose is comparable to less than one minute of natural background radiation received by an average member of the U.S. population and is well below the 10 mrem $(0.1 \mathrm{mSv})$ NESHAP limit promulgated by the EPA and mandated by DOE Order 5400.5.

Collective Population Dose. The CAP88-PC program was used to estimate the collective EDE to the population. Based upon the latest U.S. census population data collected in CY 2000, 1.54 million people were estimated to reside within $50 \mathrm{mi}$ $(80 \mathrm{~km})$ of the WVDP. This population received an estimated 0.0089 person-rem $(0.000089$ person-Sv) total EDE from radioactive nonradon airborne effluents released from WVDP point and diffuse sources during 2005. (See the discussion of radon-220 later in this chapter.) The resulting average EDE per individual was 0.000006 mrem $(0.00000006 \mathrm{mSv})$.

Iodine Emissions From the Main Stack. Iodine-129, a long-lived radionuclide, has routinely been found in main stack emissions. During the vitrification of high-level waste, iodine-129 releases increased because gaseous iodine was not as efficiently removed by the vitrification process offgas treatment system as were most other radionuclides. As more high-level radioactive waste was removed from the tanks and converted into glass, less waste was available to emit iodine129 and concentrations decreased. As of 2005, iodine- 129 concentrations are back to (or below) 


\section{Table 2-3 \\ Summary of Annual Effective Dose Equivalents to an Individual and Population From WVDP Releases in 2005}

Exposure Pathways
Annual Effective Dose Equivalent

Maximally Exposed
Off-Site Individual
mrem (mSv)

Collective Effective

Dose Equivalent ${ }^{b}$

person-rem (person-Sv)
Airborne Releases ${ }^{c}$

$\%$ EPA standard (10 mrem)

Waterborne Releases ${ }^{d}$

Effluents only

North plateau drainage

Total from all Pathways

$\%$ DOE standard (100 mrem) -

air and water combined

$\%$ of natural background

(295 mrem; 453,000 person-rem) -

received from air and water combined

Estimated Airborne Radon-220 ${ }^{e}$

\subsection{E-03 (1.2E-05) \\ $0.01 \%$}

4.6E-02 (4.6E-04)

$1.1 \mathrm{E}-02(1.1 \mathrm{E}-04)$

3.5E-02 (3.5E-04)

4.7E-02 (4.7E-04)

$0.05 \%$

$0.02 \%$

7.0E-03 $(7.0 \mathrm{E}-05)^{f}$
8.9E-03 (8.9E-05)

NA

2.2E-01 (2.2E-03)

$1.6 \mathrm{E}-02(1.6 \mathrm{E}-04)$

$2.0 \mathrm{E}-01(2.0 \mathrm{E}-03)$

2.3E-01 (2.3E-03)

NA

$0.00005 \%$

2.7E-01 (2.7E-03)

NA - Not applicable. Numerical regulatory standards are not set for the collective EDE to the population.

a The maximum exposure to air discharges is estimated to occur at a residence $1.2 \mathrm{mi}(1.9 \mathrm{~km})$ northnorthwest of the main plant building.

${ }^{b}$ A population of 1.54 million is estimated to reside within $50 \mathrm{mi}(80 \mathrm{~km})$ of the site.

c Releases are from atmospheric nonradon point and diffuse sources. Calculations use CAP88-PC to estimate individual and population doses. EPA and DOE limits for individual airborne dose are the same.

${ }^{d}$ Estimates are calculated using the methodology described in the WVDP Manual for Radiological Assessment of Environmental Releases at the WVDP (WVNSCO, 2003).

e Estimated airborne releases are based on indicator measurements and process knowledge. Dose estimates are calculated using CAP88-PC.

$f$ The estimated dose from radon-220 is specifically excluded by rule from NESHAP totals.

\section{$2-21$}




\section{Radon-220}

Radon-220, also known as thoron, is a naturally occurring gaseous decay product of thorium-232 present in the airborne emissions from the WVDP main plant. Radon-220 is also associated with the thorium reduction extraction (THOREX) process-related thorium-232 and uranium-232 in the high-level waste.

As reported in Chapter 2 of the 1996 WVDP Site Environmental Report (WVNSCO and Dames \& Moore, June 1997), thoron levels were observed to increase during startup of the 1996 high-level waste vitrification process. An estimate of the thoron released during each waste concentration cycle was developed and used to determine a theoretical annual release. During the vitrification phase, an average of about 12 curies per day were assumed to have been released. In 2005, with the vitrification process completed, the estimated average is assumed to be about three curies of thoron released per day.

Although large numbers of curies were released relative to other radionuclides, the calculated dose from thoron is quite small because of its short decay half-life and other characteristics. The NESHAP rule specifically excludes thoron from air emission dose calculations, so a dose estimate using CAP88-PC was calculated separately. The theoretical dose to the MEOSI located $1.2 \mathrm{mi}(1.9 \mathrm{~km})$ north-northwest of the site in 2005 would have been 0.007 mrem (0.00007 $m S v)$, and the collective dose to the population within an 80-kilometer radius would have been 0.27 person-rem (0.0027 person-Sv). (See Table 2-3.) These theoretical doses are within the same range as historical doses from the man-made radionuclides found in WVDP effluents.

With vitrification completed, thoron releases have decreased to pre-vitrification levels. The figure presented here provides a relative indication of recent trends in the estimated annual thoron releases.

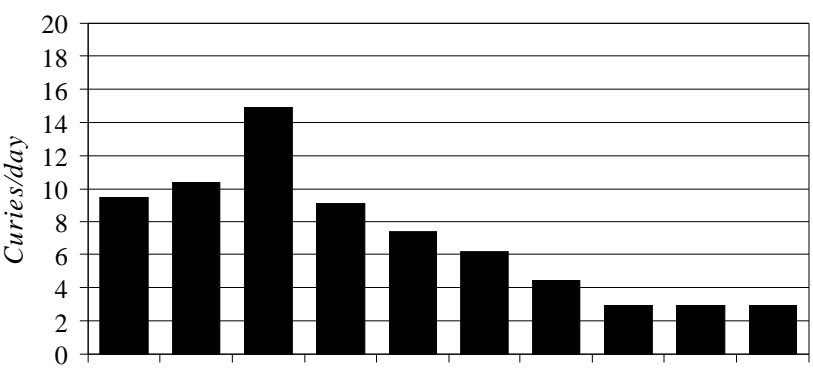

$\begin{array}{llllllllll}1996 & 1997 & 1998 & 1999 & 2000 & 2001 & 2002 & 2003 & 2004 & 2005\end{array}$

Estimated Radon-220 Releases From the WVDP

pre-vitrification levels. Even so, in 2005, iodine129 continued to account for the largest proportion of dose to an off-site individual from main stack airborne emissions. See Figure 2-6 for a comparison of doses attributable to various nuclides from WVDP air emission points.

\section{Predicted Dose From Waterborne Releases}

Currently there are no EPA standards establishing limits on the radiation dose to members of the public from liquid effluents except as applied in 40 CFR Part 141 and 40 CFR Part 143, Drinking Water Guidelines (EPA, 1984a; 1984b). Corollary limits for community water supplies are set by NYSDOH in the New York State Sanitary Code (Title 10 of the Official Compilation of Codes, Rules, and Regulations of the State of New York [NYCRR] 5-1.52). The private residential potable water wells sampled for radionuclides are upgradient of the WVDP and therefore do not represent a potential source of exposure to radiation from routine Project activities. 


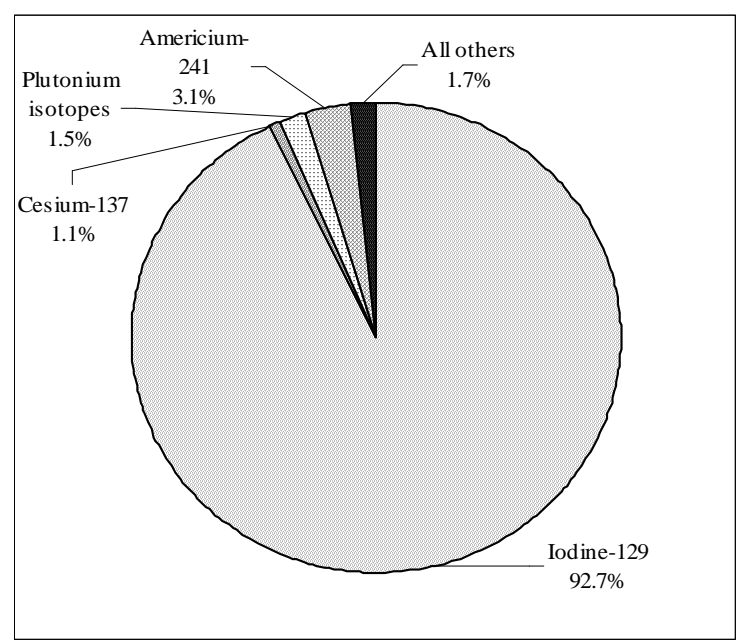

Figure 2-6. Air Emissions From Point Sources: Dose Percent by Radionuclide in CY 2005

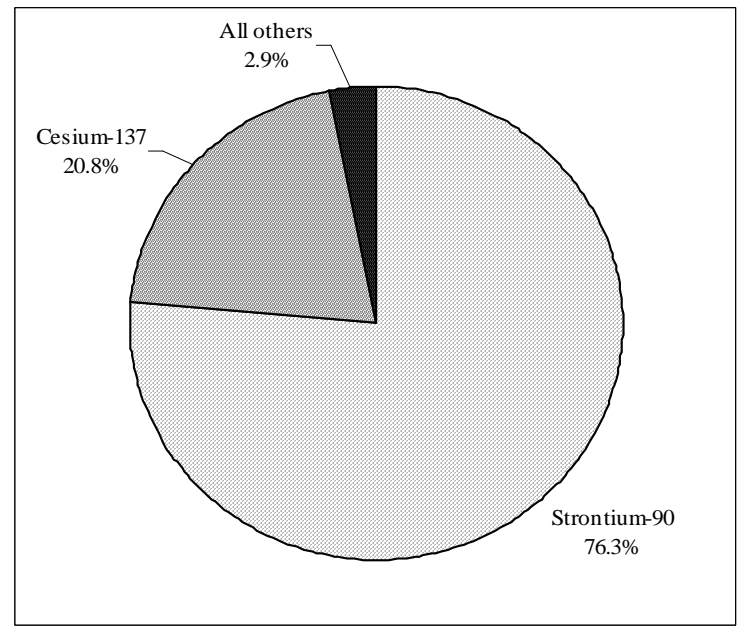

Figure 2-7. Water Effluents: Dose Percent by Radionuclide in CY 2005

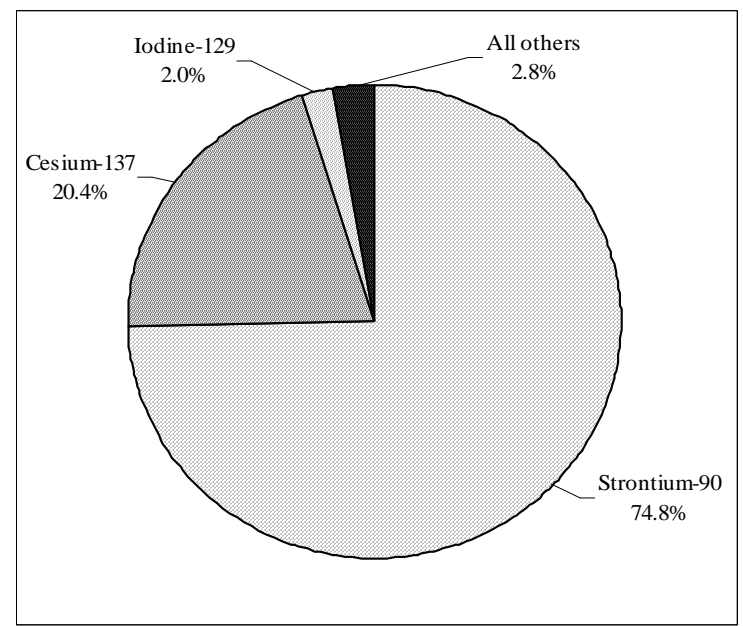

Figure 2-8. All Sources: Dose Percent by Radionuclide in CY 2005

$2-23$ 
Cattaraugus Creek is not used as a drinking water supply; therefore, a comparison of the predicted concentrations and doses with the 4-mrem/year (0.04-mSv/year) EPA and NYSDOH drinking water limits established in 40 CFR Part 141 and 40 CFR Part 143, and in 10 NYCRR §5-1.52, respectively, is not truly appropriate (although the values in creek samples are well below the EPAdrinking water limits). The estimated radiation dose was compared to the applicable guidelines provided in DOE Order 5400.5. The EDE to the MEOSI and the collective EDE to the population due to routine waterborne releases and natural drainage are calculated using dose conversion factors as tabulated in the "WVDPManual for Radiological Assessment of Environmental Releases at the WVDP" (WVNSCO, 2003).

Since the Project's liquid effluents eventually reach Cattaraugus Creek, the most important individual exposure pathway is the consumption of fish from this creek by local sportsmen. Exposure to external radiation from shoreline or water contamination is also included in the model for estimating radiation dose. Population dose estimates assume that radionuclides are further diluted in Lake Erie before reaching municipal drinking water supplies.

The computer codes GENII version 1.485 (Pacific Northwest Laboratory, 1988), which implements the models in NRC Regulatory Guide 1.109 (NRC, 1977), and LADTAP II (Simpson and McGill, 1980) were used to calculate site-specific unit dose factors for routine waterborne releases and dispersion of these effluents. Input data included local stream flow and dilution, drinking water usage, and stream usage factors.

Seven batches of liquid effluents were released from lagoon 3 (point WNSP001) during 2005. Measurements of the radioactivity discharged in these effluents, listed in Appendix C- $2^{\text {cov }}$, were combined with the unit dose factors to calculate the EDE to the
MEOSI and the collective EDE to the population living within a 50-mi $(80-\mathrm{km})$ radius of the WVDP.

In addition to measurements from WNSP001, radioactivity measurements from sewage treatment facility effluents (WNSP007) were included in the EDE calculations. Results from the sewage treatment facility are also presented in Appendix C$2^{\text {GD }}$. (The french drain at WNSP008, a third release point, has been sealed off since 2001 and was not included in this evaluation.)

Besides the two release points at WNSP001 and WNSP007, waters from two natural drainage channels originating on the Project premises contain measurable concentrations of radioactivity: the northeast swamp (WNSWAMP) and north swamp (WNSW74A). (See Northeast Swamp and North Swamp Drainage discussed earlier in this chapter.) The measured radioactivity from these points is reported in Appendix C- $4{ }^{\mathrm{CD}}$. These results are included in the EDE calculations for the MEOSI and the collective population. See Figure 2-7 for a comparison of estimated doses attributable to specific radionuclides from water effluents.

There were no unplanned releases of waterborne radioactivity to the off-site environment in 2005.

\section{Maximum Dose to an Off-Site Individual.}

Based on the radioactivity in liquid effluents discharged from the WVDP (lagoon 3 and the sewage treatment plant) during 2005, an off-site individual could have received a maximum EDE of $0.011 \mathrm{mrem}(0.00011 \mathrm{mSv})$. The maximum offsite individual EDE due to drainage from the north plateau (north swamp and northeast swamp) was 0.035 mrem $(0.00035 \mathrm{mSv})$.

The combined EDE to the maximally exposed individual from liquid effluents and drainage was $0.046 \mathrm{mrem}(0.00046 \mathrm{mSv})$. This annual dose is very small in comparison to the 295 mrem (2.95 
$\mathrm{mSv}$ ) dose that is received by an average member of the U.S. population from natural background radiation.

Collective Dose to the Population. As a result of radioactivity released in liquid effluents from the WVDP during 2005, the population living within 50 $\mathrm{mi}(80 \mathrm{~km})$ of the site received an estimated collective EDE of 0.016 person-rem ( 0.00016 person$\mathrm{Sv})$. The collective dose to the population from the effluents plus the north plateau drainage was 0.22 person-rem ( 0.0022 person-Sv). The resulting average EDE from effluent releases and north plateau drainage (north swamp and northeast swamp) per individual is $0.00014 \mathrm{mrem}(0.0000014 \mathrm{mSv})$. This dose is an inconsequential addition to the dose that an average person receives in one year from natural background radiation.

\section{Calculated Dose From Local Foodstuff Tests}

Most radionuclide concentrations in near-site food samples were statistically indistinguishable from concentrations in background samples. Conservative estimates of dose due to consuming near- site fish, deer, milk, beans, corn, and apples were about $0.1 \mathrm{mrem} / \mathrm{year}(0.001 \mathrm{mSv} / \mathrm{year})$. These independent estimates confirm the modeled dose estimates based on air and water effluent sampling results as summarized in Table 2-3.

\section{Predicted Dose From All Pathways}

The potential dose to the public from both airborne and liquid effluents released from the Project during 2005 is the sum of the individual dose contributions. (See Figure 2-8.) The calculated maximum EDE from all pathways to a nearby resident was $0.047 \mathrm{mrem}(0.00047 \mathrm{mSv})$. This dose is $0.05 \%$ of the 100-mrem (1-mSv) annual limit in DOE Order 5400.5. The estimated dose from radon-220 to the same nearby resident was about $0.01 \mathrm{mrem}$.

The total collective EDE to the population within 50 miles $(80 \mathrm{~km})$ of the site was 0.23 person-rem (0.0023 person-Sv), with an average EDE of $0.00015 \mathrm{mrem}(0.0000015 \mathrm{mSv})$ per individual. The estimated radon-220 dose to the population was approximately 0.3 person-rem.

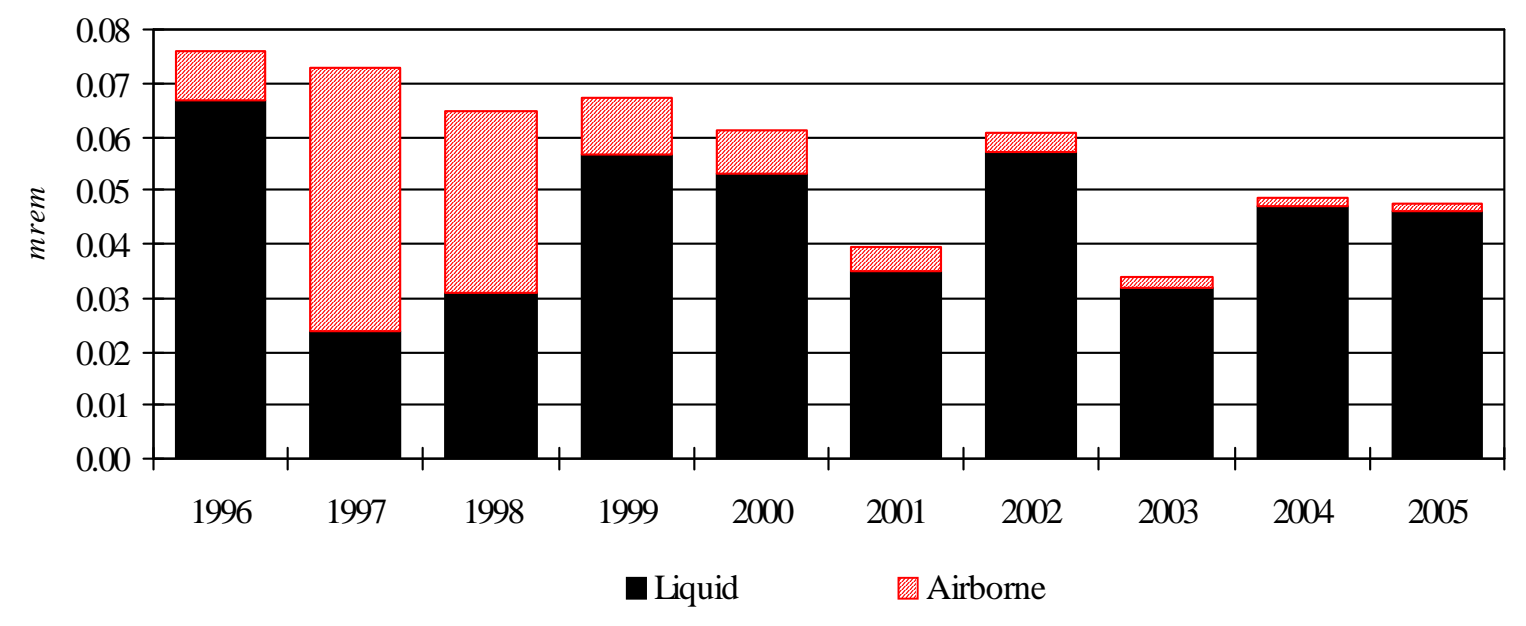

Figure 2-9. Effective Dose Equivalent From Liquid and Airborne Effluents to a Maximally Exposed Individual Residing Near the WVDP 


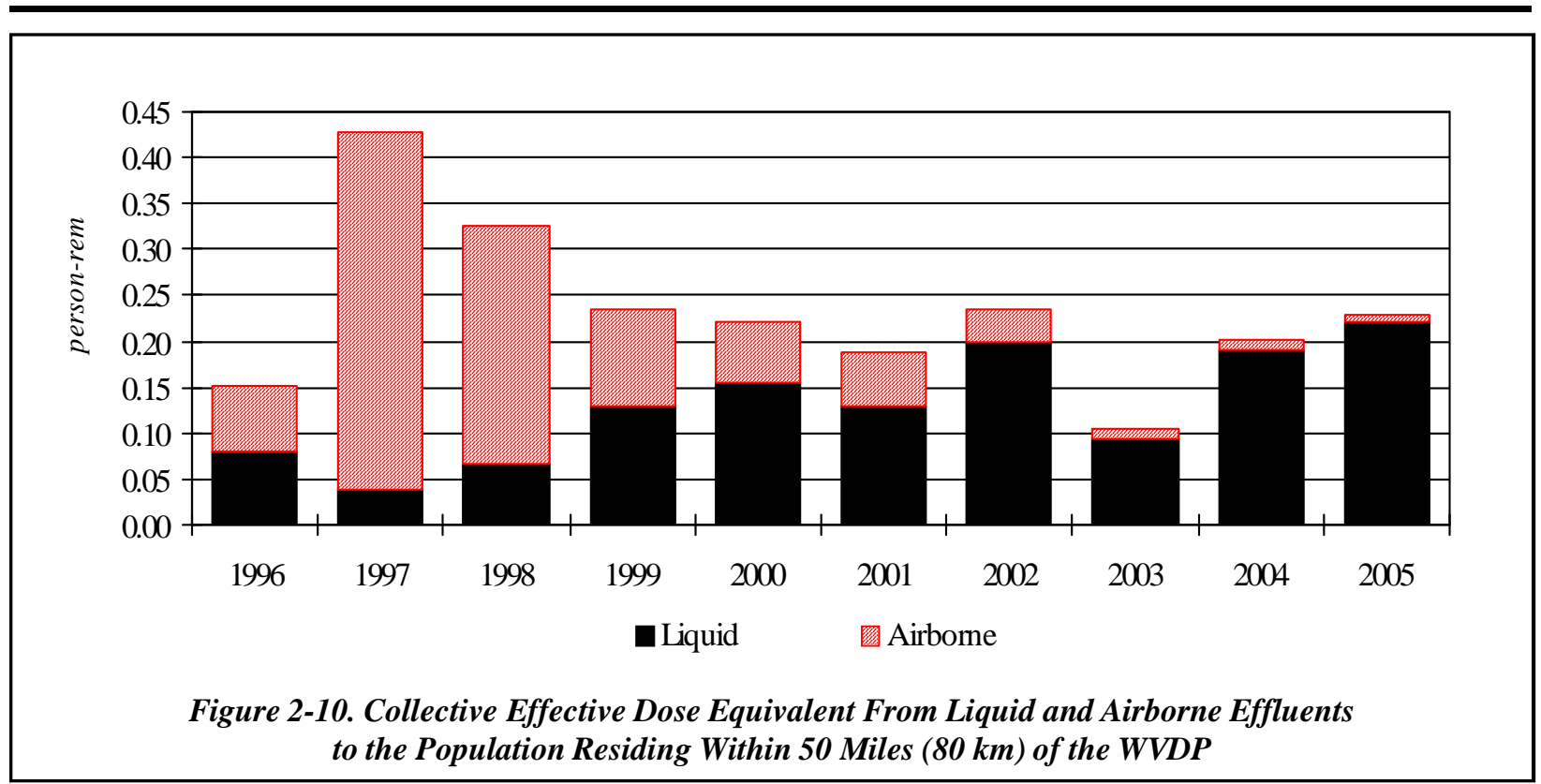

Table 2-3 summarizes the dose contributions from all pathways and compares the individual doses with the applicable standards.

Figure 2-9 shows the calculated annual dose to the hypothetical maximally exposed individual over the last ten years. The estimated doses for 2005 were very similar to those reported in 2004.

Figure 2-10 shows the collective dose to the population over the last ten years. (See Fig. A-16 for a map of the population sectors.) The overall radioactivity represented by these data confirms the continued inconsequential addition to the natural background radiation dose that individuals and population around the WVDP receive from Project activities.

\section{Risk Assessment}

Estimates of cancer risk from ionizing radiation have been presented by the National Council on Radiation Protection and Measurements (NCRP) (1987) and the National Research Council's Committee on Biological Effects of Ionizing Radiation (1990).
The NCRP estimates that the probability of fatal cancer occuring is between one and five per 10,000 people who each are exposed to one rem (i.e., a risk coefficient of between 0.0001 and 0.0005 ). DOE guidance has, in the past, recommended using a risk coefficient of 0.0005 (ICRP, 1991) to estimate risk to a MEOSI. Recent DOE guidance recommends using the even more conservative risk coefficient of 0.0006 provided by the Interagency Steering Committee on Radiation Standards (January 2003). The estimated risk to the hypothetical individual residing near the WVDP from airborne and waterborne releases in 2005 was 3 chances in 100 million (a risk coefficient of 0.00000003 ). This risk is well below the range of 0.000001 to 0.00001 per year considered by the ICRP in Report Number 26 (1977) to be a reasonable risk for any individual member of the public.

\section{Release of Materials Contain- ing Residual Radioactivity}

The release of property containing residual radioactivity from DOE facilities is carefully controlled by DOE guidelines and procedures. In two spe- 
cial memoranda issued in January and July of 2000, the Secretary of Energy placed a moratorium on release of contaminated materials and on unrestricted release for metal recycling from radiological areas within DOE facilities. The moratorium will remain in effect until directives clarifying the release criteria have been developed and implemented. Any transfer that places property (real property, structures, equipment, or scrap metal) containing radioactivity into public use is classified as a type of environmental release.

As indicated in Table 2-4, the WVDP did not release any property in 2005 classified per DOE Order 5400.5 as material containing residual radioactivity.

\section{Dose to Biota: Aquatic and Terrestrial Wildlife}

Radionuclides from both natural and man-made sources may be found in environmental media such as water, sediments, and soils. In the past, it has been assumed that if radiological controls are sufficient to protect humans, other living things are also likely to be sufficiently protected. This assumption is no longer considered adequate, since populations of plants and animals residing in or near these media or taking food or water from these media may be exposed to a greater extent than are humans. For this reason, the DOE prepared a technical standard that provides methods and guidance to be used to evaluate doses of ionizing radiation to populations of aquatic animals, riparian animals (i.e., those that live along banks of streams or rivers), terrestrial plants, and terrestrial animals.

Methods in this technical standard, "A Graded Approach for Evaluating Radiation Doses to Aquatic and Terrestrial Biota" (DOE-STD-11532002, July 2002), were used in 2005 to evaluate radiation doses to aquatic and terrestrial biota within the confines of the WNYNSC, which includes the WVDP. Doses were assessed for compliance with the limit in DOE Order 5400.5 for native aquatic animal organisms ( $1 \mathrm{rad} /$ day) and for compliance with the thresholds for terrestrial plants (also $1 \mathrm{rad} /$ day) and for terrestrial animals $(0.1 \mathrm{rad} /$ day $)$, as proposed in DOE-STD-11532002. Note that the absorbed dose unit (rad) is used for biota instead of the units used for indicating human risk (rem).

The RESRAD-BIOTA Code, a calculation tool provided by the DOE for implementing the technical standard, was used to compare existing radionuclide concentration data from environmental sampling with biota concentration guide (BCG) screening values and to estimate upper bounding doses to biota. Data collected from surface waters, sediments, and soils on and around the WNYNSC over a ten-year period (1991-2000) were used as a baseline. For a more near-term assessment, a second evaluation was completed using surface water data from 2005 , sediment data from the last five years (2001-2005), and soil data from the preceding ten years (1995-2004 [because no soil sampling was conducted in 2005]). Differing time periods were used because radionuclide concentrations change more rapidly over time in surface waters than in sediments and soils, as reflected in their sampling frequencies (monthly or quarterly for water, annually or every third year for sediments and soils).

Concentration data for radionuclides in each medium were entered into the RESRAD-BIOTA Code. The value for each radionuclide was automatically divided by its corresponding BCG to calculate a partial fraction for each nuclide in each medium. Partial fractions for each medium were added to produce a sum of fractions.

It was found that the isotopes with the highest sums of fractions - the radionuclides that contrib- 
uted the largest component of both aquatic and terrestrial dose to biota - were strontium-90 and cesium-137. Per guidance in DOE-STD-11532002, the populations of organisms most sensitive to strontium-90 and cesium-137 in this evaluation - that is, those residing on the WNYNSC that were most likely to be adversely affected via the aquatic and terrestrial pathways - were determined to be populations of the raccoon (aquatic dose) and the deer mouse (terrestrial dose). As such, this study does not pertain to pathways to humans, which were addressed earlier in this chapter.

Exposures from the aquatic pathway may be assumed to be less than the aquatic dose limit from DOE Order 5400.5 if the sum of fractions for the water medium plus that for the sediment medium is less than 1.0. Similarly, exposures from the terrestrial pathway may be assumed to be less than the proposed dose limits for both terrestrial plants and animals if the sum of fractions for the water medium plus that for the soil medium is less than 1.0.

In accordance with the approach described in DOE-STD-1153-2002, a general screening was first conducted using the maximum radionuclide concentrations from surface waters, sediments, and soils. Maximum radionuclide concentrations exceeded applicable BCG limits for both aquatic and terrestrial evaluations.

As recommended in DOE-STD-1153-2002, a sitespecific screening was then done using estimates of average radionuclide concentrations derived from measurements in surface waters, sediments, and soils. Results are summarized in Table 2-5.

At the site-specific screening level for the full tenyear baseline period, the sums of fractions for the aquatic and terrestrial system evaluations were 0.45 and 0.57 , respectively. The comparable sums of fractions using the more near-term data were
0.21 and 0.31 , respectively. The sum of fractions for each assessment was less than 1.0, indicating that applicable BCGs were met for both the aquatic and terrestrial evaluations.

Upper bounding doses associated with the aquatic system evaluation were $0.0059 \mathrm{rad} /$ day to an aquatic animal and $0.021 \mathrm{rad} /$ day to a riparian animal, far below the $1 \mathrm{rad} /$ day standard from DOE Order 5400.5 for dose to a native aquatic animal. Upper bounding doses associated with the terrestrial system evaluation were 0.031 and $0.0027 \mathrm{rad} /$ day to terrestrial animals and plants, again well below the guidance thresholds ( 0.1 and $1.0 \mathrm{rad} /$ day, respectively).

It was therefore concluded that populations of aquatic and terrestrial biota (both plants and animals) on the WNYNSC are not being exposed to doses in excess of the existing DOE dose standard for native aquatic animals (U.S. DOE, February 1990) and the international standards for terrestrial organisms (International Atomic Energy Agency [IAEA], 1992).

\section{Summary}

Predictive computer modeling of airborne and waterborne releases resulted in estimated hypothetical doses to the maximally exposed individual that were orders of magnitude below all applicable EPA standards and DOE Orders, which place limitations on the release of radioactive materials and dose to individual members of the public. The collective population dose was also assessed and found to be orders of magnitude below the natural background radiation dose. Additionally, estimates of dose to biota indicated that populations of biota at the WVDP are exposed at a fraction of the DOE and IAEA guidelines for dose to biota.

Based on the overall dose assessment, the WVDP was found to be in compliance with applicable ef- 
fluent radiological guidelines and standards during calendar year 2005. Table 2-6 provides a summary of WVDP releases and calculated doses in the specified DOE format.

Table 2-4

Release of Property Containing Residual Radioactive Material

\begin{tabular}{|ccccccccc|}
\hline $\begin{array}{c}\text { Approved } \\
\text { Limit }\end{array}$ & Rationale & $\begin{array}{c}\text { Date } \\
\text { of } \\
\text { Approval }\end{array}$ & $\begin{array}{c}\text { Type } \\
\text { of } \\
\text { Material }\end{array}$ & $\begin{array}{c}\text { Basis } \\
\text { for } \\
\text { Release }\end{array}$ & $\begin{array}{c}\text { End } \\
\text { Use }\end{array}$ & $\begin{array}{c}\text { Volume } \\
\text { of } \\
\text { Material }\end{array}$ & $\begin{array}{c}\text { Total } \\
\text { Activity }\end{array}$ & $\begin{array}{c}\text { Maximum } \\
\text { Individual } \\
\text { Dose }\end{array}$ \\
NA & $N A$ & $N A$ & None & $N A$ & $N A$ & 0 & 0 & 0 \\
Dose
\end{tabular}

NA - Not applicable 


\section{Table 2-5}

\section{Evaluation of Dose to Aquatic and Terrestrial Biota}

\begin{tabular}{|c|c|c|c|c|c|c|c|}
\hline \multicolumn{8}{|c|}{$\underline{\text { Aquatic System Evaluation (Near-Term Data Set) }}$} \\
\hline Nuclide & $\begin{array}{c}\text { Water } \\
\text { BCG* } \\
(\mathbf{p C i} / \mathbf{L})\end{array}$ & $\begin{array}{c}\text { Mean Water } \\
\text { Value } \\
(p C i / L)\end{array}$ & Ratio & $\begin{array}{l}\text { Sediment } \\
\text { BCG }^{a} \\
(\mathbf{p C i} / \mathrm{g})\end{array}$ & $\begin{array}{c}\text { Mean Sediment } \\
\text { Value } \\
(\mathbf{p C i} / \mathrm{g})\end{array}$ & Ratio & $\begin{array}{c}\text { Water and } \\
\text { Sediment } \\
\text { Sum of Fractions }\end{array}$ \\
\hline Cesium-137 & 42.7 & 2.94 & 6.89E-02 & 3,130 & 4.87 & $1.56 \mathrm{E}-03$ & 0.070 \\
\hline Strontium-90 & 279 & 37.8 & $1.36 \mathrm{E}-01$ & 583 & 0.667 & $1.14 \mathrm{E}-03$ & 0.14 \\
\hline All Others & NA & NA & $1.00 \mathrm{E}-04$ & NA & NA & $5.10 \mathrm{E}-04$ & $<0.001$ \\
\hline \multicolumn{3}{|c|}{ Sum of Fractions (Near-Term Data) } & $2.05 \mathrm{E}-01$ & & & $3.21 \mathrm{E}-03$ & 0.21 \\
\hline \multicolumn{6}{|c|}{ Sum of Fractions (Long-Term [10-Yr] Data) 4.47E-01 } & $5.65 \mathrm{E}-03$ & 0.45 \\
\hline \multicolumn{8}{|c|}{ Estimated upper bounding dose to an aquatic animal $=0.0059 \mathrm{rad} / \mathrm{day}$; to a riparian animal $=0.021 \mathrm{rad} / \mathrm{day}$. } \\
\hline \multicolumn{8}{|c|}{ Terrestrial System Evaluation (Near-Term Data Set) } \\
\hline Nuclide & $\begin{array}{c}\text { Water } \\
\text { BCG* }^{*} \\
(\mathbf{p C i} / \mathbf{L})\end{array}$ & $\begin{array}{c}\text { Mean Water } \\
\text { Value } \\
(p C i / L)\end{array}$ & Ratio & $\begin{array}{c}\text { Soil } \\
\text { BCG }^{a} \\
(\mathbf{p C i} / \mathbf{g})\end{array}$ & $\begin{array}{c}\text { Mean Soil } \\
\text { Value } \\
(\mathrm{pCi} / \mathrm{g})\end{array}$ & Ratio & $\begin{array}{c}\text { Water and } \\
\text { Soil } \\
\text { Sum of Fractions }\end{array}$ \\
\hline Cesium-137 & 599,000 & 2.94 & $4.91 \mathrm{E}-06$ & 20.8 & 4.78 & $2.30 \mathrm{E}-01$ & 0.23 \\
\hline Strontium-90 & 54,500 & 37.8 & $6.93 \mathrm{E}-04$ & 22.5 & 1.70 & $7.55 \mathrm{E}-02$ & 0.076 \\
\hline All Others & NA & NA & $2.09 \mathrm{E}-06$ & NA & NA & $5.00 \mathrm{E}-04$ & $<0.001$ \\
\hline \multicolumn{3}{|c|}{ Sum of Fractions (Near-Term Data) } & $7.00 \mathrm{E}-04$ & & & $3.06 \mathrm{E}-01$ & 0.31 \\
\hline \multicolumn{3}{|c|}{ Sum of Fractions (Long-Term [10-Yr] Data) } & $7.20 \mathrm{E}-04$ & & & $5.66 \mathrm{E}-01$ & 0.57 \\
\hline
\end{tabular}

a The biota concentration guides (BCGs) are calculated values. Except for the sums of fractions and dose estimates, which are rounded to two significant digits, all values are expressed to three significant digits.

NA - Not applicable

$$
2-30
$$


Table 2-6

\section{WVDP Radiological Dose and Release Summary}

WVDP Radiological Dose Reporting Table CY 2005

\begin{tabular}{|c|c|c|c|c|}
\hline $\begin{array}{c}\text { Dose to the } \\
\text { Maximally Exposed } \\
\text { Individual }\end{array}$ & $\begin{array}{c}\text { \% of DOE } \\
\text { 100-mrem Limit }\end{array}$ & $\begin{array}{c}\text { Estimated } \\
\text { Population Dose }\end{array}$ & $\begin{array}{c}\text { Population Within } \\
\text { 50 Miles } \\
\text { (2000 census })\end{array}$ & $\begin{array}{c}\text { Estimated Natural } \\
\text { Radiation Population } \\
\text { Dose }\end{array}$ \\
\hline $\begin{array}{cc}0.047 \\
\mathrm{mrem} \quad(\mathrm{mSv})\end{array}$ & 0.047 & $\begin{array}{c}0.23 \\
\text { person-rem } \\
(\text { person-Sv) }\end{array}$ & $1,536,000$ & $\begin{array}{c}0.0023 \\
\text { person-rem }\end{array}$ \\
\hline
\end{tabular}

\section{WVDP Radiological Atmospheric Emissions ${ }^{a}$ CY 2005 in Curies (Bq)}

\begin{tabular}{|c|c|c|c|c|c|c|c|c|c|c|}
\hline Tritium & Kr-85 & $\begin{array}{c}\text { Noble Gases } \\
\left(\mathbf{T}_{1 / 2}<\mathbf{4 0} \mathrm{dy}\right)\end{array}$ & $\begin{array}{c}\text { Short-Lived } \\
\text { Fission and } \\
\text { Activation } \\
\text { Products } \\
\left(T_{1 / 2}<3 \mathrm{hr}\right)\end{array}$ & $\begin{array}{c}\text { Fission and } \\
\text { Activation } \\
\text { Products } \\
\left(\mathrm{T}_{1 / 2}>3 \mathrm{hr}\right)\end{array}$ & $\begin{array}{c}\text { Total } \\
\text { Radioiodine }\end{array}$ & $\begin{array}{c}\text { Total } \\
\text { Radiostrontium }\end{array}$ & $\begin{array}{c}\text { Total } \\
\text { Uranium }^{b}\end{array}$ & $\begin{array}{c}\text { Total } \\
\text { Plutonium }\end{array}$ & $\begin{array}{c}\text { Total } \\
\text { Other } \\
\text { Actinides }\end{array}$ & $\begin{array}{c}\text { Other } \\
(\mathbf{R n - 2 2 0})\end{array}$ \\
\hline $\begin{array}{c}1.07 \mathrm{E}-03 \\
(3.96 \mathrm{E}+07)\end{array}$ & NA & NA & NA & $\begin{array}{c}1.11 \mathrm{E}-05 \\
(4.12 \mathrm{E}+05)\end{array}$ & $\begin{array}{c}3.80 \mathrm{E}-05 \\
(1.41 \mathrm{E}+06)\end{array}$ & $\begin{array}{c}6.93 \mathrm{E}-06 \\
(2.56 \mathrm{E}+05)\end{array}$ & $\begin{array}{c}1.30 \mathrm{E}-07 \\
(4.81 \mathrm{E}+03)\end{array}$ & $\begin{array}{c}5.34 \mathrm{E}-07 \\
(1.98 \mathrm{E}+04)\end{array}$ & $\begin{array}{c}6.95 \mathrm{E}-07 \\
(2.57 \mathrm{E}+04)\end{array}$ & $\begin{array}{c}1.10 \mathrm{E}+03 \\
(4.05 \mathrm{E}+13)\end{array}$ \\
\hline
\end{tabular}

WVDP Liquid Effluent Releases ${ }^{c}$ of Radionuclide Material CY 2005 in Curies (Bq)

\begin{tabular}{|c|c|c|c|c|c|c|}
\hline Tritium & $\begin{array}{c}\text { Fission and } \\
\text { Activation } \\
\text { Products } \\
\left(\mathbf{T}_{1 / 2}>\mathbf{3} \mathbf{h r}\right)\end{array}$ & $\begin{array}{c}\text { Total } \\
\text { Radioiodine }\end{array}$ & $\begin{array}{c}\text { Total } \\
\text { Radiostrontium }\end{array}$ & $\begin{array}{c}\text { Total } \\
\text { Uranium }\end{array}$ & $\begin{array}{c}\text { Total } \\
\text { Plutonium }\end{array}$ & $\begin{array}{c}\text { Total } \\
\text { Other } \\
\text { Actinides }\end{array}$ \\
\hline $8.12 \mathrm{E}-02$ & $\begin{array}{c}5.91 \mathrm{E}-03 \\
(2.19 \mathrm{E}+08)\end{array}$ & $\begin{array}{c}1.62 \mathrm{E}-04 \\
(5.99 \mathrm{E}+06)\end{array}$ & $\begin{array}{c}2.35 \mathrm{E}-01 \\
(8.68 \mathrm{E}+09)\end{array}$ & $\begin{array}{c}7.87 \mathrm{E}-04 \\
(2.91 \mathrm{E}+07)\end{array}$ & $\begin{array}{c}6.17 \mathrm{E}-06 \\
(2.28 \mathrm{E}+05)\end{array}$ & $\begin{array}{c}1.93 \mathrm{E}-05 \\
(7.12 \mathrm{E}+05)\end{array}$ \\
\hline
\end{tabular}

Note: There are no known significant discharges of radioactive constituents from the site other than those reported in this table.

NA - Not applicable

${ }^{a}$ Air releases are from point sources.

${ }^{b}$ Total uranium $($ grams $)=1.08 E-01$

${ }^{c}$ Water releases are from both controlled liquid effluent releases and from well-characterized site drainages.

${ }^{d}$ Total uranium $($ grams $)=5.85 E+02$

$$
2-31
$$


This page intentionally left blank

$2-32$ 


\section{ENVIRONMENTAL NONRADIOLOGICAL PROGRAM INFORMATION}

Overview of New York State Water Classifications, Water Quality Standards, and Water Effluent Limits

The objective of the Clean Water Act of 1972 (CWA) (as stated in Section 101 of the Act) is to restore and maintain the integrity of the nation's waters and ensure that, wherever attainable, waters be made useful for fishing and swimming. To achieve this goal, New York State is delegated with authority under Sections 118, 303, and 510 of the CWA to (1) classify and designate the best uses for receiving waters, such as streams and rivers, within its jurisdiction; and (2) establish and assign water quality standards - goals for achieving the designated best uses for these classified waters. In addition to achieving CWA goals for fishing and swimming, New York has further classified its jurisdictional waters and established ambient water standards, guidelines, and maximum contaminant levels (MCLs) to achieve objectives under the Safe Drinking Water Act for drinking water. These standards serve as the basis for periodic evaluation of the integrity of the receiving waters and identification of needed controls, such as New York State Pollutant Discharge Elimination System (SPDES) permits and effluent limitations.
The definitions for best usage classifications of New York's jurisdictional waters and the water quality standard goals for these classifications are provided in Title 6 of the Official Compilation of Codes, Rules, and Regulations of the State of New York (6 NYCRR) Parts 701-704. Mapping of the Cattaraugus Creek drainage basin and assignment of best usage designations and classification to each receiving water segment within this drainage basin are described in 6 NYCRR Part 838. According to these regulations, Frank's Creek, Quarry Creek, and segments of Buttermilk Creek under the influence of West Valley Demonstration Project (WVDP) water effluents are identified as Class " $C$ " receiving waters with a minimum designated best usage for fishing with conditions suitable for fish propagation and survival. Cattaraugus Creek, in the immediate downstream vicinity of the Western New York Nuclear Service Center (WNYNSC), is identified as a Class "B" receiving water with best designated usages for swimming and fishing. All fresh (nonsaline) groundwaters within New York are assigned a "GA" classification with a designated best usage as a potable water supply source.

Presented in Appendix C- $1^{\text {cod }}$ is a summary of the numerical water quality standards, guidelines, and MCLs assigned to these water classifications for those substances and parameters that are included 
in the WVDP environmental monitoring program for ambient water. Also included in Appendix $\mathrm{C}-1^{\text {(c) }}$ are SPDES permit discharge limits for site effluents.

\section{Surface Water, Subsurface Drainage Water, and Water Effluent Monitoring}

Appendix C-2 ${ }^{\mathrm{CD}}$ contains process effluent data with SPDES permit limits provided for comparison with these data. Appendix C- $3^{\text {GD }}$ contains storm water runoff monitoring data for storm water outfalls designated in the WVDP SPDES permit. Appendices C $-4^{\text {GD }}$ through C- $6^{\text {CDD }}$ present data for ambient surface water, subsurface drainage water, contained water, and potable water monitoring locations. Also provided for side-by-side comparison with these data are reference values, where available, including background ambient water monitoring data and/ or pertinent ambient water quality standards (AWQS), guidelines, or MCLs.

SPDES Permit-Required Monitoring. Liquid discharges from the WVDP are regulated under the SPDES permit as identified in Table ECS-2. This SPDES permit identifies outfalls from which liquid effluents are released to Erdman Brook (Fig. A-2) and specifies the sampling and analytical requirements for each outfall. In January 2005, the permit was modified by the New York State Department of Environmental Conservation (NYSDEC) to include monitoring requirements for 20 storm water discharge outfalls from the site. The conditions and requirements of the SPDES permit are summarized in Appendix C-1 ${ }^{\text {[DD }}$. The permit identifies 25 outfalls and compliance points with monitoring requirements and discharge limits. The monitored outfalls include:

- outfall 001 (monitoring point WNSP001), discharge from the low-level waste treatment facility (LLWTF)
- outfall 007 (monitoring point WNSP007), discharge from the sanitary and industrial wastewater treatment facility

- outfall 008 (monitoring point WNSP008), a groundwater french drain around the perimeter of the LLWTF storage lagoons (closed in May 2001 but still in the permit)

- outfall 116 (pseudo-monitoring point WNSP116), a location in Frank's Creek that represents the confluence of outfalls WNSP001, WNSP007, and WNSP008, as well as storm water runoff, groundwater seepage, and augmentation water. Samples from upstream sources are used to calculate total dissolved solids (TDS) at this location and to demonstrate compliance with the SPDES permit limit for this parameter. (Outfall 116 is referred to as a "pseudo-monitoring" point on the SPDES permit.)

- outfall 01B (monitoring point WNSP01B), an internal monitoring point for the liquid waste treatment system evaporator effluent, being monitored for flow and total mercury.

The 20 storm water discharge outfalls that also receive flows from other minor sources, such as fire hydrant testing and groundwater seepage, are required to be monitored on a rotational basis.

Some of the more significant features of the SPDES permit are the requirements to report fiveday biochemical oxygen demand $\left(\mathrm{BOD}_{5}\right)$, TDS, iron, and ammonia data as flow-weighted concentrations and to apply a net discharge limit for iron. The net limit allows the Project to account for the iron that is naturally present in the site's incoming water. The flow-weighted limits apply to the flowproportioned sum of the Project effluents.

There were no SPDES effluent limit exceptions in CY 2005. 
Mercury Analytical Method Study. In a July 2002 SPDES permit modification, NYSDEC required that samples being collected for measurement of mercury be analyzed by two different methods to conduct a comparison study. The methods are United States (U.S.) Environmental Protection Agency (EPA) Method 245.1 (or 245.2) with a detection level of 0.2 micrograms/liter $(\mu \mathrm{g} / \mathrm{L})$ (parts per billion) and EPA Method 1631E, which allows determination of mercury at a minimum level of 0.5 nanograms/liter (ng/L) (parts per trillion). The latter ("ultraclean") method supports the EPA's effort to make available an additional analytical method capable of measuring mercury accurately at ambient water quality criteria levels.

Since the SPDES permit enforcement compliance limit of $0.2 \mu \mathrm{g} / \mathrm{L}$ for total mercury is several orders of magnitude higher than the AWQS of 0.0007 $\mu \mathrm{g} / \mathrm{L}$ for dissolved mercury, the comparison study is required under the terms of the SPDES permit. A report summarizing the analytical results from these two methods and its findings is required to be submitted semiannually to NYSDEC.

Fourteen sets of samples from outfall 001 were analyzed for mercury by the two test methods in 2005. Samples were analyzed at Severn Trent Laboratories using Method 245.1 and at General Engineering Laboratories using Method 1631E.

All sample results from Method 245.1 were less than $0.2 \mu \mathrm{g} / \mathrm{L}$, the practical quantitation limit for Method 245.1. Results generated with Method $1631 \mathrm{E}$ were consistent with results generated with Method 245.1. That is, all sample results generated with Method 1631E were reported at levels below $0.2 \mu \mathrm{g} / \mathrm{L}$. The average concentration for samples collected at outfall 001 using Method $1631 \mathrm{E}$ was $0.0044 \mu \mathrm{g} / \mathrm{L}(4.4 \mathrm{ng} / \mathrm{L})$.
Storm Water Discharge Monitoring. The SPDES permit was modified by NYSDEC in January 2005 to support the regulatory objective to define and control the risk to human health and aquatic resources from contaminated storm water runoff. The objectives of permit requirements are to determine (1) the levels of water quality and specific chemicals in storm water discharges from specified locations on the WVDP, (2) the amount of rainfall, (3) duration of the storm event, and (4) the resulting flow at the outfalls. The 20 storm water outfalls at the WVDP are grouped into eight representative drainage basins that could potentially be influenced by industrial or construction activity runoff. The modified SPDES permit, effective January 1,2005 , requires that one outfall, representative of each of the eight outfall groups listed in Appen$\operatorname{dix} B^{\text {CDD }}$, be sampled on a semiannual basis.

The SPDES permit recommends the following guidelines for a qualifying storm water event eligible for monitoring:

- a period of 72 hours between the monitored event and the previous measurable event of 0.1 inches of precipitation;

- a total rainfall of more than $0.1 \mathrm{inch}$;

- resultant storm discharge at the outfall.

During the first half of 2005, five of the eight sampling groups were sampled during qualifying rain events, and all eight groups were sampled during qualifying rain events during the second half of the year. The permit requirement to sample one of each outfall group was not met due to the low precipitation during early calendar year 2005.

Appendix C- $3{ }^{\text {미 }}$ presents all storm water discharge event monitoring data. The analysis of storm water discharge samples produced noticeable concentrations of indicator parameters (in particular $\mathrm{BOD}_{5}$, 
TDS, and total suspended solids) and associated inorganic parameters (in particular aluminum, copper, iron, and lead). The sources for the noteworthy concentrations in storm water runoff of these naturally occurring substances include residuals from deicing material (sand and salt mixture) applications, fine sediments from placement of quarried materials delivered from off-site sources, residuals from corrosion of material and equipment, vegetation particles, and natural silts and fine sediments from soil erosion, including those that escape strategically placed erosion and sediment control devices, such as fabric filter fences.

\section{South Plateau Surface and Subsurface Water} Monitoring. An inactive underground radioactive waste disposal site, the U.S. Nuclear Regulatory Commission (NRC)-Licensed Disposal Area (NDA), lies on the south plateau of the site. Surface waters, which flow from the south to the north, are routinely monitored at several points around this area (Fig. A-2). Two of these points, WNNDATR and WNNDADR, are used to monitor (respectively) waters within the NDA water collection trench system and surface runoff and seepage immediately downstream of the NDA. Sampling point WNNDATR is an underground sump at the lowest point in the collection trench system that intercepts groundwater from the NDA. If radiological or nonradiological contamination were to migrate through the NDA, it would most likely be first detected in samples from WNNDATR.

Interceptor Trench and Pretreatment System. Radioactively-contaminated n-dodecane (similar to kerosene) in combination with tributyl phosphate (TBP) was discovered at the northern boundary of the NDA in 1983. To contain migration of this subsurface radioactive organic contaminant, an interceptor trench and a liquid pretreatment system (LPS) were built. (See "NRC-Licensed Disposal Area [NDA] Interceptor Trench and Pretreatment System" in Chapter 1.)
The trench was designed to intercept and collect subsurface water, which could be carrying ndodecane/TBP, to prevent the material from entering the surface water drainage ditch leading into Erdman Brook, and to prevent contamination of downgradient groundwater. The LPS was installed to separate the n-dodecane/TBP and to remove iodine-129 from the collected water before its transfer to the LLWTF. The separated ndodecane/TBP would be stored for subsequent treatment and disposal.

In 2005, as in previous years, no water containing TBP was encountered in the trench. Results of surface and groundwater monitoring in the vicinity of the trench are discussed under "South Plateau Surface Water and NDA Interceptor Trench" in Chapter 2 and "Results of Monitoring at the NDA" in Chapter 4.

Total Organic Halides. Total organic halides (TOX) measurements are used as a screening mechanism to detect the presence of certain organic compounds and associated radionuclides. In 2005, concentrations of TOX at both WNNDATR and WNNDADR remained within the range of historical values.

Other On-Site and Off-Site Surface Water Monitoring. As part of the routine monitoring program, two sets of grab samples for nonradiological parameters at WNSP006 (Frank's Creek at the security fence), WNSWAMP (northeast swamp drainage), WNSW74A (north swamp drainage), WFBCTCB (Buttermilk Creek at Thomas Corners), and WFBCBKG (Buttermilk Creek at Fox Valley) were taken in 2005. These samples were screened for organic and inorganic constituents and selected anions, cations, and metals.

At surface water monitoring locations WFBCTCB, WNSP006, and background reference location WFBCBKG, the maximum concentrations of total 
iron exceeded the water quality standard ( 0.30 milligrams/liter [mg/L]). NYSDEC, in its $2002 \mathrm{CWA}$ 303(d) report to the EPA, indicated it found the scientific basis for the $0.30 \mathrm{mg} / \mathrm{L}$ standard to be insufficient. NYSDEC also indicated that its upcoming standards review is expected to include a proposed replacement of the $0.30 \mathrm{mg} / \mathrm{L}$ standard with a 1.0 $\mathrm{mg} / \mathrm{L}$ guidance value, based on 1976 EPAcriteria. Nonetheless, iron concentrations at these locations also exceeded this replacement value. Elevated iron concentrations are attributable to elevated background concentrations, runoff from industrial activities, fine sediments from placement of quarried materials delivered from off-site sources, and natural silts and fine sediments from soil erosion.

The maximum observed concentrations of dissolved aluminum at surface water locations WFBCTCB, WNSP006, and WFBCBKG exceeded the water quality standard for this parameter. Elevated aluminum concentrations are attributable to the same sources as identified for iron.

With the exception of iron and aluminum, the other nonradiological constituents remained within the range of historical values. Results of measurements for these locations are found in Appendi-

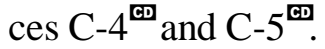

\section{Drinking Water Monitoring}

Site drinking water is monitored at the distribution entry point (WNDNKUR) and at other site tap water locations to verify compliance with EPA and New York State Department of Health (NYSDOH) regulations. (See "Safe Drinking Water Act" in the Environmental Compliance Summary.) Samples are collected and analyzed for metals, nitrate, fluoride, cyanide, principal organic contaminants, residual chlorine, and biological constituents. Adetailed sampling schedule and listing of constituents is presented in Appendix $\mathrm{B}^{\mathrm{G}}$. Analytical results may be found in Appendix C- $6^{\text {cod }}$.
Results indicated that in 2005, the Project's drinking water continued to meet MCLs and drinking water standards of the EPA, NYSDOH, and the Cattaraugus County Health Department.

\section{Soil and Sediment Monitoring}

Sediments are found at the bottom of surface waters, including streams located within the WVDP and the WNYNSC premises. Sediments provide habitat for a wide variety of bottom-dwelling (benthic) organisms, as well as juvenile forms of open-water (pelagic) organisms. These organisms in sediments are in constant contact with substances that may be adsorbed to sediment particles. Contaminated sediments are potential diffuse sources of contamination to the overlying body of water.

In 1999, NYSDEC issued updated guidance for screening contaminated aquatic sediments. This guidance includes sediment quality criteria correlated to the severity of environmental impact. These criteria, which are derived from National Oceanic and Atmospheric Administration (Long and Morgan, 1990) and 1992 Ministry of Ontario "Guidelines for the Protection and Management of Aquatic Sediment Quality in Ontario" (Persaud et al., 1992), are presented in Appendix G- $1^{\text {cod }}$.

Contaminants in soils are potential sources for contamination of groundwater, ambient air, flora, and fauna. Appendix G-1 ${ }^{\text {Go }}$ includes a summary of reference criteria, including background concentration ranges for eastern United States soils and sediment screening levels. Data for soil and sediment monitoring locations are provided in Appendix G-2 ${ }^{\text {GD }}$. Also, provided for side-by-side comparison with these data, are available reference values, including background concentrations and/or sediment screening levels. 
At SNSP006, all analytical results for sediments were below the Severe Effect Level and No Appreciable Contaminant Levels specified in the NYSDEC guidance. According to the NYSDEC "Technical Guidance for Screening Contaminated Sediments," these results suggest there is no pronounced disturbance of the sediment-dwelling biological community and that there is no significant harm to benthic life at this location.

The results for arsenic, copper, manganese, and nickel in the sediment sample obtained at SNSP006 exceeded the Lowest Effect Level but was below the Severe Effect Level. Based on the NYSDEC sediment screening guidance, moderate impacts to benthic life could be expected at this location.

At SNSW74A and SNSWAMP, concentrations of zinc exceeded the eastern United States background soil concentration range identified in the NYSDEC Technical Administrative Guidance Memorandum (TAGM) \#4046 "Determination of Soil Clean-Up Objectives and Clean-Up Levels." Calcium and magnesium at SNSW74A also exceeded the eastern background soil concentration range. Concentrations of these naturally occurring metals above the natural background ranges may be indicative of localized, naturally elevated background concentrations of metals in soils or deposition of sediment from runoff from areas where industrial activities are occurring. Calcium and magnesium are also constituents used in deicing salts on site.

Lag Storage Area (LSA) \#2 Hardstand. In 2005, soils from the truck staging area for LSA \#2, a radioactive and Resource Conservation and Recovery Act hazardous waste storage area, were sampled and analyzed for chemical residuals. The test results indicated that the soil did not have any appreciable contamination, as all but one result (lead) were within proposed site-specific soil cleanup objectives specified in NYSDEC guidance,
TAGM \#4046. The single noted result for lead was determined to be an anomaly associated with analytical imprecision as re-analysis of the same sample produced two additional results that were closer to each other, lower than the original result, and within the proposed NYSDEC guidance. Refer to Appendix G-2 ${ }^{\mathrm{WD}}$ for these test results.

\section{Air Emission Monitoring}

Nonradiological air emissions are permitted under NYSDEC and EPA regulations. The regulations that apply to the WVDP are listed in Appendix $K^{\mathrm{GD}}$. The New York State Air Facility Registration Certificate for the WVDP is described in the WVDP Environmental Permits table, ECS-2, in the "Environmental Compliance Summary."

The nonradiological air certificate covers emissions of regulated pollutants that include nitrogen oxides and sulfur dioxide.

The main source of oxides of nitrogen and sulfur at the WVDP was the vitrification system melter, which was shut down in September 2002. Site boilers are left as the only sources of nitrogen and sulfur oxides, at levels much lower than those emitted by the melter. During 2005, approximately 3,700 kilograms (kg) (4.1 tons) of nitrogen oxides and less than $10 \mathrm{~kg}$ ( 0.01 tons) of sulfur dioxide were emitted from these remaining units. These releases comprised about $4.1 \%$ and $0.01 \%$, respectively, of the 99-ton annual capping limit for each. 


\section{GROUNDWATER PROTECTION PROGRAM}

\section{Groundwater Monitoring Program Overview}

Groundwater monitoring at the West Valley Demonstration Project (WVDP or Project) complies with all applicable state and federal regulations and meets the requirements of United States (U.S.) Department of Energy (DOE) Order 450.1. Data obtained from the program enables site managers to determine baseline groundwater conditions, facilitates early detection of existing and potential groundwater contamination sources, provides surveillance of these sources, and provides information for decision-making.

The "WVDP Groundwater Protection Management Program Plan" documents the Project's approach to the protection of groundwater from on-site activities. The WVDP's groundwater monitoring program is outlined in the "Groundwater Monitoring Plan," which discusses groundwater characterization, current groundwater sampling agenda, and compliance with long-term monitoring requirements as identified in the Resource Conservation and Recovery Act (RCRA) facility investigation (RFI) and DOE Orders.

Site groundwater is not used for drinking or operational purposes, nor is effluent discharged directly to groundwater. No public water supplies are drawn from groundwater downgradient of the site or from downstream Cattaraugus Creek. Upgradient of the site, groundwater is used for drinking water by local residents.

\section{Surface Water Hydrology}

The 167-acre (68-hectare [ha]) Project site is located within the Western New York Nuclear Service Center (WNYNSC), which comprises approximately 3,338 acres $(1,351 \mathrm{ha})$ and is located near the northern border of Cattaraugus County. The WNYNSC lies within the Cattaraugus Creek watershed, which empties into Lake Erie about 27 miles (43 kilometers) southwest of Buffalo. Buttermilk Creek, a tributary of Cattaraugus Creek, drains most of the WNYNSC and all of the WVDP.

The WVDP lies within the watershed of Frank's Creek, a tributary of Buttermilk Creek, which flows along the eastern and southern boundaries of the WVDP. Quarry Creek, a tributary of Frank's Creek, flows along the northern boundary of the WVDP (Fig. A-1). Erdman Brook, another tributary of Frank's Creek, bisects the WVDP into a north and south plateau. The main plant, waste tanks, and lagoons are located on the north plateau. The drum cell, the U.S. Nuclear Regulatory Commission (NRC)-Licensed Disposal Area 
(NDA), and the New York State-Licensed Disposal

Area (SDA) are located on the south plateau.

\section{Geology}

The WNYNSC is situated upon a layered sequence of glacial-age sediments that fill a steepsided bedrock valley that is composed of interbedded shales and siltstones (Rickard, 1975).

The glacial sediments overlying the bedrock consist of a sequence of three glacial tills of Lavery, Kent, and possibly Olean age. The tills are separated by stratified fluvio-lacustrine deposits (silty or silty/sandy lakebed sediments). On the Project's north plateau, the Lavery till is capped by coarsegrained alluvial-fluvial deposits (sandy/silty/gravelly streambed sediments).

\section{Hydrogeology}

The sediments above the Kent till - the Kent recessional sequence, the Lavery till, the intra-Lavery till-sand, and the alluvial sand and gravel - are generally regarded as containing all of the potential routes for contaminant migration from the Project via groundwater. (Figs. 4-1 and 4-2 show the relative locations of these sediments on the north and south plateaus.) The Lavery till, the Kent recessional sequence, and the Kent till are common to both the north and south plateaus. The bottommost layer, the Kent till, is less permeable than the other geological units and does not provide a pathway for contaminant movement from the WVDP; therefore, it is not discussed here.

Kent Recessional Sequence. The Kent recessional sequence consists of a fine-grained lacustrine unit of interbedded clay and silty clay layers locally overlain by coarse-grained sands and gravels. These deposits underlie the Lavery till beneath most of the site, pinching out along the southwestern margin of the site where the walls of the east- ward-sloping bedrock valley intersect the sequence.

Groundwater flow in the Kent recessional sequence is predominantly to the northeast, discharging to Buttermilk Creek. Mean hydraulic conductivity is $2 \mathrm{E}-01$ feet (ft)/day (8E-05 centimeters [cm]/second [sec]) or 2.6 inches/day, based on recent testing. Recharge comes from the overlying Lavery till and inflow from the bedrock to the southwest.

Lavery Till. The Lavery till is predominantly an olive-gray, silty clay glacial till with scattered lenses of silt and sand. It underlies both the north and south plateaus and ranges up to $130 \mathrm{ft}$ (40 meters [m]) in thickness beneath the active areas of the site, slightly increasing northeastward toward Buttermilk Creek and the center of the bedrock valley.

Groundwater flow in the unweathered Lavery till is predominantly vertically downward at a relatively slow rate. Mean hydraulic conductivity is $1 \mathrm{E}-04 \mathrm{ft} /$ day $(3.5 \mathrm{E}-08 \mathrm{~cm} / \mathrm{sec})$ or 0.001 inches/ day, based on recent testing.

On the south plateau, the upper zone of the Lavery till is exposed at the ground surface and is weathered and fractured to a depth of 3 to $16 \mathrm{ft}$ ( 0.9 to $4.9 \mathrm{~m})$. This layer, referred to as the weathered Lavery till, is unique to the south plateau. The weathered Lavery till has been oxidized to a brown color and contains numerous desiccation cracks and root tubes.

Groundwater flow in the weathered till has both horizontal and vertical components. This enables groundwater to move laterally across the south plateau before moving downward into the unweathered Lavery till or discharging to nearby incised stream channels. Mean hydraulic conductivity is $5 \mathrm{E}-02 \mathrm{ft} /$ day $(2 \mathrm{E}-05 \mathrm{~cm} / \mathrm{sec})$ or 0.6 inches/day, based on recent testing. The highest 
Hydrogeology

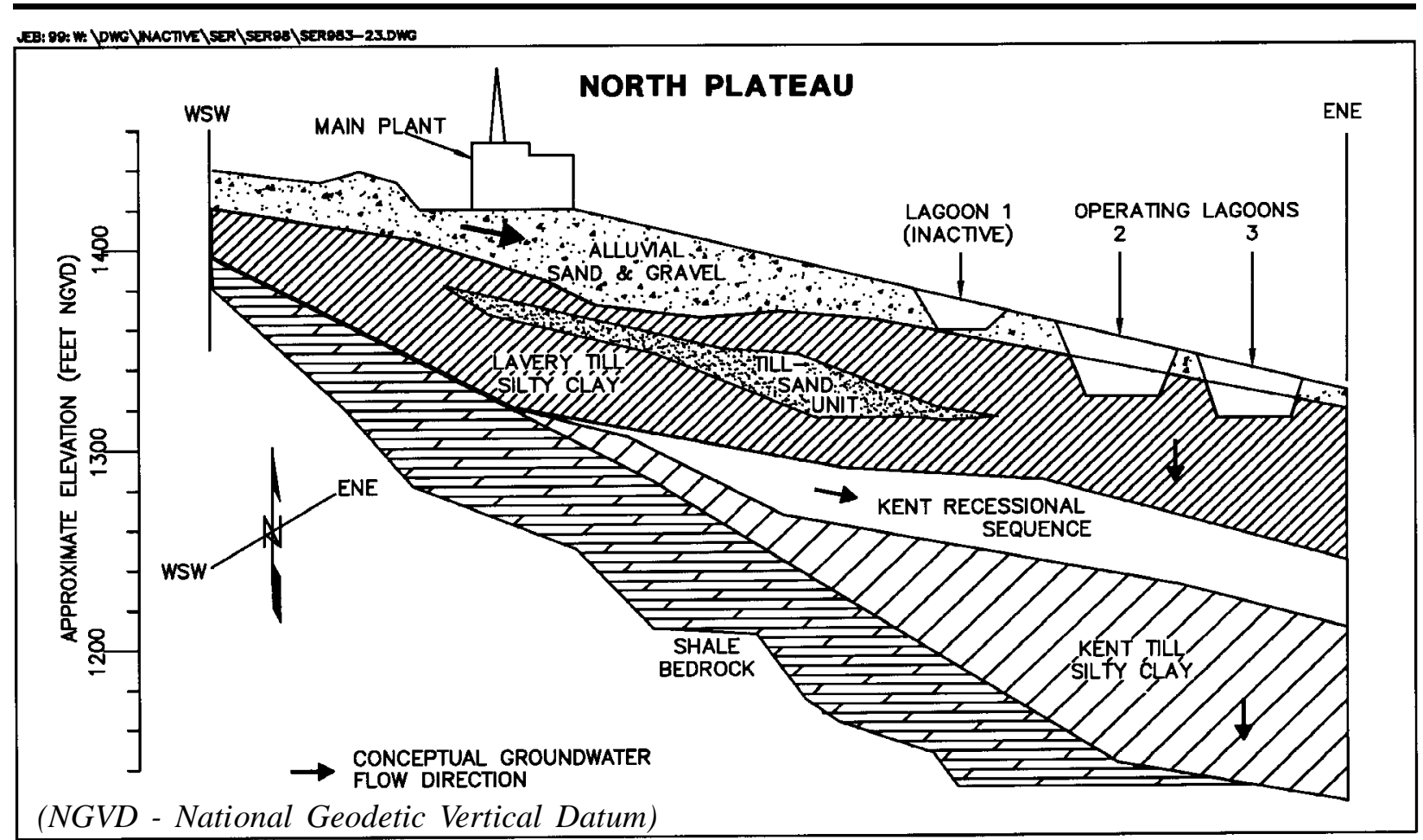

Figure 4-1. Geologic Cross Section Through the North Plateau (Vertical Exaggeration Approx. 2:1)

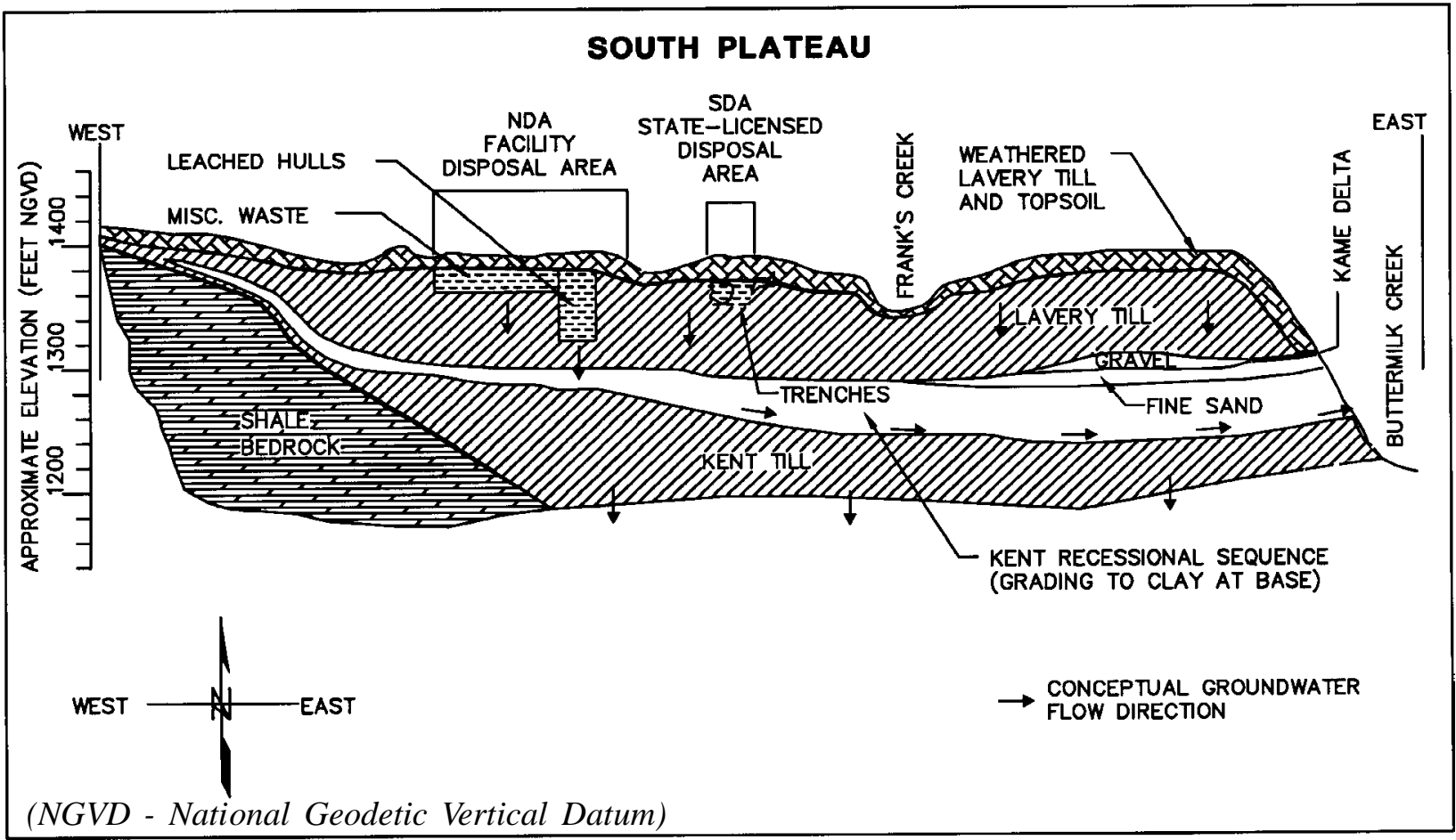

Figure 4-2. Geologic Cross Section Through the South Plateau (Vertical Exaggeration Approx. 2.5:1)

$$
4-3
$$


conductivities are associated with dense fracture zones found within the upper $7 \mathrm{ft}(2 \mathrm{~m})$ of the unit.

On the north plateau, the weathered till layer is much thinner or nonexistent and the unweathered Lavery till is directly overlain by the sand and gravel unit.

Sand and Gravel and Till-Sand Units. The sand and gravel unit and the Lavery till-sand are unique to the north plateau. The sand and gravel unit is a silty sand and gravel layer composed of younger Holocene alluvial deposits that overlie older Pleistocene-age glaciofluvial deposits. Together these two layers range up to $41 \mathrm{ft}(12.5 \mathrm{~m})$ in thickness near the center of the plateau and pinch out along the northern, eastern, and southern edges of the plateau, where they have been truncated by downward erosion of stream channels or depositional processes.

Groundwater in this unit generally flows northeastward across the plateau toward Frank's Creek. Groundwater near the northwestern and southeastern margins of the sand and gravel layer also flows radially outward toward Quarry Creek and Erdman Brook, respectively. There is minimal groundwater flow downward into the underlying Lavery till. Mean hydraulic conductivity is $16.4 \mathrm{ft} /$ day $(6 \mathrm{E}-03 \mathrm{~cm} / \mathrm{sec})$ or 200 inches/day, based on hydraulic conductivity field testing performed during the last five years.

Within the unweathered Lavery till on the north plateau is another unit, the Lavery till-sand. This thin, sandy unit of limited areal extent and variable thickness is found primarily beneath the southeastern portion of the north plateau. Groundwater flows through this unit in an east-southeast direction toward Erdman Brook, and surface seepage locations from the unit into Erdman Brook have not been observed. Mean hydraulic conductivity is $3.8 \mathrm{ft} /$ day $(1 \mathrm{E}-03 \mathrm{~cm} / \mathrm{sec})$ or 46 inches/day, based on hydraulic conductivity field testing performed during the last five years.

Hydrologic conditions of the site are more fully described in "Environmental Information Document, Volume III: Hydrology, Part 4" (West Valley Nuclear Services Co. [WVNSCO], March 1996) and in the "RCRA Facility Investigation Report Vol. 1: Introduction and General Site Overview" (WVNSCO and Dames \& Moore, July 1997).

\section{Routine Groundwater Monitoring Program}

Groundwater is routinely monitored in the five hydrogeologic units previously described: the sand and gravel, the weathered Lavery till, the unweathered Lavery till, the Lavery till-sand, and the Kent recessional sequence. In 2005, a total of 69 on-site groundwater monitoring locations were sampled. These locations included 63 monitoring wells and well points, five groundwater seepage points, and one sump/manhole. Tables 4-1 and 4-2 provide a 2005 groundwater monitoring overview by geographic area and by monitoring purpose.

Monitoring Well Network. The majority of the routine groundwater monitoring wells were originally installed to monitor one (or more) solid waste management unit (SWMU) on the WVDP premises. (See "RCRA $§ 3008(h)$ Administrative Order on Consent" [the Consent Order] in the "Environmental Compliance Summary.") Because many SWMUs are contiguous or so close together as to make their separate monitoring impractical, most SWMUs have been grouped into large units called super SWMUs (SSWMUs). The term "super SWMU" is unique to the WVDP and is not an official regulatory term. Table 4-3 describes the SSWMUs and their constituent SWMUs on site. Figures A-9 and A-10 in Appendix A show the locations of 11 of the WVDP SSWMUs. 


\section{Table 4-1 \\ Groundwater Monitoring Overview by Geographic Area: Monitoring Year 2005}

\begin{tabular}{|l|c|c|c|c|}
\hline \multicolumn{1}{|c|}{ NUMBER OF... } & $\begin{array}{c}\text { Total } \\
\text { WVDP }\end{array}$ & $\begin{array}{c}\text { North } \\
\text { Plateau }\end{array}$ & $\begin{array}{c}\text { South } \\
\text { Plateau }\end{array}$ & $\begin{array}{c}\text { Off-site } \\
\text { Residential }\end{array}$ \\
\hline Monitoring Points Sampled - Analytical $^{a}$ & 70 & 54 & 15 & 1 \\
\hline Monitoring Points - Water Elevations Only & 55 & 39 & 16 & 0 \\
\hline Monitoring Events & 5 & 4 & 4 & 1 \\
\hline Analyses & 1,247 & 1,080 & 159 & 8 \\
\hline Results & 10,767 & 9,546 & 1,203 & 18 \\
\hline Percent of Nondetectable Results & $86 \%$ & $87 \%$ & $85 \%$ & $56 \%$ \\
\hline Water Elevation Measurements & 464 & 340 & 124 & 0 \\
\hline
\end{tabular}

${ }^{a}$ Total number includes 69 on-site monitoring points and 1 off-site monitoring point.

Table 4-2

Groundwater Monitoring Overview by Monitoring Purpose: Monitoring Year 2005

\begin{tabular}{|c|c|c|}
\hline NUMBER OF... & $\begin{array}{c}\text { Regulatory/ } \\
\text { Waste Management }\end{array}$ & $\begin{array}{c}\text { Environmental } \\
\text { Surveillance }\end{array}$ \\
\hline Monitoring Points Sampled - Analytical $^{a}$ & 34 & 36 \\
\hline Monitoring Points - Water Elevations Only & 0 & 55 \\
\hline Monitoring Events & 4 & 5 \\
\hline Analyses & 619 & 619 \\
\hline Results & 5,490 & 5,277 \\
\hline Percent of Nondetectable Results & $86 \%$ & $87 \%$ \\
\hline Water Elevation Measurements & 128 & 336 \\
\hline \multicolumn{3}{|l|}{$\begin{array}{l}\text { Ranges of Results For Positive Detections For } \\
\text { Organic Compounds }(\mu \mathrm{g} / \mathrm{L})\end{array}$} \\
\hline 1,1-Dichloroethane & $7.0-11$ & NA \\
\hline 1,2-Dichloroethylene (total) & $22-30$ & NA \\
\hline Tributyl phosphate & $2.0-360^{b}$ & NA \\
\hline \multicolumn{3}{|l|}{$\begin{array}{l}\text { Maximum Concentrations For } \\
\text { Radiological Parameters }(\mu \mathrm{Ci} / \mathrm{mL})\end{array}$} \\
\hline Gross Beta & $2.04 \mathrm{E}-04$ & $1.16 \mathrm{E}-04$ \\
\hline Strontium-90 & $8.79 \mathrm{E}-05$ & $5.23 \mathrm{E}-05$ \\
\hline Tritium & $5.32 \mathrm{E}-06$ & $5.01 \mathrm{E}-05$ \\
\hline
\end{tabular}

NA - Not applicable

${ }^{a}$ Total number includes 69 on-site points and 1 off-site point.

${ }^{b}$ This value was the hightest of four analytical results reported at well WNW8605 during the third quarter of 2005; the value calculated and reported for well WNW8605 in Table E-9 $9^{\text {का }}$ is an average of all four results. 


\section{Table 4-3}

\section{WVDP RCRA SSWMUs and Constituent SWMUs}

\begin{tabular}{|c|c|}
\hline SSWMU & CONSTITUENT SWMUs \\
\hline SSWMU \#1 - Low-Level Waste Treatment Facilities (LLWTF) & $\begin{array}{l}\text { Former Lagoon } 1 \\
\text { LLWTF Lagoons } \\
\text { LLWTF Building } \\
\text { Interceptors } \\
\text { Neutralization Pit }\end{array}$ \\
\hline SSWMU \#2 - Miscellaneous Small Units & $\begin{array}{l}\text { Sludge Ponds } \\
\text { Solvent Dike } \\
\text { Equalization Mixing Basin } \\
\text { Paper Incinerator }\end{array}$ \\
\hline SSWMU \#3 - Liquid Waste Treatment System (LWTS) & $\begin{array}{l}\text { LWTS } \\
\text { Cement Solidification System } \\
\text { Main Process Building (specific areas) }\end{array}$ \\
\hline $\begin{array}{l}\text { SSWMU \#4 - High-Level Waste (HLW) Storage and Processing } \\
\text { Area }\end{array}$ & $\begin{array}{l}\text { Vitrification Facility } \\
\text { Vitrification Test Tanks } \\
\text { HLW Tanks } \\
\text { Supernatant Treatment System }\end{array}$ \\
\hline SSWMU \#5 - Maintenance Shop Leach Field & Maintenance Shop Leach Field \\
\hline SSWMU \#6 - Low-Level Waste Storage Area & $\begin{array}{l}\text { Lag Storage Additions 1, 2, 3, } 4 \\
\text { Hardstands (old and new) } \\
\text { Lag Storage }\end{array}$ \\
\hline SSWMU \#7 - Chemical Process Cell (CPC) Waste Storage Area & CPC Waste Storage Area \\
\hline SSWMU \#8 - Construction and Demolition Debris Landfill & $\begin{array}{l}\text { Former Construction and Demolition Debris } \\
\text { Landfill }\end{array}$ \\
\hline SSWMU \#9 - NRC-Licensed Disposal Area (NDA) & $\begin{array}{l}\text { NDA } \\
\text { Container Storage Area } \\
\text { Trench Interceptor Project }\end{array}$ \\
\hline $\begin{array}{l}\text { SSWMU \#10 - Integrated Radwaste Treatment System (IRTS) Drum } \\
\text { Cell }\end{array}$ & IRTS Drum Cell \\
\hline \multicolumn{2}{|l|}{ OTHER SSWMUS } \\
\hline SSWMU \#11 - New York State-Licensed Disposal Area (SDA) & $\begin{array}{l}\text { The SDA is a closed radioactive waste landfill that } \\
\text { is contiguous with the Project premises and is } \\
\text { owned and managed by the New York State Energy } \\
\text { Research and Development Authority (NYSERDA). } \\
\text { For more information, see the NYSERDA website at } \\
\text { www.nyserda.org. }\end{array}$ \\
\hline
\end{tabular}

$4-6$ 
Table E- $1^{\text {cod }}$ lists the wells in the network, sorted by the geologic unit monitored, and the analytes measured in 2005. Note that monitoring of certain wells, marked by an asterisk, are specified in RFI reports prepared in accordance with the Consent Order for the WVDP.

Groundwater Elevation Monitoring. In addition to analytical samples, potentiometric (water level) measurements are collected from wells listed in Table E- ${ }^{\text {Go }}$ in conjunction with the quarterly analytical sampling schedule (Appendix $\mathrm{E}^{\text {G0. }}$ ). Groundwater elevation data are used to produce groundwater contour maps, which delineate flow directions and gradients. Long-term trend graphs are used to illustrate changes to the groundwater system, such as seasonal fluctuations. In 2005, water levels were routinely measured at 44 locations in addition to those that were sampled. (See Figures A-8 through A-10 in Appendix A.)

Surface water elevation measurements are also collected at 11 locations on the north plateau where the water table in the sand and gravel unit intersects the ground surface in the form of standing water. These measurements are correlated with groundwater elevation measurements taken at nearby monitoring wells, and are used to help define groundwater flow direction and gradients in the sand and gravel unit in areas where monitoring well coverage is sparse or nonexistent.

Analytical Trigger Level Evaluation. A computerized data-screening program uses "trigger levels" - preset conservative values for chemical and radiological concentrations and groundwater elevation measurements - to identify and promptly respond to anomalies in monitoring results. These levels, reviewed annually, are based on regulatory limits, detection limits, or statistically derived values.
Groundwater Monitoring Program Highlights 1982 Through 2005. Program content is dictated by regulatory requirements in conjunction with current operating practices and historical knowledge of previous site activities.

- Groundwater monitoring at the WVDP began in 1982 and continued to expand through 1992 with the addition of new wells, ground water seep locations, a french drain outfall, and the NDA interceptor trench sump.

- In 1993, monitoring results indicated elevated gross beta activity in groundwater from the sand and gravel unit on the north plateau. Subsequent investigation of this area delineated a plume of contamination with a southwest to northeast orientation. (See "Special Groundwater Activities" and Figure 4-3 in this chapter for more detail.)

- An RFI expanded characterization program was conducted during 1993 and 1994 to fully assess potential releases of hazardous wastes or constituents from on-site SSWMUs. This investigation, which consisted of two rounds of sampling for a wide range of radiological and chemical parameters, provided valuable information regarding groundwater conditions near each SSWMU. Evaluation of these results influenced monitoring program modifications.

- Long-term monitoring needs were the focus of a 1995 groundwater monitoring program evaluation. After a comprehensive assessment, the number of sampling locations was reduced from 91 to 65 and analytical parameters were tailored to each sampling location for a more focused, efficient, and cost-effective program.

- In 1996, several groundwater seep monitoring locations on the northeast edge of the north plateau were added to the monitoring program and the french drain outfall was deleted for ground- 
water purposes. Five seep locations continue to be monitored.

- Four new groundwater monitoring wells were installed during August 2003 to provide upgradient and downgradient monitoring coverage for the remote-handled waste facility.

- Reductions in analytes or sampling frequencies were implemented at 14 monitoring locations in early 2005 .

\section{Results of Routine}

\section{Groundwater Monitoring}

Tables in Appendix $\mathrm{E}^{\mathbf{6 0}}$ contain results of sampling for radiological and nonradiological analytes grouped by hydrogeologic unit. The wells in each table are arranged by hydraulic position relative to other wells within the same hydrogeologic unit. Wells identified as "UP" refer to either background wells or wells that are upgradient of other wells in the same hydrogeologic unit. Wells identified as "DOWN" are downgradient of other wells in that unit. In each table, wells are presented from upgradient to furthest downgradient. Hydraulic position provides the basis for presenting groundwater monitoring data in the tables and figures in this report. Table E- $12^{\mathrm{ED}}$ lists the practical quantitation limits (PQLs) for monitored organic compounds and metals. The PQL is the lowest level of an analyte that can be measured within specified limits of precision during routine laboratory operations (New York State Department of Environmental Conservation, 1991).

\section{Sand and Gravel Unit on the North Plateau}

\section{Long-Term Trends of Gross Beta and Tritium} at Selected Groundwater Monitoring Locations. Figures 4-4 through 4-7 show the trends of gross beta and tritium concentrations at selected monitoring locations in the sand and gravel unit. Using a logarithmic scale allows locations with widely differing concentrations to be plotted against average background concentrations on each graph.

Gross Beta. In 2005, 12 wells (104, 105, 111, 116, $408,501,502,801,8603,8604,8605$, and 8609) showed gross beta concentrations that exceeded the DOE derived concentration guide (DCG) for strontium-90 (1.0E-06 microcuries/milliliter [ $\mu \mathrm{Ci} /$ $\mathrm{mL}])$. Ten of the preceeding wells are within the groundwater plume of gross beta activity in the sand and gravel unit on the north plateau (Fig. 43 ). This area continues to be monitored closely. The source of the plume's activity can be traced to the soils beneath the southwest corner of the former process building. Lagoon 1, formerly part of the low-level waste treatment facility, has been identified as a source of the gross beta activity at the remaining wells, 8605 and 111.

- Figure 4-4 shows gross beta concentrations in wells 104, 408, 501, 502, and 8609 (that are somewhat centrally located on the north plateau and are closer to the plume's suspected source beneath the main plant). As in previous years, samples from well 408 continued to show the highest gross beta concentrations of all the wells within the north plateau gross beta plume. Except for short-term seasonal variations, gross beta results for wells 408, 501, and 502 progressively decreased from 2002 through 2005. Well 104 also showed slight decreases since 2003. Well 8609 exhibited a slight increase relative to 2004 .

- Figure 4-5 shows gross beta concentrations in wells $105,116,801,8603$, and 8604 (that are located further downgradient from the plume's suspected source and are closer to the leading edges). Wells 105, 116, and 801 showed slight increases relative to 2004 values. Results in wells 8603 and 8604 were similar or slightly less than 2004 results. Well 105 shows the largest overall increase 
over the last ten years, although the rate of increase has decreased significantly.

- Figure 4-6 is a graph of gross beta concentrations at sand and gravel unit monitoring locations 111 and 8605, located near the eastern edge of the north plateau adjacent to former lagoon 1 . Gross beta concentrations at wells 111 and 8605 were slightly lower in 2005 than in 2004.

Tritium. Figure 4-7 shows the tritium concentrations in wells $111,8603,8604,8605$, and 8609 . Tritium concentrations in wells 111,8605 , and 8609 show slight decreases from 2004 to 2005 . Slight increases were noted in wells 8603 and 8604 during 2005. However, all wells exhibit an overall decrease from 1996 through 2005. Essentially all sand and gravel monitoring locations where tritium concentrations have been elevated in the past now exhibit decreasing trends. Decreasing tritium concentrations are the result of the radiological decay and/or dilution of residual tritium activity associated with previous historical site fuel reprocessing operations. Tritium at many of these locations is currently close to or within the background range.

North Plateau Seeps. Analytical results of sampling for radiological parameters from the sand and gravel unit seepage monitoring locations were compared with results from GSEEP, a seep monitored since 1991 that has not been affected by the gross beta plume. (Seep monitoring locations are noted on Figs. A-8 and A-9 in Appendix A. See Table E- $2^{\text {G0 }}$ for sampling results.)

Gross Beta. Radiological monitoring results continue to indicate that the gross beta groundwater plume has not migrated to these seepage areas. With the exception of SP11, gross beta concentrations from all seep monitoring locations were less than or similar to GSEEP concentrations during 2005. Gross beta concentrations at SP11 show a slightly increasing trend since early 1999 and somewhat steeper increases during 2001 through 2005. Contamination observed at SP11 is believed to be attributable to re-infiltration of contaminated water that has surfaced from the strontium-90 groundwater plume upgradient of this location. Although somewhat greater than values typically obtained at GSEEP, it is still well below the strontium-90 DCG (Table K-1 ${ }^{\text {Go }}$ ).

Gross Alpha. Gross alpha concentrations at all seep sampling locations were very low - generally below the associated uncertainty or less than the detection limit.

Tritium. Tritium concentrations at the seeps remained similar to or less than concentrations at GSEEP. Tritium concentrations in the north plateau seeps, including GSEEP, are slightly higher than levels reported in background wells of the sand and gravel unit. Concentrations are similar to those seen in sand and gravel unit wells monitoring the lagoon areas of the north plateau, but are still far lower than the DCG for tritium.

\section{Results for Volatile and Semivolatile Organic Compounds (VOCs and SVOCs). VOCs and} SVOCs were sampled at specific locations (wells 8612, 8609, 803, 8605, 111, and seep sampling location SP12 [Fig. A-9 in Appendix A]) that have shown historical results above the PQLs. (See Tables E- $8^{\text {[DD }}$ and E-9 ${ }^{\text {GD }}$ for sampling results and Table E- $12^{\mathrm{GD}}$ for a list of sampled analytes.) With the exception of the analytes discussed below, results are consistently nondetectable.

Total 1,2-Dichloroethylene (1,2-DCE-t). Positive detections of 1,2-DCE-t were first noticed at well 8612 in 1995. Concentrations of 1,2-DCE-t increased from 1995 through 2002, but show an overall decrease from 2002 through 2005 (Fig. 4-8). 


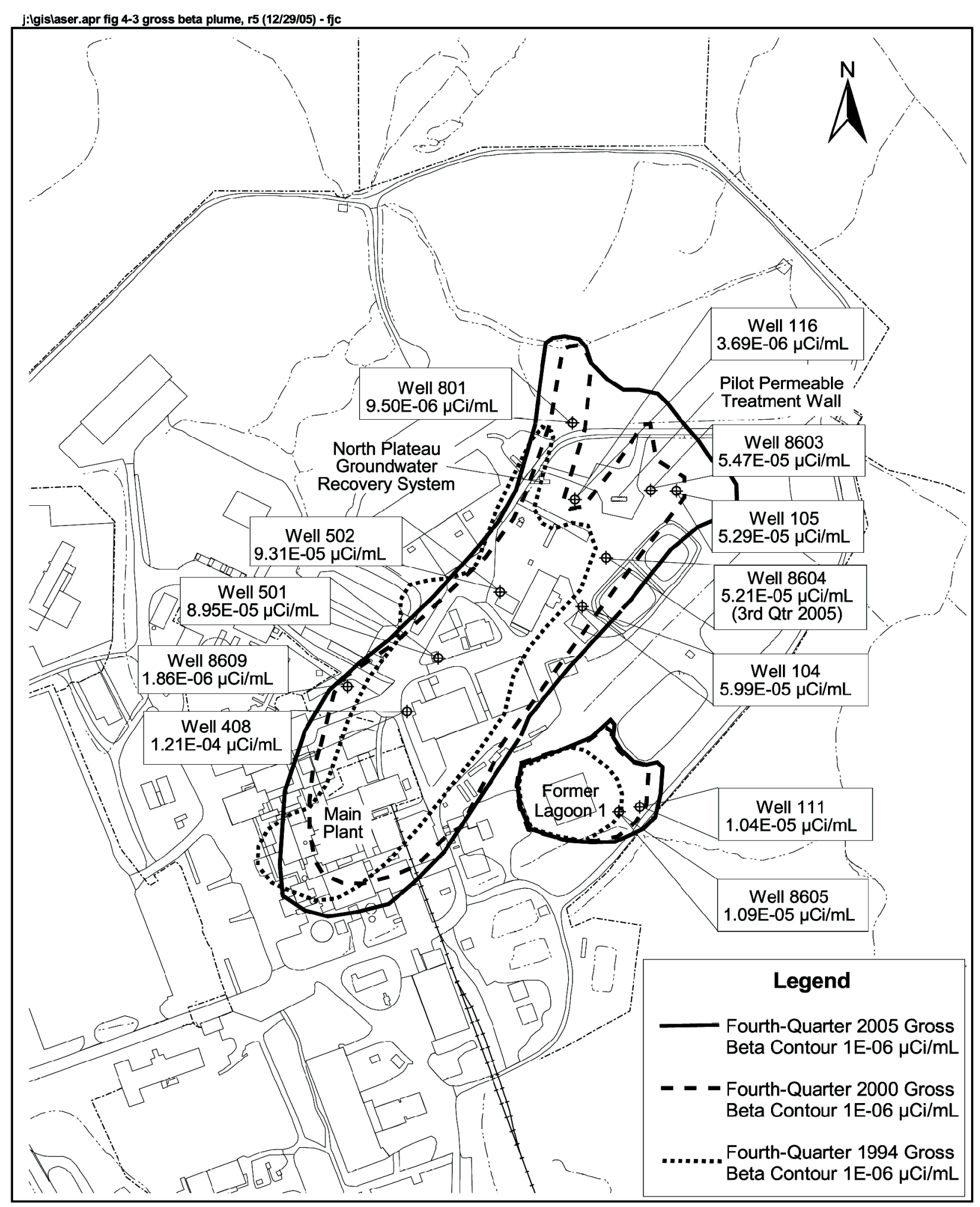

Figure 4-3. North Plateau Gross Beta Plume Area: Fourth-Quarter 2005 Results

$$
4-10
$$


1,1-Dichloroethane (1,1-DCA). Concentrations of 1,1-DCA at well 8612 decreased during 1995-1998, with a lower rate of decrease during 1999-2005 (Fig. 4-8). The compound was not detected at wells 8609,803 , or groundwater seep SP12 during 2005.

Dichlorodifluoromethane (DCDFMeth). DCDFMeth was detected at well 8612 during 2005 at relatively low concentrations near or below the PQL, but was not detected in wells 803, 8609, or seep monitoring location SP12.

1,1,1-Trichloroethane (1,1,1-TCA). The compound 1,1,1-TCA was detected in well 8612 during 2005 at estimated levels below the PQL, but was not detected in well 803,8609 , or in seep monitoring location SP12 (Fig. 4-8).

The VOCs 1,1-DCA, DCDFMeth, and 1,1,1-TCA are often found in combination with 1,2-DCE-t. In well 8612, each compound first exhibited an increasing trend that, after several years, was followed by a long-term decreasing trend. It is expected that 1,2-DCE-t will exhibit similar behavior, as indicated by its generally decreasing trend in recent years.

Tributyl Phosphate (TBP). Concentrations of TBP were detected in 2005 ground water samples from well 8605, near former lagoon 1, at concentrations somewhat lower than those in 2004. TBP also was previously detected in well 111 , located near well 8605, but at levels much lower than those at well 8605. TBP was detected at well 111 during 2005 at concentrations slightly below the PQL (Figure 4-9).

Ongoing detection of TBP in this localized area may be related to previously detected, positive concentrations of iodine-129 and uranium-232 in wells 111 and 8605, as noted in previous Annual Site Environmental Reports. The presence of these contaminants may reflect residual contamination from liquid waste management activities in the former lagoon 1 area during earlier nuclear fuel reprocessing.

Additional monitoring locations are sampled for VOCs and/or SVOCs because they are downgradient of locations that have shown positive results or to comply with the Consent Order. Results for these additional locations are consistently nondetectable.

\section{Special Groundwater Activities}

Gross Beta Plume on the North Plateau. Elevated gross beta activity has been detected in groundwater from the surficial sand and gravel unit in areas northeast of the building where Nuclear Fuel Services, Inc. reprocessed nuclear fuel (Fig. 4-3). In December 1993, elevated gross beta concentrations were detected in surface water at former sampling location WNDMPNE, located near the edge of the north plateau. This detection initiated a subsurface groundwater and soil investigation in 1994 using a Geoprobe ${ }^{\circledR}$ mobile sampling system to identify the location and extent of the gross beta plume beneath and downgradient of the former process building.

The highest gross beta concentrations in groundwater and soil were found near the southwest corner of the process building. Strontium-90 and its daughter product, yttrium-90, were identified as the major isotopic components of this elevated gross beta activity (WVNSCO, 1995). The gross beta activity in the area of former lagoon 1 is sourced by the lagoon's contents when it was closed. (See the discussion of tributyl phosphate in the previous section).

More attention was given in 1998 to the core area of the plume, determined to be beneath and immediately downgradient of the former process 
building. The 1998 study noted that, while the overall distribution of strontium-90 in groundwater within the plume was similar to 1994, concentrations detected in 1998 samples were generally lower than in 1994 samples, due to radioactive decay and continuing migration and dispersion of the plume (WVNSCO, June 1999).

North Plateau Groundwater Recovery System. In 1995, the north plateau groundwater recovery system (NPGRS) was installed to minimize the advance of the gross beta plume. The NPGRS is located near the leading edge of the western lobe of the plume where groundwater flows preferentially toward the edge of the plateau, seeps into a ditch, and flows as surface water toward monitoring location WNSWAMP. (See "Northeast Swamp Drainage Monitoring" in this chapter.) The NPGRS consists of three wells that extract contaminated groundwater, which is then treated by ion exchange to remove strontium-90. Pumping was halted at one of the three wells beginning in 2003 due to poor strontium-90 removal efficiency. Treated water is transferred to the lagoon system and is ultimately discharged to Erdman Brook.

The NPGRS operated throughout 2005, processing about 4.1 million gallons (gal) (16 million liters [L]). The system has recovered and processed approximately 43 million gal (163 million L) since November 1995.

Permeable Treatment Wall. A pilot-scale permeable treatment wall (PTW) was constructed in 1999 in the eastern lobe of the north plateau plume to test this passive, in-situ remediation technology. The PTW is a trench that is backfilled with clinoptilolite, a medium selected for its ability to adsorb strontium-90 ions from groundwater. The PTW extends vertically downward through the sand and gravel unit to the top of the underlying Lavery till and is approximately $30 \mathrm{ft}$ long by $10 \mathrm{ft}$ wide ( $9 \mathrm{~m}$ long by $3 \mathrm{~m}$ wide).
Additional test borings and monitoring well installations were completed in the vicinity of the PTW during the fall of 2001 to obtain improved definition of hydrogeologic conditions. The evaluation concluded that complex hydrogeologic conditions and disturbances from the installation are influencing groundwater flow into and around the pilot PTW. Monitoring and evaluation of water levels and radiological concentrations upgradient, within, and downgradient of the PTW continued during 2005.

Northeast Swamp Drainage Monitoring. Routine surface water sampling during 2005 continued to monitor radioactivity levels in surface water at location WNSWAMP(Appendix C-4 ${ }^{\text {G9 }}$ ). Gross beta and strontium-90 concentrations continued to fluctuate due to seasonal effects. Annualized average strontium-90 concentrations were relatively consistent during the first quarter of 2005 , followed by steady increases through the third quarter, and slight decreases during the fourth quarter. The annualized average exceeded the DOE DCG during all of CY 2005 (Fig. 4-10). The main source of the elevated strontium-90 is seepage of groundwater affected by the north plateau plume into a ditch upstream of WNSWAMP. (See Figures 4-3 and A-2.) An estimated 36 million gallons of water flowed through this monitoring point during 2005.

The annualized average concentration of strontium-90 in surface water at sampling location WNSWAMP (on the WVDP premises) remained elevated with respect to background. Even so, monitoring downstream at the first point of public access (WFFELBR) continued to show gross beta concentrations that were only slightly higher than those at background location WFBIGBR. (See also "Northeast Swamp and North Swamp Drainage" in Chapter 2.)

South Plateau Weathered Lavery Till Monitoring at the NDA. A trench system was previously constructed along the northeast and 
northwest sides of the NDA to collect groundwater that may be contaminated with a mixture of ndodecane and TBP. (See also "Environmental Program Information, Nuclear Regulatory Commission [NRC]-Licensed Disposal Area [NDA] Interceptor Trench and Pretreatment System" in Chapter 1.) Monitoring results in 2005 indicated no $n$-dodecane or TBP in groundwater near the NDA. Groundwater elevations are monitored quarterly in and around the trench to ensure that an inward gradient is maintained, thereby minimizing outward migration of potentially contaminated groundwater.

WNNDATR and Well 909. Gross beta and tritium concentrations in samples from location WNNDATR, a sump at the lowest point of the interceptor trench, and from well 909 (Fig. A-8 in Appendix A), downgradient of WNNDATR, continued to be elevated with respect to background monitoring locations on the south plateau. Concentrations were still well below the DCGs.

During 2005, gross beta and tritium concentrations at WNNDATR were similar to those seen during 2004. Overall, gross beta concentrations are slightly increasing with time, while tritium concentrations have significantly decreased over the last ten years.

Radiological indicator results at well 909 have historically fluctuated. In general, upward long-term trends in both gross beta and tritium were discernible until 1999, when both trends declined, followed by relatively consistent results during recent years. Concentrations of both gross beta and tritium during 2005 were similar to those seen during 2004. Residual soil contamination near well 909 is the suspected source of elevated gross beta concentrations, which are slightly higher than those at WNNDATR.

\section{Additional Monitoring and Investigations}

Results of Radioisotopic Sampling. Groundwater samples for radioisotopic analyses are collected regularly from selected monitoring points in the sand and gravel unit and the weathered Lavery till (Table E-11 ${ }^{\text {cos }}$ ). With the exception of strontium-90 concentrations from monitoring wells in the north plateau plume area and downgradient of the NDA, concentrations of radioisotopic analytes remained similar to previous historical results that typically are less than the detection limit and/or less than the uncertainty. Strontium-90 remained the major contributor to elevated gross beta activity in the north plateau plume and at the NDA, as indicated by the similarity between strontium- 90 trends and gross beta trends in wells showing elevated gross beta results.

Historical monitoring results and previous special investigations have identified slightly elevated levels of carbon-14, technetium-99, and iodine-129 at a small number of monitoring locations. After accounting for strontium-90, these other radionuclides contribute very small percentages to total gross beta concentrations. Carbon-14 and technetium99 have been detected in the sand and gravel unit at wells within the gross beta plume and downgradient of former lagoon 1 . Iodine-129 has also been detected in the weathered Lavery till downgradient of the NDA. None of the carbon14 , technetium-99, or iodine- 129 concentrations have been above DCGs. In general, frequent gross beta monitoring provides sufficient trend surveillance to identify any potential changes in radiological concentrations.

North Plateau Groundwater Quality Early Warning Monitoring. Early-warning monitoring of water recovered by the NPGRS is performed because this water is ultimately discharged offsite via the New York State Pollutant Discharge 
Elimination System (SPDES) permitted outfall 001. Quarterly monitoring results from well 502, located directly upgradient of the NPGRS, can be used to identify metals concentrations in groundwater that may affect compliance with the SPDES permitted effluent limits. Results of sampling for metals at well 502 can be found in Table E-10 ${ }^{\text {con }}$.

Investigation of Chromium and Nickel in the Sand and Gravel Unit and Evaluation of Corrosion in Groundwater Monitoring Wells. A 1997 and 1998 study of the effect of modifying sampling equipment and methodology on concentrations of chromium and nickel in groundwater samples from the sand and gravel unit noted that such modifications produced decreases in these concentrations. This supported the hypothesis (which is documented in the technical literature) that elevated concentrations were not representative of actual groundwater conditions, but were caused by release of metals from subsurface corrosion of stainless steel well materials (WVNSCO and Dames \& Moore, June 1998).

To ensure continued monitoring well integrity and collection of high-quality samples representative of actual groundwater conditions, wells are periodically inspected for corrosion. Approximately three-fourths of the stainless-steel wells monitoring the sand and gravel unit were internally inspected for corrosion during 2001. Wells containing corrosion were cleaned and then reinspected to verify that corrosion had been removed. Wells previously containing corrosion were inspected during late 2004 and 2005. Cleaning and reinspection are planned for 2006

Fuel Receiving and Storage (FRS) Pool Water Infiltration. During mid-2005, water was found trickling into the empty former FRS pool during a quarterly inspection. The water is directed by a slope in the floor to the deeper stainless-steellined cask unloading pool (CUP), where it has accumulated to a depth of approximately four to six inches. Analytical data for the FRS CUP water indicate that groundwater is the source of the water. The strongest evidence is the similarity of strontium-90 concentrations in groundwater and those of FRS CUP water and the hydraulic setting. The elevated cesium-137 concentration in the water is not characteristic of groundwater in the vicinity of the FRS. Note that cesium-137 was not detected in Geoprobe ${ }^{\circledR}$ water samples collected just south of the FRS in 1998 and has not been detected in downgradient wells located in the main flow path of the north plateau strontium-90 plume. Therefore, the source of cesium-137 in the FRS CUP water may be residuals associated with the FRS walls. Since the water does not pose operational or safety concerns, it was left in the CUP under routine monitoring. There has been no measureable water level change since level measurement capability was established.

Off-Site Groundwater Monitoring. Groundwater is used as a potable water supply at off-site private residences near the WVDP. Nine off-site residential supply wells, located within 4.3 miles $(7 \mathrm{~km})$ of the facility, and one background well, located $18 \mathrm{mi}(29 \mathrm{~km})$ south of the site, are routinely sampled. Additional information is provided in "Overview of Drinking Water Monitoring" in Chapter 2. 


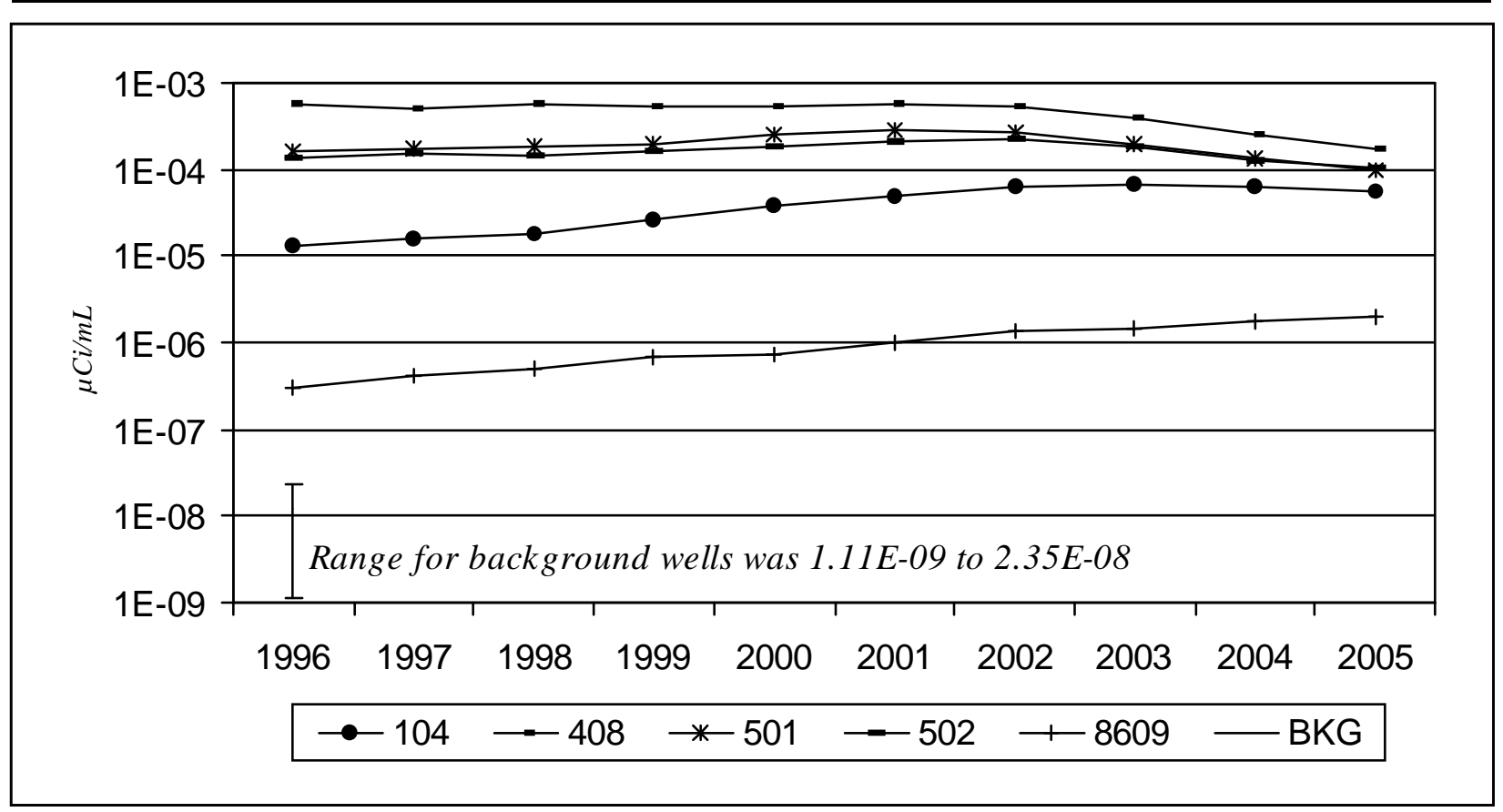

Figure 4-4. Average Annual Gross Beta Concentrations at Locations Closer to the Source of the North Plateau Plume

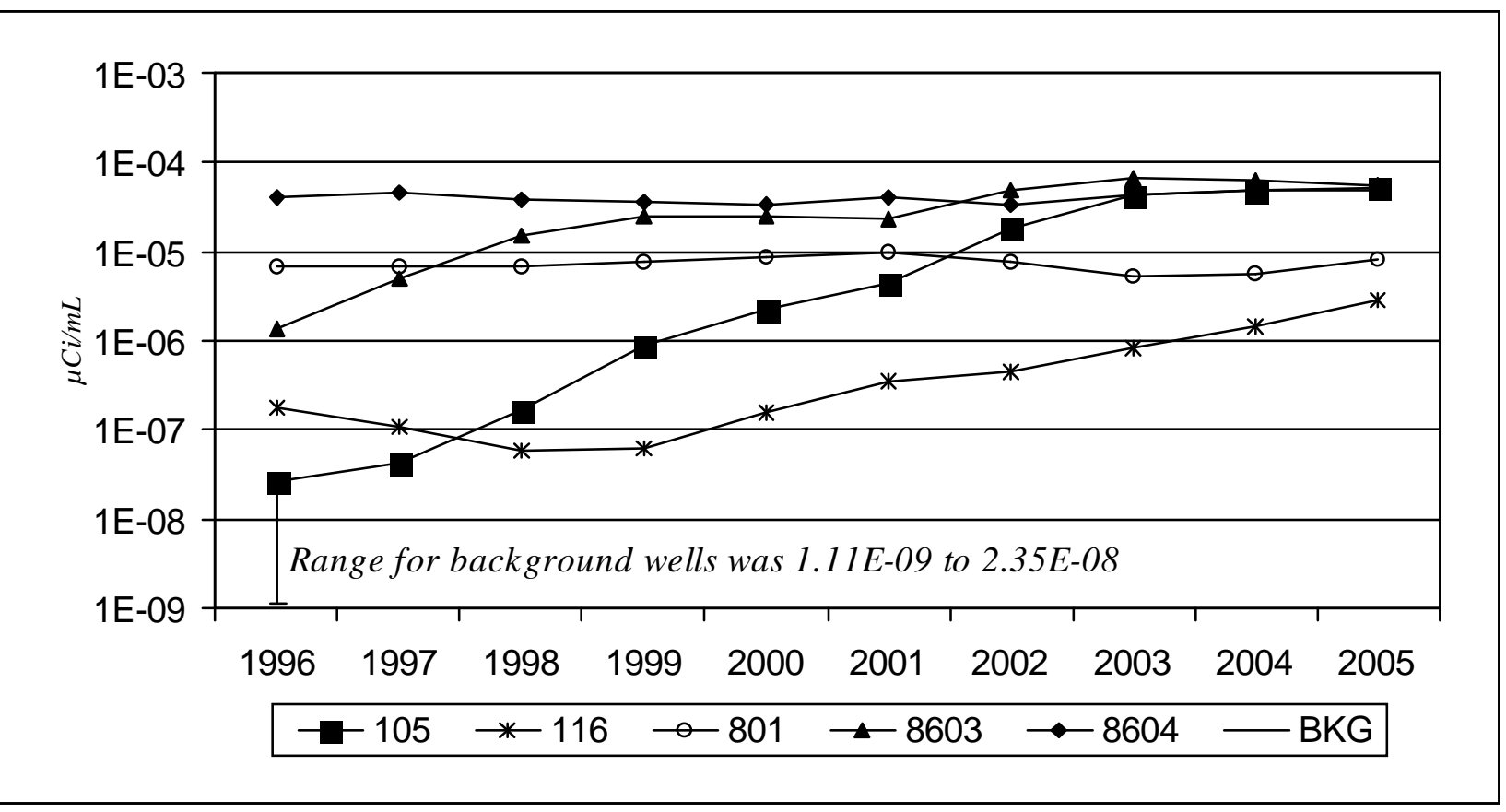

Figure 4-5. Average Annual Gross Beta Concentrations at Locations Closer to the Leading Edges of the North Plateau Plume 


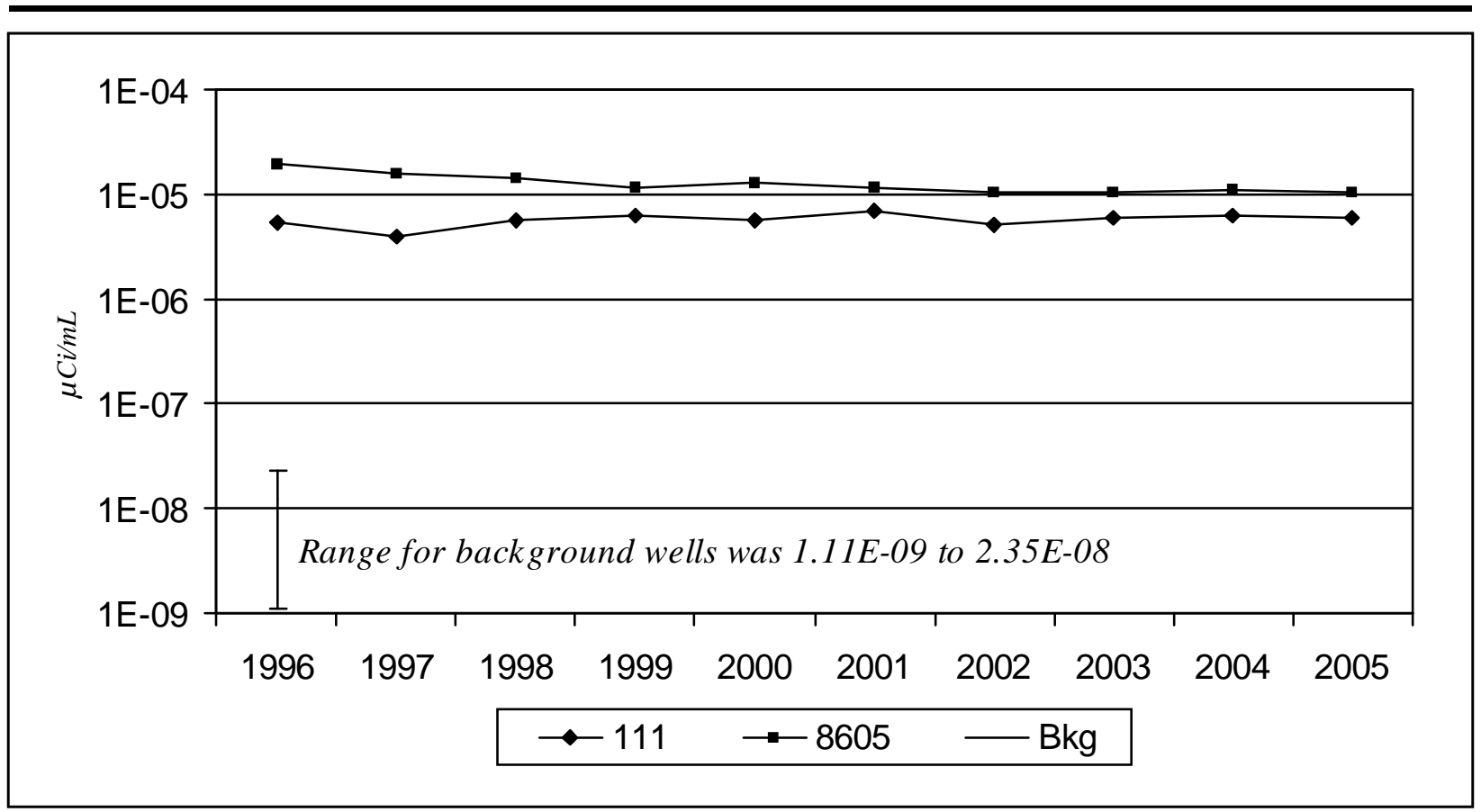

Figure 4-6. Average Annual Gross Beta Concentrations at Locations Near Former Lagoon 1

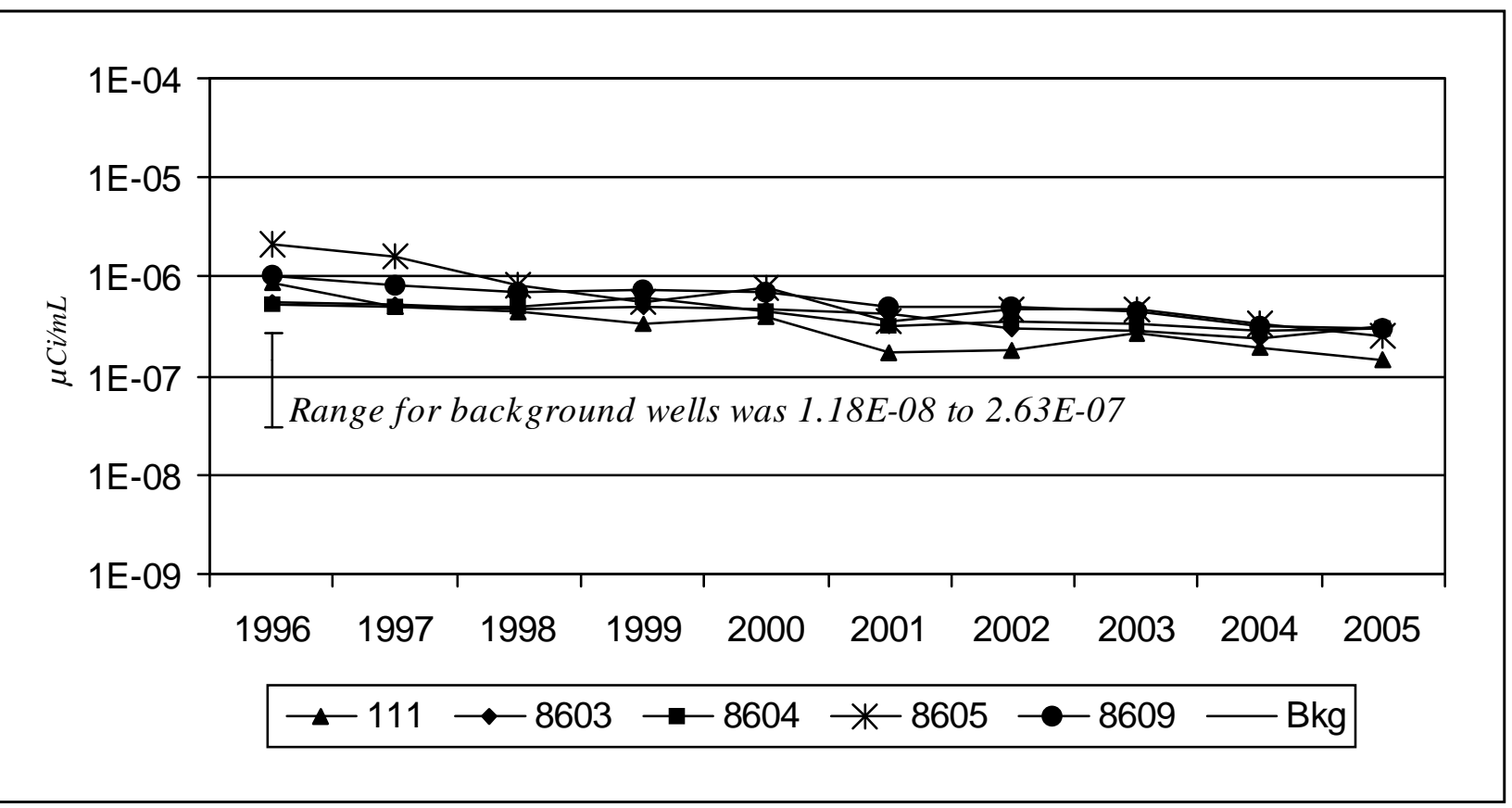

Figure 4-7. Average Annual Tritium Concentrations at Selected Locations in the Sand and Gravel Unit 


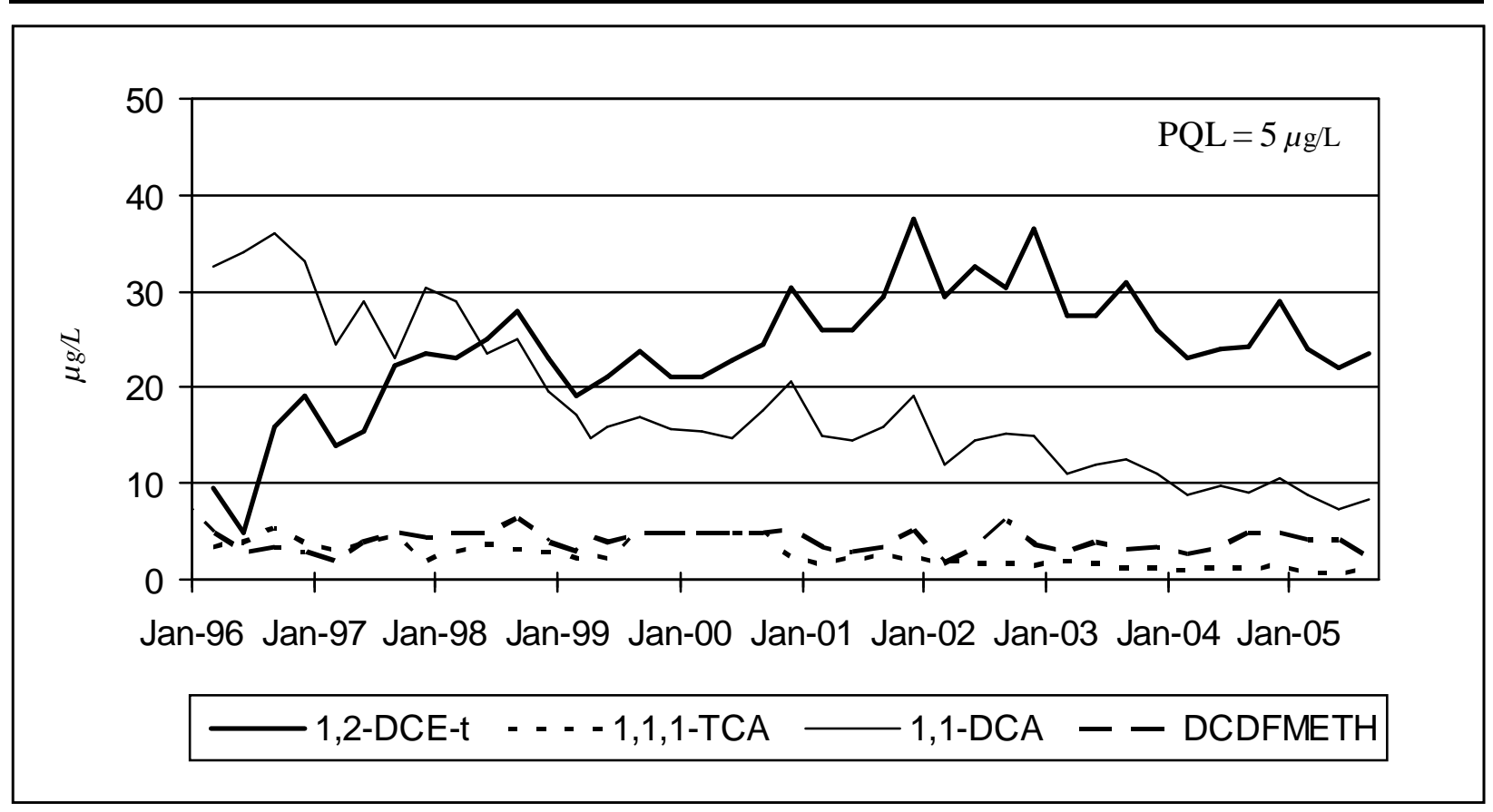

Figure 4-8. Concentrations of 1,2-DCE-t, 1,1,1-TCA, 1,1-DCA, and DCDFMeth at Well 8612 in the Sand and Gravel Unit

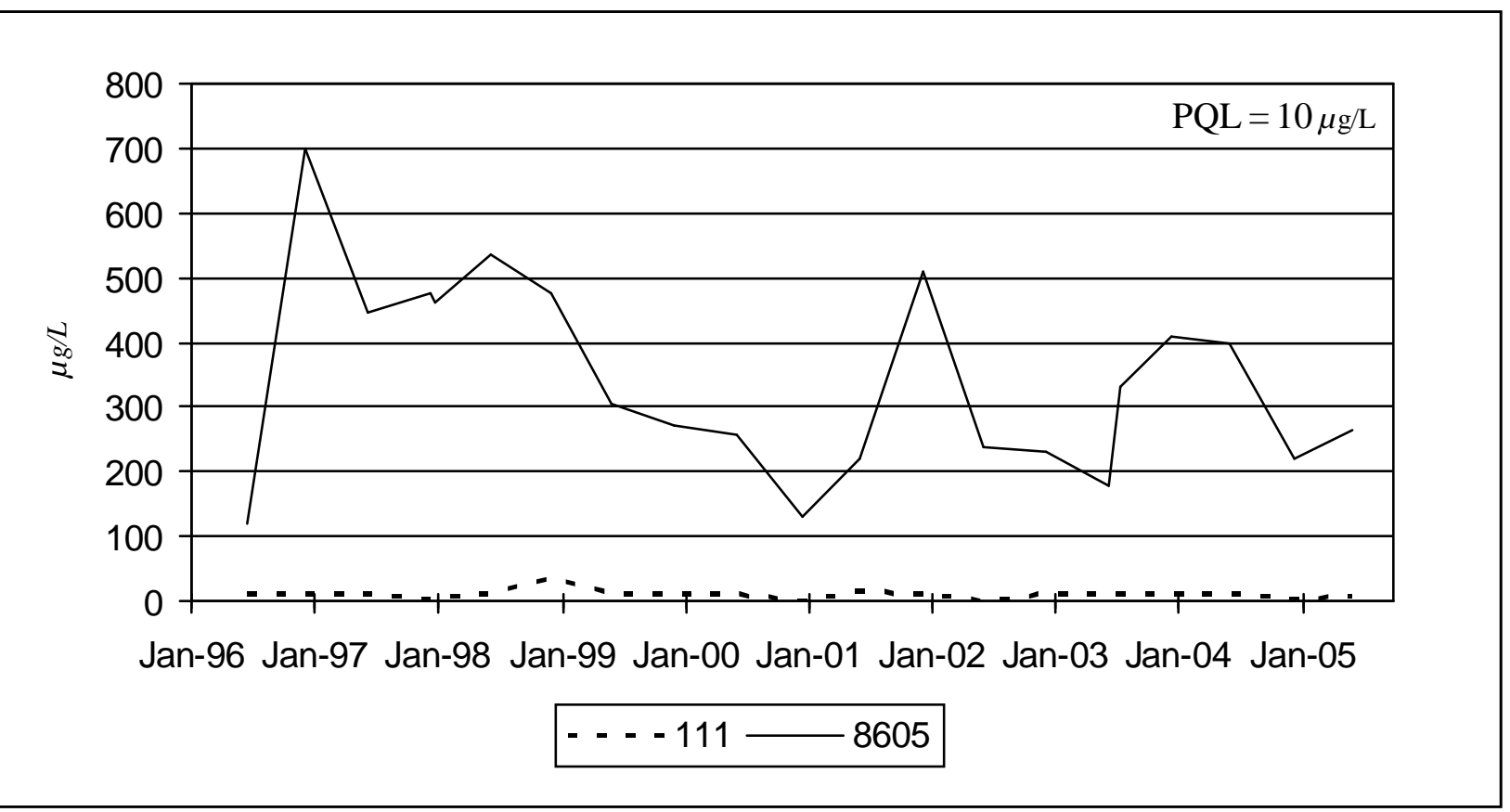

Figure 4-9. Concentrations of Tributyl Phosphate at Selected Locations in the Sand and Gravel Unit 


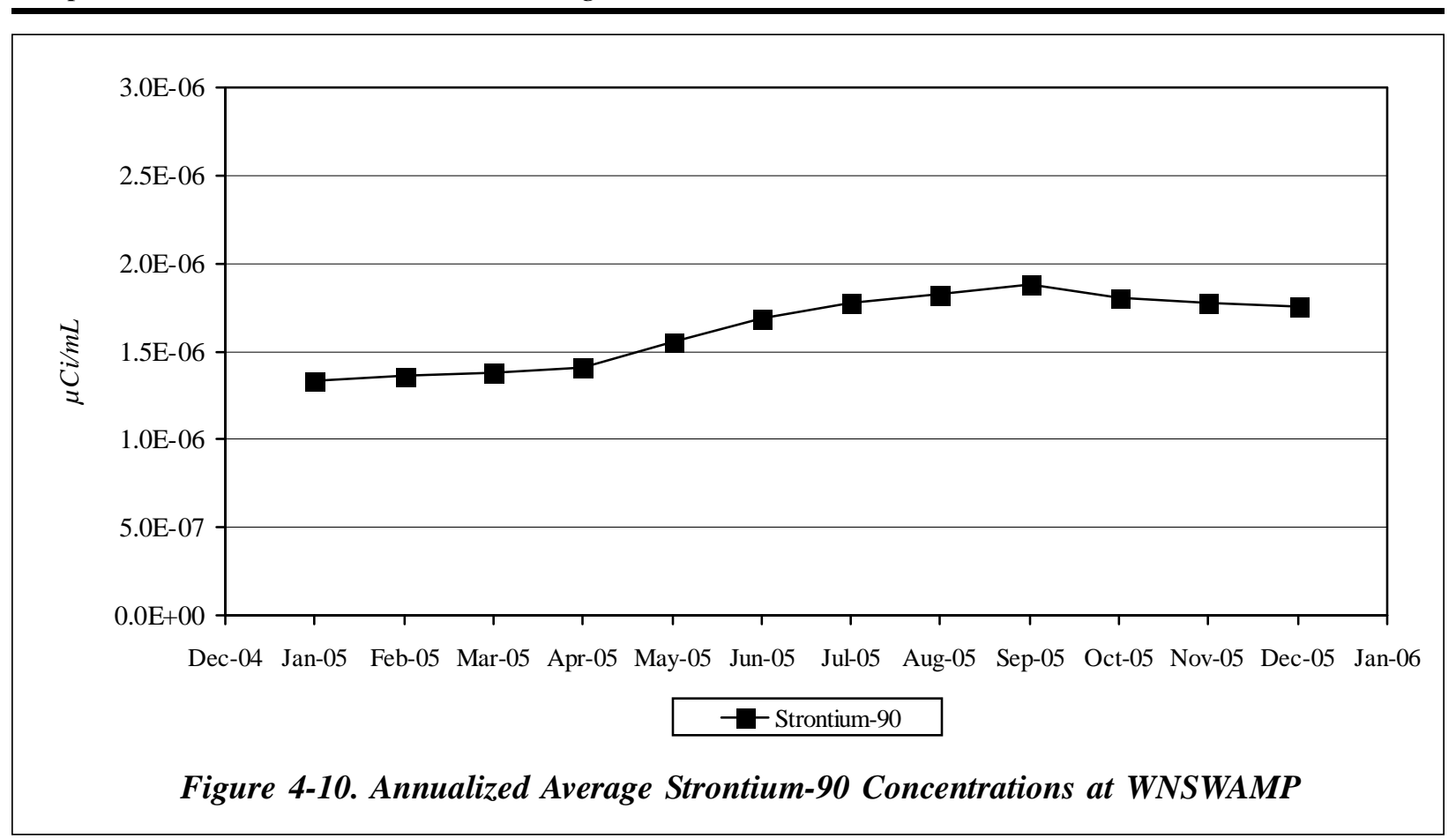

$$
4-18
$$




\section{QUALITY ASSURANCE}

\section{Quality Assurance Program}

The quality assurance (QA) program at the West Valley Demonstration Project (WVDP or Project) provides for and documents consistency, precision, and accuracy in collecting and analyzing environmental samples and in interpreting and reporting environmental monitoring data. West Valley Nuclear Services Co. (WVNSCO), by contract with the United States (U.S.) Department of Energy (DOE), implements the QA program at the WVDP. Subcontractor laboratories providing analytical services for the environmental monitoring program are contractually required to maintain a QA program consistent with WVNSCO requirements.

The quality requirements of Title 10 Code of Federal Regulations Part 830, Subpart A, "Quality Assurance Requirements," Section 830.122, "Quality Assurance Criteria," and DOE Order 414.1A, "Quality Assurance" (DOE, 1999), provide the QA program policies and requirements applicable to activities at the WVDP. The WVDP QA program serves as an implementation process for meeting the DOE Order 450.1 requirement to provide "a consistent system for collecting, assessing, and documenting environmental data of known and documented quality." The integrated QA program also incorporates the requirements from the con- sensus standard "Quality Assurance Program Requirements for Nuclear Facilities" (American Society of Mechanical Engineers NQA-1, 1989). Controlled documents specific to the WVDP are used to implement the integrated QA program. General areas addressed by the QA program include the following:

Responsibility. Responsibilities for overseeing, managing, and conducting an activity must be clearly defined. Personnel who verify that an activity has been completed correctly must be independent of those who performed it. Managers of programs, projects, and tasks at the WVDP are responsible for ensuring that QA requirements applicable to activities under their cognizance are implemented.

Planning. Work activities must be planned beforehand, the plan followed, and activities documented. Purchases of quality-affecting equipment or items must be planned, specified precisely, and verified for correctness upon receipt.

Training. Anyone performing an activity in support of the WVDP environmental monitoring program must be trained in the appropriate procedures and qualified accordingly before carrying out the activity. 
Control of Design, Procedures, Items, and Documents. Any activity, equipment, or construction must be clearly described or defined and tested. Changes in the design must be tested and documented. Procedures must clearly state how activities will be conducted. New procedures must be developed each time an activity is added to the monitoring program. Procedures are reviewed periodically, updated when necessary, and are controlled so that only approved and current procedures are used.

Equipment or particular items affecting the quality of environmental data must be identified, inspected, calibrated, and tested before use. Calibration status must be clearly indicated. Items that do not conform to requirements must be identified as nonconforming and segregated so as to prevent inadvertent use.

Corrective Action. Conditions adverse to quality must be promptly identified, a corrective action planned, responsibility assigned, and the problem remedied.

Documentation. Records of all activities must be kept to verify what was done and by whom. Records must be clearly traceable to an item or activity. Records such as field data sheets, chainof-custody forms, requests for analysis, sample shipping documents, sample logs, data packages, training records, and weather measurements, in addition to other records in both paper and electronic form, are maintained as documentation for the environmental monitoring program.

Audits and Assessments. Audits and assessments must be conducted to verify compliance with all aspects of the QA program and to determine its effectiveness. The WVDP environmental monitoring program is subjected to audits by external agencies and to internal management and self-assessments.

\section{Quality Control}

More than 9,000 environmental samples were collected and analyzed in 2005 as part of the WVDP environmental monitoring program. Quality control (QC), an integral part of QA, is used to ensure that samples are collected and analyzed in a consistent and repeatable manner. QC methods are applied both in the field and in the laboratory.

Field QC. Procedures are defined for collecting each type of sample, such as surface water, groundwater, soil, and air. Trained Environmental Laboratory (ELAB) field personnel collect the samples. Field sampling locations are clearly marked to ensure that routine samples are collected in the same location each time. Collection equipment that remains in the field is routinely inspected, calibrated, and maintained, and automated sampling stations are kept locked to prevent tampering. Samples are collected into certified precleaned containers of an appropriate material and capacity. Containers are labeled with information about the sample, such as date and time of collection, sample collection personnel, and special field conditions. Collection information is documented and kept as part of the sample record.

Chain-of-custody documentation is maintained so as to trace sample possession from time of collection through analysis. Samples brought in from the field are transferred under signature to the sample custodian in the laboratory, where the samples are stored in a lockup before analysis or shipping. Samples sent off site for analysis are accompanied by an additional chain-of-custody form. Subcontract laboratories are required by contract to maintain internal chain-of-custody records and to store the samples under secure conditions.

Special field QC samples are collected and analyzed to assess the sampling process. Duplicate field samples are used to assess sample homoge- 
neity and sampling precision. Field and trip blanks (laboratory-deionized water in sample containers) are used to detect contamination potentially introduced during sampling or shipping. Environmental background samples (samples of air, water, vegetation, venison, and milk taken from locations remote from the WVDP) are collected and analyzed to provide baseline information for comparison with on-site or near-site samples so that site influences can be evaluated.

Laboratory QC. In 2005, environmental monitoring samples were analyzed at several on-site and off-site laboratories. On-site analyses were conducted by the ELAB (radiological indicator parameters, gamma spectroscopy, strontium-90 in water, and field $\mathrm{pH}$ and conductivity), the Wastewater Treatment Facility Laboratory (total residual chlorine, $\mathrm{pH}$, and settleable solids), and the Analytical and Process Chemistry Laboratory (A\&PC, total dissolved solids).

During an internal review of the WVDP environmental monitoring program, it was determined that some key radiological water sample analyses, which are reported to the public, did not have updated and complete New York State Department of Health certifications.

Subsequently, in 2005, the ELAB initiated the process to become certified by the New York State Department of Health (NYSDOH) for gross alpha, gross beta, tritium, and gamma spectroscopy analyses in potable and nonpotable water. The ELAB also analyzes water samples for strontium90 by the $3 \mathrm{M}$ Empore ${ }^{\circledR}$ Strontium Rad Disk method, for which no NYSDOH certification is available. Advantages of this method over the classical fuming nitric acid method are enhanced worker safety, waste minimization, simplicity of analysis, and rapid turnaround time. The Empore ${ }^{\circledR}$ Strontium Rad Disk method compared favorably in an evaluation of four strontium-90 analytical methods performed by the Brookhaven National Laboratory (S. Scarpitta, J. Odin-McCabe, R. Gaschott, A. Meier, and E. Klug, 1999), and has been used by the ELAB since 1996. Analyses of DOE environmental crosscheck samples over this period have demonstrated acceptable results.

Off-site analyses were performed by General Engineering Laboratories (GEL, in Charleston, South Carolina) for multimedia radiochemical parameters and low-level mercury; Severn Trent Laboratories (STL, in Buffalo, New York) for chemical analyses; Lionville Laboratory, Inc. (LVLI, in Lionville, Pennsylvania) for chemical analysis of radiologically contaminated samples; Fruit Grower Laboratories (in Santa Paula, California) for analysis of biological contaminants in potable water; and Bechtel BWXT Idaho, LLC (at the Idaho National Laboratory) for environmental thermoluminescent dosimeters. Subcontract laboratories are required to maintain all relevant certifications, participate in applicable crosscheck programs, and maintain a level of QC as defined in their contracts with WVNSCO.

Laboratory QC practices specific to each analytical method are described in approved references or procedures. QC practices include proper training of analysts, maintaining and calibrating measuring equipment and instrumentation, and routinely processing laboratory QC samples such as standards and spikes (to assess method accuracy), duplicates and replicates (to assess precision), and blanks (to assess the possibility of contamination). Standard reference materials (materials with known quantities or concentrations of constituents of interest) traceable to the National Institute of Standards and Technology are used to calibrate counting and test instruments and to monitor their performance.

Independent Comparisons and Crosschecks. To allow for independent confirmation of environmental monitoring data, samples of air filters, wa- 
ter, milk, fish, vegetation, and sediments are split or separately collected and sent to NYSDOH for measurement and independent reporting to the public. Locations at which co-located samples are taken are listed in Appendix $\mathrm{B}^{\mathrm{GD}}$ of this report.

Crosscheck samples (performance evaluation samples) contain a quantity or concentration of a constituent of interest known to the agency conducting the crosscheck, but unknown to the participating laboratory. Crosscheck programs provide an additional means of testing accuracy of environmental measurements. Subcontract laboratories are required to perform satisfactorily on crosschecks, with satisfactory performance defined as having at least $80 \%$ of reported results falling within control limits. Crosscheck results that fall outside of control limits are addressed by formal corrective actions to determine any conditions that could adversely affect sample data and to ensure that actual sample results are reliable.

The WVDP participates in formal crosscheck programs for both radiological and nonradiological analyses.

Radiological Crosschecks. Organizations performing radiological analyses as part of effluent or environmental monitoring are encouraged by the DOE to participate in formal crosscheck programs to test the quality of environmental measurements being reported to the DOE by its contractors. Crosscheck samples for radiological constituents are analyzed on site by the ELAB and off site by GEL.

In 2005, the WVDP participated in the DOE Radiological Environmental Sciences Laboratory Mixed Analyte Performance Evaluation Program (MAPEP). Results are listed in Appendix $\mathrm{J}^{\mathrm{GD}}$. A total of 73 radiological crosscheck analyses were performed by or for the WVDP. Of these results, $72(98.6 \%)$ were within acceptance limits.
Nonradiological Crosschecks. As a New York State Pollutant Discharge Elimination System (SPDES) Permittee, the WVDP is required to participate in the U.S. Environmental Protection Agency Discharge Monitoring Report - Quality Assurance performance evaluation studies for the National Pollutant Discharge Elimination System. Samples from this program are analyzed both on site and by subcontract laboratories. To achieve and maintain certification to analyze environmental samples from the state of New York, subcontract analytical laboratories are contractually required to demonstrate evidence of satisfactory performance on samples provided by the NYSDOH Environmental Laboratory Approval Program (ELAP). In addition, subcontract laboratories performing nonradiological analyses of samples that contain radiological contamination participate in the DOE MAPEP program. This mixed analyte program provides performance evaluation samples for both radiological and nonradiological constituents.

In 2005, nonradiological crosschecks were analyzed by the WVDP Wastewater Treatment Facility Laboratory, the ELAB, LVLI, and STL. Results are summarized in Appendix $\mathrm{J}^{\text {GD }}$. A total of 115 nonradiological crosscheck analyses were performed by or for the WVDP. Of these results, a total of $111(96.5 \%)$ were within acceptance limits.

\section{Data Management}

The Environmental Laboratory Information Management System (LIMS) is a database system used at the WVDP for establishing sample identification number, maintaining the sample data $\log$, tracking samples, managing field and analytical data, and recording status and results of data validation. The LIMS is used as a controlled-source database for generating reports and statistical evaluations of data sets to support environmental 
surveillance activities. Subcontract laboratories are requested to provide data in electronic format for direct entry into the LIMS by WVDP personnel.

All software packages used to generate data are verified and validated before use. All analytical data produced in the ELAB at the bench level are reviewed and signed off by a qualified person other than the one who performed the analysis. A similar in-house review is contractually required from subcontractor laboratories.

\section{Data Verification and Validation}

Data validation is the process by which analytical data from both on-site and off-site laboratories are reviewed to verify proper documentation of sample processing and data reporting, and to determine the quality and usability of the data. A graded approach is applied that, based upon data quality objectives, dictates the rigor of review of the documentation associated with sample collection and/ or sample analysis. In the WVDP environmental program, each data point is validated per approved standard procedures before it is assigned approval status and made ready for data assessment.

\section{Data Assessment and Reporting}

Validated analytical data, field information, and historical project data are integrated and evaluated to determine whether the constituents of interest are actually present and, if so, at what concentrations. Data problems identified at this level are investigated and appropriately resolved.

Data from the environmental monitoring program are then evaluated to assess the effect, if any, of the site operations and activities on the environment and the public. Data from each sampling location are compared with historical results from the same location, with comparable background measurements, and (if applicable) with regulatory limits or guidance standards. Standard statistical methods are used to evaluate the data.

Before each technical report is issued, the final document is comprehensively reviewed by one or more persons who are knowledgeable in the technical aspects of the work.

\section{Audits, Appraisals, and Self- Assessments}

No audits or assessments of the environmental monitoring program were completed by the U.S. Nuclear Regulatory Commission, the U.S. Environmental Protection Agency, or the DOE in 2005.

In 2005, the New York State Department of Environmental Conservation (NYSDEC) performed the annual Resource Conservation and Recovery Act hazardous waste inspection of the WVDP. No findings or concerns were identified.

NYSDEC visited the site two more times in 2005 to perform a SPDES inspection and to review Discharge Monitoring Report records. Commitments to study the lagoon 3 embankment integrity in response to inquiries during the first NYSDEC Division of Water visit were initiated and discussed during the second NYSDEC Division of Water visit. No deficiencies, issues, or additional actions were identified.

In 2005, as part of the DOE Consolidated Audit Program (DOECAP), a representative from the WVNSCO QA Department participated in DOECAP audits of two laboratories that analyze environmental samples for the WVDP. WVNSCO utilized results from two additional DOECAP audits for other laboratories that had analyzed samples for WVNSCO. In 2005, the WVNSCO QA Department conducted an audit of the WVDP 
A\&PC Laboratory concurrent with a NYSDOH ELAP inspection.

In 2005, WVNSCO QA also conducted several surveillances of activities and inspections of equipment pertaining to environmental management, safety, or monitoring. Topics addressed included waste shipping and disposal practices, procurement processes, spill control practices, fire protection, compliance with process safety requirements, testing of filter banks, and inspection of stack sampling systems. Results of all were satisfactory.

One routine self-assessment of the environmental monitoring program was conducted in 2005. Topics examined were the environmental monitoring program's conformance with federal, state, and sitewide policies and procedures and compliance with the NYSDOH ELAP protocols concerning collection and documentation of field samples. Although actions were recommended to improve some program aspects, nothing was found that would compromise the quality of the data in this report or the environmental monitoring program in general.

\section{Lessons Learned}

Lessons learned data from audits, appraisals, and self-assessments are shared internally and externally through the WVDP lessons learned program. The WVDP maintains this system to promote the recurrence of desirable events and to minimize the recurrence of undesirable events.

\section{Conclusion}

The QA elements described in this chapter ensure that environmental monitoring data are consistent, precise, accurate, and complete. The multiple levels of scrutiny built into generating, verifying, validating, evaluating, and reporting data from the environmental monitoring program ensure that reli-

$5-6$ able data are reported. The effectiveness of the environmental monitoring program is evidenced by continuing favorable QA assessments. 


\section{USEFUL INFORMATION}

\section{Radiation and Radioactivity}

Radioactivity is a characteristic of some elements that have unstable atomic nuclei, which spontaneously disintegrate or "decay" into atomic nuclei of another isotope or element. The nuclei decay until only a stable, nonradioactive isotope remains. Depending on the isotope, this process can take anywhere from less than a second to billions of years.

Atoms that emit radiation are called radionuclides. Radionuclides are unstable isotopes of an element that have the same number of protons but different numbers of neutrons, resulting in different atomic masses. For example, the element hydrogen has two stable isotopes, hydrogen- $1\left({ }^{1} \mathrm{H}\right)$ and hydrogen-2 $\left({ }^{2} \mathrm{H}\right)($ deuterium$)$, and one radioactive isotope, hydrogen- $3\left({ }^{3} \mathrm{H}\right)$ (tritium). The superscript preceding the element's symbol identifies the atomic mass, which is the number of protons plus neutrons in the nucleus. Thus, ${ }^{1} \mathrm{H}$ has one proton and no neutrons, ${ }^{2} \mathrm{H}$ has one proton and one neutron, and ${ }^{3} \mathrm{H}$ has one proton and two neutrons.

When radioactive atoms decay by emitting radiation, the daughter products that result may be either radioactive or stable. Generally, radionuclides with high atomic numbers, such as uranium-238 and plutonium-239, have many generations of radioactive progeny. For example, the radioactive decay of plutonium-239 creates uranium-235, thorium-231, protactinium-231, and so on, through 11 progeny until only the stable isotope lead-207 remains.

Radionuclides with lower atomic numbers often have no more than one daughter. For example, strontium-90 has one radioactive daughter, yttrium-90, which finally decays into stable zirconium; cobalt-60 decays directly to stable nickel with no intermediate nuclide.

The time required for half of the radioactivity of a radionuclide to decay is referred to as the radionuclide's halflife. Each radionuclide has a unique half-life; both strontium-90 and cesium-137 have half-lives of approximately 30 years while plutonium-239 has a half-life of 24,110 years. Knowledge of radionuclide halflives is often used to estimate past and future inventories of radioactive material. For example, a 1.0-millicurie source of cesium-137 in 2005 would have measured 2.0 millicuries in 1975 and will be 0.5 millicuries in 2035 . For a list of half-lives of radionuclides applicable to the West Valley Demonstration Project (WVDP), see Table $\mathrm{K}-1$ in Appendix $\mathrm{K}^{\mathrm{w}}$.

\section{$U I-1$}


Radiation emitted by radionuclides may consist of charged particles, such as alpha and beta particles, or electromagnetic rays, such as $\mathrm{x}$-rays and gamma rays. A radionuclide may emit one or more of these radiations at characteristic energies that can be used to identify them.

Alpha Particles. An alpha particle is a fragment of a much larger nucleus. It consists of two protons and two neutrons (similar to the nucleus of a helium atom) and is positively charged. Compared to beta particles, alpha particles are relatively large and heavy and do not travel very far when ejected by a decaying nucleus. Therefore, alpha radiation is easily stopped by a thin layer of material, such as paper or skin. However, if radioactive material is ingested or inhaled, the alpha particles released inside the body can damage soft internal tissues because their energy can be absorbed by tissue cells in the immediate vicinity of the decay. An example of an alpha-emitting radionuclide is the uraniumisotope with an atomic weight of 232 (uranium-232). Uranium232 was in the high-level waste (HLW) mixture at the WVDP as a result of a thorium-based nuclear fuel reprocessing campaign conducted by Nuclear Fuel Services, Inc. Uranium-232 has been detected in liquid waste streams.

Beta Particles. A beta particle is an electron emitted during the breakdown of a neutron in a radioactive nucleus. Compared to alpha particles, beta particles are smaller, have less of a charge, travel at a higher speed (close to the speed of light), and can be stopped by wood or less than an inch of aluminum. If released inside the body, beta particles do much less damage than an equal number of alpha particles because beta particles deposit energy in tissue cells over a larger volume than alpha particles. Strontium-90, a fission product found in the stabilized supernatant, is an example of a beta-emitting radionuclide.

Gamma Rays. Gamma rays are high-energy "packets" of electromagnetic radiation, called photons, that are emitted from the nucleus. Gamma rays are similar to x-rays, but are generally more energetic. If an alpha or beta particle released by a decaying nucleus does not carry off all the energy generated by the nuclear disintegration, the excess energy may be emitted as gamma rays. If the released energy is high, a very penetrating gamma ray is produced that can be effectively reduced only by shielding consisting of several inches of a dense material, such as lead, or of water or concrete several feet thick. Although large amounts of gamma radiation are dangerous, gamma rays are also used in lifesaving medical procedures. An example of a gammaemitting radionuclide is barium-137m, a short-lived daughter product of cesium-137. Both barium-137m and its precursor, cesium-137, are major constituents of the WVDP HLW.

\section{Measurement of Radioactivity}

The rate at which radiation is emitted from a disintegrating nucleus can be described by the number of decay events or nuclear transformations that occur in a radioactive material over a fixed period of time. This process of emitting energy, or radioactivity, is measured in curies $(\mathrm{Ci})$ or becquerels $(\mathrm{Bq})$.

The curie is based on the decay rate of the radionuclide radium-226. One gram of radium-226 decays at the rate of 37 billion nuclear disintegrations per second $(3.7 \mathrm{E}+10 \mathrm{~d} / \mathrm{s})$, so one curie equals 37 billion nuclear disintegrations per second. One becquerel equals one decay, or disintegration, per second.

Very small amounts of radioactivity are sometimes measured in picocuries. A picocurie is one-trillionth (1E-12) of a curie, equal to 3.7E-02 d/s (3.7E-02 Bq), or 2.22 disintegrations per minute.

$U I-2$ 


\section{Background Radiation}

Background radiation is always present, and everyone is constantly exposed to low levels of such radiation from both naturally occurring and man-made sources. In the United States the average total annual exposure to lowlevel background radiation is estimated to be about 360 millirem (mrem) or 3.6 millisieverts (mSv). Most of this radiation, approximately $295 \mathrm{mrem}(2.95 \mathrm{mSv})$, comes from natural sources. The rest comes from medical procedures, consumer products, and other man-made sources (National Council on Radiation Protection and Measurements Report 93, 1987). (See Figure 2-1 in Chapter 2.)

Background radiation includes cosmic rays; the decay of natural elements, such as potassium, uranium, thorium, and radon; and radiation from sources such as chemical fertilizers, smoke detectors, and televisions. Actual doses vary depending on such factors as geographic location, building ventilation, and personal health and habits.

\section{Measurement of Dose}

The amount of energy absorbed by the receiving material is measured in rads (radiation absorbed dose). A rad is 100 ergs of radiation energy absorbed per gram of material. (An erg is the approximate amount of energy necessary to lift a mosquito one-sixteenth of an inch.) "Dose" is a means of expressing the amount of energy absorbed, taking into account the effects of different kinds of radiation.

Alpha, beta, and gamma radiation affect the body to different degrees. Each type of radiation is given a quality factor that indicates the extent of human cell damage it can cause compared with equal amounts of other ionizing radiation energy. Alpha particles cause 20 times as much damage to internal tissues as x-rays, so alpha radiation has a quality factor of 20 , compared to gamma rays, $\mathrm{x}$-rays, or beta particles, each of which have a quality factor of one.

The unit of dose measurement to humans is the rem (roentgen equivalent man). The number of rem are equal to the number of rads multiplied by the quality factor for each type of radiation. Dose can also be expressed in sieverts. One sievert (Sv) equals 100 rem.

For a more-detailed discussion of radiation dose and units of dose measurement, see the "Radiological Effluents and Dose" section of Chapter 2.

\section{Derived Concentration Guides}

A derived concentration guide (DCG) is defined in DOE Order 5400.5 as the concentration of a radionuclide in air or water that, under conditions of continuous exposure by one exposure mode (i.e., ingestion of water, immersion in air, or inhalation) for one year, would result in an effective dose equivalent of $100 \mathrm{mrem}(1 \mathrm{mSv})$ to a "reference man." These concentrations - DCGs - are used as reference screening levels to enable WVDP personnel reviewing effluent and environmental data to decide if further investigation is needed. (See Appendix $\mathrm{K}^{\mathrm{w}}$ for a list of DCGs.)

$U I-3$ 
For liquid effluent screening purposes, the percentages of the DCGs for all radionuclides present are summed. If the total is less than $100 \%$, then the effluent complies with the DOE guideline. DCGs are also compared with radionuclide concentrations from these sources to verify that Best Available Technology standards for treatment of water are being met.

The DOE provides DCGs for airborne radionuclides in locations where members of the public could, over an extended period of time, breathe air containing contaminants. DCGs are only applicable to radionuclides in air breathed by members of the public. DCGs may be used as a comparative basis for screening concentrations from air emission points.

DOE Orders and federal regulations require that the hypothetical dose to the public from facility effluents be estimated using specific computer codes. (See "Dose Assessment Methodology" in Chapter 2.) Doses estimated for WVDP activities are calculated using actual site data and are not related directly to summed DCG values. Dose estimates for liquid effluents are based on the product of radionuclide quantities released and the site-specific dose equivalent effects for that radionuclide. Although airborne DCGs are used for comparison purposes, the more stringent EPA National Emission Standards for Hazardous Air Pollutants regulate Project airborne emissions at the point of release. For a consistent guide to relative concentrations, both air and water sampling results are compared with DCGs throughout this report.

\section{Data Reporting}

In the text of this report, traditional radiological units (e.g., rem, rad, curie, roentgen) are presented first, followed by Systeme Internationale (S.I.) units. Nonradiological measurements are presented in English units, followed by metric units in parentheses. A conversion chart for comparing traditional and S.I. radiological units and English and metric nonradiological units is presented under "Units of Measure," later in this section. Regulatory or guidance standards are presented as they appear in the source document.

The number of significant digits reported depends on the precision of the measurement technique. Integer counts will be reported without rounding. Calculated values are customarily reported to three significant figures. Dose estimates may be reported to two significant figures.

Radiological Data. Because the decay of radioactive atoms is a random process, an inherent uncertainty is associated with all measurements of environmental radioactivity. This can be demonstrated by repeatedly measuring the number of atoms that decay in a radioactive sample over some fixed period of time. The result of such an experiment would be a range of values for which the average value would provide the best indication of how many radioactive atoms were present in the sample.

In actual practice, an environmental sample is usually measured for radioactivity only once over a period of time. The inherent random uncertainty of the measurement, in an efficient process, is the major reason that the reported measurement is higher or lower than the "true" value.

The term "confidence interval" is used to describe the range of measurement values above and below the test result within which the "true" value is expected to lie. This interval is derived statistically. The width of the interval is based primarily on a predetermined confidence level, that is, the probability that the confidence

$$
U I-4
$$


interval actually encompasses the "true" value. The WVDP environmental monitoring program uses a 95\% confidence level for all radioactivity measurements and calculates confidence intervals accordingly.

The confidenceinterval around a measured value is indicated by the plus-or-minus ( \pm ) value following the result (e.g., 5.30 $\pm 3.6 \mathrm{E}-09$ microcuries per milliliter $[\mu \mathrm{Ci} / \mathrm{mL}]$ ), with the exponent of $10^{-9}$ expressed as "E-09." Expressed in decimal form, the result $5.30 \pm 3.6 \mathrm{E}-09$ would be $0.00000000530 \pm 0.0000000036 \mu \mathrm{Ci} / \mathrm{mL}$. A sample measurement expressed this way is correctly interpreted to mean "there is a $95 \%$ probability that the concentration of radioactivity in this sample is between $1.7 \mathrm{E}-09 \mu \mathrm{Ci} / \mathrm{mL}$ and $8.9 \mathrm{E}-09 \mu \mathrm{Ci} / \mathrm{mL}$." If the confidence interval for the measured value includes zero (e.g., $5.30 \pm 6.5 \mathrm{E}-09 \mu \mathrm{Ci} / \mathrm{mL}$ ), the value is considered to be below the detection limit. The values listed in tables of radioactivity measurements in the appendices include the confidence interval regardless of the detection limit value.

Chemical Data. In general, the detection limit is the minimum amount of constituent or material of interest detected by an instrument or method that can be distinguished from background and instrument noise. Thus, the detection limit is the lowest value at which a sample result shows a statistically positive difference from a sample in which no constituent is present.

Nonradiological data are conventionally presented without an associated uncertainty and are expressed by the detection limit prefaced by a "less than" symbol $(<)$ if that analyte were not measurable.

$U I-5$ 


\section{Units of Measure}

\begin{tabular}{|c|c|c|c|c|c|}
\hline Radioactivity & $\underline{\text { Symbol }}$ & Name & Volume & Symbol & Name \\
\hline & $\begin{array}{l}\mathrm{C} \\
\mathrm{mCi} \\
\mu \mathrm{Ci} \\
\mathrm{nCi} \\
\mathrm{pCi} \\
\mathrm{Bq} \\
\mathrm{d} / \mathrm{s}\end{array}$ & $\begin{array}{l}\text { curie } \\
\text { millicurie }(1 \mathrm{E}-03 \mathrm{Ci}) \\
\text { microcurie }(1 \mathrm{E}-06 \mathrm{Ci}) \\
\text { nanocurie }(1 \mathrm{E}-09 \mathrm{Ci}) \\
\text { picocurie }(1 \mathrm{E}-12 \mathrm{Ci}) \\
\text { becquerel }(27 \mathrm{pCi}) \\
\text { disintegrations per second }\end{array}$ & & $\begin{array}{l}\mathrm{cm}^{3} \\
\mathrm{~L} \\
\mathrm{~mL} \\
\mathrm{~m}^{3} \\
\mathrm{gal} \\
\mathrm{ft}^{3}\end{array}$ & $\begin{array}{l}\text { cubic centimeter } \\
\text { liter } \\
\text { milliliter } \\
\text { cubic meter } \\
\text { gallon } \\
\text { cubic feet }\end{array}$ \\
\hline \multirow[t]{2}{*}{ Dose } & $\underline{\text { Symbol }}$ & Name & Area & Symbol & Name \\
\hline & $\begin{array}{l}\mathrm{Sv} \\
\mathrm{mSv} \\
\mathrm{Gy} \\
\text { mrem }\end{array}$ & $\begin{array}{l}\text { sievert (100 rem) } \\
\text { millisievert (1E-03 Sv) } \\
\text { gray (100 rad) } \\
\text { millirem(1E-03 rem) }\end{array}$ & & ha & hectare $\left(10,000 \mathrm{~m}^{2}\right)$ \\
\hline \multirow[t]{2}{*}{ Concentration } & $\underline{\text { Symbol }}$ & $\underline{\text { Name }}$ & $\underline{\text { Length }}$ & Symbol & Name \\
\hline & $\begin{array}{l}\mu \mathrm{Ci} / \mathrm{mL} \\
\mathrm{mL} / \mathrm{L} \\
\mu \mathrm{Ci} / \mathrm{g} \\
\mathrm{mg} / \mathrm{L} \\
\mathrm{mg} / \mathrm{kg} \\
\mu \mathrm{g} / \mathrm{mL} \\
\mathrm{pCi} / \mathrm{L} \\
\mathrm{ng} / \mathrm{L} \\
\mu \mathrm{g} / \mathrm{L} \\
\mu \mathrm{g} / \mathrm{g} \\
\mathrm{Bq} / \mathrm{L} \\
\mathrm{ppm} \\
\mathrm{ppb} \\
\mathrm{ppt} \\
\mathrm{NTU} \\
\mathrm{SU}\end{array}$ & $\begin{array}{l}\text { microcuries per milliliter } \\
\text { milliliters per liter } \\
\text { microcuries per gram } \\
\text { milligrams per liter }(\mathrm{ppm}) \\
\text { milligrams per kilogram }(\mathrm{ppm}) \\
\text { micrograms per milliliter }(\mathrm{ppm}) \\
\text { picocuries per liter } \\
\text { nanograms per liter }(\mathrm{ppt}) \\
\text { micrograms per liter }(\mathrm{ppb}) \\
\text { micrograms per gram }(\mathrm{ppm}) \\
\text { becquerels per liter } \\
\text { parts per million } \\
\text { parts per billion } \\
\text { parts per trillion } \\
\text { nephlemetric turbidity units } \\
\text { standard units }\end{array}$ & $\underline{\text { Exposure }}$ & $\begin{array}{l}\text { Symbol } \\
\mu \mathrm{RR} \\
\mathrm{mR}\end{array}$ & 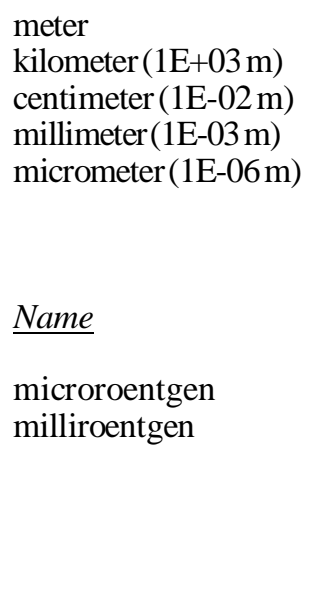 \\
\hline \multirow[t]{2}{*}{$\underline{\text { Mass }}$} & $\begin{array}{l}\text { Symbol } \\
\text { g } \\
\mathrm{kg} \\
\mathrm{mg} \\
\mu \mathrm{g} \\
\mathrm{ng} \\
\mathrm{t}\end{array}$ & $\begin{array}{l}\text { Name } \\
\text { gram } \\
\text { kilogram }(1 \mathrm{E}+03 \mathrm{~g}) \\
\text { milligram }(1 \mathrm{E}-03 \mathrm{~g}) \\
\text { microgram }(1 \mathrm{E}-06 \mathrm{~g}) \\
\text { nanogram }(1 \mathrm{E}-09 \mathrm{~g}) \\
\text { metric ton }(1 \mathrm{E}+06 \mathrm{~g})\end{array}$ & $\frac{\text { Flow Rate }}{\text { or Speed }}$ & $\begin{array}{l}\text { Symbol } \\
\mathrm{mgd} \\
\mathrm{cfm} \\
\mathrm{lpm} \\
\mathrm{gpd} \\
\mathrm{m} / \mathrm{sec}\end{array}$ & $\begin{array}{l}\text { Name } \\
\text { million gallons per day } \\
\text { cubic feet per minute } \\
\text { liters per minute } \\
\text { gallons per day } \\
\text { meters per second }\end{array}$ \\
\hline & $\begin{array}{l}\text { centi } \\
\text { milli } \\
\text { micro } \\
\text { nano } \\
\text { pico }\end{array}$ & $\begin{array}{l}1 / 100=1 \times 10^{-2}=0.01 \\
1 / 1,000=1 \times 10^{-3}=0.0 \\
1 / 1,000,000=1 \times 10^{-6}= \\
1 / 1,000,000,000=1 \times 1 \\
1 / 1,000,000,000,000=\end{array}$ & $\begin{array}{l}\text { E- } 03 \\
0001=E-06 \\
0.000000001 \\
0^{-12}=0.00000\end{array}$ & $\begin{array}{l}\text { E-09 } \\
00001=\end{array}$ & \\
\hline
\end{tabular}

$$
U I-6
$$




\section{Scientific Notation}

Scientific notation may be used to express very large or very small numbers. A number smaller than 1 is expressed with a negative exponent (e.g., $1.3 \times 10^{-6}$ ). To convert this number to decimal form, the decimal point is moved left by the number of places equal to the exponent. Thus, $1.3 \times 10^{-6}$ becomes 0.0000013 .

A number larger than 10 is expressed with a positive exponent (e.g., $\left.1.3 \times 10^{6}\right)$. To convert this number to decimal form, the decimal point is moved right by the number of places equal to the exponent. Thus, $1.3 \times 10^{6}$ becomes $1,300,000$.

The power of 10 also is expressed as E. For example, $1.3 \times 10^{-6}$ also can be written as $1.3 \mathrm{E}-06$. The chart below shows equivalent exponential and decimal values.

$\begin{array}{lllll}1.0 \times 10^{2}= & 1 \mathrm{E}+02= & 100 \\ 1.0 \times 10^{1}= & 1 \mathrm{E}+01= & 10 \\ 1.0 \times 10^{0}= & 1 \mathrm{E}+00= & 1 \\ 1.0 \times 10^{-1}= & 1 \mathrm{E}-01= & 0.1 \\ 1.0 \times 10^{-2}= & 1 \mathrm{E}-02= & 0.01 \\ 1.0 \times 10^{-3}= & 1 \mathrm{E}-03= & 0.001 \\ 1.0 \times 10^{-4}= & 1 \mathrm{E}-04= & 0.0001 & \\ 1.0 \times 10^{-5}= & 1 \mathrm{E}-05= & 0.00001 \\ 1.0 \times 10^{-6}= & 1 \mathrm{E}-06= & 0.000001 & \\ 1.0 \times 10^{-7}= & 1 \mathrm{E}-07= & 0.0000001 & \\ 1.0 \times 10^{-8}= & 1 \mathrm{E}-08= & 0.00000001 & \\ & & & \end{array}$

Both traditional radiological units (curie, roentgen, rad, rem) and the Systeme Internationale (S.I.) units (becquerel, gray, sievert) are used in this report. Nonradiological measurements are presented in both English and metric units. Frequently-used radioactivity and dose conversions are bolded.

$\begin{array}{lll}1 \text { centimeter }(\mathrm{cm}) & = & 0.3937 \text { inches }(\mathrm{in}) \\ 1 \text { meter }(\mathrm{m}) & = & 39.37 \text { inches }(\mathrm{in})=3.28 \text { feet }(\mathrm{ft}) \\ 1 \text { kilometer }(\mathrm{km}) & = & 0.62 \text { miles }(\mathrm{mi}) \\ 1 \text { milliliter }(\mathrm{mL}) & = & 0.0338 \text { ounces }(\mathrm{oz}) \\ & = & 0.061 \text { cubic inches }\left(\mathrm{in}^{3}\right) \\ & = & 1 \text { cubic centimeter }\left(\mathrm{cm}^{3}\right) \\ 1 \text { liter }(\mathrm{L}) & = & 1.057 \text { quarts }(\mathrm{qt}) ; 0.2641721 \text { gallons }(\mathrm{gal}) \\ & = & 61.02 \text { cubic inches }\left(\mathrm{in}^{3}\right) \\ 1 \text { gram }(\mathrm{g}) & = & 0.0353 \text { ounces }(\mathrm{oz}) \\ & = & 0.0022 \text { pounds }(\mathrm{lbs}) \\ 1 \text { kilogram }(\mathrm{kg}) & = & 2.2 \text { pounds }(\mathrm{lbs}) \\ 1 \text { curie }(\mathrm{Ci}) & = & 3.7 \mathrm{E}+10 \text { disintegrations per second }(\mathrm{d} / \mathrm{s}) \\ \mathbf{1} \text { becquerel }(\mathbf{B q}) & = & \mathbf{1} \text { disintegration per second }(\mathbf{d} / \mathbf{s}) \\ & = & \mathbf{2 7} \text { picocuries }(\mathbf{p C i}) \\ 1 \text { roentgen }(\mathrm{R}) & = & 2.58 \mathrm{E}-04 \text { coulombs per kilogram of air }(\mathrm{C} / \mathrm{kg}) \\ \mathbf{1} \text { rad } & = & \mathbf{0 . 0 1} \text { gray }(\mathbf{G y}) \\ \mathbf{1} \text { rem } & = & \mathbf{0 . 0 1} \text { sievert }(\mathbf{S v}) \\ 1 \text { millirem }(\mathrm{mrem}) & = & 0.001 \text { rem } \\ \mathbf{1} \text { sievert }(\mathbf{S v}) & = & \mathbf{1 0 0} \text { rem }\end{array}$


This page intentionally left blank

$$
U I-8
$$




\section{GLOSSARY}

\section{Note: Definitions given in many cases are specifically related to the WVDP, and are not intended to be comprehensive.}

$-\mathbf{A}$

accuracy. The degree of agreement between a measurement and its true value. The accuracy of a data set is assessed by evaluating results from standards or sample spikes containing known quantities of an analyte.

action plan. An action plan addresses assessment findings and root causes that have been identified in an audit or an assessment report. It is intended to define specific actions that the responsible group will undertake to remedy deficiencies. The plan includes a timetable and funding requirements for implementation of the planned activities.

alluvial fan. A cone-shaped deposit of alluvium made by a stream where it runs out onto a level plain.

alluvium. Sedimentary material deposited by flowing water, such as a river.

aquifer. A water-bearing unit of permeable rock or soil that will yield water in usable quantities to wells. Confined aquifers are bounded above and below by less permeable layers. Groundwater in a confined aquifer is under a pressure greater than the atmospheric pressure. Unconfined aquifers are bounded below by less permeable material, but are not bounded above. The pressure on the groundwater at the surface of an unconfined aquifer is equal to that of the atmosphere.

as low as reasonably achievable (ALARA). An approach to radiation protection that advocates controlling or managing exposures (both individual and collective) to the work force and the general public and releases of radioactive material to the environment as low as social, technical, economic, practical, and public policy considerations permit. As used in DOE Order 5400.5, ALARA is not a dose limit but, rather, a process that has as its objective the attainment of dose levels as far below the applicable limits of the Order as practicable.

$$
G L O-1
$$


B

background radiation. Natural and man-made radiation such as cosmic radiation and radiation from naturally radioactive elements and from commercial sources and medical procedures.

becquerel (Bq). A unit of radioactivity equal to one nuclear transformation per second.

British thermal unit (BTU, also MBTU, MMBTU). A standard unit of measurement used to denote both the amount of heat energy in fuels and the ability of appliances and air-conditioning systems to produce heating or cooling. A BTU is the amount of heat required to increase the temperature of a pint of water (which weighs exactly 16 ounces) by one degree Farenheit. One million BTUs may be expressed as one MBTU or one MMBTU (to represent a thousand thousand BTUs), which is occasionally used as a standard unit of measurement for natural gas and provides a convenient basis for comparing the energy content of various grades of natural gas and other fuels. One cubic foot of natural gas produces approximately 1,000 BTUs, so 1,000 cubic feet of gas is comparable to $1 \mathrm{MBTU}$.

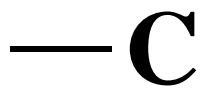

categorical exclusion (CX). A proposed action that normally does not require an environmental assessment or an environmental impact statement and that the Department of Energy has determined does not individually or cumulatively have a significant effect on the human environment. See 10 CFR 1021.410.

Class A, B, and C low-level waste. Waste classifications from the Nuclear Regulatory Commission's 10 CFR Part 61 rule. Maximum concentration limits are set for specific isotopes. Class A waste disposal is minimally restricted with respect to the form of the waste. Class B waste must meet more rigorous requirements to ensure physical stability after disposal. Higher concentration limits are set for the same isotopes in Class $\mathrm{C}$ waste, which also must meet physical stability requirements. Moreover, special measures must be taken at the disposal facility to protect against inadvertent intrusion.

compliance findings. Conditions that may not satisfy applicable environmental or safety and health regulations, DOE Orders and memoranda, enforcement actions, agreements with regulatory agencies, or permit conditions.

confidence coefficient or factor. The chance or probability, usually expressed as a percentage, that a confidence interval includes some defined parameter of a population. The confidence coefficients usually associated with confidence intervals are $90 \%, 95 \%$, and $99 \%$.

$G L O-2$ 
confidence interval. The range of values within which some parameter may be expected to lie with a stated degree of confidence. For example, a value of 10 with an uncertainty of 5 calculated at the $95 \%$ confidence level $(10 \pm 5)$ indicates there is a $95 \%$ probability that the true value of the population parameter lies between 5 and 15 .

consistency. The condition of showing steady conformity to practices. In the environmental monitoring program, approved procedures are in place so that data collection activities are carried out in a consistent manner to minimize variability.

cosmic radiation. High-energy subatomic particles from outer space that bombard the earth's atmosphere. Cosmic radiation is part of natural background radiation.

counting error. The variability caused by the inherent random nature of radioactive disintegration and by the detection process.

curie (Ci). A unit of radioactivity equal to 37 billion $\left(3.7 \times 10^{10}\right)$ nuclear transformations per second.

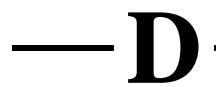

data set. A group of data (e.g., factual information such as measurements or statistics) used as a basis for reasoning, discussion, or calculation.

decay (radioactive). Disintegration of the nucleus of an unstable nuclide by spontaneous emission of charged particles and/or photons or by spontaneous fission.

derived concentration guide (DCG). The concentration of a radionuclide in air and water that, under conditions of continuous exposure for one year by one exposure mode (i.e., ingestion of water, submersion in air, or inhalation), would result in an effective dose equivalent of 100 mrem $(1 \mathrm{mSv})$. See Table $\mathrm{K}-1^{\mathrm{GD}}$ in Appendix $\mathrm{K}^{\mathrm{ED}}$.

detection limit or level (DL). This term may also be expressed as "method detection limit" (MDL). The smallest amount of a substance that can be distinguished in a sample by a given measurement procedure at a given confidence level. (See lower limit of detection.)

dispersion (groundwater). The process whereby solutes are spread or mixed as they are transported by groundwater as it moves through the subsurface.

dosimeter. A portable device for measuring the total accumulated exposure to ionizing radiation.

downgradient. The direction of water flow from a reference point to a selected point of interest at a lower elevation than the reference point. (See gradient.)

$G L O-3$ 
$\mathbf{E}$

effective dose. (See effective dose equivalent under radiation dose.)

effluent. Any treated or untreated air emission or liquid discharge to the environment, including storm water runoff.

effluent monitoring. Sampling or measuring specific liquid or gaseous effluent streams for the presence of pollutants.

enhanced work planning. A process used to evaluate and improve the program by which work is identified, planned, approved, controlled, and executed. The key elements are line management ownership, a graded approach to work management based on risk and complexity, worker involvement beginning at the earliest phases of work management, organizationally diverse teams, and organized, institution-wide communication.

environmental assessment (EA). An evaluation that provides sufficient evidence and analysis for determining whether an environmental impact statement or a finding of no significant impact is required. Detailed information found in 40 CFR 1508.9.

environmental impact statement (EIS). A detailed statement that includes the environmental impact of the proposed action, any adverse environmental effects that cannot be avoided should the proposal be implemented, and alternatives to the proposed action. Detailed information found in Section 102 (2) (C) of the National Environmental Policy Act.

environmental management system (EMS). The systematic application of business management practices to environmental issues, including defining the organizational structure, planning for activities, identifying responsibilities, and defining practices, procedures, processes, and resources.

environmental monitoring. The collection and analysis of samples or the direct measurement of environmental media. Environmental monitoring consists of two major activities: effluent monitoring and environmental surveillance.

environmental surveillance. The collection and analysis of samples or the direct measurement of air, water, soil, foodstuff, and biota in order to determine compliance with applicable standards and permit requirements.

erg. One-billionth (1E-09) of the energy released by a 100-watt bulb in one second. One dyne-cm.

$$
G L O-4
$$


evapotranspiration. The combined total precipitation returned to the air through direct evaporation and by transpiration of vegetation.

exposure. The subjection of a target (usually living tissue) to radiation.

$\mathbf{F}$

fallout. The settling to earth of radioactive materials mixed into the earth's atmosphere.

finding. A Department of Energy compliance term. A finding is a statement of fact concerning a condition in the Environmental, Safety, and Health program that was investigated during an appraisal. Findings include best management practice findings, compliance findings, and noteworthy practices. A finding may be a simple statement of proficiency or a description of deficiency (i.e., a variance from procedures or criteria). (See also self-assessment.)

fission. The act or process of splitting into parts. A nuclear reaction in which an atomic nucleus splits into fragments (i.e., fission products, usually fragments of comparable mass) with the evolution of approximately 100 million to several hundred million electron volts of energy.

$-\mathbf{G}$

gamma isotopic (also gamma scan). An analytical method by which the quantity of several gamma rayemitting radioactive isotopes may be determined simultaneously. Typical nuclear fuel cycle isotopes determined by this method include, but are not limited to, cobalt-60, zirconium-95, ruthenium-106, silver-110m, antimony-125, cesium-134, cesium-137, and europium-154. Naturally-occurring isotopes for which samples also often are analyzed are beryllium-7, potassium-40, radium-224, and radium-226.

gradient. Change in value of one variable with respect to another variable, such as a vertical change over a horizontal distance.

groundwater. Subsurface water in the pore spaces and fractures of soil and bedrock units.

$-\mathbf{H}$

half-life. The time in which half the atoms of a radionuclide disintegrate into another nuclear form. The halflife may vary from a fraction of a second to thousands of years.

$G L O-5$ 
hazardous waste. A waste or combination of wastes that because of quantity, concentration, or physical, chemical, or infectious characteristics may: a) cause or significantly contribute to an increase in mortality or an increase in serious irreversible or incapacitating reversible illness; or (b) pose a substantial present or potential hazard to human health or the environment when improperly treated, stored, transported, disposed of, or otherwise managed.

high-level waste (HLW). The highly radioactive waste material that results from the reprocessing of spent nuclear fuel, including liquid waste produced directly in reprocessing and any solid waste derived from the liquid, that contains a combination of transuranic waste and fission products in concentrations sufficient to require permanent isolation. (See also transuranic waste.)

hydraulic conductivity. The ratio of flow velocity to driving force for viscous flow under saturated conditions of a specified liquid in a porous medium; the ratio describing the rate at which water can move through a permeable medium.

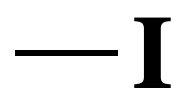

integrated safety management system (ISMS). The ISMS describes the programs, policies, and procedures used by WVNSCO and the DOE to ensure that WVNSCO establishes a safe workplace for the employees, the public, and the environment. The guiding principles of ISMS are line management responsibility for safety; clear roles and responsibilities; competence commensurate with responsibilities; balanced priorities; identification of safety standards and requirements; hazard controls; and operations authorization.

interim status. The status of any currently existing facility that becomes subject to the requirement to have a RCRA permit because of a new statutory or regulatory amendment to RCRA.

interstitial. The (annular) space between the inner and outer tank walls in a double-walled storage tank.

ion. An atom or group of atoms with an electric charge.

ion exchange. The reversible exchange of ions contained in solution with other ions that are part of the ionexchange material.

isotope. Different forms of the same chemical element that are distinguished by having the same number of protons but a different number of neutrons in the nucleus. An element can have many isotopes. For example, the three isotopes of hydrogen are protium, deuterium, and tritium, with one, two, and three neutrons in the nucleus, respectively.

$$
G L O-6
$$




\section{$\mathbf{K}$}

kame delta. A deposit, often triangular, formed where a glacial stream entered into a proglacial lake.

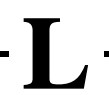

lacustrine sediments. A sedimentary deposit consisting of material pertaining to, produced by, or formed in a lake or lakes.

land disposal restrictions (LDR). Regulations promulgated by the U.S. EPA (and by NYSDEC in New York State) governing the land disposal of hazardous wastes. The wastes must be treated using the best demonstrated available technology or must meet certain treatment standards before being disposed.

lower limit of detection (LLD). The lowest limit of a given parameter that an instrument is capable of detecting. A measurement of analytical sensitivity.

low-level waste (LLW). Radioactive waste not classified as high-level waste, transuranic waste, spent fuel, or uranium mill tailings. (See Class $A, B$, and C low-level waste.)

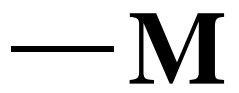

maximally exposed individual (MEI). On-site (occupational) or off-site (nonoccupational) person that receives the highest dose from a release scenario.

maximally exposed off-site individual (MEOSI). Member of the general public receiving the highest dose from the effluent release.

mean. The average value of a series of measurements.

metric ton. (See ton, metric.)

millirem (mrem). A unit of radiation dose equivalent that is equal to one one-thousandth of a rem. An individual member of the public can receive up to $500 \mathrm{mrem}$ per year according to DOE standards. This limit does not include radiation received for medical treatment or the roughly $360 \mathrm{mrem}$, on average, that people receive annually from background radiation.

$$
G L O-7
$$


minimum detectable concentration (MDC) or method detection limit (MDL). Depending on the sample medium, the smallest amount or concentration of a radioactive or nonradioactive analyte that can be reliably detected using a specific analytical method. Calculations of the minimum detectable concentrations are based on the lower limit of detection.

mixed waste (MW). A waste that is both radioactive and RCRA hazardous.

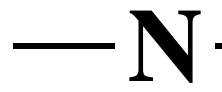

n-Dodecane/tributyl phosphate. An organic solution composed of 30\% tributyl phosphate (TBP) dissolved in n-dodecane used to first separate the uranium and plutonium from the fission products in the dissolved fuel and then to separate the uranium from the plutonium.

neutron. An electrically neutral subatomic particle in the baryon family with a mass 1,839 times that of an electron, stable when bound in an atomic nucleus, and having a mean lifetime of approximately 16.6 minutes as a free particle.

notice of violation (NOV). Generally, an official notification from a regulatory agency of noncompliance with permit requirements. (An example would be a letter of notice from a regional water engineer in response to an instance of significant noncompliance with a SPDES permit.)

nucleus. The positively-charged central region of an atom, made up of protons and neutrons and containing almost all of the mass of the atom.

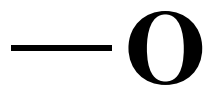

outfall. The discharge end of a drain or pipe that carries wastewater or other effluents into a ditch, pond, or river.

\section{$\mathbf{P}$}

parameter. Any of a set of physical properties whose values determine the characteristics or behavior of something (e.g., temperature, pressure, density of air). In relation to environmental monitoring, a monitoring parameter is a constituent of interest. Statistically, the term "parameter" is a calculated quantity, such as a mean or variance, that describes a statistical population.

particulates. Solid particles and liquid droplets small enough to become airborne.

$G L O-8$ 
person-rem. The sum of the individual radiation dose equivalents received by members of a certain group or population. It may be calculated by multiplying the average dose per person by the number of persons exposed. For example, a thousand people each exposed to one millirem would have a collective dose of one person-rem.

plume. The distribution of a pollutant in air or water after being released from a source.

precision. The degree of reproducibility of a measurement under a given set of conditions. Precision in a data set is assessed by evaluating results from duplicate field or analytical samples.

proglacial lake. A lake occupying a basin in front of a glacier, generally in direct contact with the ice.

proton. A stable, positively-charged subatomic particle in the baryon family with a mass 1,836 times that of an electron.

pseudo-monitoring point. A theoretical monitoring location rather than an actual physical location; a calculation based on analytical test results of samples obtained from other associated, tributary, monitored locations. (Point 116 at the WVDP is classified as a "pseudo" monitoring point because samples are not physically collected at that location. Rather, using analytical results from samples collected from "real" upstream outfall locations, compliance with the total dissolved solids limit in the WVDP's SPDES permit is calculated for this theoretical point.)

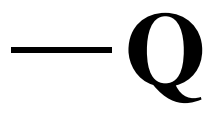

quality factor (QF). The extent of tissue damage caused by different types of radiation of the same energy. The greater the damage, the higher the quality factor. More specifically, the factor by which absorbed doses are multiplied to obtain a quantity that indicates the degree of biological damage produced by ionizing radiation. See radiation dose.) The factor is dependent upon radiation type (alpha, beta, gamma, or x-ray) and exposure (internal or external).

$-\mathbf{R}$

rad. Radiation absorbed dose. One hundred ergs of energy absorbed per gram.

radiation. The process of emitting energy in the form of rays or particles that are thrown off by disintegrating atoms. The rays or particles emitted may consist of alpha, beta, or gamma radiation.

$G L O-9$ 
alpha radiation. The least penetrating type of radiation. Alpha radiation can be stopped by a sheet of paper or the outer dead layer of skin.

beta radiation. Electrons emitted from a nucleus during fission and nuclear decay. Beta radiation can be stopped by an inch of wood or a thin sheet of aluminum.

gamma radiation. A form of electromagnetic, high-energy radiation emitted from a nucleus. Gamma rays are essentially the same as x-rays and require heavy shielding such as lead, concrete, or steel to be stopped.

internal radiation. Radiation originating from a source within the body as a result of the inhalation, ingestion, or implantation of natural or man-made radionuclides in body tissues.

\section{radiation dose:}

absorbed dose. The amount of energy absorbed per unit mass in any kind of matter from any kind of ionizing radiation. Absorbed dose is measured in rads or grays.

collective dose equivalent. The sum of the dose equivalents for all the individuals comprising a defined population. The per capita dose equivalent is the quotient of the collective dose equivalent divided by the population. The unit of collective dose equivalent is person-rem or personsievert.

collective effective dose equivalent. The sum of the effective dose equivalents for the individuals comprising a defined population. Units of measurement are person-rem or person-sievert. The per capita effective dose equivalent is obtained by dividing the collective dose equivalent by the population. Units of measurement are rem or sievert.

committed dose equivalent. A measure of internal radiation. The predicted total dose equivalent to a tissue or organ over a fifty-year period after a known intake of a radionuclide into the body. It does not include contributions from sources of external penetrating radiation. Committed dose equivalent is measured in rem or sievert.

committed effective dose equivalent. The sum of the committed dose equivalents to various tissues in the body, each multiplied by the appropriate weighting factor. Committed effective dose equivalent is measured in rem or sievert.

effective dose equivalent. The summation of the products of the dose equivalent received by specified tissues of the body and the appropriate weighting factors. It includes the dose from radiation sources internal and/or external to the body. The effective dose equivalent is expressed in units of rem or seivert.

$G L O-10$ 
radioactivity. A property possessed by some elements (such as uranium) whereby alpha, beta, or gamma rays are spontaneously emitted.

radioisotope. A radioactive isotope of a specified element. Carbon-14 is a radioisotope of carbon. Tritium is a radioisotope of hydrogen. (See isotope.)

radionuclide. A radioactive nuclide. Radionuclides are variations (isotopes) of elements. They have the same number of protons and electrons but different numbers of neutrons, resulting in different atomic masses. There are several hundred known nuclides, both manmade and naturally occurring.

reference man. A hypothetical aggregation of human physical and physiological characteristics arrived at by internal consensus. These characteristics may be used by researchers and public health workers to standardize results of experiments and to relate biological insult to a common base.

rem. An acronym for Roentgen Equivalent Man. A unit of radiation exposure that indicates the potential effect of radiation on human cells.

remote-handled waste. At the WVDP, waste that has an external surface dose rate that exceeds 100 millirem per hour or a high level of alpha and/or beta surface contamination and, therefore, must be handled in such a manner that a worker does not come into physical contact with it.

roentgen. A unit of exposure to ionizing radiation. It is that quantity of gamma or x-rays required to produce ions carrying one electrostatic unit of electrical charge in one cubic centimeter of dry air under standard conditions. The unit is named after Wilhelm Roentgen, German scientist who discovered x-rays in 1895.

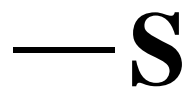

self-assessment. Appraisals of work at the WVDP by individuals, groups, or organizations responsible for overseeing and/or performing the work. Self-assessments are intended to provide an internal review of performance to determine that specific functional areas are in programmatic and site-specific compliance with applicable DOE directives, WVDP procedures, and regulations.

finding. A direct and significant violation of applicable Department of Energy, regulatory, or other procedural or programmatic requirements. A finding requires documented corrective action.

observation. A condition that, while not a direct and significant violation of applicable Department of Energy, regulatory, or other procedural or programmatic requirements, could result in a finding if not corrected. An observation requires documented corrective action.

good practice. A statement of proficiency or confirmed excellence worthy of documenting.

\section{$G L O-11$}


sievert. A unit of dose equivalent from the International System of Units (Systeme Internationale). Equal to one joule per kilogram.

solid waste management unit (SWMU). Any discernible unit at which solid wastes have been placed at any time, irrespective of whether the unit was intended for the management of solid or hazardous waste. Such units include any area at a facility at which solid wastes have been routinely and systematically released. (See also super solid waste management unit.)

spent fuel. Nuclear fuel that has been used in a nuclear reactor; this fuel contains uranium, activation products, fission products, and plutonium.

spill. A spill or release is defined as "any spilling, leaking, pumping, pouring, emitting, emptying, discharging, injecting, escaping, leaching, dumping, or otherwise disposing of substances from the ordinary containers employed in the normal course of storage, transfer, processing, or use."

stakeholder. A person or group that has an investment, share, or interest in something. At the WVDP stakeholders include Project management, scientists, other employees, politicians, regulatory agencies, local and national interest groups, and members of the general public.

standard deviation. An indication of the dispersion of a set of results around their average.

super solid waste management unit (SSWMU). Individual solid waste management units that have been grouped and ranked into larger units - super solid waste management units - because some individual units are contiguous or so close together as to make monitoring of separate units impractical. (See also solid waste management unit.)

surface water. Water that is exposed to the atmospheric conditions of temperature, pressure, and chemical composition at the surface of the earth.

surveillance. The act of monitoring or observing a process or activity to verify conformance with specified requirements.

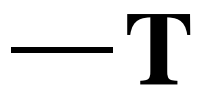

thermoluminescent dosimeter (TLD). A device that luminesces upon heating after being exposed to radiation. The amount of light emitted is proportional to the amount of radiation to which the luminescent material has been exposed.

ton, metric (also tonne). A unit of mass equal to 1,000 kilograms.

ton (short ton). A unit of weight equal to 2,000 pounds or 907.1847 kilograms.

$$
G L O-12
$$


transuranic (TRU) waste. Waste containing transuranic elements, that is, those elements with an atomic number greater than 92, including neptunium, plutonium, americium, and curium.

$-\mathbf{U}$

universal wastes. Wastes subject to special management provisions that are intended to ease the management burden and facilitate recycling of such materials. Four types of waste are currently covered under the universal waste regulations: hazardous waste batteries, hazardous waste pesticides that are either recalled or collected in waste pesticide collection programs, hazardous waste thermostats, and hazardous waste lamps.

upgradient. Referring to the flow of water or air, "upgradient" is analogous to upstream. Upgradient is a point that is "before" an area of study that is used as a baseline for comparison with downstream or downgradient data. (See gradient and downgradient.)

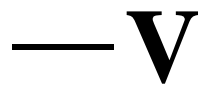

vitrification. A waste treatment process that encapsulates or immobilizes radioactive wastes in a glassy matrix to prevent them from reacting in disposal sites; involves adding chemicals and waste to a heated vessel and melting the mixture into a glass that is then poured into a canister.

\section{$\mathbf{W}$}

watershed. The area contained within a drainage divide above a specified point on a stream or river.

water table. The upper surface in a body of groundwater; the surface in an unconfined aquifer or confining bed at which the pore water pressure is equal to atmospheric pressure.

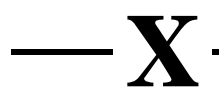

x-ray. Penetrating electromagnetic radiations having wave lengths shorter than those of visible light. They are usually produced by bombarding a metallic target with fast electrons in a high vacuum. In nuclear reactions it is customary to refer to photons originating in the nucleus as gamma rays and those originating in the extranuclear part of the atom as x-rays. These rays are sometimes called roentgen rays after their discoverer, W.C. Roentgen.

\section{$G L O-13$}


This page intentionally left blank

$$
G L O-14
$$




\title{
ACRONYMS AND ABBREVIATIONS
}

\author{
A\&PC \\ Analytical and Process Chemistry Laboratory \\ ACM \\ Asbestos-Containing Material \\ ACOE \\ (U.S.) Army Corps of Engineers \\ ALARA \\ As Low As Reasonably Achievable \\ ANSI \\ ASER \\ ASME \\ ASQ \\ AWQS \\ American National Standards Institute \\ Annual Site Environmental Report \\ American Society of Mechanical Engineers \\ American Society for Quality \\ Ambient Water Quality Standard \\ BAT \\ Best Available Technology \\ BCG \\ Biota Concentration Guide \\ BEIR \\ Biological Effects of Ionizing Radiation \\ $\mathrm{BOD}_{5}$ \\ BSW \\ Biochemical Oxygen Demand (5-day) \\ BTU \\ Bulk Storage Warehouse \\ British Thermal Unit (also MBTU, MMBTU) \\ CAA \\ Clean Air Act \\ CCHD \\ Cattaraugus County Health Department \\ CCZ \\ CD \\ Criticality Control Zone \\ CDDL \\ Compact Disk \\ CEDE \\ Construction and Demolition Debris Landfill \\ CEMP \\ Committed Effective Dose Equivalent \\ CERCLA \\ CFR \\ CMS \\ Code of Environmental Management Principles (for Federal Agencies) \\ CPC \\ CPC-WSA \\ CSPF \\ Comprehensive Environmental Response, Compensation, and Liability Act \\ Code of Federal Regulations \\ Corrective Measures Study \\ Chemical Process Cell \\ Chemical Process Cell Waste Storage Area \\ Container Sorting and Packaging Facility
}

$A \& A-1$ 


CSRF
CSS
CWA
CX
CY
D\&D
DCDFMeth
DCG
DL
DMR
DOE
DOE-EM
DOE-HQ
DOE-OH
DOE-WVDP
DOECAP
DOT

\section{EA}

EDE

EHS

EIS

ELAB

EMS

EO

EPA

EPCRA

ERA

ES\&H

ESR

FR

FRS

FY

GEL

GTAR

HEPA

HLW

HPIC
Contact Size-Reduction Facility

Cement Solidification System

Clean Water Act

Categorical Exclusion

Calendar Year

Decontamination and Decommissioning

Dichlorodifluoromethane

Derived Concentration Guide

Detection Limit or Detection Level

Discharge Monitoring Report

(U.S.) Department of Energy

Department of Energy, Office of Environmental Restoration and Waste Management

Department of Energy, Headquarters Office

Department of Energy, Ohio Field Office

Department of Energy, West Valley Demonstration Project (title as of June 2006)

Department of Energy Consolidated Audit Program

(U.S.) Department of Transportation

Environmental Assessment

Effective Dose Equivalent

Extremely Hazardous Substance

Environmental Impact Statement

(WVDP) Environmental Laboratory

Environmental Management System

Executive Order

(U.S.) Environmental Protection Agency

Emergency Planning and Community Right-to-Know Act

Environmental Research Associates

Environmental, Safety, and Health

(WVDP) Effluent Summary Report

Federal Register

Fuel Receiving and Storage

Fiscal Year

General Engineering Laboratory

Groundwater Trend Analysis Report

High-Efficiency Particulate Air (filter)

High-Level (radioactive) Waste

High-Pressure Ion Chamber

$A \& A-2$ 
HTO

HVAC

IAEA

ICRP

INL

IRTS

ISCORS

ISMS

ISO

LAS

LDR

LIMS

LLD

LLW

LLW2

LLWTF

LPS

LSA

LSA \#1

LSA \#2

LTR

LVLI

LWTS

MAPEP

MCL

MCLG

MDC

MDL

MEI

MEOSI

MGD

ML

MMBTU

MSDS

MTAR

MW

NCRP

NDA

NEPA
Hydrogen Tritium Oxide

Heating, Ventilation, and Air Conditioning

International Atomic Energy Agency

International Commission on Radiological Protection

Idaho National Laboratory

Integrated Radwaste Treatment System

Interagency Steering Committee on Radiation Standards

Integrated Safety Management System

International Organization for Standardization

Linear Alkylate Sulfonate

Land Disposal Restriction

Laboratory Information Management System

Lower Limit of Detection

Low-Level (radioactive) Waste

Low-Level (liquid) Waste Treatment Facility (new)

Low-Level (liquid) Waste Treatment Facility (old)

Liquid Pretreatment System

Lag Storage Area

Lag Storage Addition \#1

Lag Storage Hardstand

License Termination Rule

Lionville Laboratory, Inc.

Liquid Waste Treatment System

Mixed Analyte Performance Evaluation Program

Maximum Contaminant Level

Maximum Contaminant Level Goal

Minimum Detectable Concentration

Method Detection Limit (also Minimum Detection Level)

Maximally Exposed Individual

Maximally Exposed Off-Site Individual

Million Gallons per Day

Minimum Level

One million BTUs (a thousand thousand BTUs), also expressed as MBTU

Material Safety Data Sheet

Monthly Trend Analysis Report

(Radioactive and Hazardous) Mixed Waste

National Council on Radiation Protection and Measurements

Nuclear Regulatory Commission (NRC)-Licensed Disposal Area

National Environmental Policy Act

$A \& A-3$ 


\begin{tabular}{|c|c|}
\hline NESHAP & National Emission Standards for Hazardous Air Pollutants \\
\hline NFS & Nuclear Fuel Services, Inc. \\
\hline NGVD & National Geodetic Vertical Datum \\
\hline $\mathbf{N H}_{3}$ & Ammonia \\
\hline NIST & National Institute of Standards and Technology \\
\hline NOAA & National Oceanic and Atmospheric Administration \\
\hline NOI & Notice of Intent \\
\hline NOV & Notice of Violation \\
\hline $\mathbf{N O}_{\mathbf{x}}$ & Nitrogen Oxides \\
\hline NPDES & National Pollutant Discharge Elimination System \\
\hline NPGRS & North Plateau Groundwater Recovery System \\
\hline NPOC & Nonpurgeable Organic Carbon \\
\hline NRC & (U.S.) Nuclear Regulatory Commission \\
\hline NTS & Nevada Test Site \\
\hline NTU & Nephelometric Turbidity Unit \\
\hline NYCRR & New York Official Compilation of Codes, Rules, and Regulations \\
\hline NYS & New York State \\
\hline NYSDEC & New York State Department of Environmental Conservation \\
\hline NYSDOH & New York State Department of Health \\
\hline NYSDOH ELAP & (NYSDOH) Environmental Laboratory Approval Program \\
\hline NYSDOL & New York State Department of Labor \\
\hline NYSERDA & New York State Energy Research and Development Authority \\
\hline NYSGS & New York State Geological Survey \\
\hline OH/WVDP & Department of Energy, West Valley Demonstration Project \\
\hline OSHA & Occupational Safety and Health Administration \\
\hline OVE & Outdoor Ventilated Enclosure \\
\hline $\mathbf{P 2}$ & Pollution Prevention \\
\hline PCB & Polychlorinated Biphenyl \\
\hline PQL & Practical Quantitation Limit \\
\hline PTW & Permeable Treatment Wall \\
\hline PUREX & Plutonium Uranium Reduction Extraction \\
\hline PVS & Permanent Ventilation System \\
\hline PVU & Portable Ventilation Unit \\
\hline QA & Quality Assurance \\
\hline QAP & Quality Assessment Program (also Quality Assurance Program) \\
\hline QC & Quality Control \\
\hline QF & Quality Factor \\
\hline QTAR & Quarterly Trend Analysis Report \\
\hline
\end{tabular}

$A \& A-4$ 


\begin{tabular}{|c|c|}
\hline RCRA & Resource Conservation and Recovery Act \\
\hline REM & Roentgen Equivalent Man \\
\hline RFI & RCRA Facility Investigation \\
\hline RHWF & Remote-Handled Waste Facility \\
\hline ROD & Record of Decision \\
\hline SAR & Safety Analysis Report \\
\hline SARA & Superfund Amendments and Reauthorization Act \\
\hline SD & Standard Deviation \\
\hline SDA & (New York) State-Licensed Disposal Area \\
\hline SDWA & Safe Drinking Water Act \\
\hline SI & Systeme Internationale (International System of Units) \\
\hline $\mathrm{SO}_{2}$ & Sulfur Dioxide \\
\hline SPDES & (New York) State Pollutant Discharge Elimination System \\
\hline SRM & Standard Reference Material \\
\hline SSWMU & Super Solid Waste Management Unit \\
\hline STL & Severn Trent Laboratories \\
\hline STP & Site Treatment Plan \\
\hline STS & Supernatant Treatment System \\
\hline SVOC & Semivolatile Organic Compound \\
\hline SWMU & Solid Waste Management Unit \\
\hline TAGM & Technical and Administrative Guidance Memorandum \\
\hline TBP & Tributyl Phosphate \\
\hline TCE & Trichloroethylene \\
\hline TDS & Total Dissolved Solids \\
\hline THOREX & Thorium Reduction Extraction \\
\hline TKN & Total Kjeldahl Nitrogen \\
\hline TLD & Thermoluminescent Dosimeter \\
\hline TOC & Total Organic Carbon \\
\hline TOGS & Technical and Operational Guidance Series \\
\hline TOX & Total Organic Halides \\
\hline TRI & Toxic Release Inventory \\
\hline TRU & Transuranic \\
\hline TSCA & Toxic Substances Control Act \\
\hline TSDF & Treatment, Storage, and Disposal Facility \\
\hline TSS & Total Suspended Solids \\
\hline U.S. & United States \\
\hline URS & URS Group, Inc. \\
\hline USC & United States Code \\
\hline USGS & United States Geological Survey \\
\hline
\end{tabular}

$A \& A-5$ 


$\begin{array}{ll}\text { VF } & \text { Vitrification Facility } \\ \text { VOC } & \text { Volatile Organic Compound } \\ \text { VPP } & \text { (U.S. DOE) Voluntary Protection Program } \\ \text { WNYNSC } & \text { Western New York Nuclear Service Center } \\ \text { WVDP } & \text { West Valley Demonstration Project } \\ \text { WVNS } & \text { West Valley Nuclear Services Company (now WVNSCO) } \\ \text { WVNSCO } & \text { West Valley Nuclear Services Company } \\ \text { WWTF } & \text { Wastewater Treatment Facility }\end{array}$

$A \& A-6$ 


\section{REFERENCES AND BIBLIOGRAPHY}

(For a bibliographical listing that includes basis documents not specifically cited in the text, see the WVDP Annual Site Environmental Report for 2003.)

American National Standards Institute/American Society for Quality Control. 1994.

Specifications and Guidelines for Quality Systems for Environmental Data Collection and Environmental Technology Programs. ANSI/ASQC E4-1994.

American National Standards Institute, Inc. August 20, 1975. American National Standard: Performance Testing, and Procedural Specifications for Thermoluminescent Dosimetry (Environmental Applications). ANSI N545-1975.

American Society of Mechanical Engineers. 1989. Quality Assurance Program Requirements for Nuclear Facilities. ASME-NQA-1. New York: The American Society of Mechanical Engineers.

Brookhaven National Laboratory. April 2005. Nuclear Wallet Cards. National Nuclear Data Center. Upton, New York.

Citizen Task Force. July 29, 1998. West Valley Citizen Task Force Final Report.

Executive Order 11988. May 24, 1977. Floodplain Management. 42 FR 26951.

Executive Order 11990. May 25, 1977. Protection of Wetlands. 42 FR 26961.

Executive Order 13101. September 16, 1998. Greening the Government Through Waste Prevention, Recycling, and Federal Acquisition. 63 FR 49643.

Executive Order 13148. April 26, 2000. Greening the Government Through Leadership in Environmental Management. 65 FR 24595.

International Atomic Energy Agency (IAEA). 1992. Effects of Ionizing Radiation on Plants and Animals at Levels Implied by Current Radiation Protection Standards. Technical Report Series No. 332, IAEA, Vienna, Austria.

$$
R \& B-1
$$


International Commission on Radiological Protection. 1977. Recommendations of the International Commission on Radiological Protection. ICRP Publication 26. Oxford: Pergamon Press.

1979. Recommendations of the International Commission on Radiological Protection - Limits for Intakes of Radionuclides by Workers. ICRP Publication 30. Oxford: Pergamon Press.

International Organization for Standardization. 1996. Environmental Management Systems. ISO 14001:1996.

Long, E.R., and L.G. Morgan. 1990. The Potential for Biological Effects of Sediment-Sorbed Contaminants Tested in the National States and Trends Program. National Oceanic Atmospheric Administration (NOAA) Technical Memorandum No. 5, OMA52, NOAA National Ocean Service, Seattle, Washington.

Mitrey, R.J. October 28, 1986. Correspondence from New York State Department of Environmental Conservation to J.P. Hamric, Department of Energy, Idaho Operations Office, West Valley Project Office, regarding the construction landfill.

National Council on Radiation Protection and Measurements. 1987. Ionizing Radiation Exposure of the Population of the United States. NCRP-93. Bethesda, Maryland.

National Research Council. 1990. Health Effects of Exposure to Low Levels of Ionizing Radiation. Biological Effects of Ionizing Radiation (BEIR) V. Washington: National Academy Press.

New York State Department of Environmental Conservation. nd. Title 6, New York Codes, Rules, and Regulations (6 NYCRR). Environmental Conservation Rules and Regulations.

. March 29, 1991. RCRA Quality Assurance Project Plan (QAPjP) Guidance.

NYSDEC Division of Hazardous Substances Regulation.

. January 24, 1994. Determination of Soil Cleanup Objectives and Cleanup Levels. Technical and Administrative Guidance Memorandum (TAGM) \#4046.

. 1995. Appendix 33 - Groundwater Monitoring List. Title 6 NYCRR Subpart 373-2.

. September 3, 1996. Federal Facility Compliance Act: Order on Consent.

June 1998. Ambient Water Quality Standards and Guidance Values and Groundwater Effluent Limitations. Technical and Operational Guidance Series (TOGS) 1.1.1.

January 25, 1999. Technical Guidance for Screening Contaminated Sediments.

$$
R \& B-2
$$


. March 19, 1999. Stipulation of Agreement Pursuant to Section 17-0303 of the Environmental Conservation Law and Section 176 of the Navigation Law.

. January 2003. Draft Technical and Operational Guidance Series (TOGS) \#5.1.9.

In-Water and Riparian Management of Sediment and Dredge Material.

February 1, 2004. State Pollutant Discharge Elimination System (SPDES)

Discharge Permit NY0000973.

October 21, 2004. Air Facility Registration Certificate in accordance with 6 NYCRR Part 201-4.

New York State Department of Health. nd. Environmental Laboratory Approval Program (ELAP) Certification Manual.

. nd. Title 10, New York Code, Rules, and Regulations (10 NYCRR). Sources of Water Supply. Part 5 (Drinking Water Supplies) and Part 170 (Sources of Water Supply).

Pacific Northwest Laboratory (PNL). November 1988. Napier, B.A., Strenge, D.L., Pelequin, R.A., and Ramsdell, J.V. GENII - The Hanford Environmental Radiation Dosimetry Software System. Version 1.485, PNL-6584.

Parks B.L. March 1992. User's Guide for CAP88-PC. Version 1.0. Las Vegas, NV: U.S. Environmental Protection Agency Office of Radiation Programs. 402-B-92-001.

June 1997. CAP88-PC Version 2.0 User's Guide. Germantown, Maryland. U.S. Department of Energy.

Persaud, D., Jaagumagi, R., and A. Hayton. 1992. Guidelines for the Protection and Management of Aquatic Sediment Quality in Ontario. Ontario Ministry of the Environment, Queen's Printer for Ontario.

Rickard, L.V. 1975. Correlation of the Silurian and Devonian Rocks in New York State. New York State Museum and Science Service Map and Chart Series No. 24.

Scarpitta, S., J. Odin-McCabe, R. Gaschott, A. Meier, and E. Klug. June 1999. Comparison of Four ${ }^{90} \mathrm{Sr}$ Groundwater Analytical Methods. Health Physics Society. Volume 66, Number 6. pp. 644-656.

Simpson, D.B., and B.L. McGill. 1980. LADTAP II: A Computer Program for Calculating Radiation Exposure to Man from Routine Release of Nuclear Reactor Liquid Effluents. Technical Data Management Center. ORNL/NUREG/TDMC-1.

$R \& B-3$ 
Standish, P.N. 1985. Closure of the Construction Landfill Site. Letter (WD:85:0434) to W.H. Hannum, Department of Energy, West Valley Project Office.

U.S. Congress. 1918. Migratory Bird Treaty Act. 16 USC $\$ 703$ et seq.

. 1954. Atomic Energy Act of 1954. 42 United States Code (USC) §2011 et seq.

. 1966. National Historic Preservation Act of 1966. 16 USC $\S 470$ et seq.

1969. National Environmental Policy Act of 1969. 42 USC \$4321 et seq.

1970. Clean Air Act of 1970. 42 USC $\$ 7401$ et seq.

. 1973. Endangered Species Act of 1973. 16 USC $\$ 1531$ et seq.

1974. Safe Drinking Water Act. 42 USC $\$ 300 f$ et seq.

. 1976. Resource Conservation and Recovery Act of 1976. Public Law

94-580, 90 Stat. 2795, 42 USC $\$ 6901$ et seq.

. 1976. Toxic Substances Control Act. 15 USC §2601 et seq.

. 1977. Federal Water Pollution Control Act of 1977. 33 USC $\$ 1251$ et seq. (Also known as the Clean Water Act)

October 1, 1980. An Act to Authorize the Department of Energy to Carry Out a High-Level Liquid Nuclear Waste Management Demonstration Project at the Western New York Service Center in West Valley, New York. Public Law 96-368 [S. 2443]. Congressional Record, Vol. 126. (Also known as the WVDP Act)

1980. Comprehensive Environmental Response, Compensation, and Liability Act of 1980. Public Law 96-510, 42 USC $\$ 9601$ et seq.

. 1986. Emergency Planning and Community Right-to-Know Act of 1986. 42 USC $\S 11001$ et seq.

. October 17, 1986. Superfund Amendments and Reauthorization Act (SARA) of 1986. Public Law 99-499, 100 Stat. 1613, Title 10.

. 1996. Federal Insecticide, Fungicide, and Rodenticide Act. 7 USC $§ 136$ et seq.

U.S. Department of Commerce. U.S. Census Bureau. Census 2000.

$R \& B-4$ 
U.S. Department of Energy. nd. Quality Assurance Criteria. 10 CFR 830.122.

. July 1981. A Guide for Environmental Radiological Surveillance at U.S. Department of Energy Installations. DOE/EP-0023. Washington, D.C.

. July 1983. A Guide for Effluent Radiological Measurements at DOE Installations. DOE/EP-0096. Washington, D.C.

. February 8, 1990. Radiation Protection of the Public and the Environment. DOE Order 5400.5, including Change 2 (January 7, 1993). Washington, D.C.

. January 1991. Environmental Regulatory Guide for Radiological Effluent Monitoring and Environmental Surveillance. DOE/EH-0173T. Washington, D.C.

. January 1996. Draft Environmental Impact Statement for Completion of the West Valley Demonstration Project and Closure or Long-Term Management of Facilities at the Western New York Nuclear Services Center. DOE/EIS-0226-D.

. May 1997. Final Waste Management Programmatic Environmental Impact Statement for Managing Treatment, Storage, and Disposal of Radioactive and Hazardous Waste. DOE/EIS-0200-F.

. March 27, 1998. Worker Protection Management for DOE Federal and Contractor Employees. DOE Order 440.1A. Washington, D.C.

. July 9, 1999. Radioactive Waste Management. DOE Order 435.1, including Change 1 (August 28, 2001). Washington, D.C.

. September 29, 1999. Quality Assurance. DOE Order 414.1A, including Change 1 (July 12, 2001). Washington D.C. (DOE Order 414.1A was canceled by DOE Order 414.1B on April 29, 2004. DOE Order 414.1B was canceled by DOE Order 414.1C on June 17, 2005.)

February 25, 2000. Record of Decision for the DOE's Waste Management Program: Treatment and Disposal of Low-Level Waste and Mixed Low-Level Waste; Amendment of the Record of Decision for the Nevada Test Site. 65 FR 10061.

. October 26, 2000. National Environmental Policy Act Compliance Program. DOE Order 451.1B, including Change 1 (September 28, 2001). Washington, D.C.

. March 26, 2001. Revised Strategy for the Environmental Impact Statement for Completion of the West Valley Demonstration Project and Closure or Long-Term Management of Facilities at the Western New York Nuclear Service Center and Solicitation of Scoping Comments. 66 FR 16447. 
. November 6, 2001. Advance Notice of Intent to Prepare an Environmental Impact Statement to Evaluate Decommissioning and/or Long-Term Stewardship at the West Valley Demonstration Project and Western New York Nuclear Service Center. 66 FR 56090.

July 2002. DOE Standard: A Graded Approach for Evaluating Radiation Doses to Aquatic and Terrestrial Biota. DOE-STD-1153-2002. Washington, D.C.

. September 23, 2002. Radioactive Material Transportation Practices Manual.

DOE M 460.2-1.

. January 2003. Estimating Radiation Risk from Total Effective Dose Equivalent (TEDE). International Steering Committee on Radiation Standards (ISCORS) Technical Report No. 1. DOE/EH-412/0015/0502, Rev. 1.

January 15, 2003. Environmental Protection Program. DOE Order 450.1, including Change 1 (January 24, 2005). Washington, D.C. (Canceled DOE Order 5400.1, General Environmental Protection Program, November 9, 1988, including Change 1 [June 29, 1990].)

March 13, 2003. Notice of Intent to Prepare an Environmental Impact Statement for Decommissioning and/or Long-Term Stewardship at the West Valley Demonstration Project and Western New York Nuclear Services Center. 68 FR 12044.

. May 16, 2003. Notice of Availability of the West Valley Demonstration Project Draft Waste Management Environmental Impact Statement. 68 FR 26587.

August 19, 2003. Environment, Safety, and Health Reporting. DOE Order 231.1A, including Change 1 (June 3, 2004). Washington, D.C.

December 2003. West Valley Demonstration Project Waste Management Environmental Impact Statement. DOE/EIS-0337F.

. January 2004. Users Guide: RESRAD-BIOTA: A Tool for Implementing a Graded Approach to Biota Dose Evaluation. Version 1. DOE/EH-0676. (ISCORS Technical Report 2004-2).

. March 19, 2004. Environment, Safety, and Health Reporting Manual. DOE M 231.1-1A.

April 29, 2004. Quality Assurance. DOE Order 414.1B. Washington, D.C.

. June 16, 2005. Record of Decision for WVDP Waste Management Activities. 70 FR 35073.

$R \& B-6$ 
U.S. Department of Energy and New York State Energy Research and Development Authority. 1981. Cooperative Agreement between United States Department of Energy and New York State Energy Research and Development Authority on the Western New York Nuclear Service Center at West Valley, New York, effective October 1, 1980, as amended September 18, 1981.

U.S. Environmental Protection Agency. nd. 40 Code of Federal Regulations, Protection of the Environment, Chapter 1, Environmental Protection Agency.

March 1983. Mercury, Method 245.1 (Manual Cold Vapor Technique). Methods for Chemical Analysis of Water and Wastes. Environmental Monitoring and Support Laboratory. Cincinnati, Ohio.

. 1984a. Drinking Water Guidelines. 40 CFR 141, National Secondary Drinking Water Regulations, Subpart B, Maximum Contaminant Levels.

1984b. Drinking Water Guidelines. 40 CFR 143, National Secondary Drinking Water Regulations, Section 143.3, Secondary Maximum Contaminant Levels.

December 15, 1989. National Emission Standards for Hazardous Air Pollutants: Standards for Radionuclides. 40 CFR 61, including update of September 9, 2002. Washington, D.C.: U.S. Government Printing Office.

1992. Region II Administrative Order on Consent. Docket No. II RCRA 3008(h) 92-0202. In the Matter of: Western New York Nuclear Service Center.

1995. Comprehensive Procurement Guidelines for Products Containing

Recovered Material. 40 CFR 247.

. October 16, 1996. Code of Environmental Management Principles. 61 FR 54062.

. August 2002. Method 1631, Revision E: Mercury in Water by Oxidation, Purge and Trap, and Cold Vapor Atomic Fluorescence Spectrometry. EPA-821-R-02-019.

U.S. Nuclear Regulatory Commission. October 1977. Regulatory Guide 1.109: Calculation of Annual Doses to Man from Routine Releases of Reactor Effluents for the Purpose of Evaluating Compliance with 10 CFR Part 50, Appendix I.

July 1997. Radiological Criteria for License Termination. 10 CFR Part 20, Appendix E.

. February 1, 2002. Decommissioning Criteria for the West Valley Demonstration Project (M-32) at the West Valley Site; Final Policy Statement. 67 FR 5003.

$R \& B-7$ 
URS Group, Inc. April 8, 2002. Land Use Survey. Rev. 0. AR \#2002-171.

West Valley Nuclear Services Co., Inc. May 1, 1995. Subsurface Probing Investigation on the North Plateau at the West Valley Demonstration Project. Rev. 0. WVDP-220.

. March 1996. Environmental Information Document, Volume III: Hydrology, Part 4. WVDP-EIS-009.

. June 11, 1999. 1998 Geoprobe $^{\circledR}$ Investigation in the Core Area of the North Plateau Groundwater Plume. Rev. 0. WVDP-346.

. October 26, 1999. Asbestos Management Plan. Rev. 5. WVDP-072.

. April 15, 2003. Manual for Radiological Assessment of Environmental Releases at the WVDP. Rev. 4. WVDP-065.

. December 2, 2003 and December 27, 2005. Environmental Monitoring Program Plan. Rev. 12 and Rev. 13. WVDP-098.

April 22, 2004. WVDP Environmental Management System. Rev. 16. WV-980.

. July 1, 2004. Annual Status Report for the Hazardous Waste Reduction Program.

. August 2004. West Valley Demonstration Project Annual Site Environmental Report, Calendar Year 2003.

. October 27, 2004. WVDP Safety Management System (SMS) Description. Rev. 10. WVDP-310.

. November 3, 2004 and November 3, 2005. WVDP Groundwater Protection Management Program Plan. Rev. 6 and Rev. 7. WVDP-091.

. November 3, 2004 and September 19, 2005. Groundwater Monitoring Plan. Rev. 8 and Rev. 9. WVDP-239.

December 21, 2004. Clean Water Act/State Pollutant Discharge Elimination System Best Management Practices and Storm Water Pollution Prevention Plan for the West Valley Demonstration Project. Rev. 1. WVDP-206.

December 28, 2004 and November 17, 2005. PCB and PCB-Contaminated Material Management Plan. Rev. 7 and Rev. 8. WVDP-080.

$R \& B-8$ 
December 30, 2004. Waste Minimization/Pollution Prevention Awareness Plan. Rev. 8. WVDP-087.

. February 28, 2005. New York State Department of Environmental Conservation Hazardous Waste Report for 2004.

. March 30, 2005. Monitoring Plan for Storm Water Discharges at the West Valley Demonstration Project. Rev. 2. WVDP-233.

. January 2006. Draft Corrective Measures Study Work Plan for the West Valley Demonstration Project.

February 4, 2006. Site Treatment Plan: Fiscal Year 2005 Update. Rev. 11. WVDP-299.

West Valley Nuclear Services Co., Inc. and Dames \& Moore. June 1997. West Valley Demonstration Project Site Environmental Report, Calendar Year 1996.

. July 1997. Resource Conservation and Recovery Act Facility Investigation Report, Vol.1: Introduction and General Site Overview. WVDP-RFI-017.

. June 1998. Final Report: Evaluation of the Pilot Program to Investigate Chromium and Nickel Concentrations in Groundwater in the Sand and Gravel Unit.

West Valley Nuclear Services Co. and URS Group, Inc. January 2001. Results of Corrosion Evaluation in Selected Stainless Steel Monitoring Wells on the North Plateau and Recommendations for Long-Term Management.

August 2003. West Valley Demonstration Project Annual Site Environmental Report, Calendar Year 2002.

. August 2004. West Valley Demonstration Project Annual Site Environmental Report, Calendar Year 2003.

$R \& B-9$ 
This page intentionally left blank

$$
R \& B-10
$$




\section{Distribution}

$\underline{\text { Recipient }}$

Federal Organization

DOE Office of Scientific and Technical Information

C. Anderson

P. Bubar

R. Hardwick

F. Marcinowski

R. Natoli

G. Podonsky

M. Rawlings

R. Shearer

L. Camper

C. Glenn

R. Prince

R. Chaput

J. Eng

P. Giardina

W. Kappel

T. Reynolds

B. Higgins

L. Slaughter

R. Kuhl

H. Clinton

C. Schumer
DOE - HQ

DOE - HQ

DOE - HQ

DOE - HQ

DOE - HQ

DOE - HQ

DOE - HQ

DOE - HQ

NRC - HQ

NRC - Region 1

U.S. EPA - Region II

U.S. EPA - Region II

U.S. EPA - Region II

USGS

U.S. Congress, 26th Dist.

U.S. Congress, 27th Dist.

U.S. Congress, 28th Dist.

U.S. Congress, 29th Dist.

U.S. Senate, New York

U.S. Senate, New York
NRC - HQ $\underline{\text { Recipient }}$

J. Austin

L. White

E. Dassatti

S. Hammond

J. Nasca

R. Phaneuf

T. Rice

M. Wang

B. Youngberg

L. Winterberger

B. Bartz

S. Doleski

J. Sciascia

P. Concannon

M. Jackson

J. Strickland

L. Sturman

G. Baker

B. Ignatz

A. Salame Alfie

P. Piciulo

H. Brodie

P. Smith

J. Spath

R. Fakundiny

P. Tokasz

M. Schroeder

J. Quinn

D. Burling

J. Giglio

C. Young

W. Stachowski

D. Volker $\underline{\text { State Organization }}$

Executive Chamber, State Capitol, Albany

NYS Attorney Generals Office

NYSDEC - Albany

NYSDEC - Albany

NYSDEC - Albany

NYSDEC - Albany

NYSDEC - Albany

NYSDEC - Albany

NYSDEC - Albany

NYSDEC - Albany

NYSDEC - Buffalo

NYSDEC - Buffalo

NYSDEC - Buffalo

NYSDEC - Region 9

NYSDEC - Region 9

NYSDEC - Region 9

NYSDOH - Albany

NYSDOH - Buffalo

NYSDOH - Buffalo

NYSDOH - Troy

NYSERDA

NYSERDA - Albany

NYSERDA - Albany (President)

NYSERDA - Albany

NYSGS

New York Assembly, 143rd Dist.

New York Assembly, 145th Dist.

New York Assembly, 146th Dist.

New York Assembly, 147th Dist.

New York Assembly, 149th Dist.

New York Senate, 57th Dist.

New York Senate, 58th Dist.

New York Senate, 59th Dist.

DST - 1 


\section{Distribution}

\begin{tabular}{|c|c|c|c|}
\hline$\underline{\text { Recipient }}$ & $\underline{\text { Local Organization }}$ & $\underline{\text { Recipient }}$ & $\underline{\text { Local Organization }}$ \\
\hline E. Wohlers & Cattaraugus County Health Dept. & $\begin{array}{l}\text { W. Krebs } \\
\text { W. King }\end{array}$ & $\begin{array}{l}\text { Mayor, Village of Springville } \\
\text { Supervisor, Town of Ashford }\end{array}$ \\
\hline C. Abers & Cattaraugus County Legislature & G. Eppolito & Supervisor, Town of Concord \\
\hline G. Felton & Cattaraugus County Legislature & C. Gerwitz & Council, Town of Ashford \\
\hline C. Couture & Cattaraugus County Legislature & J. Pfeffer & Council, Town of Ashford \\
\hline J. Burrell & Cattaraugus County Legislature & & \\
\hline A. Billittier IV & Erie County Health Department & & \\
\hline B. Snyder, Sr. & \multirow{2}{*}{\multicolumn{3}{|c|}{$\begin{array}{l}\text { President, Seneca Nation of Indians } \\
\text { Seneca Nation of Indians Environm }\end{array}$}} \\
\hline S. Patterson & & & \\
\hline
\end{tabular}

$\underline{\text { Publication }}$

Buffalo News ${ }^{a}$, Buffalo, New York

Salamanca Republican Press ${ }^{a}$, Salamanca, New York

Springville Journal ${ }^{a}$, Springville, New York

${ }^{a}$ Notice of public availability

\section{$\underline{\text { Library }}$}

Town of Concord Hulbert Library, Springville, New York Seneca Nation of Indians Library, Cattaraugus Reservation, Irving, New York

Seneca Nation of Indians Library, Allegheny Reservation, Salamanca, New York

DST - 2 


\section{Appendix A \\ Environmental Monitoring Program Maps}

$A-i$ 
This page intentionally left blank

$A-i i$ 


\section{Environmental Monitoring Program Sample Points}

The following maps contain points sampled as part of the West Valley Demonstration Project (WVDP) routine environmental monitoring program for 2005. This program met or exceeded the requirements of U.S. Department of Energy (DOE) Order 450.1, DOE Order 5400.5, and DOE/EH-0173T. Specific methods and recommended monitoring program elements are found in DOE/EP-0096, "A Guide for Effluent Radiological Measurements at DOE Installations," and DOE/EP-0023, "A Guide for Environmental Radiological Surveillance at U.S. Department of Energy Installations," which were the bases for selecting most of the sampling locations. Additional monitoring was mandated by air and water discharge permits (40 CFR 61 and SPDES).

The index on pages A-iv through A-viii is a list of the codes used to identify the various sampling locations, which are shown on Figures A-2 through A-16. The sample location code describes the physical location where the sample is collected. The code consists of seven or eight characters: The first character identifies the sample medium as Air, Water, Soil/Sediment, Biological, or Direct Measurement. The second character specifies oN-site or oFf-site. The remaining characters describe the specific location (e.g., AFGRVAL is Air oFf-site at GReat VALley). Distances are measured in a straight line from the on-site main stack to the sampling location. Sampling points located inside buildings (e.g., on-site drinking water) or points that do not have a fixed location (e.g., outdoor ventilated enclosures) are not shown on these maps. Areas labeled as "wetlands" do not depict the WVDP's formally delineated wetlands inventory. As an aid to the reader, these polygons indicate relatively low-lying areas that almost always contain wet surface soils or standing water during years with typical precipitation totals.

\section{List of Maps}

A-1. West Valley Demonstration Project Base Map A-1

A-2. On-Site Surface Water and Soil/Sediment Sampling Locations A-2

A-3. On-Site Storm Water Outfalls A-3

A-4. Rail Spur Storm Water Outfalls A-4

A-5. Off-Site Surface Water and Soil/Sediment Sampling Locations A-5

A-6. On-Site Air Monitoring and Sampling Locations _____ A-6

A-7. Off-Site Air and Fallout Sampling Locations A-7

A-8. Active WVDP Groundwater Monitoring Locations A-8

A-9. North Plateau Groundwater Monitoring Network A-9

A-10. South Plateau Groundwater Monitoring Network A-10

A-11. Near-Site Drinking Water and Biological Sampling Locations A-11

A-12. Location of On-Site Thermoluminescent Dosimeters (TLDs) A-12

A-13. Location of Off-Site Thermoluminescent Dosimeters (TLDs) Within 5 Kilometers of the WVDP A-13

A-14. Environmental Sampling Locations Between 5 and 10 Kilometers From the WVDP A-14

A-15. Environmental Sampling Locations More Than 10 Kilometers From the WVDP A-15

A-16. Population by Sector Within 80 Kilometers of the WVDP (2002 Estimate) A-16 


\section{List of Sampling Locations}

On-Site Surface Water and Soil/Sediment Sampling Locations (Fig. A-2)

WNSP001

WNSP006

SNSP006

WNSP116

WNSP007

WNSWAMP

SNSWAMP

WNSW74A

SNSW74A

WNSDADR

WNSP008

WNSP005

WNCOOLW

WNFRC67

WNERB53

WNNDADR

WNDCELD

WNNDATR

\author{
Lagoon 3 Weir Point \\ Facility Main Drainage \\ Soil at WNSP006 \\ Pseudo-Monitoring Point in Frank's Creek \\ Sanitary Waste Discharge \\ Northeast Swamp Drainage Point \\ Soil at WNSWAMP \\ North Swamp Drainage Point \\ Soil at WNSW74A \\ SDA Runoff \\ French Drain LLWTF Area \\ South Facility Drainage \\ Cooling Tower \\ Frank's Creek East \\ Erdman Brook \\ Disposal Area Drainage \\ Drum Cell Drainage \\ NDA Trench Interceptor Project
}

\section{Storm Water Outfalls (Figs. A-3 and A-4)}

WNSO-Series Storm Water Outfalls

GROUP 1

WNSO02

WNSO04

GROUP2

WNSO06

WNSO33

GROUP 3

WNSO09

WNSO12

GROUP 4

WNSO34
CPC Waste Storage Area Swale

North Swamp Drainage (WNSW74A)

Northeast Swamp Drainage (WNSWAMP)

LAG Storage Drainage

Substation

South Facility Drainage (WNSP005)

Rail Spur Culvert

$A-i v$ 


\title{
List of Sampling Locations (continued)
}

\author{
Storm Water Outfalls (Figs. A-3 and A-4) (concluded) \\ GROUP 5 \\ WNSO14 \\ WNSO17 \\ WNSO28 \\ NDA Service Raod Drainage North \\ NDA Service Road Drainage South \\ Drum Cell West Road \\ GROUP 6 \\ WNSO36 \\ WNSO37 \\ Firing Range Wetland Drainage \\ Pump House Roadway \\ WNSO38 \\ Lake Two Roadway North \\ WNSO39 \\ Lake Two Roadway South \\ WNSO40 \\ Land Between the Lakes (Pending Removal from Permit) \\ WNSO41 \\ Lake One Roadway \\ WNSO42 \\ Pre-Railroad Spur Wetland Area (Near WFBCBKG) \\ GROUP 7 \\ WNSO20 \\ DisposalArea Drainage (WNNDADR) \\ $\underline{\text { GROUP } 8}$ \\ WNSO27 \\ WNSO35 \\ Drum Cell Drainage West \\ Drum Cell Drainage East \\ WNSWR01 \\ Storm Water Precipitation pH Measurement Location Near the Site Rain Gauge
}

\section{Off-Site Surface Water and Soil/Sediment Sampling Locations (Fig. A-5)}

$\begin{array}{ll}\text { WFBCBKG } & \text { Buttermilk Creek near Fox Valley, Background } \\ \text { WFBCTCB } & \text { Buttermilk Creek at Thomas Corners } \\ \text { WFBIGBR } & \text { Cattaraugus Creek at Bigelow Bridge, Background } \\ \text { WFFELBR } & \text { Cattaraugus Creek at Felton Bridge } \\ \text { SFSDSED } & \text { Cattaraugus Creek at Springville Dam, Sediment } \\ \text { SFCCSED } & \text { Cattaraugus Creek at Felton Bridge, Sediment } \\ \text { SFTCSED } & \text { Buttermilk Creek at Thomas Corners, Sediment } \\ \text { SFBCSED } & \text { Buttermilk Creek at Fox Valley Road, Background Sediment } \\ \text { SFRSPRD } & \text { Soil at Rock Springs Road Air Sampler } \\ \text { SFRT240 } & \text { Soil at Route 240 Air Sampler } \\ \text { SFFXVRD } & \text { Soil at Fox Valley Road Air Sampler } \\ \text { WNSTAW9 } & \text { Standing Water }\end{array}$

$A-v$ 


\section{List of Sampling Locations (continued)}

On-Site Air Monitoring and Sampling Locations (Fig. A-6)

$\begin{array}{ll}\text { ANSTACK } & \text { Main Plant } \\ \text { ANSTSTK } & \text { Supernatant Treatment System } \\ \text { ANCSSTK } & \text { 01-14Building } \\ \text { ANCSRFK } & \text { Size-Reduction Facility } \\ \text { ANCSPFK } & \text { Container Sorting and Packaging Facility } \\ \text { ANVITSK } & \text { Vitrification Heating, Ventilation, and Air Conditioning } \\ \text { ANLAGAM } & \text { Lag Storage Area (ambient air) } \\ \text { ANNDAAM } & \text { NDAArea (ambient air) } \\ \text { ANSDAT9 } & \text { SDA Trench 9 (ambient air) } \\ \text { ANRGFOP } & \text { Rain Gauge Fallout } \\ \text { ANRHWFK } & \text { Remote-Handled Waste Facility }\end{array}$

Off-Site Air and Fallout Sampling Locations (Fig. A-7)

$\begin{array}{ll}\text { AFFXVRD } & \text { Fox Valley Sampler } \\ \text { AFFXFOP } & \text { Fox Valley Fallout } \\ \text { AFTCORD } & \text { Thomas Corners Sampler } \\ \text { AFTCFOP } & \text { Thomas Corners Fallout } \\ \text { AFRT240 } & \text { Route 240 Sampler } \\ \text { AF24FOP } & \text { Route 240 Fallout } \\ \text { AFBOEHN } & \text { Dutch Hill Road Sampler } \\ \text { AFDHFOP } & \text { Dutch Hill Fallout } \\ \text { AFRSPRD } & \text { Rock Springs Road Sampler } \\ \text { AFBLKST } & \text { Bulk Storage Warehouse Sampler }\end{array}$

$A-v i$ 


\section{List of Sampling Locations (continued)}

\begin{tabular}{|c|c|}
\hline \multicolumn{2}{|c|}{$\begin{array}{l}\text { Active WVDP Groundwater Monitoring Locations (Fig. A-8) } \\
\text { North Plateau Groundwater Monitoring Network (Fig. A-9) } \\
\text { South Plateau Groundwater Monitoring Network (Fig. A-10) }\end{array}$} \\
\hline SSWMU\#1 & Low-Level Waste Treatment Facility Wells \\
\hline SSWMU \#2 & Miscellaneous Small Units Wells \\
\hline SSWMU\#3 & Liquid Waste Treatment System Wells \\
\hline SSWMU \#4 & HLW Storage and Processing Tank Wells \\
\hline SSWMU \#5 & Maintenance Shop Leach Field Wells \\
\hline SSWMU \#6 & Low-Level Waste Storage Area Wells \\
\hline SSWMU\#7 & CPC Waste Storage Area Wells \\
\hline SSWMU \#8 & CDDL Wells \\
\hline SSWMU \#9 & NDA Units Wells and NDATR \\
\hline SSWMU\#10 & IRTS Drum Cell Wells \\
\hline RHWF & Remote-Handled Waste Facility Wells \\
\hline SSWMU \#11 & SDA Unit Wells \\
\hline North Plateau Seeps & Northeastern Edge of North Plateau \\
\hline Well Points & Downgradient of Main Plant \\
\hline WNWNB1S & Former North Plateau Background Well \\
\hline
\end{tabular}

Near-Site Drinking Water and Biological Sampling Locations (Fig. A-11)

$\begin{array}{ll}\text { BFFCATC } & \text { Cattaraugus Creek Fish, Downstream } \\ \text { BFFCATD } & \text { Cattaraugus Creek Fish, Downstream of Springville Dam } \\ \text { BFMREED } & \text { North-Northwest Milk, Near-Site } \\ \text { BFMWIDR } & \text { Southeast Milk, Near-Site } \\ \text { BFMSCHT } & \text { South Milk, Near-Site } \\ \text { BFMBLSY } & \text { West-Northwest Milk, Near-Site } \\ \text { BFVNEAR } & \text { Produce, Near-Site } \\ \text { BFDNEAR } & \text { Venison, Near-Site } \\ \text { WFWEL Series } & \text { Private Wells }\end{array}$

Location of On-Site Thermoluminescent Dosimeters (TLDs) (Fig. A-12)

DNTLD Series $\quad$ On-Site Direct Radiation

Location of Off-Site Thermoluminescent Dosimeters (TLDs) Within 5 Kilometers of the WVDP (Fig. A-13)

DFTLD Series $\quad$ Off-Site Direct Radiation

$$
A-v i i
$$




\section{List of Sampling Locations (concluded)}

Environmental Sampling Locations Between 5 and 10 Kilometers From the WVDP(Fig. A-14)

$\begin{array}{ll}\text { AFSPRVL } & \text { Springville Air Sampler } \\ \text { SFSPRVL } & \text { Soil at Springville Air Sampler } \\ \text { DFTLD21 } & \text { TLD at Springville Air Sampler } \\ \text { WFWEL10 } & \text { Drinking Water at Springville Air Sampler } \\ \text { BFVNEAR } & \text { Produce, Near-site } \\ \text { DFTLD22 } & \text { TLD at West Valley Air Sampler } \\ \text { SFWEVAL } & \text { Soil at West Valley Air Sampler } \\ \text { AFWEVAL } & \text { West Valley Air Sampler }\end{array}$

Environmental Sampling Locations More Than 10 Kilometers From the WVDP(Fig. A-15)

BFMCTLS

BFVCTRL

BFFCTRL

BFDCTRL

AFGRVAL

SFGRVAL

DFTLD23

WFWEL06

\author{
Milk, South, Background \\ Produce, Background \\ Cattaraugus Creek Fish, Background \\ Venison, Background \\ Great Valley Air Sampler, Background \\ Soil at Great Valley Air Sampler, Background \\ TLD at Great Valley Air Sampler \\ Drinking Water at Great Valley Air Sampler
}

A - viii 


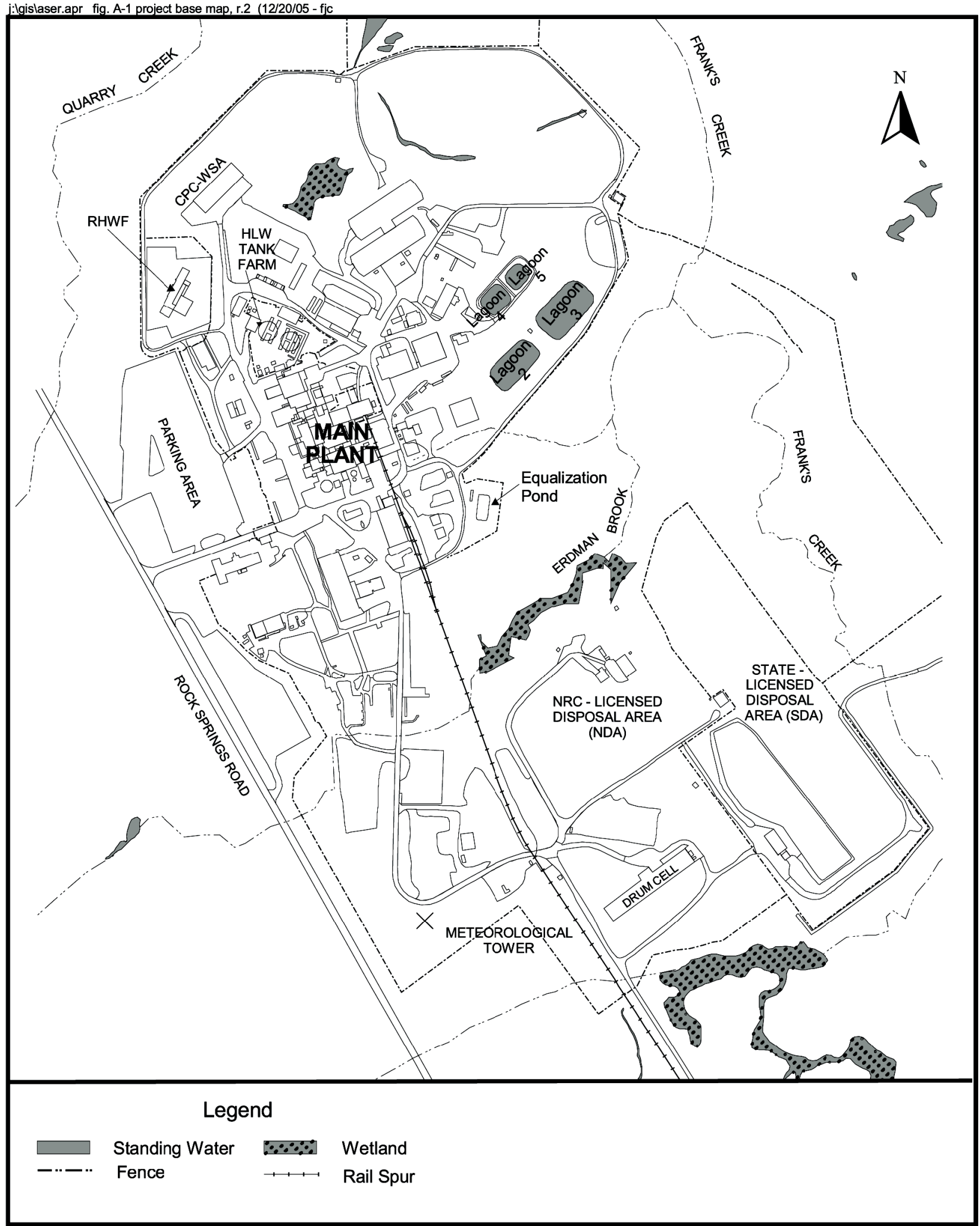

Figure A-1. West Valley Demonstration Project Base Map

$A-1$ 


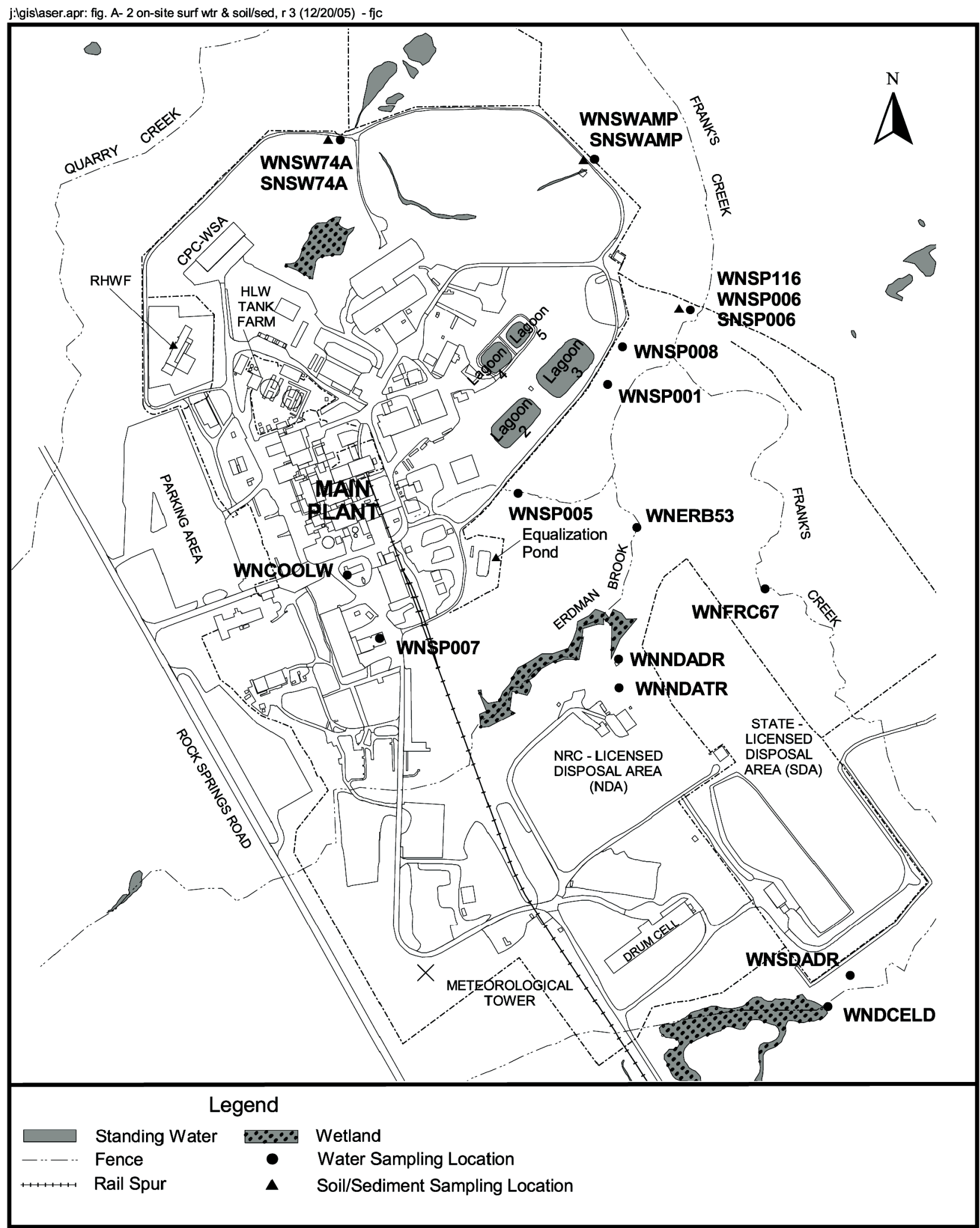

Figure A-2. On-Site Surface Water and Soil/Sediment Sampling Locations

A - 2 


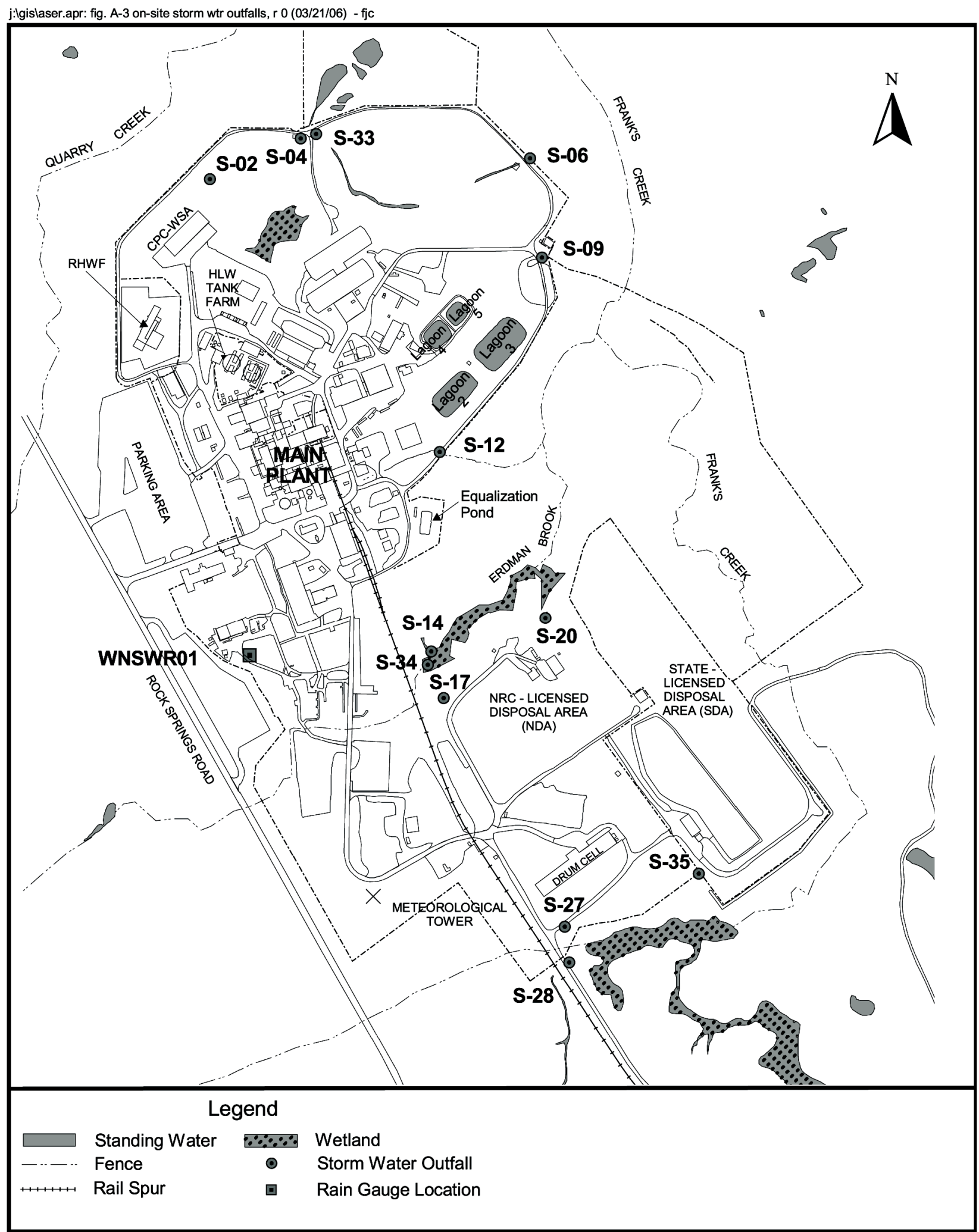

Figure A-3. On-Site Storm Water Outfalls

A - 3 


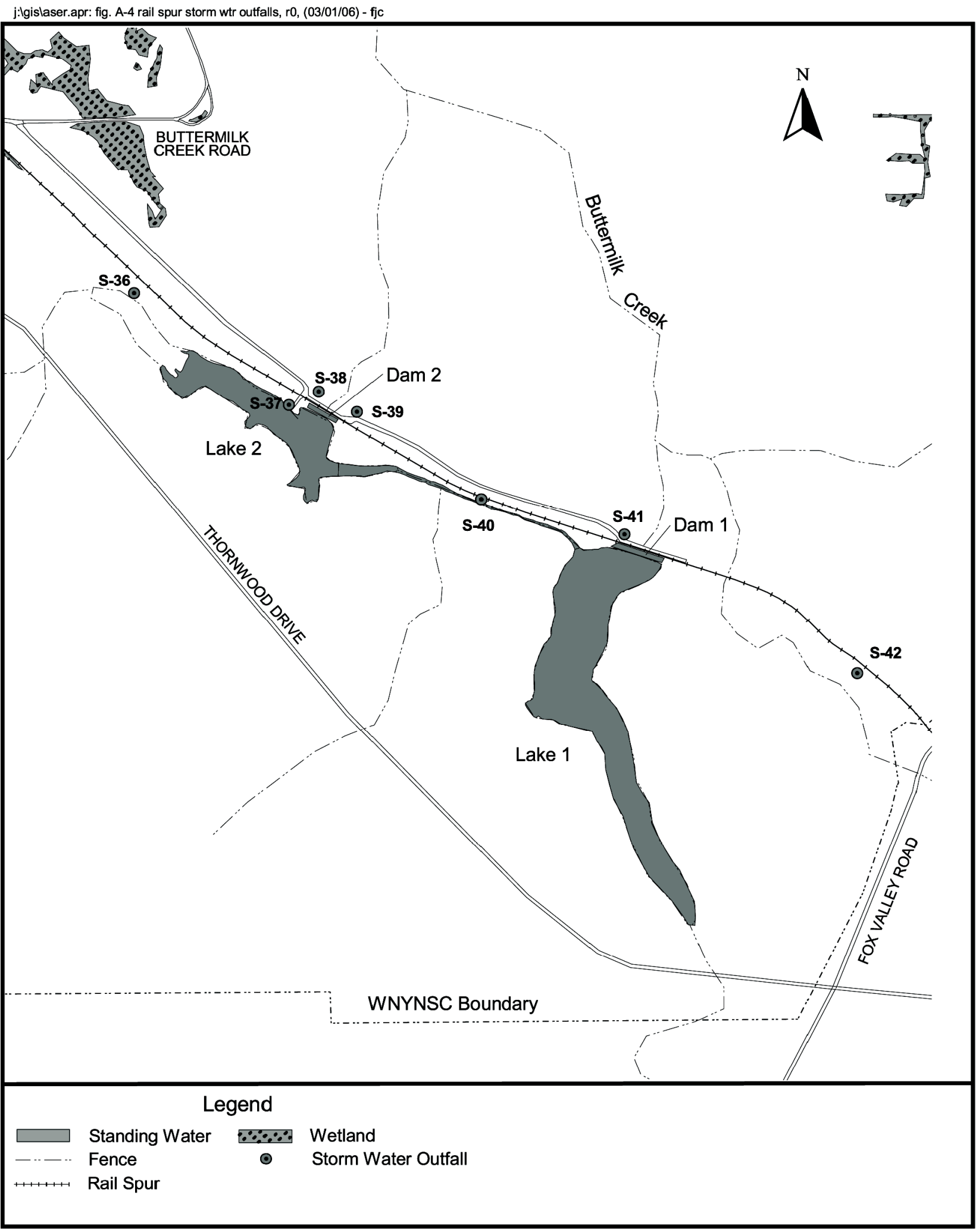

Figure A-4. Rail Spur Storm Water Outfalls

$$
\text { A - } 4
$$




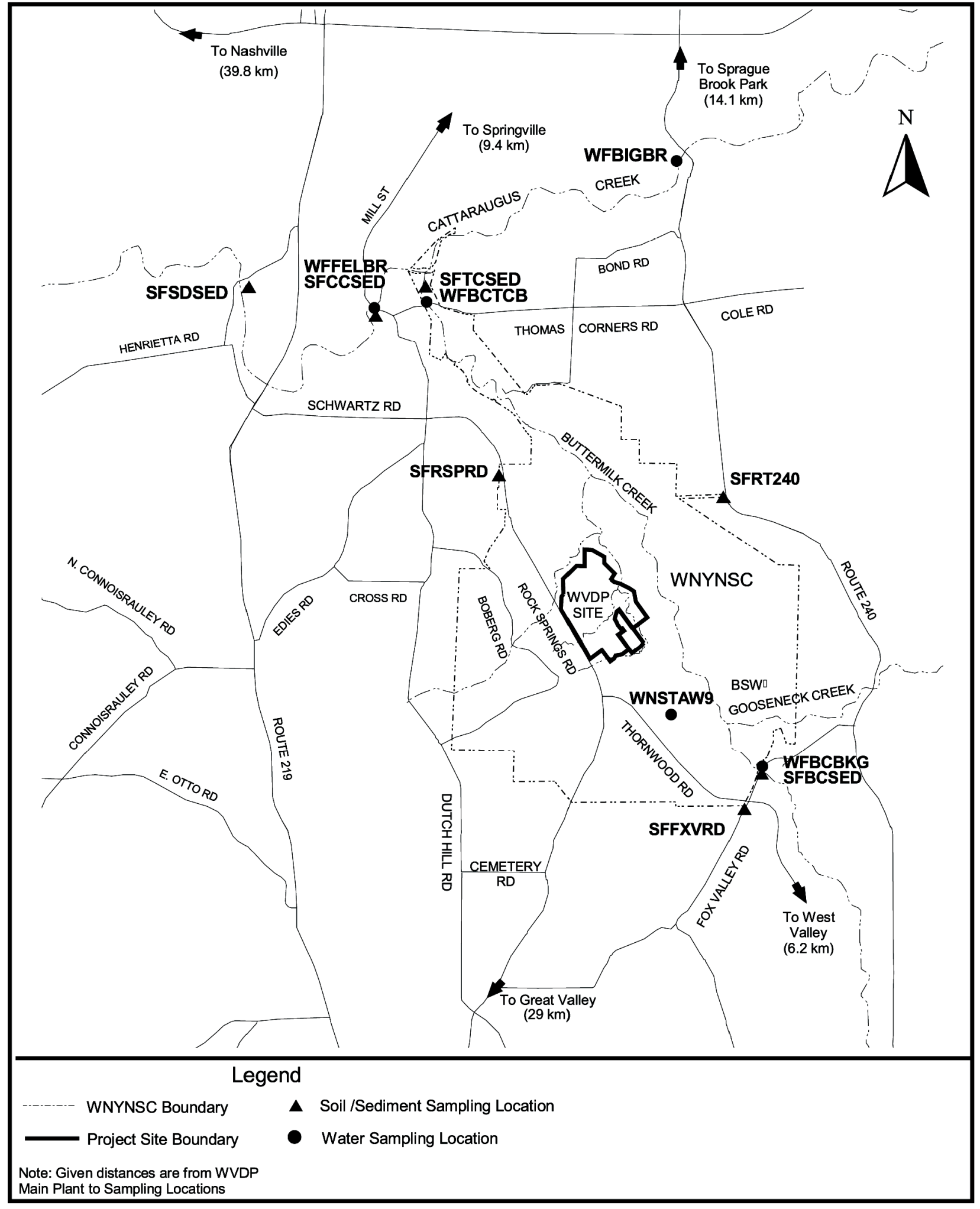

Figure A-5. Off-Site Surface Water and Soil/Sediment Sampling Locations

$$
\text { A - } 5
$$




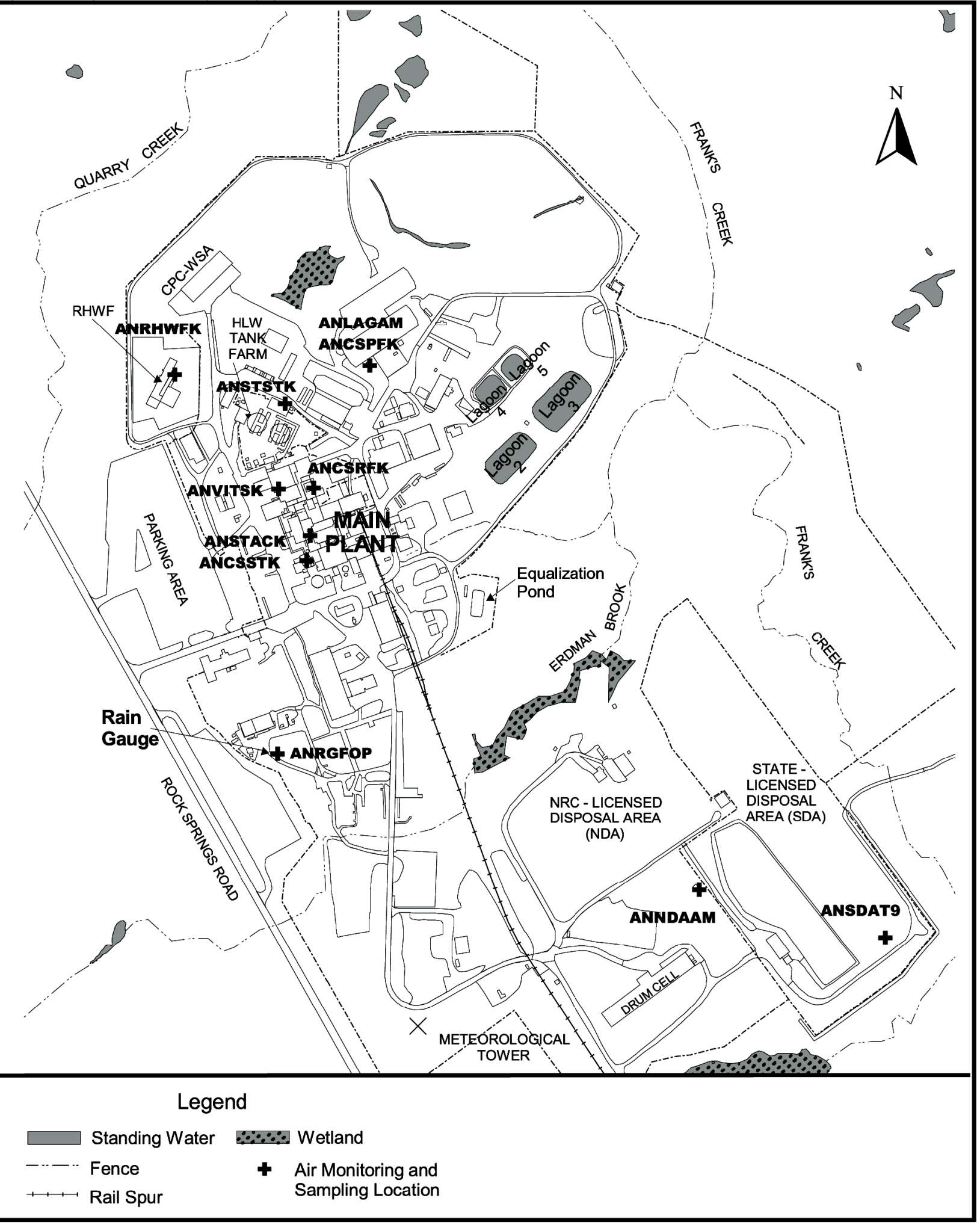

Figure A-6. On-Site Air Monitoring and Sampling Locations

A - 6 


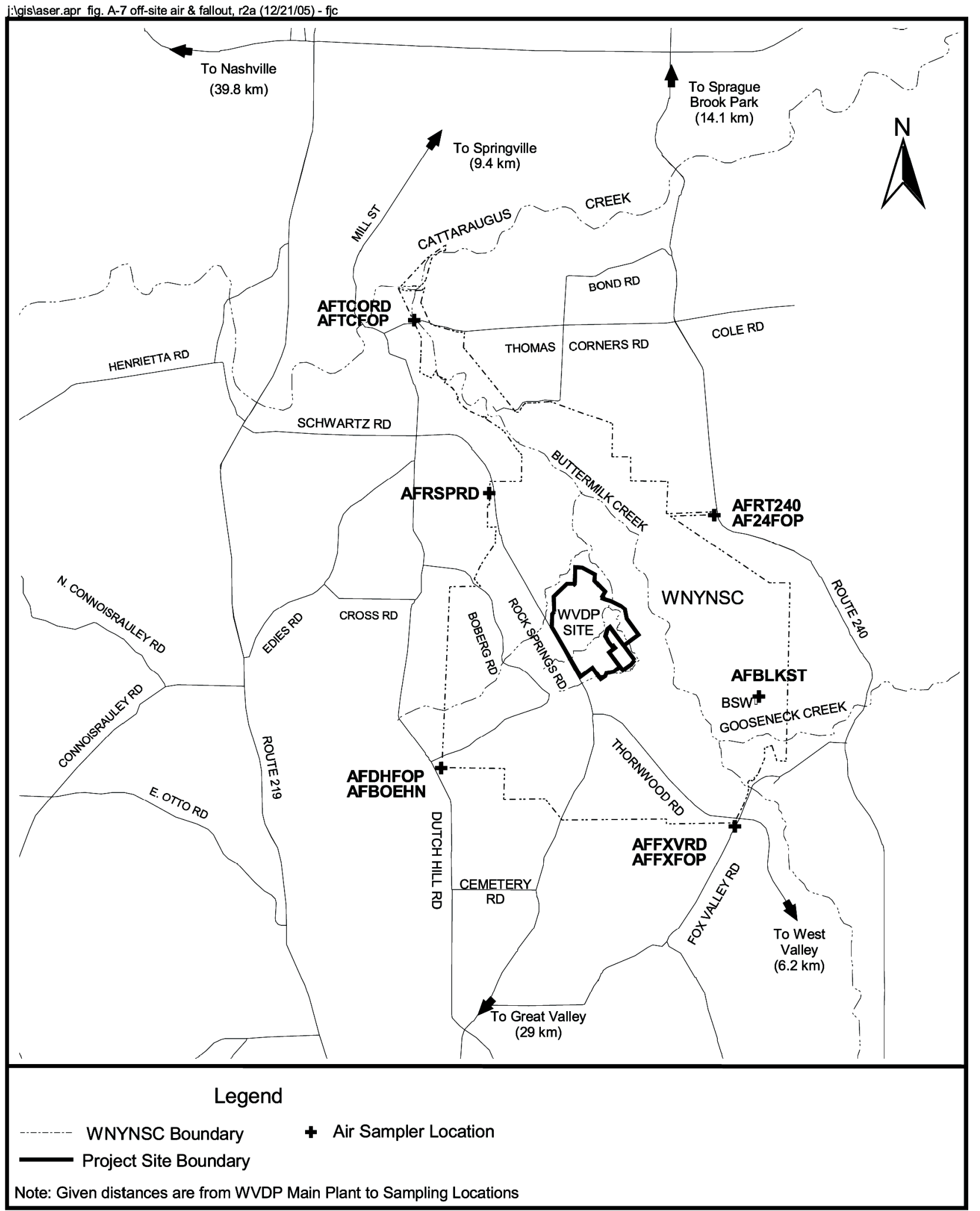

Note: Given distances are from WVDP Main Plant to Sampling Locations

Figure A-7. Off-Site Air and Fallout Sampling Locations

A - 7 


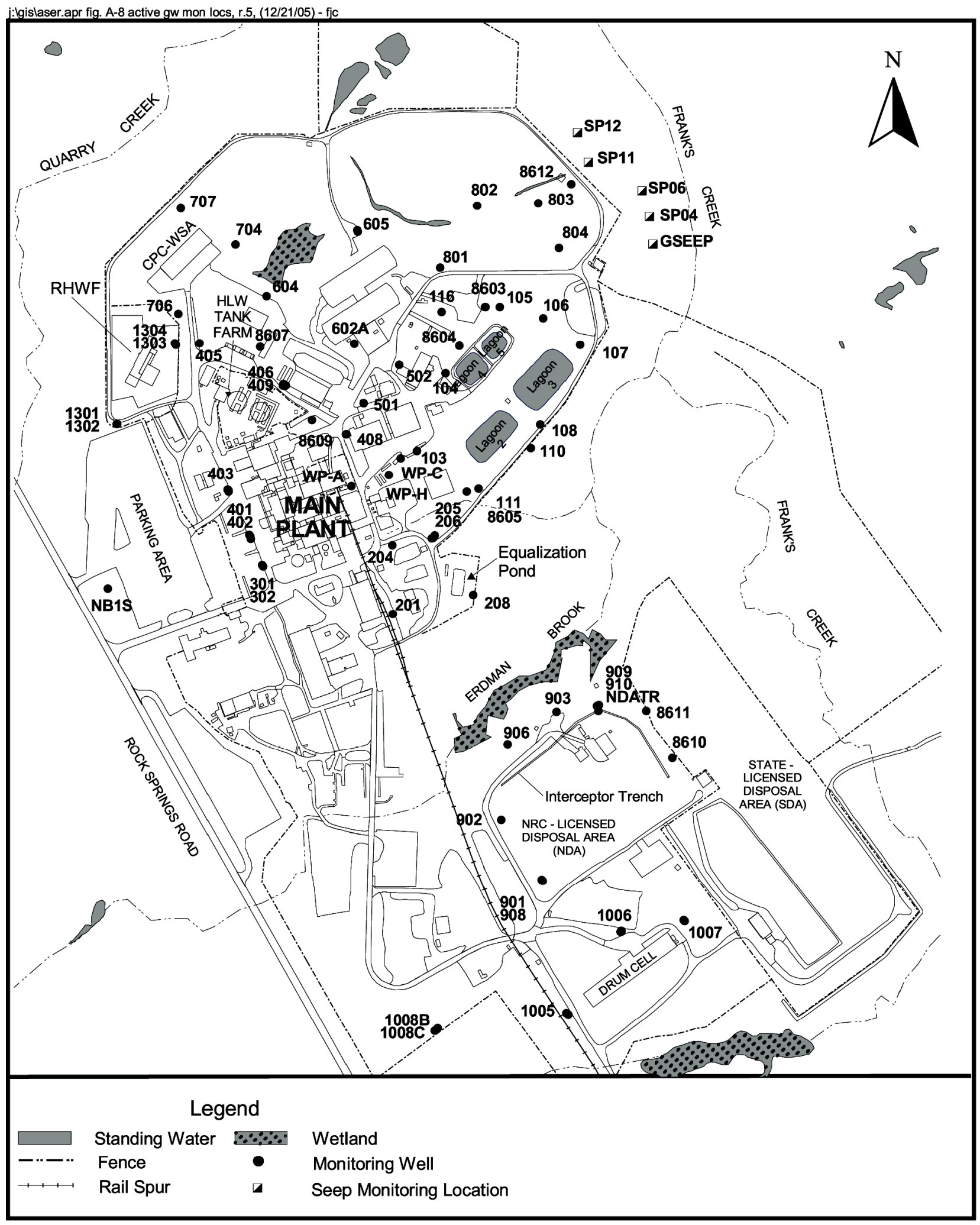

Figure A-8. Active WVDP Groundwater Monitoring Locations

A - 8 


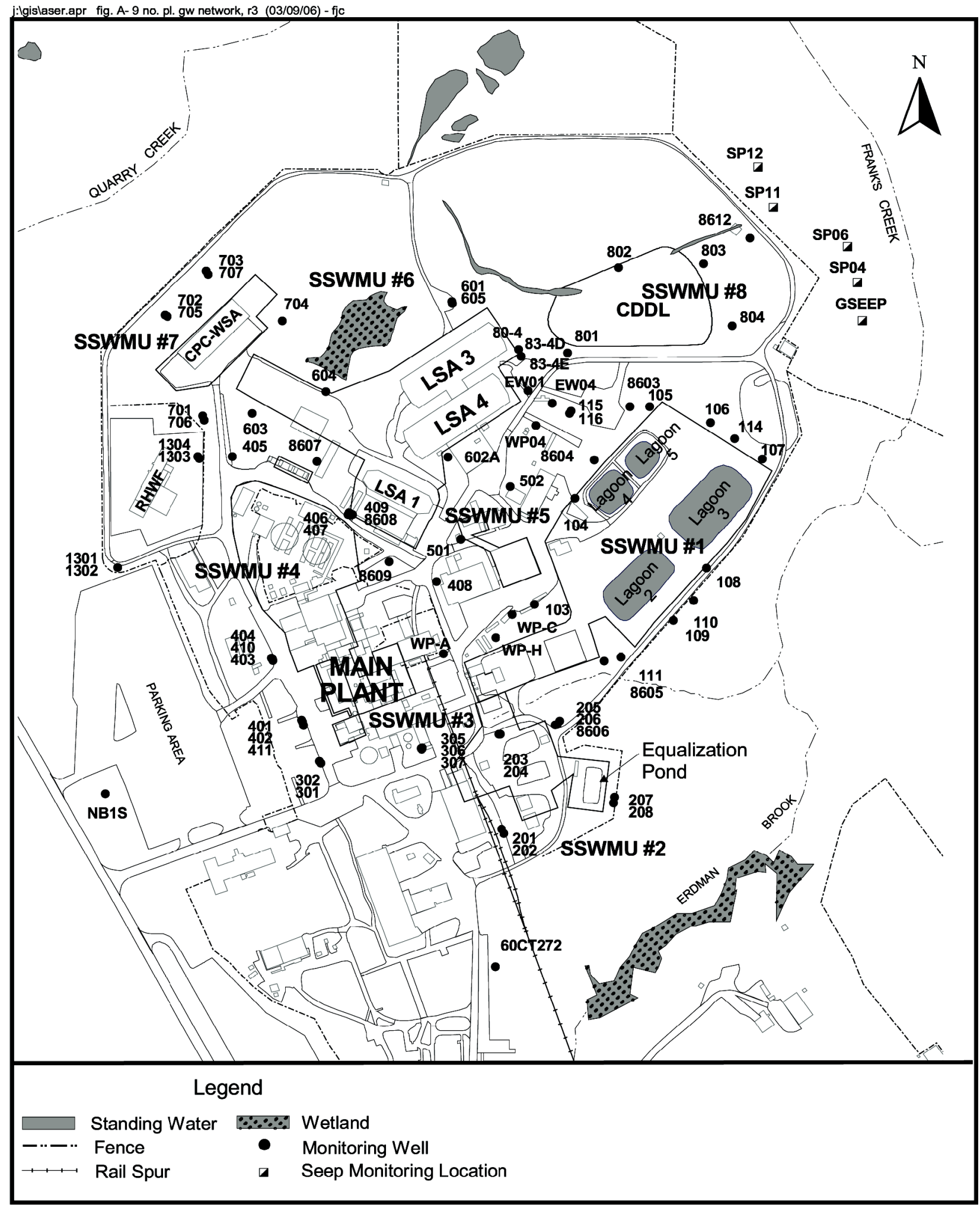

Figure A-9. North Plateau Groundwater Monitoring Network (Includes Wells Used for Water-Level Measurements)

$$
\text { A - } 9
$$




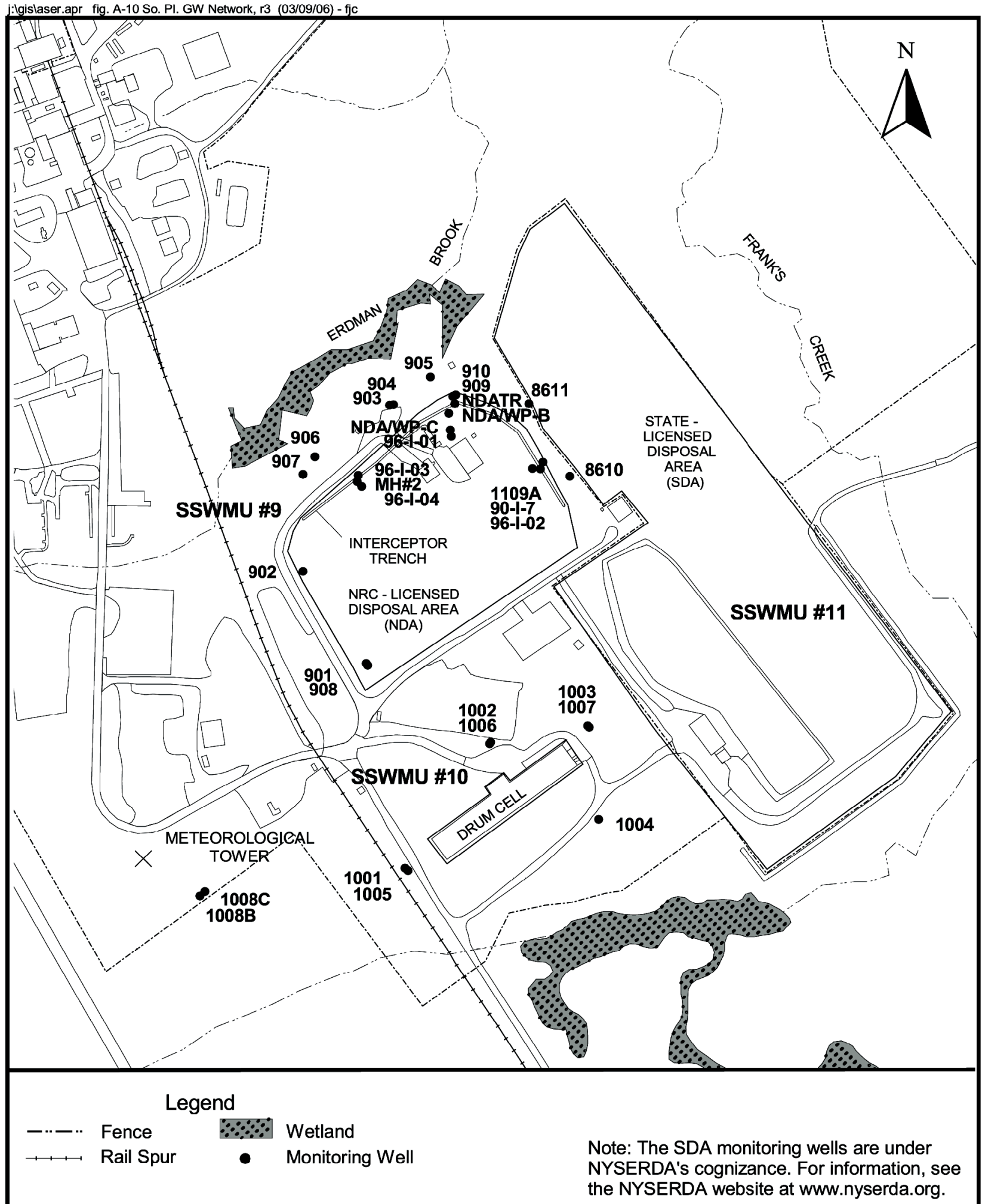

Figure A-10. South Plateau Groundwater Monitoring Network (Includes Wells Used for Water-Level Measurements)

A - 10 


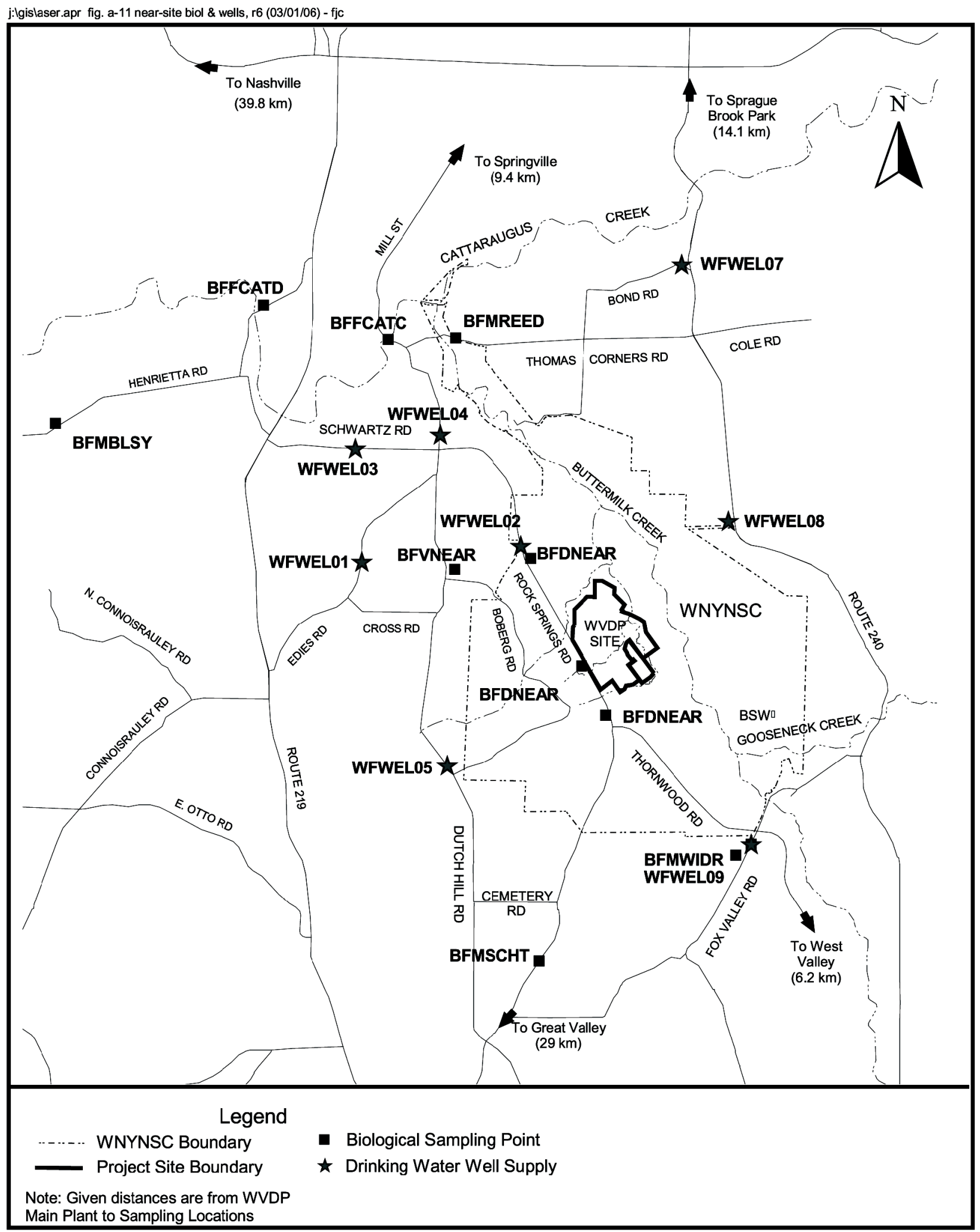

Figure A-11. Near-Site Drinking Water and Biological Sampling Locations

$$
\text { A - } 11
$$




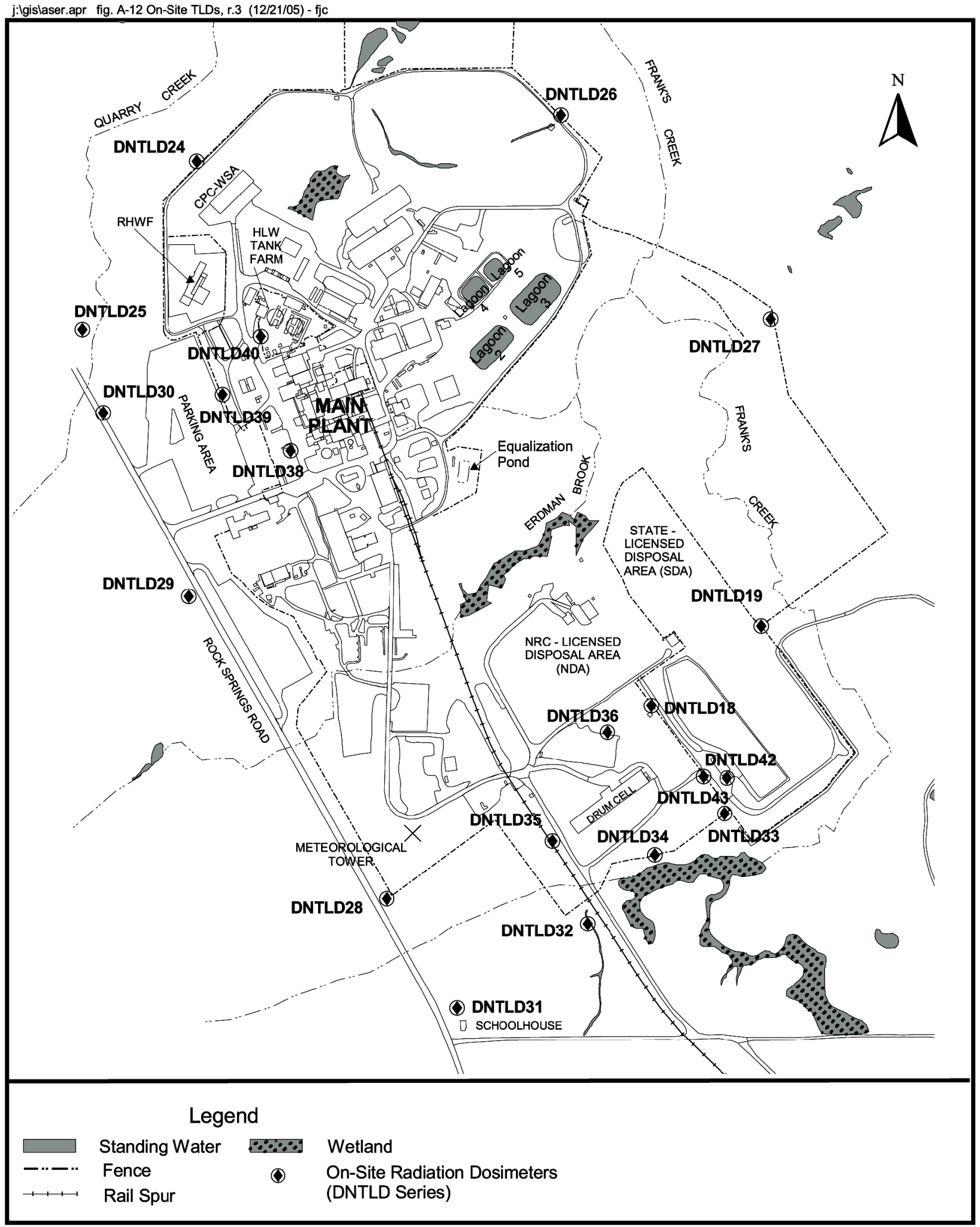

Figure A-12. Location of On-Site Thermoluminescent Dosimeters (TLDs)

$$
\text { A - } 12
$$




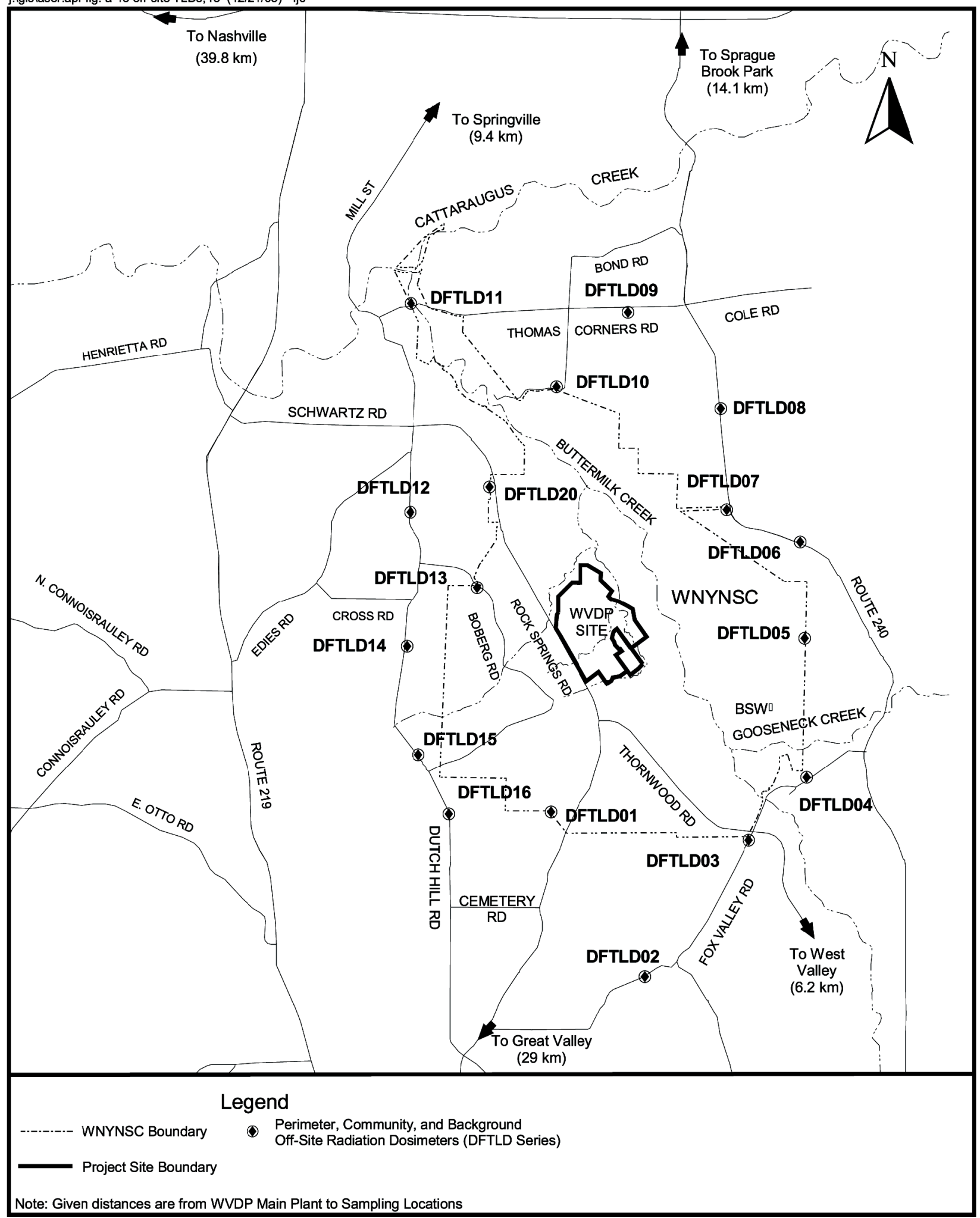

Figure A-13. Location of Off-Site Thermoluminescent Dosimeters (TLDs) Within 5 Kilometers of the WVDP

$$
\text { A - } 13
$$




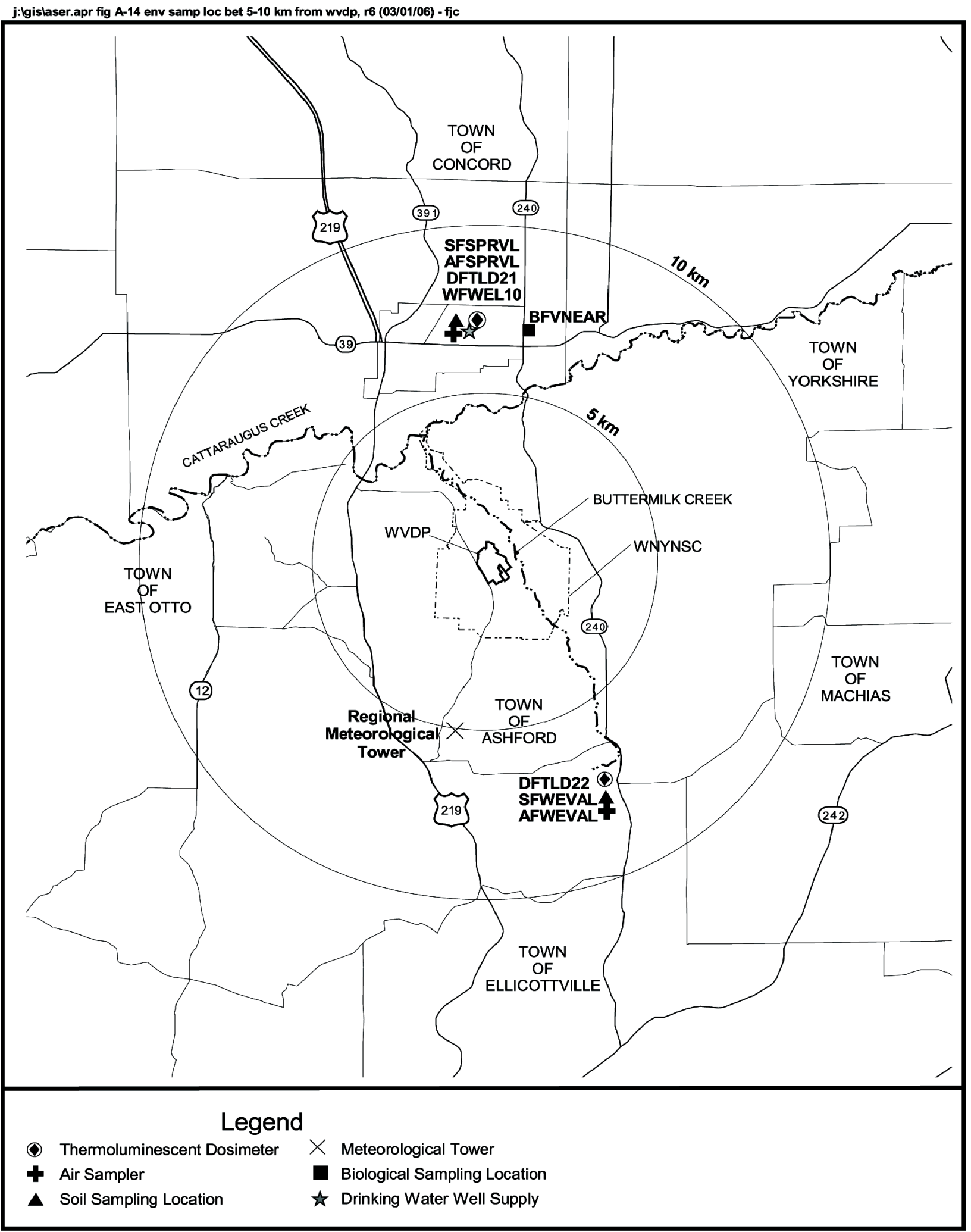

Figure A-14. Environmental Sampling Locations Between 5 and 10 Kilometers From the WVDP

$$
\text { A - } 14
$$




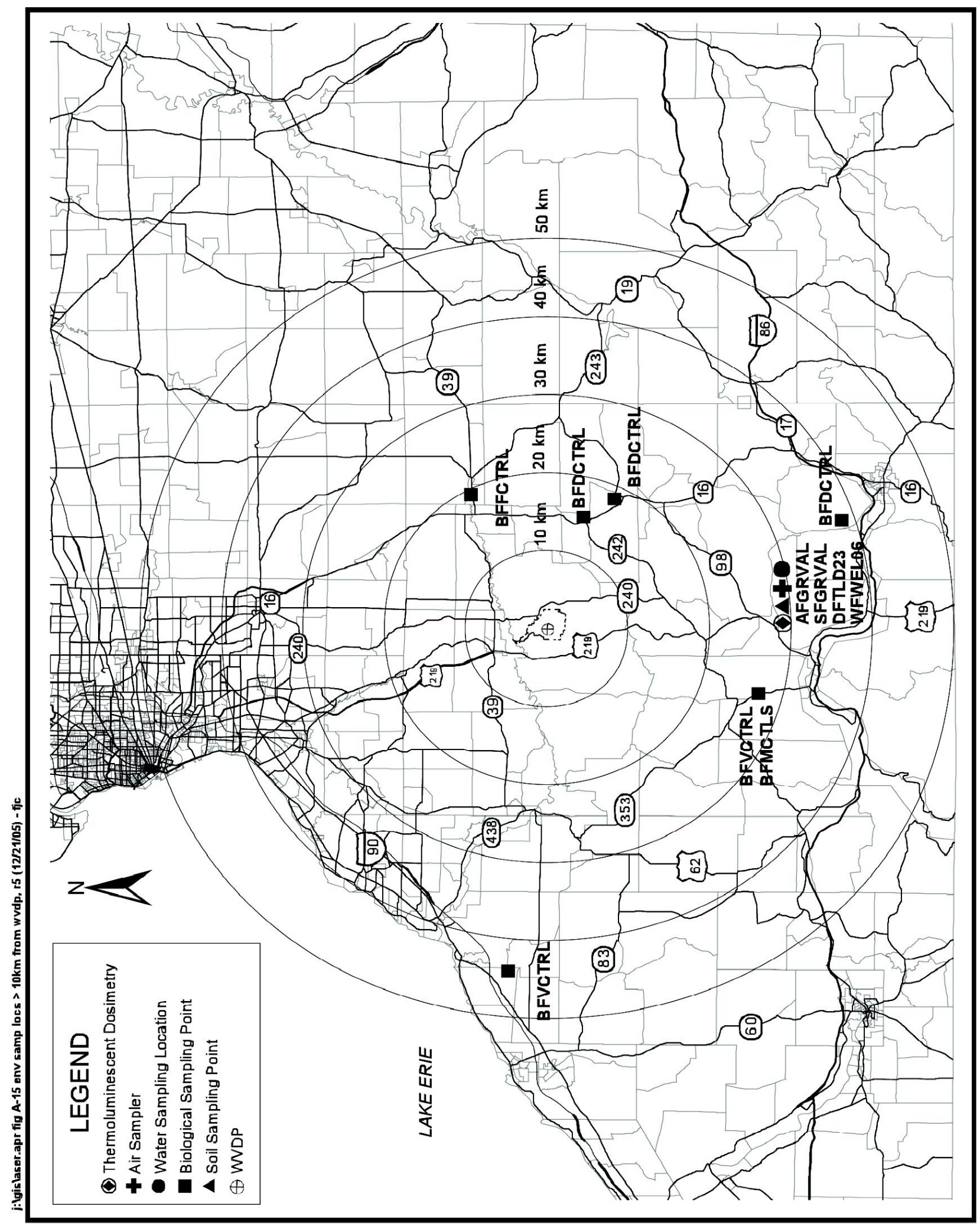

Figure A-15. Environmental Sampling Locations More Than 10 Kilometers From the WVDP

A -15 


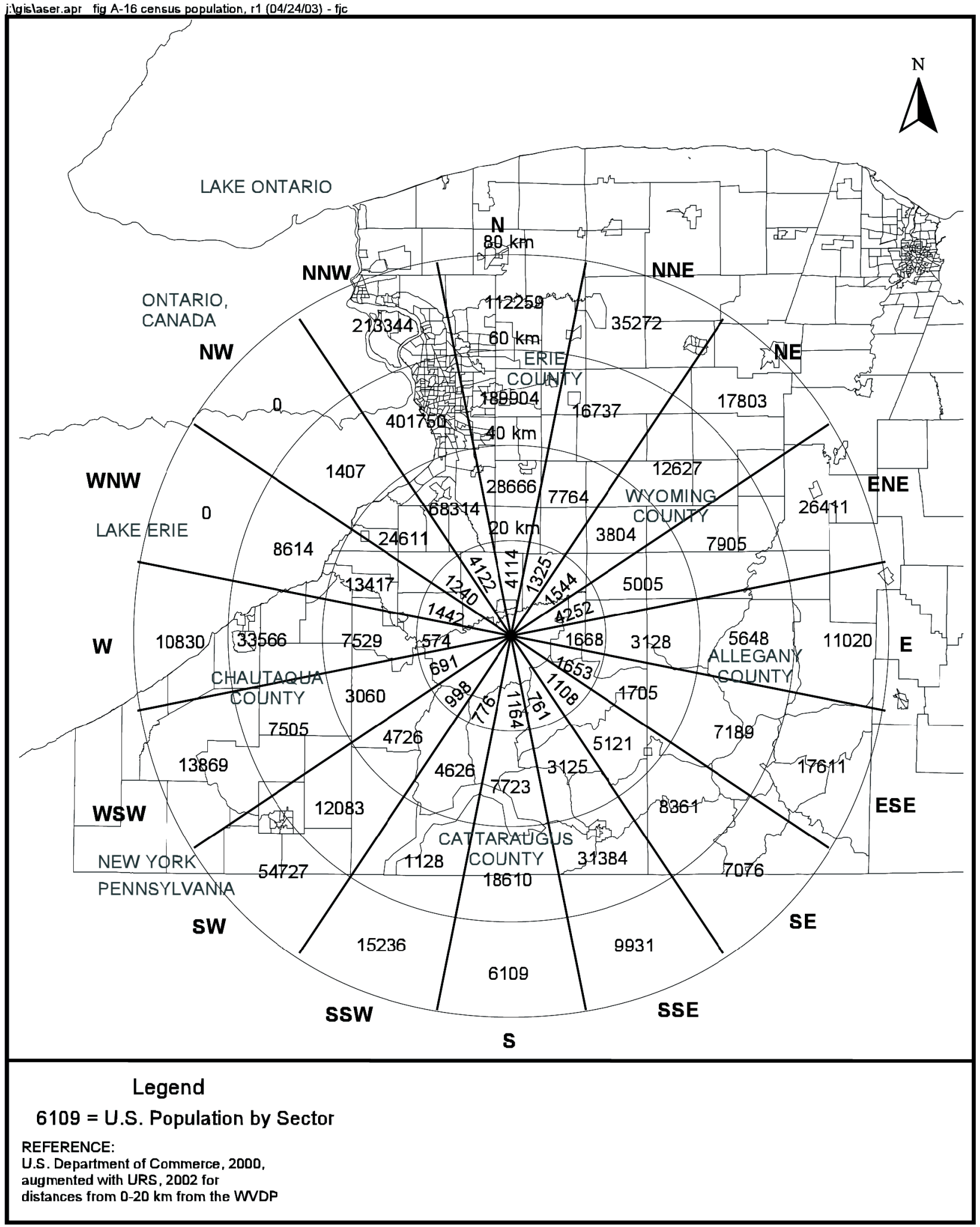

Figure A-16. Population by Sector Within 80 Kilometers of the WVDP (2002 Estimate)

$$
\text { A - } 16
$$




\section{Appendix $B$ 2005 Environmental Monitoring Program}

$B-i$ 
This page intentionally left blank

$B-i i$ 


\section{Environmental Monitoring Program}

The following schedule represents the West Valley Demonstration Project (WVDP) routine environmental monitoring program for 2005. This schedule met or exceeded the requirements of DOE Order 450.1, DOE Order 5400.5, and DOE/EH-0173T. Specific methods and recommended monitoring program elements are found in DOE/EP-0096, A Guide for Effluent Radiological Measurements at DOE Installations, and DOE/EP-0023, A Guide for Environmental Radiological Surveillance at U.S. Department of Energy Installations, which were the bases for selecting most of the schedule specifics. Additional monitoring was mandated by air and water discharge permits (40 CFR 61 and SPDES), which also required formal reports. Specifics are identified in the schedule under Monitoring/Reporting Requirements.

A computerized environmental data-screening system identifies analytical data that exceed preset limits. All locations are checked monthly for trends or notable results in accordance with criteria established in Documentation and Reporting of Environmental Monitoring Data (West Valley Nuclear Services Co., February 23, 2005). Reportable results are then described in Monthly Trend Analysis Reports (MTARs) for radiological screening and isotopic parameters together with possible causes and corrective actions, if indicated. WVDP Effluent Summary Reports (ESRs) are transmitted with the MTAR. At the end of 2005, the MTARs for November and December were combined into a new report, the Quarterly Trend Analysis Report (QTAR). The WVDP groundwater monitoring radiological screening and chemical results are reported in the quarterly Groundwater Trend Analysis Reports (GTARs).

\section{Schedule of Environmental Sampling}

The index on pages B-xvii through B-xx is a list of the codes used to identify the various sampling locations, which are shown on Figures A-2 through A-15 in Appendix A. The schedule of environmental sampling at the WVDP is found in this appendix. Table headings in the schedule are as follows:

- Sample Location Code. Describes the physical location where the sample is collected. The code consists of seven or eight characters: The first character identifies the sample medium as Air, Water, Soil/Sediment, Biological, or Direct Measurement. The second character specifies oN-site or oFf-site. The remaining characters describe the specific location (e.g., AFGRVAL is Air oFf-site at GReat VALley). Distances noted at sampling locations are as measured in a straight line from the main stack on site.

- Monitoring/Reporting Requirements. Notes the bases for monitoring the location, any additional references to permits, and the reports that are generated from the sample data. Routine reports cited in this appendix are the Effluent Summary Report (ESR), the Monthly Trend Analysis Report (MTAR), the State Pollutant Discharge Elimination System Discharge Monitoring Report (SPDES DMR), the Air Emissions Report (NESHAP), the Annual Site Environmental Report (ASER), and the quarterly Groundwater Trend Analysis Report (GTAR).

- Sampling Type/Medium. Describes the collection method and the physical characteristics of the medium.

- Collection Frequency. Indicates how often the samples are collected or retrieved.

- Total Annual Sample Collections. Specifies the number of discrete physical samples collected annually for each group of analytes.

- Analyses Performed/Composite Frequency. Notes the type of analyses of the samples taken at each collection, the frequency of composite, and the analytes determined for the composite samples.

$$
B-i i i
$$




\section{Summary of Monitoring Program Changes in 2005}

Location Code

ANSTACK

ANSTSTK

ANCSSTK

ANSCRFK

ANCSPFK

ANVITSK

ANRHWFK

OVEs/PVUs

ANLAGAM

ANSDAT9

ANNDAAM

WNSP001

WNSP006

WNURRAW

\section{Description of Changes}

As of April 2005, collection frequency was reduced from weekly to biweekly for particulate filters and charcoal cartridges at all on-site emission points and for desiccant columns at ANSTACK and ANSTSTK. Compositing frequency for all isotopic analyses was reduced from quarterly to semiannually.

Since vitrification was completed, OVEs/PVUs have been used in an expanded role to monitor decontamination activities at the site and to support waste packaging activities. As of April 2005, compositing frequency for isotopic analyses was reduced from quarterly to semiannually.

As of April 2005, collection frequency for particulate filters, and charcoal cartridges and dessicant columns at ANSDAT9, was reduced from weekly to biweekly. Compositing frequency for isotopic analyses was reduced from quarterly to semiannually.

In mid-December 2005, sample collection at ANSDAT9 was discontinued and the equipment was retained to be used for portable air monitoring during future demolition activities.

As of April 2005, sample collection was discontinued. Equipment was retained to be used for portable air monitoring during future demolition activities.

Sampling for organic compounds was modified to comply with requirements of the renewed SPDES permit, effective January 1, 2005. As of April 2005, sampling during lagoon discharges was modified to discontinue daily grab samples for gross beta and conductivity and midpoint grab samples for gross alpha/beta, tritium, strontium-90, and gamma isotopic analysis.

As of April 2005, weekly sampling for gross alpha/beta and tritium was retained when lagoon 3 is discharging. Sampling frequency was reduced to biweekly when lagoon 3 is not discharging. Weekly and biweekly samples are composited monthly for strontium-90 and gamma isotopic analysis. Quarterly compositing for all isotopic analyses was retained.

As of the end of first quarter 2005, quarterly sampling for giardia, cryptosporidium, and heterotrophic bacteria was discontinued. 


\section{Summary of Monitoring Program Changes in 2005 (continued)}

Location Code

WNSP007

WNSWR01

WNSWAMP

WNSW74A

WNSP005

WNCOOLW

WNFRC67

WNERB53

\section{Description of Changes}

As of April 2005, the frequency of sampling for gross alpha/beta and tritium was reduced from three per month to two per month, coinciding with the first and third SPDES collection weeks. Compositing frequency for strontium-90 and gamma isotopic analyses was reduced from quarterly to semiannually. The $\mathrm{pH}$ measurement for the 24-hour composite sample was discontinued because it is not SPDES reportable.

Storm Water Outfalls Twenty (20) storm water outfalls in eight groupings were added to the WVDP SPDES permit, effective January 1, 2005. Outfall location codes, collection frequencies, sampling specifics, and a full parameter list are presented on pp. B-11 through B-18.

This storm water collection point was added near the on-site rain gauge for measurement of $\mathrm{pH}$ during each storm water sampling event.

As of April 2005, sampling frequency for gross alpha/beta, tritium, and flow (at WNSWAMP only) was reduced from weekly to biweekly. Measurement of $\mathrm{pH}$ was added. Biweekly samples are composited monthly for strontium-90 and gamma isotopic analysis. Compositing frequency for isotopic analyses was reduced from quarterly to semiannually.

As of April 2005, compositing frequency for strontium-90 and gamma isotopic analyses was reduced from quarterly to semiannually.

As of April 2005, sampling frequency was reduced from quarterly to annually.

As of June 1, 2005, the collection frequency of grab samples for gross alpha/beta, tritium, and $\mathrm{pH}$ was reduced from monthly to quarterly, to be collected concurrently with the sample at WNNDADR as directed by NYSERDA. Strontium-90 and gamma isotopic analyses were added to the quarterly grab sample, and quarterly composite samples were discontinued.

As of June 1,2005, the collection frequency of grab samples for gross alpha/beta, tritium, and $\mathrm{pH}$ was reduced from weekly to quarterly, to be collected concurrently with the sample at WNNDADR as directed by NYSERDA. Compositing frequency for strontium-90 and gamma isotopic analyses was reduced from quarterly to semiannually, and gross alpha/beta and tritium analyses were added.

$$
B-v
$$




\section{Summary of Monitoring Program Changes in 2005 (continued)}

Location Code

WNNDADR

WNDCELD

WNNDATR

WNSTAW4

WNSTAW5

WNSTAW6

WNSTAWB

WNDNKMS

WNDNKMP

WNDNKEL

On-Site

Groundwater

Monitoring and

Seeps

\section{Description of Changes}

As of June 2005, the collection frequency of grab samples for $\mathrm{pH}$, tritium, NPOC, and TOX was reduced from weekly to biweekly. A quarterly grab sample for gross alpha/beta and tritium was added, as directed by NYSERDA. Collection frequency for the timed continuous composite sample was reduced from weekly to biweekly, with biweekly samples composited for monthly analysis of gross alpha/beta and gamma isotopes and for semiannual analysis of strontium-90 and iodine-129.

As of June 2005, the collection frequency of grab samples for gross alpha/beta and $\mathrm{pH}$ was reduced from monthly to once every two months and analysis of tritium was added. Four of the bimonthly grab samples are collected concurrently with the sample at WNNDADR, as directed by NYSERDA. The frequency of the composite for tritium, strontium-90, gamma isotopic, and iodine-129 analysis was reduced from quarterly to semiannually.

As of April 2005, the compositing frequency for iodine-129 analysis was reduced from quarterly to semiannually.

Sampling was discontinued at these four (of five) standing water locations. No samples were collected in 2005. (Sampling was retained at WNSTAW9, the north reservoir near the site's potable water intake, because it is considered to be in the ingestion pathway via potable water.)

As of April 2005, sampling frequency was reduced from one grab sample at one location every three months to one every fourth month. At WNDNKEL, quarterly sampling for total haloacetic acids and total trihalomethanes was reduced to annual.

A total of 17 monitoring locations were recommended for reductions in sampling frequency and/or the suites of analytical parameters. Sampling was discontinued for volatile organic compounds and semivolatile organic compounds at seven monitoring locations (wells 104, 105, 106, 201, 208, 403, and 8604). Reductions were approved by DOE and implemented.

Annual sampling was discontinued for strontium-90 at two monitoring locations (wells 602A and 605).

Sampling for $\mathrm{pH}$, specific conductance, gross alpha, gross beta, and tritium was reduced from quarterly to semiannually at ten monitoring locations (wells 201, 205, 206, 208, 302, 402, 403, 605, 8604, and NB1S).

$$
B-v i
$$




\section{Summary of Monitoring Program Changes in 2005 (continued)}

Location Code

On-Site

Groundwater

Monitoring and

Seeps (concluded)

WFBCTCB

WFBIGBR

WFFELBR

WFWEL Series

AFFXVRD

AFRT240

AFSPRVL

AFWEVAL

AFRSPRD

AFGRVAL

AFTCORD

AFBOEHN

AFBLKST

\section{Description of Changes}

These changes were effective with the start of the third-quarter 2005 (June 2005) groundwater sampling event.

The detailed current program is described in the Groundwater Monitoring Plan (WVDP-239).

As of April 2005, collection frequency for timed continuous composite samples was reduced from weekly to biweekly. Biweekly samples are composited monthly for gross alpha/beta and tritium analysis. Composite frequency for analysis of strontium-90 and gamma isotopic was reduced from quarterly to semiannually.

As of April 2005, the collection frequency of grab samples for gross alpha/beta, tritium, strontium-90, and gamma isotopic analyses was reduced from monthly to quarterly.

As of April 2005, weekly sampling for gross alpha/beta, tritium, $\mathrm{pH}$, and flow was retained during the full discharge cycle of lagoon 3. Sampling frequency was reduced to biweekly when lagoon 3 is not discharging. Weekly and biweekly samples are composited monthly (into a flow-weighted composite) for gross alpha/beta, tritium, strontium-90 and gamma isotopic analysis. Compositing frequency for analysis of technetium- 99 was reduced from quarterly to semiannually.

As of April 2005, all off-site potable water wells will be sampled once every two years, with the exception of background well WFWEL06, which will continue to be sampled annually. All wells will be sampled in 2006.

As of April 2005, the collection frequency for particulate filters at these off-site ambient air monitoring locations was reduced from weekly to biweekly. Compositing frequency was reduced from quarterly to semiannually. Collection of desiccant columns for tritium analysis at AFRSPRD and AFGRVAL was discontinued. The frequency for compositing monthly charcoal cartridges at AFRSPRD and AFGRVAL was reduced from quarterly to semiannually.

As of April 2005, sampling at these off-site ambient air monitoring locations was discontinued. 


\section{Summary of Monitoring Program Changes in 2005 (continued)}

Location Code

AFDHFOP

AFFXFOP

AFTCFOP

AF24FOP

ANRGFOP

SFFXVRD

SFRT240

SFSPRVL

SFWEVAL

SFRSPRD

SFGRVAL

SFTCORD

SFBOEHN

SFBLKST

SFBISED

BFMCTLS

BFMREED

BFMWIDR

BFMSCHT

BFMBLSY

BFBNEAR BFBCTRL
Description of Changes

As of April 2005, sampling was discontinued at these fallout pots.

As of April 2005, measurement of $\mathrm{pH}$ at the Environmental Laboratory rain gauge fallout pot was discontinued.

Collection frequency was reduced from annually to once every three years at these off-site soil sampling locations. The last samples were collected in 2004.

Sampling was discontinued at these three off-site surface soil sampling locations. The last samples were collected in 2004.

As of April 2005, sampling of off-site sediment at Bigelow Bridge, the upstream background location for Cattaraugus Creek, was discontinued.

As of April 2005, sampling frequency for milk at this background location was reduced from quarterly composites of monthly samples to one annual sample. Analysis of tritium was discontinued.

As of April 2005, analysis of tritium was discontinued in these near-site milk samples. The north near-site dairy herd was sold in May 2005. As of November 2005, sampling frequency for milk at the south near-site farm (BFMWIDR) was increased from one annual sample to quarterly composites of monthly samples.

As of November 2005, a nearby dairy farmer (west-northwest near-site) agreed to participate in the monthly sampling and analysis program by providing an annual sample as well as monthly samples to be shared with NYSDOH.

In 2005, collection of beef samples was discontinued. 
Summary of Monitoring Program Changes in 2005 (concluded)

Location Code

DNTLD18

DNTLD31

DNTLD32

DNTLD34

\section{Description of Changes}

As of April 2005, sampling was discontinued at these on-site TLD locations.

$B-i x$ 


\title{
Index of Environmental Monitoring Program Sample Points
}

\author{
Air Effluent and On-Site Ambient Air (Fig. A-6) \\ $\begin{array}{lll}\text { ANSTACK } & \text { Main Plant } & \text { B-1 }\end{array}$ \\ $\begin{array}{lll}\text { ANSTSTK } & \text { Supernatant Treatment System } & \text { B-1 }\end{array}$ \\ $\begin{array}{lll}\text { ANCSSTK 01-14Building } & \text { B-1 }\end{array}$ \\ ANCSRFK Size-Reduction Facility $\quad$ B-1 \\ ANCSPFK Container Sorting and Packaging Facility $\quad$ B-1 \\ ANVITSK Vitrification Heating, Ventilation, and Air Conditioning B-1 \\ ANRHWFK Remote-Handled Waste Facility $\quad$ B-1 \\ OVEs/PVUs $^{a} \quad$ Outdoor Ventilated Enclosures/Portable Ventilation Units $\quad$ B-3 \\ $\begin{array}{lll}\text { ANLAGAM } & \text { Lag Storage Area (ambient air) } & \text { B-3 }\end{array}$ \\ ANNDAAM NDAArea (ambient air) $\quad$ B-3 \\ $\begin{array}{llc}\text { ANSDAT9 } & \text { SDA Trench } 9 \text { (ambient air) } & \text { B-3 }\end{array}$
}

Liquid Effluent, On-Site Water, and Storm Water Outfalls (Figs. A-2 through A-5)

WNSP001 Lagoon 3 Weir Point $\quad$ B-5

$\begin{array}{lll}\mathrm{WNSP} \mathrm{B}^{a} & \text { Internal Process Monitoring Point } & \text { B-7 }\end{array}$

$\begin{array}{lll}\text { WNSP116 } & \text { Pseudo-Monitoring Point Outfall } 116 & \text { B-7 }\end{array}$

$\begin{array}{llc}\text { WNSP007 } & \text { Sanitary Waste Discharge } & \text { B-7 }\end{array}$

WNSP006 Facility Main Drainage B-9

WNURRAW $^{a} \quad$ Utility Room Raw Water $\quad$ B-9

$\underline{\text { WNSO-Series Storm Water Outfalls }}$

$\underline{\text { GROUP } 1}$

WNSO02

CPC Waste Storage Area Swale $\quad$ B-11

WNSO04 North Swamp Drainage (WNSW74A) $\quad$ B-11

GROUP 2

WNSO06

WNSO33

Northeast Swamp Drainage (WNSWAMP) B-11

LAG Storage Drainage $\quad$ B-11

$\underline{\text { GROUP } 3}$

WNSO09

Substation $\quad$ B-11

WNSO12 South Facility Drainage (WNSP005) $\quad$ B-11

$\underline{\text { GROUP } 4}$

WNSO34

Rail Spur Culvert

B-13

${ }^{a}$ Not detailed on map.

$$
B-x
$$




\section{Index of Environmental Monitoring Program Sample Points}

\section{Liquid Effluent, On-Site Water, and Storm Water Outfalls (Figs. A-2 through A-5) (concluded)}

GROUP 5

WNSO14

WNSO17

WNSO28

GROUP6

WNSO36

WNSO37

WNSO38

WNSO39

WNSO40

WNSO41

WNSO42

GROUP 7

WNSO20

GROUP 8

WNSO27

WNSO35

WNSWR01

WNSWAMP

WNSW74A

WNSDADR

WNSP008

WNSP005

WNCOOLW

WNFRC67

WNERB53

WNNDADR

WNDCELD

WNNDATR

WNSTAW 9

WNDNK Series $^{a}$
NDA Service Road Drainage North

B-13

NDA Service Road Drainage South

B-13

Drum Cell West Road

B-13

Firing Range Wetland Drainage

B-15

Pump House Roadway

B-15

Lake Two Roadway North

B-15

Lake Two Roadway South

B-15

Land Between the Lakes (Pending Removal from Permit)

B-15

Lake One Roadway

B-15

Pre-Railroad Spur Wetland Area (Near WFBCBKG)

B-15

DisposalArea Drainage (WNNDADR)

B-15

Drum Cell Drainage West

B-17

Drum Cell Drainage East

B-17

Storm Water Precipitation pH Measurement Location Near the Site

Rain Gauge

B-17

Northeast Swamp Drainage Point

B-19

North Swamp Drainage Point

B-19

SDA Runoff

B-21

B-21

French Drain LLWTF Area

B-21

South Facility Drainage

B-21

Cooling Tower

B-23

Frank's Creek East

B-23

Erdman Brook

B-23

Disposal Area Drainage

B-23

Drum Cell Drainage

B-25

NDA Trench Interceptor Project

B-25

Site Potable Water

${ }^{a}$ Not detailed on map.

$B-x i$ 


\section{Index of Environmental Monitoring Program Sample Points (continued)}

\begin{tabular}{lll}
\multicolumn{2}{l}{ On-Site Groundwater and Seeps (Figs. A-8 through A-10) } & \\
SSWMU\#1 & Low-Level Waste Treatment Facility Wells & B-29 \\
SSWMU \#2 & Miscellaneous Small Units Wells & B-29 \\
SSWMU \#3 & Liquid Waste Treatment System Wells & B-29 \\
SSWMU \#4 & HLW Storage and Processing Tank Wells & B-31 \\
SSWMU \#5 & Maintenance Shop Leach Field Wells & B-31 \\
SSWMU \#6 & Low-Level Waste Storage Area Wells & B-31 \\
SSWMU \#7 & CPC Waste Storage Area Wells & B-31 \\
SSWMU \#8 & CDDLWells & B-33 \\
SSWMU \#9 & NDA Units Wells and NDATR & B-33 \\
SSWMU\#10 & IRTS Drum Cell Wells & B-33 \\
RHWF & Remote-Handled Waste Facility Wells & B-33 \\
SSWMU \#11 & SDA Unit Wells & B-35 \\
North Plateau Seeps & Northeastern Edge of North Plateau & B-35 \\
Well Points & Downgradient of Main Plant & B-35 \\
WNWNB1S & Former North Plateau Background Well & B-35
\end{tabular}

\section{Off-Site Surface Water (Fig. A-5)}

WFBCBKG

WFBCTCB

WFBIGBR

WFFELBR
Buttermilk Creek Near Fox Valley, Background

B-37

Buttermilk Creek at Thomas Corners

B-37

Cattaraugus Creek at Bigelow Bridge, Background

Cattaraugus Creek at Felton Bridge

B-39

B-39

Off-Site Drinking Water (Figs. A-11, A-14, and A-15)

WFWEL Series Private Local Wells

B-41

Off-Site Ambient Air (Figs. A-7, A-14, and A-15)

AFFXVRD

AFTCORD

AFRT240

AFSPRVL

AFWEVAL

AFBOEHN

AFRSPRD

AFGRVAL

AFBLKST
Fox Valley Sampler

B-43

Thomas Corners Sampler

Route 240 Sampler

Springville Sampler

West Valley Sampler

Dutch Hill Road Sampler

Rock Springs Road Sampler

Great Valley Sampler, Background

Bulk Storage Warehouse Sampler
B-43

B-43

B-43

B-43

B-43

B-43

B-43

B-43

$$
B-x i i
$$




\section{Index of Environmental Monitoring Program Sample Points (concluded)}

Fallout, Sediment, and Soil (Figs. A-2, A-5 through A-7, A-14, and A-15)

$\begin{array}{llr}\text { AFDHFOP } & \text { Dutch Hill Fallout } & \text { B-45 } \\ \text { AFFXFOP } & \text { Fox Valley Fallout } & \text { B-45 } \\ \text { AFTCFOP } & \text { Thomas Corners Fallout } & \text { B-45 } \\ \text { AF24FOP } & \text { Route 240 Fallout } & \text { B-45 } \\ \text { ANRGFOP } & \text { Rain Gauge Fallout } & \text { B-45 } \\ \text { SF Soil Series } & \text { Air Sampler Area Soil } & \text { B-45 } \\ \text { SFCCSED } & \text { Cattaraugus Creek at Felton Bridge, Sediment } & \text { B-45 } \\ \text { SFSDSED } & \text { Cattaraugus Creek at Springville Dam, Sediment } & \text { B-45 } \\ \text { SFTCSED } & \text { Buttermilk Creek at Thomas Corners, Sediment } & \text { B-45 } \\ \text { SFBCSED } & \text { Buttermilk Creek at Fox Valley Road, Background Sediment } & \text { B-45 } \\ \text { SN Soil Series: } & \text { On-Site Soils/Sediments } & \text { B-45 } \\ \text { SNSW74A } & & \text { B-45 } \\ \text { SNSWAMP } & & \text { B-45 } \\ \text { SNSP006 } & & \text { B-45 }\end{array}$

Off-Site Biological (Figs. A-11, A-14, and A-15)

$\begin{array}{llr}\text { BFFCATC } & \text { Cattaraugus Creek Fish, Downstream } & \text { B-47 } \\ \text { BFFCATD } & \text { Cattaraugus Creek Fish, Downstream of Springville Dam } & \text { B-47 } \\ \text { BFFCTRL } & \text { Cattaraugus Creek Fish, Background } & \text { B-47 } \\ \text { BFMREED } & \text { North-Northwest Milk, Near-Site } & \text { B-47 } \\ \text { BFMWIDR } & \text { Southeast Milk, Near-Site } & \text { B-47 } \\ \text { BFMCTLS } & \text { Milk, South, Background } & \text { B-47 } \\ \text { BFMBLSY } & \text { West-Northwest Milk } & \text { B-47 } \\ \text { BFMSCHT }_{\text {BFVNEAR }^{a}} & \text { South Milk, Near-Site } & \text { B-47 } \\ \text { BFVCTRL }^{a} & \text { Produce, Near-Site } & \text { B-49 } \\ \text { BFDNEAR }^{\text {BFDCTRL }} & \text { Produce, Background } & \text { B-49 } \\ & \text { Venison, Near-Site } & \text { B-49 } \\ & \text { Venison, Background } & \text { B-49 }\end{array}$

Direct Measurement Dosimetry (Figs. A-12 through A-15)

DFTLD Series $\quad$ Off-Site Direct Radiation $\quad$ B-51

DNTLD Series $\quad$ On-Site Direct Radiation $\quad$ B-53

${ }^{a}$ Near-site and background produce samples (corn, apples, and beans) are identified specifically as follows:

corn = BFVNEAC and BFVCTRC; apples = BFVNEAAF and BFVCTRA; beans = BFVNEAB and BFVCTRB.

$B-x i i i$ 


\section{Monitoring Program \\ On-Site Effluent Monitoring}

Air Effluents

\begin{tabular}{|c|c|c|c|c|c|c|c|c|}
\hline $\begin{array}{l}\text { Sample Location } \\
\text { Code }\end{array}$ & $\begin{array}{l}\text { Monitoring/Reporting } \\
\text { Requirements }\end{array}$ & $\begin{array}{c}\text { Sampling } \\
\text { Type/Medium }\end{array}$ & & $\begin{array}{l}\text { Collection } \\
\text { Frequency }\end{array}$ & & $\begin{array}{c}\text { Total Annual } \\
\text { Sample Collections }\end{array}$ & & $\begin{array}{l}\text { Analyses Performed/ } \\
\text { Composite Frequency }\end{array}$ \\
\hline $\begin{array}{l}\text { ANSTACK } \\
\text { Main Plant Ventilation } \\
\text { Exhaust Stack }\end{array}$ & & $\begin{array}{l}\text { Continuous } \\
\text { off-line air } \\
\text { particulate } \\
\text { monitors }\end{array}$ & $\rightarrow$ & $\begin{array}{l}\text { Continuous } \\
\text { measurement of } \\
\text { fixed filter; } \\
\text { replaced biweekl }\end{array}$ & $\begin{array}{l}\rightarrow \\
\mathrm{fly}\end{array}$ & NA & $\rightarrow$ & $\begin{array}{l}\text { Real-time alpha and } \\
\text { beta monitoring }\end{array}$ \\
\hline $\begin{array}{l}\text { ANSTSTK } \\
\text { Supernatant Treatment } \\
\text { System (STS) Ventila- } \\
\text { tion Exhaust }\end{array}$ & $\begin{array}{l}\text { Airborne radioac- } \\
\text { tive effluent points, } \\
\text { including the LWTS }\end{array}$ & $\begin{array}{l}\text { Continuous } \\
\text { off-line air } \\
\text { particulate }\end{array}$ & $\rightarrow$ & Biweekly & $\rightarrow$ & $\begin{array}{l}26 \text { each } \\
\text { location }\end{array}$ & $\rightarrow$ & $\begin{array}{l}\text { Gross alpha/beta, } \\
\text { gamma isotopic }^{a} \\
\text { upon collection, flow }\end{array}$ \\
\hline $\begin{array}{l}\text { ANCSSTK } \\
\text { 01-14 Building } \\
\text { Ventilation Exhaust } \\
\text { ANCSRFK } \\
\text { Contact Size-Reduction } \\
\text { Facility Exhaust }\end{array}$ & $\begin{array}{l}\text { Required by: } \\
\text { - } 40 \text { CFR } 61 \\
\text { Reported in: } \\
\text { - ESR }\end{array}$ & filters & & & & $\begin{array}{l}\text { Biweekly } \\
\text { filters } \\
\text { composited to } \\
2 \text { each } \\
\text { location }\end{array}$ & $\rightarrow$ & $\begin{array}{l}\text { Semiannual compos- } \\
\text { ites for Sr-90, U-232, } \\
\text { U-233/234, } \\
\text { U-235/236, U-238, } \\
\text { total U, Pu-238, } \\
\mathrm{Pu}-239 / 240, \text { Am-241, } \\
\text { gamma isotopic, flow }\end{array}$ \\
\hline $\begin{array}{l}\text { ANCSPFK } \\
\text { Container Sorting and } \\
\text { Packaging Facility } \\
\text { Exhaust } \\
\text { ANVITSK } \\
\text { Vitrification HVAC } \\
\text { Exhaust }\end{array}$ & $\begin{array}{l}\text { - } \text { MTAR } \\
\text { - ASER } \\
\text { - Air Emissions } \\
\text { Annual Report } \\
\text { (NESHAP) }\end{array}$ & $\begin{array}{l}\text { Continuous } \\
\text { off-line } \\
\text { desiccant } \\
\text { columns for } \\
\text { water vapor } \\
\text { collection }\end{array}$ & $\rightarrow$ & Biweekly & $\rightarrow$ & $\begin{array}{l}26 \text { at each of } \\
\text { two locations }\end{array}$ & $\rightarrow$ & $\begin{array}{l}\text { H-3 (ANSTACK and } \\
\text { ANSTSTK only), flow }\end{array}$ \\
\hline $\begin{array}{l}\text { ANRHWFK } \\
\text { Remote-Handled Waste } \\
\text { Facility Exhaust }\end{array}$ & & $\begin{array}{l}\text { Continuous } \\
\text { off-line } \\
\text { charcoal } \\
\text { cartridges }\end{array}$ & $\rightarrow$ & Biweekly & $\rightarrow$ & $\begin{array}{l}\text { Biweekly } \\
\text { cartridges } \\
\text { composited to } \\
2 \text { each } \\
\text { location }\end{array}$ & $\rightarrow$ & $\begin{array}{l}\text { Semiannual composite } \\
\text { for I-129 }\end{array}$ \\
\hline
\end{tabular}

NA - Not applicable.

${ }^{a}$ Weekly gamma isotopic only if gross activity rises significantly.

$$
B-1
$$


ANSTACK

ANSTSTK

ANCSRFK

ANCSPFK

ANVITSK

ANRHWFK
DOE/EH-0173T, 3.0; DOE/EP-0096, 3.3

Monitors and samples HEPA-filtered ventilation from most process areas, including cell ventilation, vessel offgas, fuel receiving and storage (FRS), head end ventilation, and an analytical aisle. Requires continuous effluent monitoring per 40 CFR Subpart H, Section 61.93(b) because potential emissions may exceed the $0.1 \mathrm{mrem}$ limit.

DOE/EH-0173T, 3.0; DOE/EP-0096, 3.3

Monitors and samples HEPA-filtered ventilation (permanent ventilation system [PVS]) from building areas formerly involved in treatment of high-level waste supernatant. Requires continuous effluent monitoring per 40 CFR Subpart H, Section 61.93(b) because potential emissions may exceed the 0.1 mrem limit.

DOE/EH-0173T, 3.0; DOE-EP-0096, 3.3

Monitors and samples HEPA-filtered ventilation from the 01-14 building, which houses equipment formerly used to treat the ceramic melter off-gas. Requires effluent monitoring per 40 CFR Subpart H, Section 61.93(b) to confirm that emissions are less than the 0.1 mrem limit.

DOE/EH-0173T, 3.0; DOE-EP-0096, 3.3

Monitors and samples HEPA-filtered ventilation from a process area where radioactive tanks, pipes, and other equipment are size reduced.

DOE/EH-0173T, 3.0; DOE-EP-0096, 3.3

Monitors and samples ventilation from lag storage area 4, the container sorting and packaging facility.

DOE/EH-0173T, 3.0; DOE-EP-0096, 3.3

Vitrification facility heating, ventilation, and air conditioning (HVAC) effluent exhaust stack. Monitors and samples HEPA-filtered ventilation from building areas formerly involved in treatment of high-level waste supernatant. Requires effluent monitoring per 40 CFR Subpart H, Section 61.93(b) because potential emissions may exceed the 0.1 mrem limit.

DOE/EH-0173T, 3.0; DOE-EP-0096, 3.3

Monitors and samples HEPA-filtered ventilation from the remote-handled waste facility (RHWF), where contaminated waste equipment (e.g., pumps, tanks, piping) are size reduced before being packaged for disposal. Construction of the RHWF was completed early in 2004 and radiological operations began in June 2004.

Sampling locations are shown on Figure A-6.

$$
B-2
$$




\section{Monitoring Program \\ On-Site Effluent Monitoring}

Air Effluents

\begin{tabular}{|c|c|c|c|c|c|c|c|c|}
\hline $\begin{array}{l}\text { Sample Location } \\
\text { Code }\end{array}$ & $\begin{array}{l}\text { Monitoring/Reporting } \\
\text { Requirements }\end{array}$ & $\begin{array}{c}\text { Sampling } \\
\text { Type/Medium }\end{array}$ & & $\begin{array}{l}\text { Collection } \\
\text { Frequency }\end{array}$ & & $\begin{array}{c}\text { Total Annual } \\
\text { Sample Collections }\end{array}$ & & $\begin{array}{l}\text { Analyses Performed/ } \\
\text { Composite Frequency }\end{array}$ \\
\hline $\begin{array}{l}\text { OVEs/PVUs } \\
\text { Outdoor Ventilated } \\
\text { Enclosures/Portable } \\
\text { Ventilation Units }\end{array}$ & $\begin{array}{l}\begin{array}{l}\text { Airborne radioactive } \\
\text { effluent points }\end{array} \\
\text { Required by: } \\
\text { - } 40 \text { CFR } 61 \\
\text { Reported in: } \\
\text { - ESR } \\
\text { - MTAR } \\
\text { - ASER } \\
\text { - Air Emissions } \\
\text { Annual Report } \\
\text { (NESHAP) }\end{array}$ & $\begin{array}{l}\text { Continuous } \\
\text { off-line air } \\
\text { particulate } \\
\text { filter }\end{array}$ & $\rightarrow$ & As required & $\rightarrow$ & $\begin{array}{l}\text { Collected } \\
\text { filters } b \\
\text { composited to } 2\end{array}$ & $\rightarrow$ & $\begin{array}{l}\text { Semiannual composites } \\
\text { for Sr-90, U-232, } \\
\mathrm{U}-233 / 234, \mathrm{U}-235 / 236 \text {, } \\
\mathrm{U}-238 \text {, total U, Pu-238, } \\
\mathrm{Pu}-239 / 240, \mathrm{Am}-241 \text {, } \\
\text { gamma isotopic, flow }\end{array}$ \\
\hline $\begin{array}{l}\text { ANLAGAM } \\
\text { Lag Storage Area } \\
\text { Ambient Air } \\
\text { ANNDAAM } \\
\text { NDA Ambient Air }\end{array}$ & $\begin{array}{l}\text { Ambient "diffuse } \\
\text { source" air } \\
\text { emissions } \\
\text { Reported in: } \\
\text { - MTAR } \\
\text { - ASER }\end{array}$ & $\begin{array}{l}\text { Continuous } \\
\text { air particulate } \\
\text { filter }\end{array}$ & $\rightarrow$ & Biweekly & $\rightarrow$ & $\begin{array}{l}26 \text { each } \\
\text { location } \\
\text { Biweekly filters } \\
\text { composited to } 2\end{array}$ & $\rightarrow$ & $\begin{array}{l}\text { Gross alpha/beta, } \\
\text { flow } \\
\text { Semiannual composites } \\
\text { for Sr-90, U-232, } \\
\text { U-233/234, U-235/236, } \\
\text { U-238, total U, Pu-238, } \\
\text { Pu-239/240, Am-241, } \\
\text { gamma isotopic, flow }\end{array}$ \\
\hline $\begin{array}{l}\text { ANSDAT9 } c \\
\text { SDA Trench } 9 \\
\text { Ambient Air }\end{array}$ & $\begin{array}{l}\text { Ambient "diffuse } \\
\text { source" air } \\
\text { emissions } \\
\text { Reported in: } \\
\text { - ASER } \\
\text { - Reported to } \\
\text { NYSERDA }\end{array}$ & $\begin{array}{l}\text { Continuous } \\
\text { air particulate } \\
\text { filter } \\
\text { Continuous } \\
\text { off-line } \\
\text { desiccant } \\
\text { columns for } \\
\text { water vapor } \\
\text { collection } \\
\text { Continuous } \\
\text { off-line } \\
\text { charcoal } \\
\text { cartridges }\end{array}$ & $\rightarrow$ & 更 & $\rightarrow$ & $\begin{array}{l}26 \\
\text { Biweekly filters } \\
\text { composited to } 2 \\
26\end{array}$ & $\begin{array}{l}\rightarrow \\
\rightarrow \\
\rightarrow\end{array}$ & $\begin{array}{l}\text { Gross alpha/beta, } \\
\text { flow } \\
\text { Semiannual composite } \\
\text { for gamma isotopic, flow } \\
\text { H-3, flow }\end{array}$ \\
\hline
\end{tabular}

Note: Location ANNDAAM monitoring discontinued at end of $1^{\text {st }}$-quarter 2005. See p. B-iv.

${ }^{a}$ Gamma isotopic only if gross activity rises significantly.

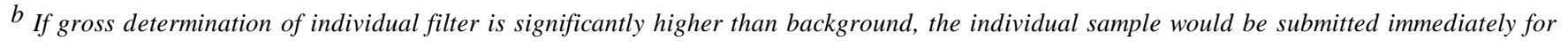
isotopic analysis.

${ }^{c}$ Sampling frequency and analytical parameters as directed by NYSERDA. Sampling at this location was discontinued in mid-December 2005.

B - 3 


\section{Sampling Rationale}

\section{OVEs/PVUs DOE/EH-0173T, 3.0; DOE/EP-0096, 3.3}

Outdoor ventilated enclosures/portable ventilation units used for handling radioactive materials or for decontamination in areas not having containment ventilation. Emissions are monitored to confirm that they are below the 0.1 mrem limit.

Sampling locations are not shown on figures, as they are portable.

ANLAGAM DOE/EH-0173T, 3.3.2

Monitors ambient air in the lag storage area, a possible diffuse source of air emissions.

ANNDAAM

DOE/EH-0173T, 3.3.2

Monitors ambient air in the NDA area, a possible source of air emissions.

ANSDAT9

DOE/EH-0173T, 3.3 .2

Monitors potential diffuse sources of air emissions at the SDA and south plateau area. WVDP support of NYSERDA.

- Sampling locations are shown on Figure A-6. 


\section{Monitoring Program \\ On-Site Effluent Monitoring}

\section{Liquid Effluents}

\begin{tabular}{|c|c|c|c|c|c|c|c|c|}
\hline $\begin{array}{l}\text { Sample Location } \\
\text { Code }\end{array}$ & $\begin{array}{l}\text { Monitoring/Reporting } \\
\text { Requirements }\end{array}$ & $\begin{array}{c}\text { Sampling } \\
\text { Type/Medium }\end{array}$ & & $\begin{array}{l}\text { Collection } \\
\text { Frequency }\end{array}$ & & $\begin{array}{c}\text { Total Annual } \\
\text { Sample Collectior }\end{array}$ & & $\begin{array}{l}\text { Analyses Performed/ } \\
\text { Composite Frequency }\end{array}$ \\
\hline \multirow{8}{*}{$\begin{array}{l}\text { WNSP001 } \\
\text { Lagoon } 3 \text { Discharge } \\
\text { Weir }\end{array}$} & \multirow{8}{*}{$\begin{array}{l}\text { Primary point of } \\
\text { liquid effluent batch } \\
\text { release } \\
\text { Required by: } \\
\text { - SPDES permit } \\
\text { Reported in: } \\
\text { - Monthly SPDES } \\
\text { DMR } \\
\text { - ESR } \\
\text { - ASAR }\end{array}$} & Grab liquid & $\rightarrow$ & $\begin{array}{l}\text { Daily, during } \\
\text { lagoon } 3 \\
\text { discharge }^{a}\end{array}$ & $\rightarrow$ & $\begin{array}{l}\text { Composite of } \\
\text { daily samples } \\
\text { for each } \\
\text { discharge, 4-8 }\end{array}$ & $\rightarrow$ & $\begin{array}{l}\text { Daily flow, hold for } \\
\text { flow-weighted composite } \\
\text { Near the start and end of } \\
\text { each discharge, a sample is } \\
\text { analyzed for gross alpha/ } \\
\text { beta, H-3, Sr-90, gamma } \\
\text { isotopic } \\
\text { Weighted composite for } \\
\text { gross alpha/beta, H-3, } \\
\text { C-14, Sr-90, Tc-99, } \\
\text { I-129, gamma isotopic, } \\
\text { U-232, U-233/234, } \\
\text { U-235/236, U-238, total } \\
\text { U, Pu-238, Pu-239/240, } \\
\text { and Am-241 for each } \\
\text { month of discharge }\end{array}$ \\
\hline & & $\begin{array}{l}\text { Composite } \\
\text { liquid }\end{array}$ & $\rightarrow$ & $\begin{array}{l}\text { Twice during } \\
\text { discharge, } \\
\text { near start and } \\
\text { near end }\end{array}$ & $\rightarrow$ & $8-16$ & $\rightarrow$ & $\begin{array}{l}\text { Two 24-hour composites } \\
\text { for } \mathrm{BOD}_{5}, \mathrm{TSS}, \mathrm{SO}_{4}, \\
\mathrm{NO}_{3}-\mathrm{N}, \mathrm{NO}_{2}-\mathrm{N}, \mathrm{NH}_{3}, \\
\text { total } \mathrm{Al}, \mathrm{Fe}, \mathrm{Hg}, \text { and } \mathrm{Mn} \text {, } \\
\text { total recoverable } \mathrm{Cd}, \mathrm{Cr} \text {, } \\
\mathrm{Cu}, \mathrm{Ni}, \mathrm{Pb} \text {, and } \mathrm{Zn}, \\
\text { dissolved As and } \mathrm{Cu} \text {, } \\
\text { dissolved sulfide }\end{array}$ \\
\hline & & Grab liquid & $\rightarrow$ & $\begin{array}{l}\text { Twice during } \\
\text { discharge, } \\
\text { near start and } \\
\text { near end }\end{array}$ & $\rightarrow$ & $8-16$ & $\rightarrow$ & $\begin{array}{l}\text { Settleable solids, TDS, pH, } \\
\text { cyanide amenable to } \\
\text { chlorination, oil \& grease, } \\
\text { surfactant (as LAS), total } \\
\text { recoverable } \mathrm{Co}, \mathrm{Cr}^{+6}, \mathrm{Se} \text {, } \\
\text { and V }\end{array}$ \\
\hline & & $\begin{array}{l}\text { Composite } \\
\text { liquid }\end{array}$ & $\rightarrow$ & Quarterly $b$ & $\rightarrow$ & 4 & $\rightarrow$ & $\begin{array}{l}\text { A 24-hour composite for } \\
\text { bromide and total B }\end{array}$ \\
\hline & & $\begin{array}{l}\text { Composite } \\
\text { liquid }\end{array}$ & $\rightarrow$ & Semiannual $^{b}$ & $\rightarrow$ & 2 & $\rightarrow$ & $\begin{array}{l}\text { A 24-hour composite } \\
\text { for total } \mathrm{Ti}\end{array}$ \\
\hline & & $\begin{array}{l}\text { Composite } \\
\text { liquid }\end{array}$ & $\rightarrow$ & Annual $^{b}$ & $\rightarrow$ & 1 & $\rightarrow$ & $\begin{array}{l}\text { A 24-hour composite for } \\
\text { total } \mathrm{Ba} \text { and } \mathrm{Sb}\end{array}$ \\
\hline & & & $\rightarrow$ & Semiannual $^{b}$ & $\rightarrow$ & 2 & $\rightarrow$ & Heptachlor \\
\hline & & Grab liquid & $\rightarrow$ & Annual $^{b}$ & $\rightarrow$ & 1 & $\rightarrow$ & $\begin{array}{l}\text { Chloroform, dichlorodi- } \\
\text { fluoromethane, } \\
\text { trichlorofluoromethane, } \\
\text { 3,3-dichlorobenzidine, } \\
\text { tributyl phosphate, } \\
\text { hexachlorobenzene, } \\
\text { alpha-BHC, xylene, } \\
\text { 2-butanone }\end{array}$ \\
\hline
\end{tabular}

${ }^{a}$ Lagoon 3 is discharged four to eight times per year, as necessary, averaging six to seven days per discharge.

${ }^{b}$ Two samples are collected, one near the start and one near the end of the discharge.

$$
B-5
$$




\section{Sampling Rationale}

WNSP001 DOE Order 5400.5; DOE/EH-0173T, 2.3.3; New York State SPDES Permit no. NY0000973; NYSDOH ELAP (nonpotable water)

By DOE Order all liquid effluent streams from DOE facilities shall be evaluated and their potential for release of radionuclides addressed. These requirements for radiological parameters are met by daily grab sampling during periods of lagoon 3 discharge.

Sampling for chemical constituents is performed near the beginning and end of each discharge period to meet the site SPDES Permit. Both grab samples and 24-hour composite samples are collected.

For permit requirements, total $\mathrm{Hg}$ is analyzed in accordance with U.S. EPA Method 245.1 and EPA Method 1631.

Sampling location is shown on Figure A-2.

$B-6$ 


\section{Monitoring Program \\ On-Site Effluent Monitoring}

\section{Liquid Effluents}

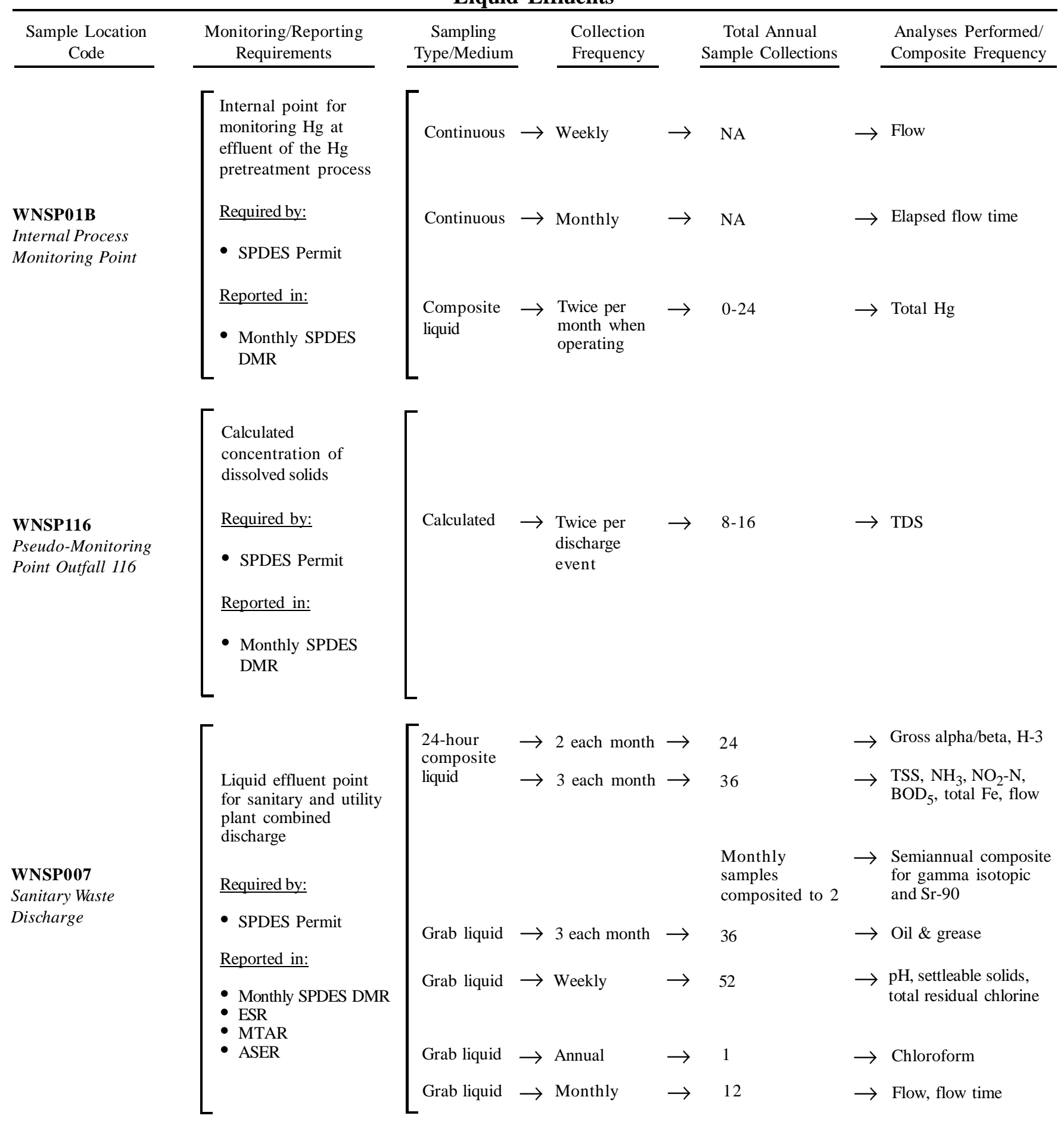

$$
B-7
$$




\section{Sampling Rationale}

WNSP01B New York State SPDES Permit no. NY0000973; NYSDOH ELAP (nonpotable water)

This internal point is used to monitor mercury in effluent from the mercury pretreatment process. Effluent from this point is subsequently released to the LLWTF, which is monitored at point WNSP001.

For permit requirements, total mercury is analyzed in accordance with U.S. EPA Method 245.1. For mercury studies, samples are analyzed in accordance with EPA Method 1631.

WNSP116 New York State SPDES Permit no. NY0000973; NYSDOH ELAP (nonpotable water)

This "pseudo-monitoring point," assumed to be in Frank's Creek, is calculated from actual total dissolved solids (TDS) measurements and flow measurements from points WNSP001 and WNSP006 and from augmentation water.

WNSP007 DOE Order 5400.5; DOE/EH-0173T, 2.3.3; New York State SPDES Permit no. NY0000973; NYSDOH ELAP (nonpotable water)

Monitoring of treated effluent from the sanitary and industrial wastewater treatment facility is performed in accordance with the New York State SPDES Permit no. NY0000973 and DOE Order 5400.5 criteria.

Sampling locations WNSP116 and WNSP007 are shown on Figure A-2. Sampling location WNSP01B is not shown on the figures.

$$
B-8
$$




\section{Monitoring Program \\ On-Site Effluent Monitoring}

\section{Liquid Effluents}

\begin{tabular}{|c|c|c|c|c|c|c|c|c|}
\hline $\begin{array}{l}\text { Sample Location } \\
\text { Code }\end{array}$ & $\begin{array}{l}\text { Monitoring/Reporting } \\
\text { Requirements }\end{array}$ & $\begin{array}{c}\text { Sampling } \\
\text { Type/Medium }\end{array}$ & & $\begin{array}{l}\text { Collection } \\
\text { Frequency }\end{array}$ & & $\begin{array}{c}\text { Total Annual } \\
\text { Sample Collections }\end{array}$ & & $\begin{array}{l}\text { Analyses Performed/ } \\
\text { Composite Frequency }\end{array}$ \\
\hline \multirow{6}{*}{$\begin{array}{l}\text { WNSP006 } \\
\text { Frank's Creek at the } \\
\text { Security Fence }\end{array}$} & \multirow{6}{*}{$\begin{array}{l}\begin{array}{l}\text { Combined facility liquid } \\
\text { discharge }\end{array} \\
\text { Required by: } \\
\text { - SPDES Permit } \\
\text { Reported in: } \\
\text { - Monthly SPDES DMR } \\
\text { - MTAR } \\
\text { - ASER }\end{array}$} & {$\left[\begin{array}{l}\text { Timed } \\
\text { continuous } \\
\text { composite } \\
\text { liquid }\end{array}\right.$} & $\rightarrow$ & $\begin{array}{l}\text { Weekly during } \\
\text { Lagoon } 3 \\
\text { discharge, } \\
\text { otherwise } \\
\text { biweekly }\end{array}$ & $\rightarrow$ & $\begin{array}{l}\text { Biweekly, } \\
\text { weekly } \\
\text { samples } \\
\text { composited to } 12\end{array}$ & $\rightarrow$ & $\begin{array}{l}\text { Monthly composite } \\
\text { for gamma isotopic } \\
\text { and Sr-90 (shared } \\
\text { with NYSDOH) }\end{array}$ \\
\hline & & & & & & $\begin{array}{l}\text { Weekly, } \\
\text { biweekly } \\
\text { samples } \\
\text { composited to } 4\end{array}$ & $\rightarrow$ & $\begin{array}{l}\text { Quarterly composite for } \\
\text { C-14, Tc-99, I-129, } \\
\text { U-232, U-233/234, } \\
\text { U-235/236, U-238, total } \\
\text { U, Pu-238, Pu-239/240, } \\
\text { Am-241 }\end{array}$ \\
\hline & & Grab liquid & $\rightarrow$ & $\begin{array}{l}\text { Five per } \\
\text { discharge; } \\
\text { baseline, before } \\
\text { start, near start, } \\
\text { near end, and } \\
\text { after end }\end{array}$ & $\rightarrow$ & $20-40$ & $\rightarrow$ & TDS \\
\hline & & Grab liquid & $\rightarrow$ & Monthly & $\rightarrow$ & 12 & $\rightarrow$ & Hardness ( $\mathrm{Ca}$ and $\mathrm{Mg}$ ) \\
\hline & & Grab liquid & $\rightarrow$ & Semiannual ${ }^{a}$ & $\rightarrow$ & 2 & $\rightarrow$ & $\begin{array}{l}\text { Temperature (field), } \\
\text { pH (field), dissolved } \\
\text { oxygen (field), TOX, } \\
\text { oil \& grease }\end{array}$ \\
\hline & & $\begin{array}{l}\text { 24-hour } \\
\text { timed } \\
\text { continuous } \\
\text { composite }\end{array}$ & $\rightarrow$ & Semiannual $^{a}$ & $\rightarrow$ & 2 & $\rightarrow$ & $\begin{array}{l}\text { TSS, NPOC, } \mathrm{NH}_{3} \text { (as N), } \\
\mathrm{NO}_{3} \text { (as N), } \mathrm{NO}_{2} \text { (as N), } \\
\text { bromide, fluoride, } \\
\text { chloride, sulfate, total } \\
\text { sulfide, surfactant (as } \\
\mathrm{LAS} \text { ), alpha-BHC, B, Ba, } \\
\mathrm{Co}, \mathrm{Fe}, \mathrm{Na}, \mathrm{Mn}, \mathrm{Sb}, \mathrm{Ti} \text {, } \\
\mathrm{Tl}, \mathrm{V} \text {, dissolved Al, As, } \\
\mathrm{Cd}, \mathrm{Cr}, \mathrm{Cu}, \mathrm{Hg} \text { (method } \\
\text { 1631), Ni, Pb, Se, Zn }\end{array}$ \\
\hline \multirow{3}{*}{$\begin{array}{l}\text { WNURRAW } \\
\text { Utility Room Raw Water }\end{array}$} & $\begin{array}{l}\text { Source water } \\
\text { Required by: }\end{array}$ & {$\left[\begin{array}{l}\text { Composite } \\
\text { liquid }\end{array}\right.$} & $\rightarrow$ & Weekly & $\rightarrow$ & 52 & $\rightarrow$ & Total Fe \\
\hline & \multirow[t]{2}{*}{$\begin{array}{l}\text { - SPDES Permit } \\
\text { Reported in: } \\
\text { - Monthly SPDES DMR }\end{array}$} & Grab liquid & $\rightarrow$ & $\begin{array}{l}\text { Four per } \\
\text { discharge, } \\
\text { baseline, } \\
\text { before start, } \\
\text { near start, and } \\
\text { near end }\end{array}$ & $\rightarrow$ & $16-32$ & $\rightarrow$ & TDS \\
\hline & & _ Grab liquid $b$ & $\rightarrow$ & Monthly & $\rightarrow$ & 12 & $\rightarrow$ & TOC, alkalinity \\
\hline
\end{tabular}

a Semiannual samples collected when points WNSP001 and WNSP007 are discharging.

${ }^{b}$ Cattaraugus County Department of Health

$$
\text { B }-9
$$




\section{Sampling Rationale}

WNSP006 DOE/EH-0173T, 5.10.1.1; New York State SPDES Permit no. NY0000973; 6 NYCRR, Parts 702-704;

NYSDOH ELAP (nonpotable water)

By DOE Order all liquid effluent streams from DOE facilities shall be evaluated and their potential for release of radionuclides addressed.

TDS is measured before the discharge begins, shortly after it begins, near the end, and after the end of each lagoon 3 discharge period to meet requirements of the site SPDES Permit. Measurements of TDS and flow are used to calculate TDS at pseudo-monitoring point outfall 116 in Frank's Creek.

Semiannual samples are collected when WNSP001 and WNSP007 are discharging.

WNURRAW New York State SPDES Permit no. NY0000973; 10 NYCRR, Part 5, Subpart 5-1; NYSDOH ELAP (nonpotable water)

TDS is measured near the beginning and end of each lagoon 3 discharge. Results are used for outfall 116 calculations. (See WNSP006 above.)

Sampling location WNSP006 is shown on Figure A-2. Sampling location WNURRAW is not shown on the figures.

$B-10$ 


\section{Monitoring Program \\ On-Site Effluent Monitoring}

Storm Water Outfalls

\begin{tabular}{|c|c|c|c|c|c|c|c|c|}
\hline $\begin{array}{l}\text { Sample Location } \\
\text { Code }\end{array}$ & $\begin{array}{l}\text { Monitoring/Reporting } \\
\text { Requirements }\end{array}$ & $\begin{array}{c}\text { Sampling } \\
\text { Type/Medium }\end{array}$ & & $\begin{array}{l}\text { Collection } \\
\text { Frequency }\end{array}$ & & $\begin{array}{c}\text { Total Annual } \\
\text { Sample Collections }\end{array}$ & & $\begin{array}{l}\text { Analyses Performed/ } \\
\text { Composite Frequency }\end{array}$ \\
\hline \multirow[t]{2}{*}{$\begin{array}{l}\frac{\text { GROUP } 1}{\text { WNSO02 }} \text { (S02) } \\
\text { WNSO04 (S04) }\end{array}$} & $\begin{array}{l}\text { Storm water runoff } \\
\text { Required by: } \\
\text { - SPDES Permit }\end{array}$ & {$\left[\begin{array}{l}\text { First flush } \\
\text { grab liquid }\end{array}\right.$} & $\rightarrow$ & Semiannual & $\rightarrow$ & 2 & $\rightarrow$ & $\begin{array}{l}\mathrm{pH}, \text { oil \& grease, } \\
\mathrm{BOD}_{5}, \mathrm{TSS}, \mathrm{TDS} \text {, total } \\
\mathrm{P}, \mathrm{Al}, \mathrm{Fe} \text {, total } \\
\text { recoverable } \mathrm{Cu}, \mathrm{Pb}, \mathrm{Zn} \text {, } \\
\mathrm{Cd}, \mathrm{Cr}, \mathrm{Se}, \mathrm{V}, \mathrm{Cr}+6 \\
\mathrm{TKN}, \text { ammonia }(\text { as } \\
\mathrm{NH}_{3} \text { ), } \mathrm{NO}_{3}-\mathrm{N}, \mathrm{NO}_{2}-\mathrm{N} \text {, } \\
\text { total nitrogen (as } \mathrm{N})\end{array}$ \\
\hline & $\begin{array}{l}\text { Reported in: } \\
\text { - Monthly SPDES } \\
\text { DMR } \\
\text { - ASER }\end{array}$ & $\begin{array}{l}\text { Flow- } \\
\text { weighted } \\
\text { composite } \\
\text { liquid }\end{array}$ & $\rightarrow$ & Semiannual & $\rightarrow$ & 2 & $\rightarrow$ & $\begin{array}{l}\text { Total flow, } \mathrm{BOD}_{5}, \mathrm{TSS} \text {, } \\
\mathrm{TDS} \text {, total } \mathrm{P}, \mathrm{Al}, \mathrm{Fe} \text {, } \\
\text { total recoverable } \mathrm{Cu} \text {, } \\
\mathrm{Pb}, \mathrm{Zn}, \mathrm{Cd}, \mathrm{Cr}, \mathrm{Se}, \mathrm{V} \text {, } \\
\mathrm{Cr}^{+6}, \mathrm{TKN}, \text { ammonia } \\
\left(\mathrm{as}_{3}\right), \mathrm{NO}_{3}-\mathrm{N} \text {, } \\
\mathrm{NO}_{2}-\mathrm{N}, \text { total nitrogen }\end{array}$ \\
\hline \multirow{2}{*}{$\begin{array}{l}\text { GROUP } 2 \\
\text { WNSO06 } \\
\text { WNSO33 }(\mathbf{S 3 3})\end{array}$} & $\begin{array}{l}\text { Storm water runoff } \\
\text { Required by: } \\
\text { - SPDES Permit }\end{array}$ & $\begin{array}{l}\text { First flush } \\
\text { grab liquid }\end{array}$ & $\rightarrow$ & Semiannual & $\rightarrow$ & 2 & $\rightarrow$ & $\begin{array}{l}\mathrm{pH} \text {, oil \& grease, } \\
\mathrm{BOD}_{5}, \mathrm{TSS}, \mathrm{TDS} \text {, total } \\
\mathrm{P}, \mathrm{Al}, \mathrm{Fe} \text {, total } \\
\text { recoverable } \mathrm{Cu}, \mathrm{Pb}, \mathrm{Zn} \text {, } \\
\text { surfactant (as LAS) }\end{array}$ \\
\hline & $\begin{array}{l}\text { Reported in: } \\
\text { - Monthly SPDES } \\
\text { DMR } \\
\text { - ASER }\end{array}$ & $\begin{array}{l}\text { Flow- } \\
\text { weighted } \\
\text { composite } \\
\text { liquid }\end{array}$ & $\rightarrow$ & Semiannual & $\rightarrow$ & 2 & $\rightarrow$ & $\begin{array}{l}\text { Total flow, } \mathrm{BOD}_{5} \text {, TSS, } \\
\text { TDS, total } \mathrm{P}, \mathrm{Al}, \mathrm{Fe} \text {, } \\
\text { total recoverable } \mathrm{Cu} \text {, } \\
\mathrm{Pb}, \mathrm{Zn} \text {, surfactant (as } \\
\mathrm{LAS} \text { ) }\end{array}$ \\
\hline \multirow[t]{2}{*}{$\begin{array}{l}\text { GROUP } 3 \\
\text { WNSO09 (S09) } \\
\text { WNSO12 (S12) }\end{array}$} & $\begin{array}{l}\text { Storm water runoff } \\
\text { Required by: } \\
\text { - SPDES Permit } \\
\text { Reported in: }\end{array}$ & $\begin{array}{l}\text { First flush } \\
\text { grab liquid }\end{array}$ & $\rightarrow$ & 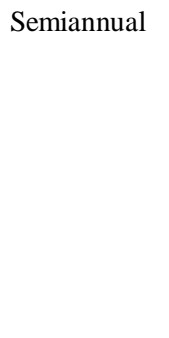 & $\rightarrow$ & 2 & $\rightarrow$ & $\begin{array}{l}\mathrm{pH} \text {, oil \& grease, } \\
\mathrm{BOD}_{5}, \mathrm{TSS}, \mathrm{TDS} \text {, total } \\
\mathrm{P}, \mathrm{Al}, \mathrm{Fe} \text {, total } \\
\text { recoverable } \mathrm{Cu}, \mathrm{Pb}, \mathrm{Zn} \text {, } \\
\mathrm{TKN}, \text { ammonia (as } \\
\left.\mathrm{NH}_{3}\right), \mathrm{NO}_{3}-\mathrm{N}, \mathrm{NO}_{2}-\mathrm{N}, \\
\text { alpha-BHC, total } \\
\text { nitrogen }\end{array}$ \\
\hline & $\begin{array}{l}\text { - Monthly SPDES } \\
\text { DMR } \\
\text { - ASER }\end{array}$ & $\begin{array}{l}\text { Flow- } \\
\text { weighted } \\
\text { composite } \\
\text { liquid }\end{array}$ & $\rightarrow$ & Semiannual & $\rightarrow$ & 2 & $\rightarrow$ & $\begin{array}{l}\text { Total flow, } \mathrm{BOD}_{5}, \mathrm{TSS} \text {, } \\
\text { TDS, total } \mathrm{P}, \mathrm{Al}, \mathrm{Fe} \text {, } \\
\text { total recoverable } \mathrm{Cu} \text {, } \\
\mathrm{Pb}, \mathrm{Zn}, \mathrm{TKN}, \text { ammonia } \\
\left(\text { as } \mathrm{NH}_{3}\right), \mathrm{NO}_{3}-\mathrm{N}, \\
\mathrm{NO}_{2}-\mathrm{N}, \text { alpha-BHC, } \\
\text { total nitrogen }\end{array}$ \\
\hline
\end{tabular}

$B-11$ 


\section{Sampling Rationale}

\begin{abstract}
Storm Water
Outfalls

New York State SPDES Permit no. NY0000973; NYSDOH ELAP (nonpotable water)

The National Pollutant Discharge Elmination System Permit (NPDES) Application Regulations for Storm Water Discharges, Final Rule (40 CFR 122, 123, and 124 as amended), and as expressed in Section 403(p) of the Clean Water Act, require that specified facilities acquire NPDES permits for the discharge of storm water associated with industrial activities. Permitted or interim status Resource Conservation and Recovery Act (RCRA) hazardous waste treatment, storage, and disposal facilities are specifically defined as associated with industrial activity in the regulations (40 CFR 122.26 [a][14][iv]). Because the West Valley Demonstration Project (WVDP) is an interim status RCRA facility, the storm water discharges from the WVDP qualify as being associated with industrial activity. Five other groups of activities at the WVDP also are subject to storm water permitting: 1) aboveground container storage; 2) aboveground and underground tank storage; 3) underground waste burial; 4) haul roads and railway lines; 5) liquid waste treatment facilities and construction activities and industrial activities.
\end{abstract}

GROUP 1

WNSO02

WNSO04

GROUP 2

WNSO06

WNSO33

GROUP 3

WNSO09

WNSO12

New York State is delegated by the U.S. Environmental Protection Agency (EPA) to administer the National Pollutant Discharge Elimination System under an equivalent state program, the State Pollutant Discharge Elimination System (SPDES).

Runoff from areas associated with Remote-Handled Waste Facility (RHWF) operation, RCRA hazardous and radioactive waste storage, radioactive waste from the vitrification facility, nonradioactive process wastewater storage and transfer, equipment and material fabrication, oil storage, North Plateau groundwater infiltration reduction/storm water diversion, and service roads. The RHWF processes expended contaminated vitrification materials and equipment for shipment and disposal. Hazardous radioactive waste storage (except for the LSA-2 Hardstand), equipment/material fabrication, oil storage, and RHWF operations occur indoors.

Runoff from areas associated with containerized radioactive waste, inactive burial area for construction and demolition debris, spent nuclear fuel receiving, storage, and shipping, high-level radioactive waste tanks, low-level radioactive wastewater evaporator and mercury abatement system, radiologically contaminated groundwater plume pumping operation, vehicle maintenance shop, and associated service roads. Vehicle maintenance, evaporator, mercury abatement, groundwater pumping operations, and spent nuclear fuel storage occur indoors. Industrial practices for the construction and demolition debris burial area include perpetual maintenance of the grass earthen cover.

Runoff areas associated with wastewater/storm water treatment lagoons, fire and potable water production, oil storage, maintenance shop, cement silo storage, and service roads. Maintenance oil, and cement storage occur indoors.

Sampling locations are shown on Figures A-3 and A-4.

$B-12$ 


\section{Monitoring Program \\ On-Site Effluent Monitoring}

\section{Storm Water Outfalls}

\begin{tabular}{|c|c|c|c|c|c|c|c|c|}
\hline $\begin{array}{l}\text { Sample Location } \\
\text { Code }\end{array}$ & $\begin{array}{l}\text { Monitoring/Reporting } \\
\text { Requirements }\end{array}$ & $\begin{array}{c}\text { Sampling } \\
\text { Type/Medium }\end{array}$ & & $\begin{array}{l}\text { Collection } \\
\text { Frequency }\end{array}$ & & $\begin{array}{c}\text { Total Annual } \\
\text { Sample Collections }\end{array}$ & & $\begin{array}{l}\text { Analyses Performed/ } \\
\text { Composite Frequency }\end{array}$ \\
\hline \multirow{2}{*}{$\frac{\text { GROUP } 4}{\text { WNSO34 }}$} & $\begin{array}{l}\text { Storm water runoff } \\
\text { Required by: }\end{array}$ & $\begin{array}{l}\text { First flush } \\
\text { grab liquid }\end{array}$ & $\rightarrow$ & Semiannual & $\rightarrow$ & 2 & $\rightarrow$ & $\begin{array}{l}\mathrm{pH} \text {, oil \& grease, } \\
\mathrm{BOD}_{5}, \mathrm{TSS}, \mathrm{TDS} \text {, total } \\
\mathrm{P}, \mathrm{Al}, \mathrm{Fe} \text {, total } \\
\text { recoverable } \mathrm{Cu}, \mathrm{Pb}, \mathrm{Zn} \text {, } \\
\text { surfactant (as LAS) }\end{array}$ \\
\hline & $\begin{array}{l}\text { - Monthly SPDES } \\
\text { DMR } \\
\text { - ASER }\end{array}$ & $\begin{array}{l}\text { Flow- } \\
\text { weighted } \\
\text { composite } \\
\text { liquid }\end{array}$ & $\rightarrow$ & Semiannual & $\rightarrow$ & 2 & $\rightarrow$ & $\begin{array}{l}\text { Total flow, } \mathrm{BOD}_{5}, \mathrm{TSS} \text {, } \\
\text { TDS, total } \mathrm{P}, \mathrm{Al}, \mathrm{Fe} \text {, } \\
\text { total recoverable } \mathrm{Cu} \text {, } \\
\mathrm{Pb}, \mathrm{Zn} \text {, surfactant (as } \\
\mathrm{LAS} \text { ) }\end{array}$ \\
\hline \multirow[t]{2}{*}{$\begin{array}{l}\text { GROUP } 5 \\
\text { WNSO14 } \\
\text { WNSO17 } \\
\text { WN17) } \\
\text { WNSO28 } \\
\text { (S28) }\end{array}$} & $\begin{array}{l}\text { Storm water runoff } \\
\text { Required by: } \\
\text { - SPDES Permit } \\
\text { Reported in: }\end{array}$ & $\begin{array}{l}\text { First flush } \\
\text { grab liquid }\end{array}$ & $\rightarrow$ & Semiannual & $\rightarrow$ & 2 & $\rightarrow$ & $\begin{array}{l}\mathrm{pH} \text {, oil \& grease, } \\
\mathrm{BOD}_{5} \text {, TSS, TDS, total } \\
\mathrm{P}, \mathrm{Al}, \mathrm{Fe} \text {, total } \\
\text { recoverable } \mathrm{Cu}, \mathrm{Pb}, \mathrm{Zn} \text {, } \\
\mathrm{V}, \mathrm{TKN}, \text { ammonia (as } \\
\mathrm{NH}_{3} \text { ), } \mathrm{NO}_{3}-\mathrm{N}, \mathrm{NO}_{2}-\mathrm{N}, \\
\text { surfactant (as LAS), } \\
\text { sulfide, settleable solids, } \\
\text { total nitrogen }\end{array}$ \\
\hline & $\begin{array}{l}\text { - Monthly SPDES } \\
\text { DMR } \\
\text { - ASER }\end{array}$ & $\begin{array}{l}\text { Flow- } \\
\text { weighted } \\
\text { composite } \\
\text { liquid }\end{array}$ & $\rightarrow$ & Semiannual & $\rightarrow$ & 2 & $\rightarrow$ & $\begin{array}{l}\text { Total flow, } \mathrm{BOD}_{5}, \mathrm{TSS} \text {, } \\
\text { TDS, total } \mathrm{P}, \mathrm{Al}, \mathrm{Fe} \text {, } \\
\text { total recoverable } \mathrm{Cu} \text {, } \\
\mathrm{Pb}, \mathrm{Zn}, \mathrm{V}, \mathrm{TKN}, \\
\text { ammonia }\left(\text { as } \mathrm{NH}_{3} \text { ), }\right. \\
\mathrm{NO}_{3}-\mathrm{N}, \mathrm{NO}_{2}-\mathrm{N}, \\
\text { surfactant (as LAS), } \\
\text { sulfide, settleable solids, } \\
\text { total nitrogen }\end{array}$ \\
\hline
\end{tabular}

$B-13$ 


\title{
Sampling Rationale
}

\begin{abstract}
Storm Water New York State SPDES Permit no. NY0000973; NYSDOH ELAP (nonpotable water) Outfalls

The National Pollutant Discharge Elmination System Permit (NPDES) Application Regulations for Storm Water Discharges, Final Rule (40 CFR 122, 123, and 124 as amended), and as expressed in Section 403(p) of the Clean Water Act, require that specified facilities acquire NPDES permits for the discharge of storm water associated with industrial activities. Permitted or interim status Resource Conservation and Recovery Act (RCRA) hazardous waste treatment, storage, and disposal facilities are specifically defined as associated with industrial activity in the regulations (40 CFR 122.26 [a][14][iv]). Because the West Valley Demonstration Project (WVDP) is an interim status RCRA facility, the storm water discharges from the WVDP qualify as being associated with industrial activity. Five other groups of activities at the WVDP also are subject to storm water permitting: 1) aboveground container storage; 2) aboveground and underground tank storage; 3 ) underground waste burial; 4) haul roads and railway lines; 5) liquid waste treatment facilities and construction activities and industrial activities.
\end{abstract}

New York State is delegated by the U.S. Environmental Protection Agency (EPA) to administer the National Pollutant Discharge Elimination System under an equivalent state program, the State Pollutant Discharge Elimination System (SPDES).

\section{GROUP 4}

Runoff from areas associated with railroad spur within WVDP premises, industrial and sanitary wastewater WNSO34

GROUP 5 WNSO14 parking, outdoor equipment staging and storage. Warehouse, oil storage, wastewater treatment, and sewage sludge storage occur indoors.

Runoff from areas associated with service roads, railroad spur, and rail staging and loading depot within WVDP premises.

Sampling locations are shown on Figures A-3 and A-4.

\section{$B-14$}




\section{Monitoring Program \\ On-Site Effluent Monitoring}

\section{Storm Water Outfalls}

\begin{tabular}{|c|c|c|c|c|c|c|c|c|}
\hline $\begin{array}{l}\text { Sample Location } \\
\text { Code }\end{array}$ & $\begin{array}{l}\text { Monitoring/Reporting } \\
\text { Requirements }\end{array}$ & $\begin{array}{c}\text { Sampling } \\
\text { Type/Medium }\end{array}$ & & $\begin{array}{l}\text { Collection } \\
\text { Frequency }\end{array}$ & & $\begin{array}{c}\text { Total Annual } \\
\text { Sample Collections }\end{array}$ & & $\begin{array}{l}\text { Analyses Performed/ } \\
\text { Composite Frequency }\end{array}$ \\
\hline $\begin{array}{l}\text { GROUP 6 } \\
\text { WNSO36 }(\mathbf{S 3 6}) \\
\text { WNSO37 }(\mathbf{S 3 7}) \\
\text { WNSO38 }(\mathbf{S 3 8}) \\
\text { WNSO39 }(\mathbf{S 3 9}) \\
\text { WNSO40 }(\mathbf{S 4 0}) \\
\text { WNSO41 }(\mathbf{S 4 1}) \\
\text { WNSO42 }(\mathbf{S 4 2})\end{array}$ & $\begin{array}{l}\text { Storm water runoff } \\
\text { Required by: } \\
\text { - SPDES Permit } \\
\text { Reported in: } \\
\text { - Monthly SPDES } \\
\text { DMR } \\
\text { - ASER } \\
\end{array}$ & $\begin{array}{l}\text { Flow- } \\
\text { weighted } \\
\text { composite } \\
\text { liquid }\end{array}$ & $\rightarrow$ & Semiannual & $\rightarrow$ & 2 & $\rightarrow$ & $\begin{array}{l}\mathrm{pH} \text {, oil \& grease, } \\
\mathrm{BOD} \text {, TSS, TDS, total } \\
\mathrm{P}, \mathrm{Al}, \mathrm{Fe} \text {, total } \\
\text { recoverable } \mathrm{Cu}, \mathrm{Pb}, \mathrm{Zn} \text {, } \\
\mathrm{V}, \mathrm{TKN}, \text { ammonia (as } \\
\mathrm{NH}_{3} \text { ), } \mathrm{NO}_{3}-\mathrm{N}, \mathrm{NO}_{2}-\mathrm{N}, \\
\text { surfactant (as LAS), } \\
\text { sulfide, settleable solids, } \\
\text { total nitrogen }\end{array}$ \\
\hline \multirow[t]{2}{*}{$\frac{\text { GROUP } 7}{\text { WNSO20 }}$} & $\begin{array}{l}\text { Storm water runoff } \\
\text { Required by: } \\
\text { - SPDES Permit } \\
\text { Reported in: }\end{array}$ & $\begin{array}{l}\text { First flush } \\
\text { grab liquid }\end{array}$ & $\rightarrow$ & Semiannual & $\rightarrow$ & 2 & $\rightarrow$ & $\begin{array}{l}\mathrm{pH}, \text { oil \& grease, } \\
\mathrm{BOD}_{5}, \mathrm{TSS}, \mathrm{TDS} \text {, total } \\
\mathrm{P}, \mathrm{Al}, \mathrm{Fe} \text {, total } \\
\text { recoverable } \mathrm{Cu}, \mathrm{Pb}, \mathrm{Zn} \text {, } \\
\mathrm{TKN}, \text { ammonia (as } \\
\mathrm{NH}_{3} \text { ), } \mathrm{NO}_{3}-\mathrm{N}, \mathrm{NO}_{2}-\mathrm{N}, \\
\text { surfactant (as LAS), } \\
\text { sulfide, total nitrogen }\end{array}$ \\
\hline & $\begin{array}{l}\text { - Monthly SPDES } \\
\text { DMR } \\
\text { - ASER }\end{array}$ & $\begin{array}{l}\text { Flow- } \\
\text { weighted } \\
\text { composite } \\
\text { liquid }\end{array}$ & $\rightarrow$ & Semiannual & $\rightarrow$ & 2 & $\rightarrow$ & $\begin{array}{l}\text { Total flow, } \mathrm{BOD}_{5} \text {, TSS, } \\
\text { TDS, total } \mathrm{P}, \mathrm{Al}, \mathrm{Fe} \text {, } \\
\text { total recoverable } \mathrm{Cu} \text {, } \\
\mathrm{Pb}, \mathrm{Zn}, \mathrm{TKN}, \text { ammonia } \\
\left(\text { as } \mathrm{NH}_{3}\right), \mathrm{NO}_{3}-\mathrm{N}, \\
\mathrm{NO}_{2}-\mathrm{N} \text {, surfactant (as } \\
\mathrm{LAS} \text { ), sulfide, total } \\
\text { nitrogen }\end{array}$ \\
\hline
\end{tabular}

$B-15$ 


\title{
Sampling Rationale
}

\begin{abstract}
Storm Water New York State SPDES Permit no. NY0000973; NYSDOH ELAP (nonpotable water) Outfalls

The National Pollutant Discharge Elmination System Permit (NPDES) Application Regulations for Storm Water Discharges, Final Rule (40 CFR 122, 123, and 124 as amended), and as expressed in Section 403(p) of the Clean Water Act, require that specified facilities acquire NPDES permits for the discharge of storm water associated with industrial activities. Permitted or interim status Resource Conservation and Recovery Act (RCRA) hazardous waste treatment, storage, and disposal facilities are specifically defined as associated with industrial activity in the regulations (40 CFR 122.26 [a][14][iv]). Because the West Valley Demonstration Project (WVDP) is an interim status RCRA facility, the storm water discharges from the WVDP qualify as being associated with industrial activity. Five other groups of activities at the WVDP also are subject to storm water permitting: 1) aboveground container storage; 2) aboveground and underground tank storage; 3) underground waste burial; 4) haul roads and railway lines; 5) liquid waste treatment facilities and construction activities and industrial activities.

New York State is delegated by the U.S. Environmental Protection Agency (EPA) to administer the National Pollutant Discharge Elimination System under an equivalent state program, the State Pollutant Discharge Elimination System (SPDES).
\end{abstract}

GROUP 6 WNSO36

WNSO37

WNSO38

WNSO39

WNSO40

WNSO41

WNSO42

GROUP 7

WNSO20
Runoff from areas along the segment of the railroad spur and service road within the Western New York Nuclear Service Center (WNYNSC) outside the WVDP fenced area.
Runoff from areas associated with inactive waste burial, groundwater/leachate storage and treatment and service roads. Groundwater/leachate storage and treatment occurs indoors. Management practices for the inactive radioactive waste burial areas include perpetual maintenance of the earthen cover.

Sampling locations are shown on Figures A-3 and A-4.

$B-16$ 


\section{Monitoring Program \\ On-Site Effluent Monitoring}

\section{Storm Water Outfalls}

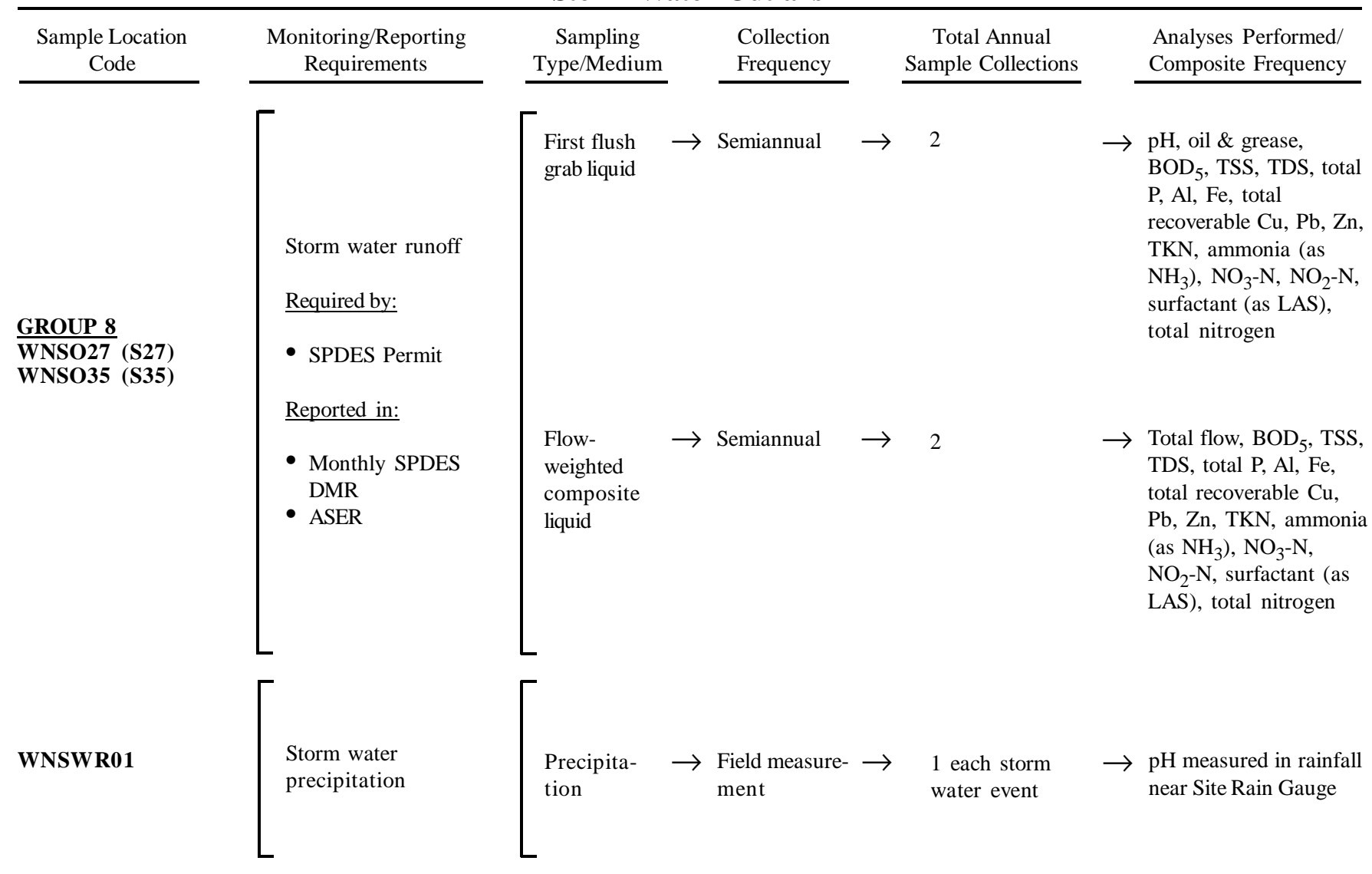

B -17 


\title{
Sampling Rationale
}

\begin{abstract}
Storm Water New York State SPDES Permit no. NY0000973; NYSDOH ELAP (nonpotable water)
Outfalls

The National Pollutant Discharge Elmination System Permit (NPDES) Application Regulations for Storm Water Discharges, Final Rule (40 CFR 122, 123, and 124 as amended), and as expressed in Section 403(p) of the Clean Water Act, require that specified facilities acquire NPDES permits for the discharge of storm water associated with industrial activities. Permitted or interim status Resource Conservation and Recovery Act (RCRA) hazardous waste treatment, storage, and disposal facilities are specifically defined as associated with industrial activity in the regulations (40 CFR 122.26 [a][14][iv]). Because the West Valley Demonstration Project (WVDP) is an interim status RCRA facility, the storm water discharges from the WVDP qualify as being associated with industrial activity. Five other groups of activities at the WVDP also are subject to storm water permitting: 1) aboveground container storage; 2) aboveground and underground tank storage; 3 ) underground waste burial; 4) haul roads and railway lines; 5) liquid waste treatment facilities and construction activities and industrial activities.
\end{abstract}

New York State is delegated by the U.S. Environmental Protection Agency (EPA) to administer the National Pollutant Discharge Elimination System under an equivalent state program, the State Pollutant Discharge Elimination System (SPDES).

GROUP 8 Runoff associated with equipment staging and indoor containerized storage of cement solidified low-level WNSO27 radioactive waste.

WNSO35

WNSWR01

New York State SPDES Permit no. NY0000973; NYSDOH ELAP (nonpotable water)

The $\mathrm{pH}$ of rainfall is measured near the site rain gauge fallout pot during each storm water discharge sampling event.

Sampling locations are shown on Figures A-3 and A-4.

\section{$B-18$}




\section{Monitoring Program \\ Environmental Surveillance}

On-Site Surface Water

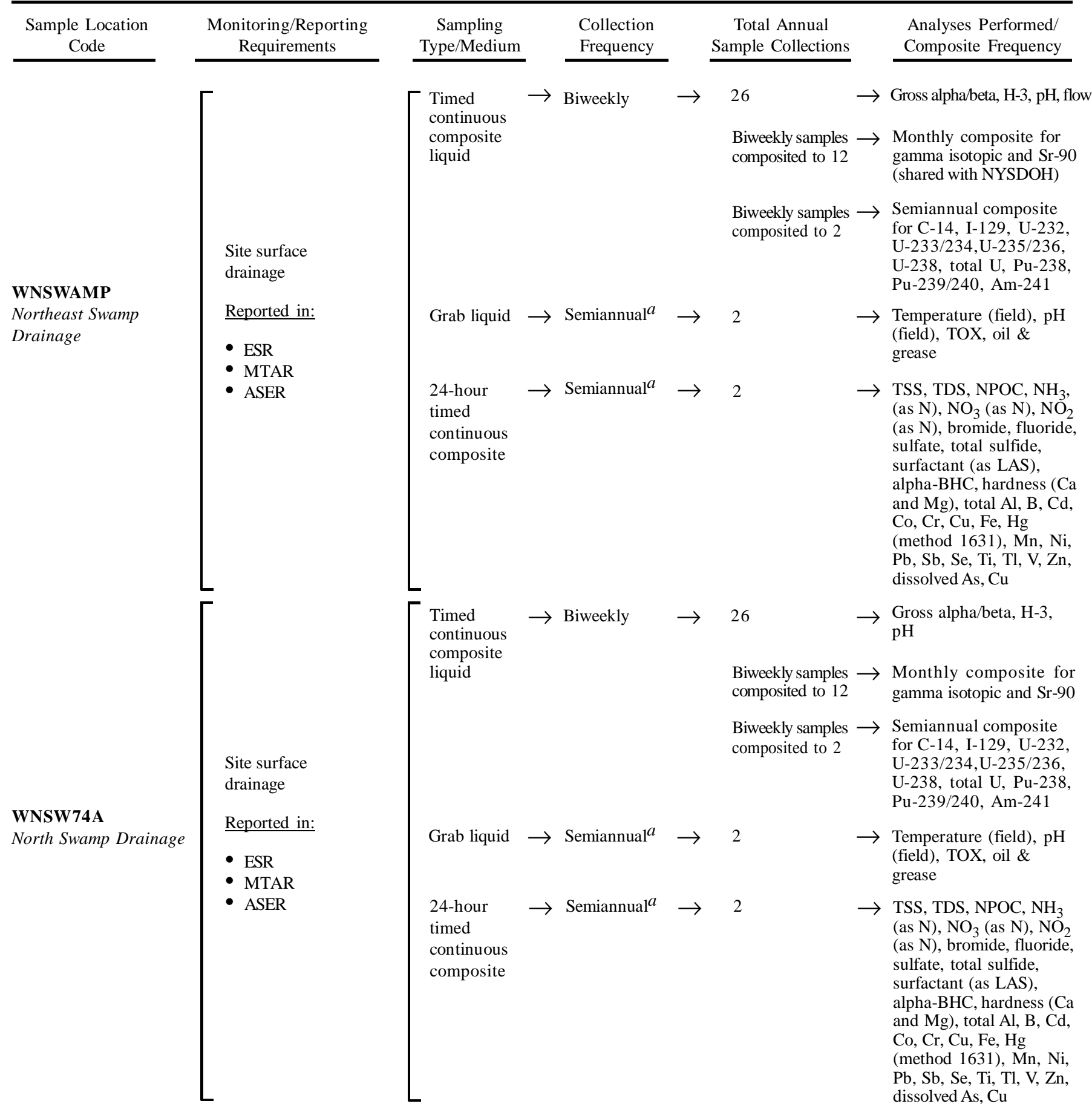

a Sampled during ambient (i.e., non-wet weather) conditions.

B - 19 


\section{Sampling Rationale}

\section{WNSWAMP DOE/EH-0173T, 5.10.1.1; 40 CFR, Part 122.26; NYSDOH ELAP (nonpotable water)}

Northeast site surface water drainage; provides for sampling of uncontrolled surface waters from this discrete drainage path just before they leave the site's controlled boundary. Waters represent surface and subsurface drainages from the construction and demolition debris landfill (CDDL), old hardstand areas, and other possible north plateau sources of radiological or nonradiological contamination on the north plateau.

Monitoring for nonradiological parameters is performed during ambient conditions to verify authorized non-storm water flows. Storm water monitoring is performed per WVDP-233, "Monitoring Plan for Storm Water Discharges at the West Valley Demonstration Project."

WNSW74A DOE/EH-0173T, 5.10.1.1; 40 CFR, Part 122.26; NYSDOH ELAP (nonpotable water)

North site surface water drainage; provides for sampling of uncontrolled surface waters from this discrete drainage path just before they leave the site's controlled boundary. Waters represent surface and subsurface drainages from lag storage areas and other possible sources of radiological or nonradiological contamination on the north plateau.

Monitoring for nonradiological parameters is performed during ambient conditions to verify authorized non-storm water flows. Storm water monitoring is performed per WVDP-233.

Sampling locations are shown on Figure A-2.

B - 20 
2005 Monitoring Program

Environmental Surveillance

On-Site Surface Water

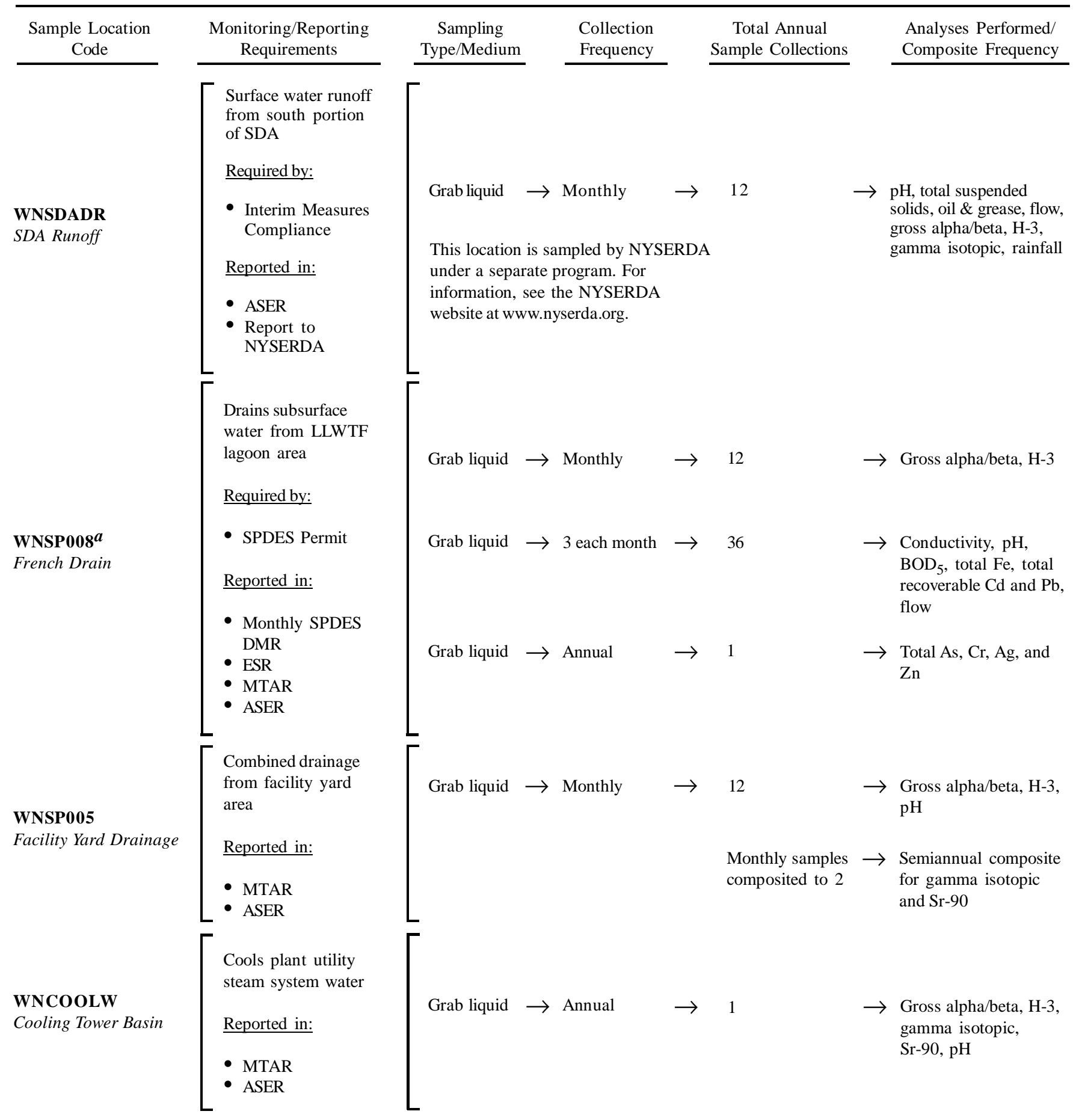

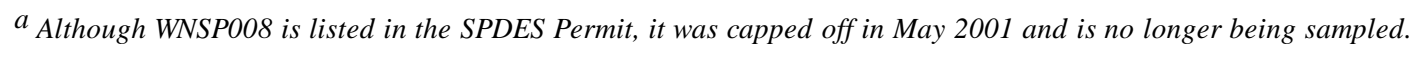

B - 21

WVDP Annual Site Environmental Report

Calendar Year 2005 


\section{Sampling Rationale}

\section{WNSDADR NYSERDA interim measures compliance.}

This location will no longer be reported by the DOE.

WNSP008 DOE/EH-0173T, 5.10.1.3; New York State SPDES Permit no. NY0000973

French drain of subsurface water from lagoon (LLWTF) area. The SPDES Permit also provides for sampling of uncontrolled subsurface water from this discrete drainage path before these waters flow into Erdman Brook. Waters represent subsurface drainages from downward infiltration around the LLWTF and lagoon systems. This point would also monitor any subsurface spillover from the overfilling of lagoons 2 and 3. Sampling is of significance for both radiological and nonradiological contamination. This point was capped off in May 2001 and is routinely checked to verify that there is no discharge.

WNSP005 Generally in accordance with DOE/EH-0173T, 5.10.1.1 (previously in accordance with SPDES permit no. NY0000973); NYSDOH ELAP (nonpotable water)

Provides for the sampling of uncontrolled surface waters from this discrete drainage path after outfall 007 discharge into the drainage and before these waters flow into Erdman Brook. Waters represent surface and subsurface drainages primarily from the main plant yard area. Historically, this point was used to monitor sludge pond and utility room discharges to the drainage. These two sources have been rerouted. Migration of residual site contamination around the main plant dictates surveillance of this point, primarily for radiological parameters.

WNCOOLW Generally in accordance with DOE/EH-0173T, 5.10.1.1; NYSDOH ELAP (nonpotable water)

Operational sampling carried out to confirm that radiological contamination is not migrating into the primary coolant loop of the high-level waste treatment facility and/or plant utility steam systems. Migration from either source might indicate radiological control failure.

Sampling locations are shown on Figure A-2.

$B-22$ 


\section{Monitoring Program \\ Environmental Surveillance}

\section{On-Site Surface Water}

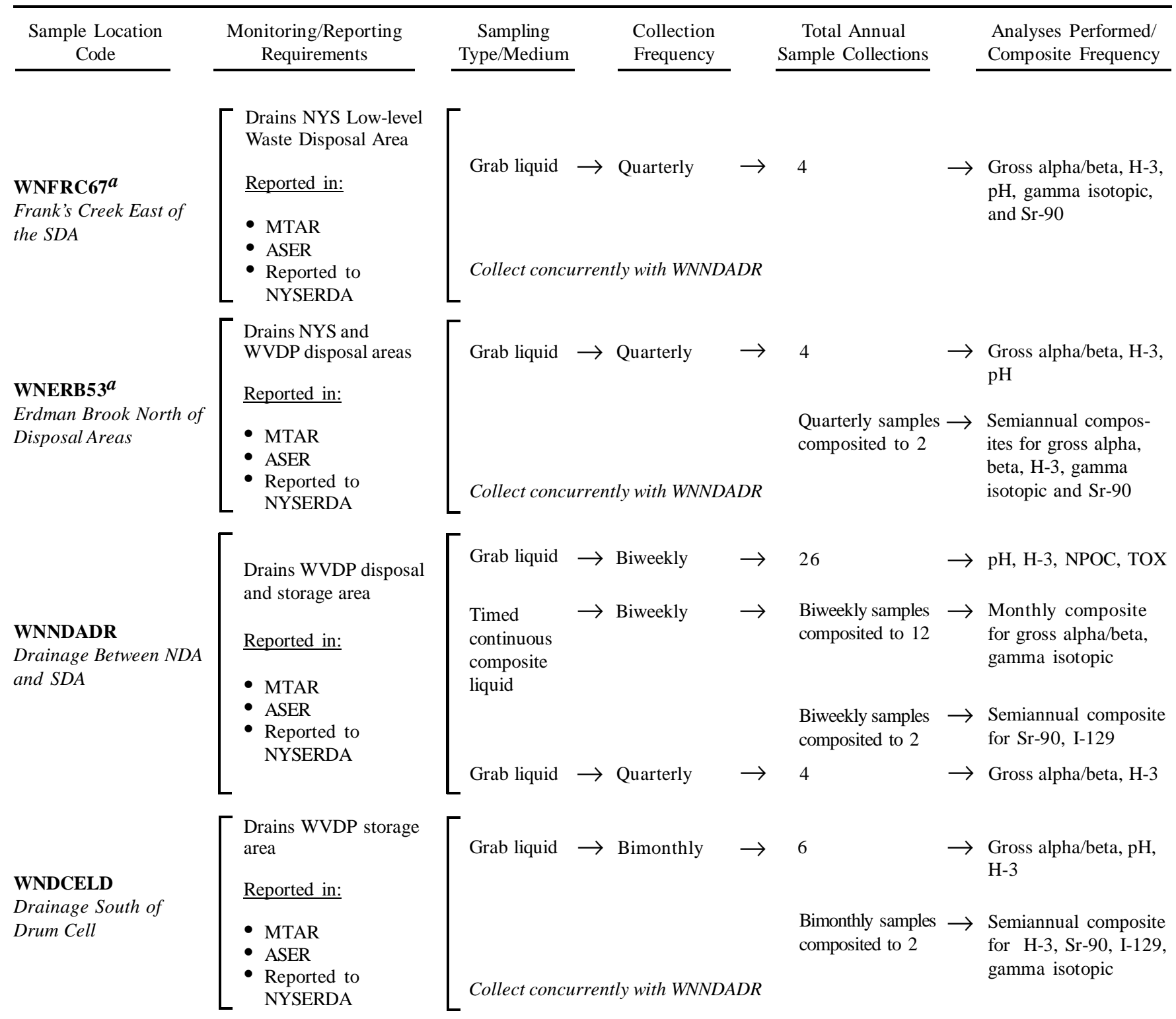

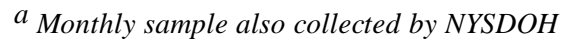


Sampling Rationale

WNFRC67 DOE/EH-0173T, 5.10.1.1; NYSDOH ELAP (nonpotable water)

Monitors the potential influence of both the SDA and drum cell drainage into Frank's Creek east of the SDA and upstream of its confluence with Erdman Brook.

WNERB53 DOE/EH-0173T, 5.10.1.1; NYSDOH ELAP (nonpotable water)

Monitors the potential influence of the drainages from the SDA and the WVDP storage and disposal area into Erdman Brook upstream of its confluence with Frank's Creek.

WNNDADR DOE/EH-0173T, 5.10.1.1; NYSDOH ELAP (nonpotable water)

Monitors the potential influence of the drainages from the SDA and the WVDP storage and disposal area into Lagoon Road creek upstream of the creek's confluence with Erdman Brook.

WNDCELD DOE/EH-0173T, 5.10.1.1; NYSDOH ELAP (nonpotable water)

Monitors the potential influence of drum cell drainage into Frank's Creek south of the SDA and upstream of WNFRC67.

Sampling locations are shown on Figure A-2.

$B-24$ 


\section{Monitoring Program \\ Environmental Surveillance}

\section{On-Site Surface Water}

\begin{tabular}{|c|c|c|c|c|c|c|c|c|}
\hline $\begin{array}{l}\text { Sample Location } \\
\text { Code }\end{array}$ & $\begin{array}{l}\text { Monitoring/Reporting } \\
\text { Requirements }\end{array}$ & $\begin{array}{c}\text { Sampling } \\
\text { Type/Medium }\end{array}$ & & $\begin{array}{l}\text { Collection } \\
\text { Frequency }\end{array}$ & & $\begin{array}{c}\text { Total Annual } \\
\text { Sample Collections }\end{array}$ & & $\begin{array}{l}\text { Analyses Performed/ } \\
\text { Composite Frequency }\end{array}$ \\
\hline \multirow[t]{2}{*}{$\begin{array}{l}\text { WNNDATR }^{\boldsymbol{a}} \\
\text { NDA Trench Interceptor } \\
\text { Project }\end{array}$} & $\begin{array}{l}\text { On-site groundwa- } \\
\text { ter interception } \\
\text { Reported in: }\end{array}$ & Grab liquid & $\rightarrow$ & Monthly & $\rightarrow$ & 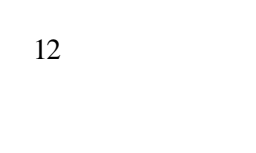 & $\rightarrow$ & $\begin{array}{l}\text { Gross alpha/beta, H-3, } \\
\text { gamma isotopic, } \\
\text { NPOC, TOX }\end{array}$ \\
\hline & $\begin{array}{l}\text { - MTAR } \\
\text { - ASER }\end{array}$ & & & & & $\begin{array}{l}\text { Monthly samples } \\
\text { composited to } 2\end{array}$ & $\rightarrow$ & $\begin{array}{l}\text { Semiannual composite } \\
\text { for I- } 129\end{array}$ \\
\hline $\begin{array}{l}\text { WNSTAW9 } \\
\text { North Reservoir Near } \\
\text { Intake }\end{array}$ & $\begin{array}{l}\text { Standing water near } \\
\text { reservoir that } \\
\text { provides site } \\
\text { drinking water } \\
\text { Reported in: } \\
\text { - MTAR } \\
\text { - ASER }\end{array}$ & Grab liquid & $\rightarrow$ & Annual & $\rightarrow$ & 1 & $\rightarrow$ & $\begin{array}{l}\text { Gross alpha/beta, } \mathrm{H}-3 \text {, } \\
\mathrm{Sr}-90 \text {, gamma isotopic, } \\
\text { pH, conductivity, } \mathrm{Cl} \text {, } \\
\mathrm{Fe}, \mathrm{Mn}, \mathrm{Na}, \\
\mathrm{NO}_{3}+\mathrm{NO}_{2}-\mathrm{N}, \mathrm{SO}_{4}\end{array}$ \\
\hline
\end{tabular}

Note: Monitoring at standing water locations WNSTAW4, WNSTAW5, WNSTAW6, and WNSTAWB discontinued. See p. B-vi.

${ }^{a}$ Coordinated with Main Plant Operations

$$
B-25
$$


Sampling Rationale

WNNDATR Generally in accordance with DOE/EH-0173T, 5.10.1.1; NYSDOH ELAP (nonpotable water)

Monitors groundwater in the vicinity of the NDA interceptor trench project. The grab sample is taken directly from the trench collection system.

WNSTAW9

DOE/EH-0173T, 5.10.1.1; NYSDOH ELAP (nonpotable water)

Monitoring of on-site standing water. Although no standing water locations received effluent directly, the potential for contamination was present except at the background location. Former collecting sites 1,2,3,7, and 8 were deleted from the monitoring program because they were either built over or were dry. Sampling at former collecting sites 4, 5, 6, and "B" (background) was discontinued in 2005.

Sampling of standing water by north reservoir near intake is retained to provide radiological data in standing water near the source of the site potable water supply south of main plant facilities, as part of the "ingestion" pathway.

Sampling locations are shown on Figures A-2 and A-5.

$B-26$ 


\section{Monitoring Program \\ Environmental Surveillance}

\section{On-Site Potable Water}

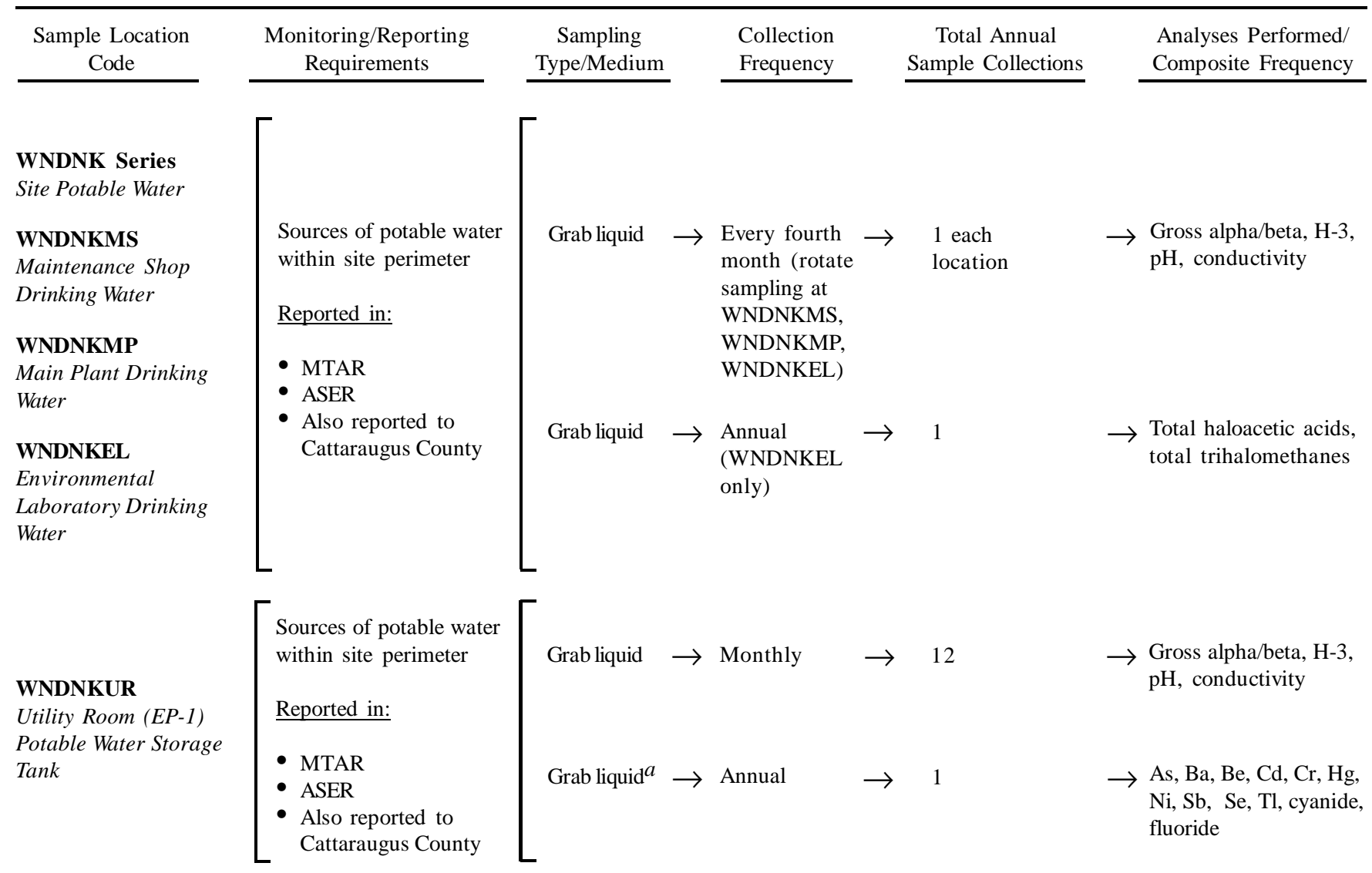

\footnotetext{
a Sample for $\mathrm{NO}_{3}$ (as total nitrate) is collected by the Cattaraugus County Health Department. Pb and Cu also are sampled at this site based upon Cattaraugus County Health Department guidance.
}

$$
\text { B }-27
$$




\section{Sampling Rationale}

WNDNK Series Site drinking water; generally according to DOE/EH-0173T, 5.10.1.2; 10 NYCRR, Part 5, Subpart 5-1; NYSDOH ELAP (potable water)

Potable water sampling to confirm no migration of radiological and/or nonradiological contamination into the site's drinking water supply.

WNDNKMS Potable water sampled at the maintenance shop in order to monitor a point that is an intermediate distance from the point of potable water generation and that is used heavily by site personnel.

WNDNKMP Same rationale as WNDNKMS but sampled at the break room sink in the main plant.

WNDNKEL Potable water sampled at the Environmental Laboratory. Disinfectant by-products are sampled at WNDNKEL, the furthest location from the entry point (WNDNKUR).

WNDNKUR Sampled at the utility room potable water storage tank before the site drinking water distribution system. Sample location is entry point EP-1.

Sampling locations are within the site facilities and are not detailed on figures.

$B-28$ 
2005 Monitoring Program

Environmental Surveillance

On-Site Groundwater

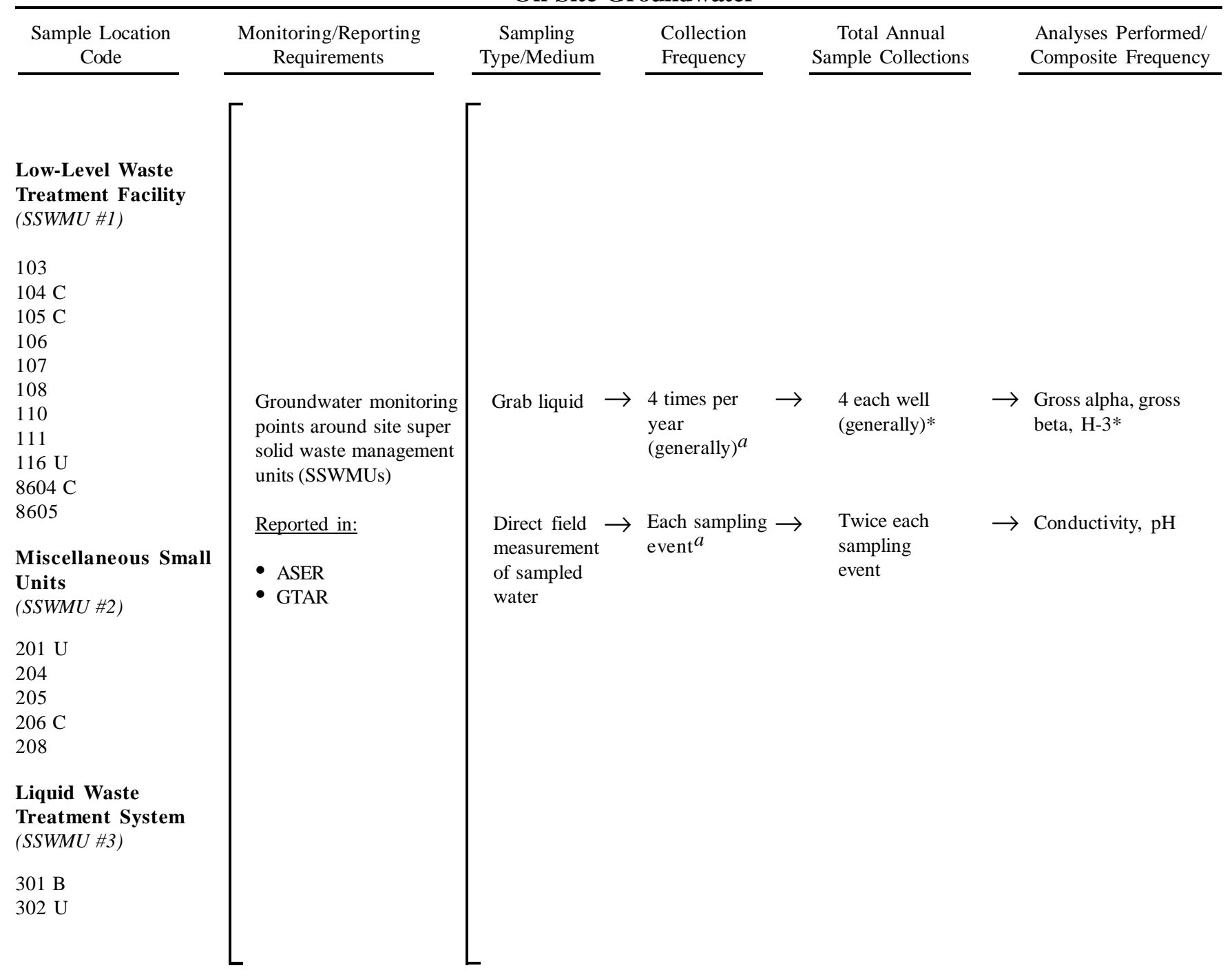

Note: "U" designates upgradient, " $B$ " designates background, and " $C$ " designates crossgradient wells. The remainder are downgradient.

${ }^{a}$ Sampling frequency and analytes vary from point to point. See Appendix $E^{\boldsymbol{C D}}$ for a summary listing of all monitored analytes, a listing of analytes monitored at each location, and results from each location.

$$
\text { B }-29
$$




\title{
Sampling Rationale
}

\begin{abstract}
On-Site $\quad$ DOE/EH-0173T, 5.10.1.3; 40 CFR, Parts 264 and 265, Subpart F; NYSDOH ELAP (nonpotable water)
Groundwater

The on-site WVDP groundwater monitoring program provides for the determination of water quality, focusing on radiological and chemical surveillance of both active and inactive super solid waste management units (SSWMUs). In addition, using wells situated hydraulically upgradient (background) and downgradient of SSWMUs allows both detection of groundwater contamination and evaluation of the effects associated with the individual SSWMUs. Groundwater protection is addressed in the "Groundwater Protection Management Program Plan," WVDP-091. Groundwater monitoring is detailed in the "Groundwater Monitoring Plan," WVDP-239.
\end{abstract}

SSWMU \#1 Low-level waste treatment facilities, including four active lagoons - lagoons 2, 3, 4, and 5 - and an inactive, filledin lagoon - lagoon 1.

SSWMU \#2 Miscellaneous small units, including the sludge pond, the solvent dike, the paper incinerator, the equalization basin, and the kerosene tank.

SSWMU \#3 Liquid waste treatment system containing effluent from the supernatant treatment system.

Sampling locations are shown on Figures A-8 and A-9.

B - 30 
2005 Monitoring Program

Environmental Surveillance

On-Site Groundwater

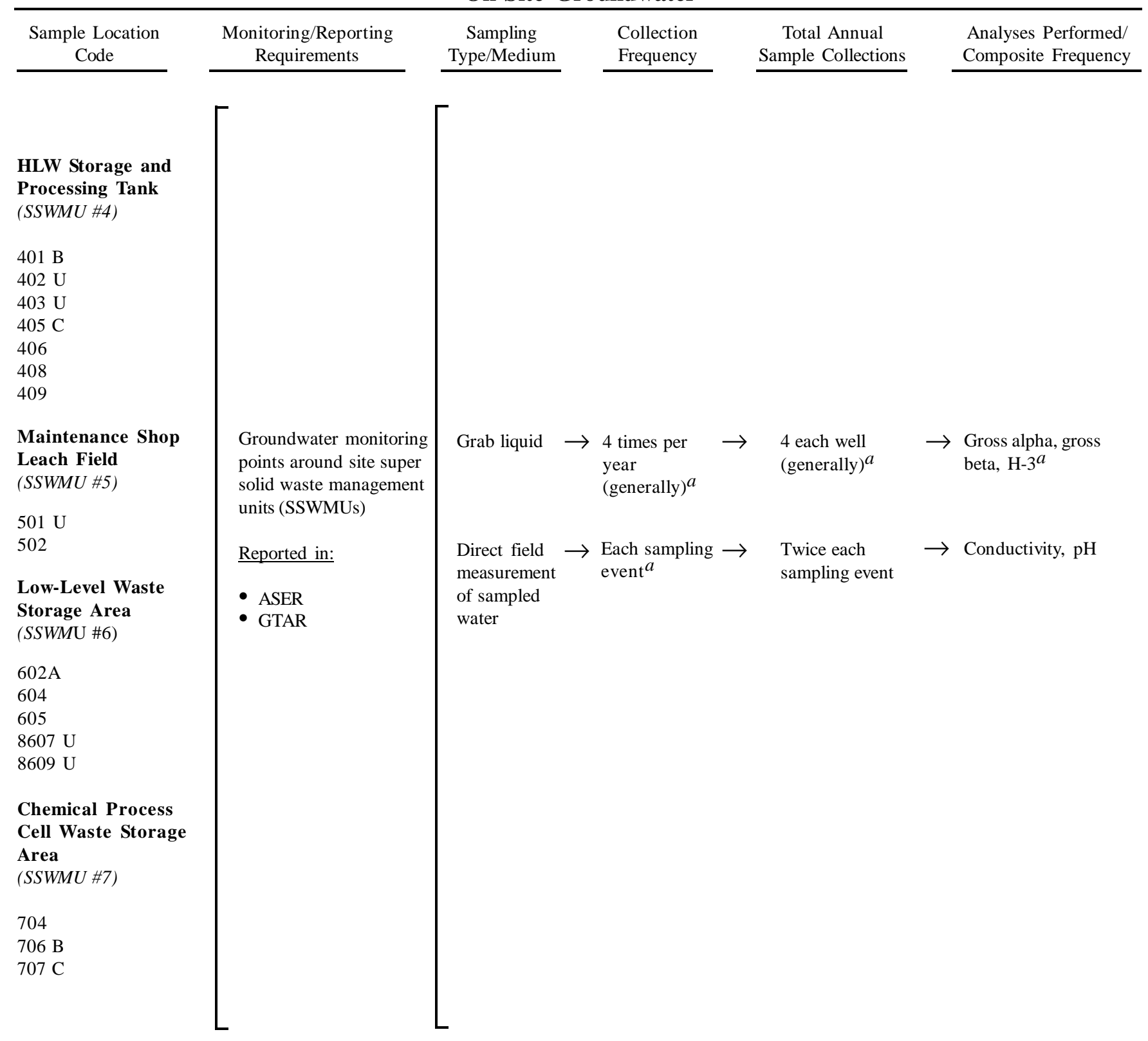

Note: "U" designates upgradient, " $B$ " designates background, and " $C$ " designates crossgradient wells. The remainder are downgradient.

a Sampling frequency and analytes vary from point to point. See Appendix $E^{\mathbf{C D}}$ for a summary listing of all monitored analytes, a listing of analytes monitored at each location, and results from each location.

$$
B-31
$$




\title{
Sampling Rationale
}

\author{
On-Site DOE/EH-0173T, 5.10.1.3; 40 CFR, Parts 264 and 265, Subpart F; NYSDOH ELAP (nonpotable water) \\ Groundwater \\ The on-site WVDP groundwater monitoring program provides for the determination of water quality, focusing on \\ radiological and chemical surveillance of both active and inactive super solid waste management units (SSWMUs). In \\ addition, using wells situated hydraulically upgradient (background) and downgradient of SSWMUs allows both detection \\ of groundwater contamination and evaluation of the effects associated with the individual SSWMUs. Groundwater \\ protection is addressed in the "Groundwater Protection Management Program Plan," WVDP-091. Groundwater \\ monitoring is detailed in the "Groundwater Monitoring Plan," WVDP-239. \\ SSWMU \#4 High-level waste storage and processing area, including the high-level radioactive waste tanks, the supernatant \\ treatment system, and the vitrification facility. \\ SSWMU \#5 Maintenance shop sanitary leach field, formerly used by Nuclear Fuel Services and the WVDP to process domestic \\ sewage generated by the maintenance shop. \\ SSWMU \#6 Low-level waste storage area; includes metal and fabric structures housing low-level radioactive waste being stored for \\ future disposal. \\ SSWMU \#7 Chemical process cell (CPC) waste storage area, which contains packages of pipes, vessels, and debris from \\ decontamination and cleanup of the chemical process cell in the former reprocessing plant.
}

Sampling locations are shown on Figures A-8 and A-9.

$B-32$ 


\section{Monitoring Program \\ Environmental Surveillance}

On-Site Groundwater

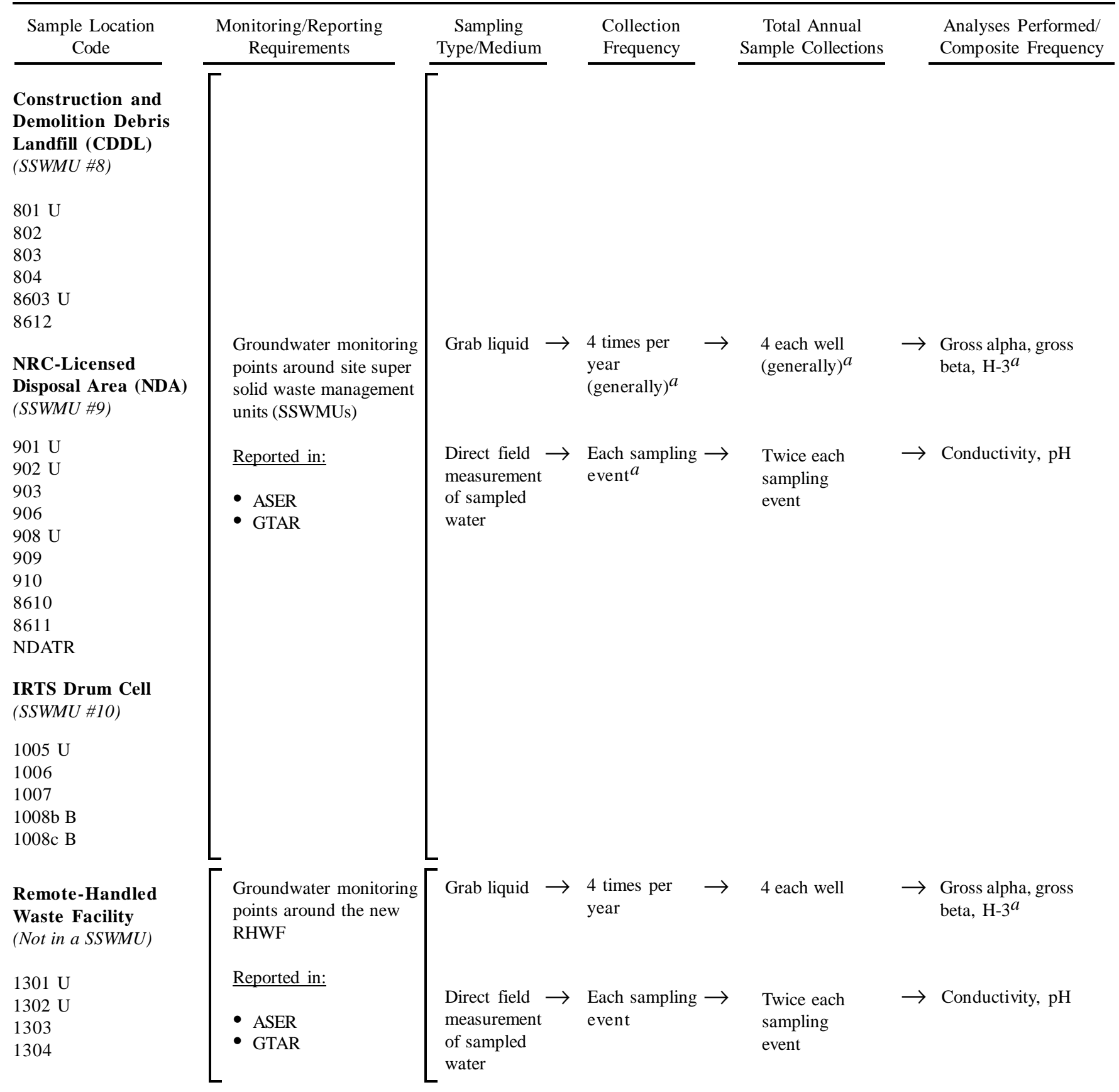

NOTE: " $U$ " designates upgradient, " $B$ " designates background, and " $C$ " designates crossgradient wells. The remainder are downgradient.

${ }^{a}$ Sampling frequency and analytes vary from point to point. See Appendix $E^{\boldsymbol{C D}}$ for a summary listing of all monitored analytes, a listing of analytes monitored at each location, and results from each location.

$$
B-33
$$




\title{
Sampling Rationale
}

\begin{abstract}
On-Site DOE/EH-0173T, 5.10.1.3; 40 CFR, Parts 264 and 265, Subpart F; NYSDOH ELAP (nonpotable water)
Groundwater

The on-site WVDP groundwater monitoring program provides for the determination of water quality, focusing on radiological and chemical surveillance of both active and inactive super solid waste management units (SSWMUs). In addition, using wells situated hydraulically upgradient (background) and downgradient of SSWMUs allows both detection of groundwater contamination and evaluation of the effects associated with the individual SSWMUs. Groundwater protection is addressed in the "Groundwater Protection Management Program Plan," WVDP-091. Groundwater monitoring is detailed in the "Groundwater Monitoring Plan," WVDP-239.

SSWMU \#8 The construction and demolition debris landfill (CDDL); used by Nuclear Fuel Services and the WVDP to dispose of nonhazardous and nonradioactive materials.

SSWMU \#9 The NRC-licensed disposal area (NDA); contains radioactive wastes generated by NFS and the WVDP. The NDA is bounded on its downgradient (northwest and northeast) perimeters by the interceptor trench, which is sampled at monitoring point NDATR.
\end{abstract}

SSWMU \#10 The integrated radioactive waste system (IRTS) treatment drum cell; stores cement-stablized low-level radioactive waste.

Remote-Handled Establish pre-operational baseline groundwater conditions in the area of the newly constructed remote-handled waste Waste Facility facility (RHWF). Monitor groundwater in the vicinity of the RHWF.

Sampling locations are shown on Figures A-8 through A-10.

$$
B-34
$$




\section{Monitoring Program \\ Environmental Surveillance}

\section{On-Site Groundwater and Seeps}

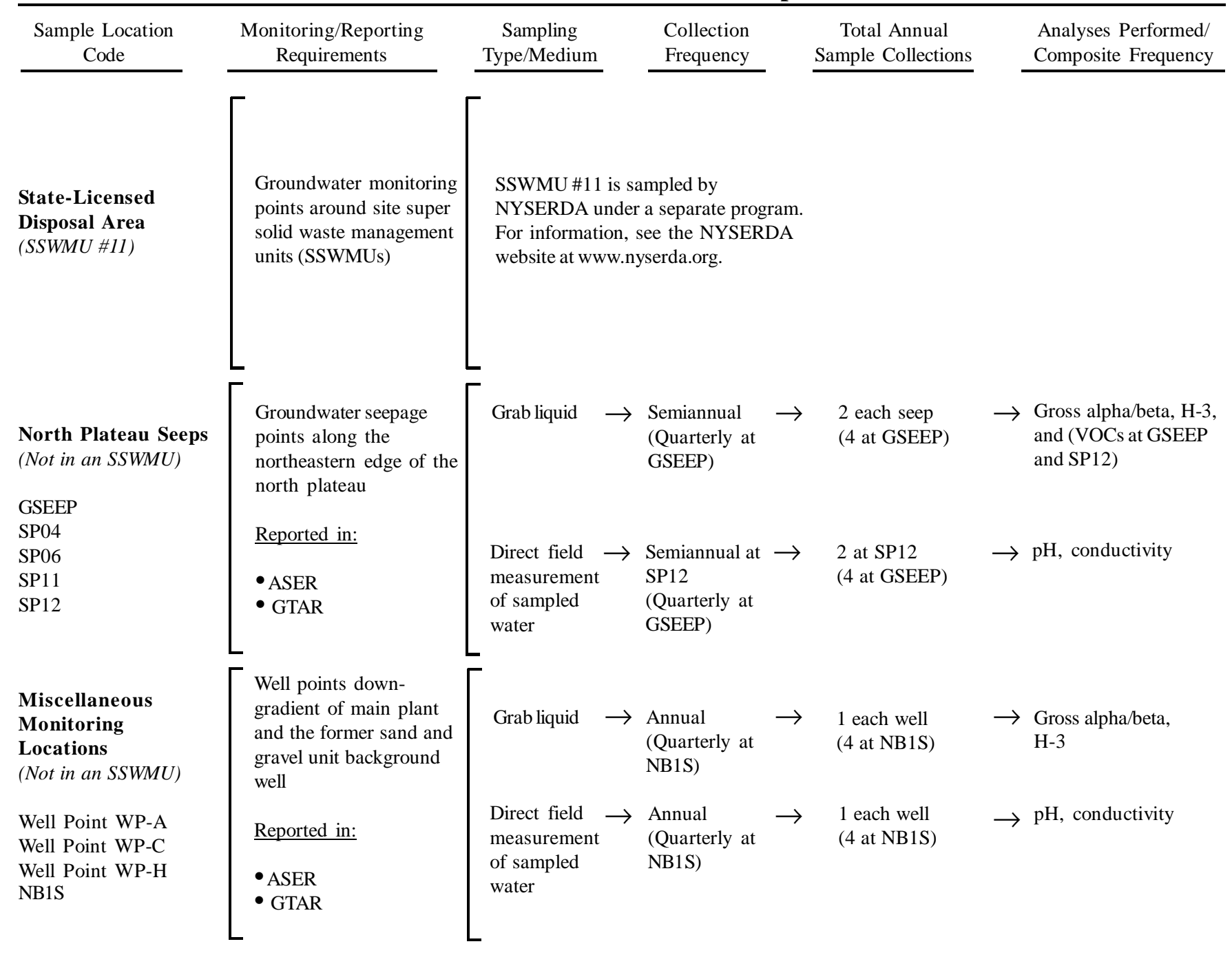

$$
\text { B - } 35
$$




\title{
Sampling Rationale
}

\begin{abstract}
On-Site $\quad$ DOE/EH-0173T, 5.10.1.3; 40 CFR, Parts 264 and 265, Subpart F; NYSDOH ELAP (nonpotable water)
Groundwater

The on-site WVDP groundwater monitoring program provides for the determination of water quality, focusing on radiological and chemical surveillance of both active and inactive super solid waste management units (SSWMUs). In addition, using wells situated hydraulically upgradient (background) and downgradient of SSWMUs allows both detection of groundwater contamination and evaluation of the effects associated with the individual SSWMUs. Groundwater protection is addressed in the "Groundwater Protection Management Program Plan," WVDP-091. Groundwater monitoring is detailed in the "Groundwater Monitoring Plan," WVDP-239.
\end{abstract}

SSWMU \#11 The New York State-licensed disposal area (SDA) was operated by Nuclear Fuel Services as a commercial low-level disposal facility; it also received wastes from NFS reprocessing operations.

North Plateau

Monitor groundwater emanating from the ground surface along the edge of the site's north plateau.

Seeps

Well Points

Monitor groundwater of known subsurface contamination in the north plateau area. All well points are downgradient of the main plant.

NB1S Former background well on the north plateau.

Sampling locations are shown on Figures A-8 through A-10.

$$
B-36
$$


2005 Monitoring Program

Environmental Surveillance

Off-Site Surface Water

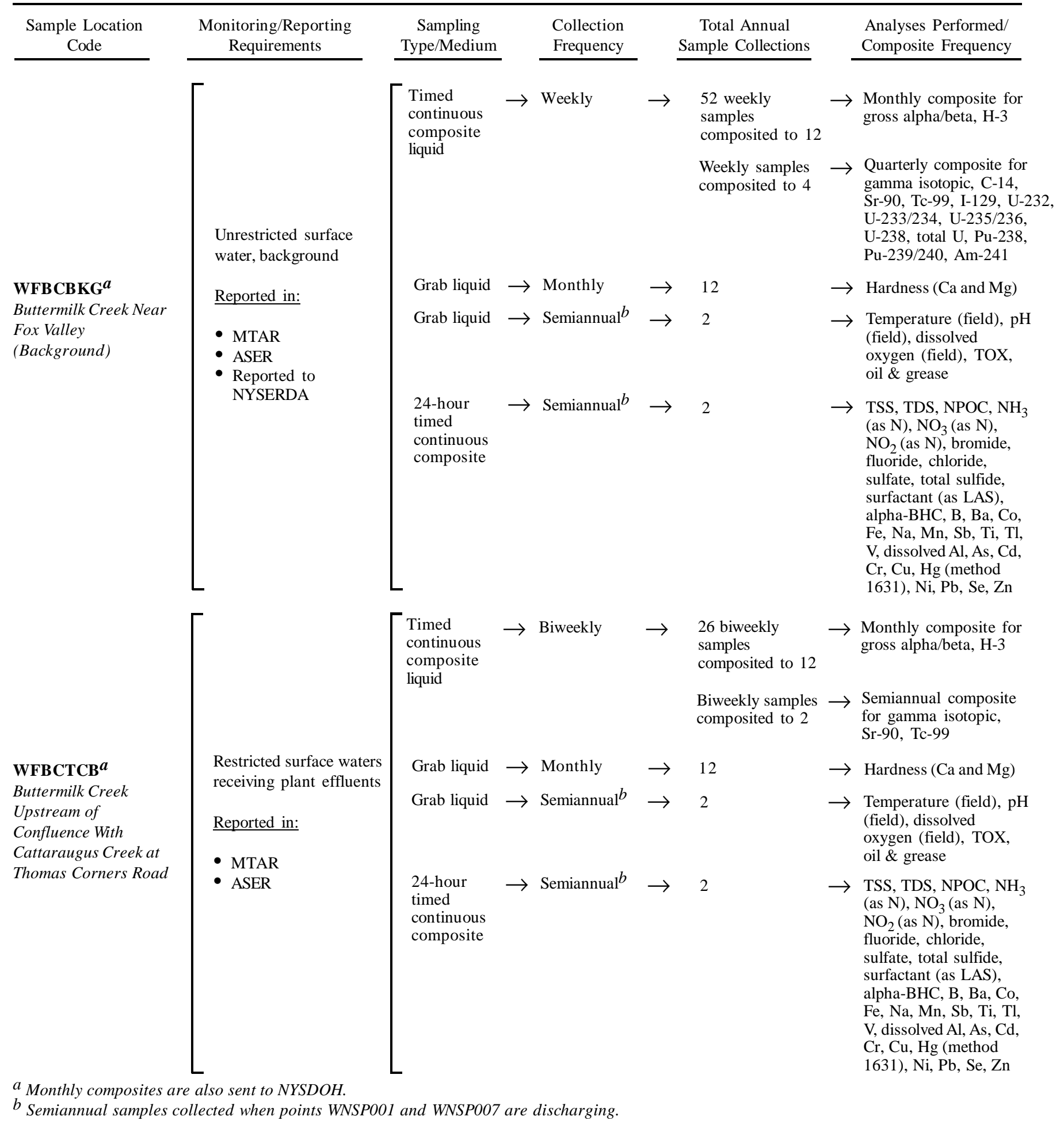

$$
B-37
$$




\section{Sampling Rationale}

WFBCBKG DOE/EH-0173T, 5.10.1.1; 6 NYCRR, Part 702-704; NYSDOH ELAP (nonpotable water)

Monitors background conditions of Buttermilk Creek upstream of the WVDP; allows for comparison to downstream conditions. Monitoring for nonradiological parameters performed during discharges from WNSP001 and WNSP007 for comparison with downstream conditions.

WFBCTCB DOE/EH-0173T, 5.10.1.1; 6 NYCRR, Part 702-704; NYSDOH ELAP (nonpotable water)

Buttermilk Creek is the surface water that receives all WVDP liquid effluents. WFBCTCB monitors the potential influence of WVDP drainage into Buttermilk Creek upstream of Buttermilk Creek's confluence with Cattaraugus Creek. Monitoring for nonradiological parameters performed during discharges from WNSP001 and WNSP007 for comparison with New York State ambient water quality standards (6 NYCRR, Part 702-704).

Sampling locations are shown on Figure A-5.

$B-38$ 


\section{Monitoring Program \\ Environmental Surveillance}

\section{Off-Site Surface Water}

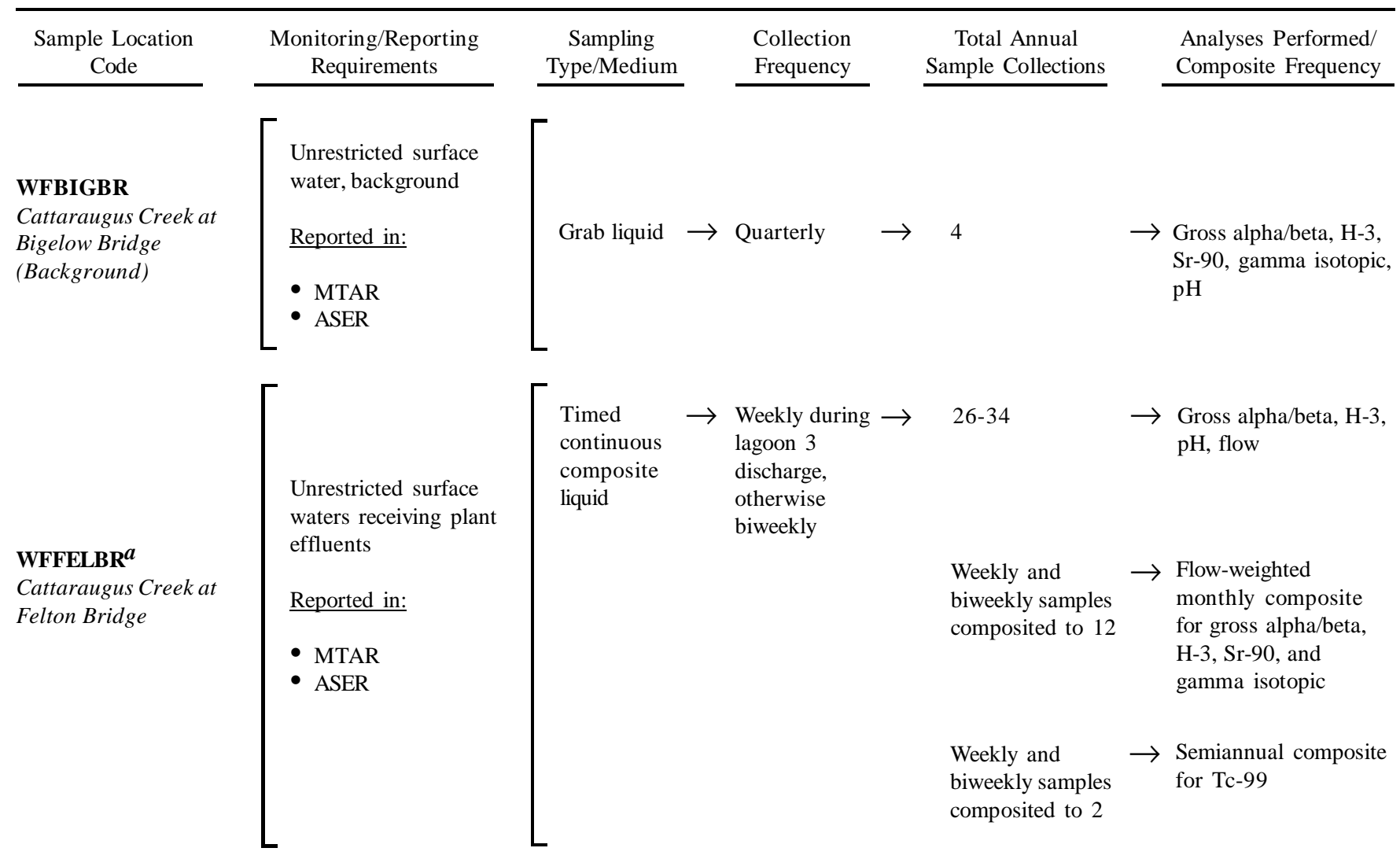

\footnotetext{
${ }^{a}$ Monthly composites are also sent to NYSDOH.
}

$$
\text { B - } 39
$$




\section{Sampling Rationale}

WFBIGBR DOE/EH-0173T, 5.10.1.1; NYSDOH ELAP (nonpotable water)

Monitors background conditions of Cattaraugus Creek at Bigelow Bridge, upstream of the WVDP; allows for comparison to downstream conditions.

WFFELBR DOE/EH-0173T, 5.10.1.1; NYSDOH ELAP (nonpotable water)

Because Buttermilk Creek empties into Cattaraugus Creek, WFFELBR monitors the potential influence of WVDP drainage into Cattaraugus Creek directly downstream of the Cattaraugus Creek confluence with Buttermilk Creek.

Sampling locations are shown on Figure A-5.

$B-40$ 


\section{Monitoring Program}

\section{Environmental Surveillance}

\section{Off-Site Drinking Water}

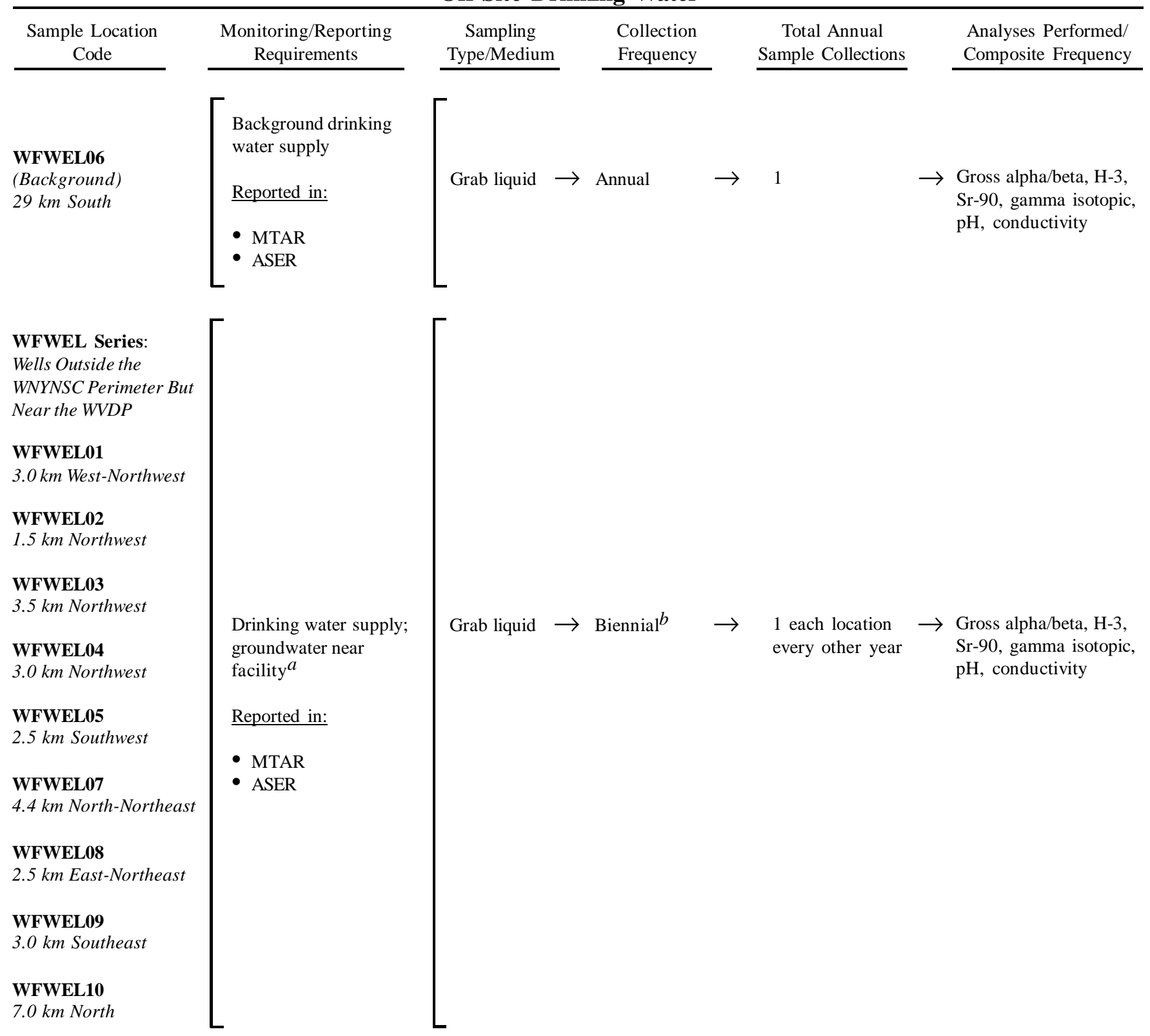

\footnotetext{
${ }^{a}$ No drinking water wells are located in hydrogeological units affected by site activity.

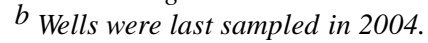

$$
B-41
$$




\section{Sampling Rationale}

Off-Site DOE/EH-0173T, 5.10.1.2; NYSDOH ELAP (potable water)

Drinking Water

WFWEL Series

Eight of the ten listed off-site private residential drinking water wells represent the nearest unrestricted uses of groundwater close to the WVDP. The ninth sample (WFWEL10) is taken from a public water supply from deep wells. The tenth drinking water well, WFWEL06, is located 29 kilometers south of the Project and is considered a background drinking water source.

Sampling locations are shown on Figures A-11, A-14, and A-15.

$B-42$ 


\section{Monitoring Program}

\section{Environmental Surveillance}

\section{Off-Site Air}

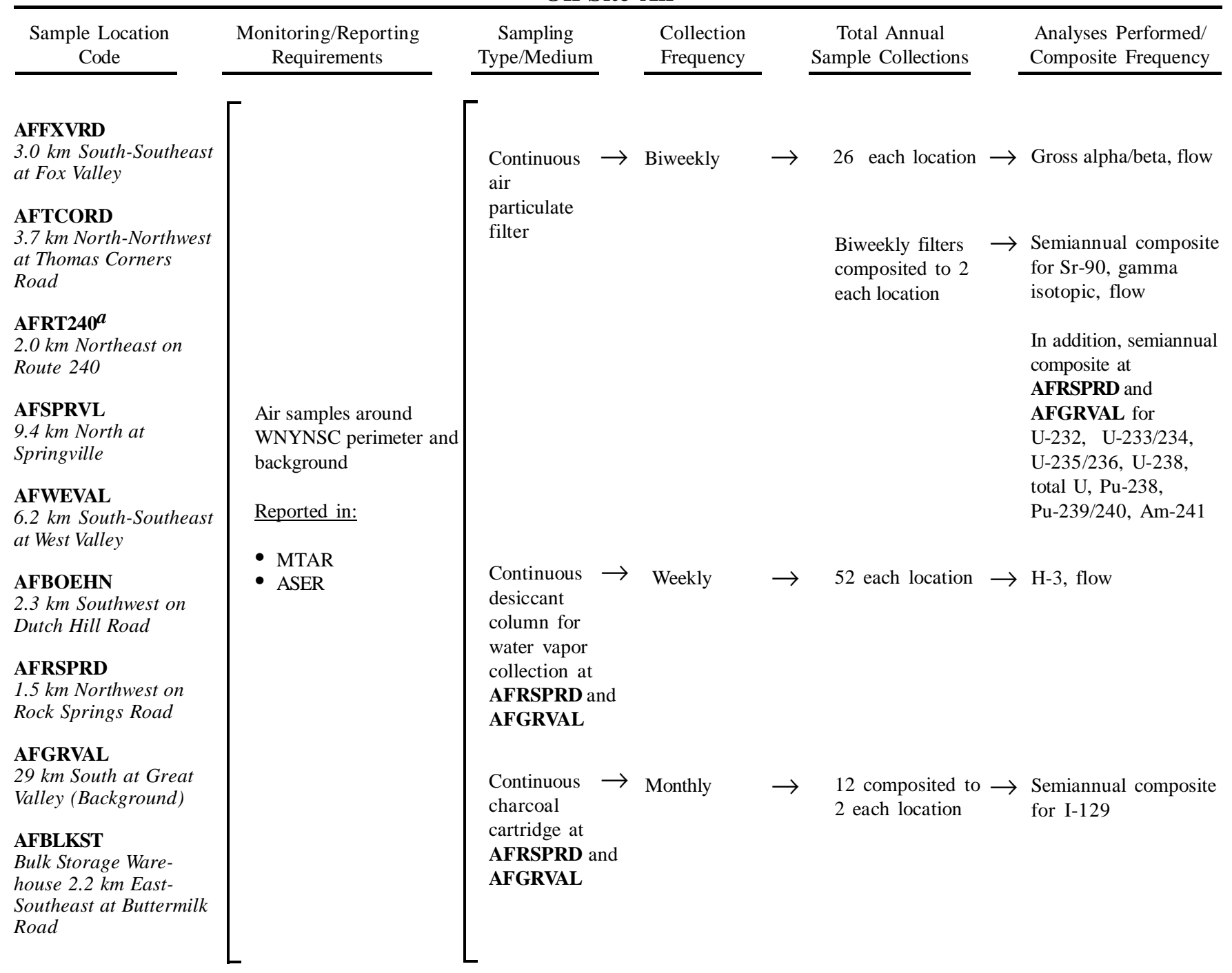

Note: Monitoring at AFTCORD, AFBOEHN, and AFBLKST and collection of desiccant columns for tritium analyses at AFRSPRD and AFGRVAL have been discontinued. See p. B-vii.

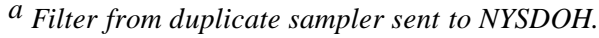

$$
\text { B }-43
$$




\title{
Sampling Rationale
}

\begin{abstract}
AFFXVRD DOE/EH-0173T, 5.7.4
AFTCORD

AFRT240

Air samplers put into service by NFS as part of the site's original monitoring program at perimeter locations chosen to obtain data from places most likely to provide highest concentrations. Choice of location based on meteorological data.
\end{abstract}

AFSPRVL DOE/EH-0173T, 5.7.4; DOE/EP-0023, 4.2.3

Off-site (remote) sampler located on private property in a nearby community within 15 kilometers of the site (north).

AFWEVAL DOE/EH-0173T, 5.7.4; DOE/EP-0023, 4.2.3

Off-site (remote) sampler located in a nearby community within 15 kilometers of the site (southeast).

AFBOEHN

DOE/EH-0173T, 5.7.4; DOE/EP-0023, 4.2.3

Perimeter location chosen to obtain data from the place most likely to provide the highest elevated release concentrations. AFBOEHN is located on NYSERDA property at the perimeter. Choice of location based on meteorological data.

AFRSPRD

DOE/EH-0173T, 5.7.4

Perimeter location chosen to obtain data from the place most likely to provide the highest ground-level release concentrations. AFRSPRD is on WNYNSC property outside the main plant operations fenceline. I-129 is sampled here because the sampling train was easy to incorporate and the location was most likely to receive effluent releases. Choice of location based on meteorological data.

AFGRVAL DOE/EH-0173T, 5.7.4; DOE/EP-0023, 4.2.3

Off-site (remote) sampler considered representative of natural background radiation. Located on privately owned property 29 kilometers south of the site (typically upwind). I-129 sampled here also.

AFBLKST

DOE/EH-0173T, 5.7.4

Off-site monitoring of bulk storage warehouse, near the site perimeter.

Sampling locations are shown on Figures A-7, A-14, and A-15.

B -44 


\section{Monitoring Program \\ Environmental Surveillance}

Fallout, Sediment, and Soil

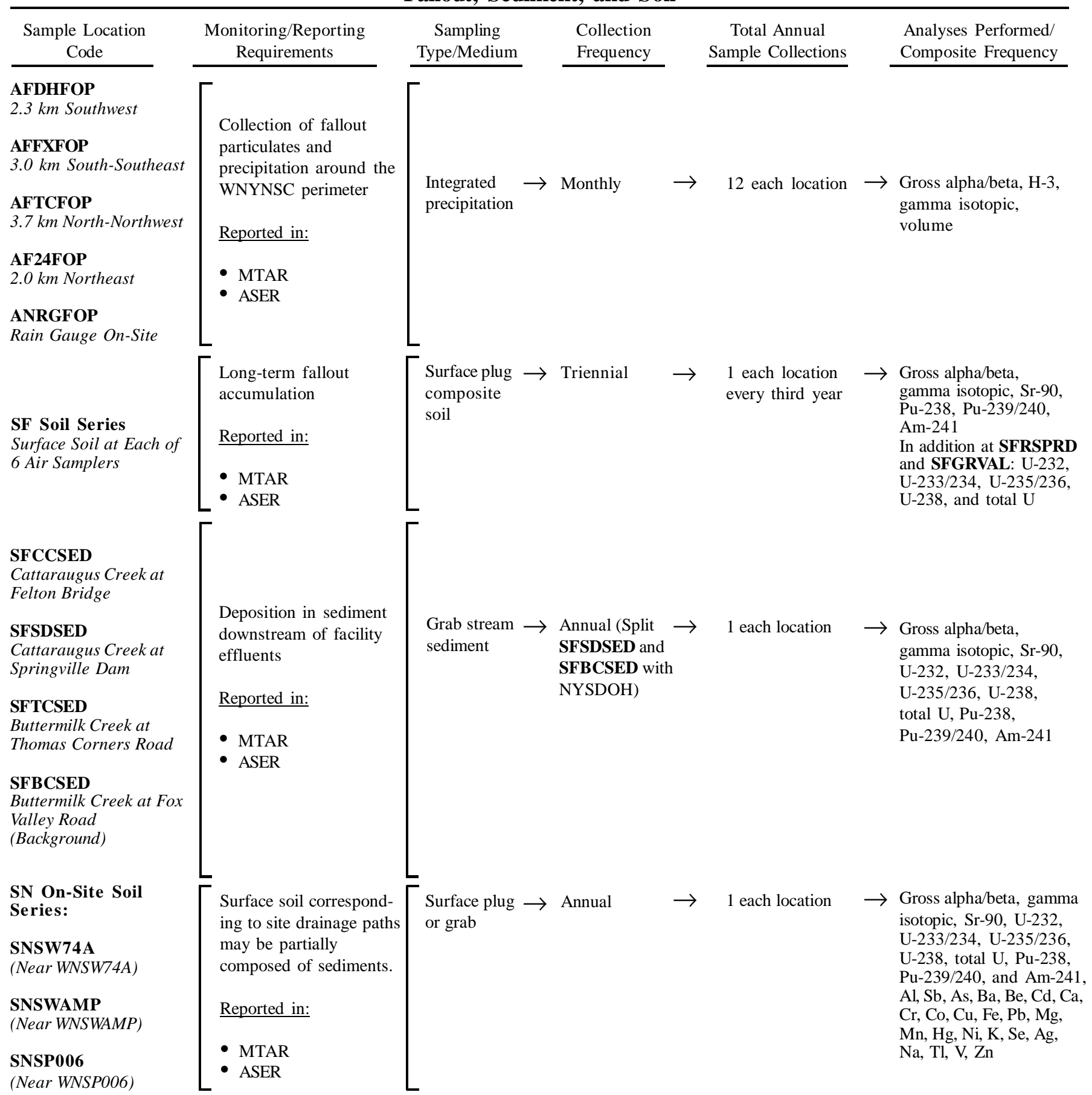

Note: Monitoring at fallout pot locations AFDHFOP, AFFXFOP, AFTCFOP, and AF24FOP was discontinued at the end of $1^{\text {st }}$ quarter 2005. Off-site soil monitoring at SFTCORD, SFBOEHN, SFBLKST, and off-site sediment at SFBISED was discontinued and no samples were collected in 2005. See p. B-viii.

$$
B-45
$$




\section{AFDHFOP \\ AFFXFOP \\ AFTCFOP \\ AF24FOP}

ANRGFOP
SF Soil Series

SN Soil Series

DOE/EP-0023, 4.7

Collection of fallout particles and precipitation around the site perimeter at established air sampling locations: AFDHFOP (Dutch Hill at Boehn Road), AFFXFOP (Fox Valley Road), AFTCFOP (Thomas Corners), AF24FOP (Route 240). Indicates short-term effects.

DOE/EP-0023, 4.7

Fallout particles and precipitation collected on site by the Environmental Laboratory at the rain gauge. Indicates short-term effects.

DOE/EH-0173T, 5.9.1

Off-site soils collected at air sampling locations: SFWEVAL (West Valley), SFFXVRD (Fox Valley Road), SFSPRVL (Springville), SFRT240 (Route 240), SFGRVAL (Great Valley), and SFRSPRD (Rock Springs Road): Collection of long-term fallout data at established air sampler locations via soil sampling.

DOE/EH-0173T, 5.12.1

Sediment deposition in Cattaraugus Creek at Felton Bridge. Location is the first point of public access to Cattaraugus Creek downstream of its confluence with Buttermilk Creek.

DOE/EH-0173T, 5.12.1

Sediment deposition in Cattaraugus Creek at Springville Dam. Reservoir provides ideal settling and collection location for sediments downstream of the Buttermilk Creek confluence with Cattaraugus Creek. Located downstream of SFCCSED.

SFTCSED DOE/EH-0173T, 5.12.1

Sediment deposition in Buttermilk Creek at Thomas Corners immediately downstream of all facility liquid effluents.

DOE/EH-0173T, 5.12.1

Sediment deposition in Buttermilk Creek upsteam of facility effluents (background).

DOE/EH-0173T, 5.9.1.

On-site soil. (Samples may be partially composed of sediments.) SNSW74A (surface soil near WNSW74A), SNSWAMP (surface soil near WNSWAMP), and SNSP006 (surface soil near WNSP006): Locations to be specifically defined by geographic coordinates. Correspond to site drainage pattern flows (i.e., most likely area of radiological deposition/accumulation).

Sampling locations are shown on Figures A-2, A-5 through A-7, A-14, and A-15.

$B-46$ 


\section{Monitoring Program \\ Environmental Surveillance}

\section{Off-Site Biological}

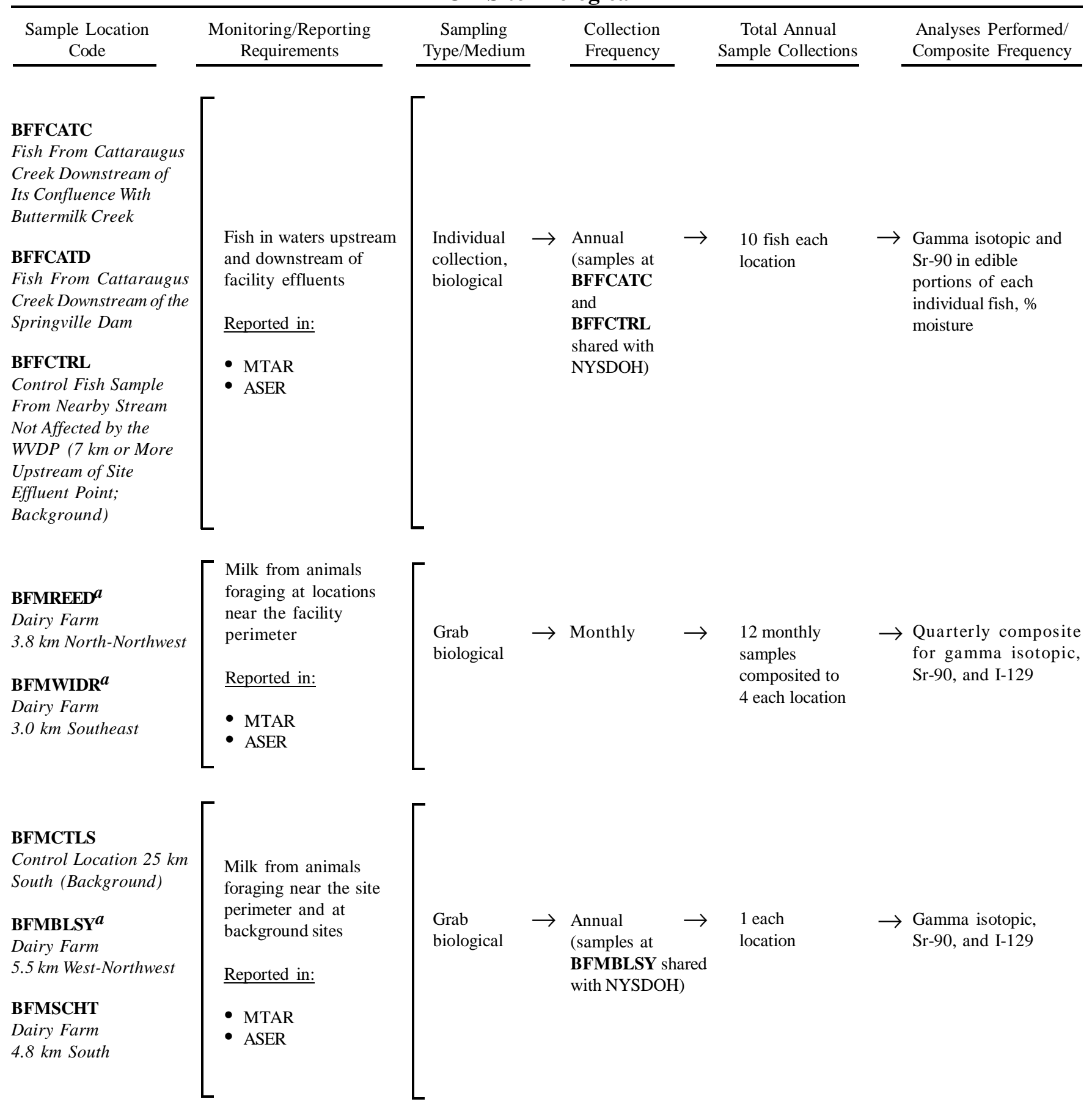

a BFMREED dairy cattle herd was dispersed in May 2005 and sample collection was discontinued. Sampling milk from BFMWIDR was changed from annually to monthly. Sampling of milk from BFMBLSY was added to the program in the fall of 2005. See p. B-viii.

$$
B-47
$$




\section{Sampling Rationale}

$\begin{array}{ll}\begin{array}{l}\text { BFFCATC } \\ \text { BFTCATD }\end{array} & \text { DOE/EH-0173T, 5.11.1.1 } \\ & \begin{array}{l}\text { Radioactivity may enter a food chain in which fish are a major component and are consumed by the local } \\ \text { population. }\end{array} \\ \text { BFFCTRL } & \begin{array}{l}\text { Control fish sample; provides background data for comparison with data from fish caught downstream of facility } \\ \text { effluents. }\end{array} \\ \text { BFMREED } & \text { DOE/EH-0173T, 5.8.2.1 } \\ \text { BFMWIDR } & \text { Milk is consumed by all age groups and is frequently the most important food that could contribute to the } \\ \text { BFMCTLS } & \text { radiation dose. Dairy animals pastured near the site allow adequate monitoring. Control milk samples are collected } \\ \text { BFMSCHT } & \text { far from the site to provide background data for comparison with data from near-site milk samples. }\end{array}$

Sampling locations are shown on Figures A-11, A-14, and A-15.

$B-48$ 


\section{Monitoring Program \\ Environmental Surveillance}

Off-Site Biological

\begin{tabular}{|c|c|c|c|c|c|c|c|c|}
\hline $\begin{array}{l}\text { Sample Location } \\
\text { Code }\end{array}$ & $\begin{array}{l}\text { Monitoring/Reporting } \\
\text { Requirements }\end{array}$ & $\begin{array}{c}\text { Sampling } \\
\text { Type/Medium }\end{array}$ & & $\begin{array}{l}\text { Collection } \\
\text { Frequency }\end{array}$ & & $\begin{array}{c}\text { Total Annual } \\
\text { Sample Collections }\end{array}$ & & $\begin{array}{l}\text { Analyses Performed/ } \\
\text { Composite Frequency }\end{array}$ \\
\hline $\begin{array}{l}\text { BFVNEAR }^{\boldsymbol{a}} \\
\text { Nearby Locations } \\
\text { BFVCTRL }^{\boldsymbol{a}} \\
\text { Remote Locations (16 } \\
\text { km or More From } \\
\text { Facility; Background) }\end{array}$ & $\begin{array}{l}\text { Fruit and vegetables } \\
\text { grown near facility } \\
\text { perimeter, downwind if } \\
\text { possible, and at back- } \\
\text { ground locations } \\
\text { Reported in: } \\
\text { - MTAR } \\
\text { - ASER }\end{array}$ & $\begin{array}{l}\text { Grab } \\
\text { biological } \\
\text { (fruits and } \\
\text { vegetables) }\end{array}$ & $\rightarrow$ & $\begin{array}{l}\text { Annual } \\
\text { (at harvest) }\end{array}$ & $\rightarrow$ & $\begin{array}{l}3 \text { each (split with } \\
\text { NYSDOH) }\end{array}$ & $\rightarrow$ & $\begin{array}{l}\text { Gamma isotopic and } \\
\text { Sr- } 90 \text { analysis of } \\
\text { edible portions, H-3 in } \\
\text { free moisture, \% } \\
\text { moisture }\end{array}$ \\
\hline $\begin{array}{l}\text { BFDNEAR } \\
\text { Deer in Vicinity of the } \\
\text { Site }\end{array}$ & $\begin{array}{l}\text { Venison (deer foraging } \\
\text { near facility perimeter } \\
\text { and at background } \\
\text { locations) }\end{array}$ & $\begin{array}{l}\text { Individual } \\
\text { collection, } \\
\text { biological }\end{array}$ & $\rightarrow$ & $\begin{array}{l}\text { Annual, during } \\
\text { hunting season } \\
\text { (BFDNEAR } \\
\text { sample split } \\
\text { with NYSDOH) }\end{array}$ & $\rightarrow$ & 3 & $\rightarrow$ & $\begin{array}{l}\text { Gamma isotopic and } \\
\text { Sr-90 analysis of } \\
\text { meat, } \mathrm{H}-3 \text { in free } \\
\text { moisture, \% moisture }\end{array}$ \\
\hline $\begin{array}{l}\text { BFDCTRL } \\
\text { Control Deer } 16 \mathrm{~km} \text { or } \\
\text { More From the Facility } \\
\text { (Background) }\end{array}$ & $\begin{array}{l}\text { Reported in: } \\
\text { - MTAR } \\
\text { - ASER }\end{array}$ & & & $\begin{array}{l}\text { During year as } \\
\text { available } \\
\text { (BFDCTRL } \\
\text { sample split } \\
\text { with NYSDOH) }\end{array}$ & $\rightarrow$ & 3 & $\rightarrow$ & $\begin{array}{l}\text { Gamma isotopic and } \\
\text { Sr-90 analysis of } \\
\text { meat, } \mathrm{H}-3 \text { in free } \\
\text { moisture, \% moisture }\end{array}$ \\
\hline
\end{tabular}

Note: Beef sample collections BFBNEAR and BFBCTRL were discontinued, none were collected during 2005. See p. B-viii.

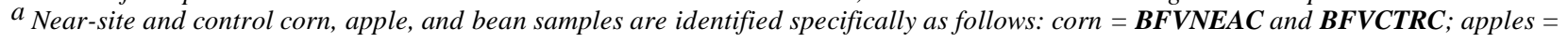
BFVNEAAF and BFVCTRA; beans = BFVNEAB and BFVCTRB.

$$
\text { B }-49
$$


Sampling Rationale

BFVNEAR

DOE/EH-0173T, 5.8.2.2

Fruits and vegetables (corn, apples, and beans or leafy vegetables, if available) collected from areas near the site. These samples are collected, if possible, from areas near the site predicted to have worst-case downwind concentrations of radionuclides in air and soil. Sample analysis reflects steady state/chronic uptake or contamination of foodstuffs as a result of site activities. Possible pathway directly to humans or indirectly through animals.

BFVCTRL

DOE/EH-0173T, 5.8.2.2

Fruits and vegetables collected from an area remote from the site. Background fruits and vegetables collected for comparison with near-site samples. Collected in area(s) of no possible site effects.

BFDNEAR

DOE/EH-0173T, 5.8.3

Venison from near-site deer. Samples are taken from deer killed in collisions with vehicles. Edible portion is analyzed to determine possible radionuclide content passable directly to humans.

BFDCTRL DOE/EH-0173T, 5.8.3

Venison from deer living far from the site. Background deer meat collected for comparison with near-site samples. Collected in area(s) of no possible site effects.

Sampling locations are shown on Figures A-11, A-14, and A-15.

$B-50$ 


\section{Monitoring Program \\ Environmental Surveillance}

\section{Off-Site Direct Radiation}

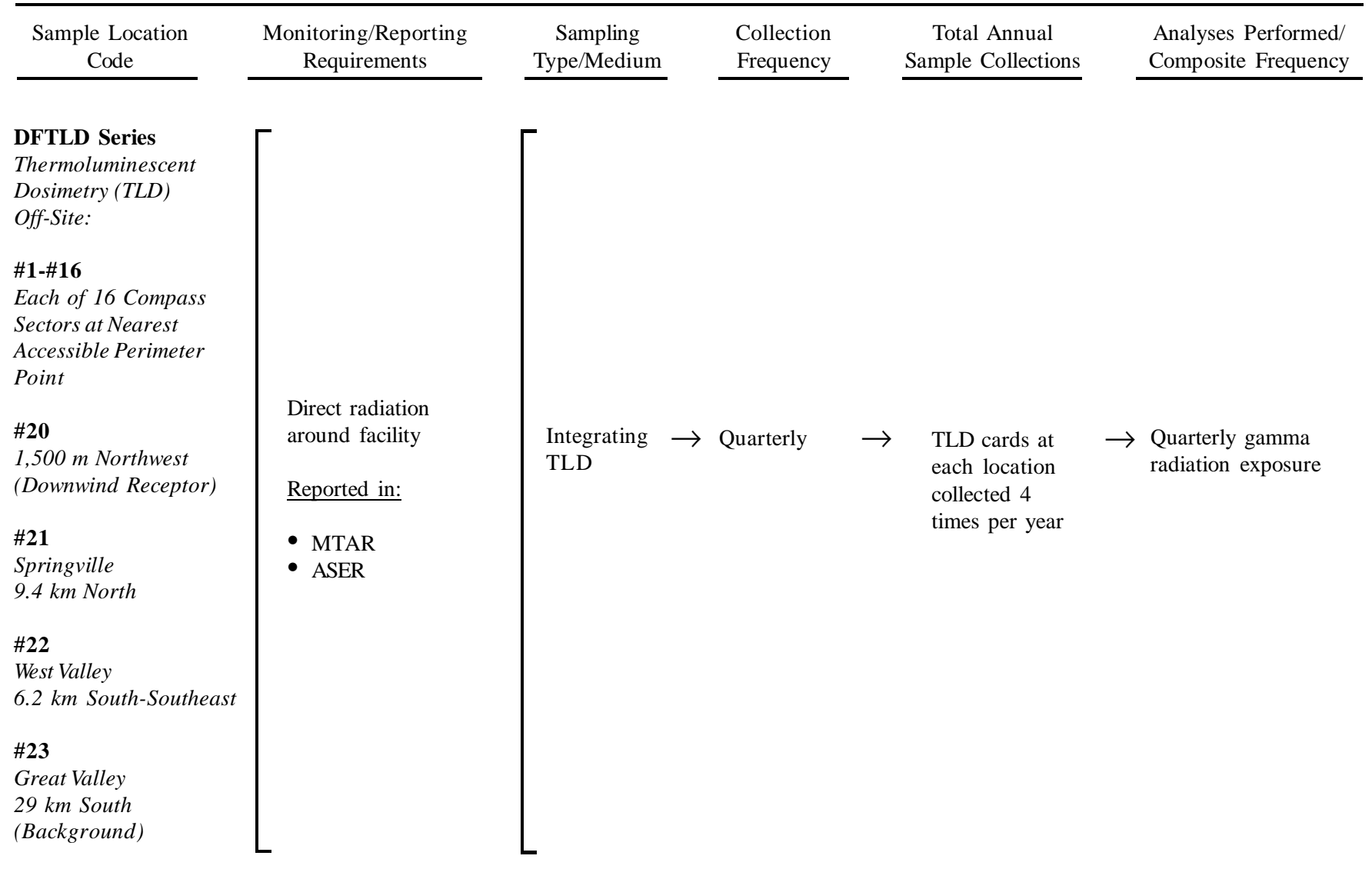

$B-51$ 


\section{Sampling Rationale}

Direct Radiation DOE/EH-0173T, 5.5; DOE/EP-0023, 4.6.3

Off-Site

TLDs offer continuous integrated environmental gamma-ray monitoring and have been deployed systematically about the site. Off-site TLDs are used to verify that site activities have not adversely affected the surrounding environs.

A high-pressure ion chamber (HPIC) gamma radiation measurement was completed at all locations in order to confirm TLD measurements.

Sampling locations are shown on Figures A-13 through A-15.

$B-52$ 


\section{Monitoring Program}

Environmental Surveillance

On-Site Direct Radiation

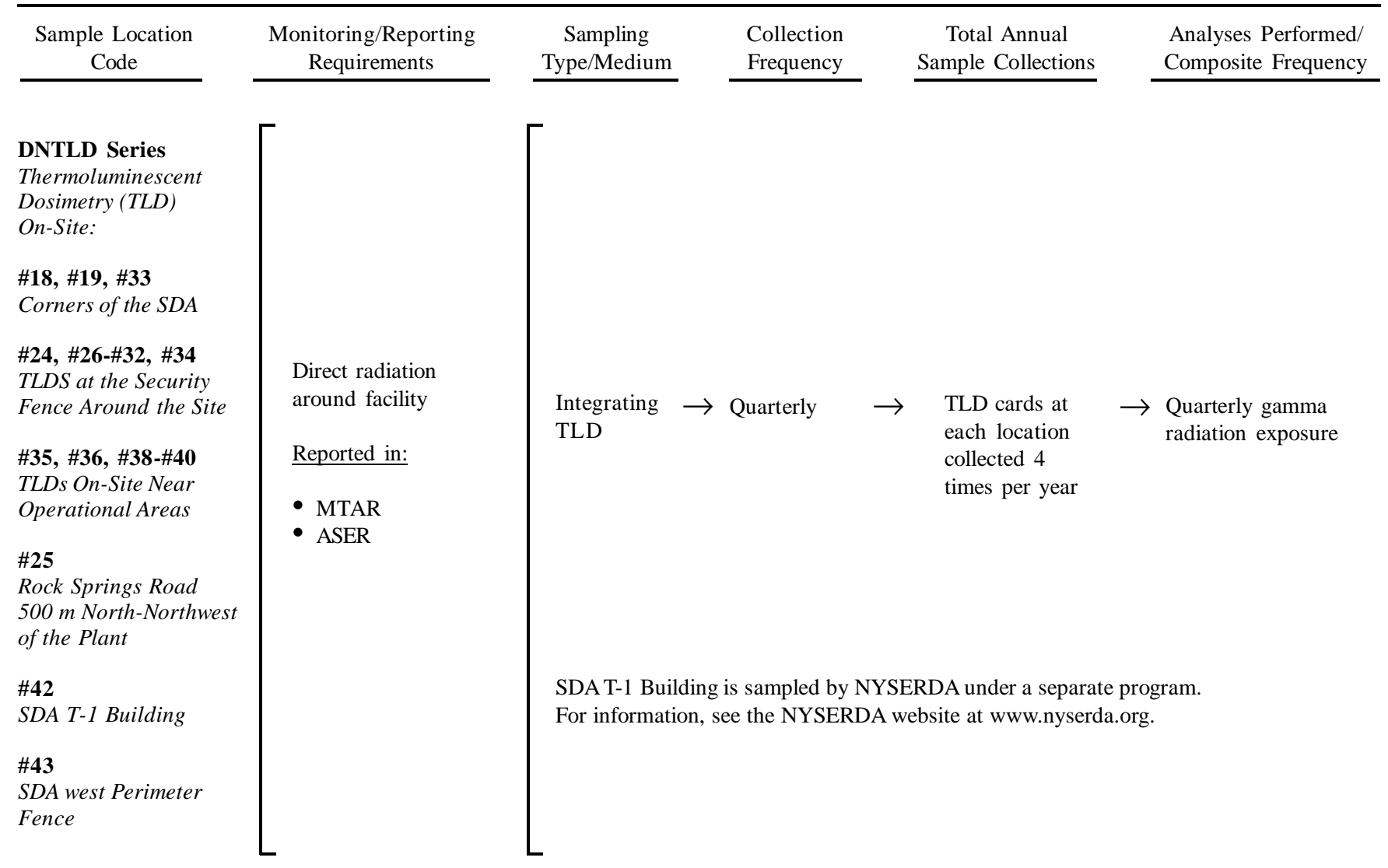

Note: TLDs were discontinued at locations DNTLD18, DNTLD31, DNTLD32, and DNTLD 34 at the end of 1st quarter 2005. See p. B-ix.

$$
\text { B }-53
$$




\section{Sampling Rationale}

Direct Radiation DOE/EH-0173T, 5.4 and 5.5
On-Site

On-site TLDs monitor waste management units and verify that the potential dose rate to the general public (i.e., at Rock Springs Road) is below $100 \mathrm{mrem} / \mathrm{year}(1 \mathrm{mSv} / \mathrm{year})$ from site activities.

A high-pressure ion chamber (HPIC) gamma radiation measurement is completed at all locations in order to confirm TLD measurements.

Potential TLD sampling locations are continually evaluated with respect to site activities.

Sampling at TLD location \#42 will no longer be monitored by the DOE.

Sampling locations are shown on Figure A-12.

$$
B-54
$$


This page intentionally left blank

$$
\text { B - } 55
$$




\section{Appendix C-1 \\ Summary of Water Limits, Guidelines, and Standards}

$C-1$ 
This page intentionally left blank

$C-2$ 


\section{Table C-1A \\ West Valley Demonstration Project State Pollutant Discharge Elimination System (SPDES) Sampling Program}

\section{Outfall}

001 (Process and Storm Wastewater)

\author{
Parameter \\ Flow \\ Aluminum, total \\ Ammonia $\left(\mathrm{NH}_{3}\right)$ \\ Arsenic, dissolved \\ $\mathrm{BOD}_{5}$ \\ Iron, total \\ Zinc, total recoverable \\ Solids, total suspended \\ Cyanide, amenable to chlorination \\ Settleable solids \\ $\mathrm{pH}$ (range) \\ Oil and grease \\ Sulfate (as S) \\ Sulfide, dissolved \\ Manganese, total \\ Nitrate (as N) \\ Nitrite (as N) \\ Chromium, total recoverable \\ Cadmium, total recoverable \\ Copper, total recoverable \\ Copper, dissolved \\ Lead, total recoverable \\ Nickel, total recoverable \\ Dichlorodifluoromethane \\ Trichlorofluoromethane \\ 3,3-dichlorobenzidine \\ Tributyl phosphate \\ Vanadium, total recoverable \\ Cobalt, total recoverable \\ Selenium, total recoverable \\ Hexachlorobenzene \\ Alpha - BHC \\ Heptachlor \\ Surfactants (as LAS) \\ Xylene \\ 2-butanone \\ Total dissolved solids \\ Mercury, total
}

Chromium, hexavalent, total recoverable

\section{Daily Maximum Limit ${ }^{a}$}

Monitor

$14.0 \mathrm{mg} / \mathrm{L}$

Monitor

$0.15 \mathrm{mg} / \mathrm{L}$

$10.0 \mathrm{mg} / \mathrm{L}$

Monitor

$0.48 \mathrm{mg} / \mathrm{L}$

$45 \mathrm{mg} / \mathrm{L}$

$0.022 \mathrm{mg} / \mathrm{L}$

$0.3 \mathrm{~mL} / \mathrm{L}$

6.5-8.5 S.U.

$15.0 \mathrm{mg} / \mathrm{L}$

Monitor

$0.4 \mathrm{mg} / \mathrm{L}$

$2.0 \mathrm{mg} / \mathrm{L}$

Monitor

$0.1 \mathrm{mg} / \mathrm{L}$

$0.3 \mathrm{mg} / \mathrm{L}$

$0.011 \mathrm{mg} / \mathrm{L}$

$0.002 \mathrm{mg} / \mathrm{L}$

$0.030 \mathrm{mg} / \mathrm{L}$

Monitor

$0.006 \mathrm{mg} / \mathrm{L}$

$0.14 \mathrm{mg} / \mathrm{L}$

$0.01 \mathrm{mg} / \mathrm{L}$

$0.01 \mathrm{mg} / \mathrm{L}$

$0.01 \mathrm{mg} / \mathrm{L}$

$32 \mathrm{mg} / \mathrm{L}$

$0.014 \mathrm{mg} / \mathrm{L}$

$0.005 \mathrm{mg} / \mathrm{L}$

$0.004 \mathrm{mg} / \mathrm{L}$

$0.02 \mathrm{mg} / \mathrm{L}$

$0.00001 \mathrm{mg} / \mathrm{L}$

$0.00001 \mathrm{mg} / \mathrm{L}$

$0.4 \mathrm{mg} / \mathrm{L}$

$0.05 \mathrm{mg} / \mathrm{L}$

$0.5 \mathrm{mg} / \mathrm{L}$

Monitor

$0.0002 \mathrm{mg} / \mathrm{L}$
Sample Frequency

2 per discharge

2 per discharge

2 per discharge

2 per discharge

2 per discharge

2 per discharge

2 per discharge

2 per discharge

2 per discharge

2 per discharge

2 per discharge

2 per discharge

2 per discharge

2 per discharge

2 per discharge

2 per discharge

2 per discharge

2 per discharge

2 per discharge

2 per discharge

2 per discharge

2 per discharge

2 per discharge

2 per discharge

annual

annual

annual

annual

2 per discharge

2 per discharge

2 per discharge

annual

annual

semiannual

2 per discharge annual

annual

2 per discharge

2 per discharge

${ }^{a}$ Daily average limitations are also identified in the permit but require only monitoring for all parameters except total aluminum (daily average limit - $7.0 \mathrm{mg} / \mathrm{L}$ ); total suspended solids (daily average limit - $30.0 \mathrm{mg} / \mathrm{L}$ ); $B O D_{5}$ for the sum of outfalls 001, 007, and 008 (daily average limit $-5.0 \mathrm{mg} / \mathrm{L}$ ); and ammonia for the sum of outfalls 001 and 007 (daily average limit $-1.49 \mathrm{mg} / \mathrm{L}$ ).

$$
C-3
$$




\section{Table C-1A (concluded) \\ West Valley Demonstration Project State Pollutant Discharge Elimination System (SPDES) Sampling Program}

\begin{tabular}{|c|c|c|c|}
\hline Outfall & Parameter & Daily Maximum Limit ${ }^{a}$ & Sample Frequency \\
\hline 001 (concluded) & $\begin{array}{l}\text { Barium } \\
\text { Antimony } \\
\text { Chloroform } \\
\text { Titanium } \\
\text { Bromide } \\
\text { Boron }\end{array}$ & $\begin{array}{l}0.5 \mathrm{mg} / \mathrm{L} \\
1.0 \mathrm{mg} / \mathrm{L} \\
0.3 \mathrm{mg} / \mathrm{L} \\
0.65 \mathrm{mg} / \mathrm{L} \\
5.0 \mathrm{mg} / \mathrm{L} \\
2.0 \mathrm{mg} / \mathrm{L}\end{array}$ & $\begin{array}{l}\text { annual } \\
\text { annual } \\
\text { annual } \\
\text { semiannual } \\
\text { quarterly } \\
\text { quarterly }\end{array}$ \\
\hline $\begin{array}{l}\text { 01B (Internal Process } \\
\text { Monitoring Point) }\end{array}$ & $\begin{array}{l}\text { Flow } \\
\text { Mercury, total }\end{array}$ & $\begin{array}{l}\text { Monitor } \\
10.0 \mu \mathrm{g} / \mathrm{L}\end{array}$ & $\begin{array}{l}\text { weekly } \\
2 \text { per month }\end{array}$ \\
\hline $\begin{array}{l}007 \text { (Sanitary and } \\
\text { Utility Wastewater) }\end{array}$ & $\begin{array}{l}\text { Flow } \\
\text { Ammonia }\left(\mathrm{as} \mathrm{NH}_{3}\right) \\
\mathrm{BOD}_{5} \\
\text { Iron, total } \\
\text { Solids, total suspended } \\
\text { Solids, settleable } \\
\mathrm{pH}(\text { range }) \\
\text { Nitrite }(\text { as } \mathrm{N}) \\
\text { Oil and grease } \\
\text { Chlorine, total residual } \\
\text { Chloroform }\end{array}$ & $\begin{array}{l}\text { Monitor } \\
\text { Monitor } \\
10.0 \mathrm{mg} / \mathrm{L} \\
\text { Monitor } \\
45 \mathrm{mg} / \mathrm{L} \\
0.3 \mathrm{~mL} / \mathrm{L} \\
6.5-8.5 \mathrm{~S} . \mathrm{U} . \\
0.1 \mathrm{mg} / \mathrm{L} \\
15.0 \mathrm{mg} / \mathrm{L} \\
0.1 \mathrm{mg} / \mathrm{L} \\
0.20 \mathrm{mg} / \mathrm{L}\end{array}$ & $\begin{array}{l}3 \text { per month } \\
3 \text { per month } \\
3 \text { per month } \\
3 \text { per month } \\
3 \text { per month } \\
\text { weekly } \\
\text { weekly } \\
3 \text { per month } \\
3 \text { per month } \\
\text { weekly } \\
\text { annual }\end{array}$ \\
\hline $\begin{array}{l}008 \text { (French Drain } \\
\text { Wastewater) }\end{array}$ & $\begin{array}{l}\text { Flow } \\
\text { BOD }_{5} \\
\text { Iron, total } \\
\text { pH(range) } \\
\text { Cadmium, total recoverable } \\
\text { Lead, total recoverable } \\
\text { Silver, total } \\
\text { Zinc, total } \\
\text { Arsenic } \\
\text { Chromium }\end{array}$ & $\begin{array}{l}\text { Monitor } \\
5.0 \mathrm{mg} / \mathrm{L} \\
\text { Monitor } \\
6.5-8.5 \mathrm{~S} . \mathrm{U} . \\
0.002 \mathrm{mg} / \mathrm{L} \\
0.006 \mathrm{mg} / \mathrm{L} \\
0.008 \mathrm{mg} / \mathrm{L} \\
0.100 \mathrm{mg} / \mathrm{L} \\
0.17 \mathrm{mg} / \mathrm{L} \\
0.13 \mathrm{mg} / \mathrm{L}\end{array}$ & $\begin{array}{l}3 \text { per month } \\
3 \text { per month } \\
3 \text { per month } \\
3 \text { per month } \\
3 \text { per month } \\
3 \text { per month } \\
\text { annual } \\
\text { annual } \\
\text { annual } \\
\text { annual }\end{array}$ \\
\hline $\begin{array}{l}\text { Sum of Outfalls 001, } \\
007 \text {, and } 008\end{array}$ & $\begin{array}{l}\text { Iron, total } \\
\mathrm{BOD}_{5}\end{array}$ & $\begin{array}{l}0.30 \mathrm{mg} / \mathrm{L} \\
\text { Monitor }\end{array}$ & $\begin{array}{l}3 \text { per month } \\
3 \text { per month }\end{array}$ \\
\hline $\begin{array}{l}\text { Sum of Outfalls } 001 \\
\text { and } 007\end{array}$ & Ammonia (as $\mathrm{NH}_{3}$ ) & $2.1 \mathrm{mg} / \mathrm{L}$ & 3 per month \\
\hline $\begin{array}{l}\text { Pseudo-monitoring } \\
\text { point (116) }\end{array}$ & Solids, total dissolved & $500 \mathrm{mg} / \mathrm{L}$ & 2 per discharge \\
\hline
\end{tabular}

\footnotetext{
${ }^{a}$ Daily average limitations are also identified in the permit but require only monitoring for all parameters except total aluminum (daily average limit - $7.0 \mathrm{mg} / \mathrm{L}$ ); total suspended solids (daily average limit - $30.0 \mathrm{mg} / \mathrm{L}$ ); $B O D_{5}$ for the sum of outfalls 001, 007, and 008 (daily average limit - $5.0 \mathrm{mg} / \mathrm{L}$ ); and ammonia for the sum of outfalls 001 and 007 (daily average limit $-1.49 \mathrm{mg} / \mathrm{L}$ ).
}

$$
\text { C- } 4
$$


Table C-1B

New York State Water Quality Standards and Guidelines ${ }^{a}$

\begin{tabular}{|c|c|c|c|c|c|c|}
\hline Parameter & Units & Class A & Class B & Class $\mathrm{C}$ & Class D & Class GA \\
\hline Gross Alpha $^{b}$ & $\mathrm{pCi} / \mathrm{L}(\mu \mathrm{Ci} / \mathrm{mL})$ & $15(1.5 \mathrm{E}-08)$ & -- & -- & -- & $15(1.5 \mathrm{E}-08)$ \\
\hline Gross Beta $^{c}$ & $\mathrm{pCi} / \mathrm{L}(\mu \mathrm{Ci} / \mathrm{mL})$ & $1,000(1 \mathrm{E}-06)$ & -- & -- & -- & $1,000(1 \mathrm{E}-06)$ \\
\hline Tritium (H-3) & $\mathrm{pCi} / \mathrm{L}(\mu \mathrm{Ci} / \mathrm{mL})$ & $20,000(2 \mathrm{E}-05)$ & -- & -- & -- & -- \\
\hline Strontium-90 & $\mathrm{pCi} / \mathrm{L}(\mu \mathrm{Ci} / \mathrm{mL})$ & $8(8 \mathrm{E}-09)$ & -- & -- & -- & -- \\
\hline Alpha BHC & $\mathrm{mg} / \mathrm{L}$ & 0.000002 & 0.000002 & 0.000002 & 0.000002 & 0.00001 \\
\hline Aluminum, Dissolved & $\mathrm{mg} / \mathrm{L}$ & 0.10 & 0.10 & 0.10 & -- & -- \\
\hline Aluminum, Total & $\mathrm{mg} / \mathrm{L}$ & -- & -- & -- & -- & -- \\
\hline Ammonia, Total as $\mathbf{N}$ & $\mathrm{mg} / \mathrm{L}$ & $0.09-2.1$ & $0.09-2.1$ & $0.09-2.1$ & $0.67-29$ & 2.0 \\
\hline Antimony, Total & $\mathrm{mg} / \mathrm{L}$ & 0.003 & -- & -- & -- & 0.003 \\
\hline Arsenic, Dissolved & $\mathrm{mg} / \mathrm{L}$ & 0.050 & 0.150 & 0.150 & 0.340 & -- \\
\hline Arsenic, Total & $\mathrm{mg} / \mathrm{L}$ & 0.050 & -- & -- & -- & 0.025 \\
\hline Barium, Total & $\mathrm{mg} / \mathrm{L}$ & 1.00 & -- & -- & -- & 1.00 \\
\hline Beryllium, Total & $\mathrm{mg} / \mathrm{L}$ & 0.003 & d & d & -- & 0.003 \\
\hline Boron, Total & $\mathrm{mg} / \mathrm{L}$ & 10.0 & 10.0 & 10.0 & -- & 1.00 \\
\hline Bromide & $\mathrm{mg} / \mathrm{L}$ & 2.00 & -- & -- & -- & 2.00 \\
\hline Cadmium, Dissolved $^{e}$ & $\mathrm{mg} / \mathrm{L}$ & -- & -- & -- & -- & -- \\
\hline Cadmium, Total & $\mathrm{mg} / \mathrm{L}$ & 0.005 & -- & -- & -- & 0.005 \\
\hline Calcium, Total & $\mathrm{mg} / \mathrm{L}$ & -- & -- & -- & -- & -- \\
\hline Chloride & $\mathrm{mg} / \mathrm{L}$ & 250 & - & -- & -- & 250 \\
\hline Chromium, Dissolved $^{e}$ & $\mathrm{mg} / \mathrm{L}$ & -- & -- & -- & -- & -- \\
\hline Chromium, Total & $\mathrm{mg} / \mathrm{L}$ & 0.05 & -- & -- & -- & 0.05 \\
\hline Cobalt, Totaf $f$ & $\mathrm{mg} / \mathrm{L}$ & 0.005 & 0.005 & 0.005 & 0.110 & -- \\
\hline Conductivity & $\mu \mathrm{mhos} / \mathrm{cm} @ 25^{\circ} \mathrm{C}$ & -- & -- & -- & -- & -- \\
\hline${\text { Copper, } \text { Dissolved }^{e}}$ & $\mathrm{mg} / \mathrm{L}$ & -- & -- & -- & -- & -- \\
\hline Copper, Total & $\mathrm{mg} / \mathrm{L}$ & 0.20 & -- & -- & -- & 0.20 \\
\hline Cyanide & $\mathrm{mg} / \mathrm{L}$ & 0.0052 & 0.0052 & 0.0052 & 0.22 & 0.200 \\
\hline Dissolved Oxygen (minimum) & $\mathrm{mg} / \mathrm{L}$ & 4.0 & 4.0 & 4.0 & 3.0 & -- \\
\hline Fluoride $^{e}$ & $\mathrm{mg} / \mathrm{L}$ & -- & -- & -- & -- & 1.5 \\
\hline Hardness & $\mathrm{mg} / \mathrm{L}$ & -- & -- & -- & -- & -- \\
\hline Iron and Manganese (sum) & $\mathrm{mg} / \mathrm{L}$ & -- & -- & -- & -- & 0.500 \\
\hline
\end{tabular}

-- No applicable guideline or reference standard available

Note: All water quality and metals standards are presented in $\mathrm{mg} / \mathrm{L}(\mathrm{ppm})$ to provide consistency in comparisons.

${ }^{a}$ Source: 6 NYCRR Parts 701-704; The most stringent applicable pathway (e.g., wildlife, aquatic, human health)

values are reported.

${ }^{b}$ Gross alpha standard includes radium-226, but excludes radon and uranium; however WVDP results include

these isotopes.

${ }^{c}$ Gross beta standard excludes strontium-90 and alpha emitters, however WVDP results include these isotopes.

${ }^{d}$ Beryllium standard for classes " $B$ " and " $C$ " are based on stream hardness values.

" Standards for these constituents vary according to stream location hardness values.

${ }^{f}$ Standards for cobalt, thallium, and vanadium are applicable to the acid-soluble fraction.

${ }^{g}$ Applies to the sum of those organic substances which have individual human health water source standards listed at $0.100 \mathrm{mg} / \mathrm{L}$ or less in 6 NYCRR Part 703.5

${ }^{h} \mathrm{pH}$ shall not be lower than 6.5 or the $\mathrm{pH}$ of natural groundwater, whichever is lower, nor shall $\mathrm{pH}$ be greater than 8.5 or the $\mathrm{pH}$ of the natural groundwater, whichever is greater.

$C-5$ 


\section{Table C-1B (concluded)}

\section{New York State Water Quality Standards and Guidelines ${ }^{a}$}

\begin{tabular}{|c|c|c|c|c|c|c|}
\hline Parameter & Units & Class A & Class B & Class C & Class D & Class GA \\
\hline Iron, Total & $\mathrm{mg} / \mathrm{L}$ & 0.30 & 0.30 & 0.30 & 0.30 & 0.30 \\
\hline Lead, Dissolved $^{e}$ & $\mathrm{mg} / \mathrm{L}$ & -- & -- & -- & -- & -- \\
\hline Lead, Total & $\mathrm{mg} / \mathrm{L}$ & 0.050 & -- & -- & -- & 0.025 \\
\hline Magnesium, Total & $\mathrm{mg} / \mathrm{L}$ & 35.0 & -- & -- & -- & 35.0 \\
\hline Manganese, Total & $\mathrm{mg} / \mathrm{L}$ & 0.30 & -- & -- & -- & 0.30 \\
\hline Mercury, Dissolved & $\mathrm{mg} / \mathrm{L}$ & 0.0000007 & 0.0000007 & 0.0000007 & 0.0000007 & -- \\
\hline Mercury, Total & $\mathrm{mg} / \mathrm{L}$ & 0.0007 & -- & -- & -- & 0.0007 \\
\hline Nickel, Dissolved $^{e}$ & $\mathrm{mg} / \mathrm{L}$ & -- & -- & -- & -- & -- \\
\hline Nickel, Total & $\mathrm{mg} / \mathrm{L}$ & 0.10 & -- & -- & -- & 0.10 \\
\hline Nitrate-N & $\mathrm{mg} / \mathrm{L}$ & 10.0 & -- & -- & -- & 10.0 \\
\hline Nitrate + Nitrite & $\mathrm{mg} / \mathrm{L}$ & 10.0 & 10.0 & 10.0 & 10.0 & 10.0 \\
\hline Nitrite-N & $\mathrm{mg} / \mathrm{L}$ & 0.10 & 0.10 & 0.10 & -- & 1.00 \\
\hline $\mathrm{NPOC}^{g}$ & $\mathrm{mg} / \mathrm{L}$ & 0.10 & -- & -- & -- & -- \\
\hline Oil \& Grease & $\mathrm{mg} / \mathrm{L}$ & -- & -- & -- & -- & -- \\
\hline pH & SU & $6.5-8.5^{h}$ & $6.5-8.5^{h}$ & $6.5-8.5^{h}$ & $6.0-9.5$ & $6.5-8.5^{h}$ \\
\hline Potassium, Total & $\mathrm{mg} / \mathrm{L}$ & -- & -- & -- & -- & -- \\
\hline Selenium, Dissolved & $\mathrm{mg} / \mathrm{L}$ & 0.0046 & 0.0046 & 0.0046 & -- & -- \\
\hline Selenium, Total & $\mathrm{mg} / \mathrm{L}$ & 0.01 & -- & -- & -- & 0.01 \\
\hline Silver, Total & $\mathrm{mg} / \mathrm{L}$ & 0.05 & -- & -- & -- & 0.05 \\
\hline Sodium, Total & $\mathrm{mg} / \mathrm{L}$ & -- & -- & -- & -- & 20.0 \\
\hline Solids, Settleable & $\mathrm{mg} / \mathrm{L}$ & -- & -- & -- & -- & -- \\
\hline Solids, Total Dissolved & $\mathrm{mg} / \mathrm{L}$ & 500 & 500 & 500 & -- & 500 \\
\hline Solids, Total Suspended & $\mathrm{mg} / \mathrm{L}$ & -- & -- & -- & -- & -- \\
\hline Sulfate & $\mathrm{mg} / \mathrm{L}$ & 250 & -- & -- & -- & 250 \\
\hline Sulfide (undissociated form) & $\mathrm{mg} / \mathrm{L}$ & 0.002 & 0.002 & 0.002 & -- & 0.050 (as HS) \\
\hline Surfactants (as LAS) & $\mathrm{mg} / \mathrm{L}$ & 0.04 & 0.04 & 0.04 & -- & -- \\
\hline Thallium, Total $f$ & $\mathrm{mg} / \mathrm{L}$ & 0.0005 & 0.008 & 0.008 & 0.020 & 0.0005 \\
\hline Titanium, Total & $\mathrm{mg} / \mathrm{L}$ & -- & -- & -- & -- & -- \\
\hline TOX (total organic halides) ${ }^{g}$ & $\mathrm{mg} / \mathrm{L}$ & 0.10 & -- & -- & -- & -- \\
\hline Vanadium, Total $f$ & $\mathrm{mg} / \mathrm{L}$ & 0.014 & 0.014 & 0.014 & 0.190 & -- \\
\hline Zinc, Dissolved $^{e}$ & $\mathrm{mg} / \mathrm{L}$ & -- & -- & -- & -- & -- \\
\hline Zinc, Total & $\mathrm{mg} / \mathrm{L}$ & 2.00 & -- & -- & -- & 2.00 \\
\hline
\end{tabular}

-- No applicable guideline or reference standard available

Note: All water quality and metals standards are presented in $\mathrm{mg} / \mathrm{L}(\mathrm{ppm})$ to provide consistency in comparisons. HS - Hydrogen sulfide

a Source: 6 NYCRR Parts 701-704; The most stringent applicable pathway (e.g., wildlife, aquatic, human health) values are reported.

${ }^{b}$ Gross alpha standard includes radium-226, but excludes radon and uranium; however WVDP results include these isotopes.

${ }^{c}$ Gross beta standard excludes strontium-90 and alpha emitters, however WVDP results include these isotopes.

${ }^{d}$ Beryllium standard for classes " $B$ " and " $C$ " are based on stream hardness.

e Standards for these constituents vary according to stream location hardness values.

${ }^{f}$ Standards for cobalt, thallium, and vanadium are applicable to the acid-soluble fraction.

${ }^{g}$ Applies to the sum of those organic substances which have individual human health water source standards listed at $0.100 \mathrm{mg} / \mathrm{L}$ or less in 6 NYCRR Part 703.5

${ }^{h} \mathrm{pH}$ shall not be lower than 6.5 or the $\mathrm{pH}$ of natural groundwater, whichever is lower, nor shall pH be greater than 8.5 or the $\mathrm{pH}$ of the natural groundwater, whichever is greater.

$$
C-6
$$




\section{Table C-1C \\ New York State Department of Health/U.S. Environmental Protection Agency MCLs, MCLGs, and Raw Water Standards}

\begin{tabular}{|c|c|c|c|c|}
\hline Parameter & Units & $\begin{array}{l}\text { NYSDOH or } \\
\text { EPA MCL }^{a}\end{array}$ & EPA MCLG ${ }^{b}$ & $\begin{array}{c}\text { NYSDOH Raw } \\
\text { Water Standards }\end{array}$ \\
\hline Gross Alpha & $\mathrm{pCi} / \mathrm{L}(\mu \mathrm{Ci} / \mathrm{mL})$ & $15(1.5 \mathrm{E}-08)^{d}$ & 0 & -- \\
\hline Gross Beta & $\mathrm{pCi} / \mathrm{L}(\mu \mathrm{Ci} / \mathrm{mL})$ & $50(5 \mathrm{E}-08)^{e}$ & 0 & $1,000(1 \mathrm{E}-06)$ \\
\hline Tritium (H-3) & $\mathrm{pCi} / \mathrm{L}(\mu \mathrm{Ci} / \mathrm{mL})$ & $20,000(2 \mathrm{E}-05)$ & -- & -- \\
\hline Strontium-90 & $\mathrm{pCi} / \mathrm{L}(\mu \mathrm{Ci} / \mathrm{mL})$ & $8(8 \mathrm{E}-09)$ & -- & $10(1 \mathrm{E}-08)$ \\
\hline Antimony, Total & $\mathrm{mg} / \mathrm{L}$ & 0.006 & 0.006 & -- \\
\hline Arsenic, Total & $\mathrm{mg} / \mathrm{L}$ & 0.05 & -- & 0.05 \\
\hline Barium, Total & $\mathrm{mg} / \mathrm{L}$ & 2.00 & 2.00 & 1.0 \\
\hline Beryllium, Total & $\mathrm{mg} / \mathrm{L}$ & 0.004 & 0.004 & -- \\
\hline Cadmium, Total & $\mathrm{mg} / \mathrm{L}$ & 0.005 & 0.005 & 0.01 \\
\hline Chromium, Total & $\mathrm{mg} / \mathrm{L}$ & 0.10 & 0.10 & -- \\
\hline Conductivity & $\mu \mathrm{mhos} / \mathrm{cm} @ 25^{\circ} \mathrm{C}$ & -- & -- & -- \\
\hline Copper, Total & $\mathrm{mg} / \mathrm{L}$ & 1.3 & 1.3 & $<0.2$ \\
\hline Cyanide & $\mathrm{mg} / \mathrm{L}$ & 0.2 & 0.2 & $<0.1$ \\
\hline E. Coli & NA & one positive sample & 0 & -- \\
\hline Fluoride & $\mathrm{mg} / \mathrm{L}$ & 2.2 & -- & $<1.5$ \\
\hline Free Residual Chlorine & $\mathrm{mg} / \mathrm{L}$ & $0.02(\min ) \quad 4.0(\max )$ & -- & -- \\
\hline Haloacetic Acids-Five (5) & $\mathrm{mg} / \mathrm{L}$ & 0.060 & -- & -- \\
\hline Iron, Total & $\mathrm{mg} / \mathrm{L}$ & 0.3 & -- & -- \\
\hline Lead, Total & $\mathrm{mg} / \mathrm{L}$ & 0.015 & 0 & 0.05 \\
\hline Mercury, Total & $\mathrm{mg} / \mathrm{L}$ & 0.002 & 0.002 & 0.005 \\
\hline Nickel, Total & $\mathrm{mg} / \mathrm{L}$ & -- & -- & -- \\
\hline Nitrate-N & $\mathrm{mg} / \mathrm{L}$ & 10 & 10 & -- \\
\hline pH & SU & -- & -- & $6.5-8.5$ \\
\hline POC (Principle Organic Contaminant) & $\mathrm{mg} / \mathrm{L}$ & -- & 0.0005 & -- \\
\hline Selenium, Total & $\mathrm{mg} / \mathrm{L}$ & 0.05 & 0.05 & 0.01 \\
\hline Solids, Total Dissolved & $\mathrm{mg} / \mathrm{L}$ & -- & -- & 500 \\
\hline Thallium, Total & $\mathrm{mg} / \mathrm{L}$ & 0.002 & 0.0005 & -- \\
\hline Total Coliform & NA & 2 or more positive samples & 0 & -- \\
\hline Total Trihalomethanes & $\mathrm{mg} / \mathrm{L}$ & 0.080 & -- & -- \\
\hline Turbidity & NTU & $1(\max )$ & -- & -- \\
\hline
\end{tabular}

-- No applicable guideline or reference standard available

Note: All water quality and metals standards are presented in $\mathrm{mg} / \mathrm{L}(\mathrm{ppm})$ to provide consistency in comparisons.

NA - Not applicable

${ }^{a}$ MCL - Listed is NYSDOH or EPA Maximum Contaminant Level. Sources: 40 CFR 141 and/or 5 NYCRR 5-1.52,

whichever is more stringent.

${ }^{b}$ MCLG - Maximum Contaminant Level Goal (non-enforceable) as listed in 40 CFR Part 141

c Source: 10 NYCRR Part 170.4

${ }^{d}$ Alpha guideline includes radium-226, but excludes uranium; however, WVDP results include these isotopes.

${ }^{e}$ Average annual concentration assumed to produce a total body organ dose of $4 \mathrm{mrem} / \mathrm{year}$

$$
\text { C - } 7
$$


Table C-1D

\section{U.S. Department of Energy Derived Concentration Guides $(D C G s)^{a}$}

\begin{tabular}{|l|l|c|}
\hline \multicolumn{1}{|c|}{ Radionuclide } & Units & Concentration in Ingested Water \\
\hline Gross Alpha (as Am-241) & $\mu \mathrm{Ci} / \mathrm{mL}$ & $3 \mathrm{E}-08$ \\
\hline Gross Beta (as Sr-90) & $\mu \mathrm{Ci} / \mathrm{mL}$ & $1 \mathrm{E}-06$ \\
\hline Tritium $(\mathbf{H}-3)$ & $\mu \mathrm{Ci} / \mathrm{mL}$ & $2 \mathrm{E}-03$ \\
\hline Carbon-14 (C-14) & $\mu \mathrm{Ci} / \mathrm{mL}$ & $7 \mathrm{E}-05$ \\
\hline Potassium-40 (K-40) & $\mu \mathrm{Ci} / \mathrm{mL}$ & $7 \mathrm{E}-06$ \\
\hline Cobalt-60 (Co-60) & $\mu \mathrm{Ci} / \mathrm{mL}$ & $5 \mathrm{E}-06$ \\
\hline Strontium-90 (Sr-90) & $\mu \mathrm{Ci} / \mathrm{mL}$ & $1 \mathrm{E}-06$ \\
\hline Technetium-99 (Tc-99) & $\mu \mathrm{Ci} / \mathrm{mL}$ & $1 \mathrm{E}-04$ \\
\hline Iodine-129 (I-129) & $\mu \mathrm{Ci} / \mathrm{mL}$ & $5 \mathrm{E}-07$ \\
\hline Cesium-137 (Cs-137) & $\mu \mathrm{Ci} / \mathrm{mL}$ & $3 \mathrm{E}-06$ \\
\hline Europium-154 (Eu-154) & $\mu \mathrm{Ci} / \mathrm{mL}$ & $2 \mathrm{E}-05$ \\
\hline Uranium-232 (U-232) & $\mu \mathrm{Ci} / \mathrm{mL}$ & $1 \mathrm{E}-07$ \\
\hline Uranium-233 (U-233) & $\mu \mathrm{Ci} / \mathrm{mL}$ & $5 \mathrm{E}-07$ \\
\hline Uranium-234 (U-234) & $\mu \mathrm{Ci} / \mathrm{mL}$ & $5 \mathrm{E}-07$ \\
\hline Uranium-235 (U-235) & $\mu \mathrm{Ci} / \mathrm{mL}$ & $6 \mathrm{E}-07$ \\
\hline Uranium-236 (U-236) & $\mu \mathrm{Ci} / \mathrm{mL}$ & $5 \mathrm{E}-07$ \\
\hline Uranium-238 (U-238) & $\mu \mathrm{Ci} / \mathrm{mL}$ & $6 \mathrm{E}-07$ \\
\hline Plutonium-238 (Pu-238) & $\mu \mathrm{Ci} / \mathrm{mL}$ & $4 \mathrm{E}-08$ \\
\hline Plutonium-239 (Pu-239) & $\mu \mathrm{Ci} / \mathrm{mL}$ & $3 \mathrm{E}-08$ \\
\hline Plutonium-240 (Pu-240) & $\mu \mathrm{Ci} / \mathrm{mL}$ & $3 \mathrm{E}-08$ \\
\hline Americium-241 (Am-241) & $\mu \mathrm{Ci} / \mathrm{mL}$ & $3 \mathrm{E}-08$ \\
\hline & & \\
\hline & & \\
\hline
\end{tabular}

${ }^{a}$ DCGs are established in DOE Order 5400.5 and are defined as the concentration of a radionuclide that, under conditions of continuous exposure for one year by one exposure mode, would result in an effective dose equivalent of $100 \mathrm{mrem}(1 \mathrm{mSv})$.

${ }^{b}$ Because there are no DCGs for gross alpha and gross beta concentrations, the DCGs for the most restrictive alpha and beta emitters at the WVDP, americium-241 and strontium-90 (3E-08 and $1 \mathrm{E}-06 \mu \mathrm{Ci} / \mathrm{mL}$, respectively) are used as a conservative basis for comparison at locations for which there are no radionuclide-specific data, in which case a more appropriate DCG may be applied. 


\section{Appendix C-2 Process Effluent Data}

C -9 
Table C-2A contains a bolding convention devised to help the reader, when viewing the data, to quickly see the range of detectable measurements within a data series. A data series is a set of chemical or radionuclide measurements (e.g., gross alpha, gross beta, tritium) from a single location or from similar locations. Note that some tables contain data that should not be technically evaluated under this convention.

\section{Key to bolding convention:}

Results for each constituent constitute a single data series. If a radiological result is larger than the uncertainty term, the measurement is considered positive. Otherwise, a result is considered nondetectable. Chemical results preceded by "less than" (<) are considered nondetectable.

If all results in a data series are positive, the lowest and highest values are bolded. If a data series contains some positive results, the highest value is bolded. If all values in a data series are nondetectable, no values are bolded. 


\section{Table C-2A}

\section{Total Radioactivity (curies) of Liquid Effluents Released From Lagoon 3}

(WNSP001) in 2005

\begin{tabular}{|c|c|c|c|c|c|}
\hline Isotope & 1st Quarter & 2nd Quarter & 3rd Quarter & 4th Quarter & Annual Total \\
\hline Gross Alpha & $3.77 \pm 0.39 \mathrm{E}-04$ & $1.09 \pm 0.22 \mathrm{E}-04$ & $1.61 \pm 0.30 \mathrm{E}-04$ & $1.91 \pm 0.25 \mathrm{E}-04$ & $8.38 \pm 0.59 \mathrm{E}-04$ \\
\hline Gross Beta & $5.12 \pm 0.09 \mathrm{E}-03$ & $4.00 \pm 0.08 \mathrm{E}-03$ & $6.89 \pm 0.08 \mathrm{E}-03$ & $6.05 \pm 0.08 \mathrm{E}-03$ & $2.21 \pm 0.02 \mathrm{E}-02$ \\
\hline H-3 & $2.55 \pm 0.13 \mathrm{E}-02$ & $7.65 \pm 0.72 \mathrm{E}-03$ & $6.63 \pm 0.88 \mathrm{E}-03$ & $2.26 \pm 0.17 \mathrm{E}-02$ & $6.25 \pm 0.24 \mathrm{E}-02$ \\
\hline C-14 & $1.52 \pm 3.67 \mathrm{E}-04$ & $-0.82 \pm 2.71 \mathrm{E}-04$ & $2.57 \pm 2.95 \mathrm{E}-04$ & $2.27 \pm 2.51 \mathrm{E}-04$ & $5.54 \pm 5.98 \mathrm{E}-04$ \\
\hline K-40 & $2.80 \pm 7.61 \mathrm{E}-04$ & $0.00 \pm 5.03 \mathrm{E}-04$ & $-1.18 \pm 3.43 \mathrm{E}-04$ & $3.14 \pm 2.88 \mathrm{E}-04$ & $0.48 \pm 1.02 \mathrm{E}-03$ \\
\hline Co-60 & $0.58 \pm 2.76 \mathrm{E}-05$ & $-0.15 \pm 1.76 \mathrm{E}-05$ & $1.40 \pm 1.97 \mathrm{E}-05$ & $1.05 \pm 1.71 \mathrm{E}-05$ & $2.89 \pm 4.18 \mathrm{E}-05$ \\
\hline Sr-90 & $2.22 \pm 0.09 \mathrm{E}-03$ & $1.83 \pm 0.07 E-03$ & $2.84 \pm 0.07 \mathrm{E}-03$ & $2.39 \pm 0.05 \mathrm{E}-03$ & $9.27 \pm 0.14 \mathrm{E}-03$ \\
\hline Tc-99 & $2.52 \pm 0.32 \mathrm{E}-04$ & $9.49 \pm 2.05 \mathrm{E}-05$ & $2.16 \pm 0.25 \mathrm{E}-04$ & $2.90 \pm 0.31 \mathrm{E}-04$ & $8.54 \pm 0.55 \mathrm{E}-04$ \\
\hline I-129 & $0.61 \pm 2.63 \mathrm{E}-05$ & $0.32 \pm 1.04 \mathrm{E}-05$ & $1.13 \pm 1.00 \mathrm{E}-05$ & $4.62 \pm 1.11 \mathrm{E}-05$ & $6.68 \pm 3.20 \mathrm{E}-05$ \\
\hline Cs-137 & $6.36 \pm 0.72 \mathrm{E}-04$ & $1.71 \pm 0.33 \mathrm{E}-04$ & $3.00 \pm 0.38 \mathrm{E}-04$ & $8.57 \pm 0.80 \mathrm{E}-04$ & $1.96 \pm 0.12 \mathrm{E}-03$ \\
\hline U-232 & $1.42 \pm 0.08 \mathrm{E}-04$ & $5.02 \pm 0.36 \mathrm{E}-05$ & $5.78 \pm 0.34 \mathrm{E}-05$ & $8.44 \pm 0.41 \mathrm{E}-05$ & $3.34 \pm 0.11 \mathrm{E}-04$ \\
\hline U-233/234 & $1.00 \pm 0.07 \mathrm{E}-04$ & $2.75 \pm 0.37 \mathrm{E}-05$ & $3.62 \pm 0.26 \mathrm{E}-05$ & $5.01 \pm 0.39 \mathrm{E}-05$ & $2.14 \pm 0.09 \mathrm{E}-04$ \\
\hline U-235/236 & $7.05 \pm 1.52 \mathrm{E}-06$ & $1.17 \pm 0.83 E-06$ & $3.84 \pm 0.84 \mathrm{E}-06$ & $4.05 \pm 1.12 \mathrm{E}-06$ & $1.61 \pm 0.22 \mathrm{E}-05$ \\
\hline U-238 & $7.30 \pm 0.56 \mathrm{E}-05$ & $3.09 \pm 0.40 \mathrm{E}-05$ & $3.16 \pm 0.24 \mathrm{E}-05$ & $4.73 \pm 0.38 \mathrm{E}-05$ & $1.83 \pm 0.08 \mathrm{E}-04$ \\
\hline Total U (g) & $2.14 \pm 0.04 \mathrm{E}+02$ & $8.99 \pm 0.31 \mathrm{E}+01$ & $1.07 \pm 0.02 \mathrm{E}+02$ & $1.19 \pm 0.02 \mathrm{E}+02$ & $5.30 \pm 0.06 \mathrm{E}+02$ \\
\hline Pu-238 & $1.62 \pm 1.02 \mathrm{E}-06$ & $1.30 \pm 2.94 \mathrm{E}-07$ & $-0.07 \pm 1.35 \mathrm{E}-07$ & $7.68 \pm 5.33 \mathrm{E}-07$ & $2.51 \pm 1.20 \mathrm{E}-06$ \\
\hline Pu-239/240 & $1.43 \pm 0.84 \mathrm{E}-06$ & $3.05 \pm 3.45 \mathrm{E}-07$ & $0.83 \pm 2.18 \mathrm{E}-07$ & $6.43 \pm 4.96 \mathrm{E}-07$ & $2.46 \pm 1.05 \mathrm{E}-06$ \\
\hline Am-241 & $1.09 \pm 0.79 \mathrm{E}-06$ & $4.73 \pm 4.51 \mathrm{E}-07$ & $3.10 \pm 2.95 \mathrm{E}-07$ & $1.32 \pm 0.58 \mathrm{E}-06$ & $3.19 \pm 1.12 \mathrm{E}-06$ \\
\hline
\end{tabular}

Note: Bolding convention applied to these data. See page C-10.

Note: Strontium-90 (Sr-90) analysis in water was performed by a non-NYSDOH ELAP-certified analytical method. See Chapter 5. 
Table C-2B

\section{Comparison of 2005 Lagoon 3 (WNSP001) Liquid Effluent Radioactivity Concentrations With U.S. Department of Energy Guidelines}

\begin{tabular}{|c|c|c|c|c|c|}
\hline Isotope $^{a}$ & $\begin{array}{c}\text { Discharge Activity }^{b} \\
\text { (Ci) }\end{array}$ & $\begin{array}{r}\text { Radioactivity }^{c} \\
\text { (Becquerels) }\end{array}$ & $\begin{array}{c}\text { Average } \\
\text { Concentration } \\
(\mu \mathrm{Ci} / \mathrm{mL})\end{array}$ & $\begin{array}{c}\text { DCG } \\
(\mu \mathrm{Ci} / \mathrm{mL})\end{array}$ & $\%$ of DCG \\
\hline Gross Alpha & $8.38 \pm 0.59 \mathrm{E}-04$ & $3.10 \pm 0.22 \mathrm{E}+07$ & $1.63 \pm 0.11 \mathrm{E}-08$ & $\mathrm{NA}^{d}$ & NA \\
\hline Gross Beta & $2.21 \pm 0.02 \mathrm{E}-02$ & $8.16 \pm 0.06 \mathrm{E}+08$ & $4.29 \pm 0.03 \mathrm{E}-07$ & $\mathrm{NA}^{d}$ & NA \\
\hline H-3 & $6.25 \pm 0.24 \mathrm{E}-02$ & $2.31 \pm 0.09 \mathrm{E}+09$ & $1.21 \pm 0.05 \mathrm{E}-06$ & 2E-03 & 0.06 \\
\hline C-14 & $5.54 \pm 5.98 \mathrm{E}-04$ & $2.05 \pm 2.21 \mathrm{E}+07$ & $1.08 \pm 1.16 \mathrm{E}-08$ & 7E-05 & $<0.02$ \\
\hline K-40 & $0.48 \pm 1.02 \mathrm{E}-03$ & $1.76 \pm 3.76 \mathrm{E}+07$ & $0.93 \pm 1.98 \mathrm{E}-08$ & $\mathrm{NA}^{e}$ & NA \\
\hline Co-60 & $2.89 \pm 4.18 \mathrm{E}-05$ & $1.07 \pm 1.55 \mathrm{E}+06$ & $5.61 \pm 8.13 \mathrm{E}-10$ & 5E-06 & $<0.02$ \\
\hline Sr-90 & $9.27 \pm 0.14 \mathrm{E}-03$ & $3.43 \pm 0.05 \mathrm{E}+08$ & $1.80 \pm 0.03 \mathrm{E}-07$ & $1 \mathrm{E}-06$ & 18.0 \\
\hline Tc-99 & $8.54 \pm 0.55 \mathrm{E}-04$ & $3.16 \pm 0.20 \mathrm{E}+07$ & $1.66 \pm 0.11 \mathrm{E}-08$ & $1 \mathrm{E}-04$ & 0.02 \\
\hline I-129 & $6.68 \pm 3.20 \mathrm{E}-05$ & $2.47 \pm 1.18 \mathrm{E}+06$ & $1.30 \pm 0.62 \mathrm{E}-09$ & 5E-07 & 0.26 \\
\hline Cs-137 & $1.96 \pm 0.12 \mathrm{E}-03$ & $7.27 \pm 0.44 \mathrm{E}+07$ & $3.82 \pm 0.23 \mathrm{E}-08$ & 3E-06 & 1.27 \\
\hline $\mathrm{U}-232^{f}$ & $3.34 \pm 0.11 \mathrm{E}-04$ & $1.24 \pm 0.04 \mathrm{E}+07$ & $6.49 \pm 0.21 \mathrm{E}-09$ & 1E-07 & 6.49 \\
\hline $\mathrm{U}-233 / 234^{f}$ & $2.14 \pm 0.09 \mathrm{E}-04$ & $7.91 \pm 0.33 \mathrm{E}+06$ & $4.16 \pm 0.17 \mathrm{E}-09$ & $5 \mathrm{E}-07$ & 0.83 \\
\hline $\mathrm{U}-235 / 236^{f}$ & $1.61 \pm 0.22 \mathrm{E}-05$ & $5.96 \pm 0.83 \mathrm{E}+05$ & $3.13 \pm 0.43 \mathrm{E}-10$ & $5 \mathrm{E}-07^{g}$ & 0.06 \\
\hline U-238 & $1.83 \pm 0.08 \mathrm{E}-04$ & $6.76 \pm 0.30 \mathrm{E}+06$ & $3.55 \pm 0.16 \mathrm{E}-09$ & $6 \mathrm{E}-07$ & 0.59 \\
\hline Pu-238 & $2.51 \pm 1.20 \mathrm{E}-06$ & $9.29 \pm 4.44 \mathrm{E}+04$ & $4.88 \pm 2.33 \mathrm{E}-11$ & 4E-08 & 0.12 \\
\hline Pu-239/240 & $2.46 \pm 1.05 \mathrm{E}-06$ & $9.11 \pm 3.90 \mathrm{E}+04$ & $4.78 \pm 2.05 \mathrm{E}-11$ & 3E-08 & 0.16 \\
\hline Am-241 & $3.19 \pm 1.12 \mathrm{E}-06$ & $1.18 \pm 0.41 \mathrm{E}+05$ & $6.21 \pm 2.17 \mathrm{E}-11$ & 3E-08 & 0.21 \\
\hline \multicolumn{5}{|c|}{ Total \% of DCGs } & 28.1 \\
\hline
\end{tabular}

NA - Not applicable

Note: Strontium-90 (Sr-90) analysis in water was performed by a non-NYSDOH ELAP-certified analytical method. See Chapter 5.

${ }^{a}$ Half-lives are listed in Table $K$ - 1 무

${ }^{b}$ Total volume released: $5.14 E+10 \mathrm{~mL}(1.36 E+07 \mathrm{gal})$

${ }^{c} 1$ curie $(\mathrm{Ci})=3.7 \mathrm{E}+10$ becquerels $(\mathrm{Bq}) ; 1 \mathrm{~Bq}=2.7 \mathrm{E}-11 \mathrm{Ci}$

${ }^{d}$ DOE-derived concentration guides (DCGs) do not exist for indicator parameters gross alpha and gross beta.

${ }^{e}$ Potassium-40 activity is not applicable because of its natural origin.

${ }^{f}$ Total $U(\mathrm{~g})=5.30 \pm 0.06 \mathrm{E}+02$; Average $U(\mu \mathrm{g} / \mathrm{mL})=1.03 \pm 0.01 \mathrm{E}-02$

${ }^{8}$ DCG for $U-236$ is used for this comparison. 
Table C-2C

2005 SPDES Results for Outfall 001 (WNSP001):

Water Quality

\begin{tabular}{|c|c|c|c|c|c|c|c|c|}
\hline & \multicolumn{2}{|c|}{$\begin{array}{c}\text { Ammonia } \\
(\mathrm{mg} / \mathrm{L})\end{array}$} & \multicolumn{2}{|c|}{$\begin{array}{c}\text { BOD }_{\mathbf{5}} \text { day } \\
(\mathrm{mg} / \mathrm{L})\end{array}$} & \multicolumn{2}{|c|}{$\begin{array}{c}\text { Cyanide } \\
\text { (amenable to } \\
\text { chlorination) }\end{array}$} & \multicolumn{2}{|c|}{$\begin{array}{l}\text { Discharge Rate } \\
\text { (MGD) }\end{array}$} \\
\hline Permit limit & \multicolumn{2}{|c|}{ Monitor } & \multicolumn{2}{|c|}{$\begin{array}{l}10.0 \mathrm{mg} / \mathrm{L} \text { daily } \\
\text { maximum }\end{array}$} & \multicolumn{2}{|c|}{$\begin{array}{l}0.022 \mathrm{mg} / \mathrm{L} \text { daily } \\
\text { maximum }\end{array}$} & \multicolumn{2}{|c|}{ Monitor } \\
\hline Month & Avg & Max & Avg & Max & Avg & Max & Avg & Max \\
\hline January & 0.13 & 0.14 & $<2.0$ & $<2.0$ & $<0.003$ & $<0.003$ & 0.292 & 0.381 \\
\hline February $^{a}$ & -- & -- & -- & -- & -- & -- & -- & -- \\
\hline March & 0.11 & 0.13 & $<2.0$ & $<2.0$ & $<0.0030$ & $<0.0030$ & 0.312 & 0.433 \\
\hline April & 0.05 & 0.07 & $<3.0$ & 4.0 & $<0.0043$ & 0.0055 & 0.271 & 0.334 \\
\hline May $^{a}$ & -- & -- & -- & -- & -- & -- & -- & -- \\
\hline June ${ }^{a}$ & -- & -- & -- & -- & -- & -- & -- & -- \\
\hline July & $<0.015$ & 0.018 & $<2.0$ & $<2.0$ & $<0.0030$ & $<0.0030$ & 0.203 & 0.211 \\
\hline August $^{a}$ & -- & -- & -- & -- & -- & -- & -- & -- \\
\hline September & $<0.014$ & 0.016 & $<2.3$ & 2.6 & $<0.0030$ & $<0.0030$ & 0.235 & 0.289 \\
\hline October $^{a}$ & -- & -- & -- & -- & -- & -- & -- & -- \\
\hline November & $<0.011$ & $<0.011$ & $<2.0$ & $<2.0$ & $<0.0052$ & 0.0074 & 0.193 & 0.243 \\
\hline December & 0.048 & 0.059 & $<2.0$ & $<2.0$ & $<0.0030$ & $<0.0030$ & 0.319 & 0.353 \\
\hline
\end{tabular}

\begin{tabular}{|c|c|c|c|c|c|c|}
\hline & \multicolumn{2}{|c|}{$\begin{array}{l}\text { Nitrate (as N) } \\
\quad(\mathrm{mg} / \mathrm{L})\end{array}$} & \multicolumn{2}{|c|}{$\begin{array}{l}\text { Nitrite (as N) } \\
\quad(\mathrm{mg} / \mathrm{L})\end{array}$} & \multicolumn{2}{|c|}{$\begin{array}{c}\text { Oil \& Grease } \\
\quad(\mathrm{mg} / \mathrm{L})\end{array}$} \\
\hline Permit limit & \multicolumn{2}{|c|}{ Monitor } & \multicolumn{2}{|c|}{$\begin{array}{l}0.1 \mathrm{mg} / \mathrm{L} \text { daily } \\
\text { maximum }\end{array}$} & \multicolumn{2}{|c|}{$\begin{array}{l}15.0 \mathrm{mg} / \mathrm{L} \text { daily } \\
\text { maximum }\end{array}$} \\
\hline Month & Avg & Max & Avg & Max & Avg & Max \\
\hline January & 0.88 & 0.91 & $<0.05$ & $<0.05$ & $<2.7$ & $<2.7$ \\
\hline February $^{a}$ & -- & -- & -- & -- & -- & -- \\
\hline March & 1.1 & 1.1 & $<0.05$ & $<0.05$ & $<2.7$ & $<2.7$ \\
\hline April & 0.71 & 0.73 & $<0.05$ & $<0.05$ & $<2.7$ & $<2.7$ \\
\hline $\operatorname{May}^{a}$ & -- & -- & -- & -- & -- & -- \\
\hline June ${ }^{a}$ & -- & -- & -- & -- & -- & -- \\
\hline July & $<0.036$ & $<0.036$ & $<0.05$ & $<0.05$ & $<2.7$ & $<2.7$ \\
\hline August $^{a}$ & -- & -- & -- & -- & -- & -- \\
\hline September & $<0.036$ & $<0.036$ & $<0.05$ & $<0.05$ & $<2.7$ & $<2.7$ \\
\hline October $^{a}$ & -- & -- & -- & -- & -- & -- \\
\hline November & $<0.011$ & $<0.011$ & $<0.02$ & $<0.02$ & $<3.6$ & 5.0 \\
\hline December & 0.27 & 0.28 & $<0.02$ & $<0.02$ & $<2.2$ & $<2.2$ \\
\hline
\end{tabular}

Note: No results exceeded the permit limits.

a No discharge this month 
Table C-2C (concluded)

2005 SPDES Results for Outfall 001 (WNSP001):

Water Quality

\begin{tabular}{|c|c|c|c|c|c|c|c|c|}
\hline \multirow{3}{*}{$\begin{array}{l}\text { Permit limit } \\
\text { Month }\end{array}$} & \multicolumn{2}{|c|}{$\begin{array}{c}\mathbf{p H} \\
\text { (standard units) }\end{array}$} & \multicolumn{2}{|c|}{$\begin{array}{c}\text { Solids } \\
\text { Settleable } \\
(\mathrm{mL} / \mathrm{L})\end{array}$} & \multicolumn{2}{|c|}{$\begin{array}{c}\text { Solids } \\
\text { Total Dissolved } \\
(\mathrm{mg} / \mathrm{L})\end{array}$} & \multicolumn{2}{|c|}{$\begin{array}{c}\text { Solids } \\
\text { Total Suspended } \\
\text { (mg/L) }\end{array}$} \\
\hline & \multicolumn{2}{|c|}{$6.5-8.5$} & \multicolumn{2}{|c|}{$\begin{array}{l}0.3 \mathrm{~mL} / \mathrm{L} \text { daily } \\
\text { maximum }\end{array}$} & \multicolumn{2}{|c|}{ Monitor } & \multicolumn{2}{|c|}{$\begin{array}{c}45 \mathrm{mg} / \mathrm{L} \text { daily maximum; } \\
30 \text { daily average }\end{array}$} \\
\hline & Min & Max & Avg & Max & Avg & Max & Avg & Max \\
\hline January & 7.3 & 7.4 & $<0.1$ & $<0.1$ & 682 & 695 & $<4.0$ & $<4.0$ \\
\hline February $^{a}$ & -- & -- & -- & -- & -- & -- & -- & -- \\
\hline March & 7.6 & 7.7 & $<0.1$ & $<0.1$ & 709 & 709 & $<4.0$ & $<4.0$ \\
\hline April & 7.6 & 7.9 & $<0.1$ & $<0.1$ & 561 & 635 & $<4.0$ & $<4.0$ \\
\hline May $^{a}$ & -- & -- & -- & -- & -- & -- & -- & -- \\
\hline June ${ }^{a}$ & -- & -- & -- & -- & -- & -- & -- & -- \\
\hline July & 7.7 & 8.1 & $<0.1$ & $<0.1$ & 767 & 779 & $<4.0$ & $<4.0$ \\
\hline August ${ }^{a}$ & -- & -- & -- & -- & -- & -- & -- & -- \\
\hline September & 7.4 & 8.0 & $<0.1$ & $<0.1$ & 723 & 724 & $<5.5$ & 7.0 \\
\hline October $^{a}$ & -- & -- & -- & -- & -- & -- & -- & -- \\
\hline November & 7.3 & 7.9 & $<0.1$ & $<0.1$ & 712 & 723 & $<4.5$ & 5.0 \\
\hline December & 7.6 & 7.8 & $<0.1$ & $<0.1$ & 660 & 660 & $<7.0$ & 10.0 \\
\hline
\end{tabular}

\begin{tabular}{|c|c|c|c|c|c|c|}
\hline \multirow{3}{*}{$\begin{array}{l}\text { Permit limit } \\
\text { Month }\end{array}$} & \multicolumn{2}{|c|}{$\begin{array}{c}\text { Sulfate (as S) } \\
(\mathrm{mg} / \mathrm{L})\end{array}$} & \multicolumn{2}{|c|}{$\begin{array}{c}\text { Sulfide (as S) } \\
\text { Dissolved } \\
(\mathrm{mg} / \mathrm{L})\end{array}$} & \multicolumn{2}{|c|}{$\begin{array}{c}\text { Surfactant } \\
\text { as LAS } \\
(\mathrm{mg} / \mathrm{L})\end{array}$} \\
\hline & \multicolumn{2}{|c|}{ Monitor } & \multicolumn{2}{|c|}{$\begin{array}{l}0.4 \mathrm{mg} / \mathrm{L} \text { daily } \\
\text { maximum }\end{array}$} & \multicolumn{2}{|c|}{$\begin{array}{l}0.4 \mathrm{mg} / \mathrm{L} \text { daily } \\
\text { maximum }\end{array}$} \\
\hline & Avg & Max & Avg & Max & Avg & Max \\
\hline January & 49 & 50 & $<0.04$ & $<0.04$ & $<0.01$ & 0.02 \\
\hline February $^{a}$ & -- & -- & -- & -- & -- & -- \\
\hline March & 31 & 32 & $<0.04$ & $<0.04$ & 0.04 & 0.06 \\
\hline April & 19 & 19 & $<0.04$ & $<0.04$ & 0.04 & 0.05 \\
\hline$M a y^{a}$ & -- & -- & -- & -- & -- & -- \\
\hline June ${ }^{a}$ & -- & -- & -- & -- & -- & -- \\
\hline July & 42 & 43 & $<0.04$ & $<0.04$ & $<0.04$ & 0.06 \\
\hline August $^{a}$ & -- & -- & -- & -- & -- & -- \\
\hline September & 49 & 51 & $<0.04$ & $<0.04$ & 0.03 & 0.05 \\
\hline October $^{a}$ & -- & -- & -- & -- & -- & -- \\
\hline November & 36 & 56 & $<0.03$ & 0.03 & $<0.01$ & $<0.01$ \\
\hline December & 45 & 47 & $<0.02$ & $<0.02$ & 0.06 & 0.1 \\
\hline
\end{tabular}

Note: No results exceeded the permit limits.

a No discharge this month 
Table C-2D

2005 SPDES Results for Outfall 001 (WNSP001):

Metals

\begin{tabular}{|c|c|c|c|c|c|c|c|c|}
\hline \multirow{3}{*}{$\begin{array}{l}\text { Permit limit } \\
\text { Month }\end{array}$} & \multicolumn{2}{|c|}{$\begin{array}{l}\text { Aluminum } \\
\text { Total } \\
(\mathrm{mg} / \mathrm{L})\end{array}$} & \multicolumn{2}{|c|}{$\begin{array}{c}\text { Arsenic } \\
\text { Dissolved } \\
(\mathrm{mg} / \mathrm{L})\end{array}$} & \multicolumn{2}{|c|}{$\begin{array}{c}\text { Cadmium } \\
\text { Total Recoverable } \\
(\mathrm{mg} / \mathrm{L})\end{array}$} & \multicolumn{2}{|c|}{$\begin{array}{c}\text { Cobalt } \\
\text { Total Recoverable } \\
(\mathrm{mg} / \mathrm{L})\end{array}$} \\
\hline & $\begin{array}{r}14.0 \mathrm{mg} / \mathrm{I} \\
7.0 \mathrm{mg} /\end{array}$ & $\begin{array}{l}\text { maximum; } \\
\text { y average }\end{array}$ & $\begin{array}{r}0.15 \\
\mathrm{~m}\end{array}$ & daily & $\begin{array}{r}0.002 \\
\mathrm{~m}\end{array}$ & $\begin{array}{l}\text { L daily } \\
\text { lum }\end{array}$ & $\begin{array}{r}0.00 \\
\mathrm{n}\end{array}$ & $\begin{array}{l}\text { L daily } \\
\text { uum }\end{array}$ \\
\hline & Avg & Max & Avg & Max & Avg & Max & Avg & Max \\
\hline January & 0.145 & 0.199 & 0.0015 & 0.0019 & $<0.0006$ & $<0.0006$ & $<0.002$ & $<0.002$ \\
\hline February $^{a}$ & -- & -- & -- & -- & -- & -- & -- & -- \\
\hline March & 0.068 & 0.0749 & 0.00066 & 0.00068 & $<0.0003$ & $<0.0003$ & $<0.0008$ & $<0.0008$ \\
\hline April & 0.21 & 0.320 & 0.00068 & 0.00073 & $<0.0003$ & $<0.0003$ & $<0.0008$ & $<0.0008$ \\
\hline May $^{a}$ & -- & - & -- & -- & -- & -- & -- & -- \\
\hline June $^{a}$ & -- & - & -- & -- & -- & -- & -- & -- \\
\hline July & 0.465 & 0.904 & $<0.0026$ & $<0.0029$ & $<0.0003$ & $<0.0003$ & $<0.0008$ & $<0.0008$ \\
\hline August $^{a}$ & -- & - & -- & -- & -- & -- & -- & -- \\
\hline September & 0.145 & 0.229 & $<0.0026$ & $<0.0034$ & $<0.0003$ & $<0.0003$ & $<0.0008$ & $<0.0008$ \\
\hline October $^{a}$ & -- & - & -- & -- & -- & -- & -- & -- \\
\hline November & 0.222 & 0.270 & 0.0018 & 0.0019 & $<0.0003$ & $<0.0003$ & $<0.0008$ & $<0.0008$ \\
\hline December & 0.869 & 1.35 & $<0.0034$ & $<0.0034$ & $<0.0003$ & $<0.0003$ & $<0.0008$ & $<0.0008$ \\
\hline
\end{tabular}

\begin{tabular}{|c|c|c|c|c|c|c|c|c|}
\hline \multirow{3}{*}{$\begin{array}{l}\text { Permit limit } \\
\text { Month }\end{array}$} & \multirow{2}{*}{\multicolumn{2}{|c|}{$\begin{array}{c}\text { Chromium } \\
\text { Total Recoverable } \\
(\mathrm{mg} / \mathrm{L})\end{array}$}} & \multirow{2}{*}{\multicolumn{2}{|c|}{$\begin{array}{c}\text { Chromium VI } \\
\text { Total Recoverable } \\
(\mathrm{mg} / \mathrm{L})\end{array}$}} & \multirow{2}{*}{\multicolumn{2}{|c|}{$\begin{array}{c}\text { Copper } \\
\text { Dissolved } \\
(\mathrm{mg} / \mathrm{L})\end{array}$}} & \multirow{2}{*}{\multicolumn{2}{|c|}{$\begin{array}{c}\text { Copper } \\
\text { Total Recoverable } \\
(\mathrm{mg} / \mathrm{L})\end{array}$}} \\
\hline & & & & & & & & \\
\hline & Avg & Max & Avg & Max & Avg & Max & Avg & Max \\
\hline January & $<0.0009$ & $<0.0009$ & $<0.008$ & $<0.008$ & 0.0057 & 0.0084 & 0.0042 & 0.0045 \\
\hline February $^{a}$ & -- & - & -- & -- & -- & -- & -- & -- \\
\hline March & $<0.0009$ & $<0.0009$ & $<0.008$ & $<0.008$ & 0.0023 & 0.0027 & 0.0024 & 0.0026 \\
\hline April & $<0.0009$ & $<0.0009$ & $<0.008$ & $<0.008$ & 0.003 & 0.004 & 0.0022 & 0.0029 \\
\hline $\operatorname{May}^{a}$ & -- & - & -- & -- & -- & -- & -- & -- \\
\hline June ${ }^{a}$ & -- & - & -- & -- & -- & -- & -- & -- \\
\hline July & $<0.0009$ & $<0.0009$ & $<0.008$ & $<0.008$ & 0.0020 & 0.0027 & 0.0024 & 0.0024 \\
\hline August $^{a}$ & -- & - & -- & -- & -- & -- & -- & -- \\
\hline September & $<0.0009$ & $<0.0009$ & $<0.008$ & $<0.008$ & 0.0035 & 0.0038 & 0.0022 & 0.0022 \\
\hline October $^{a}$ & -- & - & -- & -- & -- & -- & -- & -- \\
\hline November & $<0.0009$ & $<0.0009$ & $<0.0045$ & $<0.008$ & 0.0050 & 0.0062 & 0.0045 & 0.0046 \\
\hline December & $<0.0009$ & $<0.0009$ & $<0.008$ & $<0.008$ & 0.0024 & 0.0030 & $<0.0016$ & $<0.0016$ \\
\hline
\end{tabular}

Note: No results exceeded the permit limits.

a No discharge this month 
Table C-2D (concluded)

\section{SPDES Results for Outfall 001 (WNSP001): Metals}

\begin{tabular}{|c|c|c|c|c|c|c|c|c|c|c|}
\hline & \multicolumn{2}{|c|}{$\begin{array}{l}\text { Iron } \\
\text { Total } \\
(\mathrm{mg} / \mathrm{L})\end{array}$} & \multicolumn{2}{|c|}{$\begin{array}{c}\text { Lead } \\
\text { Total Recoverable } \\
(\mathrm{mg} / \mathrm{L})\end{array}$} & \multicolumn{2}{|c|}{$\begin{array}{c}\text { Manganese } \\
\text { Total } \\
(\mathrm{mg} / \mathrm{L})\end{array}$} & \multicolumn{2}{|c|}{$\begin{array}{l}\text { Mercury, Total } \\
\text { (per EPA Method } \\
\text { 245.1) }(\mathrm{mg} / \mathrm{L})\end{array}$} & \multicolumn{2}{|c|}{$\begin{array}{l}\text { Mercury, Total } \\
\text { (per EPA Method } \\
\text { 1631) }(\mu \mathrm{g} / \mathrm{L})\end{array}$} \\
\hline Permit limit & \multicolumn{2}{|c|}{ Monitor } & \multicolumn{2}{|c|}{$\begin{array}{l}0.006 \mathrm{mg} / \mathrm{L} \text { daily } \\
\text { maximum }\end{array}$} & \multicolumn{2}{|c|}{$\begin{array}{l}2.0 \mathrm{mg} / \mathrm{L} \text { daily } \\
\text { maximum }\end{array}$} & \multicolumn{2}{|c|}{$\begin{array}{c}0.0002 \mathrm{mg} / \mathrm{L} \text { daily } \\
\text { maximum }\end{array}$} & \multicolumn{2}{|c|}{ Monitor } \\
\hline Month & Avg & Max & Avg & Max & Avg & Max & Avg & Max & Avg & Max \\
\hline January & 0.133 & 0.171 & $<0.0003$ & 0.0004 & 0.057 & 0.063 & $<0.0002$ & $<0.0002$ & 0.0082 & 0.0086 \\
\hline February $^{a}$ & -- & -- & -- & -- & -- & -- & -- & -- & -- & -- \\
\hline March & 0.0703 & 0.0756 & $<0.0003$ & $<0.0003$ & 0.031 & 0.032 & $<0.0002$ & $<0.0002$ & 0.0072 & 0.0075 \\
\hline April & 0.154 & 0.204 & $<0.0003$ & $<0.0003$ & 0.015 & 0.019 & $<0.0002$ & $<0.0002$ & 0.0026 & 0.0028 \\
\hline May $^{a}$ & -- & -- & -- & -- & -- & -- & -- & -- & -- & -- \\
\hline June ${ }^{a}$ & -- & -- & -- & -- & -- & -- & -- & -- & -- & -- \\
\hline July & 0.140 & 0.206 & $<0.0003$ & $<0.0003$ & 0.050 & 0.055 & $<0.0002$ & $<0.0002$ & 0.0025 & 0.0027 \\
\hline August $^{a}$ & -- & -- & -- & -- & -- & -- & -- & -- & -- & -- \\
\hline September & 0.169 & 0.246 & $<0.0003$ & $<0.0003$ & 0.056 & 0.071 & $<0.0002$ & $<0.0002$ & 0.0016 & 0.0018 \\
\hline October $^{a}$ & -- & -- & -- & -- & -- & -- & -- & -- & -- & -- \\
\hline November & 0.188 & 0.232 & 0.0004 & 0.0004 & 0.014 & 0.014 & $<0.0002$ & $<0.0002$ & 0.0041 & 0.0047 \\
\hline December & 0.641 & 0.957 & 0.0009 & 0.0009 & 0.028 & 0.031 & $<0.0002$ & $<0.0002$ & 0.0045 & 0.0046 \\
\hline
\end{tabular}

\begin{tabular}{|c|c|c|c|c|c|c|c|c|}
\hline \multirow{3}{*}{$\begin{array}{l}\text { Permit limit } \\
\text { Month }\end{array}$} & \multicolumn{2}{|c|}{$\begin{array}{c}\text { Nickel } \\
\text { Total Recoverable } \\
(\mathrm{mg} / \mathrm{L})\end{array}$} & \multicolumn{2}{|c|}{$\begin{array}{c}\text { Selenium } \\
\text { Total Recoverable } \\
(\mathrm{mg} / \mathrm{L})\end{array}$} & \multicolumn{2}{|c|}{$\begin{array}{c}\text { Vanadium } \\
\text { Total Recoverable } \\
(\mathrm{mg} / \mathrm{L})\end{array}$} & \multicolumn{2}{|c|}{$\begin{array}{c}\text { Zinc } \\
\text { Total Recoverable } \\
(\mathrm{mg} / \mathrm{L})\end{array}$} \\
\hline & $\begin{array}{r}0.14 \mathrm{~ms} \\
\max \end{array}$ & $\begin{array}{l}\text { L daily } \\
\text { num }\end{array}$ & $\begin{array}{r}0.004 \mathrm{~m} \\
\max \end{array}$ & $\begin{array}{l}\text { L daily } \\
\text { num }\end{array}$ & $\begin{array}{r}0.014 \mathrm{~m} \\
\max \end{array}$ & $\begin{array}{l}\mathrm{g} / \mathrm{L} \text { daily } \\
\text { mum }\end{array}$ & $\begin{array}{r}0.48 \mathrm{n} \\
\mathrm{ma}\end{array}$ & $\begin{array}{l}\text { L daily } \\
\text { num }\end{array}$ \\
\hline & Avg & Max & Avg & Max & Avg & Max & Avg & Max \\
\hline January & $<0.0019$ & & 0.0008 & & $<0.0011$ & $<0.0011$ & 0.0079 & 0.0096 \\
\hline February $^{a}$ & -- & -- & -- & -- & -- & -- & -- & -- \\
\hline March & 0.0017 & 0.0018 & $<0.0006$ & 0.0008 & $<0.00098$ & $<0.00098$ & 0.0058 & 0.0063 \\
\hline April & 0.0013 & 0.0017 & $<0.0004$ & $<0.0004$ & $<0.00098$ & $<0.00098$ & 0.0053 & 0.0072 \\
\hline May ${ }^{a}$ & -- & -- & -- & -- & -- & -- & -- & -- \\
\hline June ${ }^{a}$ & -- & -- & -- & -- & -- & -- & - & -- \\
\hline July & 0.0019 & 0.0022 & $<0.0004$ & $<0.0004$ & $<0.00098$ & $<0.00098$ & 0.0072 & 0.010 \\
\hline August $^{a}$ & -- & -- & -- & -- & -- & -- & -- & -- \\
\hline September & 0.0014 & 0.0014 & $<0.0004$ & $<0.0004$ & $<0.00098$ & $<0.00098$ & 0.0040 & 0.0043 \\
\hline October $^{a}$ & -- & -- & -- & -- & -- & -- & -- & -- \\
\hline November & 0.0018 & 0.0022 & $<0.0004$ & $<0.0004$ & $<0.00098$ & $<0.00098$ & 0.0065 & 0.0072 \\
\hline December & 0.0022 & 0.0027 & $<0.0004$ & $<0.0004$ & 0.0014 & 0.0017 & 0.0083 & 0.013 \\
\hline
\end{tabular}

Note: No results exceeded the permit limits.

${ }^{a}$ No discharge this month 
Table C-2E

2005 SPDES Results for Outfall 007 (WNSP007):

Water Quality and Iron

\begin{tabular}{|c|c|c|c|c|c|c|c|c|c|c|}
\hline & \multicolumn{2}{|c|}{$\begin{array}{c}\text { Ammonia } \\
\left(\text { as } \mathbf{N H}_{3}\right) \\
(\mathrm{mo} / \mathrm{L})\end{array}$} & \multicolumn{2}{|c|}{$\begin{array}{l}\text { BOD }_{\mathbf{5}} \\
(\mathrm{mg} / \mathrm{L})\end{array}$} & \multicolumn{2}{|c|}{$\begin{array}{c}\text { Chlorine } \\
\text { Total Residual } \\
(\mathrm{m} / \mathrm{L})\end{array}$} & \multicolumn{2}{|c|}{$\begin{array}{l}\text { Discharge Rate } \\
\text { (MGD) }\end{array}$} & \multicolumn{2}{|c|}{$\begin{array}{c}\text { Iron } \\
\text { Total } \\
(\mathrm{mg} / \mathrm{L})\end{array}$} \\
\hline $\begin{array}{l}\text { Permit } \\
\text { limit }\end{array}$ & \multicolumn{2}{|c|}{ Monitor } & \multicolumn{2}{|c|}{$\begin{array}{l}10.0 \mathrm{mg} / \mathrm{L} \text { daily } \\
\text { maximum }\end{array}$} & \multicolumn{2}{|c|}{$\begin{array}{l}0.1 \mathrm{mg} / \mathrm{L} \text { daily } \\
\text { maximum }\end{array}$} & \multicolumn{2}{|c|}{ Monitor } & \multicolumn{2}{|c|}{ Monitor } \\
\hline Month & Avg & Max & Avg & Max & Avg & Max & Avg & Max & Avg & Max \\
\hline January & $<0.020$ & 0.030 & $<2.27$ & 2.8 & 0.02 & 0.03 & 0.023 & 0.033 & $<0.047$ & 0.091 \\
\hline February & $<0.020$ & 0.037 & $<2.0$ & $<2.0$ & 0.02 & 0.02 & 0.024 & 0.032 & 0.137 & 0.195 \\
\hline March & $<0.033$ & 0.046 & $<2.0$ & $<2.0$ & 0.03 & 0.06 & 0.026 & 0.033 & 0.114 & 0.187 \\
\hline April & $<0.036$ & 0.055 & $<2.5$ & 3.4 & 0.03 & 0.06 & 0.028 & 0.031 & 0.101 & 0.169 \\
\hline May & $<0.023$ & 0.046 & $<3.2$ & 4.2 & 0.01 & 0.02 & 0.020 & 0.035 & 0.0954 & 0.115 \\
\hline June & 0.033 & 0.044 & $<2.0$ & $<2.0$ & 0.01 & 0.02 & 0.017 & 0.026 & 0.072 & 0.088 \\
\hline July & $<0.019$ & 0.022 & $<2.3$ & 2.9 & 0.01 & 0.01 & 0.019 & 0.023 & 0.0351 & 0.0577 \\
\hline August & $<0.051$ & 0.13 & $<2.7$ & 3.4 & $<0.01$ & 0.02 & 0.023 & 0.028 & 0.048 & 0.059 \\
\hline September & $<0.022$ & 0.028 & $<2.0$ & $<2.0$ & $<0.01$ & 0.02 & 0.011 & 0.024 & $<0.034$ & 0.0495 \\
\hline October & $<0.016$ & 0.022 & $<2.9$ & 4.6 & $<0.02$ & 0.02 & 0.010 & 0.012 & 0.0437 & 0.0682 \\
\hline November & $<0.011$ & $<0.011$ & $<2.77$ & 4.0 & $<0.01$ & 0.02 & 0.012 & 0.016 & 0.0547 & 0.117 \\
\hline December & $<0.011$ & $<0.011$ & $<2.33$ & 3.0 & 0.02 & 0.04 & 0.009 & 0.012 & 0.0575 & 0.0686 \\
\hline
\end{tabular}

\begin{tabular}{|c|c|c|c|c|c|c|c|c|c|c|}
\hline \multirow{3}{*}{\begin{tabular}{|c|} 
\\
$\begin{array}{c}\text { Permit } \\
\text { limit }\end{array}$ \\
Month \\
\end{tabular}} & \multirow{2}{*}{\multicolumn{2}{|c|}{$\begin{array}{c}\begin{array}{c}\text { Nitrite } \\
(\operatorname{as} \mathbf{N}) \\
(\mathrm{mg} / \mathrm{L})\end{array} \\
0.1 \mathrm{mg} / \mathrm{L} \text { daily } \\
\text { maximum }\end{array}$}} & \multirow{2}{*}{\multicolumn{2}{|c|}{$\begin{array}{c}\begin{array}{c}\text { Oil \& Grease } \\
(\mathrm{mg} / \mathrm{L})\end{array} \\
\begin{array}{c}15.0 \mathrm{mg} / \mathrm{L} \text { daily } \\
\text { maximum }\end{array}\end{array}$}} & \multirow{2}{*}{\multicolumn{2}{|c|}{$\begin{array}{c}\mathbf{p H} \\
\text { (standard units) } \\
6.5 \text { to } 8.5\end{array}$}} & \multirow{2}{*}{\multicolumn{2}{|c|}{$\begin{array}{c}\text { Solids } \\
\text { Settleable } \\
(\mathrm{mL} / \mathrm{L}) \\
0.3 \mathrm{~mL} / \mathrm{L} \text { daily } \\
\text { maximum }\end{array}$}} & \multirow{2}{*}{\multicolumn{2}{|c|}{$\begin{array}{c}\text { Solids } \\
\text { Total Suspended } \\
(\mathrm{mg} / \mathrm{L})\end{array}$}} \\
\hline & & & & & & & & & & \\
\hline & Avg & Max & Avg & Max & Min & Max & Avg & Max & Avg & Max \\
\hline January & $<0.05$ & $<0.05$ & $<2.7$ & $<2.7$ & 7.3 & 7.8 & $<0.1$ & $<0.1$ & $<4.0$ & $<4.0$ \\
\hline February & $<0.05$ & $<0.05$ & $<2.7$ & $<2.7$ & 7.2 & 7.9 & $<0.1$ & $<0.1$ & $<5.3$ & 8.0 \\
\hline March & $<0.05$ & $<0.05$ & $<2.7$ & $<2.7$ & 7.0 & 7.9 & $<0.1$ & $<0.1$ & $<4.0$ & $<4.0$ \\
\hline April & $<0.05$ & $<0.05$ & $<2.7$ & $<2.7$ & 7.5 & 7.5 & $<0.1$ & $<0.1$ & $<5.7$ & 9.0 \\
\hline May & $<0.05$ & $<0.05$ & $<2.7$ & $<2.7$ & 7.4 & 7.7 & $<0.1$ & $<0.1$ & $<4.0$ & $<4.0$ \\
\hline June & $<0.05$ & $<0.05$ & $<2.7$ & $<2.7$ & 7.4 & 7.6 & $<0.1$ & $<0.1$ & $<4.0$ & $<4.0$ \\
\hline July & $<0.05$ & $<0.05$ & $<2.7$ & $<2.7$ & 7.5 & 7.9 & $<0.1$ & 0.1 & $<4.0$ & 4.0 \\
\hline August & $<0.05$ & $<0.05$ & $<2.7$ & $<2.7$ & 7.3 & 7.6 & $<0.1$ & $<0.1$ & $<4.0$ & $<4.0$ \\
\hline September & $<0.05$ & $<0.05$ & $<2.7$ & $<2.7$ & 7.1 & 7.4 & $<0.1$ & 0.1 & $<4.0$ & 4.0 \\
\hline October & $<0.04$ & $<0.05$ & $<2.3$ & 2.6 & 7.6 & 7.9 & $<0.1$ & $<0.1$ & $<4.0$ & $<4.0$ \\
\hline November & $<0.02$ & $<0.02$ & $<3.1$ & 4.8 & 7.4 & 7.9 & $<0.1$ & $<0.1$ & $<4.0$ & $<4.0$ \\
\hline December & $<0.02$ & $<0.02$ & $<2.3$ & 2.6 & 7.2 & 7.9 & $<0.1$ & $<0.1$ & $<4.0$ & $<4.0$ \\
\hline
\end{tabular}

Note: No results exceeded the permit limits. 
Table C-2F

2005 SPDES Results for Sums of Outfalls 001, 007, 008, and 116:

Water Quality

\section{Results for Sums of Outfalls 001, 007 and 008}

\begin{tabular}{|c|c|c|c|c|c|c|}
\hline \multirow{3}{*}{$\begin{array}{l}\text { Permit limit } \\
\text { Month }\end{array}$} & \multicolumn{2}{|c|}{$\begin{array}{c}\text { Ammonia }^{\mathbf{a}} \\
\text { Flow-Weighted } \\
(\mathrm{mg} / \mathrm{L})\end{array}$} & \multirow{2}{*}{\multicolumn{2}{|c|}{$\begin{array}{c}\begin{array}{c}\text { BOD }_{5} \text { day } \\
(\mathrm{mg} / \mathrm{L})\end{array} \\
5.0 \text { daily average }\end{array}$}} & \multicolumn{2}{|c|}{$\begin{array}{c}\text { Iron Total } \\
\text { Flow-Weighted } \\
(\mathrm{mg} / \mathrm{L})\end{array}$} \\
\hline & \multirow{2}{*}{$\begin{array}{c}1.49 \text { daily } \\
\text { average } \\
\text { Avg }\end{array}$} & \multirow{2}{*}{$\begin{array}{c}2.1 \text { daily } \\
\text { maximum } \\
\mathbf{M a x}\end{array}$} & & & Monitor & 0.30 daily \\
\hline & & & Avg & Max & Avg & Max \\
\hline January & $<0.087$ & 0.14 & $<2.0$ & $<2.1$ & 0.00 & 0.00 \\
\hline February & $<0.020$ & 0.037 & $<2.0$ & $<2.0$ & 0.00 & 0.00 \\
\hline March & $<0.077$ & 0.12 & $<2.0$ & $<2.0$ & 0.00 & 0.00 \\
\hline April & $<0.050$ & 0.067 & $<2.7$ & 3.9 & 0.00 & 0.00 \\
\hline May & $<0.023$ & 0.046 & $<3.2$ & 4.2 & 0.00 & 0.00 \\
\hline June & 0.033 & 0.044 & $<2.0$ & $<2.0$ & 0.00 & 0.00 \\
\hline July & $<0.017$ & 0.022 & $<2.0$ & $<2.1$ & 0.00 & 0.00 \\
\hline August & $<0.051$ & 0.13 & $<2.7$ & 3.4 & 0.00 & 0.00 \\
\hline September & $<0.014$ & 0.016 & $<2.2$ & $<2.6$ & 0.00 & 0.00 \\
\hline October & $<0.016$ & 0.022 & $<2.9$ & 4.6 & 0.00 & 0.00 \\
\hline November & $<0.011$ & $<0.011$ & $<2.7$ & 4.0 & 0.00 & 0.00 \\
\hline December & $<0.035$ & $<0.057$ & $<2.3$ & 3.0 & 0.00 & 0.00 \\
\hline
\end{tabular}

\section{$\underline{2005}$ Results for Outfall 116}

\begin{tabular}{|c|c|c|}
\hline & \multicolumn{2}{|c|}{$\begin{array}{c}\text { Total Dissolved Solids } \\
(\mathrm{mg} / \mathrm{L})\end{array}$} \\
\hline Permit limit & \multicolumn{2}{|c|}{$\begin{array}{l}500 \mathrm{mg} / \mathrm{L} \text { daily } \\
\text { maximum }\end{array}$} \\
\hline Month & Avg & Max \\
\hline January & 353 & 381 \\
\hline February $^{b}$ & -- & -- \\
\hline March & 387 & 396 \\
\hline April & 293 & 348 \\
\hline$M a y^{b}$ & -- & -- \\
\hline June $e^{b}$ & -- & -- \\
\hline July & 380 & 405 \\
\hline August $^{b}$ & -- & -- \\
\hline September & 313 & 320 \\
\hline October ${ }^{b}$ & -- & -- \\
\hline November & 227 & 258 \\
\hline December & 387 & 432 \\
\hline
\end{tabular}

Note: No results exceeded the permit limits.

a Sum of Outfalls 001 and 007 only

${ }^{b}$ No discharge this month 


\section{Table C-2G}

\section{Quarterly/Semiannual/Annual SPDES Results for Outfall 001 (WNSP001): Water Quality, Metals, and Organics}

\begin{tabular}{|c|c|c|c|c|}
\hline Permit Limit Parameters & Permit Limit & $\begin{array}{l}\text { Monitoring } \\
\text { Frequency }\end{array}$ & $\begin{array}{l}\text { Collection } \\
\text { Date }\end{array}$ & $\begin{array}{l}\text { Maximum } \\
\text { Measured }\end{array}$ \\
\hline $\begin{array}{c}\text { 2-Butanone } \\
(\mathrm{mg} / \mathrm{L})\end{array}$ & $\begin{array}{l}0.5 \mathrm{mg} / \mathrm{L} \text { daily } \\
\text { maximum }\end{array}$ & Annual & March 2005 & $<0.005$ \\
\hline $\begin{array}{c}\text { 3,3-Dichlorobenzidine } \\
(\mathrm{mg} / \mathrm{L})\end{array}$ & $\begin{array}{l}0.01 \mathrm{mg} / \mathrm{L} \text { daily } \\
\text { maximum }\end{array}$ & Annual & March 2005 & $<0.007$ \\
\hline $\begin{array}{c}\text { Alpha-BHC } \\
(\mathrm{mg} / \mathrm{L})\end{array}$ & $\begin{array}{c}0.00001 \mathrm{mg} / \mathrm{L} \text { daily } \\
\text { maximum }\end{array}$ & Annual & March 2005 & $<0.000001$ \\
\hline $\begin{array}{l}\text { Dichlorodifluoromethane } \\
(\mathrm{mg} / \mathrm{L})\end{array}$ & $\begin{array}{l}0.01 \mathrm{mg} / \mathrm{L} \text { daily } \\
\text { maximum }\end{array}$ & Annual & March 2005 & $<0.002$ \\
\hline $\begin{array}{c}\text { Heptachlor } \\
(\mathrm{mg} / \mathrm{L})\end{array}$ & $\begin{array}{l}0.00001 \mathrm{mg} / \mathrm{L} \text { daily } \\
\text { maximum }\end{array}$ & Semiannual & $\begin{array}{c}\text { March } 2005 \\
\text { September } 2005\end{array}$ & $\begin{array}{l}<0.0000008 \\
<0.0000008\end{array}$ \\
\hline $\begin{array}{c}\text { Hexachlorobenzene } \\
(\mathrm{mg} / \mathrm{L})\end{array}$ & $\begin{array}{l}0.02 \mathrm{mg} / \mathrm{L} \text { daily } \\
\text { maximum }\end{array}$ & Annual & March 2005 & $<0.007$ \\
\hline $\begin{array}{c}\text { Tributyl Phosphate } \\
(\mathrm{mg} / \mathrm{L})\end{array}$ & $\begin{array}{l}32 \mathrm{mg} / \mathrm{L} \text { daily } \\
\text { maximum }\end{array}$ & Annual & March 2005 & $<0.0013$ \\
\hline $\begin{array}{c}\text { Trichlorofluoromethane } \\
(\mathrm{mg} / \mathrm{L})\end{array}$ & $\begin{array}{l}0.01 \mathrm{mg} / \mathrm{L} \text { daily } \\
\text { maximum }\end{array}$ & Annual & March 2005 & $<0.002$ \\
\hline $\begin{array}{l}\text { Xylene } \\
(\mathrm{mg} / \mathrm{L})\end{array}$ & $\begin{array}{l}0.05 \mathrm{mg} / \mathrm{L} \text { daily } \\
\text { maximum }\end{array}$ & Annual & March 2005 & $<0.007$ \\
\hline Action Level Parameters & Action Level & $\begin{array}{l}\text { Monitoring } \\
\text { Frequency }\end{array}$ & $\begin{array}{l}\text { Collection } \\
\text { Date }\end{array}$ & $\begin{array}{l}\text { Maximum } \\
\text { Measured }\end{array}$ \\
\hline $\begin{array}{c}\text { Antimony, Total } \\
(\mathrm{mg} / \mathrm{L})\end{array}$ & $\begin{array}{l}1.0 \mathrm{mg} / \mathrm{L} \text { daily } \\
\text { maximum }\end{array}$ & Annual & March 2005 & $<0.020$ \\
\hline $\begin{array}{c}\text { Barium, Total } \\
(\mathrm{mg} / \mathrm{L})\end{array}$ & $\begin{array}{l}0.5 \mathrm{mg} / \mathrm{L} \text { daily } \\
\text { maximum }\end{array}$ & Annual & March 2005 & 0.03 \\
\hline $\begin{array}{l}\text { Boron, Total } \\
(\mathrm{mg} / \mathrm{L})\end{array}$ & $\begin{array}{l}2.0 \mathrm{mg} / \mathrm{L} \text { daily } \\
\text { maximum }\end{array}$ & Quarterly & $\begin{array}{c}\text { March } 2005 \\
\text { July } 2005 \\
\text { September } 2005 \\
\text { November } 2005\end{array}$ & $\begin{array}{l}0.034 \\
0.036 \\
0.040 \\
0.042\end{array}$ \\
\hline $\begin{array}{c}\text { Bromide, Total } \\
(\mathrm{mg} / \mathrm{L})\end{array}$ & $\begin{array}{l}5.0 \mathrm{mg} / \mathrm{L} \text { daily } \\
\text { maximum }\end{array}$ & Quarterly & $\begin{array}{c}\text { March } 2005 \\
\text { July } 2005 \\
\text { September } 2005 \\
\text { November } 2005\end{array}$ & $\begin{array}{c}1.2 \\
1.4 \\
1.4 \\
0.85\end{array}$ \\
\hline $\begin{array}{c}\text { Chloroform } \\
(\mathrm{mg} / \mathrm{L})\end{array}$ & $\begin{array}{l}0.3 \mathrm{mg} / \mathrm{L} \text { daily } \\
\text { maximum }\end{array}$ & Annual & March 2005 & $<0.0009$ \\
\hline $\begin{array}{c}\text { Titanium, Total } \\
(\mathrm{mg} / \mathrm{L})\end{array}$ & $\begin{array}{l}0.65 \mathrm{mg} / \mathrm{L} \text { daily } \\
\text { maximum }\end{array}$ & Semiannual & $\begin{array}{c}\text { March } 2005 \\
\text { September } 2005\end{array}$ & $\begin{array}{l}0.0011 \\
0.0052\end{array}$ \\
\hline
\end{tabular}

Note: No results exceeded the permit limits or action levels. 
Table $\mathrm{C}-2 \mathrm{H}$

2005 Annual SPDES Results for Outfall 007 (WNSP007):

Water Quality

\begin{tabular}{|c|c|c|c|c|}
\hline & $\begin{array}{c}\text { Action } \\
\text { Level }\end{array}$ & $\begin{array}{c}\text { Monitoring } \\
\text { Frequency }\end{array}$ & $\begin{array}{c}\text { Collection } \\
\text { Date }\end{array}$ & $\begin{array}{c}\text { Maximum } \\
\text { Measured }\end{array}$ \\
\hline $\begin{array}{c}\text { Chloroform } \\
(\mathrm{mg} / \mathrm{L})\end{array}$ & $\begin{array}{c}0.20 \mathrm{mg} / \mathrm{L} \text { daily } \\
\text { maximum }\end{array}$ & Annual & February 2005 & $<0.005$ \\
\hline
\end{tabular}

Table C-2I

2005 Annual SPDES Results for Outfall 01B (WNSP01B):

Water Quality

\begin{tabular}{|c|c|c|c|c|c|c|c|}
\hline \multirow{3}{*}{$\begin{array}{l}\text { Permit limit } \\
\text { Month }\end{array}$} & \multirow{2}{*}{\multicolumn{2}{|c|}{$\begin{array}{c}\text { Discharge Rate } \\
\text { (GPD) } \\
\text { Monitor }\end{array}$}} & \multirow[t]{3}{*}{$\mathbf{N}$} & \multirow{2}{*}{\multicolumn{2}{|c|}{$\begin{array}{c}\text { Mercury, Total } \\
\text { (per EPA Method 245.1) } \\
(\mu \mathrm{g} / \mathrm{L})\end{array}$}} & \multirow{2}{*}{\multicolumn{2}{|c|}{$\begin{array}{c}\text { Mercury, Total } \\
\text { (per EPA Method 1631) } \\
(\mu \mathrm{g} / \mathrm{L}) \\
\text { No Limit }\end{array}$}} \\
\hline & & & & & & & \\
\hline & Avg & Max & & Avg & Max & Avg & Max \\
\hline January & -- & -- & -- & -- & -- & -- & -- \\
\hline February & -- & -- & -- & -- & -- & -- & -- \\
\hline March & -- & -- & -- & -- & -- & -- & -- \\
\hline April & -- & -- & -- & -- & -- & -- & -- \\
\hline May & -- & -- & -- & -- & -- & -- & -- \\
\hline June & -- & -- & -- & -- & -- & -- & -- \\
\hline July & -- & -- & -- & -- & -- & -- & -- \\
\hline August & 5,251 & 6,492 & 2 & $<0.2$ & $<0.2$ & 0.00856 & 0.00921 \\
\hline September & -- & -- & -- & -- & -- & -- & -- \\
\hline October & -- & -- & -- & -- & -- & -- & -- \\
\hline November & -- & -- & -- & -- & -- & -- & -- \\
\hline December & -- & -- & -- & -- & -- & -- & -- \\
\hline
\end{tabular}

$N$ - Number of samples

\section{Table C-2J \\ 2005 SPDES Results for Outfall 008 (WNSP008): \\ Water Quality}

NO DISCHARGE;

DRAINAGE PIPE CAPPED IN MAY 2001

WVDP Annual Site Environmental Report

C -20

Calendar Year 2005 


\section{Table C-2K}

\section{Radioactivity at Sewage Treatment Outfall (WNSP007)}

\begin{tabular}{|l|c|c|c|c|c|c|}
\hline \multicolumn{1}{|c|}{ Isotope $^{\boldsymbol{a}}$} & $\mathbf{N}$ & $\begin{array}{c}\text { Discharge } \\
\text { Activity }^{\boldsymbol{b}} \\
\mathbf{( C i )}\end{array}$ & $\begin{array}{c}\text { Radioactivity }^{\boldsymbol{c}} \\
\text { Becquerels }\end{array}$ & $\begin{array}{c}\text { Average } \\
\text { Concentration } \\
(\boldsymbol{\mu C i} / \mathbf{m L})\end{array}$ & $\begin{array}{c}\text { DCG } \\
(\boldsymbol{\mu C i} / \mathbf{m L})\end{array}$ & \% of DCG \\
\hline Gross Alpha & 27 & $0.77 \pm 1.91 \mathrm{E}-05$ & $2.84 \pm 7.08 \mathrm{E}+05$ & $3.01 \pm 7.50 \mathrm{E}-10$ & NA $^{d}$ & NA \\
\hline Gross Beta & 27 & $3.38 \pm 0.32 \mathrm{E}-04$ & $1.25 \pm 0.12 \mathrm{E}+07$ & $1.32 \pm 0.12 \mathrm{E}-08$ & NA $^{d}$ & NA \\
\hline Tritium & 27 & $7.27 \pm 6.09 \mathrm{E}-04$ & $2.69 \pm 2.25 \mathrm{E}+07$ & $2.85 \pm 2.39 \mathrm{E}-08$ & $2 \mathrm{E}-03$ & $<0.01$ \\
\hline Sr-90 & 3 & $1.05 \pm 0.23 \mathrm{E}-04$ & $3.87 \pm 0.84 \mathrm{E}+06$ & $4.10 \pm 0.89 \mathrm{E}-09$ & $1 \mathrm{E}-06$ & 0.41 \\
\hline Cs-137 & 3 & $2.59 \pm 2.56 \mathrm{E}-05$ & $9.58 \pm 9.46 \mathrm{E}+05$ & $1.01 \pm 1.00 \mathrm{E}-09$ & $3 \mathrm{E}-06$ & 0.03 \\
\hline Total \% DCG & & & & & 0.44 \\
\hline
\end{tabular}

Note: Strontium-90 (Sr-90) analysis in water was performed by a non-NYSDOH ELAP-certified analytical method. See Chapter 5.

$\mathrm{N}$ - Number of samples

NA - Not applicable

${ }^{a}$ Half-lives are listed in Table $K-1$ 무

${ }^{b}$ Total volume released: $2.55 E+10 \mathrm{~mL}(6.74 E+06$ gal $)$

${ }^{c} 1$ curie $(\mathrm{Ci})=3.7 \mathrm{E}+10$ becquerels $(\mathrm{Bq}) ; 1 \mathrm{~Bq}=2.7 \mathrm{E}-11 \mathrm{Ci}$

${ }^{d}$ DOE-derived concentration guides (DCGs) do not exist for indicator parameters gross alpha and gross beta. 
This page intentionally left blank

$C-22$ 


\section{Appendix C-3 \\ SPDES-Permitted Storm Water Outfall Discharge Data}

$$
\text { C }-23
$$


This page intentionally left blank

$$
\text { C }-24
$$


Table C-3A

\section{Storm Water Discharge Monitoring Data for Outfall Group 1}

Storm Water Outfall S04

\begin{tabular}{|c|c|c|c|c|}
\hline Analyte & Units & $\mathbf{N}$ & $\begin{array}{c}\text { First Flush Grab } \\
7 / 5 / 2005\end{array}$ & $\begin{array}{c}\text { Flow-weighted Composite } \\
7 / 6 / 2005 \\
\end{array}$ \\
\hline Aluminum, Total & $\mathrm{mg} / \mathrm{L}$ & 2 & 7.14 & 2.31 \\
\hline Ammonia Nitrogen $\left(\right.$ as $\mathrm{NH}_{3}$ ) & $\mathrm{mg} / \mathrm{L}$ & 2 & 0.370 & 0.244 \\
\hline $\mathrm{BOD}_{5}$ & $\mathrm{mg} / \mathrm{L}$ & 2 & 8.5 & 6.7 \\
\hline Cadmium, Total Recoverable & $\mathrm{mg} / \mathrm{L}$ & 2 & $<0.00089$ & $<0.00089$ \\
\hline Chromium, Total Recoverable & $\mathrm{mg} / \mathrm{L}$ & 2 & 0.0091 & 0.0037 \\
\hline Chromium, Hexavalent, Total Recoverable & $\mathrm{mg} / \mathrm{L}$ & 2 & $<0.016$ & $<0.008$ \\
\hline Copper, Total Recoverable & $\mathrm{mg} / \mathrm{L}$ & 2 & 0.0247 & 0.0089 \\
\hline Iron, Total & $\mathrm{mg} / \mathrm{L}$ & 2 & 11.6 & 3.02 \\
\hline Lead, Total Recoverable & $\mathrm{mg} / \mathrm{L}$ & 2 & 0.0138 & 0.0034 \\
\hline Nitrogen, Nitrate (as $\mathrm{N}$ ) & $\mathrm{mg} / \mathrm{L}$ & 2 & 0.79 & 1.00 \\
\hline Nitrogen, Nitrite (as N) & $\mathrm{mg} / \mathrm{L}$ & 2 & 0.083 & $<0.049$ \\
\hline Nitrogen, Total (as N) & $\mathrm{mg} / \mathrm{L}$ & 2 & 1.87 & $<2.03$ \\
\hline Nitrogen, Total Kjeldahl & $\mathrm{mg} / \mathrm{L}$ & 2 & 1.00 & 0.98 \\
\hline 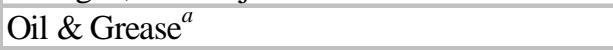 & $\mathrm{mg} / \mathrm{L}$ & 1 & $<2.7$ & NR \\
\hline $\mathrm{pH}^{b}$ & SU & 1 & 7.85 & NR \\
\hline Phosphorous, Total & $\mathrm{mg} / \mathrm{L}$ & 2 & 0.58 & 0.11 \\
\hline Selenium, Total Recoverable & $\mathrm{mg} / \mathrm{L}$ & 2 & $<0.0056$ & $<0.0056$ \\
\hline Solids, Total Dissolved & $\mathrm{mg} / \mathrm{L}$ & 2 & 199 & 241 \\
\hline Solids, Total Suspended & $\mathrm{mg} / \mathrm{L}$ & 2 & 395 & 65 \\
\hline Vanadium, Total Recoverable & $\mathrm{mg} / \mathrm{L}$ & 2 & 0.0112 & 0.0041 \\
\hline Zinc, Total Recoverable & $\mathrm{mg} / \mathrm{L}$ & 2 & 0.212 & 0.0598 \\
\hline \multicolumn{5}{|c|}{ Rain Event Summary } \\
\hline pH of Rainfall During Sampling Event & SU & 1 & \multicolumn{2}{|c|}{4.96} \\
\hline Rainfall During Sampling Event & inches & -- & \multicolumn{2}{|c|}{0.16} \\
\hline Total Flow During Sampling Event & gallons & -- & \multicolumn{2}{|c|}{118,982} \\
\hline Maximum Flow Rate During Sampling Event & gpm & -- & \multicolumn{2}{|c|}{2,400} \\
\hline
\end{tabular}

$N$ - Number of samples

$N R$ - Not required by permit

${ }^{a}$ The SPDES permit specifies that oil and grease concentrations shall not exceed $15 \mathrm{mg} / \mathrm{L}$.

${ }^{b}$ The SPDES permit specifies that $\mathrm{pH}$ shall not be less than the measured $\mathrm{pH}$ of rainfall collected from the site rain gauge at WNSWRO1 during storm water discharge sampling or $6.0 \mathrm{SU}$, whichever is less, and the pH shall not exceed 9.0. 
Table C-3B

2005 Storm Water Discharge Monitoring Data for Outfall Group 2

Storm Water Outfall S06

\begin{tabular}{|c|c|c|c|c|}
\hline Analyte & Units & $\mathbf{N}$ & $\begin{array}{c}\text { First Flush Grab } \\
\text { 4/20/2005 }\end{array}$ & $\begin{array}{c}\text { Flow-weighted Composite } \\
4 / 21 / 2005 \\
\end{array}$ \\
\hline Aluminum, Total & $\mathrm{mg} / \mathrm{L}$ & 2 & 0.0681 & 2.54 \\
\hline $\mathrm{BOD}_{5}$ & $\mathrm{mg} / \mathrm{L}$ & 2 & 2.0 & 3.0 \\
\hline Copper, Total Recoverable & $\mathrm{mg} / \mathrm{L}$ & 2 & 0.00094 & 0.0125 \\
\hline Iron, Total & $\mathrm{mg} / \mathrm{L}$ & 2 & 0.226 & 5.38 \\
\hline Lead, Total Recoverable & $\mathrm{mg} / \mathrm{L}$ & 2 & $<0.0025$ & 0.0056 \\
\hline Oil \& Grease $^{a}$ & $\mathrm{mg} / \mathrm{L}$ & 1 & $<1.0$ & NR \\
\hline $\mathrm{pH}^{o}$ & SU & 1 & 7.34 & NR \\
\hline Phosphorous, Total & $\mathrm{mg} / \mathrm{L}$ & 2 & $<0.020$ & 0.062 \\
\hline Solids, Total Dissolved & $\mathrm{mg} / \mathrm{L}$ & 2 & 928 & 658 \\
\hline Solids, Total Suspended & $\mathrm{mg} / \mathrm{L}$ & 2 & $<5.0$ & 111 \\
\hline Surfactant & $\mathrm{mg} / \mathrm{L}$ & 2 & $<0.100$ & 0.160 \\
\hline Zinc, Total Recoverable & $\mathrm{mg} / \mathrm{L}$ & 2 & 0.013 & 0.291 \\
\hline \multicolumn{5}{|c|}{ Rain Event Summary } \\
\hline pH of Rainfall During Sampling Event & SU & 1 & \multicolumn{2}{|c|}{6.05} \\
\hline Rainfall During Sampling Event & inches & -- & \multicolumn{2}{|c|}{0.41} \\
\hline Total Flow During Sampling Event & gallons & -- & \multicolumn{2}{|c|}{11,468} \\
\hline Maximum Flow Rate During Sampling Event & gpm & -- & \multicolumn{2}{|c|}{165} \\
\hline
\end{tabular}

$N$ - Number of samples

$N R$ - Not required by permit

${ }^{a}$ The SPDES permit specifies that oil and grease concentrations shall not exceed $15 \mathrm{mg} / \mathrm{L}$.

${ }^{b}$ The SPDES permit specifies that $\mathrm{pH}$ shall not be less than the measured $\mathrm{pH}$ of rainfall collected from the site rain gauge at WNSWROI during storm water discharge sampling or $6.0 \mathrm{SU}$, whichever is less, and the pH shall not exceed 9.0. 
Table C-3B (concluded)

2005 Storm Water Discharge Monitoring Data for Outfall Group 2

Storm Water Outfall S33

\begin{tabular}{|c|c|c|c|c|}
\hline Analyte & Units & $\mathbf{N}$ & $\begin{array}{c}\text { First Flush Grab } \\
11 / 9 / 2005 \\
\end{array}$ & $\begin{array}{c}\text { Flow-weighted Composite } \\
11 / 9 / 2005 \\
\end{array}$ \\
\hline Aluminum, Total & $\mathrm{mg} / \mathrm{L}$ & 2 & 0.060 & 0.155 \\
\hline $\mathrm{BOD}_{5}$ & $\mathrm{mg} / \mathrm{L}$ & 2 & 3.5 & 3.8 \\
\hline Copper, Total Recoverable & $\mathrm{mg} / \mathrm{L}$ & 2 & 0.0025 & 0.0019 \\
\hline Iron, Total & $\mathrm{mg} / \mathrm{L}$ & 2 & 1.25 & 1.36 \\
\hline Lead, Total Recoverable & $\mathrm{mg} / \mathrm{L}$ & 2 & $<0.0016$ & $<0.0016$ \\
\hline Oil \& Grease $^{a}$ & $\mathrm{mg} / \mathrm{L}$ & 1 & 2.4 & NR \\
\hline $\mathrm{pH}^{b}$ & SU & 1 & 7.24 & NR \\
\hline Phosphorous, Total & $\mathrm{mg} / \mathrm{L}$ & 2 & 0.057 & 0.010 \\
\hline Solids, Total Dissolved & $\mathrm{mg} / \mathrm{L}$ & 2 & 330 & 315 \\
\hline Solids, Total Suspended & $\mathrm{mg} / \mathrm{L}$ & 2 & 16.0 & 11.0 \\
\hline Surfactant & $\mathrm{mg} / \mathrm{L}$ & 2 & 0.095 & 0.100 \\
\hline Zinc, Total Recoverable & $\mathrm{mg} / \mathrm{L}$ & 2 & 0.0052 & 0.0033 \\
\hline \multicolumn{5}{|c|}{ Rain Event Summary } \\
\hline pH of Rainfall During Sampling Event & SU & 1 & \multicolumn{2}{|c|}{5.87} \\
\hline Rainfall During Sampling Event & inches & -- & \multicolumn{2}{|c|}{0.50} \\
\hline Total Flow During Sampling Event & gallons & -- & \multicolumn{2}{|c|}{15,073} \\
\hline Maximum Flow Rate During Sampling Event & gpm & -- & \multicolumn{2}{|c|}{100} \\
\hline
\end{tabular}

$N$ - Number of samples

NR - Not required by permit

${ }^{a}$ The SPDES permit specifies that oil and grease concentrations shall not exceed $15 \mathrm{mg} / \mathrm{L}$.

${ }^{b}$ The SPDES permit specifies that $\mathrm{pH}$ shall not be less than the measured $\mathrm{pH}$ of rainfall collected from the site rain gauge at WNSWRO1 during storm water discharge sampling or $6.0 \mathrm{SU}$, whichever is less, and the pH shall not exceed 9.0. 
Table C-3C

\section{Storm Water Discharge Monitoring Data for Outfall Group 3}

Storm Water Outfall S09

\begin{tabular}{|c|c|c|c|c|}
\hline Analyte & Units & $\mathbf{N}$ & $\begin{array}{c}\text { First Flush Grab } \\
11 / 9 / 2005\end{array}$ & $\begin{array}{c}\text { Flow-weighted Composite } \\
11 / 9 / 2005 \\
\end{array}$ \\
\hline Alpha-BHC & $\mathrm{mg} / \mathrm{L}$ & 2 & $<0.000002$ & $<0.000002$ \\
\hline Aluminum, Total & $\mathrm{mg} / \mathrm{L}$ & 2 & 2.80 & 2.83 \\
\hline Ammonia Nitrogen (as $\mathrm{NH}_{3}$ ) & $\mathrm{mg} / \mathrm{L}$ & 2 & $<0.011$ & 0.014 \\
\hline $\mathrm{BOD}_{5}$ & $\mathrm{mg} / \mathrm{L}$ & 2 & 4.0 & 3.3 \\
\hline Copper, Total Recoverable & $\mathrm{mg} / \mathrm{L}$ & 2 & 0.0092 & 0.0138 \\
\hline Iron, Total & $\mathrm{mg} / \mathrm{L}$ & 2 & 2.55 & 2.58 \\
\hline Lead, Total Recoverable & $\mathrm{mg} / \mathrm{L}$ & 2 & 0.002 & $<0.0016$ \\
\hline Nitrogen, Nitrate (as N) & $\mathrm{mg} / \mathrm{L}$ & 2 & 0.20 & 0.29 \\
\hline Nitrogen, Nitrite (as N) & $\mathrm{mg} / \mathrm{L}$ & 2 & $<0.020$ & $<0.020$ \\
\hline Nitrogen, Total (as N) & $\mathrm{mg} / \mathrm{L}$ & 2 & $<0.42$ & $<0.56$ \\
\hline Nitrogen, Total Kjeldhal & $\mathrm{mg} / \mathrm{L}$ & 2 & 0.200 & 0.250 \\
\hline Oil \& Grease $^{a}$ & $\mathrm{mg} / \mathrm{L}$ & 1 & $<2.2$ & NR \\
\hline $\mathrm{pH}^{b}$ & SU & 1 & 8.18 & NR \\
\hline Phosphorous, Total & $\mathrm{mg} / \mathrm{L}$ & 2 & 0.16 & 0.061 \\
\hline Solids, Total Dissolved & $\mathrm{mg} / \mathrm{L}$ & 2 & 88 & 112 \\
\hline Solids, Total Suspended & $\mathrm{mg} / \mathrm{L}$ & 2 & 58 & 48 \\
\hline Zinc, Total Recoverable & $\mathrm{mg} / \mathrm{L}$ & 2 & 0.0195 & 0.0204 \\
\hline \multicolumn{5}{|c|}{ Rain Event Summary } \\
\hline pH of Rainfall During Sampling Event & SU & 1 & \multicolumn{2}{|c|}{5.87} \\
\hline Rainfall During Sampling Event & inches & -- & \multicolumn{2}{|c|}{0.50} \\
\hline Total Flow During Sampling Event & gallons & -- & \multicolumn{2}{|c|}{358} \\
\hline Maximum Flow Rate During Sampling Event & gpm & -- & \multicolumn{2}{|c|}{5.2} \\
\hline
\end{tabular}

$N$ - Number of samples

$N R$ - Not required by permit

${ }^{a}$ The SPDES permit specifies that oil and grease concentrations shall not exceed $15 \mathrm{mg} / \mathrm{L}$.

${ }^{b}$ The SPDES permit specifies that $\mathrm{pH}$ shall not be less than the measured $\mathrm{pH}$ of rainfall collected from the site rain gauge at WNSWROI during storm water discharge sampling or $6.0 \mathrm{SU}$, whichever is less, and the pH shall not exceed 9.0. 
Table C-3C (concluded)

2005 Storm Water Discharge Monitoring Data for Outfall Group 3

Storm Water Outfall S12

\begin{tabular}{|c|c|c|c|c|}
\hline Analyte & Units & $\mathbf{N}$ & $\begin{array}{c}\text { First Flush Grab } \\
10 / 7 / 2005\end{array}$ & $\begin{array}{c}\text { Flow-weighted Composite } \\
10 / 7 / 2005\end{array}$ \\
\hline Alpha-BHC & $\mathrm{mg} / \mathrm{L}$ & 2 & $<0.000002$ & $<0.000002$ \\
\hline Aluminum, Total & $\mathrm{mg} / \mathrm{L}$ & 2 & 0.406 & 0.407 \\
\hline Ammonia Nitrogen $\left(\right.$ as $\mathrm{NH}_{3}$ ) & $\mathrm{mg} / \mathrm{L}$ & 2 & $<0.011$ & 0.019 \\
\hline $\mathrm{BOD}_{5}$ & $\mathrm{mg} / \mathrm{L}$ & 2 & $<2.0$ & 2.0 \\
\hline Copper, Total Recoverable & $\mathrm{mg} / \mathrm{L}$ & 2 & 0.0019 & 0.0052 \\
\hline Iron, Total & $\mathrm{mg} / \mathrm{L}$ & 2 & 0.719 & 1.10 \\
\hline Lead, Total Recoverable & $\mathrm{mg} / \mathrm{L}$ & 2 & $<0.0016$ & $<0.0016$ \\
\hline Nitrogen, Nitrate (as N) & $\mathrm{mg} / \mathrm{L}$ & 2 & 0.06 & 0.07 \\
\hline Nitrogen, Nitrite (as N) & $\mathrm{mg} / \mathrm{L}$ & 2 & $<0.049$ & $<0.049$ \\
\hline Nitrogen, Total (as N) & $\mathrm{mg} / \mathrm{L}$ & 2 & $<0.21$ & $<0.59$ \\
\hline Nitrogen, Total Kjeldahl & $\mathrm{mg} / \mathrm{L}$ & 2 & 0.100 & 0.470 \\
\hline 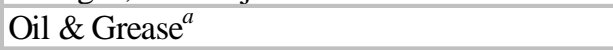 & $\mathrm{mg} / \mathrm{L}$ & 1 & $<2.2$ & NR \\
\hline $\mathrm{pH}^{b}$ & SU & 1 & 7.20 & NR \\
\hline Phosphorous, Total & $\mathrm{mg} / \mathrm{L}$ & 2 & 0.059 & 0.12 \\
\hline Solids, Total Dissolved & $\mathrm{mg} / \mathrm{L}$ & 2 & 365 & 227 \\
\hline Solids, Total Suspended & $\mathrm{mg} / \mathrm{L}$ & 2 & 13 & 25 \\
\hline Zinc, Total Recoverable & $\mathrm{mg} / \mathrm{L}$ & 2 & 0.0106 & 0.0257 \\
\hline \multicolumn{5}{|c|}{ Rain Event Summary } \\
\hline pH of Rainfall During Sampling Event & SU & 1 & \multicolumn{2}{|c|}{7.78} \\
\hline Rainfall During Sampling Event & inches & & \multicolumn{2}{|c|}{0.25} \\
\hline Total Flow During Sampling Event & gallons & & \multicolumn{2}{|c|}{62,577} \\
\hline Maximum Flow Rate During Sampling Event & gpm & & \multicolumn{2}{|c|}{720} \\
\hline
\end{tabular}

$N$ - Number of samples

NR - Not required by permit

${ }^{a}$ The SPDES permit specifies that oil and grease concentrations shall not exceed $15 \mathrm{mg} / \mathrm{L}$.

${ }^{b}$ The SPDES permit specifies that $\mathrm{pH}$ shall not be less than the measured $\mathrm{pH}$ of rainfall collected from the site rain gauge at WNSWRO1 during storm water discharge sampling or $6.0 \mathrm{SU}$, whichever is less, and the pH shall not exceed 9.0. 
Table C-3D

2005 Storm Water Discharge Monitoring Data for Outfall Group 4

Storm Water Outfall S34

\begin{tabular}{|c|c|c|c|c|}
\hline Analyte & Units & $\mathbf{N}$ & $\begin{array}{c}\text { First Flush Grab }^{a} \\
\text { 4/20/2005 }\end{array}$ & $\begin{array}{c}\text { Flow-weighted Composite }^{a} \\
4 / 21 / 2005\end{array}$ \\
\hline Aluminum, Total & $\mathrm{mg} / \mathrm{L}$ & 4 & 16.3 & 12.1 \\
\hline $\mathrm{BOD}_{5}$ & $\mathrm{mg} / \mathrm{L}$ & 4 & 5.9 & 5.9 \\
\hline Copper, Total Recoverable & $\mathrm{mg} / \mathrm{L}$ & 4 & 0.0471 & 0.0386 \\
\hline Iron, Total & $\mathrm{mg} / \mathrm{L}$ & 4 & 31.6 & 19.2 \\
\hline Lead, Total Recoverable & $\mathrm{mg} / \mathrm{L}$ & 4 & 0.0258 & 0.0145 \\
\hline Oil \& Grease ${ }^{b}$ & $\mathrm{mg} / \mathrm{L}$ & 2 & 3.2 & NR \\
\hline $\mathrm{pH}^{c}$ & SU & 2 & 7.84 & NR \\
\hline Phosphorous, Total & $\mathrm{mg} / \mathrm{L}$ & 4 & 0.440 & 0.260 \\
\hline Solids, Total Dissolved & $\mathrm{mg} / \mathrm{L}$ & 4 & 495 & 453 \\
\hline Solids, Total Suspended & $\mathrm{mg} / \mathrm{L}$ & 4 & 896 & 436 \\
\hline Surfactant & $\mathrm{mg} / \mathrm{L}$ & 4 & 0.041 & 0.067 \\
\hline Zinc, Total Recoverable & $\mathrm{mg} / \mathrm{L}$ & 4 & 0.406 & 0.232 \\
\hline \multicolumn{5}{|c|}{ Rain Event Summary } \\
\hline pH of Rainfall During Sampling Event & SU & 1 & \multicolumn{2}{|r|}{6.05} \\
\hline Rainfall During Sampling Event & inches & -- & \multicolumn{2}{|r|}{0.41} \\
\hline Total Flow During Sampling Event & gallons & -- & \multicolumn{2}{|c|}{347,712} \\
\hline Maximum Flow Rate During Sampling Event & gpm & -- & \multicolumn{2}{|c|}{4,043} \\
\hline
\end{tabular}

$N$ - Number of samples

NR - Not required by permit

${ }^{a}$ The first flush grab and the flow-weighted composite were sampled and analyzed in duplicate and data were averaged.

${ }^{b}$ The SPDES permit specifies that oil and grease concentrations shall not exceed $15 \mathrm{mg} / \mathrm{L}$.

${ }^{c}$ The SPDES permit specifies that $\mathrm{pH}$ shall not be less than the measured $\mathrm{pH}$ of rainfall collected from the site rain gauge at WNSWRO1 during storm water discharge sampling or 6.0 SU, whichever is less, and the pH shall not exceed 9.0. 
Table C-3D (concluded)

2005 Storm Water Discharge Monitoring Data for Outfall Group 4

Storm Water Outfall S34

\begin{tabular}{|c|c|c|c|c|}
\hline Analyte & Units & $\mathbf{N}$ & $\begin{array}{c}\text { First Flush Grab } \\
\text { 9/8/2005 }\end{array}$ & $\begin{array}{c}\text { Flow-weighted Composite } \\
\text { 9/8/2005 }\end{array}$ \\
\hline Aluminum, Total & $\mathrm{mg} / \mathrm{L}$ & 2 & 3.01 & 1.54 \\
\hline $\mathrm{BOD}_{5}$ & $\mathrm{mg} / \mathrm{L}$ & 2 & 5.4 & 3.4 \\
\hline Copper, Total Recoverable & $\mathrm{mg} / \mathrm{L}$ & 2 & 0.018 & 0.0071 \\
\hline Iron, Total & $\mathrm{mg} / \mathrm{L}$ & 2 & 8.26 & 2.77 \\
\hline Lead, Total Recoverable & $\mathrm{mg} / \mathrm{L}$ & 2 & 0.0071 & 0.0027 \\
\hline 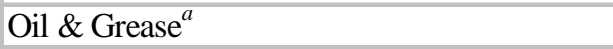 & $\mathrm{mg} / \mathrm{L}$ & 1 & $<2.7$ & NR \\
\hline $\mathrm{pH}^{b}$ & SU & 1 & 7.62 & NR \\
\hline Phosphorous, Total & $\mathrm{mg} / \mathrm{L}$ & 2 & 0.29 & 0.078 \\
\hline Solids, Total Dissolved & $\mathrm{mg} / \mathrm{L}$ & 2 & 699 & 353 \\
\hline Solids, Total Suspended & $\mathrm{mg} / \mathrm{L}$ & 2 & 334 & 71 \\
\hline Surfactant & $\mathrm{mg} / \mathrm{L}$ & 2 & 0.044 & 0.130 \\
\hline Zinc, Total Recoverable & $\mathrm{mg} / \mathrm{L}$ & 2 & 0.282 & 0.0723 \\
\hline \multicolumn{5}{|c|}{ Rain Event Summary } \\
\hline pH of Rainfall During Sampling Event & SU & 1 & \multicolumn{2}{|c|}{4.70} \\
\hline Rainfall During Sampling Event & inches & -- & \multicolumn{2}{|c|}{0.14} \\
\hline Total Flow During Sampling Event & gallons & -- & \multicolumn{2}{|c|}{218,377} \\
\hline Maximum Flow Rate During Sampling Event & gpm & -- & \multicolumn{2}{|c|}{4,000} \\
\hline
\end{tabular}

$N$ - Number of samples

NR - Not required by permit

${ }^{a}$ The SPDES permit specifies that oil and grease concentrations shall not exceed $15 \mathrm{mg} / \mathrm{L}$.

${ }^{b}$ The SPDES permit specifies that $\mathrm{pH}$ shall not be less than the measured $\mathrm{pH}$ of rainfall collected from the site rain gauge at WNSWRO1 during storm water discharge sampling or 6.0 SU, whichever is less, and the pH shall not exceed 9.0. 
Table C-3E

2005 Storm Water Discharge Monitoring Data for Outfall Group 5

Storm Water Outfall S17

\begin{tabular}{|c|c|c|c|c|}
\hline Analyte & Units & $\mathbf{N}$ & $\begin{array}{c}\text { First Flush Grab } \\
\text { 11/9/2005 }\end{array}$ & $\begin{array}{c}\text { Flow-weighted Composite } \\
11 / 9 / 2005\end{array}$ \\
\hline Aluminum, Total & $\mathrm{mg} / \mathrm{L}$ & 2 & 0.879 & 0.844 \\
\hline Ammonia Nitrogen $\left(\right.$ as $\left.\mathrm{NH}_{3}\right)$ & $\mathrm{mg} / \mathrm{L}$ & 2 & $<0.011$ & $<0.011$ \\
\hline $\mathrm{BOD}_{5}$ & $\mathrm{mg} / \mathrm{L}$ & 2 & 6.1 & 3.2 \\
\hline Copper. Total Recoverable & $\mathrm{mg} / \mathrm{L}$ & 2 & 0.0039 & 0.0033 \\
\hline Iron, Total & $\mathrm{mg} / \mathrm{L}$ & 2 & 0.695 & 0.548 \\
\hline Lead, Total Recoverable & $\mathrm{mg} / \mathrm{L}$ & 2 & $<0.0016$ & $<0.0016$ \\
\hline Nitrogen, Nitrate (as N) & $\mathrm{mg} / \mathrm{L}$ & 2 & 0.062 & 0.20 \\
\hline Nitrogen, Nitrite (as N) & $\mathrm{mg} / \mathrm{L}$ & 2 & $<0.020$ & $<0.020$ \\
\hline Nitrogen, Total (as N) & $\mathrm{mg} / \mathrm{L}$ & 2 & $<0.472$ & $<0.390$ \\
\hline Nitrogen, Total Kjeldahl & $\mathrm{mg} / \mathrm{L}$ & 2 & 0.390 & 0.170 \\
\hline 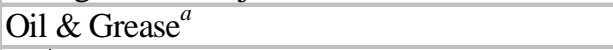 & $\mathrm{mg} / \mathrm{L}$ & 1 & $<2.2$ & $\mathrm{NR}$ \\
\hline $\mathrm{pH}^{b}$ & SU & 1 & 7.47 & NR \\
\hline Phosphorous, Total & $\mathrm{mg} / \mathrm{L}$ & 2 & $<0.008$ & 0.058 \\
\hline Solids, Setttleable & $\mathrm{mg} / \mathrm{L}$ & 2 & 0.3 & $<0.1$ \\
\hline Solids, Total Dissolved & $\mathrm{mg} / \mathrm{L}$ & 2 & 264 & 228 \\
\hline Solids, Total Suspended & $\mathrm{mg} / \mathrm{L}$ & 2 & 34 & 18 \\
\hline Sulfide & $\mathrm{mg} / \mathrm{L}$ & 2 & $<0.03$ & $<0.03$ \\
\hline Surfactant & $\mathrm{mg} / \mathrm{L}$ & 2 & 0.120 & 0.088 \\
\hline Vanadium, Total Recoverable & $\mathrm{mg} / \mathrm{L}$ & 2 & 0.0013 & 0.0028 \\
\hline Zinc, Total Recoverable & $\mathrm{mg} / \mathrm{L}$ & 2 & 0.0197 & 0.0144 \\
\hline \multicolumn{5}{|c|}{ Rain Event Summary } \\
\hline pH of Rainfall During Sampling Event & SU & 1 & \multicolumn{2}{|c|}{5.87} \\
\hline Rainfall During Sampling Event & inches & -- & \multicolumn{2}{|c|}{0.50} \\
\hline Total Flow During Sampling Event & gallons & -- & \multicolumn{2}{|c|}{77,085} \\
\hline Maximum Flow Rate During Sampling Event & gpm & -- & \multicolumn{2}{|c|}{470} \\
\hline
\end{tabular}

$N$ - Number of samples

NR - Not required by permit

${ }^{a}$ The SPDES permit specifies that oil and grease concentrations shall not exceed $15 \mathrm{mg} / \mathrm{L}$.

${ }^{b}$ The SPDES permit specifies that $\mathrm{pH}$ shall not be less than the measured $\mathrm{pH}$ of rainfall collected from the site rain gauge at WNSWROI during storm water discharge sampling or $6.0 \mathrm{SU}$, whichever is less, and the pH shall not exceed 9.0. 
Table C-3F

\section{Storm Water Discharge Monitoring Data for Outfall Group 6}

Storm Water Outfall S36

\begin{tabular}{|c|c|c|c|c|}
\hline Analyte & Units & $\mathbf{N}$ & $\begin{array}{c}\text { First Flush Grab } \\
10 / 7 / 2005\end{array}$ & $\begin{array}{c}\text { Flow-weighted Composite } \\
10 / 7 / 2005\end{array}$ \\
\hline Aluminum, Total & $\mathrm{mg} / \mathrm{L}$ & 2 & 0.0932 & 0.158 \\
\hline Ammonia Nitrogen (as $\mathrm{NH}_{3}$ ) & $\mathrm{mg} / \mathrm{L}$ & 2 & 0.028 & $<0.011$ \\
\hline $\mathrm{BOD}_{5}$ & $\mathrm{mg} / \mathrm{L}$ & 2 & $<2.0$ & $<2.0$ \\
\hline Copper, Total Recoverable & $\mathrm{mg} / \mathrm{L}$ & 2 & $<0.0016$ & $<0.0016$ \\
\hline Iron, Total & $\mathrm{mg} / \mathrm{L}$ & 2 & 0.170 & 0.305 \\
\hline Lead, Total Recoverable & $\mathrm{mg} / \mathrm{L}$ & 2 & $<0.0016$ & $<0.0016$ \\
\hline Nitrogen, Nitrate (as N) & $\mathrm{mg} / \mathrm{L}$ & 2 & 0.07 & 0.29 \\
\hline Nitrogen, Nitrite (as $\mathrm{N}$ ) & $\mathrm{mg} / \mathrm{L}$ & 2 & $<0.049$ & $<0.049$ \\
\hline Nitrogen, Total (as N) & $\mathrm{mg} / \mathrm{L}$ & 2 & $<0.50$ & $<0.47$ \\
\hline Nitrogen, Total Kjeldahl & $\mathrm{mg} / \mathrm{L}$ & 2 & 0.380 & 0.130 \\
\hline 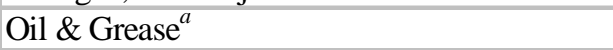 & $\mathrm{mg} / \mathrm{L}$ & 1 & $<2.2$ & NR \\
\hline $\mathrm{pH}^{b}$ & SU & 1 & 7.48 & NR \\
\hline Phosphorous, Total & $\mathrm{mg} / \mathrm{L}$ & 2 & 0.02 & $<0.008$ \\
\hline Solids, Settleable & $\mathrm{mg} / \mathrm{L}$ & 2 & $<0.1$ & $<0.1$ \\
\hline Solids, Total Dissolved & $\mathrm{mg} / \mathrm{L}$ & 2 & 300 & 320 \\
\hline Solids, Total Suspended & $\mathrm{mg} / \mathrm{L}$ & 2 & 8.0 & 7.0 \\
\hline Sulfide & $\mathrm{mg} / \mathrm{L}$ & 2 & 0.03 & $<0.03$ \\
\hline Surfactant & $\mathrm{mg} / \mathrm{L}$ & 2 & $<0.012$ & 0.014 \\
\hline Vanadium, Total Recoverable & $\mathrm{mg} / \mathrm{L}$ & 2 & $<0.00098$ & $<0.00098$ \\
\hline Zinc, Total Recoverable & $\mathrm{mg} / \mathrm{L}$ & 2 & 0.013 & 0.0101 \\
\hline \multicolumn{5}{|c|}{ Rain Event Summary } \\
\hline pH of Rainfall During Sampling Event & SU & 1 & \multicolumn{2}{|c|}{7.78} \\
\hline Rainfall During Sampling Event & inches & -- & \multicolumn{2}{|c|}{0.25} \\
\hline Total Flow During Sampling Event & gallons & -- & \multicolumn{2}{|c|}{1,189} \\
\hline Maximum Flow Rate During Sampling Event & gpm & -- & \multicolumn{2}{|c|}{7.7} \\
\hline
\end{tabular}

$N$ - Number of samples

NR - Not required by permit

${ }^{a}$ The SPDES permit specifies that oil and grease concentrations shall not exceed $15 \mathrm{mg} / \mathrm{L}$.

${ }^{b}$ The SPDES permit specifies that $\mathrm{pH}$ shall not be less than the measured $\mathrm{pH}$ of rainfall collected from the site rain gauge at WNSWRO1 during storm water discharge sampling or $6.0 \mathrm{SU}$, whichever is less, and the pH shall not exceed 9.0. 
Table C-3G

\section{Storm Water Discharge Monitoring Data for Outfall Group 7}

Storm Water Outfall S20

\begin{tabular}{|c|c|c|c|c|}
\hline Analyte & Units & $\mathbf{N}$ & $\begin{array}{c}\text { First Flush Grab } \\
\text { 4/20/2005 }\end{array}$ & $\begin{array}{c}\text { Flow-weighted Composite } \\
4 / 21 / 2005\end{array}$ \\
\hline Aluminum, Total & $\mathrm{mg} / \mathrm{L}$ & 2 & 8.91 & 1.74 \\
\hline Ammonia Nitrogen (as $\mathrm{NH}_{3}$ ) & $\mathrm{mg} / \mathrm{L}$ & 2 & 0.77 & 0.46 \\
\hline $\mathrm{BOD}_{5}$ & $\mathrm{mg} / \mathrm{L}$ & 2 & 34.6 & 4.9 \\
\hline Copper, Total Recoverable & $\mathrm{mg} / \mathrm{L}$ & 2 & 0.023 & 0.0039 \\
\hline Iron, Total & $\mathrm{mg} / \mathrm{L}$ & 2 & 23.1 & 2.99 \\
\hline Lead, Total Recoverable & $\mathrm{mg} / \mathrm{L}$ & 2 & 0.0127 & $<0.0013$ \\
\hline Nitrogen, Nitrate (as N) & $\mathrm{mg} / \mathrm{L}$ & 2 & 2.60 & 0.62 \\
\hline Nitrogen, Nitrite (as N) & $\mathrm{mg} / \mathrm{L}$ & 2 & 0.079 & 0.052 \\
\hline Nitrogen, Total (as N) & $\mathrm{mg} / \mathrm{L}$ & 2 & 9.0 & 2.0 \\
\hline Nitrogen, Total Kjeldahl & $\mathrm{mg} / \mathrm{L}$ & 2 & 6.30 & 1.30 \\
\hline 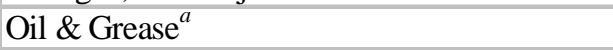 & $\mathrm{mg} / \mathrm{L}$ & 1 & 3.0 & NR \\
\hline $\mathrm{pH}^{b}$ & SU & 1 & 7.97 & NR \\
\hline Phosphorous, Total & $\mathrm{mg} / \mathrm{L}$ & 2 & 0.47 & 0.095 \\
\hline Solids, Total Dissolved & $\mathrm{mg} / \mathrm{L}$ & 2 & 210 & 124 \\
\hline Solids, Total Suspended & $\mathrm{mg} / \mathrm{L}$ & 2 & 78 & 94 \\
\hline Sulfide & $\mathrm{mg} / \mathrm{L}$ & 2 & $<0.04$ & $<0.04$ \\
\hline Surfactant & $\mathrm{mg} / \mathrm{L}$ & 2 & $<0.012$ & 0.14 \\
\hline Zinc, Total Recoverable & $\mathrm{mg} / \mathrm{L}$ & 2 & 0.348 & 0.0362 \\
\hline \multicolumn{5}{|c|}{ Rain Event Summary } \\
\hline pH of Rainfall During Sampling Event & SU & 1 & \multicolumn{2}{|c|}{6.05} \\
\hline Total Rainfall During Sampling Event & inches & -- & \multicolumn{2}{|c|}{0.41} \\
\hline Total Flow During SamplingEvent & gallons & -- & \multicolumn{2}{|c|}{46,005} \\
\hline Maximum Flow Rate During Sampling Event & gpm & -- & \multicolumn{2}{|c|}{494} \\
\hline
\end{tabular}

$N$ - Number of samples

NR - Not required by permit

${ }^{a}$ The SPDES permit specifies that oil and grease concentrations shall not exceed $15 \mathrm{mg} / \mathrm{L}$.

${ }^{b}$ The SPDES permit specifies that $\mathrm{pH}$ shall not be less than the measured $\mathrm{pH}$ of rainfall collected from the site rain gauge at WNSWRO1 during storm water discharge sampling or $6.0 \mathrm{SU}$, whichever is less, and the pH shall not exceed 9.0. 
Table C-3G (concluded)

2005 Storm Water Discharge Monitoring Data for Outfall Group 7

Storm Water Outfall S20

\begin{tabular}{|c|c|c|c|c|}
\hline Analyte & Units & $\mathbf{N}$ & $\begin{array}{c}\text { First Flush Grab }^{a} \\
\text { 9/8/2005 }\end{array}$ & $\begin{array}{c}\text { Flow-weighted Composite } \\
\text { 9/8/2005 }\end{array}$ \\
\hline Aluminum, Total & $\mathrm{mg} / \mathrm{L}$ & 3 & 0.575 & 0.260 \\
\hline Ammonia Nitrogen (as $\mathrm{NH}_{3}$ ) & $\mathrm{mg} / \mathrm{L}$ & 3 & 0.055 & $<0.012$ \\
\hline $\mathrm{BOD}_{5}$ & $\mathrm{mg} / \mathrm{L}$ & 3 & 11.1 & $<2.0$ \\
\hline Copper, Total Recoverable & $\mathrm{mg} / \mathrm{L}$ & 3 & 0.0029 & 0.002 \\
\hline Iron, Total & $\mathrm{mg} / \mathrm{L}$ & 3 & 0.931 & 0.357 \\
\hline Lead, Total Recoverable & $\mathrm{mg} / \mathrm{L}$ & 3 & $<0.0022$ & $<0.0016$ \\
\hline Nitrogen, Nitrate (as N) & $\mathrm{mg} / \mathrm{L}$ & 3 & 1.15 & 0.49 \\
\hline Nitrogen, Nitrite (as N) & $\mathrm{mg} / \mathrm{L}$ & 3 & $<0.049$ & $<0.049$ \\
\hline Nitrogen, Total (as N) & $\mathrm{mg} / \mathrm{L}$ & 3 & $<2.50$ & $<1.26$ \\
\hline Nitrogen, Total Kjeldahl & $\mathrm{mg} / \mathrm{L}$ & 3 & 1.30 & 0.720 \\
\hline Oil \& Grease ${ }^{b}$ & $\mathrm{mg} / \mathrm{L}$ & 2 & $<2.7$ & $\mathrm{NR}$ \\
\hline $\mathrm{pH}^{\mathrm{c}}$ & SU & 1 & 7.76 & $\mathrm{NR}$ \\
\hline Phosphorous, Total & $\mathrm{mg} / \mathrm{L}$ & 3 & 0.086 & 0.045 \\
\hline Solids, Total Dissolved & $\mathrm{mg} / \mathrm{L}$ & 3 & 187 & 111 \\
\hline Solids, Total Suspended & $\mathrm{mg} / \mathrm{L}$ & 3 & 45.5 & 7.0 \\
\hline Sulfide & $\mathrm{mg} / \mathrm{L}$ & 3 & $<0.04$ & $<0.04$ \\
\hline Surfactant & $\mathrm{mg} / \mathrm{L}$ & 3 & 0.026 & $<0.012$ \\
\hline Zinc, Total Recoverable & $\mathrm{mg} / \mathrm{L}$ & 3 & 0.013 & 0.005 \\
\hline \multicolumn{5}{|c|}{ Rain Event Summary } \\
\hline pH of Rainfall During Sampling Event & SU & 1 & \multicolumn{2}{|r|}{4.70} \\
\hline Rainfall During Sampling Event & inches & -- & \multicolumn{2}{|c|}{0.14} \\
\hline Total Flow During Sampling Event & gallons & -- & \multicolumn{2}{|c|}{21,377} \\
\hline Maximum Flow Rate During Sampling Event & gpm & -- & \multicolumn{2}{|c|}{440} \\
\hline
\end{tabular}

$N$ - Number of samples

NR - Not required by permit

${ }^{a}$ The first flush grab was sampled and analyzed in duplicate and data were averaged.

${ }^{b}$ The SPDES permit specifies that oil and grease concentrations shall not exceed $15 \mathrm{mg} / \mathrm{L}$.

${ }^{c}$ The SPDES permit specifies that $\mathrm{pH}$ shall not be less than the measured $\mathrm{pH}$ of rainfall collected from the site rain gauge at WNSWROI during storm water discharge sampling or $6.0 \mathrm{SU}$, whichever is less, and the pH shall not exceed 9.0. 
Table C-3H

\section{Storm Water Discharge Monitoring Data for Outfall Group 8}

Storm Water Outfall S27

\begin{tabular}{|c|c|c|c|c|}
\hline Analyte & Units & $\mathbf{N}$ & $\begin{array}{c}\text { First Flush Grab } \\
\mathbf{4 / 2 0 / 2 0 0 5}\end{array}$ & $\begin{array}{c}\text { Flow-weighted Composite } \\
4 / 21 / 2005 \\
\end{array}$ \\
\hline Aluminum, Total & $\mathrm{mg} / \mathrm{L}$ & 2 & 14.6 & 6.28 \\
\hline Ammonia Nitrogen $\left(\right.$ as $\mathrm{NH}_{3}$ ) & $\mathrm{mg} / \mathrm{L}$ & 2 & 0.29 & 0.12 \\
\hline $\mathrm{BOD}_{5}$ & $\mathrm{mg} / \mathrm{L}$ & 2 & 19.5 & 6.4 \\
\hline Copper, Total Recoverable & $\mathrm{mg} / \mathrm{L}$ & 2 & 0.0258 & 0.0118 \\
\hline Iron, Total & $\mathrm{mg} / \mathrm{L}$ & 2 & 17.9 & 7.68 \\
\hline Lead, Total Recoverable & $\mathrm{mg} / \mathrm{L}$ & 2 & 0.0165 & 0.0069 \\
\hline Nitrogen, Nitrate (as N) & $\mathrm{mg} / \mathrm{L}$ & 2 & 1.40 & 0.50 \\
\hline Nitrogen, Nitrite (as N) & $\mathrm{mg} / \mathrm{L}$ & 2 & $<0.049$ & 0.14 \\
\hline Nitrogen, Total (as N) & $\mathrm{mg} / \mathrm{L}$ & 2 & $<7.7$ & 2.3 \\
\hline Nitrogen, Total Kjeldahl & $\mathrm{mg} / \mathrm{L}$ & 2 & 6.30 & 1.70 \\
\hline 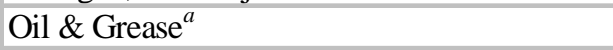 & $\mathrm{mg} / \mathrm{L}$ & 1 & $<2.7$ & NR \\
\hline $\mathrm{pH}^{b}$ & SU & 1 & 7.11 & NR \\
\hline Phosphorous, Total & $\mathrm{mg} / \mathrm{L}$ & 2 & 1.4 & 0.20 \\
\hline Solids, Total Dissolved & $\mathrm{mg} / \mathrm{L}$ & 2 & 323 & 249 \\
\hline Solids, Total Suspended & $\mathrm{mg} / \mathrm{L}$ & 2 & 3,870 & 181 \\
\hline Surfactant & $\mathrm{mg} / \mathrm{L}$ & 2 & 0.042 & 0.027 \\
\hline Zinc, Total Recoverable & $\mathrm{mg} / \mathrm{L}$ & 2 & 0.141 & 0.0473 \\
\hline \multicolumn{5}{|c|}{ Rain Event Summary } \\
\hline pH of Rainfall During Sampling Event & SU & 1 & \multicolumn{2}{|c|}{6.05} \\
\hline Rainfall During Sampling Event & inches & -- & \multicolumn{2}{|c|}{0.41} \\
\hline Total Flow During Sampling Event & gallons & -- & \multicolumn{2}{|c|}{3,106} \\
\hline Maximum Flow Rate During Sampling Event & gpm & -- & \multicolumn{2}{|c|}{45} \\
\hline
\end{tabular}

$N$ - Number of samples

NR - Not required by permit

${ }^{a}$ The SPDES permit specifies that oil and grease concentrations shall not exceed $15 \mathrm{mg} / \mathrm{L}$.

${ }^{b}$ The SPDES permit specifies that $\mathrm{pH}$ shall not be less than the measured $\mathrm{pH}$ of rainfall collected from the site rain gauge at WNSWROI during storm water discharge sampling or $6.0 \mathrm{SU}$, whichever is less, and the pH shall not exceed 9.0. 


\section{Table C-3H (concluded) \\ 2005 Storm Water Discharge Monitoring Data for Outfall Group 8}

\section{Storm Water Outfall S35}

\begin{tabular}{|c|c|c|c|c|}
\hline Analyte & Units & $\mathbf{N}$ & $\begin{array}{c}\text { First Flush Grab } \\
10 / 7 / 2005\end{array}$ & $\begin{array}{c}\text { Flow-weighted Composite } \\
10 / 7 / 2005\end{array}$ \\
\hline Aluminum, Total & $\mathrm{mg} / \mathrm{L}$ & 2 & 0.192 & 0.118 \\
\hline Ammonia Nitrogen $\left(\right.$ as $\left.\mathrm{NH}_{3}\right)$ & $\mathrm{mg} / \mathrm{L}$ & 2 & 0.023 & 0.017 \\
\hline $\mathrm{BOD}_{5}$ & $\mathrm{mg} / \mathrm{L}$ & 2 & 9.1 & 2.9 \\
\hline Copper, Total Recoverable & $\mathrm{mg} / \mathrm{L}$ & 2 & 0.0016 & $<0.0016$ \\
\hline Iron, Total & $\mathrm{mg} / \mathrm{L}$ & 2 & 0.330 & 0.158 \\
\hline Lead, Total Recoverable & $\mathrm{mg} / \mathrm{L}$ & 2 & $<0.0016$ & $<0.0016$ \\
\hline Nitrogen, Nitrate (as N) & $\mathrm{mg} / \mathrm{L}$ & 2 & $<0.011$ & $<0.011$ \\
\hline Nitrogen, Nitrite (as N) & $\mathrm{mg} / \mathrm{L}$ & 2 & $<0.049$ & $<0.049$ \\
\hline Nitrogen, Total (as N) & $\mathrm{mg} / \mathrm{L}$ & 2 & $<1.16$ & $<0.91$ \\
\hline Nitrogen, Total Kjeldahl & $\mathrm{mg} / \mathrm{L}$ & 2 & 1.10 & 0.850 \\
\hline Oil \& Grease $^{a}$ & $\mathrm{mg} / \mathrm{L}$ & 1 & $<2.2$ & NR \\
\hline $\mathrm{pH}^{b}$ & SU & 1 & 7.32 & NR \\
\hline Phosphorous, Total & $\mathrm{mg} / \mathrm{L}$ & 2 & 0.068 & 0.030 \\
\hline Solids, Total Dissolved & $\mathrm{mg} / \mathrm{L}$ & 2 & 366 & 324 \\
\hline Solids, Total Suspended & $\mathrm{mg} / \mathrm{L}$ & 2 & 10.0 & 5.0 \\
\hline Surfactant & $\mathrm{mg} / \mathrm{L}$ & 2 & 0.021 & 0.012 \\
\hline Zinc, Total Recoverable & $\mathrm{mg} / \mathrm{L}$ & 2 & 0.0287 & 0.0133 \\
\hline \multicolumn{5}{|c|}{ Rain Event Summary } \\
\hline pH of Rainfall During Sampling Event & SU & 1 & \multicolumn{2}{|c|}{7.78} \\
\hline Rainfall During Sampling Event & inches & -- & \multicolumn{2}{|c|}{0.25} \\
\hline Total Flow During Sampling Event & gallons & -- & \multicolumn{2}{|c|}{242} \\
\hline Maximum Flow Rate During Sampling Event & gpm & -- & \\
\hline
\end{tabular}

$N$ - Number of samples

NR - Not required by permit

${ }^{a}$ The SPDES permit specifies that oil and grease concentrations shall not exceed $15 \mathrm{mg} / \mathrm{L}$.

${ }^{b}$ The SPDES permit specifies that $p H$ shall not be less than the measured $p H$ of rainfall collected from the site rain gauge at WNSWRO1 during storm water discharge sampling or $6.0 \mathrm{SU}$, whichever is less, and the pH shall not exceed 9.0. 
This page intentionally left blank

$$
\text { C }-38
$$




\section{Appendix C-4 \\ Site Surface Drainage, Subsurface Drainage, and Contained Water Data}


This page intentionally left blank

$C-40$ 
Table C-4A

2005 Radioactivity and $\mathrm{pH}$ in Surface Water at Facility Yard Drainage (WNSP005)

\begin{tabular}{|c|c|c|c|c|c|c|}
\hline \multirow{2}{*}{ Analyte } & \multirow{2}{*}{ Units } & \multirow{2}{*}{$\mathbf{N}$} & \multicolumn{3}{|c|}{ WNSP005 Concentrations } & \multirow{2}{*}{$\begin{array}{l}\text { Guideline }^{a} \text { or } \\
\text { Standard }^{b}\end{array}$} \\
\hline & & & Minimum & Average & Maximum & \\
\hline Gross Alpha & $\mu \mathrm{Ci} / \mathrm{mL}$ & 12 & $<8.56 \mathrm{E}-10$ & $1.38 \pm 2.85 \mathrm{E}-09$ & 7.71E-09 & $3 \mathrm{E}-08^{c}$ \\
\hline Gross Beta & $\mu \mathrm{Ci} / \mathrm{mL}$ & 12 & $1.02 \mathrm{E}-07$ & $2.37 \pm 0.09 \mathrm{E}-07$ & 4.14E-07 & $1 \mathrm{E}-06^{d}$ \\
\hline Tritium & $\mu \mathrm{Ci} / \mathrm{mL}$ & 12 & $<7.81 \mathrm{E}-08$ & $6.29 \pm 9.19 \mathrm{E}-08$ & $1.64 \mathrm{E}-07$ & $2 \mathrm{E}-03$ \\
\hline Sr-90 & $\mu \mathrm{Ci} / \mathrm{mL}$ & 3 & $9.45 \mathrm{E}-08$ & $1.20 \pm 0.06 \mathrm{E}-07$ & 1.44E-07 & $1 \mathrm{E}-06$ \\
\hline Cs-137 & $\mu \mathrm{Ci} / \mathrm{mL}$ & 3 & $<1.78 \mathrm{E}-09$ & $0.07 \pm 2.60 \mathrm{E}-09$ & $<3.69 \mathrm{E}-09$ & 3E-06 \\
\hline pH & SU & 12 & 7.19 & 7.57 & 8.35 & $6.0-9.5$ \\
\hline
\end{tabular}

Note: Strontium-90 (Sr-90) analysis in water was performed by a non-NYSDOH ELAP-certified analytical method. See Chapter 5.

$N$ - Number of samples

${ }^{a}$ DOE ingestion-based DCGs for $100 \mathrm{mrem} / \mathrm{yr}$ dose limit are provided as a guideline for radiological results.

${ }^{b}$ New York State Water Quality Standards for Class " $D$ " as a comparative reference for nonradiological results

${ }^{c}$ Alpha as Am-241

${ }^{\text {¿ }}$ Beta as $\mathrm{Sr}-90$

Table C-4B

2005 Radioactivity in Surface Water at French Drain (WNSP008)

\author{
NO DISCHARGE FROM THE \\ FRENCH DRAIN SINCE MAY 2001
}

WVDP Annual Site Environmental Report

$C-41$ 


\section{Table $C-4 C$ \\ 2005 Water Quality of Surface Water at the North Swamp (WNSW74A)}

RADIOACTIVE CONSTITUENTS

\begin{tabular}{|c|c|c|c|c|c|c|}
\hline Isotope $^{a}$ & $\mathbf{N}$ & $\begin{array}{l}\text { Discharge } \\
\text { Activity }^{b} \\
\text { (Ci) }\end{array}$ & $\begin{array}{r}\text { Radioactivity }^{c} \\
\text { (Becquerels) }\end{array}$ & $\begin{array}{c}\text { Average } \\
\text { Concentration } \\
(\mu \mathrm{Ci} / \mathrm{mL})\end{array}$ & $\begin{array}{c}\text { DCG } \\
(\mu \mathrm{Ci} / \mathrm{mL})\end{array}$ & $\%$ of DCG \\
\hline Gross Alpha & 32 & $0.76 \pm 3.67 \mathrm{E}-05$ & $0.28 \pm 1.36 \mathrm{E}+06$ & $1.66 \pm 7.99 \mathrm{E}-10$ & $\mathrm{NA}^{d}$ & $\mathrm{NA}$ \\
\hline Gross Beta & 32 & $5.88 \pm 0.55 \mathrm{E}-04$ & $2.18 \pm 0.20 \mathrm{E}+07$ & $1.28 \pm 0.12 \mathrm{E}-08$ & $\mathrm{NA}^{d}$ & NA \\
\hline Tritium & 32 & $2.10 \pm 1.27 \mathrm{E}-03$ & $7.77 \pm 4.68 \mathrm{E}+07$ & $4.57 \pm 2.76 \mathrm{E}-08$ & $2 \mathrm{E}-03$ & $<0.01$ \\
\hline C-14 & 2 & $-4.00 \pm 8.34 \mathrm{E}-04$ & $-1.48 \pm 3.09 \mathrm{E}+07$ & $-0.87 \pm 1.82 \mathrm{E}-08$ & 7E-05 & $<0.01$ \\
\hline Sr-90 & 12 & $2.12 \pm 0.21 \mathrm{E}-04$ & $7.84 \pm 0.78 \mathrm{E}+06$ & $4.62 \pm 0.46 \mathrm{E}-09$ & $1 \mathrm{E}-06$ & 0.05 \\
\hline I-129 & 2 & $0.22 \pm 1.82 \mathrm{E}-05$ & $0.81 \pm 6.75 E+05$ & $0.47 \pm 3.97 \mathrm{E}-10$ & $5 \mathrm{E}-07$ & 0.01 \\
\hline Cs-137 & 12 & $2.98 \pm 5.79 \mathrm{E}-05$ & $1.10 \pm 2.14 \mathrm{E}+06$ & $0.65 \pm 1.26 \mathrm{E}-09$ & $3 \mathrm{E}-06$ & 0.02 \\
\hline $\mathrm{U}-232^{e}$ & 2 & $0.13 \pm 1.71 \mathrm{E}-06$ & $0.50 \pm 6.33 \mathrm{E}+04$ & $0.29 \pm 3.72 \mathrm{E}-11$ & $1 \mathrm{E}-07$ & $<0.01$ \\
\hline $\mathrm{U}-233 / 234^{e}$ & 2 & $6.45 \pm 3.02 \mathrm{E}-06$ & $2.39 \pm 1.12 \mathrm{E}+05$ & $1.40 \pm 0.66 \mathrm{E}-10$ & $5 \mathrm{E}-07$ & 0.03 \\
\hline $\mathrm{U}-235 / 236^{e}$ & 2 & $1.90 \pm 1.71 \mathrm{E}-06$ & $7.04+-6.32 \mathrm{E}+04$ & $4.14 \pm 3.72 \mathrm{E}-11$ & $5 \mathrm{E}-07^{f}$ & 0.01 \\
\hline $\mathrm{U}-238^{e}$ & 2 & $5.40 \pm 2.77 \mathrm{E}-06$ & $2.00 \pm 1.03 \mathrm{E}+05$ & $1.18 \pm 0.60 \mathrm{E}-10$ & $6 \mathrm{E}-07$ & 0.02 \\
\hline Pu-238 & 2 & $-3.05 \pm 3.79 \mathrm{E}-07$ & $-1.13 \pm 1.40 \mathrm{E}+04$ & $-6.63 \pm 8.25 \mathrm{E}-12$ & $4 \mathrm{E}-08$ & $<0.01$ \\
\hline Pu-239/240 & 2 & $-1.35 \pm 9.00 \mathrm{E}-07$ & $-0.50 \pm 3.33 \mathrm{E}+04$ & $-0.30 \pm 1.96 \mathrm{E}-11$ & $3 \mathrm{E}-08$ & $<0.01$ \\
\hline Am-241 & 2 & $1.20 \pm 1.27 \mathrm{E}-06$ & $4.45 \pm 4.69 \mathrm{E}+04$ & $2.62 \pm 2.76 \mathrm{E}-11$ & $3 \mathrm{E}-08$ & 0.09 \\
\hline \multicolumn{6}{|c|}{ Total \% of DCG } & 0.23 \\
\hline
\end{tabular}

Note: Strontium-90 (Sr-90) analysis in water was performed by a non-NYSDOH ELAP-certified analytical method. See Chapter 5.

$N$ - Number of samples

NA - Not applicable

${ }^{a}$ Half-lives are listed in Table $K-1$ 뚜

${ }^{b}$ Total volume released: $4.59 \mathrm{E}+10 \mathrm{~mL}(1.21 \mathrm{E}+07 \mathrm{gal})$

${ }^{c} 1$ curie $(\mathrm{Ci})=3.7 \mathrm{E}+10$ becquerels $(\mathrm{Bq}) ; 1 \mathrm{~Bq}=2.7 \mathrm{E}-11 \mathrm{Ci}$

${ }^{d}$ DOE-derived concentration guides (DCGs) do not exist for indicator parameters gross alpha and gross beta.

${ }^{e}$ Total Uranium $(\mathrm{g})=1.47 \pm 0.04 E+01$; Average Total Uranium $(\mu \mathrm{g} / \mathrm{mL})=3.20 \pm 0.08 E-04$

${ }^{f} D C G$ for $U-236$ is used for this comparison. 


\section{Table C-4C (continued) \\ 2005 Water Quality of Surface Water at the North Swamp (WNSW74A)}

CHEMICAL CONSTITUENTS

\begin{tabular}{|c|c|c|c|c|c|c|c|}
\hline \multirow{3}{*}{ Analyte } & \multirow{3}{*}{ Units } & \multirow{3}{*}{$\mathbf{N}$} & \multirow{2}{*}{\multicolumn{2}{|c|}{$\begin{array}{c}\text { WNSW74A } \\
\text { Concentrations }\end{array}$}} & \multirow{3}{*}{$\mathbf{N}$} & \multicolumn{2}{|c|}{ Reference Values } \\
\hline & & & & & & \multirow{2}{*}{$\begin{array}{l}\text { Background Range } \\
\text { WFBCBKG }^{a}\end{array}$} & \multirow{2}{*}{ Standard } \\
\hline & & & Average & Maximum & & & \\
\hline Alpha-BHC & $\mathrm{mg} / \mathrm{L}$ & 2 & $<0.000010$ & $<0.000010$ & 2 & $<0.000008-<0.000009$ & 0.000002 \\
\hline Aluminum, Total & $\mathrm{mg} / \mathrm{L}$ & 2 & $<0.11$ & 0.12 & 0 & NA & -- \\
\hline Ammonia-N & $\mathrm{mg} / \mathrm{L}$ & 2 & $<0.05$ & $<0.05$ & 2 & $<0.05-<0.05$ & $0.67-29$ \\
\hline Antimony, Total & $\mathrm{mg} / \mathrm{L}$ & 2 & $<0.003$ & $<0.003$ & 2 & $<0.003-<0.003$ & -- \\
\hline Arsenic, Dissolved & $\mathrm{mg} / \mathrm{L}$ & 2 & $<0.005$ & $<0.005$ & 2 & $<0.005-<0.005$ & 0.340 \\
\hline Boron, Total & $\mathrm{mg} / \mathrm{L}$ & 2 & 0.02 & 0.03 & 2 & $0.01-0.02$ & -- \\
\hline Bromide & $\mathrm{mg} / \mathrm{L}$ & 2 & $<0.50$ & $<0.50$ & 2 & $<0.50-<0.50$ & -- \\
\hline Cadmium, Total & $\mathrm{mg} / \mathrm{L}$ & 2 & $<0.001$ & $<0.001$ & 0 & NA & -- \\
\hline Calcium Total & $\mathrm{mg} / \mathrm{L}$ & 2 & 74.8 & 79.2 & 12 & $19.8-51.3$ & -- \\
\hline Chromium, Total & $\mathrm{mg} / \mathrm{L}$ & 2 & $<0.010$ & $<0.010$ & 0 & NA & -- \\
\hline Cobalt, Total & $\mathrm{mg} / \mathrm{L}$ & 2 & $<0.005$ & $<0.005$ & 2 & $<0.005-<0.005$ & $0.110^{c}$ \\
\hline Copper, Dissolved & $\mathrm{mg} / \mathrm{L}$ & 2 & $<0.005$ & $<0.005$ & 2 & $<0.005-<0.005$ & $0.039^{d}$ \\
\hline Copper, Total & $\mathrm{mg} / \mathrm{L}$ & 2 & $<0.005$ & $<0.005$ & 0 & NA & -- \\
\hline Fluoride & $\mathrm{mg} / \mathrm{L}$ & 2 & 0.16 & 0.21 & 2 & $<0.10-<0.10$ & $23.6^{d}$ \\
\hline Hardness & $\mathrm{mg} / \mathrm{L}$ & 2 & 228 & 242 & 12 & $62-158$ & -- \\
\hline Iron, Total & $\mathrm{mg} / \mathrm{L}$ & 2 & $<0.13$ & 0.21 & 2 & $0.24-0.72$ & 0.30 \\
\hline Lead, Total & $\mathrm{mg} / \mathrm{L}$ & 2 & $<0.0005$ & $<0.0005$ & 0 & NA & -- \\
\hline Magnesium, Total & $\mathrm{mg} / \mathrm{L}$ & 2 & 10.16 & 10.80 & 12 & $2.92-9.52$ & -- \\
\hline Manganese, Total & $\mathrm{mg} / \mathrm{L}$ & 2 & 0.04 & 0.06 & 2 & $0.02-0.02$ & -- \\
\hline Mercury, Total, Method 1631 & $\mathrm{mg} / \mathrm{L}$ & 2 & 0.000000974 & 0.00000114 & 0 & NA & -- \\
\hline Nickel, Total & $\mathrm{mg} / \mathrm{L}$ & 2 & $<0.04$ & $<0.04$ & 0 & NA & -- \\
\hline Nitrate-N & $\mathrm{mg} / \mathrm{L}$ & 2 & 0.15 & 0.20 & 2 & $<0.05-0.25$ & -- \\
\hline Nitrite-N & $\mathrm{mg} / \mathrm{L}$ & 2 & $<0.05$ & $<0.05$ & 2 & $<0.05-<0.05$ & -- \\
\hline NPOC & $\mathrm{mg} / \mathrm{L}$ & 2 & 2.2 & 2.3 & 2 & $1.5-1.9$ & -- \\
\hline Oil \& Grease & $\mathrm{mg} / \mathrm{L}$ & 2 & $<5$ & $<5$ & 2 & $<5-<5$ & -- \\
\hline pH & $\mathrm{SU}$ & 22 & 7.55 & 8.05 & 2 & $7.29-8.19$ & $6.0-9.5$ \\
\hline Selenium, Total & $\mathrm{mg} / \mathrm{L}$ & 2 & $<0.001$ & $<0.001$ & 0 & NA & -- \\
\hline Solids, Total Dissolved & $\mathrm{mg} / \mathrm{L}$ & 2 & 624 & 638 & 2 & $132-292$ & -- \\
\hline Solids, Total Suspended & $\mathrm{mg} / \mathrm{L}$ & 2 & $<4$ & $<4$ & 2 & $<4-20$ & -- \\
\hline
\end{tabular}

$N$ - Number of samples

NA - No data available

-- No guideline or standard available for these analytes

${ }^{a}$ Background location

${ }^{b}$ New York State Water Quality Standards, Class "D" as a comparative reference for nonradiological results at WNSW74A

${ }^{c}$ Standards for cobalt, thallium, and vanadium are applicable to the acid-soluble fraction.

${ }^{d}$ Calculated from maximum measurement of hardness of surface water drainage at WNSW74A 


\section{Table C-4C (concluded) \\ 2005 Water Quality of Surface Water at the North Swamp (WNSW74A) \\ CHEMICAL CONSTITUENTS (concluded)}

\begin{tabular}{|c|c|c|c|c|c|c|c|}
\hline \multirow{3}{*}{ Analyte } & \multirow{3}{*}{ Units } & \multirow{3}{*}{$\mathbf{N}$} & \multirow{2}{*}{\multicolumn{2}{|c|}{$\begin{array}{c}\text { WNSW74A } \\
\text { Concentrations }\end{array}$}} & \multirow{3}{*}{$\mathbf{N}$} & \multicolumn{2}{|c|}{ Reference Values } \\
\hline & & & & & & Background Range & \\
\hline & & & Average & Maximum & & WFBCBKG $^{a}$ & Standard \\
\hline Sulfate & $\mathrm{mg} / \mathrm{L}$ & 2 & 29.9 & 31.6 & 2 & $16.8-23.8$ & -- \\
\hline Sulfide & $\mathrm{mg} / \mathrm{L}$ & 2 & $<0.04$ & $<0.04$ & 2 & $<0.04-<0.04$ & -- \\
\hline Surfactants & $\mathrm{mg} / \mathrm{L}$ & 2 & $<0.10$ & $<0.10$ & 2 & $<0.02-<0.10$ & -- \\
\hline Thallium, Total & $\mathrm{mg} / \mathrm{L}$ & 2 & $<0.008$ & $<0.008$ & 2 & $<0.008-<0.008$ & $0.020^{c}$ \\
\hline Titanium, Total & $\mathrm{mg} / \mathrm{L}$ & 2 & $<0.05$ & $<0.05$ & 2 & $<0.05-<0.05$ & -- \\
\hline TOX & $\mathrm{mg} / \mathrm{L}$ & 2 & 0.05 & 0.05 & 2 & $<0.005-0.006$ & -- \\
\hline Vanadium, Total & $\mathrm{mg} / \mathrm{L}$ & 2 & $<0.01$ & $<0.01$ & 2 & $<0.01-<0.01$ & $0.190^{c}$ \\
\hline Zinc, Total & $\mathrm{mg} / \mathrm{L}$ & 2 & $<0.02$ & $<0.02$ & 0 & NA & -- \\
\hline
\end{tabular}

$N$ - Number of samples

NA - No data available

-- No guideline or standard available for these analytes

${ }^{a}$ Background location

${ }^{b}$ New York State Water Quality Standards, Class "D" as a comparative reference for nonradiological results at WNSW74A

${ }^{c}$ Standards for cobalt, thallium, and vanadium are applicable to the acid-soluble fraction. 


\section{Table C-4D}

\section{Water Quality of Surface Water at the Northeast Swamp (WNSWAMP)}

RADIOACTIVE CONSTITUENTS

\begin{tabular}{|c|c|c|c|c|c|c|}
\hline Isotope $^{a}$ & $\mathbf{N}$ & $\begin{array}{l}\text { Discharge } \\
\text { Activity }^{b} \\
\text { (Ci) }\end{array}$ & $\begin{array}{r}\text { Radioactivity }^{c} \\
\text { (Becquerels) }\end{array}$ & $\begin{array}{c}\text { Average } \\
\text { Concentration } \\
(\mu \mathrm{Ci} / \mathbf{m L})\end{array}$ & $\begin{array}{c}\text { DCG } \\
(\mu \mathrm{Ci} / \mathrm{mL})\end{array}$ & $\%$ of DCG \\
\hline Gross Alpha & 32 & $0.87 \pm 8.73 \mathrm{E}-05$ & $0.32 \pm 3.23 \mathrm{E}+06$ & $0.65 \pm 6.47 \mathrm{E}-10$ & $\mathrm{NA}^{d}$ & NA \\
\hline Gross Beta & 32 & $4.60 \pm 0.01 \mathrm{E}-01$ & $1.70 \pm 0.01 \mathrm{E}+10$ & $3.41 \pm 0.01 \mathrm{E}-06$ & $\mathrm{NA}^{d}$ & NA \\
\hline Tritium & 32 & $1.59 \pm 0.36 \mathrm{E}-02$ & $5.87 \pm 1.31 \mathrm{E}+08$ & $1.18 \pm 0.26 \mathrm{E}-07$ & 2E-03 & 0.01 \\
\hline C-14 & 2 & $0.85 \pm 2.79 \mathrm{E}-03$ & $0.32 \pm 1.03 \mathrm{E}+08$ & $0.63 \pm 2.07 \mathrm{E}-08$ & 7E-05 & 0.01 \\
\hline Sr-90 & 12 & $2.25 \pm 0.01 \mathrm{E}-01$ & $8.34 \pm 0.04 \mathrm{E}+09$ & $1.67 \pm 0.01 \mathrm{E}-06$ & $1 \mathrm{E}-06$ & 167 \\
\hline I-129 & 2 & $0.93 \pm 1.44 \mathrm{E}-04$ & $3.44 \pm 5.32 \mathrm{E}+06$ & $0.69 \pm 1.07 \mathrm{E}-09$ & $5 \mathrm{E}-07$ & 0.14 \\
\hline Cs-137 & 12 & $2.34 \pm 9.18 \mathrm{E}-05$ & $0.87 \pm 3.40 \mathrm{E}+06$ & $1.73 \pm 6.81 \mathrm{E}-10$ & 3E-06 & 0.01 \\
\hline $\mathrm{U}-232^{e}$ & 2 & $-2.48 \pm 1.35 \mathrm{E}-05$ & $-9.18 \pm 5.00 \mathrm{E}+05$ & $-1.84 \pm 1.00 \mathrm{E}-10$ & $1 \mathrm{E}-07$ & $<0.01$ \\
\hline $\mathrm{U}-233 / 234^{e}$ & 2 & $2.75 \pm 1.04 \mathrm{E}-05$ & $1.02 \pm 0.39 \mathrm{E}+06$ & $2.04 \pm 0.77 \mathrm{E}-10$ & $5 \mathrm{E}-07$ & 0.04 \\
\hline $\mathrm{U}-235 / 236^{e}$ & 2 & $8.16 \pm 6.56 \mathrm{E}-06$ & $3.02 \pm 2.43 \mathrm{E}+05$ & $6.05 \pm 4.86 \mathrm{E}-11$ & $5 \mathrm{E}-07^{f}$ & 0.01 \\
\hline $\mathbf{U}-238^{e}$ & 2 & $1.52 \pm 0.75 \mathrm{E}-05$ & $5.62 \pm 2.78 \mathrm{E}+05$ & $1.12 \pm 0.56 \mathrm{E}-10$ & $6 \mathrm{E}-07$ & 0.02 \\
\hline Pu-238 & 2 & $-0.21 \pm 3.24 \mathrm{E}-06$ & $-0.01 \pm 1.20 \mathrm{E}+05$ & $-0.15 \pm 2.40 \mathrm{E}-11$ & 4E-08 & 0.28 \\
\hline Pu-239/240 & 2 & $0.19 \pm 2.31 \mathrm{E}-06$ & $0.70 \pm 8.55 \mathrm{E}+04$ & $0.14 \pm 1.71 \mathrm{E}-11$ & 3E-08 & $<0.01$ \\
\hline Am-241 & 2 & $-1.19 \pm 1.73 \mathrm{E}-06$ & $-4.40 \pm 6.40 \mathrm{E}+04$ & $-0.88 \pm 1.28 \mathrm{E}-11$ & $3 \mathrm{E}-08$ & $<0.01$ \\
\hline \multicolumn{6}{|c|}{ Total \% of DCG } & 167 \\
\hline
\end{tabular}

Note: Strontium-90 (Sr-90) analysis in water was performed by a non-NYSDOH ELAP-certified analytical method. See Chapter 5.

$N$ - Number of samples

NA - Not applicable

${ }^{a}$ Half-lives are listed in Table $K-1$ 미

${ }^{b}$ Total volume released: $1.35 E+11 \mathrm{~mL}(3.56 E+07 \mathrm{gal})$

${ }^{c} 1$ curie $(\mathrm{Ci})=3.7 \mathrm{E}+10$ becquerels $(\mathrm{Bq}) ; 1 \mathrm{~Bq}=2.7 \mathrm{E}-11 \mathrm{Ci}$

${ }^{d} D O E$-derived concentration guides (DCGs) do not exist for indicator parameters gross alpha and gross beta.

${ }^{e}$ Total Uranium $(\mathrm{g})=4.01 \pm 0.09 \mathrm{E}+01$; Average Total Uranium $(\mu \mathrm{g} / \mathrm{mL})=2.97 \pm 0.07 \mathrm{E}-04$

${ }^{f} D C G$ for $U-236$ is used for this comparison. 
Table C-4D (continued)

2005 Water Quality of Surface Water at the Northeast Swamp (WNSWAMP)

CHEMICAL CONSTITUENTS

\begin{tabular}{|c|c|c|c|c|c|c|c|}
\hline \multirow{3}{*}{ Analyte } & \multirow{3}{*}{ Units } & \multirow{3}{*}{$\mathbf{N}$} & \multirow{2}{*}{\multicolumn{2}{|c|}{$\begin{array}{l}\text { WNSWAMP } \\
\text { Concentrations }\end{array}$}} & \multirow{3}{*}{$\mathbf{N}$} & \multicolumn{2}{|c|}{ Reference Values } \\
\hline & & & & & & \multirow{2}{*}{$\begin{array}{c}\text { WFBCBKG }^{a} \\
\text { Background Range }\end{array}$} & \multirow{2}{*}{ Standard $^{b}$} \\
\hline & & & Average & Maximum & & & \\
\hline Alpha-BHC & $\mathrm{mg} / \mathrm{L}$ & 2 & $<0.00002$ & $<0.00002$ & 2 & $<0.000008-<0.000009$ & 0.000002 \\
\hline Aluminum, Total & $\mathrm{mg} / \mathrm{L}$ & 2 & $<0.04$ & 0.06 & 0 & NA & -- \\
\hline Ammonia-N & $\mathrm{mg} / \mathrm{L}$ & 2 & $<0.10$ & $<0.10$ & 2 & $<0.05-<0.05$ & $0.67-29$ \\
\hline Antimony, Total & $\mathrm{mg} / \mathrm{L}$ & 2 & $<0.004$ & $<0.004$ & 2 & $<0.003-<0.003$ & -- \\
\hline Arsenic, Dissolved & $\mathrm{mg} / \mathrm{L}$ & 2 & $<0.005$ & $<0.005$ & 2 & $<0.005-<0.005$ & 0.340 \\
\hline Boron, Total & $\mathrm{mg} / \mathrm{L}$ & 2 & 0.09 & 0.13 & 2 & $0.07-0.10$ & -- \\
\hline Bromide & $\mathrm{mg} / \mathrm{L}$ & 2 & 1.4 & 1.6 & 2 & $<0.50-<0.50$ & -- \\
\hline Cadmium, Total & $\mathrm{mg} / \mathrm{L}$ & 2 & $<0.0004$ & $<0.0004$ & 0 & NA & - \\
\hline Calcium, Total & $\mathrm{mg} / \mathrm{L}$ & 2 & 121 & 125 & 12 & $19.8-51.3$ & -- \\
\hline Chromium, Total & $\mathrm{mg} / \mathrm{L}$ & 2 & $<0.0007$ & $<0.0007$ & 0 & & - \\
\hline Cobalt, Total & $\mathrm{mg} / \mathrm{L}$ & 2 & $<0.001$ & $<0.001$ & 2 & $<0.005-<0.005$ & $0.110^{c}$ \\
\hline Copper, Dissolved & $\mathrm{mg} / \mathrm{L}$ & 2 & $<0.002$ & $<0.003$ & 2 & $<0.005-<0.005$ & $0.048^{d}$ \\
\hline Copper, Total & $\mathrm{mg} / \mathrm{L}$ & 2 & $<0.002$ & $<0.003$ & 0 & NA & -- \\
\hline Fluoride & $\mathrm{mg} / \mathrm{L}$ & 2 & $<0.10$ & 0.11 & 2 & $<0.10-<0.10$ & $35.8^{d}$ \\
\hline Hardness & $\mathrm{mg} / \mathrm{L}$ & 2 & 368 & 383 & 12 & $62-158$ & -- \\
\hline Iron, Total & $\mathrm{mg} / \mathrm{L}$ & 2 & 0.15 & 0.18 & 2 & $0.24-0.72$ & 0.30 \\
\hline Lead, Total & $\mathrm{mg} / \mathrm{L}$ & 2 & $<0.0027$ & $<0.0029$ & 0 & NA & -- \\
\hline Magnesium, Total & $\mathrm{mg} / \mathrm{L}$ & 2 & 16.1 & 17.2 & 12 & $2.92-9.52$ & -- \\
\hline Manganese, Total & $\mathrm{mg} / \mathrm{L}$ & 2 & 0.26 & 0.28 & 2 & $0.02-0.02$ & -- \\
\hline Mercury, Total, Method 1631 & $\mathrm{mg} / \mathrm{L}$ & 2 & $<0.00000472$ & 0.00000894 & 0 & NA & -- \\
\hline Nickel, Total & $\mathrm{mg} / \mathrm{L}$ & 2 & $<0.0018$ & $<0.0022$ & 0 & NA & -- \\
\hline Nitrate-N & $\mathrm{mg} / \mathrm{L}$ & 2 & $<0.08$ & 0.1 & 2 & $<0.05-0.25$ & -- \\
\hline Nitrite-N & $\mathrm{mg} / \mathrm{L}$ & 2 & $<0.42$ & $<0.76$ & 2 & $<0.05-<0.05$ & -- \\
\hline NPOC & $\mathrm{mg} / \mathrm{L}$ & 2 & 3.8 & 4.2 & 2 & $1.5-1.9$ & -- \\
\hline Oil \& Grease & $\mathrm{mg} / \mathrm{L}$ & 2 & $<1$ & $<1$ & 2 & $<5-<5$ & -- \\
\hline pH & SU & 21 & 7.48 & 8.11 & 2 & $7.29-8.19$ & $6.0-9.5$ \\
\hline Selenium, Total & $\mathrm{mg} / \mathrm{L}$ & 2 & $<0.005$ & $<0.005$ & 0 & NA & -- \\
\hline Solids, Total Dissolved & $\mathrm{mg} / \mathrm{L}$ & 2 & 1,135 & 1,190 & 2 & $132-292$ & -- \\
\hline Solids, Total Suspended & $\mathrm{mg} / \mathrm{L}$ & 2 & $<5$ & $<5$ & 2 & $<4-20$ & -- \\
\hline
\end{tabular}

$N$ - Number of samples

NA - No data available

-- No guideline or standard available for these analytes

${ }^{a}$ Background location

${ }^{b}$ New York State Water Quality Standards, Class “D” as a comparative reference for nonradiological results at WNSWAMP

${ }^{c}$ Standards for cobalt, thallium, and vanadium are applicable to the acid-soluble fraction.

${ }^{d}$ Calculated from maximum measurement of hardness of surface water drainage at WNSWAMP 
Table C-4D (concluded)

2005 Water Quality of Surface Water at the Northeast Swamp (WNSWAMP)

CHEMICAL CONSTITUENTS (concluded)

\begin{tabular}{|c|c|c|c|c|c|c|c|}
\hline \multirow{3}{*}{ Analyte } & \multirow{3}{*}{ Units } & \multirow{3}{*}{$\mathbf{N}$} & \multirow{2}{*}{\multicolumn{2}{|c|}{$\begin{array}{l}\text { WNSWAMP } \\
\text { Concentrations }\end{array}$}} & \multirow{3}{*}{$\mathbf{N}$} & \multicolumn{2}{|c|}{ Reference Values } \\
\hline & & & & & & \multirow{2}{*}{$\begin{array}{c}\text { WFBCBKG }^{a} \\
\text { Background Range }\end{array}$} & \multirow{2}{*}{ Standard $^{b}$} \\
\hline & & & Average & Maximum & & & \\
\hline Sulfate & $\mathrm{mg} / \mathrm{L}$ & 2 & 22.6 & 22.7 & 2 & $16.8-23.8$ & -- \\
\hline Sulfide & $\mathrm{mg} / \mathrm{L}$ & 2 & $<1.00$ & $<1.00$ & 2 & $<0.04-<0.04$ & -- \\
\hline Surfactant & $\mathrm{mg} / \mathrm{L}$ & 2 & $<0.10$ & $<0.10$ & 2 & $<0.02-<0.10$ & -- \\
\hline Thallium, Total & $\mathrm{mg} / \mathrm{L}$ & 2 & $<0.008$ & $<0.008$ & 2 & $<0.008-<0.008$ & $0.020^{c}$ \\
\hline Titanium, Total & $\mathrm{mg} / \mathrm{L}$ & 2 & $<0.0004$ & $<0.0004$ & 2 & $<0.05-<0.05$ & -- \\
\hline TOX & $\mathrm{mg} / \mathrm{L}$ & 2 & 0.01 & 0.02 & 2 & $<0.00-0.01$ & -- \\
\hline Vanadium, Total & $\mathrm{mg} / \mathrm{L}$ & 2 & $<0.0006$ & $<0.0006$ & 2 & $<0.01-<0.01$ & $0.190^{c}$ \\
\hline Zinc, Total & $\mathrm{mg} / \mathrm{L}$ & 2 & 0.04 & 0.06 & 0 & NA & -- \\
\hline
\end{tabular}

$N$ - Number of samples

NA - No data available

-- No guideline or standard available for these analytes

${ }^{a}$ Background location

${ }^{b}$ New York State Water Quality Standards, Class “D” as a comparative reference for nonradiological results at WNSWAMP

${ }^{c}$ Standards for cobalt, thallium, and vanadium are applicable to the acid-soluble fraction. 


\section{Table C-4E}

\section{Indicator Results at Storage and Disposal Area Drainage (WNNDADR)}

\begin{tabular}{|c|c|c|c|c|c|c|}
\hline \multirow{2}{*}{ Analyte } & \multirow{2}{*}{ Units } & \multirow{2}{*}{$\mathbf{N}$} & \multicolumn{3}{|c|}{ WNNDADR Concentrations } & \multirow{2}{*}{ Standard } \\
\hline & & & Minimum & Average & Maximum & \\
\hline Gross Alpha & $\mu \mathrm{Ci} / \mathrm{mL}$ & 14 & $<9.60 \mathrm{E}-10$ & $1.08 \pm 1.16 \mathrm{E}-09$ & $2.12 \mathrm{E}-09$ & -- \\
\hline Gross Beta & $\mu \mathrm{Ci} / \mathrm{mL}$ & 14 & $6.41 \mathrm{E}-08$ & $1.93 \pm 0.06 \mathrm{E}-07$ & 3.23E-07 & -- \\
\hline Tritium & $\mu \mathrm{Ci} / \mathrm{mL}$ & 42 & $9.39 \mathrm{E}-08$ & $7.39 \pm 1.05 \mathrm{E}-07$ & $1.46 \mathrm{E}-06$ & -- \\
\hline Sr-90 & $\mu \mathrm{Ci} / \mathrm{mL}$ & 3 & 7.84E-08 & $8.16 \pm 0.45 \mathrm{E}-08$ & 8.71E-08 & -- \\
\hline I-129 & $\mu \mathrm{Ci} / \mathrm{mL}$ & 2 & $6.14 \mathrm{E}-10$ & $3.58 \pm 6.87 \mathrm{E}-10$ & $6.14 \mathrm{E}-10$ & -- \\
\hline Cs-137 & $\mu \mathrm{Ci} / \mathrm{mL}$ & 12 & $<1.42 \mathrm{E}-09$ & $1.64 \pm 5.50 \mathrm{E}-09$ & $1.15 \mathrm{E}-08$ & -- \\
\hline NPOC & $\mathrm{mg} / \mathrm{L}$ & 36 & $<1.0$ & $<5.6$ & 20.3 & -- \\
\hline pH & $\mathrm{SU}$ & 36 & 6.5 & 7.46 & 8.08 & $6.0-9.5$ \\
\hline TOX & $\mathrm{mg} / \mathrm{L}$ & 36 & $<0.01$ & $<0.01$ & 0.04 & -- \\
\hline
\end{tabular}

Note: Strontium-90 (Sr-90) analysis in water was performed by a non-NYSDOH ELAP-certified analytical method. See Chapter 5.

$N$ - Number of samples

-- No applicable reference standard available

${ }^{a}$ New York State Water Quality Standards, Class "D" as a comparative reference for nonradiological results at WNNDADR

Table $\mathrm{C}-\mathbf{4 F}$

\section{Indicator Results in Subsurface Water at the NDA Interceptor Trench (WNNDATR)}

\begin{tabular}{|l|c|c|c|c|c|}
\hline \multirow{2}{*}{\multicolumn{1}{c|}{ Analyte }} & \multirow{2}{*}{ Units } & \multirow{2}{*}{ N } & \multicolumn{3}{c|}{ WNNDATR Concentrations } \\
\cline { 4 - 6 } & & & Minimum & Average & Maximum \\
\hline Gross Alpha & $\mu \mathrm{Ci} / \mathrm{mL}$ & 12 & $<1.05 \mathrm{E}-09$ & $1.67 \pm 1.81 \mathrm{E}-09$ & $6.13 \mathrm{E}-09$ \\
\hline Gross Beta & $\mu \mathrm{Ci} / \mathrm{mL}$ & 12 & $1.42 \mathrm{E}-07$ & $2.03 \pm 0.08 \mathrm{E}-07$ & $3.28 \mathrm{E}-07$ \\
\hline Tritium & $\mu \mathrm{Ci} / \mathrm{mL}$ & 12 & $5.08 \mathrm{E}-07$ & $2.50 \pm 0.15 \mathrm{E}-06$ & $4.90 \mathrm{E}-06$ \\
\hline I-129 & $\mu \mathrm{Ci} / \mathrm{mL}$ & 2 & $<6.86 \mathrm{E}-10$ & $6.95 \pm 8.12 \mathrm{E}-10$ & $1.39 \mathrm{E}-09$ \\
\hline Cs-137 & $\mu \mathrm{Ci} / \mathrm{mL}$ & 12 & $<1.76 \mathrm{E}-09$ & $1.44 \pm 4.95 \mathrm{E}-09$ & $<6.79 \mathrm{E}-09$ \\
\hline NPOC & $\mathrm{mg} / \mathrm{L}$ & 12 & $<1.0$ & $<4.6$ & 6.7 \\
\hline TOX & $\mathrm{mg} / \mathrm{L}$ & 12 & $<0.01$ & $<0.02$ & 0.03 \\
\hline
\end{tabular}

Note: No applicable reference standard available for this location. These waters are pumped and treated at the LLWTF prior to discharge at outfall WNSP001.

$N$ - Number of samples 
Table $C-4 G$

\section{Indicator Results at SDA Drainage (WNSDADR)}

\begin{tabular}{|c|c|c|c|c|c|c|}
\hline \multirow{2}{*}{ Analyte } & \multirow{2}{*}{ Units } & \multirow{2}{*}{$\mathbf{N}$} & \multicolumn{3}{|c|}{ WNSDADR Concentrations } & \multirow{2}{*}{$\begin{array}{l}\text { Guideline or } \\
\text { Standard }^{a}\end{array}$} \\
\hline & & & Minimum & Average & Maximum & \\
\hline Gross Alpha & $\mu \mathrm{Ci} / \mathrm{mL}$ & 12 & $<2.83 \mathrm{E}-10$ & $9.70 \pm 6.33 \mathrm{E}-10$ & 2.83E-09 & -- \\
\hline Gross Beta & $\mu \mathrm{Ci} / \mathrm{mL}$ & 12 & $1.08 \mathrm{E}-09$ & $5.11 \pm 1.02 \mathrm{E}-09$ & 2.71E-08 & -- \\
\hline Tritium & $\mu \mathrm{Ci} / \mathrm{mL}$ & 12 & $1.90 \mathrm{E}-07$ & $5.07 \pm 1.01 \mathrm{E}-07$ & $1.04 \mathrm{E}-06$ & -- \\
\hline Cs-137 & $\mu \mathrm{Ci} / \mathrm{mL}$ & 12 & $<1.99 \mathrm{E}-09$ & $0.94 \pm 5.45 \mathrm{E}-09$ & 8.67E-09 & -- \\
\hline pH & SU & 12 & 6.39 & 7.07 & 7.83 & $6.5-8.5$ \\
\hline
\end{tabular}

Note: As of the end of 2005, sampling at this location is under NYSERDA's cognizance. For information, see the NYSERDA website at www.nyserda.org.

$N$ - Number of samples

-- No applicable reference standard available

${ }^{a}$ New York State Water Quality Standards, Class "C" as a comparative reference for nonradiological results at WNSDADR

Table $\mathrm{C}-4 \mathrm{H}$

2005 Indicator Results in Surface Water at Cooling Tower Basin (WNCOOLW)

\begin{tabular}{|l|c|c|c|}
\hline \multicolumn{1}{|c|}{ Analyte } & Units & N & WNCOOLW \\
\hline Gross Alpha & $\mu \mathrm{Ci} / \mathrm{mL}$ & 1 & $1.52 \pm 0.90 \mathrm{E}-09$ \\
\hline Gross Beta & $\mu \mathrm{Ci} / \mathrm{mL}$ & 1 & $-0.21 \pm 2.36 \mathrm{E}-09$ \\
\hline Tritium & $\mu \mathrm{Ci} / \mathrm{mL}$ & 1 & $-1.88 \pm 0.80 \mathrm{E}-07$ \\
\hline Sr-90 & $\mu \mathrm{Ci} / \mathrm{mL}$ & 1 & $2.26 \pm 1.40 \mathrm{E}-09$ \\
\hline Cs-137 & $\mu \mathrm{Ci} / \mathrm{mL}$ & 1 & $3.67 \pm 7.20 \mathrm{E}-09$ \\
\hline pH & $\mathrm{SU}$ & 1 & 7.16 \\
\hline
\end{tabular}

Note: No standards are applicable for this location. These waters are pumped and treated at the LLWTF prior to discharge at outfall WNSPOO1.

Note: Strontium-90 (Sr-90) analysis in water was performed by a non-NYSDOH ELAP-certified analytical method. See Chapter 5.

$N$ - Number of samples 
This page intentionally left blank

$$
\text { C - } 50
$$




\section{Appendix C-5 Ambient Surface Water Data}

$C-51$ 
This page intentionally left blank

C - 52 
Table C-5A

2005 Radioactivity and $p H$ in Surface Water Downstream of the WVDP in Cattaraugus Creek at Felton Bridge (WFFELBR)

\begin{tabular}{|c|c|c|c|c|c|c|c|}
\hline \multirow{3}{*}{ Analyte } & \multirow{3}{*}{ Units } & \multirow{3}{*}{$\mathbf{N}$} & \multirow{2}{*}{\multicolumn{2}{|c|}{$\begin{array}{c}\text { WFFELBR } \\
\text { Concentrations }\end{array}$}} & \multirow{3}{*}{$\mathbf{N}$} & \multicolumn{2}{|c|}{ Reference Values } \\
\hline & & & & & & \multirow{2}{*}{$\begin{array}{c}\text { WFBIGBR }^{a} \\
\text { Background Range }\end{array}$} & \multirow{2}{*}{$\begin{array}{c}\text { Guideline }^{b} \\
\text { or Standard }^{c}\end{array}$} \\
\hline & & & Average & Maximum & & & \\
\hline Gross Alpha & $\mu \mathrm{Ci} / \mathrm{mL}$ & 12 & $1.28 \pm 1.26 \mathrm{E}-09$ & $3.94 \mathrm{E}-09$ & 6 & $<8.55 \mathrm{E}-10-<2.71 \mathrm{E}-09$ & $3 \mathrm{E}-08^{d}$ \\
\hline Gross Beta & $\mu \mathrm{Ci} / \mathrm{mL}$ & 12 & $4.37 \pm 1.61 \mathrm{E}-09$ & 9.19E-09 & 6 & 2.11E-09-5.24E-09 & $1 \mathrm{E}-06^{e}$ \\
\hline Tritium & $\mu \mathrm{Ci} / \mathrm{mL}$ & 12 & $5.15 \pm 9.10 \mathrm{E}-08$ & $1.25 \mathrm{E}-07$ & 6 & $<5.63 \mathrm{E}-08-1.70 \mathrm{E}-07$ & $2 \mathrm{E}-03$ \\
\hline Sr-90 & $\mu \mathrm{Ci} / \mathrm{mL}$ & 12 & $1.38 \pm 1.26 \mathrm{E}-09$ & 3.52E-09 & 6 & $<6.79 \mathrm{E}-10-1.94 \mathrm{E}-09$ & $1 \mathrm{E}-06$ \\
\hline Tc-99 & $\mu \mathrm{Ci} / \mathrm{mL}$ & 2 & $1.08 \pm 1.64 \mathrm{E}-09$ & $2.24 \mathrm{E}-09$ & 0 & NA & $1 \mathrm{E}-04$ \\
\hline Cs-137 & $\mu \mathrm{Ci} / \mathrm{mL}$ & 12 & $0.45 \pm 2.78 \mathrm{E}-09$ & $<5.40 \mathrm{E}-09$ & 6 & $<1.81 \mathrm{E}-09-<2.60 \mathrm{E}-09$ & $3 \mathrm{E}-06$ \\
\hline pH & $\mathrm{SU}$ & 38 & 7.25 & 8.28 & 6 & $6.74-8.27$ & $6.5-8.5$ \\
\hline
\end{tabular}

Note: Strontium-90 (Sr-90) analysis in water was performed by a non-NYSDOH ELAP-certified analytical method. See Chapter 5.

$N$ - Number of samples

NA - Data not available

${ }^{a}$ Background location

${ }^{b}$ DOE ingestion-based DCGs for $100 \mathrm{mrem} / \mathrm{yr}$ dose limit are provided as a guideline for radiological results in the absence of water quality standards.

"New York State Water Quality Standards, Class "B" as a comparative reference for nonradiological results

${ }^{d}$ Alpha as Am-241

${ }^{e}$ Beta as Sr-90 
Table C-5B

2005 Water Quality of Surface Water Downstream of the WVDP in Buttermilk Creek at Thomas Corners Bridge (WFBCTCB)

RADIOACTIVITY CONCENTRATIONS

\begin{tabular}{|c|c|c|c|c|c|c|c|}
\hline \multirow{3}{*}{ Analyte } & \multirow{3}{*}{ Units } & \multirow{3}{*}{$\mathbf{N}$} & \multirow{2}{*}{\multicolumn{2}{|c|}{$\begin{array}{c}\text { WFBCTCB } \\
\text { Concentrations }\end{array}$}} & \multirow{3}{*}{$\mathbf{N}$} & \multicolumn{2}{|c|}{ Reference Values } \\
\hline & & & & & & \multirow{2}{*}{$\begin{array}{c}\text { WFBCBKG }^{a} \\
\text { Background Range }\end{array}$} & \multirow{2}{*}{ Guideline $^{b}$} \\
\hline & & & Average & Maximum & & & \\
\hline Gross Alpha & $\mu \mathrm{Ci} / \mathrm{mL}$ & 12 & $6.51 \pm 9.25 \mathrm{E}-10$ & $1.75 \mathrm{E}-09$ & 12 & $<2.81 \mathrm{E}-10-1.60 \mathrm{E}-09$ & $3 \mathrm{E}-08^{c}$ \\
\hline Gross Beta & $\mu \mathrm{Ci} / \mathrm{mL}$ & 12 & $1.09 \pm 0.16 \mathrm{E}-08$ & 1.97E-08 & 12 & $1.12 \mathrm{E}-09-5.88 \mathrm{E}-09$ & $1 \mathrm{E}-06^{d}$ \\
\hline Tritium & $\mu \mathrm{Ci} / \mathrm{mL}$ & 12 & $3.45 \pm 8.68 \mathrm{E}-08$ & $2.44 \mathrm{E}-07$ & 12 & $<5.49 \mathrm{E}-08-1.38 \mathrm{E}-07$ & $2 \mathrm{E}-03$ \\
\hline Sr-90 & $\mu \mathrm{Ci} / \mathrm{mL}$ & 3 & $3.10 \pm 1.61 \mathrm{E}-09$ & 3.92E-09 & 4 & $<5.54 \mathrm{E}-10-2.80 \mathrm{E}-09$ & $1 \mathrm{E}-06$ \\
\hline Tc-99 & $\mu \mathrm{Ci} / \mathrm{mL}$ & 2 & $1.15 \pm 1.55 \mathrm{E}-09$ & 2.01E-09 & 4 & $<1.33 \mathrm{E}-09-<2.03 \mathrm{E}-09$ & $1 \mathrm{E}-04$ \\
\hline Cs-137 & $\mu \mathrm{Ci} / \mathrm{mL}$ & 3 & $2.12 \pm 2.13 \mathrm{E}-09$ & $2.56 \mathrm{E}-09$ & 4 & $<1.30 \mathrm{E}-09-3.99 \mathrm{E}-09$ & $3 \mathrm{E}-06$ \\
\hline
\end{tabular}

Note: Strontium-90 (Sr-90) analysis in water was performed by a non-NYSDOH ELAP-certified analytical method. See Chapter 5.

$N$ - Number of samples

${ }^{a}$ Background location

${ }^{b}$ DOE ingestion-based DCGs for $100 \mathrm{mrem} / \mathrm{yr}$ dose limit are provided as a guideline for radiological results in the absence of water quality standards.

${ }^{c}$ Alpha as Am-241

${ }^{d}$ Beta as $\mathrm{Sr}-90$ 
Table C-5B (continued)

2005 Water Quality of Surface Water Downstream of the WVDP in Buttermilk Creek at Thomas Corners Bridge (WFBCTCB)

CHEMICAL CONSTITUENTS

\begin{tabular}{|c|c|c|c|c|c|c|c|}
\hline \multirow{3}{*}{ Analyte } & \multirow{3}{*}{ Units } & \multirow{3}{*}{$\mathbf{N}$} & \multirow{2}{*}{\multicolumn{2}{|c|}{$\begin{array}{c}\text { WFBCTCB } \\
\text { Concentrations }\end{array}$}} & \multirow{3}{*}{$\mathbf{N}$} & \multicolumn{2}{|l|}{ Reference Values } \\
\hline & & & & & & \multirow{2}{*}{$\begin{array}{c}\text { WFBCBKG }^{a} \\
\text { Background Range }\end{array}$} & \multirow{2}{*}{ Standard $^{b}$} \\
\hline & & & Average & Maximum & & & \\
\hline Alpha-BHC & $\mathrm{mg} / \mathrm{L}$ & 2 & $<0.000009$ & $<0.000009$ & 2 & $<0.000008-<0.000009$ & 0.000002 \\
\hline Aluminum, Dissolved & $\mathrm{mg} / \mathrm{L}$ & 2 & $<0.266$ & 0.433 & 2 & $<0.100-0.149$ & 0.10 \\
\hline Ammonia-N & $\mathrm{mg} / \mathrm{L}$ & 2 & $<0.05$ & $<0.05$ & 2 & $<0.05-<0.05$ & $0.09-2.1$ \\
\hline Antimony, Total & $\mathrm{mg} / \mathrm{L}$ & 2 & $<0.003$ & $<0.003$ & 2 & $<0.003-<0.003$ & -- \\
\hline Arsenic, Dissolved & $\mathrm{mg} / \mathrm{L}$ & 2 & $<0.005$ & $<0.005$ & 2 & $<0.005-<0.005$ & 0.150 \\
\hline Barium, Total & $\mathrm{mg} / \mathrm{L}$ & 2 & 0.06 & 0.07 & 2 & $0.07-0.10$ & -- \\
\hline Boron, Total & $\mathrm{mg} / \mathrm{L}$ & 2 & 0.02 & 0.02 & 2 & $0.01-0.02$ & 10.0 \\
\hline Bromide & $\mathrm{mg} / \mathrm{L}$ & 2 & $<0.50$ & $<0.50$ & 2 & $<0.50-<0.50$ & -- \\
\hline Cadmium, Dissolved & $\mathrm{mg} / \mathrm{L}$ & 2 & $<0.001$ & $<0.001$ & 2 & $<0.001-<0.001$ & $0.003^{c}$ \\
\hline Calcium, Total & $\mathrm{mg} / \mathrm{L}$ & 12 & 40.5 & 54.6 & 12 & $19.8-51.3$ & -- \\
\hline Chloride & $\mathrm{mg} / \mathrm{L}$ & 2 & 25 & 30 & 2 & 15-16 & -- \\
\hline Chromium, Dissolved & $\mathrm{mg} / \mathrm{L}$ & 2 & $<0.01$ & $<0.01$ & 2 & $<0.01-<0.01$ & $0.116^{c}$ \\
\hline Cobalt, Total & $\mathrm{mg} / \mathrm{L}$ & 2 & $<0.005$ & $<0.005$ & 2 & $<0.005-<0.005$ & $0.005^{d}$ \\
\hline Copper, Dissolved & $\mathrm{mg} / \mathrm{L}$ & 2 & $<0.005$ & $<0.005$ & 2 & $<0.005-<0.005$ & $0.014^{c}$ \\
\hline Dissolved, Oxygen & $\mathrm{mg} / \mathrm{L}$ & 2 & 10.1 & 11.3 & 2 & $8.2-11.1$ & 4.0 (min) \\
\hline Fluoride & $\mathrm{mg} / \mathrm{L}$ & 2 & $<0.10$ & $<0.10$ & 2 & $<0.10-<0.10$ & $3.47^{c}$ \\
\hline Hardness & $\mathrm{mg} / \mathrm{L}$ & 12 & 130 & 172 & 12 & 62-158 & -- \\
\hline Iron, Total & $\mathrm{mg} / \mathrm{L}$ & 2 & 1.94 & 3.41 & 2 & $0.24-0.72$ & 0.30 \\
\hline Lead, Dissolved & $\mathrm{mg} / \mathrm{L}$ & 2 & $<0.0005$ & $<0.0005$ & 2 & $<0.0005-<0.0005$ & $0.007^{c}$ \\
\hline Magnesium, Total & $\mathrm{mg} / \mathrm{L}$ & 12 & 6.87 & 11.8 & 12 & $2.92-9.52$ & -- \\
\hline Manganese, Total & $\mathrm{mg} / \mathrm{L}$ & 2 & 0.04 & 0.06 & 2 & $0.02-0.02$ & -- \\
\hline Mercury, Dissolved, Method 1631 & $\mathrm{mg} / \mathrm{L}$ & 2 & 0.00000111 & 0.00000147 & 2 & $<0.00000050-0.00000102$ & -- \\
\hline Nickel, Dissolved & $\mathrm{mg} / \mathrm{L}$ & 2 & $<0.04$ & $<0.04$ & 2 & $<0.04<0.04$ & $0.082^{c}$ \\
\hline Nitrate-N & $\mathrm{mg} / \mathrm{L}$ & 2 & 0.56 & 0.56 & 2 & $<0.05-0.25$ & -- \\
\hline Nitrite-N & $\mathrm{mg} / \mathrm{L}$ & 2 & $<0.05$ & $<0.05$ & 2 & $<0.05-<0.05$ & 0.10 \\
\hline NPOC & $\mathrm{mg} / \mathrm{L}$ & 2 & 2.1 & 2.2 & 2 & $1.5-1.9$ & -- \\
\hline
\end{tabular}

$N$ - Number of samples

-- No reference standard available for this analyte

${ }^{a}$ Background location

${ }^{b}$ New York State Water Quality Standards, Class “C” as a comparative reference for nonradiological results

${ }^{c}$ Calculated from maximum measurement of hardness of surface water stream at WFBCTCB

${ }^{d}$ Standards for cobalt, thallium, and vanadium are applicable to the acid-soluble fraction. 


\section{Table C-5B (concluded)}

\section{Water Quality of Surface Water Downstream of the WVDP in Buttermilk Creek at Thomas Corners Bridge (WFBCTCB)}

\section{CHEMICAL CONSTITUENTS (concluded)}

\begin{tabular}{|c|c|c|c|c|c|c|c|}
\hline \multirow{3}{*}{ Analyte } & \multirow{3}{*}{ Units } & \multirow{3}{*}{$\mathbf{N}$} & \multirow{2}{*}{\multicolumn{2}{|c|}{$\begin{array}{c}\text { WFBCTCB } \\
\text { Concentrations }\end{array}$}} & \multirow{3}{*}{$\mathbf{N}$} & \multicolumn{2}{|c|}{ Reference Values } \\
\hline & & & & & & \multirow{2}{*}{$\begin{array}{c}\text { WFBCBKG }^{a} \\
\text { Background Range }\end{array}$} & \multirow{2}{*}{ Standard $^{b}$} \\
\hline & & & Average & Maximum & & & \\
\hline Oil \& Grease & $\mathrm{mg} / \mathrm{L}$ & 2 & $<5$ & $<5$ & 2 & $<5-<5$ & -- \\
\hline pH & $\mathrm{SU}$ & 2 & 8.00 & 8.16 & 2 & $7.29-8.19$ & $6.5-8.5$ \\
\hline Selenium, Dissolved & $\mathrm{mg} / \mathrm{L}$ & 2 & $<0.001$ & $<0.001$ & 2 & $<0.001-<0.001$ & 0.0046 \\
\hline Sodium, Total & $\mathrm{mg} / \mathrm{L}$ & 2 & 15.2 & 18.9 & 2 & $8.7-11.5$ & -- \\
\hline Solids, Total Dissolved & $\mathrm{mg} / \mathrm{L}$ & 2 & 184 & 252 & 2 & $132-292$ & 500 \\
\hline Solids, Total Suspended & $\mathrm{mg} / \mathrm{L}$ & 2 & $<18$ & 32 & 2 & $<4-20$ & -- \\
\hline Sulfate & $\mathrm{mg} / \mathrm{L}$ & 2 & 22 & 26.2 & 2 & $16.8-23.8$ & -- \\
\hline Sulfide & $\mathrm{mg} / \mathrm{L}$ & 2 & $<0.04$ & $<0.04$ & 2 & $<0.04-<0.04$ & 0.002 \\
\hline Surfactant & $\mathrm{mg} / \mathrm{L}$ & 2 & $<0.10$ & $<0.10$ & 2 & $<0.02-<0.10$ & 0.04 \\
\hline Thallium, Total & $\mathrm{mg} / \mathrm{L}$ & 2 & $<0.008$ & $<0.008$ & 2 & $<0.008-<0.008$ & $0.008^{d}$ \\
\hline Titanium, Total & $\mathrm{mg} / \mathrm{L}$ & 2 & $<0.05$ & $<0.05$ & 2 & $<0.05-<0.05$ & -- \\
\hline TOX & $\mathrm{mg} / \mathrm{L}$ & 2 & $<0.01$ & 0.01 & 2 & $<0.00-0.01$ & -- \\
\hline Vanadium, Total & $\mathrm{mg} / \mathrm{L}$ & 2 & $<0.01$ & $<0.01$ & 2 & $<0.01-<0.01$ & $0.014^{d}$ \\
\hline Zinc, Dissolved & $\mathrm{mg} / \mathrm{L}$ & 2 & $<0.02$ & $<0.02$ & 2 & $<0.02-<0.02$ & $0.131^{c}$ \\
\hline
\end{tabular}

$N$ - Number of samples

-- No reference standard available for this analyte

a Background location

${ }^{b}$ New York State Water Quality Standards, Class “C” as a comparative reference for nonradiological results

${ }^{c}$ Calculated from maximum measurement of hardness of surface water stream at WFBCTCB

${ }^{d}$ Standards for cobalt, thallium, and vanadium are applicable to the acid-soluble fraction. 


\section{Table C-5C}

\section{Water Quality of Surface Water Downstream of the WVDP at Frank's Creek (WNSP006)}

\section{RADIOACTIVITY CONCENTRATIONS}

\begin{tabular}{|c|c|c|c|c|c|c|c|}
\hline \multirow{3}{*}{ Analyte } & \multirow{3}{*}{ Units } & \multirow{3}{*}{$\mathbf{N}$} & \multirow{2}{*}{\multicolumn{2}{|c|}{$\begin{array}{c}\text { WNSP006 } \\
\text { Concentrations }\end{array}$}} & \multirow{3}{*}{$\mathbf{N}$} & \multicolumn{2}{|c|}{ Reference Values } \\
\hline & & & & & & \multirow{2}{*}{$\begin{array}{c}\text { WFBCBKG }^{a} \\
\text { Background Range }\end{array}$} & \multirow{2}{*}{ Guideline $^{b}$} \\
\hline & & & Average & Maximum & & & \\
\hline Gross Alpha & $\mu \mathrm{Ci} / \mathrm{mL}$ & 36 & $1.66 \pm 1.57 \mathrm{E}-09$ & $5.61 \mathrm{E}-09$ & 12 & $<2.81 \mathrm{E}-10-1.60 \mathrm{E}-09$ & $3 \mathrm{E}-08^{c}$ \\
\hline Gross Beta & $\mu \mathrm{Ci} / \mathrm{mL}$ & 36 & $6.68 \pm 0.40 \mathrm{E}-08$ & $1.75 \mathrm{E}-07$ & 12 & $1.12 \mathrm{E}-09-5.88 \mathrm{E}-09$ & $1 \mathrm{E}-06^{d}$ \\
\hline Tritium & $\mu \mathrm{Ci} / \mathrm{mL}$ & 36 & $1.69 \pm 0.99 \mathrm{E}-07$ & $1.42 \mathrm{E}-06$ & 12 & $<5.49 \mathrm{E}-08-1.38 \mathrm{E}-07$ & $2 \mathrm{E}-03$ \\
\hline C-14 & $\mu \mathrm{Ci} / \mathrm{mL}$ & 4 & $0.40 \pm 2.63 \mathrm{E}-08$ & $<3.07 \mathrm{E}-08$ & 4 & $<2.23 \mathrm{E}-08-<3.06 \mathrm{E}-08$ & $7 E-05$ \\
\hline Sr-90 & $\mu \mathrm{Ci} / \mathrm{mL}$ & 12 & $3.04 \pm 0.31 \mathrm{E}-08$ & $4.96 \mathrm{E}-08$ & 4 & $<5.54 \mathrm{E}-10-2.80 \mathrm{E}-09$ & $1 \mathrm{E}-06$ \\
\hline Tc-99 & $\mu \mathrm{Ci} / \mathrm{mL}$ & 4 & $0.93 \pm 1.83 \mathrm{E}-09$ & $<2.08 \mathrm{E}-09$ & 4 & $<1.33 \mathrm{E}-09-<2.03 \mathrm{E}-09$ & $1 \mathrm{E}-04$ \\
\hline I-129 & $\mu \mathrm{Ci} / \mathrm{mL}$ & 4 & $5.35 \pm 8.21 \mathrm{E}-10$ & $7.49 \mathrm{E}-10$ & 4 & $<5.21 \mathrm{E}-10-<1.10 \mathrm{E}-09$ & $5 \mathrm{E}-07$ \\
\hline Cs-137 & $\mu \mathrm{Ci} / \mathrm{mL}$ & 12 & $5.37 \pm 7.22 \mathrm{E}-09$ & $1.65 \mathrm{E}-08$ & 4 & $<1.30 \mathrm{E}-09-3.99 \mathrm{E}-09$ & $3 E-06$ \\
\hline U-232 & $\mu \mathrm{Ci} / \mathrm{mL}$ & 4 & $3.52 \pm 1.31 \mathrm{E}-10$ & $6.24 \mathrm{E}-10$ & 4 & $<2.02 \mathrm{E}-11-<1.06 \mathrm{E}-10$ & $1 \mathrm{E}-07$ \\
\hline U-233/234 & $\mu \mathrm{Ci} / \mathrm{mL}$ & 4 & $4.07 \pm 1.41 \mathrm{E}-10$ & $5.78 \mathrm{E}-10$ & 4 & 8.16E-11-2.01E-10 & $5 \mathrm{E}-07$ \\
\hline $\mathrm{U}-235 / 236$ & $\mu \mathrm{Ci} / \mathrm{mL}$ & 4 & $5.40 \pm 5.46 \mathrm{E}-11$ & $9.43 \mathrm{E}-11$ & 4 & $3.27 \mathrm{E}-11-6.43 \mathrm{E}-11$ & $5 \mathrm{E}-07^{e}$ \\
\hline U-238 & $\mu \mathrm{Ci} / \mathrm{mL}$ & 4 & $4.03 \pm 1.41 \mathrm{E}-10$ & 7.43E-10 & 4 & $4.31 \mathrm{E}-11-2.26 \mathrm{E}-10$ & $6 \mathrm{E}-07$ \\
\hline Total U & $\mu \mathrm{g} / \mathrm{mL}$ & 4 & $9.89 \pm 0.23 \mathrm{E}-04$ & $1.38 \mathrm{E}-03$ & 4 & 2.17E-04-3.61E-04 & -- \\
\hline Pu-238 & $\mu \mathrm{Ci} / \mathrm{mL}$ & 4 & $0.99 \pm 2.76 \mathrm{E}-11$ & $<4.59 \mathrm{E}-11$ & 4 & $<7.27 \mathrm{E}-12-<4.13 \mathrm{E}-11$ & $4 \mathrm{E}-08$ \\
\hline $\mathrm{Pu}-239 / 240$ & $\mu \mathrm{Ci} / \mathrm{mL}$ & 4 & $-0.19 \pm 2.43 \mathrm{E}-11$ & $<3.17 \mathrm{E}-11$ & 4 & $<5.54 \mathrm{E}-12-<2.86 \mathrm{E}-11$ & $3 \mathrm{E}-08$ \\
\hline Am-241 & $\mu \mathrm{Ci} / \mathrm{mL}$ & 4 & $2.15 \pm 3.01 \mathrm{E}-11$ & 3.24E-11 & 4 & $<1.37 \mathrm{E}-11-<3.05 \mathrm{E}-11$ & $3 \mathrm{E}-08$ \\
\hline
\end{tabular}

Note: Strontium-90 (Sr-90) analysis in water was performed by a non-NYSDOH ELAP-certified analytical method. See Chapter 5.

$N$ - Number of samples

-- No guideline or standard available for these analytes

${ }^{a}$ Background location

${ }^{b}$ DOE ingestion-based DCGs for $100 \mathrm{mrem} / y \mathrm{r}$ dose limit are provided as a guideline for radiological results.

${ }^{c}$ Alpha as Am-241

${ }^{d}$ Beta as $\operatorname{Sr}-90$

${ }^{e}$ DCG for U-236 is used for this comparison. 


\section{Table C-5C (continued) \\ 2005 Water Quality of Surface Water Downstream of the WVDP at Frank's Creek (WNSP006)}

CHEMICAL CONSTITUENTS

\begin{tabular}{|c|c|c|c|c|c|c|c|}
\hline \multirow{3}{*}{ Analyte } & \multirow{3}{*}{ Units } & \multirow{3}{*}{$\mathbf{N}$} & \multirow{2}{*}{\multicolumn{2}{|c|}{$\begin{array}{c}\text { WNSP006 } \\
\text { Concentrations }\end{array}$}} & \multirow{3}{*}{$\mathbf{N}$} & \multicolumn{2}{|c|}{ Reference Values } \\
\hline & & & & & & \multirow{2}{*}{$\begin{array}{c}\text { WFBCBKG }^{a} \\
\text { Background Range }\end{array}$} & \multirow{2}{*}{ Standard ${ }^{b}$} \\
\hline & & & Average & Maximum & & & \\
\hline Alpha-BHC & $\mathrm{mg} / \mathrm{L}$ & 2 & $<0.000008$ & $<0.000009$ & 2 & $<0.000008-<0.000009$ & 0.000002 \\
\hline Aluminum, Dissolved & $\mathrm{mg} / \mathrm{L}$ & 2 & 0.347 & 0.397 & 2 & $<0.100-0.149$ & 0.10 \\
\hline Ammonia-N & $\mathrm{mg} / \mathrm{L}$ & 2 & $<0.05$ & 0.06 & 2 & $<0.05-<0.05$ & $0.09-2.1$ \\
\hline Antimony, Total & $\mathrm{mg} / \mathrm{L}$ & 2 & $<0.003$ & $<0.003$ & 2 & $<0.003-<0.003$ & -- \\
\hline Arsenic, Dissolved & $\mathrm{mg} / \mathrm{L}$ & 2 & $<0.005$ & $<0.005$ & 2 & $<0.005-<0.005$ & 0.150 \\
\hline Barium, Total & $\mathrm{mg} / \mathrm{L}$ & 2 & $<0.05$ & 0.06 & 2 & $0.07-0.10$ & -- \\
\hline Boron, Total & $\mathrm{mg} / \mathrm{L}$ & 2 & 0.02 & 0.02 & 2 & $0.01-0.02$ & 10.0 \\
\hline Bromide & $\mathrm{mg} / \mathrm{L}$ & 2 & $<0.50$ & 0.5 & 2 & $<0.50-<0.50$ & -- \\
\hline Cadmium, Dissolved & $\mathrm{mg} / \mathrm{L}$ & 2 & $<0.001$ & $<0.001$ & 2 & $<0.001-<0.001$ & $0.005^{c}$ \\
\hline Calcium, Total & $\mathrm{mg} / \mathrm{L}$ & 12 & 48.7 & 86.7 & 12 & $19.8-51.3$ & -- \\
\hline Chloride & $\mathrm{mg} / \mathrm{L}$ & 2 & 105 & 114 & 2 & $15-16$ & -- \\
\hline Chromium, Dissolved & $\mathrm{mg} / \mathrm{L}$ & 2 & $<0.01$ & $<0.01$ & 2 & $<0.01-<0.01$ & $0.167^{c}$ \\
\hline Cobalt, Total & $\mathrm{mg} / \mathrm{L}$ & 2 & $<0.005$ & $<0.005$ & 2 & $<0.005-<0.005$ & $0.005^{d}$ \\
\hline Copper, Dissolved & $\mathrm{mg} / \mathrm{L}$ & 2 & $<0.005$ & $<0.005$ & 2 & $<0.005-<0.005$ & $0.021^{c}$ \\
\hline Dissolved Oxygen & $\mathrm{mg} / \mathrm{L}$ & 2 & 10.1 & 12 & 2 & $8.2-11.1$ & $4.0(\mathrm{~min})$ \\
\hline Fluoride & $\mathrm{mg} / \mathrm{L}$ & 2 & $<0.10$ & 0.1 & 2 & $<0.10-<0.10$ & $4.72^{c}$ \\
\hline Hardness & $\mathrm{mg} / \mathrm{L}$ & 12 & 154 & 270 & 12 & 62-158 & -- \\
\hline Iron, Total & $\mathrm{mg} / \mathrm{L}$ & 2 & 1.6 & 1.84 & 2 & $0.24-0.72$ & 0.30 \\
\hline Lead, Dissolved & $\mathrm{mg} / \mathrm{L}$ & 2 & $<0.0005$ & $<0.0005$ & 2 & $<0.0005-<0.0005$ & $0.011^{c}$ \\
\hline Magnesium, Total & $\mathrm{mg} / \mathrm{L}$ & 12 & 7.97 & 13.1 & 12 & $2.92-9.52$ & -- \\
\hline Manganese, Total & $\mathrm{mg} / \mathrm{L}$ & 2 & 0.11 & 0.15 & 2 & $0.02-0.02$ & -- \\
\hline Mercury, Dissolved, Method 1631 & $\mathrm{mg} / \mathrm{L}$ & 2 & 0.00000456 & 0.00000658 & 2 & $<0.0000005-0.00000102$ & -- \\
\hline Nickel, Dissolved & $\mathrm{mg} / \mathrm{L}$ & 2 & $<0.04$ & $<0.04$ & 2 & $<0.04-<0.04$ & $0.121^{c}$ \\
\hline Nitrate-N & $\mathrm{mg} / \mathrm{L}$ & 2 & 0.73 & 0.81 & 2 & $<0.05-0.25$ & -- \\
\hline Nitrite-N & $\mathrm{mg} / \mathrm{L}$ & 2 & $<0.05$ & $<0.05$ & 2 & $<0.05-<0.05$ & 0.10 \\
\hline NPOC & $\mathrm{mg} / \mathrm{L}$ & 2 & 3.0 & 3.5 & 2 & $1.5-1.9$ & -- \\
\hline Oil \& Grease & $\mathrm{mg} / \mathrm{L}$ & 2 & $<5$ & $<5$ & 2 & $<5-<5$ & -- \\
\hline pH & $\mathrm{SU}$ & 2 & 7.87 & 7.92 & 2 & $7.29-8.19$ & $6.5-8.5$ \\
\hline
\end{tabular}

$N$ - Number of samples

-- No guideline or standard available for these analytes

${ }^{a}$ Background location

${ }^{b}$ New York Water Quality Standards for Class "C" surface waters as a comparative reference for nonradiological results.

${ }^{c}$ Calculated from maximum measured hardness of surface water stream at WNSP006.

${ }^{d}$ Standards for cobalt, thallium, and vanadium are applicable to the acid-soluble fraction. 
Table C-5C (concluded)

2005 Water Quality of Surface Water Downstream of the WVDP at Frank's Creek (WNSP006)

CHEMICAL CONSTITUENTS (concluded)

\begin{tabular}{|c|c|c|c|c|c|c|c|}
\hline \multirow{3}{*}{ Analyte } & \multirow{3}{*}{ Units } & \multirow{3}{*}{$\mathbf{N}$} & \multirow{2}{*}{\multicolumn{2}{|c|}{$\begin{array}{c}\text { WNSP006 } \\
\text { Concentrations }\end{array}$}} & \multirow{3}{*}{$\mathbf{N}$} & \multicolumn{2}{|c|}{ Reference Values } \\
\hline & & & & & & \multirow{2}{*}{$\begin{array}{c}\text { WFBCBKG }^{a} \\
\text { Background Range }\end{array}$} & \multirow{2}{*}{ Standard $^{b}$} \\
\hline & & & Average & Maximum & & & \\
\hline Selenium, Dissolved & $\mathrm{mg} / \mathrm{L}$ & 2 & $<0.001$ & $<0.001$ & 2 & $<0.001-<0.001$ & 0.0046 \\
\hline Sodium, Total & $\mathrm{mg} / \mathrm{L}$ & 2 & 65.2 & 74.7 & 2 & $8.7-11.5$ & -- \\
\hline Solids, Total Dissolved & $\mathrm{mg} / \mathrm{L}$ & 35 & 340 & 619 & 2 & $132-292$ & 500 \\
\hline Solids, Total Suspended & $\mathrm{mg} / \mathrm{L}$ & 2 & 44 & 60 & 2 & $<4-20$ & -- \\
\hline Sulfate & $\mathrm{mg} / \mathrm{L}$ & 2 & 36.6 & 45.1 & 2 & $16.8-23.8$ & -- \\
\hline Sulfide & $\mathrm{mg} / \mathrm{L}$ & 2 & $<0.04$ & $<0.04$ & 2 & $<0.04-<0.04$ & 0.002 \\
\hline Surfactants & $\mathrm{mg} / \mathrm{L}$ & 2 & $<0.06$ & $<0.10$ & 2 & $<0.02-<0.10$ & 0.40 \\
\hline Thallium, Total & $\mathrm{mg} / \mathrm{L}$ & 2 & $<0.008$ & $<0.008$ & 2 & $<0.008-<0.008$ & $0.008^{d}$ \\
\hline Titanium, Total & $\mathrm{mg} / \mathrm{L}$ & 2 & $<0.05$ & $<0.05$ & 2 & $<0.05-<0.05$ & -- \\
\hline TOX & $\mathrm{mg} / \mathrm{L}$ & 2 & 0.01 & 0.01 & 2 & $<0.00-0.01$ & -- \\
\hline Vanadium, Total & $\mathrm{mg} / \mathrm{L}$ & 2 & $<0.01$ & $<0.01$ & 2 & $<0.01-<0.01$ & $0.014^{d}$ \\
\hline Zinc, Dissolved & $\mathrm{mg} / \mathrm{L}$ & 2 & $<0.02$ & $<0.02$ & 2 & $<0.02-<0.02$ & $0.192^{c}$ \\
\hline
\end{tabular}

$N$ - Number of samples

-- No guideline or standard available for these analytes

a Background location

${ }^{b}$ New York Water Quality Standards for Class “C” surface waters as a comparative reference for nonradiological results.

${ }^{c}$ Calculated from maximum measured hardness of surface water stream at WNSP006.

${ }^{d}$ Standards for cobalt, thallium, and vanadium are applicable to the acid-soluble fraction. 
Table C-5D

2005 Total Dissolved Solids From Outfall WNSP116

\begin{tabular}{|c|c|c|c|c|c|}
\hline \multirow{2}{*}{ Month } & \multirow{2}{*}{ Units } & \multirow{2}{*}{$\mathbf{N}$} & \multicolumn{2}{|c|}{ Total Dissolved Solids } & \multirow{2}{*}{$\begin{array}{c}\text { Daily Maximum } \\
\text { Limit }\end{array}$} \\
\hline & & & Average & Maximum & \\
\hline January & $\mathrm{mg} / \mathrm{L}$ & 2 & 353 & 381 & 500 \\
\hline February $^{a}$ & $\mathrm{mg} / \mathrm{L}$ & 0 & -- & -- & 500 \\
\hline March & $\mathrm{mg} / \mathrm{L}$ & 2 & 387 & 396 & 500 \\
\hline April & $\mathrm{mg} / \mathrm{L}$ & 2 & 293 & 348 & 500 \\
\hline May $^{a}$ & $\mathrm{mg} / \mathrm{L}$ & 0 & -- & -- & 500 \\
\hline June $^{a}$ & $\mathrm{mg} / \mathrm{L}$ & 0 & -- & -- & 500 \\
\hline July & $\mathrm{mg} / \mathrm{L}$ & 2 & 380 & 405 & 500 \\
\hline August $^{a}$ & $\mathrm{mg} / \mathrm{L}$ & 0 & -- & -- & 500 \\
\hline September & $\mathrm{mg} / \mathrm{L}$ & 2 & 313 & 320 & 500 \\
\hline October $^{a}$ & $\mathrm{mg} / \mathrm{L}$ & 0 & -- & -- & 500 \\
\hline November & $\mathrm{mg} / \mathrm{L}$ & 2 & 227 & 258 & 500 \\
\hline December & $\mathrm{mg} / \mathrm{L}$ & 2 & 387 & 432 & 500 \\
\hline
\end{tabular}

$N$ - Number of samples

${ }^{a}$ No discharge this month

Table C-5E

2005 Indicator Results in Surface Water at Erdman Brook (WNERB53)

\begin{tabular}{|c|c|c|c|c|c|c|}
\hline \multirow{3}{*}{ Analyte } & \multirow{3}{*}{ Units } & \multirow{3}{*}{$\mathbf{N}$} & \multirow{2}{*}{\multicolumn{3}{|c|}{ WNERB53 Concentrations }} & \multirow{3}{*}{$\begin{array}{c}\text { Reference } \\
\text { Guideline }^{a} \text { or } \\
\text { Standard }^{b}\end{array}$} \\
\hline & & & & & & \\
\hline & & & Minimum & Average & Maximum & \\
\hline Gross Alpha & $\mu \mathrm{Ci} / \mathrm{mL}$ & 24 & $<8.86 \mathrm{E}-10$ & $0.33 \pm 1.54 \mathrm{E}-09$ & $2.07 \mathrm{E}-09$ & $3 \mathrm{E}-08^{c}$ \\
\hline Gross Beta & $\mu \mathrm{Ci} / \mathrm{mL}$ & 24 & $8.69 \mathrm{E}-09$ & $1.59 \pm 0.27 \mathrm{E}-08$ & $2.96 \mathrm{E}-08$ & $1 \mathrm{E}-06^{d}$ \\
\hline Tritium & $\mu \mathrm{Ci} / \mathrm{mL}$ & 24 & $<5.58 \mathrm{E}-08$ & $5.92 \pm 7.64 \mathrm{E}-08$ & $1.74 \mathrm{E}-07$ & $2 \mathrm{E}-03$ \\
\hline Sr-90 & $\mu \mathrm{Ci} / \mathrm{mL}$ & 3 & $5.30 \mathrm{E}-09$ & $6.92 \pm 1.64 \mathrm{E}-09$ & $8.75 \mathrm{E}-09$ & $1 \mathrm{E}-06$ \\
\hline Cs-137 & $\mu \mathrm{Ci} / \mathrm{mL}$ & 3 & $<1.54 \mathrm{E}-09$ & $2.59 \pm 4.25 \mathrm{E}-09$ & $<6.92 \mathrm{E}-09$ & $3 \mathrm{E}-06$ \\
\hline pH & SU & 24 & 6.60 & 7.47 & 8.08 & $6.0-9.5$ \\
\hline
\end{tabular}

Note: Strontium-90 (Sr-90) analysis in water was performed by a non-NYSDOH ELAP-certified analytical method. See Chapter 5.

$N$ - Number of samples

${ }^{a}$ DOE ingestion-based DCGs for 100 mrem/yr dose limit are provided as a guideline for radiological results.

${ }^{b}$ New York State Water Quality Standards, Class “D” for surface waters as a standard for nonradiological results

${ }^{c}$ Alpha as Am-241

${ }^{d}$ Beta as Sr-90 


\section{Table C-5F \\ 2005 Indicator Results in Surface Water at Frank's Creek East of the SDA (WNFRC67)}

\begin{tabular}{|l|c|c|c|c|c|c|}
\hline \multirow{2}{*}{\multicolumn{1}{c|}{ Analyte }} & \multirow{2}{*}{ Units } & \multirow{2}{*}{$\mathbf{N}$} & \multicolumn{3}{c|}{ WNFRC67 Concentrations } & $\begin{array}{c}\text { Reference } \\
\text { Guideline }^{\boldsymbol{a}} \text { or } \\
\text { Standard }^{\boldsymbol{b}}\end{array}$ \\
\cline { 4 - 7 } & & & Minimum & Average & Maximum & $3 \mathrm{E}-08^{c}$ \\
\hline Gross Alpha & $\mu \mathrm{Ci} / \mathrm{mL}$ & 8 & $<5.02 \mathrm{E}-10$ & $1.54 \pm 7.55 \mathrm{E}-10$ & $1.95 \mathrm{E}-09$ & $1 \mathrm{E}-06^{d}$ \\
\hline Gross Beta & $\mu \mathrm{Ci} / \mathrm{mL}$ & 8 & $8.07 \mathrm{E}-10$ & $2.32 \pm 1.27 \mathrm{E}-09$ & $6.74 \mathrm{E}-09$ & $2 \mathrm{E}-03$ \\
\hline Tritium & $\mu \mathrm{Ci} / \mathrm{mL}$ & 8 & $<7.80 \mathrm{E}-08$ & $1.51 \pm 8.56 \mathrm{E}-08$ & $1.60 \mathrm{E}-07$ & $1 \mathrm{E}-06$ \\
\hline Sr-90 & $\mu \mathrm{Ci} / \mathrm{mL}$ & 4 & $1.28 \mathrm{E}-09$ & $0.97 \pm 1.16 \mathrm{E}-09$ & $1.37 \mathrm{E}-09$ & $3 \mathrm{E}-06$ \\
\hline Cs-137 & $\mu \mathrm{Ci} / \mathrm{mL}$ & 4 & $<1.83 \mathrm{E}-09$ & $0.68 \pm 2.00 \mathrm{E}-09$ & $2.26 \mathrm{E}-09$ & $6.5-8.5$ \\
\hline pH & $\mathrm{SU}$ & 7 & 7.08 & 7.45 & 7.98 & \\
\hline
\end{tabular}

Note: Strontium-90 (Sr-90) analysis in water was performed by a non-NYSDOH ELAP-certified analytical method. See Chapter 5.

$N$ - Number of samples

${ }^{a}$ DOE ingestion-based DCGs for $100 \mathrm{mrem} / \mathrm{yr}$ dose limit are provided as a guideline for radiological results in the absence of water quality standards.

${ }^{b}$ New York State Water Quality Standards for Class "C" surface waters as a comparative reference for nonradiological results.

c Alpha as Am-241

${ }^{d}$ Beta as $\mathrm{Sr}-90$

Table $C-5 G$

2005 Indicator Results in Surface Water at Drum Cell Drainage (WNDCELD)

\begin{tabular}{|c|c|c|c|c|c|c|}
\hline \multirow{3}{*}{ Analyte } & \multirow{3}{*}{ Units } & \multirow{3}{*}{$\mathbf{N}$} & \multirow{2}{*}{\multicolumn{3}{|c|}{ WNDCELD Concentrations }} & \multirow{3}{*}{$\begin{array}{c}\text { Reference } \\
\text { Guideline }^{a} \\
\text { or Standard }^{b}\end{array}$} \\
\hline & & & & & & \\
\hline & & & Minimum & Average & Maximum & \\
\hline Gross Alpha & $\mu \mathrm{Ci} / \mathrm{mL}$ & 9 & $<5.39 \mathrm{E}-10$ & $3.21 \pm 7.59 \mathrm{E}-10$ & $1.57 \mathrm{E}-09$ & $3 \mathrm{E}-08^{c}$ \\
\hline Gross Beta & $\mu \mathrm{Ci} / \mathrm{mL}$ & 9 & $<1.20 \mathrm{E}-09$ & $2.17 \pm 1.25 \mathrm{E}-09$ & $3.60 \mathrm{E}-09$ & $1 \mathrm{E}-06^{d}$ \\
\hline Tritium & $\mu \mathrm{Ci} / \mathrm{mL}$ & 6 & $<7.81 \mathrm{E}-08$ & $0.05 \pm 1.03 \mathrm{E}-07$ & $1.52 \mathrm{E}-07$ & $2 \mathrm{E}-03$ \\
\hline Sr-90 & $\mu \mathrm{Ci} / \mathrm{mL}$ & 3 & $<5.78 \mathrm{E}-10$ & $0.88 \pm 1.16 \mathrm{E}-09$ & $2.57 \mathrm{E}-09$ & $1 \mathrm{E}-06$ \\
\hline I-129 & $\mu \mathrm{Ci} / \mathrm{mL}$ & 2 & $<8.44 \mathrm{E}-10$ & $0.61 \pm 1.13 \mathrm{E}-09$ & $<1.36 \mathrm{E}-09$ & $5 \mathrm{E}-07$ \\
\hline Cs-137 & $\mu \mathrm{Ci} / \mathrm{mL}$ & 3 & $<3.18 \mathrm{E}-09$ & $1.10 \pm 5.44 \mathrm{E}-09$ & $<6.33 \mathrm{E}-09$ & $3 \mathrm{E}-06$ \\
\hline pH & SU & 8 & 7.49 & 7.65 & 8.44 & $6.5-8.5$ \\
\hline
\end{tabular}

Note: Strontium-90 (Sr-90) analysis in water was performed by a non-NYSDOH ELAP-certified analytical method. See Chapter 5.

$N$ - Number of samples

${ }^{a}$ DOE ingestion-based DCGs for 100 mrem/yr dose limit are provided as a guideline for radiological results in the absence of water quality standards.

${ }^{b}$ New York State Water Quality Standards for Class “C” surface waters as a comparative reference for nonradiological results.

${ }^{c}$ Alpha as Am-241

${ }^{d}$ Beta as $\mathrm{Sr}-90$

WVDP Annual Site Environmental Report

$C-61$

Calendar Year 2005 


\section{Table C-5H}

\section{Water Quality of Surface Water at the Standing Water Location (WNSTAW9)}

\begin{tabular}{|c|c|c|c|c|}
\hline \multirow[b]{2}{*}{ Analyte } & \multirow[b]{2}{*}{ Units } & \multirow[b]{2}{*}{$\mathbf{N}$} & \multirow[b]{2}{*}{ WNSTAW9 } & Reference Values \\
\hline & & & & Guideline $^{a}$ or Standard ${ }^{b}$ \\
\hline Gross Alpha & $\mu \mathrm{Ci} / \mathrm{mL}$ & 1 & $0.11 \pm 2.49 \mathrm{E}-10$ & $3 \mathrm{E}-08^{c}$ \\
\hline Gross Beta & $\mu \mathrm{Ci} / \mathrm{mL}$ & 1 & $2.06 \pm 0.81 \mathrm{E}-09$ & $1 \mathrm{E}-06^{d}$ \\
\hline Tritium & $\mu \mathrm{Ci} / \mathrm{mL}$ & 1 & $0.04 \pm 1.12 \mathrm{E}-07$ & $2 \mathrm{E}-03$ \\
\hline Sr-90 & $\mu \mathrm{Ci} / \mathrm{mL}$ & 1 & $2.69 \pm 6.70 \mathrm{E}-10$ & $1 \mathrm{E}-06$ \\
\hline Cs-137 & $\mu \mathrm{Ci} / \mathrm{mL}$ & 1 & $0.00 \pm 2.85 \mathrm{E}-09$ & $3 \mathrm{E}-06$ \\
\hline Chloride & $\mathrm{mg} / \mathrm{L}$ & 1 & 12 & -- \\
\hline Conductivity & $\mu \mathrm{mhos} / \mathrm{cm} @ 25^{\circ} \mathrm{C}$ & 1 & 210 & -- \\
\hline Iron, Total & $\mathrm{mg} / \mathrm{L}$ & 1 & 0.24 & 0.3 \\
\hline Manganese, Total & $\mathrm{mg} / \mathrm{L}$ & 1 & 0.25 & -- \\
\hline Nitrate+Nitrite & $\mathrm{mg} / \mathrm{L}$ & 1 & 0.07 & -- \\
\hline pH & SU & 1 & 7.85 & $6.5-8.5$ \\
\hline Sodium, Total & $\mathrm{mg} / \mathrm{L}$ & 1 & 6.9 & -- \\
\hline Sulfate & $\mathrm{mg} / \mathrm{L}$ & 1 & 18.2 & -- \\
\hline
\end{tabular}

Note: Strontium-90 (Sr-90) analysis in water was performed by a non-NYSDOH ELAP-certified analytical method. See Chapter 5.

$N$ - Number of samples

-- No guideline or standard available for these analytes

${ }^{a}$ DOE ingestion-based DCGs for 100 mrem/yr dose limit are provided as a guideline for radiological results.

${ }^{b}$ New York State Water Quality Standards Class “D” surface waters as a comparative standard for nonradiological results

c Alpha as Am-241

${ }^{d}$ Beta as $\mathrm{Sr}-90$ 


\section{Appendix C-6 \\ Potable Water (Drinking Water) Data}


This page intentionally left blank

$$
\text { C }-64
$$


Table C-6A

2005 Indicator Results in Background Potable Well Water

\begin{tabular}{|l|c|c|c|c|}
\hline \multicolumn{1}{|c|}{ Analyte } & Units & N & $\begin{array}{c}\text { Background } \\
\text { WFWEL06 }\end{array}$ & Standard $^{a, b}$ \\
\hline Gross Alpha & $\mu \mathrm{Ci} / \mathrm{mL}$ & 1 & $-5.04 \pm 7.90 \mathrm{E}-10$ & $1.5 \mathrm{E}-08^{c}$ \\
\hline Gross Beta & $\mu \mathrm{Ci} / \mathrm{mL}$ & 1 & $1.30 \pm 1.28 \mathrm{E}-09$ & $1 \mathrm{E}-06^{d}$ \\
\hline Tritium & $\mu \mathrm{Ci} / \mathrm{mL}$ & 1 & $1.22 \pm 1.19 \mathrm{E}-07$ & -- \\
\hline Sr-90 & $\mu \mathrm{Ci} / \mathrm{mL}$ & 1 & $-3.00 \pm 5.11 \mathrm{E}-10$ & -- \\
\hline Cs-137 & $\mu \mathrm{Ci} / \mathrm{mL}$ & 1 & $0.38 \pm 1.69 \mathrm{E}-09$ & -- \\
\hline Conductivity & $\mu \mathrm{mhos} / \mathrm{cm} @ 25^{\circ} \mathrm{C}$ & 1 & 292 & -- \\
\hline pH & $\mathrm{SU}$ & 1 & 8.41 & $6.5-8.5$ \\
\hline
\end{tabular}

Note: Strontium-90 (Sr-90) analysis in water was performed by a non-NYSDOH ELAP-certified analytical method. See Chapter 5.

Note: As of April 2005, all off-site potable wells are sampled once every two years, with the exception of the background well WFWELO6, which is sampled annually. The remaining wells are scheduled to be sampled in CY 2006.

N - Number of samples

-- No guideline or standard available for these analytes

${ }^{a}$ New York State Water Quality Standard for Class “GA” for fresh groundwater

${ }^{b}$ NYSDOH raw water supply standards (10 NYCRR Part 170.4)

${ }^{c}$ Alpha standard excludes radon and uranium, however, the WVDP results include these isotopes.

${ }^{d}$ Beta standard excludes strontium and alpha emitters, however the WVDP results include these isotopes. 
Table C-6B

2005 Indicator Results in Main Plant Potable Water (WNDNKMP)

\begin{tabular}{|c|c|c|c|c|c|c|}
\hline \multirow{2}{*}{ Analyte } & \multirow{2}{*}{ Units } & \multirow{2}{*}{$\mathbf{N}$} & \multicolumn{3}{|c|}{ Annual Concentration } & \multirow{2}{*}{ Standard } \\
\hline & & & Minimum & Average & Maximum & \\
\hline Gross Alpha & $\mu \mathrm{Ci} / \mathrm{mL}$ & 1 & $5.64 \mathrm{E}-10$ & $5.64 \pm 3.72 \mathrm{E}-10$ & $5.64 \mathrm{E}-10$ & $1.5 \mathrm{E}-08$ \\
\hline Gross Beta & $\mu \mathrm{Ci} / \mathrm{mL}$ & 1 & $<7.23 \mathrm{E}-10$ & $5.58 \pm 7.23 \mathrm{E}-10$ & $<7.23 \mathrm{E}-10$ & $5 \mathrm{E}-08$ \\
\hline Tritium & $\mu \mathrm{Ci} / \mathrm{mL}$ & 1 & $<5.66 \mathrm{E}-08$ & $-1.50 \pm 0.57 \mathrm{E}-07$ & $<5.66 \mathrm{E}-08$ & $2 \mathrm{E}-05$ \\
\hline Conductivity & $\mu \mathrm{mhos} / \mathrm{cm} @ 25^{\circ} \mathrm{C}$ & 1 & 167 & 167 & 167 & -- \\
\hline pH & SU & 1 & 7.42 & 7.42 & 7.42 & -- \\
\hline
\end{tabular}

2005 Indicator Results in Environmental Laboratory Potable Water (WNDNKEL)

\begin{tabular}{|c|c|c|c|c|c|c|}
\hline \multirow{2}{*}{ Analyte } & \multirow{2}{*}{ Units } & \multirow{2}{*}{$\mathbf{N}$} & \multicolumn{3}{|c|}{ Annual Concentration } & \multirow{2}{*}{ Standard } \\
\hline & & & Minimum & Average & Maximum & \\
\hline Gross Alpha & $\mu \mathrm{Ci} / \mathrm{mL}$ & 2 & $<4.86 \mathrm{E}-10$ & $2.80 \pm 5.00 \mathrm{E}-10$ & $<5.13 \mathrm{E}-10$ & $1.5 \mathrm{E}-08$ \\
\hline Gross Beta & $\mu \mathrm{Ci} / \mathrm{mL}$ & 2 & $1.38 \mathrm{E}-09$ & $1.77 \pm 0.93 \mathrm{E}-09$ & $2.16 \mathrm{E}-09$ & $5 \mathrm{E}-08$ \\
\hline Tritium & $\mu \mathrm{Ci} / \mathrm{mL}$ & 2 & $<7.75 \mathrm{E}-08$ & $-0.36 \pm 9.17 \mathrm{E}-08$ & $<1.04 \mathrm{E}-07$ & $2 \mathrm{E}-05$ \\
\hline Conductivity & $\mu \mathrm{mhos} / \mathrm{cm} @ 25^{\circ} \mathrm{C}$ & 2 & 179 & 194 & 209 & -- \\
\hline Haloacetic Acids-Five (5) & $\mathrm{mg} / \mathrm{L}$ & 3 & $<0.028$ & $<0.029$ & $<0.031$ & 0.06 \\
\hline pH & SU & 2 & 7.32 & 7.57 & 8.26 & -- \\
\hline Total Trihalomethanes & $\mathrm{mg} / \mathrm{L}$ & 3 & $<0.010$ & $<0.041$ & $<0.057$ & 0.08 \\
\hline
\end{tabular}

2005 Indicator Results in Maintenance Shop Potable Water (WNDNKMS)

\begin{tabular}{|l|c|c|c|c|c|c|}
\hline \multirow{2}{*}{\multicolumn{1}{c|}{ Analyte }} & \multirow{2}{*}{ Units } & \multirow{2}{*}{$\mathbf{N}$} & \multicolumn{4}{c|}{ Annual Concentration } \\
\cline { 3 - 7 } & & & Minimum & Average & Maximum & Standard $^{a}$ \\
\hline Gross Alpha & $\mu \mathrm{Ci} / \mathrm{mL}$ & 2 & $<3.80 \mathrm{E}-10$ & $2.27 \pm 4.66 \mathrm{E}-10$ & $<5.38 \mathrm{E}-10$ & $1.5 \mathrm{E}-08$ \\
\hline Gross Beta & $\mu \mathrm{Ci} / \mathrm{mL}$ & 2 & $<7.14 \mathrm{E}-10$ & $6.77 \pm 7.19 \mathrm{E}-10$ & $9.11 \mathrm{E}-10$ & $5 \mathrm{E}-08$ \\
\hline Tritium & $\mu \mathrm{Ci} / \mathrm{mL}$ & 2 & $<7.80 \mathrm{E}-08$ & $3.98 \pm 7.93 \mathrm{E}-08$ & $<8.06 \mathrm{E}-08$ & $2 \mathrm{E}-05$ \\
\hline Conductivity & $\mu \mathrm{mhos} / \mathrm{cm} @ 25^{\circ} \mathrm{C}$ & 2 & 180 & 185 & 190 & -- \\
\hline pH & $\mathrm{SU}$ & 2 & 8.00 & 8.11 & 8.26 & -- \\
\hline
\end{tabular}

$N$ - Number of samples

-- No guideline or standard available for these analytes

${ }^{a}$ New York State Department of Health MCLs for drinking water used as a comparative reference 
Table C-6C

2005 Water Quality Results in Utility Room Potable Water (WNDNKUR)

\begin{tabular}{|c|c|c|c|c|c|c|}
\hline \multirow{2}{*}{ Analyte } & \multirow{2}{*}{ Units } & \multirow{2}{*}{$\mathbf{N}$} & \multicolumn{3}{|c|}{ WNDNKUR Concentrations } & \multirow{2}{*}{$\begin{array}{c}\text { Standard } \\
\text { or } \\
\text { Guideline }\end{array}$} \\
\hline & & & Minimum & Average & Maximum & \\
\hline Gross Alpha & $\mu \mathrm{Ci} / \mathrm{mL}$ & 12 & $<3.14 \mathrm{E}-10$ & $3.54 \pm 4.99 \mathrm{E}-10$ & $1.86 \mathrm{E}-09$ & $1.5 \mathrm{E}-08$ \\
\hline Gross Beta & $\mu \mathrm{Ci} / \mathrm{mL}$ & 12 & $<7.21 \mathrm{E}-10$ & $2.18 \pm 0.94 \mathrm{E}-09$ & 7.94E-09 & $5 \mathrm{E}-08$ \\
\hline Tritium & $\mu \mathrm{Ci} / \mathrm{mL}$ & 12 & $<5.43 \mathrm{E}-08$ & $2.06 \pm 9.60 \mathrm{E}-08$ & $1.42 \mathrm{E}-07$ & $2 \mathrm{E}-05$ \\
\hline Antimony, Total & $\mathrm{mg} / \mathrm{L}$ & 1 & NA & NA & $<0.0008$ & 0.006 \\
\hline Arsenic, Total & $\mathrm{mg} / \mathrm{L}$ & 1 & NA & NA & $<0.001$ & 0.05 \\
\hline Barium, Total & $\mathrm{mg} / \mathrm{L}$ & 1 & NA & NA & $<0.20$ & 2.00 \\
\hline Beryllium, Total & $\mathrm{mg} / \mathrm{L}$ & 1 & NA & NA & $<0.0003$ & 0.004 \\
\hline Cadmium, Total & $\mathrm{mg} / \mathrm{L}$ & 1 & NA & NA & $<0.002$ & 0.005 \\
\hline Chromium, Total & $\mathrm{mg} / \mathrm{L}$ & 1 & NA & NA & $<0.01$ & 0.10 \\
\hline Conductivity & $\mu \mathrm{mhos} / \mathrm{cm} @ 25^{\circ} \mathrm{C}$ & 12 & 127 & 197 & 255 & -- \\
\hline Cyanide, Total & $\mathrm{mg} / \mathrm{L}$ & 1 & NA & NA & $<0.01$ & 0.2 \\
\hline Fluoride & $\mathrm{mg} / \mathrm{L}$ & 1 & NA & NA & $<0.20$ & 2.2 \\
\hline Free Residual Chlorine & $\mathrm{mg} / \mathrm{L}$ & 1,095 & 0.10 & NR & 2.2 & $0.2-4.0$ \\
\hline Mercury, Total & $\mathrm{mg} / \mathrm{L}$ & 1 & NA & NA & $<0.0004$ & 0.002 \\
\hline Nickel, Total & $\mathrm{mg} / \mathrm{L}$ & 1 & NA & NA & $<0.005$ & -- \\
\hline pH & $\mathrm{SU}$ & 12 & 7.58 & 7.97 & 8.35 & -- \\
\hline Selenium, Total & $\mathrm{mg} / \mathrm{L}$ & 1 & NA & NA & $<0.002$ & 0.05 \\
\hline Thallium, Total & $\mathrm{mg} / \mathrm{L}$ & 1 & NA & NA & $<0.001$ & 0.002 \\
\hline Turbidity & NTU & 2,190 & 0.1 & NR & 0.5 & $1.0^{b}$ \\
\hline
\end{tabular}

$N$ - Number of samples

NA - Not available

NR - Not reported

-- No guideline or standard available for these analytes

${ }^{a}$ New York State Department of Health MCLs for drinking water or EPA MCLGs, whichever is more stringent

${ }^{b} A$ treatment standard of 0.3 NTU applies to the 95th percentile on a monthly basis.

Table C-6D

2005 Water Quality Results in Utility Room Raw (Untreated) Water (WNURRAW)

\begin{tabular}{|l|c|c|c|c|c|}
\hline \multicolumn{1}{c|}{ Analyte } & \multirow{2}{*}{ Units } & \multirow{2}{*}{$\mathbf{N}$} & \multicolumn{3}{c|}{ WNURRAW Concentrations } \\
\cline { 4 - 6 } & & & Minimum & Average & Maximum \\
\hline Gross Alpha & $\mu \mathrm{Ci} / \mathrm{mL}$ & 2 & $<4.94 \mathrm{E}-09$ & $2.83 \pm 5.35 \mathrm{E}-09$ & $<5.72 \mathrm{E}-09$ \\
\hline Gross Beta & $\mu \mathrm{Ci} / \mathrm{mL}$ & 2 & $<5.79 \mathrm{E}-09$ & $5.58 \pm 6.18 \mathrm{E}-09$ & $1.01 \mathrm{E}-08$ \\
\hline Tritium & $\mu \mathrm{Ci} / \mathrm{mL}$ & 2 & $<6.57 \mathrm{E}-07$ & $4.15 \pm 7.12 \mathrm{E}-07$ & $<7.63 \mathrm{E}-07$ \\
\hline Iron, Total & $\mathrm{mg} / \mathrm{L}$ & 52 & 0.13 & 0.74 & 10.1 \\
\hline Solids, Total Dissolved & $\mathrm{mg} / \mathrm{L}$ & 14 & 54 & 111 & 150 \\
\hline
\end{tabular}

$N$ - Number of samples

WVDP Annual Site Environmental Report

$$
C-67
$$

Calendar Year 2005 
Table C-6E

2005 Biological and Chlorine Results From Various Site Tap Water Locations (Analyzed by Cattaraugus County Health Department)

\begin{tabular}{|l|c|c|c|c|}
\hline \multicolumn{1}{|c|}{ Analyte } & Units & N & $\begin{array}{c}\text { Various Site Tap Water Locations } \\
\text { Results }\end{array}$ & Standard $^{a}$ \\
\hline E. coli & NA & 12 & Negative & one positive sample \\
\hline Free Residual Chlorine & mg/L & 12 & Range: $0.31-0.98$ & 4.0 (max) \\
\hline Total Coliform & NA & 12 & Negative & two or more positive samples \\
\hline
\end{tabular}

$N$ - Number of samples

NA - Not applicable

${ }^{a}$ New York State Department of Health MCLs for drinking water or EPA MCLGs, whichever is more stringent

\section{Table C-6F}

2005 Tap Water Nitrate Results From WVDP Restroom Sink (Analyzed by Cattaraugus County Health Department)

\begin{tabular}{|c|c|c|c|c|c|}
\hline \multicolumn{1}{|c|}{ Analyte } & Units & $\mathbf{N}$ & Date Collected & Annual Concentration & Standard $^{a}$ \\
\hline Nitrate-N & $\mathrm{mg} / \mathrm{L}$ & 1 & $03 / 14 / 05$ & 1.74 & 10 \\
\hline
\end{tabular}

$N$ - Number of samples

${ }^{a}$ New York State Department of Health MCLs for drinking water or EPA MCLGs, whichever is more stringent

Table C-6G

2005 Copper and Lead Results From On-Site Tap Water Locations at the WVDP

\begin{tabular}{|l|c|c|c|c|c|c|c|c|}
\hline \multicolumn{1}{|c|}{ Analyte } & Units & N & WNDNK01 & WNDNK06 & WNDNK10 & WNDNK14 & WNDNK15 $^{\text {Standard }^{a}}$ \\
\hline Copper, Total & $\mathrm{mg} / \mathrm{L}$ & 1 & $<0.05$ & 0.269 & 0.057 & 0.254 & 0.213 & 1.3 \\
\hline Lead, Total & $\mathrm{mg} / \mathrm{L}$ & 1 & 0.0014 & 0.0062 & 0.0019 & $<0.001$ & 0.002 & $<0.015$ \\
\hline
\end{tabular}

$N$ - Number of samples

${ }^{a}$ New York State Department of Health MCLs for drinking water used as a comparative reference 


\section{Appendix D Summary of Air Monitoring Data}

$D-1$ 
This page intentionally left blank

$D-2$ 
Table D-1

2005 Effluent Airborne Radioactivity at Main Stack

(ANSTACK)

\begin{tabular}{|c|c|c|c|c|c|c|}
\hline Isotope $^{a}$ & $\mathbf{N}$ & $\begin{array}{c}\text { Total } \\
\text { Activity Released }^{b} \\
\text { (Ci) }\end{array}$ & $\begin{array}{c}\text { Average } \\
\text { Concentration } \\
(\mu \mathrm{Ci} / \mathbf{m L})\end{array}$ & $\begin{array}{c}\text { Maximum } \\
\text { Concentration } \\
(\mu \mathrm{Ci} / \mathbf{m L})\end{array}$ & $\begin{array}{c}D_{C G}^{c} \\
(\mu \mathrm{Ci} / \mathrm{mL})\end{array}$ & $\begin{array}{l}\text { Average } \\
\text { \% DCG }\end{array}$ \\
\hline Gross Alpha & 32 & $1.17 \pm 0.09 \mathrm{E}-06$ & $1.61 \pm 0.13 \mathrm{E}-15$ & $1.82 \mathrm{E}-14$ & -- & -- \\
\hline Gross Beta & 32 & $3.95 \pm 0.04 \mathrm{E}-05$ & $5.43 \pm 0.06 \mathrm{E}-14$ & $8.32 \mathrm{E}-13$ & -- & -- \\
\hline H-3 & 32 & $1.07 \pm 0.27 \mathrm{E}-03$ & $1.46 \pm 0.38 \mathrm{E}-12$ & $7.08 \mathrm{E}-12$ & $1 \mathrm{E}-07$ & $<0.01$ \\
\hline Co-60 & 2 & $-5.66 \pm 9.06 \mathrm{E}-08$ & $-0.78 \pm 1.24 \mathrm{E}-16$ & $<2.00 \mathrm{E}-16$ & $8 \mathrm{E}-11$ & $<0.01$ \\
\hline Sr-90 & 2 & $6.92 \pm 0.20 \mathrm{E}-06$ & $9.50 \pm 0.27 \mathrm{E}-15$ & $1.58 \mathrm{E}-14$ & $9 \mathrm{E}-12$ & 0.11 \\
\hline I-129 & 2 & $2.74 \pm 0.26 \mathrm{E}-05$ & $3.76 \pm 3.58 \mathrm{E}-14$ & $4.58 \mathrm{E}-14$ & 7E-11 & 0.05 \\
\hline Cs-137 & 2 & $1.08 \pm 0.08 \mathrm{E}-05$ & $1.48 \pm 0.11 \mathrm{E}-14$ & 2.34E-14 & $4 \mathrm{E}-10$ & $<0.01$ \\
\hline Eu-154 & 2 & $0.45 \pm 2.38 \mathrm{E}-07$ & $0.61 \pm 3.27 \mathrm{E}-16$ & $<5.32 \mathrm{E}-16$ & $5 \mathrm{E}-11$ & $<0.01$ \\
\hline $\mathrm{U}-\mathbf{2 3 2}^{d}$ & 2 & $2.86 \pm 5.83 \mathrm{E}-09$ & $3.93 \pm 8.01 \mathrm{E}-18$ & $<1.12 \mathrm{E}-17$ & $2 \mathrm{E}-14$ & 0.02 \\
\hline $\mathrm{U}-\mathbf{2 3 3} / 234^{d}$ & 2 & $2.50 \pm 0.84 \mathrm{E}-08$ & $3.44 \pm 1.16 \mathrm{E}-17$ & $4.05 \mathrm{E}-17$ & 9E-14 & 0.04 \\
\hline $\mathrm{U}-235 / 236^{d}$ & 2 & $8.16 \pm 5.72 \mathrm{E}-09$ & $1.12 \pm 0.79 \mathrm{E}-17$ & $1.54 \mathrm{E}-17$ & $1 \mathrm{E}-13$ & 0.01 \\
\hline $\mathrm{U}-\mathbf{2 3 8}^{d}$ & 2 & $1.76 \pm 0.72 \mathrm{E}-08$ & $2.42 \pm 0.99 \mathrm{E}-17$ & $2.25 \mathrm{E}-17$ & $1 \mathrm{E}-13$ & 0.02 \\
\hline Pu-238 & 2 & $2.12 \pm 0.17 \mathrm{E}-07$ & $2.92 \pm 0.24 \mathrm{E}-16$ & $4.59 \mathrm{E}-16$ & $3 \mathrm{E}-14$ & 0.97 \\
\hline Pu-239/240 & 2 & $3.21 \pm 0.21 \mathrm{E}-07$ & $4.41 \pm 0.29 \mathrm{E}-16$ & 7.01E-16 & $2 \mathrm{E}-14$ & 2.21 \\
\hline Am-241 & 2 & $6.96 \pm 0.32 \mathrm{E}-07$ & $9.56 \pm 0.44 \mathrm{E}-16$ & $1.55 \mathrm{E}-15$ & $2 \mathrm{E}-14$ & 4.78 \\
\hline Total \% of DCGs & & & & & & 8.22 \\
\hline
\end{tabular}

$N$ - Number of samples

-- DCGs are not specified for gross alpha and beta activity.

${ }^{a}$ Half-lives are listed in Table $K-1$ 뚜

${ }^{b}$ Total volume released at 50,000 $\mathrm{cfm}=7.28 \mathrm{E}+14 \mathrm{~mL} / \mathrm{year}$

${ }^{c}$ Derived concentration guides (DCGs) are listed for reference only. They are applicable to average concentrations at the site boundary but not to stack concentrations, as might be inferred from their inclusion in this table.

${ }^{d}$ Total Uranium: $4.17 \pm 0.17 E-02 \mathrm{~g}$; average $=5.73 E \pm 0.24 E-11 \mu \mathrm{g} / \mathrm{mL}$ 
Table D-2

2005 Effluent Airborne Radioactivity at Vitrification System HVAC (ANVITSK)

\begin{tabular}{|c|c|c|c|c|c|}
\hline Isotope & $\mathbf{N}$ & $\begin{array}{c}\text { Total } \\
\text { Activity Released } \\
\text { (Ci) }\end{array}$ & $\begin{array}{c}\text { Average } \\
\text { Concentration } \\
(\mu \mathrm{Ci} / \mathrm{mL})\end{array}$ & $\begin{array}{c}\text { Maximum } \\
\text { Concentration } \\
(\mu \mathrm{Ci} / \mathrm{mL})\end{array}$ & $\begin{array}{c}\mathrm{DCG}^{a} \\
(\mu \mathrm{Ci} / \mathrm{mL})\end{array}$ \\
\hline Gross Alpha & 32 & $-1.37 \pm 1.77 \mathrm{E}-08$ & $-3.77 \pm 4.87 \mathrm{E}-17$ & $1.88 \mathrm{E}-16$ & -- \\
\hline Gross Beta & 32 & $-0.67 \pm 4.49 \mathrm{E}-08$ & $-0.18 \pm 1.23 \mathrm{E}-16$ & $<1.55 \mathrm{E}-15$ & -- \\
\hline Co-60 & 2 & $-1.42 \pm 2.07 \mathrm{E}-08$ & $-3.89 \pm 5.69 \mathrm{E}-17$ & $<9.73 \mathrm{E}-17$ & $8 \mathrm{E}-11$ \\
\hline Sr-90 & 2 & $-0.09 \pm 1.55 \mathrm{E}-08$ & $-0.25 \pm 4.25 \mathrm{E}-17$ & $<6.58 \mathrm{E}-17$ & $9 \mathrm{E}-12$ \\
\hline I-129 & 2 & $1.34 \pm 0.90 \mathrm{E}-07$ & $3.68 \pm 2.47 \mathrm{E}-16$ & $4.33 \mathrm{E}-16$ & 7E-11 \\
\hline Cs-137 & 2 & $-1.26 \pm 1.79 \mathrm{E}-08$ & $-3.48 \pm 4.91 \mathrm{E}-17$ & $<8.41 \mathrm{E}-17$ & $4 \mathrm{E}-10$ \\
\hline Eu-154 & 2 & $3.83 \pm 5.11 \mathrm{E}-08$ & $1.05 \pm 1.40 \mathrm{E}-16$ & $1.90 \mathrm{E}-16$ & $5 \mathrm{E}-11$ \\
\hline $\mathbf{U}-\mathbf{2 3 2}^{b}$ & 2 & $-0.16 \pm 2.27 \mathrm{E}-09$ & $-0.45 \pm 6.25 \mathrm{E}-18$ & $<1.05 \mathrm{E}-17$ & $2 \mathrm{E}-14$ \\
\hline $\mathrm{U}-\mathbf{2 3 3} / 234^{b}$ & 2 & $1.24 \pm 0.38 \mathrm{E}-08$ & $3.40 \pm 1.05 \mathrm{E}-17$ & $3.58 \mathrm{E}-17$ & 9E-14 \\
\hline $\mathrm{U}-235 / 236^{b}$ & 2 & $4.47 \pm 2.60 \mathrm{E}-09$ & $1.23 \pm 0.72 \mathrm{E}-17$ & $1.42 \mathrm{E}-17$ & $1 \mathrm{E}-13$ \\
\hline $\mathbf{U}-\mathbf{2 3 8}^{b}$ & 2 & $6.47 \pm 2.70 \mathrm{E}-09$ & $1.78 \pm 0.74 \mathrm{E}-17$ & $1.93 \mathrm{E}-17$ & $1 \mathrm{E}-13$ \\
\hline Pu-238 & 2 & $0.06 \pm 1.29 \mathrm{E}-09$ & $0.16 \pm 3.55 \mathrm{E}-18$ & $<6.40 \mathrm{E}-18$ & $3 \mathrm{E}-14$ \\
\hline $\mathrm{Pu}-239 / 240$ & 2 & $0.95 \pm 1.45 \mathrm{E}-09$ & $2.61 \pm 3.97 \mathrm{E}-18$ & $<6.06 \mathrm{E}-18$ & $2 \mathrm{E}-14$ \\
\hline Am-241 & 2 & $-0.21 \pm 1.10 \mathrm{E}-09$ & $-0.58 \pm 3.02 \mathrm{E}-18$ & $<5.23 \mathrm{E}-18$ & $2 \mathrm{E}-14$ \\
\hline
\end{tabular}

$N$ - Number of samples

-- DCGs are not specified for gross alpha and beta activity.

${ }^{a}$ Derived concentration guides (DCGs) are listed for reference only. They are applicable to average concentrations at the site boundary but not to stack concentrations, as might be inferred from their inclusion in this table.

${ }^{b}$ Total Uranium: $2.30 \pm 0.09 E-02 \mathrm{~g}$; average $=6.33 \pm 0.25 \mathrm{E}-11 \mu \mathrm{g} / \mathrm{mL}$

$D-4$ 
Table D-3

2005 Effluent Airborne Radioactivity at 01-14 Building (ANCSSTK)

\begin{tabular}{|c|c|c|c|c|c|}
\hline Isotope & $\mathbf{N}$ & $\begin{array}{c}\text { Total } \\
\text { Activity Released } \\
\text { (Ci) }\end{array}$ & $\begin{array}{c}\text { Average } \\
\text { Concentration } \\
(\mu \mathrm{Ci} / \mathbf{m L})\end{array}$ & $\begin{array}{c}\text { Maximum } \\
\text { Concentration } \\
(\mu \mathrm{Ci} / \mathrm{mL})\end{array}$ & $\begin{array}{c}\mathrm{DCG}^{a} \\
(\mu \mathrm{Ci} / \mathrm{mL})\end{array}$ \\
\hline Gross Alpha & 32 & $3.32 \pm 7.41 \mathrm{E}-09$ & $2.35 \pm 5.25 \mathrm{E}-17$ & 4.12E-16 & -- \\
\hline Gross Beta & 32 & $3.52 \pm 1.81 \mathrm{E}-08$ & $2.49 \pm 1.28 \mathrm{E}-16$ & $1.55 \mathrm{E}-15$ & -- \\
\hline Co-60 & 2 & $3.28 \pm 7.25 \mathrm{E}-09$ & $2.32 \pm 5.13 \mathrm{E}-17$ & $<8.69 \mathrm{E}-17$ & $8 \mathrm{E}-11$ \\
\hline Sr-90 & 2 & $3.49 \pm 8.05 \mathrm{E}-09$ & $2.47 \pm 5.70 \mathrm{E}-17$ & $<7.79 \mathrm{E}-17$ & $9 \mathrm{E}-12$ \\
\hline I-129 & 2 & $2.29 \pm 2.86 \mathrm{E}-08$ & $1.62 \pm 2.03 \mathrm{E}-16$ & $<3.18 \mathrm{E}-16$ & 7E-11 \\
\hline Cs-137 & 2 & $0.69 \pm 2.49 \mathrm{E}-09$ & $0.49 \pm 1.76 \mathrm{E}-17$ & $<8.88 \mathrm{E}-17$ & $4 \mathrm{E}-10$ \\
\hline Eu-154 & 2 & $-1.09 \pm 1.99 \mathrm{E}-08$ & $-0.77 \pm 1.41 \mathrm{E}-16$ & $<2.44 \mathrm{E}-16$ & $5 \mathrm{E}-11$ \\
\hline $\mathrm{U}-\mathbf{2 3 2}^{b}$ & 2 & $0.32 \pm 1.12 \mathrm{E}-09$ & $2.24 \pm 7.95 \mathrm{E}-18$ & $<1.18 \mathrm{E}-17$ & $2 \mathrm{E}-14$ \\
\hline $\mathrm{U}-\mathbf{2 3 3} / 234^{b}$ & 2 & $7.24 \pm 1.87 \mathrm{E}-09$ & $5.13 \pm 1.33 \mathrm{E}-17$ & $6.13 \mathrm{E}-17$ & $9 \mathrm{E}-14$ \\
\hline $\mathrm{U}-235 / 236^{b}$ & 2 & $1.70 \pm 0.97 \mathrm{E}-09$ & $1.20 \pm 0.68 \mathrm{E}-18$ & $1.67 \mathrm{E}-17$ & $1 \mathrm{E}-13$ \\
\hline $\mathbf{U}-\mathbf{2 3 8}^{b}$ & 2 & $6.92 \pm 1.82 \mathrm{E}-09$ & $4.90 \pm 1.29 \mathrm{E}-17$ & $6.57 \mathrm{E}-17$ & $1 \mathrm{E}-13$ \\
\hline Pu-238 & 2 & $1.28 \pm 4.35 \mathrm{E}-10$ & $0.91 \pm 3.08 \mathrm{E}-18$ & $<4.92 \mathrm{E}-18$ & $3 \mathrm{E}-14$ \\
\hline Pu-239/240 & 2 & $-1.13 \pm 4.43 \mathrm{E}-10$ & $-0.80 \pm 3.14 \mathrm{E}-18$ & $<5.41 \mathrm{E}-18$ & 2E-14 \\
\hline Am-241 & 2 & $-1.16 \pm 6.13 \mathrm{E}-10$ & $-0.82 \pm 4.34 \mathrm{E}-18$ & $<7.24 \mathrm{E}-18$ & 2E-14 \\
\hline
\end{tabular}

$N$ - Number of samples

-- DCGs are not specified for gross alpha and beta activity.

${ }^{a}$ Derived concentration guides (DCGs) are listed for reference only. They are applicable to average concentrations at the site boundary but not to stack concentrations, as might be inferred from their inclusion in this table.

${ }^{b}$ Total Uranium: $1.42 \pm 0.03 E-02 \mathrm{~g}$; average $=1.01 \pm 0.02 \mathrm{E}-10 \mu \mathrm{g} / \mathrm{mL}$ 
Table D-4

2005 Airborne Radioactivity at Contact Size-Reduction Facility

(ANCSRFK)

\begin{tabular}{|c|c|c|c|c|c|}
\hline Isotope & $\mathbf{N}$ & $\begin{array}{c}\text { Total } \\
\text { Activity Released } \\
\text { (Ci) }\end{array}$ & $\begin{array}{c}\text { Average } \\
\text { Concentration } \\
(\mu \mathrm{Ci} / \mathrm{mL})\end{array}$ & $\begin{array}{c}\text { Maximum } \\
\text { Concentration } \\
(\mu \mathrm{Ci} / \mathrm{mL})\end{array}$ & $\begin{array}{c}\mathrm{DCG}^{a} \\
(\mu \mathrm{Ci} / \mathbf{m L})\end{array}$ \\
\hline Gross Alpha & 2 & $0.00 \pm 7.86 \mathrm{E}-10$ & $0.00 \pm 2.76 \mathrm{E}-16$ & $<8.17 \mathrm{E}-16$ & -- \\
\hline Gross Beta & 2 & $3.40 \pm 2.60 \mathrm{E}-09$ & $1.19 \pm 0.91 \mathrm{E}-15$ & 2.64E-15 & -- \\
\hline Co-60 & 1 & $2.44 \pm 3.00 \mathrm{E}-09$ & $0.86 \pm 1.05 \mathrm{E}-15$ & $<2.11 \mathrm{E}-15$ & $8 \mathrm{E}-11$ \\
\hline Sr-90 & 1 & $3.11 \pm 2.61 \mathrm{E}-09$ & $1.09 \pm 0.92 \mathrm{E}-15$ & $2.18 \mathrm{E}-15$ & $9 \mathrm{E}-12$ \\
\hline I-129 & 1 & $9.63 \pm 5.73 \mathrm{E}-09$ & $3.38 \pm 2.01 \mathrm{E}-15$ & $6.49 \mathrm{E}-15$ & $7 \mathrm{E}-11$ \\
\hline Cs-137 & 1 & $0.27 \pm 2.06 \mathrm{E}-09$ & $0.93 \pm 7.24 \mathrm{E}-16$ & $<1.45 \mathrm{E}-15$ & $4 \mathrm{E}-10$ \\
\hline Eu-154 & 1 & $-0.71 \pm 7.60 \mathrm{E}-09$ & $-0.25 \pm 2.67 \mathrm{E}-15$ & $<5.33 \mathrm{E}-15$ & $5 \mathrm{E}-11$ \\
\hline $\mathrm{U}-\mathbf{2 3 2}^{b}$ & 1 & $2.23 \pm 2.54 \mathrm{E}-10$ & $7.82 \pm 8.93 \mathrm{E}-17$ & $<1.79 \mathrm{E}-16$ & 2E-14 \\
\hline $\mathrm{U}-233 / 234^{b}$ & 1 & $2.70 \pm 0.81 \mathrm{E}-09$ & $9.47 \pm 2.83 \mathrm{E}-16$ & $1.89 \mathrm{E}-15$ & $9 \mathrm{E}-14$ \\
\hline $\mathrm{U}-235 / 236^{b}$ & 1 & $4.35 \pm 3.47 \mathrm{E}-10$ & $1.53 \pm 1.22 \mathrm{E}-16$ & $3.05 \mathrm{E}-16$ & $1 \mathrm{E}-13$ \\
\hline $\mathrm{U}-\mathbf{2 3 8}^{b}$ & 1 & $2.81 \pm 0.81 \mathrm{E}-09$ & $9.86 \pm 2.84 \mathrm{E}-16$ & $1.97 \mathrm{E}-15$ & $1 \mathrm{E}-13$ \\
\hline Pu-238 & 1 & $0.22 \pm 2.78 \mathrm{E}-10$ & $0.78 \pm 9.76 \mathrm{E}-17$ & $<1.95 \mathrm{E}-16$ & $3 E-14$ \\
\hline Pu-239/240 & 1 & $-0.79 \pm 1.10 \mathrm{E}-10$ & $-2.78 \pm 3.86 \mathrm{E}-17$ & $<7.71 \mathrm{E}-17$ & $2 \mathrm{E}-14$ \\
\hline Am-241 & 1 & $-2.03 \pm 1.51 \mathrm{E}-10$ & $-7.11 \pm 5.31 \mathrm{E}-17$ & $<1.06 \mathrm{E}-16$ & $2 \mathrm{E}-14$ \\
\hline
\end{tabular}

$N$ - Number of samples

-- DCGs are not specified for gross alpha and beta activity.

${ }^{a}$ Derived concentration guides (DCGs) are listed for reference only. They are applicable to average concentrations at the site boundary but not to stack concentrations, as might be inferred from their inclusion in this table.

${ }^{b}$ Total Uranium: $7.16 \pm 0.19 E-03 \mathrm{~g}$; average $=2.51 \pm 0.07 E-09 \mu \mathrm{g} / \mathrm{mL}$ 
Table D-5

2005 Effluent Airborne Radioactivity at Supernatant Treatment System (ANSTSTK)

\begin{tabular}{|c|c|c|c|c|c|}
\hline Isotope & $\mathbf{N}$ & $\begin{array}{c}\text { Total } \\
\text { Activity Released } \\
\text { (Ci) }\end{array}$ & $\begin{array}{c}\text { Average } \\
\text { Concentration } \\
(\mu \mathrm{Ci} / \mathbf{m L})\end{array}$ & $\begin{array}{c}\text { Maximum } \\
\text { Concentration } \\
(\mu \mathrm{Ci} / \mathrm{mL})\end{array}$ & $\begin{array}{c}\mathrm{DCG}^{a} \\
(\mu \mathrm{Ci} / \mathrm{mL})\end{array}$ \\
\hline Gross Alpha & 32 & $-2.34 \pm 3.78 \mathrm{E}-09$ & $-3.57 \pm 5.77 \mathrm{E}-17$ & $3.68 \mathrm{E}-16$ & -- \\
\hline Gross Beta & 32 & $8.53 \pm 9.79 \mathrm{E}-09$ & $1.30 \pm 1.49 \mathrm{E}-16$ & $1.12 \mathrm{E}-15$ & -- \\
\hline H-3 & 31 & $-0.02 \pm 1.03 \mathrm{E}-05$ & $-0.03 \pm 1.57 \mathrm{E}-13$ & $2.04 \mathrm{E}-12$ & $1 \mathrm{E}-07$ \\
\hline Co-60 & 2 & $0.43 \pm 3.19 \mathrm{E}-09$ & $0.66 \pm 4.88 \mathrm{E}-17$ & $<7.15 \mathrm{E}-17$ & $8 \mathrm{E}-11$ \\
\hline Sr-90 & 2 & $-0.55 \pm 2.57 \mathrm{E}-09$ & $-0.84 \pm 3.93 \mathrm{E}-17$ & $<5.11 \mathrm{E}-17$ & $9 \mathrm{E}-12$ \\
\hline I-129 & 2 & $1.03 \pm 0.09 \mathrm{E}-05$ & $1.57 \pm 0.14 \mathrm{E}-13$ & $1.73 \mathrm{E}-13$ & $7 \mathrm{E}-11$ \\
\hline Cs-137 & 2 & $8.46 \pm 5.60 \mathrm{E}-09$ & $1.29 \pm 0.86 \mathrm{E}-16$ & $1.96 \mathrm{E}-16$ & $4 \mathrm{E}-10$ \\
\hline Eu-154 & 2 & $2.13 \pm 8.75 \mathrm{E}-09$ & $0.32 \pm 1.34 \mathrm{E}-16$ & $<1.88 \mathrm{E}-16$ & $5 \mathrm{E}-11$ \\
\hline $\mathrm{U}-\mathbf{2 3 2}^{b}$ & 2 & $1.45 \pm 4.21 \mathrm{E}-10$ & $2.21 \pm 6.42 \mathrm{E}-18$ & $<9.56 \mathrm{E}-18$ & $2 \mathrm{E}-14$ \\
\hline $\mathrm{U}-\mathbf{2 3 3} / \mathbf{2 3 4}^{b}$ & 2 & $2.43 \pm 0.76 \mathrm{E}-09$ & $3.70 \pm 1.17 \mathrm{E}-17$ & $3.89 \mathrm{E}-17$ & $9 \mathrm{E}-14$ \\
\hline $\mathrm{U}-235 / 236^{b}$ & 2 & $7.85 \pm 4.86 \mathrm{E}-10$ & $1.20 \pm 0.74 \mathrm{E}-17$ & $1.06 \mathrm{E}-17$ & $1 \mathrm{E}-13$ \\
\hline $\mathrm{U}-238^{b}$ & 2 & $1.92 \pm 0.65 \mathrm{E}-09$ & $2.93 \pm 0.99 \mathrm{E}-17$ & $2.92 \mathrm{E}-17$ & $1 \mathrm{E}-13$ \\
\hline Pu-238 & 2 & $0.19 \pm 2.78 \mathrm{E}-10$ & $0.28 \pm 4.24 \mathrm{E}-18$ & $<6.07 \mathrm{E}-18$ & $3 \mathrm{E}-14$ \\
\hline Pu-239/240 & 2 & $-1.79 \pm 2.83 \mathrm{E}-10$ & $-2.74 \pm 4.32 \mathrm{E}-18$ & $<5.68 \mathrm{E}-18$ & $2 \mathrm{E}-14$ \\
\hline Am-241 & 2 & $0.26 \pm 3.60 \mathrm{E}-10$ & $0.40 \pm 5.50 \mathrm{E}-18$ & $<8.13 \mathrm{E}-18$ & $2 \mathrm{E}-14$ \\
\hline
\end{tabular}

$N$ - Number of samples

-- DCGs are not specified for gross alpha and beta activity.

${ }^{a}$ Derived concentration guides (DCGs) are listed for reference only. They are applicable to average concentrations at the site boundary but not to stack concentrations, as might be inferred from their inclusion in this table.

${ }^{b}$ Total Uranium: $5.24 \pm 0.16 E-03 \mathrm{~g}$; average $=8.00 \pm 0.24 E-11 \mu \mathrm{g} / \mathrm{mL}$

$D-7$ 
Table D-6

2005 Effluent Airborne Radioactivity at Container Sorting and Packaging Facility (ANCSPFK)

\begin{tabular}{|c|c|c|c|c|c|}
\hline Isotope & $\mathbf{N}$ & $\begin{array}{c}\text { Total } \\
\text { Activity Released } \\
\text { (Ci) }\end{array}$ & $\begin{array}{c}\text { Average } \\
\text { Concentration } \\
(\mu \mathrm{Ci} / \mathrm{mL})\end{array}$ & $\begin{array}{c}\text { Maximum } \\
\text { Concentration } \\
(\mu \mathrm{Ci} / \mathrm{mL})\end{array}$ & $\begin{array}{c}\mathrm{DCG}^{a} \\
(\mu \mathrm{Ci} / \mathbf{m L})\end{array}$ \\
\hline Gross Alpha & 30 & $-2.15 \pm 8.37 \mathrm{E}-10$ & $-1.38 \pm 5.35 \mathrm{E}-17$ & $2.86 \mathrm{E}-16$ & -- \\
\hline Gross Beta & 30 & $2.49 \pm 2.11 \mathrm{E}-09$ & $1.59 \pm 1.35 \mathrm{E}-16$ & $6.53 \mathrm{E}-16$ & -- \\
\hline Co-60 & 2 & $0.24 \pm 1.17 \mathrm{E}-09$ & $1.56 \pm 7.48 \mathrm{E}-17$ & $<1.38 \mathrm{E}-16$ & $8 \mathrm{E}-11$ \\
\hline Sr-90 & 2 & $-0.73 \pm 8.83 \mathrm{E}-10$ & $-0.47 \pm 5.64 \mathrm{E}-17$ & $<8.13 \mathrm{E}-17$ & $9 \mathrm{E}-12$ \\
\hline I-129 & 2 & $6.85 \pm 0.96 \mathrm{E}-08$ & $4.38 \pm 0.61 \mathrm{E}-15$ & $7.02 \mathrm{E}-15$ & $7 \mathrm{E}-11$ \\
\hline Cs-137 & 2 & $7.93 \pm 7.98 \mathrm{E}-10$ & $5.07 \pm 5.10 \mathrm{E}-17$ & $7.40 \mathrm{E}-17$ & $4 \mathrm{E}-10$ \\
\hline Eu-154 & 2 & $-1.64 \pm 2.29 \mathrm{E}-09$ & $-1.05 \pm 1.46 \mathrm{E}-16$ & $<2.52 \mathrm{E}-16$ & $5 \mathrm{E}-11$ \\
\hline $\mathrm{U}-\mathbf{2 3 2}^{b}$ & 2 & $-0.91 \pm 8.61 \mathrm{E}-11$ & $-0.58 \pm 5.50 \mathrm{E}-18$ & $<9.69 \mathrm{E}-18$ & $2 \mathrm{E}-14$ \\
\hline $\mathrm{U}-\mathbf{2 3 3} / 234^{b}$ & 2 & $5.75 \pm 1.62 \mathrm{E}-10$ & $3.67 \pm 1.03 \mathrm{E}-17$ & $4.66 \mathrm{E}-17$ & $9 \mathrm{E}-14$ \\
\hline $\mathrm{U}-235 / 236^{b}$ & 2 & $1.31 \pm 1.07 \mathrm{E}-10$ & $8.40 \pm 6.81 \mathrm{E}-18$ & $1.09 \mathrm{E}-17$ & $1 \mathrm{E}-13$ \\
\hline $\mathrm{U}-\mathbf{2 3 8}^{b}$ & 2 & $3.91 \pm 1.38 \mathrm{E}-10$ & $2.50 \pm 0.88 \mathrm{E}-17$ & $3.73 \mathrm{E}-17$ & $1 \mathrm{E}-13$ \\
\hline Pu-238 & 2 & $-2.93 \pm 5.65 \mathrm{E}-11$ & $-1.88 \pm 3.61 \mathrm{E}-18$ & $<6.52 \mathrm{E}-18$ & $3 \mathrm{E}-14$ \\
\hline Pu-239/240 & 2 & $-0.81 \pm 5.86 \mathrm{E}-11$ & $-0.52 \pm 3.74 \mathrm{E}-18$ & $<5.31 \mathrm{E}-18$ & $2 \mathrm{E}-14$ \\
\hline Am-241 & 2 & $0.10 \pm 7.64 \mathrm{E}-11$ & $0.06 \pm 4.88 \mathrm{E}-18$ & $<7.56 \mathrm{E}-18$ & 2E-14 \\
\hline
\end{tabular}

$N$ - Number of samples

-- DCGs are not specified for gross alpha and gross beta activity.

${ }^{a}$ Derived concentration guides (DCGs) are listed for reference only. They are applicable to average concentrations at the site boundary but not to stack concentrations, as might be inferred from their inclusion in this table.

${ }^{b}$ Total Uranium: $9.12 \pm 0.20 E-04 \mathrm{~g}$; average $=5.83 \pm 0.13 \mathrm{E}-11 \mu \mathrm{g} / \mathrm{mL}$ 
Table D-7

2005 Effluent Airborne Radioactivity at Outdoor Ventilation Enclosures/ Portable Ventilation Units (OVEs/PVUs)

\begin{tabular}{|c|c|c|c|c|c|}
\hline Isotope & $\mathbf{N}$ & $\begin{array}{c}\text { Total } \\
\text { Activity Released } \\
\text { (Ci) }\end{array}$ & $\begin{array}{c}\text { Average } \\
\text { Concentration } \\
(\mu \mathrm{Ci} / \mathbf{m L})\end{array}$ & $\begin{array}{c}\text { Maximum } \\
\text { Concentration } \\
(\mu \mathrm{Ci} / \mathrm{mL})\end{array}$ & $\begin{array}{c}\mathrm{DCG}^{a} \\
(\mu \mathrm{Ci} / \mathrm{mL})\end{array}$ \\
\hline Gross Alpha & 37 & $-1.00 \pm 1.51 \mathrm{E}-09$ & $-2.75 \pm 4.15 \mathrm{E}-17$ & $<6.03 \mathrm{E}-14$ & -- \\
\hline Gross Beta & 37 & $-2.09 \pm 4.76 \mathrm{E}-09$ & $-0.57 \pm 1.31 \mathrm{E}-16$ & $8.58 \mathrm{E}-16$ & -- \\
\hline Co-60 & 1 & $0.84 \pm 1.69 \mathrm{E}-09$ & $2.31 \pm 4.63 \mathrm{E}-17$ & $<4.17 \mathrm{E}-17$ & $8 \mathrm{E}-11$ \\
\hline Sr-90 & 1 & $0.59 \pm 7.73 \mathrm{E}-10$ & $0.16 \pm 2.12 \mathrm{E}-17$ & $<1.91 \mathrm{E}-17$ & $9 \mathrm{E}-12$ \\
\hline Cs-137 & 1 & $-0.95 \pm 1.60 \mathrm{E}-09$ & $-2.61 \pm 4.40 \mathrm{E}-17$ & $<3.69 \mathrm{E}-17$ & $4 \mathrm{E}-10$ \\
\hline Eu-154 & 1 & $0.56 \pm 5.02 \mathrm{E}-09$ & $0.16 \pm 1.38 \mathrm{E}-16$ & $<1.24 \mathrm{E}-16$ & $5 \mathrm{E}-11$ \\
\hline $\mathrm{U}^{-232}{ }^{b}$ & 1 & $-0.64 \pm 1.63 \mathrm{E}-10$ & $-1.74 \pm 4.47 \mathrm{E}-18$ & $<4.02 \mathrm{E}-18$ & 2E-14 \\
\hline $\mathrm{U}-233 / 234^{b}$ & 1 & $8.07 \pm 3.23 \mathrm{E}-10$ & $2.21 \pm 0.89 \mathrm{E}-17$ & $1.99 \mathrm{E}-17$ & $9 \mathrm{E}-14$ \\
\hline $\mathrm{U}-235 / 236^{b}$ & 1 & $0.33 \pm 1.33 \mathrm{E}-10$ & $0.91 \pm 3.65 \mathrm{E}-18$ & $<3.28 \mathrm{E}-18$ & $1 \mathrm{E}-13$ \\
\hline $\mathbf{U}-\mathbf{2 3 8}^{b}$ & 1 & $5.06 \pm 2.36 \mathrm{E}-10$ & $1.39 \pm 0.65 \mathrm{E}-17$ & $1.25 \mathrm{E}-17$ & $1 \mathrm{E}-13$ \\
\hline Pu-238 & 1 & $-0.15 \pm 1.32 \mathrm{E}-10$ & $-0.42 \pm 3.61 \mathrm{E}-18$ & $<3.25 \mathrm{E}-18$ & $3 \mathrm{E}-14$ \\
\hline Pu-239/240 & 1 & $0.31 \pm 1.05 \mathrm{E}-10$ & $0.85 \pm 2.87 \mathrm{E}-18$ & $<2.58 \mathrm{E}-18$ & 2E-14 \\
\hline Am-241 & 1 & $1.76 \pm 1.69 \mathrm{E}-10$ & $4.83 \pm 4.63 \mathrm{E}-18$ & $4.35 \mathrm{E}-18$ & $2 \mathrm{E}-14$ \\
\hline
\end{tabular}

$N$ - Number of samples

-- DCGs are not specified for gross alpha and gross beta activity.

${ }^{a}$ Derived concentration guides (DCGs) are listed for reference only. They are applicable to average concentrations at the site boundary but not to stack concentrations, as might be inferred from their inclusion in this table.

${ }^{b}$ Total Uranium: $1.46 \pm 0.11 \mathrm{E}-03 \mathrm{~g}$; average $=4.01 \pm 0.31 \mathrm{E}-11 \mu \mathrm{g} / \mathrm{mL}$

$D-9$ 
Table D-8

2005 Effluent Airborne Radioactivity at Remote-Handled Waste Facility Stack (ANRHWFK)

\begin{tabular}{|c|c|c|c|c|c|}
\hline Isotope & $\mathbf{N}$ & $\begin{array}{c}\text { Total } \\
\text { Activity Released } \\
\text { (Ci) }\end{array}$ & $\begin{array}{c}\text { Average } \\
\text { Concentration } \\
(\mu \mathrm{Ci} / \mathrm{mL})\end{array}$ & $\begin{array}{c}\text { Maximum } \\
\text { Concentration } \\
(\mu \mathrm{Ci} / \mathrm{mL})\end{array}$ & $\begin{array}{c}\mathrm{DCG}^{a} \\
(\mu \mathrm{Ci} / \mathrm{mL})\end{array}$ \\
\hline Gross Alpha & 32 & $-1.02 \pm 1.02 \mathrm{E}-08$ & $-9.25 \pm 9.23 \mathrm{E}-17$ & 4.41E-16 & -- \\
\hline Gross Beta & 32 & $-0.62 \pm 2.56 \mathrm{E}-08$ & $-0.56 \pm 2.33 \mathrm{E}-16$ & 4.99E-09 & -- \\
\hline Co-60 & 2 & $-0.52 \pm 1.13 \mathrm{E}-08$ & $-0.47 \pm 1.00 \mathrm{E}-16$ & $<1.17 \mathrm{E}-16$ & $8 \mathrm{E}-11$ \\
\hline Sr-90 & 2 & $2.68 \pm 9.79 \mathrm{E}-09$ & $2.43 \pm 8.90 \mathrm{E}-17$ & $<9.07 \mathrm{E}-17$ & $9 \mathrm{E}-12$ \\
\hline I-129 & 2 & $5.82 \pm 2.55 \mathrm{E}-08$ & $5.28 \pm 2.30 \mathrm{E}-16$ & $9.00 \mathrm{E}-16$ & $7 \mathrm{E}-11$ \\
\hline Cs-137 & 2 & $5.02 \pm 9.97 \mathrm{E}-09$ & $4.55 \pm 9.00 \mathrm{E}-17$ & $<1.03 \mathrm{E}-16$ & $4 \mathrm{E}-10$ \\
\hline Eu-154 & 2 & $0.65 \pm 3.03 \mathrm{E}-08$ & $0.59 \pm 2.70 \mathrm{E}-16$ & $<3.03 \mathrm{E}-16$ & $5 \mathrm{E}-11$ \\
\hline $\mathrm{U}-232^{b}$ & 2 & $0.89 \pm 1.32 \mathrm{E}-09$ & $0.81 \pm 1.20 \mathrm{E}-17$ & $<1.37 \mathrm{E}-17$ & $2 \mathrm{E}-14$ \\
\hline $\mathrm{U}-233 / 234^{b}$ & 2 & $1.11 \pm 0.29 \mathrm{E}-08$ & $1.01 \pm 0.26 \mathrm{E}-16$ & $6.80 \mathrm{E}-17$ & 9E-14 \\
\hline $\mathrm{U}-235 / 236^{b}$ & 2 & $3.04 \pm 1.93 \mathrm{E}-09$ & $2.76 \pm 1.70 \mathrm{E}-17$ & $3.01 \mathrm{E}-17$ & $1 \mathrm{E}-13$ \\
\hline $\mathbf{U}-238^{b}$ & 2 & $5.82 \pm 2.17 \mathrm{E}-09$ & $5.28 \pm 2.00 \mathrm{E}-17$ & $3.46 \mathrm{E}-17$ & $1 \mathrm{E}-13$ \\
\hline Pu-238 & 2 & $4.96 \pm 8.29 \mathrm{E}-10$ & $4.51 \pm 7.50 \mathrm{E}-18$ & $<8.23 \mathrm{E}-18$ & 3E-14 \\
\hline Pu-239/240 & 2 & $-1.09 \pm 9.77 \mathrm{E}-10$ & $-0.99 \pm 8.90 \mathrm{E}-18$ & $<8.51 \mathrm{E}-18$ & $2 \mathrm{E}-14$ \\
\hline Am-241 & 2 & $-2.13 \pm 4.73 \mathrm{E}-10$ & $-1.94 \pm 4.30 \mathrm{E}-18$ & $<4.92 \mathrm{E}-18$ & $2 \mathrm{E}-14$ \\
\hline
\end{tabular}

$N$ - Number of samples

-- DCGs are not specified for gross alpha and gross beta activity.

${ }^{a}$ Derived concentration guides (DCGs) are listed for reference only. They are applicable to average concentrations at the site boundary but not to stack concentrations, as might be inferred from their inclusion in this table.

${ }^{b}$ Total Uranium: $1.45 \pm 0.04 \mathrm{E}-02 \mathrm{~g}$; average $=1.31 \pm 0.04 \mathrm{E}-10 \mu \mathrm{g} / \mathrm{mL}$ 
Table D-9

2005 Ambient Airborne Radioactivity at Lag Storage

(ANLAGAM)

\begin{tabular}{|c|c|c|c|c|c|c|}
\hline \multirow[t]{2}{*}{ Isotope } & \multirow[t]{2}{*}{$\mathbf{N}$} & \multicolumn{2}{|c|}{$\begin{array}{c}\text { ANLAGAM } \\
\mu \mathrm{Ci} / \mathrm{mL}\end{array}$} & \multirow[t]{2}{*}{$\mathbf{N}$} & \multirow{2}{*}{$\begin{array}{c}\text { AFGRVAL }^{a} \\
\mu \mathrm{Ci} / \mathrm{mL} \\
\text { Background Range }\end{array}$} & \multirow[t]{2}{*}{$\mathbf{D C G}^{b}$} \\
\hline & & Average & Maximum & & & \\
\hline Gross Alpha & 32 & $7.54 \pm 5.95 \mathrm{E}-16$ & $1.71 \mathrm{E}-15$ & 33 & 4.55E-16-1.62E-15 & -- \\
\hline Gross Beta & 32 & $1.78 \pm 0.20 \mathrm{E}-14$ & $3.15 \mathrm{E}-14$ & 33 & 7.03E-15-3.05E-14 & -- \\
\hline K-40 & 2 & $0.55 \pm 1.28 \mathrm{E}-15$ & $<1.45 \mathrm{E}-15$ & 2 & $<1.35 \mathrm{E}-15-<2.02 \mathrm{E}-15$ & 9E-10 \\
\hline Co-60 & 2 & $0.25 \pm 7.16 \mathrm{E}-17$ & $<8.69 \mathrm{E}-17$ & 2 & $<7.49 \mathrm{E}-17-<1.15 \mathrm{E}-16$ & $8 \mathrm{E}-11$ \\
\hline Sr-90 & 2 & $0.11 \pm 6.66 \mathrm{E}-17$ & $<8.45 \mathrm{E}-17$ & 2 & $<1.09 \mathrm{E}-16-<1.16 \mathrm{E}-16$ & $9 \mathrm{E}-12$ \\
\hline Cs-137 & 2 & $1.88 \pm 5.54 \mathrm{E}-17$ & $<6.43 \mathrm{E}-17$ & 2 & $<6.08 \mathrm{E}-17-<1.31 \mathrm{E}-16$ & $4 \mathrm{E}-10$ \\
\hline Eu-154 & 2 & $-0.16 \pm 1.69 \mathrm{E}-16$ & $<1.93 \mathrm{E}-16$ & 2 & $<1.93 \mathrm{E}-16-<4.47 \mathrm{E}-16$ & $5 \mathrm{E}-11$ \\
\hline $\mathrm{U}-232^{c}$ & 2 & $0.34 \pm 1.40 \mathrm{E}-17$ & $<1.60 \mathrm{E}-17$ & 2 & $<1.14 \mathrm{E}-17-<1.46 \mathrm{E}-17$ & $2 \mathrm{E}-14$ \\
\hline $\mathrm{U}-233 / 234^{c}$ & 2 & $3.77 \pm 1.60 \mathrm{E}-17$ & $4.24 \mathrm{E}-17$ & 2 & 4.41E-17-4.64E-17 & $9 \mathrm{E}-14$ \\
\hline $\mathrm{U}-235 / 236$ & 2 & $8.23 \pm 7.95 \mathrm{E}-18$ & $1.19 \mathrm{E}-17$ & 2 & 1.66E-17-1.87E-17 & $1 \mathrm{E}-13$ \\
\hline $\mathrm{U}-238^{c}$ & 2 & $2.25 \pm 1.28 \mathrm{E}-17$ & $2.37 \mathrm{E}-17$ & 2 & 1.81E-17-3.49E-17 & $1 \mathrm{E}-13$ \\
\hline Pu-238 & 2 & $-2.23 \pm 5.02 \mathrm{E}-18$ & $<5.37 \mathrm{E}-18$ & 2 & $<4.98 \mathrm{E}-18-<5.18 \mathrm{E}-18$ & $3 \mathrm{E}-14$ \\
\hline Pu-239/240 & 2 & $1.29 \pm 5.50 \mathrm{E}-18$ & $<5.90 \mathrm{E}-18$ & 2 & $<7.30 \mathrm{E}-18-<1.43 \mathrm{E}-17$ & $2 \mathrm{E}-14$ \\
\hline Am-241 & 2 & $-0.70 \pm 4.40 \mathrm{E}-18$ & $<5.26 \mathrm{E}-18$ & 2 & $<8.43 \mathrm{E}-18-1.11 \mathrm{E}-17$ & $2 \mathrm{E}-14$ \\
\hline
\end{tabular}

$N$ - Number of samples

-- DCGs are not specified for gross alpha and gross beta activity.

${ }^{a}$ Background air sampling location

${ }^{b}$ Derived concentration guides (DCGs) are applicable to average concentrations at the site boundary.

${ }^{c}$ Total Uranium: ANLAGAM average $=6.06 \pm 0.21 \mathrm{E}-11 \mu \mathrm{g} / \mathrm{mL} ;$ AFGRVAL average $=9.38 \pm 0.32 \mathrm{E}-11 \mu \mathrm{g} / \mathrm{mL}$ 
Table D-10

2005 Ambient Airborne Radioactivity at the NDA (ANNDAAM)

\begin{tabular}{|c|c|c|c|c|c|c|}
\hline \multirow[t]{2}{*}{ Isotope } & \multirow[t]{2}{*}{$\mathbf{N}$} & \multicolumn{2}{|c|}{$\begin{array}{c}\text { ANNDAAM } \\
\mu \mathrm{Ci} / \mathrm{mL}\end{array}$} & \multirow[t]{2}{*}{$\mathbf{N}$} & \multirow{2}{*}{$\begin{array}{c}\text { AFGRVAL }^{a} \\
\mu \mathrm{Ci} / \mathrm{mL} \\
\text { Background Range }\end{array}$} & \multirow[t]{2}{*}{$\mathrm{DCG}^{b}$} \\
\hline & & Average & Maximum & & & \\
\hline Gross Alpha & 13 & $8.45 \pm 8.01 \mathrm{E}-16$ & $1.74 \mathrm{E}-15$ & 33 & 4.55E-16-1.62E-15 & -- \\
\hline Gross Beta & 13 & $1.81 \pm 0.25 \mathrm{E}-14$ & 3.63E-14 & 33 & 7.03E-15-3.05E-14 & -- \\
\hline K-40 & 1 & $0.00 \pm 2.93 \mathrm{E}-15$ & $<2.93 \mathrm{E}-15$ & 2 & $<1.35 \mathrm{E}-15-<2.02 \mathrm{E}-15$ & 9E-10 \\
\hline Co-60 & 1 & $-0.59 \pm 1.76 \mathrm{E}-16$ & $<1.76 \mathrm{E}-16$ & 2 & $<7.49 \mathrm{E}-17-<1.15 \mathrm{E}-16$ & $8 \mathrm{E}-11$ \\
\hline Sr-90 & 1 & $8.45 \pm 8.62 \mathrm{E}-17$ & $<8.62 \mathrm{E}-17$ & 2 & $<1.09 \mathrm{E}-16-<1.16 \mathrm{E}-16$ & $9 \mathrm{E}-12$ \\
\hline Cs-137 & 1 & $1.03 \pm 1.66 \mathrm{E}-16$ & $<1.66 \mathrm{E}-16$ & 2 & $<6.08 \mathrm{E}-17-<1.31 \mathrm{E}-16$ & $4 \mathrm{E}-10$ \\
\hline Eu-154 & 1 & $0.97 \pm 3.70 \mathrm{E}-16$ & $<3.70 \mathrm{E}-16$ & 2 & $<1.93 \mathrm{E}-16-<4.47 \mathrm{E}-16$ & $5 \mathrm{E}-11$ \\
\hline $\mathrm{U}-232^{c}$ & 1 & $4.04 \pm 2.61 \mathrm{E}-17$ & $4.04 \mathrm{E}-17$ & 2 & $<1.14 \mathrm{E}-17-<1.46 \mathrm{E}-17$ & $2 \mathrm{E}-14$ \\
\hline U-233/234 ${ }^{c}$ & 1 & $9.80 \pm 3.16 \mathrm{E}-17$ & $9.80 \mathrm{E}-17$ & 2 & $4.41 \mathrm{E}-17-4.64 \mathrm{E}-17$ & $9 \mathrm{E}-14$ \\
\hline $\mathrm{U}-235 / 236$ & 1 & $1.06 \pm 1.28 \mathrm{E}-17$ & $<1.28 \mathrm{E}-17$ & 2 & $1.66 \mathrm{E}-17-1.87 \mathrm{E}-17$ & $1 \mathrm{E}-13$ \\
\hline $\mathrm{U}-238^{c}$ & 1 & $5.04 \pm 2.38 \mathrm{E}-17$ & $5.04 \mathrm{E}-17$ & 2 & $1.81 \mathrm{E}-17-3.49 \mathrm{E}-17$ & $1 \mathrm{E}-13$ \\
\hline Pu-238 & 1 & $2.31 \pm 1.85 \mathrm{E}-17$ & $2.31 \mathrm{E}-17$ & 2 & $<4.98 \mathrm{E}-18-<5.18 \mathrm{E}-18$ & 3E-14 \\
\hline Pu-239/240 & 1 & $1.73 \pm 1.73 \mathrm{E}-17$ & $1.73 \mathrm{E}-17$ & 2 & $<7.30 \mathrm{E}-18-<1.43 \mathrm{E}-17$ & $2 \mathrm{E}-14$ \\
\hline Am-241 & 1 & $-0.13 \pm 1.08 \mathrm{E}-17$ & $<1.08 \mathrm{E}-17$ & 2 & $<8.43 \mathrm{E}-18-1.11 \mathrm{E}-17$ & 2E-14 \\
\hline
\end{tabular}

Note: As of April 2005, monitoring at this location was discontinued.

$N$ - Number of samples

-- DCGs are not specified for gross alpha and gross beta activity.

${ }^{a}$ Background air sampling location

${ }^{b}$ Derived concentration guides (DCGs) are applicable to average concentrations at the site boundary.

${ }^{c}$ Total Uranium: ANNDAAM average $=8.58 \pm 0.39 \mathrm{E}-11 \mu \mathrm{g} / \mathrm{mL} ;$ AFGRVAL average $=9.38 \pm 0.32 \mathrm{E}-11 \mu \mathrm{g} / \mathrm{mL}$

Table D-11

2005 Ambient Airborne Radioactivity at SDA Trench 9 (ANSDAT9)

\begin{tabular}{|c|c|c|c|c|c|c|}
\hline \multirow[t]{2}{*}{ Isotope } & \multirow[t]{2}{*}{$\mathbf{N}$} & \multicolumn{2}{|c|}{$\begin{array}{c}\text { ANSDAT9 } \\
\mu \mathrm{Ci} / \mathrm{mL}\end{array}$} & \multirow[t]{2}{*}{$\mathbf{N}$} & \multirow{2}{*}{$\begin{array}{c}\text { AFGRVAL }^{a} \\
\mu \mathrm{Ci} / \mathrm{mL} \\
\text { Background Range }\end{array}$} & \multirow[t]{2}{*}{$\mathrm{DCG}^{b}$} \\
\hline & & Average & Maximum & & & \\
\hline Gross Alpha & 36 & $0.75 \pm 1.07 \mathrm{E}-15$ & $1.46 \mathrm{E}-15$ & 33 & 4.55E-16-1.62E-15 & -- \\
\hline Gross Beta & 36 & $1.63 \pm 0.33 \mathrm{E}-14$ & $3.08 \mathrm{E}-14$ & 33 & 7.03E-15-3.05E-14 & -- \\
\hline Tritium & 36 & $9.06 \pm 6.08 \mathrm{E}-13$ & 3.62E-12 & 13 & $<7.59 \mathrm{E}-14-5.76 \mathrm{E}-13$ & $1 \mathrm{E}-07$ \\
\hline K-40 & 3 & $0.54 \pm 3.26 \mathrm{E}-15$ & $<4.55 \mathrm{E}-15$ & 2 & $<1.35 \mathrm{E}-15-<2.02 \mathrm{E}-15$ & $9 \mathrm{E}-10$ \\
\hline Co-60 & 3 & $1.29 \pm 2.08 \mathrm{E}-16$ & $3.13 \mathrm{E}-16$ & 2 & $<7.49 \mathrm{E}-17-<1.15 \mathrm{E}-16$ & $8 \mathrm{E}-11$ \\
\hline I-129 & 3 & $0.10 \pm 2.61 \mathrm{E}-16$ & $<3.28 \mathrm{E}-16$ & 2 & $<1.07 \mathrm{E}-16-<1.73 \mathrm{E}-16$ & $7 \mathrm{E}-11$ \\
\hline Cs-137 & 3 & $0.58 \pm 1.67 \mathrm{E}-16$ & $<2.43 \mathrm{E}-16$ & 2 & $<6.08 \mathrm{E}-17-<1.31 \mathrm{E}-16$ & $4 \mathrm{E}-10$ \\
\hline
\end{tabular}

Note: As of December 2005, monitoring at this location was discontinued.

$N$ - Number of samples

-- DCGs are not specified for gross alpha and gross beta activity.

${ }^{a}$ Background air sampling location

${ }^{b}$ Derived concentration guides (DCGs) are applicable to average concentrations at the site boundary.

$D-12$ 
Table D-12

2005 Ambient Airborne Radioactivity at Rock Springs Road (AFRSPRD)

\begin{tabular}{|c|c|c|c|c|c|c|}
\hline \multirow[t]{2}{*}{ Isotope } & \multirow[t]{2}{*}{$\mathbf{N}$} & \multicolumn{2}{|c|}{$\begin{array}{c}\text { AFRSPRD } \\
\mu \mathrm{Ci} / \mathrm{mL}\end{array}$} & \multirow[t]{2}{*}{$\mathbf{N}$} & \multirow{2}{*}{$\begin{array}{c}\text { AFGRVAL }^{a} \\
\mu \mathrm{Ci} / \mathrm{mL} \\
\text { Background Range }\end{array}$} & \multirow[t]{2}{*}{$\mathbf{D C G}^{b}$} \\
\hline & & Average & Maximum & & & \\
\hline Gross Alpha & 32 & $0.70 \pm 1.37 \mathrm{E}-15$ & $1.29 \mathrm{E}-15$ & 33 & 4.55E-16-1.62E-15 & -- \\
\hline Gross Beta & 32 & $1.72 \pm 0.35 \mathrm{E}-14$ & $2.88 \mathrm{E}-14$ & 33 & 7.03E-15-3.05E-14 & -- \\
\hline Tritium & 13 & $2.37 \pm 6.78 \mathrm{E}-13$ & $9.21 \mathrm{E}-13$ & 13 & $<7.59 \mathrm{E}-14-5.76 \mathrm{E}-13$ & $1 \mathrm{E}-07$ \\
\hline K-40 & 2 & $1.47 \pm 1.73 \mathrm{E}-15$ & $2.57 \mathrm{E}-15$ & 2 & $<1.35 \mathrm{E}-15-<2.02 \mathrm{E}-15$ & $9 \mathrm{E}-10$ \\
\hline Co-60 & 2 & $-0.03 \pm 1.21 \mathrm{E}-16$ & $<1.44 \mathrm{E}-16$ & 2 & $<7.49 \mathrm{E}-17-<1.15 \mathrm{E}-16$ & $8 \mathrm{E}-11$ \\
\hline Sr-90 & 2 & $0.18 \pm 1.09 \mathrm{E}-16$ & $<1.14 \mathrm{E}-16$ & 2 & $<1.09 \mathrm{E}-16-<1.16 \mathrm{E}-16$ & $9 \mathrm{E}-12$ \\
\hline I-129 & 2 & $-1.02 \pm 1.09 \mathrm{E}-16$ & $<1.13 \mathrm{E}-16$ & 2 & $<1.07 \mathrm{E}-16-<1.73 \mathrm{E}-16$ & 7E-11 \\
\hline Cs-137 & 2 & $0.46 \pm 9.80 \mathrm{E}-17$ & $<1.21 \mathrm{E}-16$ & 2 & $<6.08 \mathrm{E}-17-<1.31 \mathrm{E}-16$ & $4 \mathrm{E}-10$ \\
\hline Eu-154 & 2 & $1.18 \pm 3.17 \mathrm{E}-16$ & $<3.72 \mathrm{E}-16$ & 2 & $<1.93 \mathrm{E}-16-<4.47 \mathrm{E}-16$ & $5 \mathrm{E}-11$ \\
\hline $\mathrm{U}-232^{c}$ & 2 & $0.79 \pm 1.89 \mathrm{E}-17$ & $<2.34 \mathrm{E}-17$ & 2 & $<1.14 \mathrm{E}-17-<1.46 \mathrm{E}-17$ & $2 \mathrm{E}-14$ \\
\hline $\mathrm{U}-233 / 234^{c}$ & 2 & $4.60 \pm 2.16 \mathrm{E}-17$ & $4.99 \mathrm{E}-17$ & 2 & 4.41E-17-4.64E-17 & $9 \mathrm{E}-14$ \\
\hline $\mathrm{U}-235 / 236^{c}$ & 2 & $1.98 \pm 1.45 \mathrm{E}-17$ & $2.35 \mathrm{E}-17$ & 2 & 1.66E-17-1.87E-17 & $1 \mathrm{E}-13$ \\
\hline $\mathbf{U}-\mathbf{2 3 8}^{c}$ & 2 & $3.80 \pm 1.87 \mathrm{E}-17$ & $6.09 \mathrm{E}-17$ & 2 & 1.81E-17-3.49E-17 & $1 \mathrm{E}-13$ \\
\hline Pu-238 & 2 & $-1.49 \pm 3.71 \mathrm{E}-18$ & $<4.13 \mathrm{E}-18$ & 2 & $<4.98 \mathrm{E}-18-<5.18 \mathrm{E}-18$ & $3 \mathrm{E}-14$ \\
\hline Pu-239/240 & 2 & $2.07 \pm 7.27 \mathrm{E}-18$ & 7.44E-18 & 2 & $<7.30 \mathrm{E}-18-<1.43 \mathrm{E}-17$ & $2 \mathrm{E}-14$ \\
\hline Am-241 & 2 & $0.91 \pm 1.18 \mathrm{E}-17$ & $<1.21 \mathrm{E}-17$ & 2 & $<8.43 \mathrm{E}-18-1.11 \mathrm{E}-17$ & $2 \mathrm{E}-14$ \\
\hline
\end{tabular}

$N$ - Number of samples

-- DCGs are not specified for gross alpha and gross beta activity.

${ }^{a}$ Background air sampling location

${ }^{b}$ Derived concentration guides (DCGs) are applicable to average concentrations at the site boundary.

${ }^{c}$ Total Uranium: AFRSPRD average $=9.03 \pm 0.30 \mathrm{E}-11 \mu \mathrm{g} / \mathrm{mL} ;$ AFGRVAL average $=9.38 \pm 0.32 \mathrm{E}-11 \mu \mathrm{g} / \mathrm{mL}$ 
Table D-13

2005 Ambient Airborne Radioactivity at Dutch Hill Road

(AFBOEHN)

\begin{tabular}{|c|c|c|c|c|c|c|}
\hline \multirow[t]{2}{*}{ Isotope } & \multirow[t]{2}{*}{$\mathbf{N}$} & \multicolumn{2}{|c|}{$\begin{array}{c}\text { AFBOEHN } \\
\mu \mathrm{Ci} / \mathrm{mL}\end{array}$} & \multirow[t]{2}{*}{$\mathbf{N}$} & \multirow{2}{*}{$\begin{array}{c}\text { AFGRVAL }^{a} \\
\mu \mathrm{Ci} / \mathrm{mL} \\
\text { Background Range }\end{array}$} & \multirow[t]{2}{*}{$\mathrm{DCG}^{b}$} \\
\hline & & Average & Maximum & & & \\
\hline Gross Alpha & 13 & $0.75 \pm 1.07 \mathrm{E}-15$ & $2.97 \mathrm{E}-15$ & 33 & 4.55E-16-1.62E-15 & -- \\
\hline Gross Beta & 13 & $1.84 \pm 0.32 \mathrm{E}-14$ & $3.22 \mathrm{E}-14$ & 33 & 7.03E-15-3.05E-14 & -- \\
\hline K-40 & 1 & $1.22 \pm 3.03 \mathrm{E}-15$ & $<3.03 \mathrm{E}-15$ & 2 & $<1.35 \mathrm{E}-15-<2.02 \mathrm{E}-15$ & $9 \mathrm{E}-10$ \\
\hline Co-60 & 1 & $1.54 \pm 2.73 \mathrm{E}-16$ & $<2.73 \mathrm{E}-16$ & 2 & $<7.49 \mathrm{E}-17-<1.15 \mathrm{E}-16$ & $8 \mathrm{E}-11$ \\
\hline Sr-90 & 1 & $-0.59 \pm 1.52 \mathrm{E}-16$ & $<1.52 \mathrm{E}-16$ & 2 & $<1.09 \mathrm{E}-16-<1.16 \mathrm{E}-16$ & $9 \mathrm{E}-12$ \\
\hline Cs-137 & 1 & $2.59 \pm 2.44 \mathrm{E}-16$ & $2.59 \mathrm{E}-16$ & 2 & $<6.08 \mathrm{E}-17-<1.31 \mathrm{E}-16$ & $4 \mathrm{E}-10$ \\
\hline
\end{tabular}

Note: As of April 2005, monitoring at this location was discontinued.

$N$ - Number of samples

-- DCGs are not specified for gross alpha and gross beta activity.

${ }^{a}$ Background air sampling location

${ }^{b}$ Derived concentration guides (DCGs) are applicable to average concentrations at the site boundary.

Table D-14

2005 Ambient Airborne Radioactivity at Fox Valley Road (AFFXVRD)

\begin{tabular}{|c|c|c|c|c|c|c|}
\hline \multirow[t]{2}{*}{ Isotope } & \multirow[t]{2}{*}{$\mathbf{N}$} & \multicolumn{2}{|c|}{$\begin{array}{c}\text { AFFXVRD } \\
\mu \mathrm{Ci} / \mathrm{mL}\end{array}$} & \multirow[t]{2}{*}{$\mathbf{N}$} & \multirow{2}{*}{$\begin{array}{c}\text { AFGRVAL }^{a} \\
\mu \mathrm{Ci} / \mathrm{mL} \\
\text { Background Range }\end{array}$} & \multirow[t]{2}{*}{$\mathbf{D C G}^{b}$} \\
\hline & & Average & Maximum & & & \\
\hline Gross Alpha & 32 & $9.72 \pm 8.55 \mathrm{E}-16$ & $2.39 \mathrm{E}-15$ & 33 & 4.55E-16-1.62E-15 & -- \\
\hline Gross Beta & 32 & $1.79 \pm 0.25 \mathrm{E}-14$ & $2.87 \mathrm{E}-14$ & 33 & 7.03E-15-3.05E-14 & -- \\
\hline K-40 & 2 & $2.80 \pm 1.82 \mathrm{E}-15$ & 4.19E-15 & 2 & $<1.35 \mathrm{E}-15-<2.02 \mathrm{E}-15$ & $9 \mathrm{E}-10$ \\
\hline Co-60 & 2 & $-0.43 \pm 1.44 \mathrm{E}-16$ & $<1.77 \mathrm{E}-16$ & 2 & $<7.49 \mathrm{E}-17-<1.15 \mathrm{E}-16$ & $8 \mathrm{E}-11$ \\
\hline Sr-90 & 2 & $5.88 \pm 8.69 \mathrm{E}-17$ & $<1.08 \mathrm{E}-16$ & 2 & $<1.09 \mathrm{E}-16-<1.16 \mathrm{E}-16$ & $9 \mathrm{E}-12$ \\
\hline Cs-137 & 2 & $-0.55 \pm 1.14 \mathrm{E}-16$ & $<1.32 \mathrm{E}-16$ & 2 & $<6.08 \mathrm{E}-17-<1.31 \mathrm{E}-16$ & $4 \mathrm{E}-10$ \\
\hline
\end{tabular}

$N$ - Number of samples

-- DCGs are not specified for gross alpha and gross beta activity.

${ }^{a}$ Background air sampling location

${ }^{b}$ Derived concentration guides (DCGs) are applicable to average concentrations at the site boundary. 
Table D-15

2005 Ambient Airborne Radioactivity at the Bulk Storage Warehouse (AFBLKST)

\begin{tabular}{|c|c|c|c|c|c|c|}
\hline \multirow[t]{2}{*}{ Isotope } & \multirow[t]{2}{*}{$\mathbf{N}$} & \multicolumn{2}{|c|}{$\begin{array}{c}\text { AFBLKST } \\
\mu \mathrm{Ci} / \mathrm{mL}\end{array}$} & \multirow[t]{2}{*}{$\mathbf{N}$} & \multirow{2}{*}{$\begin{array}{c}\text { AFGRVAL }^{a} \\
\mu \mathrm{Ci} / \mathrm{mL} \\
\text { Background Range }\end{array}$} & \multirow[t]{2}{*}{$\mathrm{DCG}^{b}$} \\
\hline & & Average & Maximum & & & \\
\hline Gross Alpha & 13 & $0.66 \pm 1.04 \mathrm{E}-15$ & 1.49E-15 & 33 & 4.55E-16-1.62E-15 & -- \\
\hline Gross Beta & 13 & $1.76 \pm 0.31 \mathrm{E}-14$ & $3.23 \mathrm{E}-14$ & 33 & 7.03E-15-3.05E-14 & -- \\
\hline K-40 & 1 & $0.94 \pm 5.12 \mathrm{E}-15$ & $<5.12 \mathrm{E}-15$ & 2 & $<1.35 \mathrm{E}-15-<2.02 \mathrm{E}-15$ & $9 \mathrm{E}-10$ \\
\hline Co-60 & 1 & $0.10 \pm 1.94 \mathrm{E}-16$ & $<1.94 \mathrm{E}-16$ & 2 & $<7.49 \mathrm{E}-17-<1.15 \mathrm{E}-16$ & $8 \mathrm{E}-11$ \\
\hline Sr-90 & 1 & $2.15 \pm 1.66 \mathrm{E}-16$ & $2.15 \mathrm{E}-16$ & 2 & $<1.09 \mathrm{E}-16-<1.16 \mathrm{E}-16$ & $9 \mathrm{E}-12$ \\
\hline Cs-137 & 1 & $-0.63 \pm 1.69 \mathrm{E}-16$ & $<1.69 \mathrm{E}-16$ & 2 & $<6.08 \mathrm{E}-17-<1.31 \mathrm{E}-16$ & $4 \mathrm{E}-10$ \\
\hline
\end{tabular}

Note: As of April 2005, monitoring at this location was discontinued.

$N$ - Number of samples

-- DCGs are not specified for gross alpha and gross beta activity.

${ }^{a}$ Background air sampling location

${ }^{b}$ Derived concentration guides (DCGs) are applicable to average concentrations at the site boundary.

Table D-16

2005 Ambient Airborne Radioactivity at Route 240

(AFRT240)

\begin{tabular}{|c|c|c|c|c|c|c|}
\hline \multirow[t]{2}{*}{ Isotope } & \multirow[t]{2}{*}{$\mathbf{N}$} & \multicolumn{2}{|c|}{$\begin{array}{c}\text { AFRT240 } \\
\mu \mathrm{Ci} / \mathrm{mL}\end{array}$} & \multirow[t]{2}{*}{$\mathbf{N}$} & \multirow{2}{*}{$\begin{array}{c}\text { AFGRVAL }^{a} \\
\mu \mathrm{Ci} / \mathrm{mL} \\
\text { Background Range }\end{array}$} & \multirow[t]{2}{*}{$\mathrm{DCG}^{b}$} \\
\hline & & Average & Maximum & & & \\
\hline Gross Alpha & 32 & $8.02 \pm 7.91 \mathrm{E}-16$ & $2.18 \mathrm{E}-15$ & 33 & 4.55E-16-1.62E-15 & -- \\
\hline Gross Beta & 32 & $1.82 \pm 0.25 \mathrm{E}-14$ & $2.90 \mathrm{E}-14$ & 33 & 7.03E-15-3.05E-14 & -- \\
\hline K-40 & 2 & $0.02 \pm 1.98 \mathrm{E}-15$ & $<2.45 \mathrm{E}-15$ & 2 & $<1.35 \mathrm{E}-15-<2.02 \mathrm{E}-15$ & $9 \mathrm{E}-10$ \\
\hline Co-60 & 2 & $-0.50 \pm 9.65 \mathrm{E}-17$ & $<1.24 \mathrm{E}-16$ & 2 & $<7.49 \mathrm{E}-17-<1.15 \mathrm{E}-16$ & $8 \mathrm{E}-11$ \\
\hline Sr-90 & 2 & $5.54 \pm 7.66 \mathrm{E}-17$ & $1.02 \mathrm{E}-16$ & 2 & $<1.09 \mathrm{E}-16-<1.16 \mathrm{E}-16$ & $9 \mathrm{E}-12$ \\
\hline Cs-137 & 2 & $-0.92 \pm 8.49 \mathrm{E}-17$ & $<1.07 \mathrm{E}-16$ & 2 & $<6.08 \mathrm{E}-17-<1.31 \mathrm{E}-16$ & $4 \mathrm{E}-10$ \\
\hline
\end{tabular}

$N$ - Number of samples

-- DCGs are not specified for gross alpha and gross beta activity.

${ }^{a}$ Background air sampling location

${ }^{b}$ Derived concentration guides (DCGs) are applicable to average concentrations at the site boundary. 
Table D-17

2005 Ambient Airborne Radioactivity at Thomas Corners Road (AFTCORD)

\begin{tabular}{|c|c|c|c|c|c|c|}
\hline \multirow[t]{2}{*}{ Isotope } & \multirow[t]{2}{*}{$\mathbf{N}$} & \multicolumn{2}{|c|}{$\begin{array}{c}\text { AFTCORD } \\
\mu \mathrm{Ci} / \mathrm{mL}\end{array}$} & \multirow[t]{2}{*}{$\mathbf{N}$} & \multirow{2}{*}{$\begin{array}{c}\text { AFGRVAL }^{a} \\
\mu \mathrm{Ci} / \mathrm{mL} \\
\text { Background Range }\end{array}$} & \multirow[t]{2}{*}{$\mathrm{DCG}^{b}$} \\
\hline & & Average & Maximum & & & \\
\hline Gross Alpha & 13 & $0.65 \pm 1.05 \mathrm{E}-15$ & $1.52 \mathrm{E}-15$ & 33 & 4.55E-16-1.62E-15 & -- \\
\hline Gross Beta & 13 & $1.78 \pm 0.32 \mathrm{E}-14$ & $3.10 \mathrm{E}-14$ & 33 & 7.03E-15-3.05E-14 & -- \\
\hline K-40 & 1 & $4.37 \pm 4.60 \mathrm{E}-15$ & $<4.60 \mathrm{E}-15$ & 2 & $<1.35 \mathrm{E}-15-<2.02 \mathrm{E}-15$ & $9 \mathrm{E}-10$ \\
\hline Co-60 & 1 & $-1.50 \pm 2.76 \mathrm{E}-16$ & $<2.76 \mathrm{E}-16$ & 2 & $<7.49 \mathrm{E}-17-<1.15 \mathrm{E}-16$ & $8 \mathrm{E}-11$ \\
\hline Sr-90 & 1 & $2.09 \pm 1.53 \mathrm{E}-16$ & $2.09 \mathrm{E}-16$ & 2 & $<1.09 \mathrm{E}-16-<1.16 \mathrm{E}-16$ & $9 \mathrm{E}-12$ \\
\hline Cs-137 & 1 & $-1.10 \pm 3.26 \mathrm{E}-16$ & $<3.26 \mathrm{E}-16$ & 2 & $<6.08 \mathrm{E}-17-<1.31 \mathrm{E}-16$ & $4 \mathrm{E}-10$ \\
\hline
\end{tabular}

Note: As of April 2005, monitoring at this location was discontinued.

$N$ - Number of samples

-- DCGs are not specified for gross alpha and gross beta activity.

${ }^{a}$ Background air sampling location

${ }^{b}$ Derived concentration guides (DCGs) are applicable to average concentrations at the site boundary.

Table D-18

2005 Ambient Airborne Radioactivity at West Valley

(AFWEVAL)

\begin{tabular}{|c|c|c|c|c|c|c|}
\hline \multirow[t]{2}{*}{ Isotope } & \multirow[t]{2}{*}{$\mathbf{N}$} & \multicolumn{2}{|c|}{$\begin{array}{c}\text { AFWEVAL } \\
\mu \mathrm{Ci} / \mathrm{mL}\end{array}$} & \multirow[t]{2}{*}{$\mathbf{N}$} & \multirow{2}{*}{$\begin{array}{c}\text { AFGRVAL }^{a} \\
\mu \mathrm{Ci} / \mathrm{mL} \\
\text { Background Range }\end{array}$} & \multirow[t]{2}{*}{$\mathbf{D C G}^{b}$} \\
\hline & & Average & Maximum & & & \\
\hline Gross Alpha & 32 & $9.07 \pm 8.06 \mathrm{E}-16$ & $2.28 \mathrm{E}-15$ & 33 & 4.55E-16-1.62E-15 & -- \\
\hline Gross Beta & 32 & $1.82 \pm 0.25 \mathrm{E}-14$ & $3.20 \mathrm{E}-14$ & 33 & 7.03E-15-3.05E-14 & -- \\
\hline K-40 & 2 & $0.81 \pm 1.45 \mathrm{E}-15$ & $<1.63 \mathrm{E}-15$ & 2 & $<1.35 \mathrm{E}-15-<2.02 \mathrm{E}-15$ & $9 \mathrm{E}-10$ \\
\hline Co-60 & 2 & $1.44 \pm 1.85 \mathrm{E}-16$ & $<2.51 \mathrm{E}-16$ & 2 & $<7.49 \mathrm{E}-17-<1.15 \mathrm{E}-16$ & $8 \mathrm{E}-11$ \\
\hline Sr-90 & 2 & $0.30 \pm 1.08 \mathrm{E}-16$ & $<1.24 \mathrm{E}-16$ & 2 & $<1.09 \mathrm{E}-16-<1.16 \mathrm{E}-16$ & $9 \mathrm{E}-12$ \\
\hline Cs-137 & 2 & $0.81 \pm 1.12 \mathrm{E}-16$ & $1.55 \mathrm{E}-16$ & 2 & $<6.08 \mathrm{E}-17-<1.31 \mathrm{E}-16$ & $4 \mathrm{E}-10$ \\
\hline
\end{tabular}

$N$ - Number of samples

-- DCGs are not specified for gross alpha and gross beta activity.

${ }^{a}$ Background air sampling location

${ }^{b}$ Derived concentration guides (DCGs) are applicable to average concentrations at the site boundary. 
Table D-19

2005 Ambient Airborne Radioactivity at Springville

(AFSPRVL)

\begin{tabular}{|c|c|c|c|c|c|c|}
\hline \multirow[t]{2}{*}{ Isotope } & \multirow[t]{2}{*}{$\mathbf{N}$} & \multicolumn{2}{|c|}{$\begin{array}{c}\text { AFSPRVL } \\
\mu \mathrm{Ci} / \mathbf{m L}\end{array}$} & \multirow[t]{2}{*}{$\mathbf{N}$} & \multirow{2}{*}{$\begin{array}{c}\text { AFGRVAL }^{a} \\
\mu \mathrm{Ci} / \mathrm{mL} \\
\text { Background Range }\end{array}$} & \multirow[t]{2}{*}{$\mathbf{D C G}^{b}$} \\
\hline & & Average & Maximum & & & \\
\hline Gross Alpha & 32 & $8.61 \pm 8.11 \mathrm{E}-16$ & $1.91 \mathrm{E}-15$ & 33 & 4.55E-16-1.62E-15 & -- \\
\hline Gross Beta & 32 & $1.87 \pm 0.25 \mathrm{E}-14$ & $3.00 \mathrm{E}-14$ & 33 & 7.03E-15-3.05E-14 & -- \\
\hline K-40 & 2 & $2.67 \pm 2.62 \mathrm{E}-15$ & $5.35 \mathrm{E}-15$ & 2 & $<1.35 \mathrm{E}-15-<2.02 \mathrm{E}-15$ & $9 \mathrm{E}-10$ \\
\hline Co-60 & 2 & $0.00 \pm 3.49 \mathrm{E}-16$ & $<4.14 \mathrm{E}-16$ & 2 & $<7.49 \mathrm{E}-17-<1.15 \mathrm{E}-16$ & $8 \mathrm{E}-11$ \\
\hline Sr-90 & 2 & $0.79 \pm 1.16 \mathrm{E}-16$ & $<1.23 \mathrm{E}-16$ & 2 & $<1.09 \mathrm{E}-16-<1.16 \mathrm{E}-16$ & $9 \mathrm{E}-12$ \\
\hline Cs-137 & 2 & $0.84 \pm 1.35 \mathrm{E}-16$ & $<1.48 \mathrm{E}-16$ & 2 & $<6.08 \mathrm{E}-17-<1.31 \mathrm{E}-16$ & $4 \mathrm{E}-10$ \\
\hline
\end{tabular}

$N$ - Number of samples

-- DCGs are not specified for gross alpha and gross beta activity.

${ }^{a}$ Background air sampling location

${ }^{b}$ Derived concentration guides (DCGs) are applicable to average concentrations at the site boundary.

$D-17$ 
Table D-20

2005 Radioactivity in Fallout: Dutch Hill (AFDHFOP)

\begin{tabular}{|l|c|c|c|c|c|}
\hline \multicolumn{1}{|c|}{ Analyte } & Units & N & Minimum & Average & Maximum \\
\hline Gross Alpha & $\mathrm{nCi} / \mathrm{m}^{2}$ & 3 & $2.12 \mathrm{E}-02$ & $2.20 \pm 0.80 \mathrm{E}-02$ & $2.27 \mathrm{E}-02$ \\
\hline Gross Beta & $\mathrm{nCi} / \mathrm{m}^{2}$ & 3 & $2.39 \mathrm{E}-01$ & $3.02 \pm 0.29 \mathrm{E}-01$ & $3.35 \mathrm{E}-01$ \\
\hline H-3 & $\mu \mathrm{Ci} / \mathrm{mL}$ & 3 & $<7.69 \mathrm{E}-08$ & $4.86 \pm 7.87 \mathrm{E}-08$ & $9.32 \mathrm{E}-08$ \\
\hline K-40 & $\mathrm{nCi} / \mathrm{m}^{2}$ & 3 & $<1.91 \mathrm{E}+00$ & $-2.16 \pm 4.79 \mathrm{E}+00$ & $<7.24 \mathrm{E}+00$ \\
\hline Cs-137 & $\mathrm{nCi} / \mathrm{m}^{2}$ & 3 & $<8.76 \mathrm{E}-02$ & $0.19 \pm 3.64 \mathrm{E}-01$ & $<5.68 \mathrm{E}-01$ \\
\hline
\end{tabular}

$N$ - Number of samples

Note: As of April 2005, sampling was discontinued at this location.

Table D-21

2005 Radioactivity in Fallout: Rain Gauge (ANRGFOP)

\begin{tabular}{|l|c|c|c|c|c|}
\hline \multicolumn{1}{|c|}{ Analyte } & Units & N & Minimum & Average & Maximum \\
\hline Gross Alpha & $\mathrm{nCi} / \mathrm{m}^{2}$ & 12 & $6.92 \mathrm{E}-03$ & $6.27 \pm 2.74 \mathrm{E}-02$ & $1.55 \mathrm{E}-01$ \\
\hline Gross Beta & $\mathrm{nCi} / \mathrm{m}^{2}$ & 12 & $1.17 \mathrm{E}-01$ & $3.71 \pm 0.42 \mathrm{E}-01$ & $7.54 \mathrm{E}-01$ \\
\hline H-3 & $\mu \mathrm{Ci} / \mathrm{mL}$ & 11 & $<7.55 \mathrm{E}-08$ & $1.23 \pm 7.72 \mathrm{E}-08$ & $1.54 \mathrm{E}-07$ \\
\hline K-40 & $\mathrm{nCi} / \mathrm{m}^{2}$ & 12 & $<6.98 \mathrm{E}-01$ & $-1.65 \pm 7.02 \mathrm{E}+00$ & $<1.26 \mathrm{E}+01$ \\
\hline Cs-137 & $\mathrm{nCi} / \mathrm{m}^{2}$ & 12 & $<4.43 \mathrm{E}-02$ & $0.73 \pm 4.85 \mathrm{E}-01$ & $4.43 \mathrm{E}-01$ \\
\hline
\end{tabular}

$N$ - Number of samples

Table D-22

2005 Radioactivity in Fallout: Route 240 (AF24FOP)

\begin{tabular}{|l|c|c|c|c|c|}
\hline \multicolumn{1}{|c|}{ Analyte } & Units & N & Minimum & Average & Maximum \\
\hline Gross Alpha & $\mathrm{nCi} / \mathrm{m}^{2}$ & 3 & $<1.54 \mathrm{E}-02$ & $2.69 \pm 2.81 \mathrm{E}-02$ & $<3.46 \mathrm{E}-02$ \\
\hline Gross Beta & $\mathrm{nCi} / \mathrm{m}^{2}$ & 3 & $3.51 \mathrm{E}-01$ & $3.74 \pm 0.36 \mathrm{E}-01$ & $4.06 \mathrm{E}-01$ \\
\hline H-3 & $\mu \mathrm{Ci} / \mathrm{mL}$ & 3 & $<7.61 \mathrm{E}-08$ & $3.25 \pm 7.85 \mathrm{E}-08$ & $1.27 \mathrm{E}-07$ \\
\hline K-40 & $\mathrm{nCi} / \mathrm{m}^{2}$ & 3 & $<3.42 \mathrm{E}+00$ & $-2.04 \pm 5.73 \mathrm{E}+00$ & $<7.70 \mathrm{E}+00$ \\
\hline Cs-137 & $\mathrm{nCi} / \mathrm{m}^{2}$ & 3 & $<2.00 \mathrm{E}-01$ & $2.18 \pm 3.78 \mathrm{E}-01$ & $5.61 \mathrm{E}-01$ \\
\hline
\end{tabular}

$N$ - Number of samples

Note: As of April 2005, sampling was discontinued at this location.

WVDP Annual Site Environmental Report

$D-18$

Calendar Year 2005 
Table D-23

2005 Radioactivity in Fallout: Thomas Corners (AFTCFOP)

\begin{tabular}{|l|c|c|c|c|c|}
\hline \multicolumn{1}{|c|}{ Analyte } & Units & N & Minimum & Average & Maximum \\
\hline Gross Alpha & $\mathrm{nCi} / \mathrm{m}^{2}$ & 3 & $1.84 \mathrm{E}-02$ & $2.59 \pm 1.31 \mathrm{E}-02$ & $3.69 \mathrm{E}-02$ \\
\hline Gross Beta & $\mathrm{nCi} / \mathrm{m}^{2}$ & 3 & $3.03 \mathrm{E}-01$ & $4.06 \pm 0.45 \mathrm{E}-01$ & $5.06 \mathrm{E}-01$ \\
\hline H-3 & $\mu \mathrm{Ci} / \mathrm{mL}$ & 3 & $<7.72 \mathrm{E}-08$ & $6.36 \pm 7.89 \mathrm{E}-08$ & $9.55 \mathrm{E}-08$ \\
\hline K-40 & $\mathrm{nCi} / \mathrm{m}^{2}$ & 3 & $<3.39 \mathrm{E}+00$ & $-5.39 \pm 7.84 \mathrm{E}+00$ & $<1.14 \mathrm{E}-+01$ \\
\hline Cs-137 & $\mathrm{nCi} / \mathrm{m}^{2}$ & 3 & $<2.68 \mathrm{E}-01$ & $-0.45 \pm 4.35 \mathrm{E}-01$ & $<5.46 \mathrm{E}-01$ \\
\hline
\end{tabular}

$N$ - Number of samples

Note: As of April 2005, sampling was discontinued at this location.

Table D-24

2005 Radioactivity in Fallout: Fox Valley Road (AFFXFOP)

\begin{tabular}{|l|c|c|c|c|c|}
\hline \multicolumn{1}{|c|}{ Analyte } & Units & N & Minimum & Average & Maximum \\
\hline Gross Alpha & $\mathrm{nCi} / \mathrm{m}^{2}$ & 3 & $1.33 \mathrm{E}-02$ & $2.06 \pm 1.09 \mathrm{E}-02$ & $2.69 \mathrm{E}-02$ \\
\hline Gross Beta & $\mathrm{nCi} / \mathrm{m}^{2}$ & 3 & $2.44 \mathrm{E}-01$ & $3.03 \pm 0.37 \mathrm{E}-01$ & $3.73 \mathrm{E}-01$ \\
\hline Tritium & $\mu \mathrm{Ci} / \mathrm{mL}$ & 3 & $<7.66 \mathrm{E}-08$ & $1.64 \pm 7.81 \mathrm{E}-08$ & $<8.00 \mathrm{E}-08$ \\
\hline K-40 & $\mathrm{nCi} / \mathrm{m}^{2}$ & 3 & $<4.33 \mathrm{E}+00$ & $-3.85 \pm 7.50 \mathrm{E}+00$ & $<1.09 \mathrm{E}+01$ \\
\hline Cs-137 & $\mathrm{nCi} / \mathrm{m}^{2}$ & 3 & $<2.43 \mathrm{E}-01$ & $1.41 \pm 4.54 \mathrm{E}-01$ & $<6.25 \mathrm{E}-01$ \\
\hline
\end{tabular}

$N$ - Number of samples

Note: As of April 2005, sampling was discontinued at this location.

D -19 
This page intentionally left blank

$$
\text { D - } 20
$$




\section{Appendix $E$ Summary of Groundwater Monitoring Data}

E - 1 


\section{Groundwater Sampling Methodology}

Groundwater samples are collected from monitoring wells using either dedicated Teflon ${ }^{\circledR}$ well bailers or bladder pumps. Bailers are used in low-yield wells; bladder pumps are used in wells with good water-yielding characteristics. This sampling equipment is dedicated to an individual well to reduce the likelihood of sample contamination from external materials or cross contamination.

To ensure that only representative groundwater is sampled, three well volumes are removed (purged) from the well before the actual samples are collected. In low-yield wells, pumping or bailing to dryness provides sufficient purging. Conductivity and $\mathrm{pH}$ are measured before and after sampling to confirm the geochemical stability of the groundwater during sampling.

The bailer, a tube with a check valve at the bottom, is lowered slowly into the well to minimize agitation of the water column. The bailer containing the groundwater is then withdrawn from the well and emptied into a sample container. Bladder pumps use compressed air to gently squeeze a Teflon ${ }^{\circledR}$ bladder that prevents contact with the groundwater as it is pumped into a sample container with a minimum of agitation and mixing. A check valve ensures that the water flows in only one direction.

Groundwater samples are cooled and preserved, with chemicals if required, to minimize chemical and/or biological changes after sample collection. A strict chain-of-custody protocol is followed for all samples collected by the WVDP.

\section{Key to bolding convention:}

Tables E-2 $\mathbf{6 0}$ through E-11 $\mathbf{6 0}$ contain a bolding convention devised to help the reader, when viewing the data, to quickly see the range of detectable measurements within a data series. A data series is a set of chemical or radionuclide measurements (e.g., gross alpha, gross beta, tritium) from a single location or from similar locations. Note that some tables contain data that should not be technically evaluated under this convention.

Results for each analyte constitute a single data series. If a radiological result is larger than the uncertainty term, the measurement is considered positive. Otherwise, a result is considered nondetectable. Chemical results preceded by "less than" $(<)$ are considered nondetectable. The bolding convention is not applied to data series consisting of less than three values.

If all results in a data series are positive, the lowest and highest values are bolded.

If a data series contains some positive results, the highest value is bolded.

If all values in a data series are nondetectable, no values are bolded.

$$
E-2
$$




\section{Groundwater Sampling and Analysis Agenda}

\section{Analyte Group}

Contamination Indicator Parameters (I)

Radiological Indicator Parameters (RI)

Volatile Organic Compounds (V)

Semivolatile Organic Compounds (SV)

6 NYCRR Appendix 33 Metals (M)

Special Monitoring Parameters

for Early Warning Wells (SM)

Radioisotopic Analyses:

alpha-, beta-, and gamma-emitters (R)

Strontium-90 (S)

\section{Description of Parameters ${ }^{a}$}

$\mathrm{pH}$, specific conductance (field measurements)

Gross alpha, gross beta, tritium

6 NYCRR Appendix 33 Volatile Organic Compounds (VOCs) (See Table E-12 $2^{\text {at }}$ )

6 NYCRR Appendix 33 Semivolatile Organic Compounds (SVOCs) and tributyl phosphate (TBP) (See Table E-12 ${ }^{\mathrm{Wx}}$.)

Antimony, arsenic, barium, beryllium, cadmium, chromium, cobalt, copper, lead, mercury, nickel, selenium, silver, thallium, tin, vanadium, zinc

Aluminum, iron, manganese

Carbon-14, strontium-90, technetium-99, iodine-129, cesium-137, radium-226, radium-228, uranium-232, uranium-233/234, uranium-235/236, uranium-238, total uranium

Strontium-90

2005 Quarterly Monitoring Schedule:

1st Qtr-December 1, 2004 to February 28, 2005

2nd Qtr - March 1, 2005 to May 31, 2005

3rd Qtr - June 1, 2005 to August 31, 2005

4th Qtr-September 1, 2005 to November 30, 2005

${ }^{a}$ Analysis performed for selected active monitoring locations only. See Table E-1 ${ }^{\mathbf{6 0}}$ for the analytes assigned to each monitoring location.

$$
\text { E - } 3
$$


Table E-1

Groundwater Monitoring Network Sorted by Geologic Unit

Sand and Gravel Wells

\begin{tabular}{|c|c|c|c|c|c|c|c|}
\hline Well ID & SSWMU & $\begin{array}{l}\text { Gradient } \\
\text { Position }\end{array}$ & $\begin{array}{c}\text { Analytical } \\
\text { Parameters in } 2005^{a}\end{array}$ & Well ID & SSWMU & $\begin{array}{l}\text { Gradient } \\
\text { Position }\end{array}$ & $\begin{array}{c}\text { Analytical } \\
\text { Parameters in } 2005^{a}\end{array}$ \\
\hline $103^{b}$ & 1,3 & $\mathrm{D}$ & I, RI, V & 802 & 8 & $\mathrm{D}$ & I, RI, V \\
\hline 104 & 1 & $\mathrm{C}$ & I, RI, SV, V & 803 & 8 & D & I, RI, SV, V \\
\hline 105 & 1 & $\mathrm{C}$ & I, RI, V & $804^{b}$ & 8 & $\mathrm{D}$ & I, RI, V \\
\hline 106 & 1 & $\mathrm{D}$ & I, RI, V & 1302 & $\mathrm{NA}^{c}$ & $\mathrm{D}$ & I, RI, M, R, SV, V \\
\hline $111^{b}$ & 1 & $\mathrm{D}$ & I, RI, M, S, SV, V & 1304 & $\mathrm{NA}^{c}$ & $\mathrm{U}$ & I, RI, M, R, SV, V \\
\hline $116^{b}$ & 1,8 & $\mathrm{C}, \mathrm{U}$ & I, RI, S, V & 8603 & 8 & $\mathrm{U}$ & I, RI, S \\
\hline 201 & 2 & $\mathrm{U}$ & I, RI, V & 8604 & 1 & $\mathrm{C}$ & I, RI, V \\
\hline 205 & 2,3 & $\mathrm{D}$ & I, RI & $8605^{b}$ & 1,2 & $\mathrm{D}$ & I, RI, M, S, SV, V \\
\hline $301^{b}$ & 3 & $\mathrm{~B}$ & I, RI & $8607^{b}$ & 6,4 & U, D & I, RI, V \\
\hline $401^{b}$ & 4,3 & B & I, RI, R & $8609^{b}$ & $3,4,6$ & $\mathrm{D}, \mathrm{D}, \mathrm{U}$ & I, RI, S, V \\
\hline 403 & 4 & $\mathrm{U}$ & I, RI, V & $8612^{b}$ & 8 & $\mathrm{D}$ & I, RI, SV, V \\
\hline $406^{b}$ & 4,6 & $\mathrm{D}, \mathrm{U}$ & $\mathrm{I}, \mathrm{RI}, \mathrm{R}, \mathrm{V}$ & NB-1S & $\mathrm{NA}^{d}$ & $\mathrm{~B}$ & I, RI \\
\hline $408^{b}$ & 4,3 & $\mathrm{D}$ & I, RI, R, V & WP-A & $\mathrm{NA}^{e}$ & NA & I, RI \\
\hline $501^{b}$ & 5 & $\mathrm{U}$ & I, RI, S, V & WP-C & $\mathrm{NA}^{e}$ & NA & I, RI \\
\hline $502^{b}$ & 5 & $\mathrm{D}$ & I, RI, S, SM, V & WP-H & $\mathrm{NA}^{e}$ & NA & I, RI \\
\hline $602 \mathrm{~A}$ & 6 & $\mathrm{D}$ & I, RI, S & SP04 & $\mathrm{NA}^{f}$ & $\mathrm{D}$ & RI \\
\hline 604 & 6 & $\mathrm{D}$ & I, RI & SP06 & $\mathrm{NA}^{f}$ & $\mathrm{D}$ & RI \\
\hline 605 & 6 & $\mathrm{D}$ & I, RI, S & SP11 & $\mathrm{NA}^{f}$ & $\mathrm{D}$ & RI \\
\hline $706^{b}$ & 7 & B & I, RI, M, R, SV, V & SP12 & $\mathrm{NA}^{f}$ & $\mathrm{D}$ & I, RI, V \\
\hline $801^{b}$ & 8,6 & U, D & I, RI, S, V & GSEEP & $\mathrm{NA}^{f}$ & $\mathrm{D}$ & I, RI, V \\
\hline
\end{tabular}

Legend: $\quad$ Gradient Positions

$B$ (background)

$C$ (crossgradient)

$D$ (downgradient)

$U$ (upgradient)

NA - Not applicable

${ }^{a}$ See p. E-3 $\mathbf{\text { GD }}$ for a description of codes and analytes.

${ }^{b}$ Monitoring for certain parameters is required by the RCRA $\$ 3008(h)$ Order on Consent.

${ }^{c}$ Monitor upgradient and downgradient of remote-handled waste facility

${ }^{d}$ Former background well

${ }^{e}$ Monitor locations north and east of main plant

${ }^{f}$ Monitor groundwater emanating from seeps along the edge of the north plateau 
Table E-1 (continued)

Groundwater Monitoring Network Sorted by Geologic Unit

Lavery Till Sand Wells

\begin{tabular}{|c|c|c|c|c|c|c|c|}
\hline Well ID & SSWMU & $\begin{array}{c}\text { Gradient } \\
\text { Position }\end{array}$ & $\begin{array}{c}\text { Analytical } \\
\text { Parameters in } 2005^{a}\end{array}$ & Well ID & SSWMU & $\begin{array}{c}\text { Gradient } \\
\text { Position }\end{array}$ & $\begin{array}{c}\text { Analytical } \\
\text { Parameters in } 2005^{a}\end{array}$ \\
\hline $204^{b}$ & 2,3 & D & I, RI & 302 & 3 & U & I, RI \\
\hline 206 & 2 & C & I, RI & 402 & 4 & B & I, RI \\
\hline 208 & 2 & D & I, RI, V & & & & \\
\hline
\end{tabular}

Weathered Lavery Till Wells

\begin{tabular}{|c|c|c|c|c|c|c|c|}
\hline Well ID & SSWMU & $\begin{array}{c}\text { Gradient } \\
\text { Position }\end{array}$ & $\begin{array}{c}\text { Analytical } \\
\text { Parameters in } 2005^{a}\end{array}$ & Well ID & SSWMU & $\begin{array}{c}\text { Gradient } \\
\text { Position }\end{array}$ & $\begin{array}{c}\text { Analytical } \\
\text { Parameters in } 2005^{a}\end{array}$ \\
\hline $906^{b}$ & 9 & D & I, RI & $1005^{b}$ & 9,10 & C, U & I, RI \\
\hline $908^{b}$ & 9 & B & I, RI & $1006^{b}$ & 9,10 & C, D & I, RI \\
\hline $909^{b}$ & 9 & D & I, RI, M, R, SV, V & 1007 & 10 & D & I, RI \\
\hline NDATR $^{b}$ & 9 & D & I, RI, M, R, SV, V & $1008 C^{b}$ & 9,10 & U & I, RI \\
\hline
\end{tabular}

Unweathered Lavery Till Wells

\begin{tabular}{|c|c|c|c|c|c|c|c|}
\hline Well ID & SSWMU & $\begin{array}{c}\text { Gradient } \\
\text { Position }\end{array}$ & $\begin{array}{c}\text { Analytical } \\
\text { Parameters in } 2005^{a}\end{array}$ & Well ID & SSWMU & $\begin{array}{c}\text { Gradient } \\
\text { Position }\end{array}$ & $\begin{array}{c}\text { Analytical } \\
\text { Parameters in } 2005^{a}\end{array}$ \\
\hline 107 & 1 & D & I, RI, V & 704 & 7 & D & I, RI, V \\
\hline 108 & 1 & D & I, RI, V & $910^{b}$ & 9 & D & I, RI \\
\hline $110^{b}$ & 1 & D & I, RI, V & 1301 & NA $^{c}$ & D & I, RI, M, R, SV, V \\
\hline 405 & 4 & B & I, RI, M, R, SV, V & 1303 & NA $^{c}$ & U & I, RI, M, R, SV, V \\
\hline 409 & 4 & D & I, RI & & & & \\
\hline
\end{tabular}

Kent Recessional Sequence Wells

\begin{tabular}{|c|c|c|c|c|c|c|c|}
\hline Well ID & SSWMU & $\begin{array}{c}\text { Gradient } \\
\text { Position }\end{array}$ & $\begin{array}{c}\text { Analytical } \\
\text { Parameters in } 2005^{a}\end{array}$ & Well ID & SSWMU & $\begin{array}{c}\text { Gradient } \\
\text { Position }\end{array}$ & $\begin{array}{c}\text { Analytical } \\
\text { Parameters in } 2005^{a}\end{array}$ \\
\hline $901^{b}$ & 4 & $\mathrm{~B}$ & I, RI & $1008 \mathrm{~B}$ & 10 & $\mathrm{U}$ & I, RI \\
\hline $902^{b}$ & 9 & $\mathrm{U}$ & I, RI & $8610^{b}$ & 9 & $\mathrm{D}$ & I, RI \\
\hline $903^{b}$ & 9 & $\mathrm{D}$ & I, RI & $8611^{b}$ & 9 & $\mathrm{D}$ & I, RI \\
\hline
\end{tabular}

Legend:

Gradient Positions

$B$ (background)

$C$ (crossgradient)

$D$ (downgradient)

$U$ (upgradient)

NA - Not applicable

${ }^{a}$ See p. E-3 ${ }^{\mathbf{C D}}$ for a description of codes and analytes.

${ }^{b}$ Monitoring for certain parameters is required by the RCRA $\$ 3008(h)$ Order on Consent.

${ }^{c}$ Monitor upgradient and downgradient of remote-handled waste facility

$$
\text { E- } 5
$$


Table E-2

\section{Indicator Results From the Sand and Gravel Unit}

\begin{tabular}{|c|c|c|c|c|c|c|}
\hline $\begin{array}{l}\text { Location } \\
\text { Code }\end{array}$ & $\begin{array}{l}\text { Hydraulic } \\
\text { Position }\end{array}$ & $\begin{array}{c}\mathbf{p H} \\
(\mathrm{SU})\end{array}$ & $\begin{array}{c}\text { Conductivity } \\
\left(\mu \mathrm{mhos} / \mathrm{cm} @ 25^{\circ} \mathrm{C}\right)\end{array}$ & $\begin{array}{l}\text { Gross Alpha } \\
\qquad(\mu \mathrm{Ci} / \mathrm{mL})\end{array}$ & $\begin{array}{c}\text { Gross Beta } \\
(\mu \mathrm{Ci} / \mathrm{mL})\end{array}$ & $\begin{array}{l}\text { Tritium } \\
(\mu \mathrm{Ci} / \mathrm{mL})\end{array}$ \\
\hline 301 & $\mathrm{UP}(1)$ & 6.62 & 948 & $1.52 \pm 1.86 \mathrm{E}-09$ & $7.05 \pm 2.63 \mathrm{E}-09$ & $1.88 \pm 0.80 E-07$ \\
\hline 301 & $\mathrm{UP}(2)$ & 6.60 & 1,023 & $-1.76 \pm 2.20 \mathrm{E}-09$ & $5.79 \pm 3.86 \mathrm{E}-09$ & $-0.72 \pm 8.05 E-08$ \\
\hline 301 & $\mathrm{UP}(3)$ & 6.79 & 844 & $1.33 \pm 2.91 \mathrm{E}-09$ & $5.74 \pm 3.76 \mathrm{E}-09$ & $1.16 \pm 0.77 \mathrm{E}-07$ \\
\hline 301 & $\mathrm{UP}(4)$ & 6.35 & 1,011 & $-1.90 \pm 2.05 \mathrm{E}-09$ & $9.78 \pm 3.16 \mathrm{E}-09$ & $-0.91 \pm 1.20 \mathrm{E}-07$ \\
\hline 401 & $\mathrm{UP}(1)$ & 6.49 & 1,965 & $0.94 \pm 4.72 \mathrm{E}-09$ & $6.53 \pm 6.90 \mathrm{E}-09$ & $1.85 \pm 0.80 \mathrm{E}-07$ \\
\hline 401 & $\mathrm{UP}(2)$ & 6.83 & 2,056 & $-1.63 \pm 4.91 E-09$ & $3.96 \pm 7.33 \mathrm{E}-09$ & $-9.16 \pm 7.96 \mathrm{E}-08$ \\
\hline 401 & $\mathrm{UP}(3)$ & 7.17 & 725 & $-0.68 \pm 3.17 E-09$ & $6.26 \pm 6.94 \mathrm{E}-09$ & $1.56 \pm 0.55 \mathrm{E}-07$ \\
\hline 401 & $\mathrm{UP}(4)$ & 6.59 & 3,154 & $-6.44 \pm 3.88 \mathrm{E}-09$ & $1.11 \pm 0.81 \mathrm{E}-08$ & $-0.84 \pm 1.23 \mathrm{E}-07$ \\
\hline 403 & UP(1) & 7.14 & 897 & $-2.20 \pm 2.03 \mathrm{E}-09$ & $3.49 \pm 2.58 \mathrm{E}-09$ & $1.92 \pm 0.81 \mathrm{E}-07$ \\
\hline 403 & $\mathrm{UP}(2)$ & 6.92 & 1,187 & $-1.04 \pm 2.47 \mathrm{E}-09$ & $3.26 \pm 2.70 \mathrm{E}-09$ & $1.28 \pm 0.58 E-07$ \\
\hline 403 & $\mathrm{UP}(3)$ & 7.33 & 1,245 & $0.59 \pm 3.16 \mathrm{E}-09$ & $5.63 \pm 2.75 \mathrm{E}-09$ & $1.50 \pm 0.81 \mathrm{E}-07$ \\
\hline 706 & $\mathrm{UP}(1)$ & 6.30 & 870 & $0.41 \pm 1.85 \mathrm{E}-09$ & $8.12 \pm 2.26 E-09$ & $-4.98 \pm 7.68 \mathrm{E}-08$ \\
\hline 706 & $\mathrm{UP}(2)$ & 6.55 & 1,001 & $1.30 \pm 1.95 \mathrm{E}-09$ & $1.03 \pm 0.23 \mathrm{E}-08$ & $4.34 \pm 8.11 \mathrm{E}-08$ \\
\hline 706 & $\mathrm{UP}(3)$ & 6.77 & 1,481 & $-0.91 \pm 2.10 \mathrm{E}-09$ & $1.00 \pm 0.28 \mathrm{E}-08$ & $3.11 \pm 8.17 \mathrm{E}-08$ \\
\hline 706 & $\mathrm{UP}(4)$ & 6.74 & 1,099 & $1.74 \pm 1.20 \mathrm{E}-09$ & $1.12 \pm 0.25 E-08$ & $1.61 \pm 1.29 \mathrm{E}-07$ \\
\hline 1304 & $\mathrm{UP}(1)$ & 7.10 & 1,860 & $0.00 \pm 4.44 \mathrm{E}-09$ & $1.14 \pm 0.73 E-08$ & $1.25 \pm 0.79 E-07$ \\
\hline 1304 & $\mathrm{UP}(2)$ & 6.91 & 5,031 & $2.08 \pm 6.83 \mathrm{E}-09$ & $8.42 \pm 7.49 \mathrm{E}-09$ & $-1.42 \pm 7.98 \mathrm{E}-08$ \\
\hline 1304 & $\mathrm{UP}(3)$ & 7.11 & 3,688 & $-3.46 \pm 8.02 \mathrm{E}-09$ & $6.36 \pm 6.68 \mathrm{E}-09$ & $6.08 \pm 7.79 \mathrm{E}-08$ \\
\hline 1304 & $\mathrm{UP}(4)$ & 7.47 & 1,644 & $-1.35 \pm 1.75 \mathrm{E}-09$ & $5.67 \pm 3.16 \mathrm{E}-09$ & $0.82 \pm 1.27 \mathrm{E}-07$ \\
\hline NB1S & $\mathrm{UP}(1)$ & 6.37 & 439 & $0.63 \pm 1.10 \mathrm{E}-09$ & $2.07 \pm 1.74 \mathrm{E}-09$ & $-1.44 \pm 8.45 \mathrm{E}-08$ \\
\hline NB1S & $\mathrm{UP}(2)$ & 6.71 & 583 & $0.47 \pm 1.09 \mathrm{E}-09$ & $2.59 \pm 1.79 \mathrm{E}-09$ & $3.54 \pm 7.75 \mathrm{E}-08$ \\
\hline NB1S & $\mathrm{UP}(3)$ & 6.71 & 742 & $-1.47 \pm 2.38 \mathrm{E}-09$ & $1.38 \pm 2.38 \mathrm{E}-09$ & $-1.02 \pm 0.55 \mathrm{E}-07$ \\
\hline 201 & DOWN(1) & 6.21 & 2,681 & $-0.34 \pm 5.01 \mathrm{E}-09$ & $4.10 \pm 0.68 \mathrm{E}-08$ & $1.78 \pm 0.79 E-07$ \\
\hline 201 & DOWN(2) & 6.41 & 3,340 & $-5.22 \pm 5.78 \mathrm{E}-09$ & $5.44 \pm 1.01 \mathrm{E}-08$ & $-0.27 \pm 8.04 \mathrm{E}-08$ \\
\hline 201 & $\operatorname{DOWN}(3)$ & 6.25 & 4,605 & $-2.53 \pm 9.60 \mathrm{E}-09$ & $7.33 \pm 1.08 E-08$ & $1.44 \pm 0.78 \mathrm{E}-07$ \\
\hline 1302 & $\operatorname{DOWN}(1)$ & 7.38 & 1,855 & $2.14 \pm 4.18 \mathrm{E}-09$ & $5.58 \pm 6.30 \mathrm{E}-09$ & $-2.81 \pm 7.73 E-08$ \\
\hline 1302 & $\operatorname{DOWN}(2)$ & 7.06 & 4,473 & $2.57 \pm 5.71 \mathrm{E}-09$ & $1.94 \pm 9.06 \mathrm{E}-09$ & $3.63 \pm 8.04 \mathrm{E}-08$ \\
\hline 1302 & $\operatorname{DOWN}(3)$ & 6.90 & 4,983 & $0.34 \pm 1.11 \mathrm{E}-08$ & $0.89 \pm 1.35 \mathrm{E}-08$ & $5.12 \pm 7.78 \mathrm{E}-08$ \\
\hline 1302 & DOWN(4) & 6.73 & 5,092 & $-0.02 \pm 1.09 \mathrm{E}-08$ & $6.81 \pm 9.74 \mathrm{E}-09$ & $0.77 \pm 1.20 \mathrm{E}-07$ \\
\hline 103 & DOWN(1) & 8.30 & 1,915 & $1.28 \pm 3.05 \mathrm{E}-09$ & $2.50 \pm 0.56 \mathrm{E}-08$ & $1.86 \pm 8.45 \mathrm{E}-08$ \\
\hline 103 & DOWN(2) & 8.02 & 10,967 & $0.41 \pm 1.08 \mathrm{E}-08$ & $4.88 \pm 0.25 E-07$ & $3.79 \pm 8.00 \mathrm{E}-08$ \\
\hline 103 & DOWN(3) & 7.92 & 8,650 & $-0.23 \pm 1.20 \mathrm{E}-08$ & $3.03 \pm 0.17 \mathrm{E}-07$ & 7.57士7.72E-08 \\
\hline 103 & DOWN(4) & 7.62 & 5,156 & $3.56 \pm 6.25 \mathrm{E}-09$ & $1.20 \pm 0.13 \mathrm{E}-07$ & $0.82 \pm 1.26 \mathrm{E}-07$ \\
\hline 104 & DOWN(1) & 6.71 & 1,532 & $1.28 \pm 2.51 \mathrm{E}-09$ & $5.51 \pm 0.01 \mathrm{E}-05$ & $3.08 \pm 0.81 \mathrm{E}-07$ \\
\hline 104 & DOWN(2) & 7.14 & 1,508 & $2.33 \pm 2.86 \mathrm{E}-09$ & $4.93 \pm 0.01 E-05$ & $3.73 \pm 0.81 E-07$ \\
\hline 104 & DOWN(3) & 7.18 & 1,685 & $3.37 \pm 3.46 \mathrm{E}-09$ & $6.19 \pm 0.01 E-05$ & $3.02 \pm 0.81 \mathrm{E}-07$ \\
\hline 104 & DOWN(4) & 7.12 & $\mathbf{1 , 5 0 2}$ & $0.41 \pm 2.52 \mathrm{E}-09$ & $5.99 \pm 0.01 \mathrm{E}-05$ & $2.39 \pm 1.26 \mathrm{E}-07$ \\
\hline
\end{tabular}

Note: Bolding convention applied to these data. (See p. E-2 $\mathbf{6 0}$ )

Sample collection quarter is noted in parentheses next to hydraulic position. Hydraulic position is relative to other wells within the same hydrogeologic unit.

$$
E-6
$$




\section{Table E-2 (continued)}

\section{Indicator Results From the Sand and Gravel Unit}

\begin{tabular}{|c|c|c|c|c|c|c|}
\hline $\begin{array}{l}\text { Location } \\
\text { Code }\end{array}$ & $\begin{array}{l}\text { Hydraulic } \\
\text { Position }\end{array}$ & $\underset{(\mathrm{SU})}{\mathbf{p H}}$ & $\begin{array}{c}\text { Conductivity } \\
\left(\mu \mathrm{mhos} / \mathrm{cm} @ 25^{\circ} \mathrm{C}\right)\end{array}$ & $\begin{array}{l}\text { Gross Alpha } \\
(\mu \mathrm{Ci} / \mathrm{mL})\end{array}$ & $\begin{array}{c}\text { Gross Beta } \\
(\mu \mathrm{Ci} / \mathrm{mL})\end{array}$ & $\begin{array}{l}\text { Tritium } \\
(\mu \mathrm{Ci} / \mathrm{mL})\end{array}$ \\
\hline 111 & DOWN(1) & 6.85 & 552 & $2.54 \pm 2.21 \mathrm{E}-09$ & $2.80 \pm 0.03 E-06$ & $1.45 \pm 0.57 \mathrm{E}-07$ \\
\hline 111 & DOWN(2) & 6.55 & 630 & $0.89 \pm 2.27 \mathrm{E}-09$ & $4.40 \pm 0.04 \mathrm{E}-06$ & $1.95 \pm 0.59 \mathrm{E}-07$ \\
\hline 111 & DOWN(3) & 6.72 & 668 & $4.03 \pm 3.02 E-09$ & $5.70 \pm 0.05 \mathrm{E}-06$ & $2.00 \pm 0.80 E-07$ \\
\hline 111 & DOWN(4) & 6.65 & 1,341 & $0.45 \pm 3.24 \mathrm{E}-09$ & $1.04 \pm 0.01 E-05$ & $0.33 \pm 1.30 \mathrm{E}-07$ \\
\hline 205 & $\operatorname{DOWN}(1)$ & 6.80 & 2,492 & $-5.80 \pm 4.44 \mathrm{E}-09$ & $5.39 \pm 7.20 \mathrm{E}-09$ & $2.09 \pm 0.81 E-07$ \\
\hline 205 & $\operatorname{DOWN}(2)$ & 7.02 & 4,517 & $-1.78 \pm 7.24 \mathrm{E}-09$ & $1.97 \pm 0.86 \mathrm{E}-08$ & $2.52 \pm 8.03 \mathrm{E}-08$ \\
\hline 205 & $\operatorname{DOWN}(3)$ & 6.92 & 8,178 & $0.68 \pm 1.31 \mathrm{E}-08$ & $3.11 \pm 1.48 \mathrm{E}-08$ & $1.26 \pm 0.78 \mathrm{E}-07$ \\
\hline 406 & $\operatorname{DOWN}(1)$ & 6.94 & 904 & $0.00 \pm 2.12 \mathrm{E}-09$ & $5.82 \pm 3.89 \mathrm{E}-09$ & $3.99 \pm 8.45 \mathrm{E}-08$ \\
\hline 406 & $\operatorname{DOWN}(2)$ & 6.52 & 1,500 & $2.43 \pm 3.46 \mathrm{E}-09$ & $7.02 \pm 4.00 \mathrm{E}-09$ & $1.44 \pm 0.78 \mathrm{E}-07$ \\
\hline 406 & DOWN(3) & 7.08 & 956 & $1.83 \pm 2.79 \mathrm{E}-09$ & $7.82 \pm 3.63 E-09$ & $1.84 \pm 0.82 E-07$ \\
\hline 406 & DOWN(4) & 6.86 & 1,105 & $1.62 \pm 1.84 \mathrm{E}-09$ & $7.22 \pm 2.45 \mathrm{E}-09$ & $1.45 \pm 1.32 \mathrm{E}-07$ \\
\hline 408 & $\operatorname{DOWN}(1)$ & 6.92 & 1,312 & $4.73 \pm 5.15 \mathrm{E}-09$ & $1.63 \pm 0.01 \mathrm{E}-04$ & $1.93 \pm 1.20 \mathrm{E}-07$ \\
\hline 408 & $\operatorname{DOWN}(2)$ & 7.22 & 1,415 & $-1.88 \pm 1.92 \mathrm{E}-09$ & $1.84 \pm 0.01 \mathrm{E}-04$ & $3.04 \pm 1.29 \mathrm{E}-07$ \\
\hline 408 & DOWN(3) & 7.29 & 1,553 & $-1.77 \pm 1.31 \mathrm{E}-09$ & $2.04 \pm 0.01 E-04$ & $1.63 \pm 1.15 \mathrm{E}-07$ \\
\hline 408 & DOWN(4) & 6.90 & 1,248 & $-0.78 \pm 1.85 \mathrm{E}-09$ & $1.21 \pm 0.01 E-04$ & $0.10 \pm 1.31 \mathrm{E}-07$ \\
\hline 501 & $\operatorname{DOWN}(1)$ & 7.20 & 1,126 & $1.50 \pm 2.82 \mathrm{E}-09$ & $1.01 \pm 0.01 \mathrm{E}-04$ & $3.15 \pm 0.80 E-07$ \\
\hline 501 & $\operatorname{DOWN}(2)$ & 7.43 & 1,184 & $0.17 \pm 2.99 \mathrm{E}-09$ & $9.63 \pm 0.02 \mathrm{E}-05$ & $-0.22 \pm 8.20 \mathrm{E}-08$ \\
\hline 501 & DOWN(3) & 7.60 & 1,266 & $1.57 \pm 4.10 \mathrm{E}-09$ & $1.16 \pm 0.01 E-04$ & $1.40 \pm 0.79 \mathrm{E}-07$ \\
\hline 501 & DOWN(4) & 7.50 & 1,021 & $0.00 \pm 1.55 \mathrm{E}-09$ & $8.95 \pm 0.03 E-05$ & $-0.33 \pm 1.30 \mathrm{E}-07$ \\
\hline 502 & $\operatorname{DOWN}(1)$ & 7.24 & 1,250 & $1.45 \pm 2.87 \mathrm{E}-09$ & $1.08 \pm 0.01 \mathrm{E}-04$ & $1.93 \pm 0.84 E-07$ \\
\hline 502 & $\operatorname{DOWN}(2)$ & 7.27 & 1,275 & $-1.24 \pm 2.88 \mathrm{E}-09$ & $9.54 \pm 0.02 \mathrm{E}-05$ & $1.31 \pm 0.83 \mathrm{E}-07$ \\
\hline 502 & DOWN(3) & 7.54 & 1,306 & $1.47 \pm 3.84 \mathrm{E}-09$ & $1.11 \pm 0.01 E-04$ & $1.61 \pm 0.78 \mathrm{E}-07$ \\
\hline 502 & DOWN(4) & 7.52 & 1,100 & $0.44 \pm 2.33 \mathrm{E}-09$ & $9.31 \pm 0.03 E-05$ & $-0.25 \pm 1.31 \mathrm{E}-07$ \\
\hline $602 \mathrm{~A}$ & $\operatorname{DOWN}(1)$ & 7.02 & 434 & $-0.21 \pm 1.35 \mathrm{E}-09$ & $1.02 \pm 0.23 E-08$ & $4.88 \pm 0.84 E-07$ \\
\hline $602 \mathrm{~A}$ & $\operatorname{DOWN}(2)$ & 6.81 & 705 & $2.51 \pm 1.81 \mathrm{E}-09$ & $1.15 \pm 0.23 \mathrm{E}-08$ & $3.55 \pm 0.85 \mathrm{E}-07$ \\
\hline $602 \mathrm{~A}$ & DOWN(3) & 7.00 & 857 & $0.90 \pm 1.98 \mathrm{E}-09$ & $1.15 \pm 0.23 \mathrm{E}-08$ & $3.11 \pm 0.58 \mathrm{E}-07$ \\
\hline $602 \mathrm{~A}$ & $\operatorname{DOWN}(4)$ & 7.03 & 695 & $-0.07 \pm 1.69 \mathrm{E}-09$ & $2.15 \pm 0.30 E-08$ & $2.36 \pm 1.37 E-07$ \\
\hline 604 & $\operatorname{DOWN}(1)$ & 6.06 & 1,530 & $1.45 \pm 3.23 \mathrm{E}-09$ & $1.01 \pm 0.29 \mathrm{E}-08$ & $7.32 \pm 7.83 \mathrm{E}-08$ \\
\hline 604 & $\operatorname{DOWN}(2)$ & 6.24 & 1,326 & $0.95 \pm 2.39 \mathrm{E}-09$ & $7.66 \pm 2.77 \mathrm{E}-09$ & $1.29 \pm 0.78 E-07$ \\
\hline 604 & $\operatorname{DOWN}(3)$ & 6.23 & 1,490 & $-0.92 \pm 2.77 \mathrm{E}-09$ & $8.09 \pm 2.89 \mathrm{E}-09$ & $5.80 \pm 7.68 \mathrm{E}-08$ \\
\hline 604 & DOWN(4) & 5.94 & 1,382 & $1.75 \pm 1.49 \mathrm{E}-09$ & $8.33 \pm 2.90 \mathrm{E}-09$ & $-0.35 \pm 1.03 \mathrm{E}-07$ \\
\hline 8605 & $\operatorname{DOWN}(1)$ & 6.72 & 1,804 & $5.50 \pm 4.42 \mathrm{E}-09$ & $1.12 \pm 0.01 E-05$ & $1.98 \pm 0.81 \mathrm{E}-07$ \\
\hline 8605 & $\operatorname{DOWN}(2)$ & 6.88 & 1,114 & $2.28 \pm 3.49 \mathrm{E}-09$ & $1.04 \pm 0.01 \mathrm{E}-05$ & $3.75 \pm 0.57 E-07$ \\
\hline 8605 & DOWN(3) & 6.94 & 2,006 & $6.82 \pm 6.56 \mathrm{E}-09$ & $9.44 \pm 0.07 E-06$ & $1.77 \pm 0.81 E-07$ \\
\hline 8605 & DOWN(4) & 6.64 & 2,154 & $7.18 \pm 3.75 \mathrm{E}-09$ & $1.09 \pm 0.01 \mathrm{E}-05$ & $2.75 \pm 1.12 \mathrm{E}-07$ \\
\hline
\end{tabular}

Note: Bolding convention applied to these data. (See p. E-2 $\mathbf{6 0}$ )

Sample collection quarter is noted in parentheses next to hydraulic position. Hydraulic position is relative to other wells within the same hydrogeologic unit.

$E-7$ 


\section{Table E-2 (continued)}

\section{Indicator Results From the Sand and Gravel Unit}

\begin{tabular}{|c|c|c|c|c|c|c|}
\hline $\begin{array}{l}\text { Location } \\
\text { Code }\end{array}$ & $\begin{array}{l}\text { Hydraulic } \\
\text { Position }\end{array}$ & $\begin{array}{c}\mathbf{p H} \\
(\mathrm{SU})\end{array}$ & $\begin{array}{c}\text { Conductivity } \\
\left(\mu \mathrm{mhos} / \mathrm{cm} @ 25^{\circ} \mathrm{C}\right)\end{array}$ & $\begin{array}{l}\text { Gross Alpha } \\
\quad(\mu \mathrm{Ci} / \mathrm{mL})\end{array}$ & $\begin{array}{c}\text { Gross Beta } \\
(\mu \mathrm{Ci} / \mathrm{mL})\end{array}$ & $\begin{array}{c}\text { Tritium } \\
(\mu \mathrm{Ci} / \mathrm{mL})\end{array}$ \\
\hline 8607 & DOWN(1) & 6.55 & 654 & $1.87 \pm 1.74 \mathrm{E}-09$ & $1.34 \pm 0.29 \mathrm{E}-08$ & $0.92 \pm 6.29 \mathrm{E}-08$ \\
\hline 8607 & $\operatorname{DOWN}(2)$ & 6.14 & 4,493 & $2.12 \pm 9.29 \mathrm{E}-09$ & $7.63 \pm 1.12 \mathrm{E}-08$ & $-0.78 \pm 8.49 \mathrm{E}-08$ \\
\hline 8607 & DOWN(3) & 6.54 & 2,368 & $-5.53 \pm 7.96 \mathrm{E}-09$ & $2.57 \pm 0.85 \mathrm{E}-08$ & $1.30 \pm 0.79 E-07$ \\
\hline 8607 & DOWN(4) & 6.32 & 1,516 & $0.71 \pm 1.56 \mathrm{E}-09$ & $2.54 \pm 0.35 \mathrm{E}-08$ & $0.81 \pm 1.26 \mathrm{E}-07$ \\
\hline 8609 & $\operatorname{DOWN}(1)$ & 6.81 & 2,166 & $1.94 \pm 3.51 \mathrm{E}-09$ & $2.28 \pm 0.02 E-06$ & $2.61 \pm 0.82 E-07$ \\
\hline 8609 & DOWN(2) & 7.00 & 2,202 & $2.75 \pm 5.40 \mathrm{E}-09$ & $1.89 \pm 0.03 \mathrm{E}-06$ & $3.56 \pm 0.81 E-07$ \\
\hline 8609 & $\operatorname{DOWN}(3)$ & 7.07 & 2,376 & $1.39 \pm 3.54 \mathrm{E}-09$ & $1.82 \pm 0.02 E-06$ & $2.86 \pm 0.81 \mathrm{E}-07$ \\
\hline 8609 & DOWN(4) & 6.90 & 2,044 & $-2.19 \pm 2.69 \mathrm{E}-09$ & $1.86 \pm 0.02 \mathrm{E}-06$ & $2.90 \pm 1.37 \mathrm{E}-07$ \\
\hline 105 & $\operatorname{DOWN}(1)$ & 7.08 & 1,734 & $-2.47 \pm 4.05 \mathrm{E}-09$ & $5.75 \pm 0.02 E-05$ & $2.38 \pm 0.81 E-07$ \\
\hline 105 & DOWN(2) & 7.31 & 1,732 & $0.00 \pm 4.21 \mathrm{E}-09$ & $4.98 \pm 0.02 \mathrm{E}-05$ & 3.61 $\pm 0.81 E-07$ \\
\hline 105 & DOWN(3) & 7.32 & 1,612 & $3.71 \pm 4.72 \mathrm{E}-09$ & $4.77 \pm 0.01 \mathrm{E}-05$ & $2.44 \pm 0.81 \mathrm{E}-07$ \\
\hline 105 & DOWN(4) & 7.22 & 1,575 & $0.51 \pm 2.30 \mathrm{E}-09$ & $5.29 \pm 0.01 \mathrm{E}-05$ & $2.79 \pm 1.30 \mathrm{E}-07$ \\
\hline 106 & DOWN(1) & 6.55 & 1,496 & $2.30 \pm 3.65 \mathrm{E}-09$ & $3.57 \pm 0.53 E-08$ & $1.03 \pm 0.09 E-06$ \\
\hline 106 & DOWN(2) & 6.79 & 1,560 & $-0.58 \pm 2.15 \mathrm{E}-09$ & $5.31 \pm 0.43 \mathrm{E}-08$ & 5.41 $\pm 0.91 E-07$ \\
\hline 106 & DOWN(3) & 6.93 & 1,573 & $9.80 \pm 5.88 \mathrm{E}-09$ & $9.16 \pm 0.73 \mathrm{E}-08$ & $6.43 \pm 0.87 \mathrm{E}-07$ \\
\hline 106 & DOWN(4) & 6.72 & 1,460 & $0.23 \pm 1.30 \mathrm{E}-09$ & $9.98 \pm 0.50 \mathrm{E}-08$ & $8.07 \pm 1.48 \mathrm{E}-07$ \\
\hline 116 & DOWN(1) & 6.58 & 1,275 & $1.18 \pm 2.81 \mathrm{E}-09$ & $2.10 \pm 0.03 E-06$ & $4.50 \pm 7.78 \mathrm{E}-08$ \\
\hline 116 & DOWN(2) & 7.22 & 1,862 & $1.77 \pm 5.24 \mathrm{E}-09$ & $2.65 \pm 0.04 \mathrm{E}-06$ & $1.91 \pm 0.79 \mathrm{E}-07$ \\
\hline 116 & DOWN(3) & 7.01 & 1,670 & $0.89 \pm 5.30 \mathrm{E}-09$ & $3.13 \pm 0.04 \mathrm{E}-06$ & $2.13 \pm 0.80 \mathrm{E}-07$ \\
\hline 116 & DOWN(4) & 7.08 & 1,541 & $-0.68 \pm 1.33 \mathrm{E}-09$ & $3.69 \pm 0.03 \mathrm{E}-06$ & $3.13 \pm 1.15 \mathrm{E}-07$ \\
\hline 605 & DOWN(1) & 6.92 & 469 & $4.11 \pm 8.79 \mathrm{E}-10$ & $3.37 \pm 0.22 E-08$ & $1.44 \pm 0.80 \mathrm{E}-07$ \\
\hline 605 & $\operatorname{DOWN}(2)$ & 7.02 & 762 & $0.82 \pm 1.62 \mathrm{E}-09$ & $3.19 \pm 0.32 \mathrm{E}-08$ & $1.80 \pm 8.11 \mathrm{E}-08$ \\
\hline 605 & DOWN(3) & 7.09 & 836 & $-1.32 \pm 1.62 \mathrm{E}-09$ & $2.94 \pm 0.22 E-08$ & $6.26 \pm 8.13 \mathrm{E}-08$ \\
\hline 801 & DOWN(1) & 6.69 & 1,228 & $0.63 \pm 2.84 \mathrm{E}-09$ & $4.88 \pm 0.05 E-06$ & $7.63 \pm 6.78 \mathrm{E}-08$ \\
\hline 801 & $\operatorname{DOWN}(2)$ & 6.76 & 1,693 & $-0.66 \pm 3.71 \mathrm{E}-09$ & $8.46 \pm 0.06 \mathrm{E}-06$ & $1.82 \pm 0.79 \mathrm{E}-07$ \\
\hline 801 & DOWN(3) & 6.53 & 1,683 & $1.42 \pm 5.11 \mathrm{E}-09$ & $9.41 \pm 0.07 \mathrm{E}-06$ & $6.32 \pm 8.31 \mathrm{E}-08$ \\
\hline 801 & DOWN(4) & 6.65 & 1,543 & $0.91 \pm 1.78 \mathrm{E}-09$ & $9.50 \pm 0.05 E-06$ & $3.12 \pm 1.10 \mathrm{E}-07$ \\
\hline 802 & DOWN(1) & 6.50 & 448 & $2.28 \pm 1.92 \mathrm{E}-09$ & $2.89 \pm 0.46 \mathrm{E}-08$ & $1.09 \pm 0.58 \mathrm{E}-07$ \\
\hline 802 & $\operatorname{DOWN}(2)$ & 6.73 & 236 & $0.11 \pm 1.15 \mathrm{E}-09$ & $1.64 \pm 0.40 \mathrm{E}-08$ & $1.28 \pm 0.83 E-07$ \\
\hline 802 & DOWN(3) & 7.10 & 335 & $0.57 \pm 1.25 \mathrm{E}-09$ & $3.16 \pm 0.31 \mathrm{E}-08$ & $-8.12 \pm 8.07 \mathrm{E}-08$ \\
\hline 802 & DOWN(4) & 6.81 & 1,444 & $-2.33 \pm 1.76 \mathrm{E}-09$ & $1.56 \pm 0.06 \mathrm{E}-07$ & $0.96 \pm 1.30 \mathrm{E}-07$ \\
\hline 803 & DOWN(1) & 7.02 & 1,338 & $0.47 \pm 3.51 \mathrm{E}-09$ & $1.46 \pm 0.42 \mathrm{E}-08$ & $1.06 \pm 0.82 \mathrm{E}-07$ \\
\hline 803 & DOWN(2) & 7.04 & 1,204 & $-1.76 \pm 2.91 \mathrm{E}-09$ & $1.07 \pm 0.42 E-08$ & $2.72 \pm 8.81 \mathrm{E}-08$ \\
\hline 803 & DOWN(3) & 7.11 & 1,251 & $8.96 \pm 4.84 \mathrm{E}-09$ & $1.12 \pm 0.41 \mathrm{E}-08$ & $3.58 \pm 8.15 \mathrm{E}-08$ \\
\hline 803 & DOWN(4) & 6.92 & 1,300 & $0.00 \pm 1.76 \mathrm{E}-09$ & $1.84 \pm 0.33 E-08$ & $0.84 \pm 1.34 \mathrm{E}-07$ \\
\hline
\end{tabular}

Note: Bolding convention applied to these data. (See p. E-2 $\mathbf{6 0}$ )

Sample collection quarter is noted in parentheses next to hydraulic position. Hydraulic position is relative to other wells within the same hydrogeologic unit.

$$
E-8
$$


Table E-2 (concluded)

\section{Indicator Results From the Sand and Gravel Unit}

\begin{tabular}{|c|c|c|c|c|c|c|}
\hline $\begin{array}{l}\text { Location } \\
\text { Code }\end{array}$ & $\begin{array}{l}\text { Hydraulic } \\
\text { Position }\end{array}$ & $\begin{array}{c}\mathbf{p H} \\
(\mathrm{SU})\end{array}$ & $\begin{array}{c}\text { Conductivity } \\
\left(\mu \mathrm{mhos} / \mathrm{cm} @ 25^{\circ} \mathrm{C}\right)\end{array}$ & $\begin{array}{l}\text { Gross Alpha } \\
\qquad(\mu \mathrm{Ci} / \mathrm{mL})\end{array}$ & $\begin{array}{c}\text { Gross Beta } \\
(\mu \mathrm{Ci} / \mathrm{mL})\end{array}$ & $\begin{array}{c}\text { Tritium } \\
(\mu \mathrm{Ci} / \mathrm{mL})\end{array}$ \\
\hline 804 & $\operatorname{DOWN}(1)$ & 6.70 & 946 & $0.00 \pm 2.04 \mathrm{E}-09$ & $2.02 \pm 0.08 \mathrm{E}-07$ & $2.35 \pm 0.83 E-07$ \\
\hline 804 & $\operatorname{DOWN}(2)$ & 6.66 & 1,400 & $-0.38 \pm 2.34 \mathrm{E}-09$ & 3.14 $\pm 0.10 \mathrm{E}-07$ & $6.58 \pm 8.10 \mathrm{E}-08$ \\
\hline 804 & DOWN(3) & 6.71 & 1,434 & $-1.54 \pm 2.95 \mathrm{E}-09$ & $2.67 \pm 0.09 \mathrm{E}-07$ & $3.35 \pm 8.17 \mathrm{E}-08$ \\
\hline 804 & DOWN(4) & 6.50 & 1,120 & $-0.83 \pm 1.70 \mathrm{E}-09$ & $2.35 \pm 0.07 \mathrm{E}-07$ & $-0.58 \pm 1.28 \mathrm{E}-07$ \\
\hline 8603 & $\operatorname{DOWN}(1)$ & 6.93 & 1,629 & $1.94 \pm 3.65 \mathrm{E}-09$ & $5.86 \pm 0.02 \mathrm{E}-05$ & $2.99 \pm 0.82 \mathrm{E}-07$ \\
\hline 8603 & $\operatorname{DOWN}(2)$ & 7.22 & 1,697 & $-1.47 \pm 4.02 \mathrm{E}-09$ & $5.12 \pm 0.02 E-05$ & $3.50 \pm 0.81 E-07$ \\
\hline 8603 & $\operatorname{DOWN}(3)$ & 7.32 & 1,670 & $0.00 \pm 4.75 \mathrm{E}-09$ & $5.89 \pm 0.02 E-05$ & $3.41 \pm 0.81 \mathrm{E}-07$ \\
\hline 8603 & DOWN(4) & 7.02 & 1,556 & $-1.15 \pm 2.08 \mathrm{E}-09$ & $5.47 \pm 0.01 \mathrm{E}-05$ & $2.99 \pm 1.36 \mathrm{E}-07$ \\
\hline 8604 & $\operatorname{DOWN}(1)$ & 6.95 & 1,516 & $1.10 \pm 3.63 \mathrm{E}-09$ & $5.05 \pm 0.02 \mathrm{E}-05$ & $3.18 \pm 0.82 \mathrm{E}-07$ \\
\hline 8604 & $\operatorname{DOWN}(2)$ & 7.47 & 1,495 & $0.82 \pm 3.60 \mathrm{E}-09$ & $4.68 \pm 0.01 E-05$ & $3.46 \pm 0.81 E-07$ \\
\hline 8604 & $\operatorname{DOWN}(3)$ & 7.35 & 1,549 & $-1.10 \pm 4.68 \mathrm{E}-09$ & $5.21 \pm 0.02 E-05$ & $2.53 \pm 0.80 E-07$ \\
\hline 8612 & $\operatorname{DOWN}(1)$ & 7.17 & 1,481 & $-2.24 \pm 3.61 \mathrm{E}-09$ & $-0.34 \pm 3.45 E-09$ & $2.85 \pm 0.89 \mathrm{E}-07$ \\
\hline 8612 & $\operatorname{DOWN}(2)$ & 7.24 & 1,387 & $-1.66 \pm 3.24 \mathrm{E}-09$ & $-0.58 \pm 3.69 E-09$ & $3.26 \pm 0.59 \mathrm{E}-07$ \\
\hline 8612 & DOWN(3) & 7.35 & 1,525 & $1.24 \pm 4.03 \mathrm{E}-09$ & $4.89 \pm 3.61 \mathrm{E}-09$ & $3.41 \pm 0.82 \mathrm{E}-07$ \\
\hline 8612 & DOWN(4) & 6.97 & 1,500 & $2.09 \pm 2.17 \mathrm{E}-09$ & $1.59 \pm 3.14 \mathrm{E}-09$ & $1.52 \pm 1.32 \mathrm{E}-07$ \\
\hline GSEEP & $\operatorname{DOWN}(1)$ & 6.53 & 1,010 & $-1.71 \pm 1.85 \mathrm{E}-09$ & $4.94 \pm 2.57 \mathrm{E}-09$ & $5.49 \pm 0.87 \mathrm{E}-07$ \\
\hline GSEEP & $\operatorname{DOWN}(2)$ & 6.70 & 983 & $-0.63 \pm 1.89 \mathrm{E}-09$ & $0.82 \pm 2.46 \mathrm{E}-09$ & $4.84 \pm 0.86 \mathrm{E}-07$ \\
\hline GSEEP & DOWN(3) & 6.44 & 1,066 & $-0.44 \pm 2.53 \mathrm{E}-09$ & $4.09 \pm 2.63 \mathrm{E}-09$ & $3.97 \pm 0.83 \mathrm{E}-07$ \\
\hline GSEEP & DOWN(4) & 6.51 & 970 & $0.00 \pm 1.21 \mathrm{E}-09$ & $4.33 \pm 2.46 \mathrm{E}-09$ & $1.35 \pm 1.30 \mathrm{E}-07$ \\
\hline SP04 & $\operatorname{DOWN}(1)$ & NS & NS & $1.96 \pm 2.85 \mathrm{E}-09$ & $8.56 \pm 3.81 \mathrm{E}-09$ & $2.39 \pm 0.57 \mathrm{E}-07$ \\
\hline SP04 & DOWN(3) & NS & NS & $1.38 \pm 3.64 \mathrm{E}-09$ & $8.15 \pm 3.78 \mathrm{E}-09$ & $2.70 \pm 0.80 \mathrm{E}-07$ \\
\hline SP06 & $\operatorname{DOWN}(1)$ & NS & NS & $0.11 \pm 1.65 \mathrm{E}-09$ & $4.40 \pm 1.98 \mathrm{E}-09$ & $-8.48 \pm 8.33 \mathrm{E}-08$ \\
\hline SP06 & $\operatorname{DOWN}(3)$ & NS & NS & $0.00 \pm 2.14 \mathrm{E}-09$ & $4.15 \pm 1.93 \mathrm{E}-09$ & $1.20 \pm 0.79 \mathrm{E}-07$ \\
\hline SP11 & DOWN(1) & NS & NS & $2.11 \pm 2.84 \mathrm{E}-09$ & $7.12 \pm 0.51 \mathrm{E}-08$ & $2.40 \pm 8.47 \mathrm{E}-08$ \\
\hline SP11 & DOWN(3) & NS & NS & $2.60 \pm 3.31 \mathrm{E}-09$ & $7.72 \pm 0.53 \mathrm{E}-08$ & $1.80 \pm 0.80 \mathrm{E}-07$ \\
\hline SP12 & $\operatorname{DOWN}(1)$ & 6.51 & 834 & $2.74 \pm 2.02 \mathrm{E}-09$ & $2.97 \pm 0.26 \mathrm{E}-08$ & $2.61 \pm 0.86 \mathrm{E}-07$ \\
\hline SP12 & DOWN(3) & 7.50 & 1,012 & $2.35 \pm 3.34 \mathrm{E}-09$ & $2.65 \pm 2.57 \mathrm{E}-09$ & $1.60 \pm 0.80 \mathrm{E}-07$ \\
\hline WP-A & DOWN(4) & 8.20 & 81 & $0.75 \pm 2.15 \mathrm{E}-10$ & $1.73 \pm 0.10 \mathrm{E}-08$ & $1.23 \pm 0.04 \mathrm{E}-05$ \\
\hline WP-C & DOWN(4) & 6.91 & 176 & $6.55 \pm 7.80 \mathrm{E}-10$ & $2.41 \pm 0.13 \mathrm{E}-08$ & $5.01 \pm 0.08 \mathrm{E}-05$ \\
\hline WP-H & DOWN(4) & 6.94 & 1,154 & $3.29 \pm 1.77 \mathrm{E}-09$ & $6.02 \pm 0.03 \mathrm{E}-06$ & $1.67 \pm 0.19 \mathrm{E}-06$ \\
\hline
\end{tabular}

Note: Bolding convention applied to these data. (See p. E-2 $\mathbf{6 0}$ )

NS - Not sampled

Sample collection quarter is noted in parentheses next to hydraulic position. Hydraulic position is relative to other wells within the same hydrogeologic unit.

$E-9$ 
Table E-3

\section{Indicator Results From the Lavery Till-Sand Unit}

\begin{tabular}{|c|c|c|c|c|c|c|}
\hline $\begin{array}{l}\text { Location } \\
\text { Code }\end{array}$ & $\begin{array}{l}\text { Hydraulic } \\
\text { Position }\end{array}$ & $\begin{array}{c}\mathbf{p H} \\
(\mathrm{SU})\end{array}$ & $\begin{array}{c}\text { Conductivity } \\
\left(\mu \mathrm{mhos} / \mathrm{cm} @ 25^{\circ} \mathrm{C}\right)\end{array}$ & $\begin{array}{l}\text { Gross Alpha } \\
\qquad(\mu \mathrm{Ci} / \mathrm{mL})\end{array}$ & $\begin{array}{c}\text { Gross Beta } \\
(\mu \mathrm{Ci} / \mathrm{mL})\end{array}$ & $\begin{array}{l}\text { Tritium } \\
(\mu \mathrm{Ci} / \mathrm{mL})\end{array}$ \\
\hline 302 & UP(1) & 6.72 & 3,568 & $-2.40 \pm 4.64 \mathrm{E}-09$ & $-2.60 \pm 4.99 \mathrm{E}-09$ & $1.37 \pm 0.79 E-07$ \\
\hline 302 & $\mathrm{UP}(2)$ & 6.90 & 3,374 & $1.16 \pm 7.53 \mathrm{E}-09$ & $-0.23 \pm 7.39 \mathrm{E}-09$ & $-3.65 \pm 8.07 \mathrm{E}-08$ \\
\hline 302 & $\mathrm{UP}(3)$ & 6.93 & 4,001 & $1.51 \pm 5.25 \mathrm{E}-09$ & $0.48 \pm 5.18 \mathrm{E}-09$ & $8.20 \pm 7.69 \mathrm{E}-08$ \\
\hline 402 & $\mathrm{UP}(1)$ & 6.89 & 2,958 & $1.77 \pm 6.72 \mathrm{E}-09$ & $2.85 \pm 6.49 \mathrm{E}-09$ & $1.17 \pm 0.81 E-07$ \\
\hline 402 & $\mathrm{UP}(2)$ & 7.15 & 2,703 & $0.91 \pm 5.91 \mathrm{E}-09$ & $-2.66 \pm 7.00 \mathrm{E}-09$ & $-8.35 \pm 8.06 \mathrm{E}-08$ \\
\hline 402 & $\mathrm{UP}(3)$ & 7.11 & 2,759 & $-0.61 \pm 8.73 \mathrm{E}-09$ & $1.64 \pm 7.19 \mathrm{E}-09$ & $4.66 \pm 7.50 \mathrm{E}-08$ \\
\hline 204 & $\operatorname{DOWN}(1)$ & 7.31 & 1,128 & $1.28 \pm 2.83 \mathrm{E}-09$ & $4.50 \pm 3.61 \mathrm{E}-09$ & $1.76 \pm 0.80 \mathrm{E}-07$ \\
\hline 204 & DOWN(2) & 7.59 & 1,078 & $0.00 \pm 2.54 \mathrm{E}-09$ & $0.11 \pm 3.56 \mathrm{E}-09$ & $0.44 \pm 5.71 \mathrm{E}-08$ \\
\hline 204 & $\operatorname{DOWN}(3)$ & 7.50 & 1,224 & $2.14 \pm 2.31 \mathrm{E}-09$ & $5.93 \pm 2.52 \mathrm{E}-09$ & $1.02 \pm 0.78 \mathrm{E}-07$ \\
\hline 204 & DOWN(4) & 7.50 & 1,132 & $1.28 \pm 2.15 \mathrm{E}-09$ & $2.40 \pm 2.81 \mathrm{E}-09$ & $-0.93 \pm 1.28 \mathrm{E}-07$ \\
\hline 206 & DOWN(1) & 7.30 & 1,240 & $-0.39 \pm 2.83 E-09$ & $3.62 \pm 3.60 \mathrm{E}-09$ & $2.07 \pm 0.80 \mathrm{E}-07$ \\
\hline 206 & $\operatorname{DOWN}(2)$ & 7.47 & 1,256 & $0.00 \pm 2.48 \mathrm{E}-09$ & $2.40 \pm 3.45 \mathrm{E}-09$ & $2.31 \pm 8.07 \mathrm{E}-08$ \\
\hline 206 & DOWN(3) & 7.29 & 1,542 & $-0.23 \pm 3.58 E-09$ & $4.18 \pm 3.83 E-09$ & $1.48 \pm 0.78 \mathrm{E}-07$ \\
\hline 208 & $\operatorname{DOWN}(1)$ & 7.88 & 264 & $-1.65 \pm 6.88 \mathrm{E}-10$ & $-0.50 \pm 1.11 \mathrm{E}-09$ & $7.82 \pm 7.87 \mathrm{E}-08$ \\
\hline 208 & DOWN(2) & 8.08 & 257 & $2.25 \pm 6.42 \mathrm{E}-10$ & $1.69 \pm 1.17 \mathrm{E}-09$ & $4.18 \pm 8.07 \mathrm{E}-08$ \\
\hline 208 & DOWN(3) & 7.87 & 258 & $0.77 \pm 1.09 \mathrm{E}-09$ & $0.26 \pm 1.15 \mathrm{E}-09$ & $6.25 \pm 7.65 \mathrm{E}-08$ \\
\hline
\end{tabular}

Note: Bolding convention applied to these data. (See p. E-2 $\mathbf{6 0}$ )

Sample collection quarter is noted in parentheses next to hydraulic position. Hydraulic position is relative to other wells within the same hydrogeologic unit. 


\section{Table E-4}

\section{Indicator Results From the Weathered Lavery Till Unit}

\begin{tabular}{|c|c|c|c|c|c|c|}
\hline $\begin{array}{l}\text { Location } \\
\text { Code }\end{array}$ & $\begin{array}{l}\text { Hydraulic } \\
\text { Position }\end{array}$ & $\begin{array}{c}\mathbf{p H} \\
(\mathrm{SU})\end{array}$ & $\begin{array}{c}\text { Conductivity } \\
\left(\mu \mathrm{mhos} / \mathrm{cm} @ 25^{\circ} \mathrm{C}\right)\end{array}$ & $\begin{array}{l}\text { Gross Alpha } \\
\qquad(\mu \mathrm{Ci} / \mathrm{mL})\end{array}$ & $\begin{array}{c}\text { Gross Beta } \\
(\mu \mathrm{Ci} / \mathrm{mL})\end{array}$ & $\begin{array}{l}\text { Tritium } \\
(\mu \mathrm{Ci} / \mathrm{mL})\end{array}$ \\
\hline 908 & UP(1) & 7.08 & 2,683 & $1.42 \pm 0.82 \mathrm{E}-08$ & $2.33 \pm 0.82 \mathrm{E}-08$ & $3.35 \pm 8.17 \mathrm{E}-08$ \\
\hline 908 & $\mathrm{UP}(3)$ & 6.77 & 2,778 & $1.68 \pm 1.09 \mathrm{E}-08$ & $2.11 \pm 0.84 \mathrm{E}-08$ & $-7.77 \pm 7.99 \mathrm{E}-08$ \\
\hline 1005 & $\mathrm{UP}(1)$ & 7.05 & 804 & $0.33 \pm 2.31 \mathrm{E}-09$ & $5.14 \pm 2.57 \mathrm{E}-09$ & $9.27 \pm 8.23 \mathrm{E}-08$ \\
\hline 1005 & $\mathrm{UP}(3)$ & 7.08 & 796 & $2.40 \pm 2.60 \mathrm{E}-09$ & $2.15 \pm 2.46 \mathrm{E}-09$ & $-6.41 \pm 7.95 \mathrm{E}-08$ \\
\hline $1008 \mathrm{C}$ & $\mathrm{UP}(1)$ & 7.28 & 608 & $0.56 \pm 1.60 \mathrm{E}-09$ & $1.00 \pm 1.76 \mathrm{E}-09$ & $5.20 \pm 8.23 \mathrm{E}-08$ \\
\hline $1008 \mathrm{C}$ & $\mathrm{UP}(3)$ & 7.47 & 621 & $-0.13 \pm 1.89 \mathrm{E}-09$ & $0.23 \pm 1.78 \mathrm{E}-09$ & $4.84 \pm 7.66 \mathrm{E}-08$ \\
\hline 906 & $\operatorname{DOWN}(1)$ & 7.40 & 630 & $1.53 \pm 1.74 \mathrm{E}-09$ & $2.71 \pm 1.92 \mathrm{E}-09$ & $-5.63 \pm 8.39 \mathrm{E}-08$ \\
\hline 906 & DOWN(3) & 7.21 & 612 & $1.73 \pm 2.20 \mathrm{E}-09$ & $4.74 \pm 1.88 \mathrm{E}-09$ & $9.00 \pm 5.84 \mathrm{E}-08$ \\
\hline 1006 & $\operatorname{DOWN}(1)$ & 6.89 & 1,772 & $6.45 \pm 4.71 \mathrm{E}-09$ & $5.29 \pm 4.82 \mathrm{E}-09$ & $1.91 \pm 8.17 \mathrm{E}-08$ \\
\hline 1006 & DOWN(3) & 6.96 & 1,790 & $3.29 \pm 3.49 \mathrm{E}-09$ & $3.15 \pm 3.43 \mathrm{E}-09$ & $-0.67 \pm 8.07 \mathrm{E}-08$ \\
\hline 1007 & $\operatorname{DOWN}(1)$ & 6.88 & 1,364 & $1.06 \pm 0.53 \mathrm{E}-08$ & $5.36 \pm 3.80 \mathrm{E}-09$ & $1.06 \pm 0.84 \mathrm{E}-07$ \\
\hline 1007 & DOWN(3) & 6.75 & 1,377 & $-0.79 \pm 4.04 \mathrm{E}-09$ & $5.22 \pm 3.96 \mathrm{E}-09$ & $-3.75 \pm 8.06 \mathrm{E}-08$ \\
\hline NDATR & DOWN(1) & 7.98 & 221 & $0.31 \pm 1.20 \mathrm{E}-09$ & $1.90 \pm 0.08 \mathrm{E}-07$ & $4.60 \pm 0.89 \mathrm{E}-07$ \\
\hline NDATR & $\operatorname{DOWN}(2)$ & 8.16 & 612 & $2.62 \pm 1.62 \mathrm{E}-09$ & $1.76 \pm 0.07 \mathrm{E}-07$ & $1.69 \pm 0.11 \mathrm{E}-06$ \\
\hline NDATR & DOWN(3) & 7.48 & 1,054 & $1.63 \pm 3.38 \mathrm{E}-09$ & $1.46 \pm 0.07 E-07$ & $5.26 \pm 0.15 \mathrm{E}-06$ \\
\hline NDATR & DOWN(4) & 7.35 & 1,075 & $1.43 \pm 0.63 \mathrm{E}-09$ & $2.58 \pm 0.04 E-07$ & $3.82 \pm 1.33 E-07$ \\
\hline 909 & DOWN(1) & 6.68 & 1,349 & $0.79 \pm 2.45 \mathrm{E}-09$ & $3.65 \pm 0.11 \mathrm{E}-07$ & $8.56 \pm 0.89 \mathrm{E}-07$ \\
\hline 909 & DOWN(3) & 6.65 & 1,396 & $1.14 \pm 0.57 \mathrm{E}-08$ & $3.21 \pm 0.14 \mathrm{E}-07$ & $6.09 \pm 0.89 \mathrm{E}-07$ \\
\hline
\end{tabular}

Note: Bolding convention applied to these data. (See p. E-2 $\mathbf{6 0}$ )

Sample collection quarter is noted in parentheses next to hydraulic position. Hydraulic position is relative to other wells within the same hydrogeologic unit. 


\section{Table E-5 \\ 2005 Indicator Results From the Unweathered Lavery Till Unit}

\begin{tabular}{|c|c|c|c|c|c|c|}
\hline $\begin{array}{l}\text { Location } \\
\text { Code }\end{array}$ & $\begin{array}{l}\text { Hydraulic } \\
\text { Position }\end{array}$ & $\begin{array}{c}\mathbf{p H} \\
(\mathrm{SU})\end{array}$ & $\begin{array}{c}\text { Conductivity } \\
\left(\mu \mathrm{mhos} / \mathrm{cm} @ 25^{\circ} \mathrm{C}\right)\end{array}$ & $\begin{array}{l}\text { Gross Alpha } \\
\qquad(\mu \mathrm{Ci} / \mathrm{mL})\end{array}$ & $\begin{array}{c}\text { Gross Beta } \\
(\mu \mathrm{Ci} / \mathrm{mL})\end{array}$ & $\begin{array}{l}\text { Tritium } \\
(\mu \mathrm{Ci} / \mathrm{mL})\end{array}$ \\
\hline 405 & UP(1) & 7.09 & 877 & $3.72 \pm 4.35 \mathrm{E}-09$ & $7.56 \pm 5.01 \mathrm{E}-09$ & $1.03 \pm 8.45 \mathrm{E}-08$ \\
\hline 405 & $\mathrm{UP}(2)$ & 6.80 & 1,347 & $-0.70 \pm 2.36 \mathrm{E}-09$ & $5.31 \pm 4.60 \mathrm{E}-09$ & $2.76 \pm 8.04 \mathrm{E}-08$ \\
\hline 405 & $\mathrm{UP}(3)$ & 6.97 & 1,640 & $0.14 \pm 1.02 \mathrm{E}-08$ & $2.82 \pm 1.31 E-08$ & $3.69 \pm 7.97 \mathrm{E}-08$ \\
\hline 405 & $\mathrm{UP}(4)$ & 7.20 & 1,851 & $3.40 \pm 1.62 \mathrm{E}-09$ & $1.29 \pm 0.32 \mathrm{E}-08$ & $1.20 \pm 1.26 \mathrm{E}-07$ \\
\hline 1303 & $\mathrm{UP}(1)$ & 7.84 & 300 & $1.17 \pm 0.88 E-09$ & $1.88 \pm 1.20 \mathrm{E}-09$ & $-5.65 \pm 7.77 \mathrm{E}-08$ \\
\hline 1303 & $\mathrm{UP}(2)$ & 7.83 & 259 & $8.56 \pm 7.11 \mathrm{E}-10$ & $1.74 \pm 1.18 \mathrm{E}-09$ & $2.30 \pm 8.02 \mathrm{E}-08$ \\
\hline 1303 & $\mathrm{UP}(3)$ & 7.87 & 315 & $3.10 \pm 8.14 \mathrm{E}-10$ & $2.17 \pm 1.17 \mathrm{E}-09$ & $-2.20 \pm 7.65 E-08$ \\
\hline 1303 & $\mathrm{UP}(4)$ & 7.95 & 336 & $9.42 \pm 4.95 \mathrm{E}-10$ & $1.78 \pm 0.66 \mathrm{E}-09$ & $0.82 \pm 1.26 \mathrm{E}-07$ \\
\hline 110 & $\operatorname{DOWN}(1)$ & 7.20 & 530 & $-1.51 \pm 1.57 \mathrm{E}-09$ & $1.61 \pm 1.81 \mathrm{E}-09$ & $1.28 \pm 0.10 \mathrm{E}-06$ \\
\hline 110 & $\operatorname{DOWN}(2)$ & 7.47 & 490 & $0.63 \pm 1.42 \mathrm{E}-09$ & $0.83 \pm 1.84 \mathrm{E}-09$ & $1.06 \pm 0.10 \mathrm{E}-06$ \\
\hline 110 & DOWN(3) & 7.35 & 515 & $2.19 \pm 1.77 \mathrm{E}-09$ & $3.30 \pm 1.93 \mathrm{E}-09$ & $1.26 \pm 0.10 \mathrm{E}-06$ \\
\hline 110 & DOWN(4) & 7.38 & 490 & $0.00 \pm 9.51 \mathrm{E}-10$ & $1.15 \pm 1.56 \mathrm{E}-09$ & $8.86 \pm 1.49 \mathrm{E}-07$ \\
\hline 704 & $\operatorname{DOWN}(1)$ & 6.42 & 798 & $-0.15 \pm 2.02 \mathrm{E}-09$ & $6.91 \pm 2.66 \mathrm{E}-09$ & $2.36 \pm 5.84 \mathrm{E}-08$ \\
\hline 704 & $\operatorname{DOWN}(2)$ & 6.58 & 763 & $-0.16 \pm 1.98 \mathrm{E}-09$ & $5.05 \pm 2.68 \mathrm{E}-09$ & $-1.35 \pm 7.97 \mathrm{E}-08$ \\
\hline 704 & $\operatorname{DOWN}(3)$ & 6.55 & 836 & $-1.37 \pm 2.90 \mathrm{E}-09$ & $5.38 \pm 2.73 \mathrm{E}-09$ & $-4.28 \pm 8.06 \mathrm{E}-08$ \\
\hline 704 & DOWN(4) & 6.45 & 810 & $0.16 \pm 1.38 \mathrm{E}-09$ & $6.38 \pm 2.62 \mathrm{E}-09$ & $0.39 \pm 1.19 \mathrm{E}-07$ \\
\hline 707 & $\operatorname{DOWN}(1)$ & 6.38 & 395 & $0.00 \pm 9.22 \mathrm{E}-10$ & $5.46 \pm 1.64 \mathrm{E}-09$ & $3.07 \pm 8.24 \mathrm{E}-08$ \\
\hline 707 & $\operatorname{DOWN}(2)$ & 6.46 & 466 & $3.17 \pm 9.06 \mathrm{E}-10$ & $6.78 \pm 1.70 \mathrm{E}-09$ & $-3.00 \pm 8.02 \mathrm{E}-08$ \\
\hline 707 & $\operatorname{DOWN}(3)$ & 6.48 & 647 & $2.22 \pm 1.96 \mathrm{E}-09$ & $2.45 \pm 1.58 \mathrm{E}-09$ & $-4.44 \pm 8.40$ E -08 \\
\hline 707 & DOWN(4) & 6.57 & 574 & $1.13 \pm 0.99 \mathrm{E}-09$ & $3.06 \pm 1.44 \mathrm{E}-09$ & $1.18 \pm 1.23 \mathrm{E}-07$ \\
\hline 107 & $\operatorname{DOWN}(1)$ & 7.36 & 829 & $1.11 \pm 2.17 \mathrm{E}-09$ & $1.25 \pm 0.30 \mathrm{E}-08$ & 3.37 $\pm 0.82 E-07$ \\
\hline 107 & $\operatorname{DOWN}(2)$ & 7.29 & 793 & $1.51 \pm 1.87 \mathrm{E}-09$ & $1.13 \pm 0.29 E-08$ & $1.33 \pm 0.82 E-07$ \\
\hline 107 & $\operatorname{DOWN}(3)$ & 7.13 & 893 & $0.18 \pm 2.88 \mathrm{E}-09$ & $1.26 \pm 0.31 \mathrm{E}-08$ & $2.66 \pm 0.80 \mathrm{E}-07$ \\
\hline 107 & DOWN(4) & 6.81 & 932 & $-2.14 \pm 3.33 \mathrm{E}-09$ & $2.22 \pm 0.42 \mathrm{E}-08$ & $2.76 \pm 1.40 \mathrm{E}-07$ \\
\hline 108 & $\operatorname{DOWN}(1)$ & 7.59 & 526 & $1.85 \pm 1.52 \mathrm{E}-09$ & $0.83 \pm 1.81 \mathrm{E}-09$ & $2.28 \pm 0.80 E-07$ \\
\hline 108 & $\operatorname{DOWN}(2)$ & 7.76 & 512 & $0.96 \pm 1.36 \mathrm{E}-09$ & $2.47 \pm 1.91 E-09$ & $2.00 \pm 0.83 \mathrm{E}-07$ \\
\hline 108 & DOWN(3) & 7.48 & 607 & $0.98 \pm 1.66 \mathrm{E}-09$ & $0.28 \pm 1.70 \mathrm{E}-09$ & $2.27 \pm 0.56 \mathrm{E}-07$ \\
\hline 108 & DOWN(4) & 7.81 & 464 & $1.59 \pm 0.81 \mathrm{E}-09$ & $1.26 \pm 1.21 \mathrm{E}-09$ & $0.89 \pm 1.28 \mathrm{E}-07$ \\
\hline 409 & $\operatorname{DOWN}(1)$ & 7.11 & 342 & $8.06 \pm 9.17 \mathrm{E}-10$ & $1.99 \pm 1.25 \mathrm{E}-09$ & $2.07 \pm 0.57 \mathrm{E}-07$ \\
\hline 409 & $\operatorname{DOWN}(2)$ & 7.96 & 326 & $8.19 \pm 6.71 \mathrm{E}-10$ & $1.43 \pm 0.90 \mathrm{E}-09$ & $0.00 \pm 7.93 \mathrm{E}-08$ \\
\hline 409 & $\operatorname{DOWN}(3)$ & 7.80 & 378 & $0.57 \pm 1.18 \mathrm{E}-09$ & $2.06 \pm 1.26 \mathrm{E}-09$ & $3.84 \pm 7.90 \mathrm{E}-08$ \\
\hline 409 & DOWN(4) & 7.30 & 333 & $1.01 \pm 0.59 \mathrm{E}-09$ & $9.71 \pm 8.02 E-10$ & $2.10 \pm 1.37 \mathrm{E}-07$ \\
\hline 910 & $\operatorname{DOWN}(1)$ & 7.26 & 1,186 & $2.78 \pm 2.25 \mathrm{E}-09$ & $2.44 \pm 0.33 \mathrm{E}-08$ & $1.33 \pm 8.13 \mathrm{E}-08$ \\
\hline 910 & DOWN(3) & 8.63 & 823 & $0.60 \pm 2.24 \mathrm{E}-09$ & $5.04 \pm 0.57 \mathrm{E}-08$ & $-5.48 \pm 8.05 \mathrm{E}-08$ \\
\hline
\end{tabular}

Note: Bolding convention applied to these data. (See p. E-2 $\mathbf{6 0}$ )

Sample collection quarter is noted in parentheses next to hydraulic position. Hydraulic position is relative to other wells within the same hydrogeologic unit.

$E-12$ 


\begin{tabular}{|c|c|c|c|c|c|c|}
\hline \multicolumn{7}{|c|}{ Table E-6 } \\
\hline $\begin{array}{l}\text { Location } \\
\text { Code }\end{array}$ & $\begin{array}{c}\text { Hydraulic } \\
\text { Position }\end{array}$ & $\begin{array}{l}\mathbf{p H} \\
(\mathrm{SU})\end{array}$ & $\begin{array}{c}\text { Conductivity } \\
\left(\mu \mathrm{mhos} / \mathrm{cm} @ 25^{\circ} \mathrm{C}\right)\end{array}$ & $\begin{array}{c}\text { Gross Alpha } \\
(\mu \mathrm{Ci} / \mathrm{mL})\end{array}$ & $\begin{array}{c}\text { Gross Beta } \\
(\mu \mathrm{Ci} / \mathrm{mL})\end{array}$ & $\underset{(\mu \mathrm{Ci} / \mathrm{mL})}{\text { Tritium }}$ \\
\hline 901 & $\mathrm{UP}(1)$ & 7.01 & 350 & $4.05 \pm 1.37 \mathrm{E}-09$ & $3.92 \pm 1.34 \mathrm{E}-09$ & $-4.80 \pm 8.12 \mathrm{E}-08$ \\
\hline 901 & $\mathrm{UP}(3)$ & 7.66 & 359 & $1.22 \pm 1.18 \mathrm{E}-09$ & $3.52 \pm 1.29 \mathrm{E}-09$ & $-4.83 \pm 8.19 \mathrm{E}-08$ \\
\hline 902 & UP(1) & 8.18 & 390 & $0.94 \pm 1.19 \mathrm{E}-09$ & $2.66 \pm 1.49 \mathrm{E}-09$ & $-6.07 \pm 8.00 \mathrm{E}-08$ \\
\hline 902 & UP(3) & 7.86 & 437 & $3.80 \pm 1.74 \mathrm{E}-09$ & $2.26 \pm 1.53 \mathrm{E}-09$ & $-7.32 \pm 8.03 \mathrm{E}-08$ \\
\hline $1008 \mathrm{~B}$ & $\mathrm{UP}(1)$ & 7.71 & 454 & $2.13 \pm 1.34 \mathrm{E}-09$ & $2.14 \pm 1.27 \mathrm{E}-09$ & $8.04 \pm 8.31 \mathrm{E}-08$ \\
\hline $1008 \mathrm{~B}$ & $\mathrm{UP}(3)$ & 7.85 & 368 & $1.43 \pm 1.18 \mathrm{E}-09$ & $3.02 \pm 1.26 \mathrm{E}-09$ & $0.85 \pm 7.68 \mathrm{E}-08$ \\
\hline 903 & DOWN(1) & 7.50 & 864 & $3.84 \pm 2.57 \mathrm{E}-09$ & $0.90 \pm 2.33 \mathrm{E}-09$ & $5.14 \pm 8.28 \mathrm{E}-08$ \\
\hline 903 & DOWN(3) & 7.33 & 940 & $-1.35 \pm 2.85 \mathrm{E}-09$ & $-0.32 \pm 2.39 \mathrm{E}-09$ & $-8.04 \pm 8.08 \mathrm{E}-08$ \\
\hline 8610 & DOWN(1) & 7.67 & 1,104 & $6.35 \pm 2.98 \mathrm{E}-09$ & $6.24 \pm 2.66 \mathrm{E}-09$ & $1.20 \pm 0.83 \mathrm{E}-07$ \\
\hline 8610 & DOWN(3) & 7.80 & 755 & $-1.14 \pm 2.83 \mathrm{E}-09$ & $4.24 \pm 2.61 \mathrm{E}-09$ & $-2.87 \pm 5.42 \mathrm{E}-08$ \\
\hline 8611 & DOWN(1) & 7.07 & 689 & $2.29 \pm 2.37 \mathrm{E}-09$ & $2.23 \pm 2.40 \mathrm{E}-09$ & $-3.76 \pm 8.41 \mathrm{E}-08$ \\
\hline 8611 & DOWN(3) & 7.46 & 905 & $1.81 \pm 1.70 \mathrm{E}-09$ & $4.23 \pm 1.69 \mathrm{E}-09$ & $-1.83 \pm 7.65 \mathrm{E}-08$ \\
\hline
\end{tabular}

Note: Bolding convention is not applicable to these data.

Sample collection quarter is noted in parentheses next to hydraulic position. Hydraulic position is relative to other wells within the same hydrogeologic unit.

\section{Table E-7 \\ 2005 Metals Results for Early Warning Monitoring Wells}

$\begin{array}{ccccc}\begin{array}{c}\text { Location } \\ \text { Code }\end{array} & \begin{array}{c}\text { Sample } \\ \text { Quarter }\end{array} & \begin{array}{c}\text { Aluminum } \\ \text { Total } \\ (\mu \mathrm{g} / \mathrm{L})\end{array} & \begin{array}{c}\text { Iron } \\ \text { Total } \\ (\mu \mathrm{g} / \mathrm{L})\end{array} & \begin{array}{c}\text { Manganese } \\ \text { Total } \\ (\mu \mathrm{g} / \mathrm{L})\end{array} \\ 502 & 356 & 17,490 & 16.5 \\ & (1) & 196 & 4,420 & 8.0\end{array}$

Note: Bolding convention is not applicable to these data.

$E-13$

WVDP Annual Site Environmental Report

Calendar Year 2005 


\section{Table E-8 \\ 2005 Volatile Organic Compound Results \\ at Selected Groundwater Monitoring Locations}

\begin{tabular}{|c|c|c|c|c|c|c|c|c|}
\hline $\begin{array}{l}\text { Location } \\
\text { Code }\end{array}$ & $\begin{array}{c}\text { Sampling } \\
\text { Quarter }\end{array}$ & $\begin{array}{c}\text { 1,1-DCA } \\
(\mu \mathrm{g} / \mathrm{L})\end{array}$ & $\begin{array}{c}\text { DCDFMeth } \\
(\mu \mathrm{g} / \mathrm{L})\end{array}$ & $\begin{array}{c}\text { 1,1-DCE } \\
(\mu \mathrm{g} / \mathrm{L})\end{array}$ & $\begin{array}{c}\text { 1,2-DCE } \\
\text { (total) } \\
(\mu \mathrm{g} / \mathrm{L})\end{array}$ & $\begin{array}{c}\text { 1,2-DCE } \\
(\text { trans }) \\
(\mu \mathrm{g} / \mathrm{L})\end{array}$ & $\begin{array}{c}\text { 1,1,1-TCA } \\
(\mu \mathrm{g} / \mathrm{L})\end{array}$ & $\begin{array}{c}\text { Vinyl } \\
\text { Chloride } \\
(\mu \mathrm{g} / \mathrm{L})\end{array}$ \\
\hline SP12 & $\begin{array}{l}1 \\
3\end{array}$ & $\begin{array}{l}<5.0 \\
<5.0\end{array}$ & $\begin{array}{l}<1.0 \\
<1.0\end{array}$ & $\begin{array}{l}<5.0 \\
<5.0\end{array}$ & $\begin{array}{l}\text { NS } \\
\text { NS }\end{array}$ & $\begin{array}{l}<1.0 \\
<1.0\end{array}$ & $\begin{array}{l}<5.0 \\
<5.0\end{array}$ & $\begin{array}{l}<10.0 \\
<10.0\end{array}$ \\
\hline 803 & $\begin{array}{l}1 \\
2 \\
3 \\
4\end{array}$ & $\begin{array}{l}<5.0 \\
<5.0 \\
<5.0 \\
<5.0\end{array}$ & $\begin{array}{l}<1.0 \\
<1.0 \\
<1.0 \\
<1.0\end{array}$ & $\begin{array}{l}<5.0 \\
<5.0 \\
<5.0 \\
<5.0\end{array}$ & $\begin{array}{l}\text { NS } \\
\text { NS } \\
\text { NS } \\
\text { NS }\end{array}$ & $\begin{array}{l}<1.0 \\
<1.0 \\
<1.0 \\
<1.0\end{array}$ & $\begin{array}{l}<5.0 \\
<5.0 \\
<5.0 \\
<5.0\end{array}$ & $\begin{array}{l}<10.0 \\
<10.0 \\
<10.0 \\
<10.0\end{array}$ \\
\hline 8609 & 1 & $<5.0$ & $<5.0$ & $<5.0$ & NS & $<5.0$ & $<5.0$ & $<10.0$ \\
\hline 8612 & $\begin{array}{l}1 \\
2 \\
3 \\
4\end{array}$ & $\begin{array}{c}\mathbf{1 0 . 5} \\
8.8 \\
\mathbf{7 . 5} \\
8.5\end{array}$ & $\begin{array}{l}<5.0^{a} \\
<5.0^{a} \\
<5.0^{a} \\
<5.0^{a}\end{array}$ & $\begin{array}{l}<5.0^{a} \\
<5.0^{a} \\
<5.0^{a} \\
<5.0\end{array}$ & $\begin{array}{l}\mathbf{2 9 . 0} \\
24.0 \\
\mathbf{2 2 . 0} \\
23.5\end{array}$ & $\begin{array}{l}<5.0 \\
<5.0 \\
<5.0^{a} \\
<5.0\end{array}$ & $\begin{array}{l}<5.0^{a} \\
<5.0^{a} \\
<5.0^{a} \\
<5.0^{a}\end{array}$ & $\begin{array}{l}<10.0^{a} \\
<10.0 \\
<10.0^{a} \\
<10.0\end{array}$ \\
\hline
\end{tabular}

See Table E-12 ${ }^{\text {जo }}$ for compound definition.

Note: Bolding convention applied to these data. (See p. E-2 6 .

NS - Not sampled.

${ }^{a}$ Compound was reported at an estimated concentration less than the practical quantitation limit.

\section{Table E-9 \\ 2005 Tributyl Phosphate Results at Selected Groundwater Monitoring Locations}

$\begin{array}{ccc}\begin{array}{c}\text { Location } \\ \text { Code }\end{array} & \begin{array}{c}\text { Sampling } \\ \text { Quarter }\end{array} & \begin{array}{c}\text { Tributyl Phosphate (TBP) } \\ (\mu \mathrm{g} / \mathrm{L})\end{array} \\ 111 & 1 & <10.0^{a} \\ & 3 & <10.0^{a} \\ 8605 & 1 & 220 \\ & 3 & 263\end{array}$

Practical quantitation limit is $10 \mu \mathrm{g} / \mathrm{L}$.

Note: Bolding convention not applicable to these data.

${ }^{a}$ Compound was reported at an estimated concentration less than the practical quantitation limit.

$E-14$

WVDP Annual Site Environmental Report

Calendar Year 2005 
Table E-10

2005 Results for Metals in Groundwater

Title 6 NYCRR Appendix 33 List

\begin{tabular}{|c|c|c|c|c|c|c|c|c|}
\hline & & $\begin{array}{c}\text { Antimony } \\
(\mu \mathrm{g} / \mathrm{L})\end{array}$ & $\begin{array}{c}\text { Arsenic } \\
(\mu \mathrm{g} / \mathrm{L})\end{array}$ & $\begin{array}{c}\text { Barium } \\
(\mu \mathrm{g} / \mathrm{L})\end{array}$ & $\begin{array}{c}\text { Beryllium } \\
(\mu \mathrm{g} / \mathrm{L})\end{array}$ & $\underset{(\mu \mathrm{g} / \mathrm{L})}{\text { Cadmium }}$ & $\begin{array}{c}\text { Chromium } \\
(\mu \mathrm{g} / \mathrm{L})\end{array}$ & $\begin{array}{l}\text { Cobalt } \\
(\mu \mathrm{g} / \mathrm{L})\end{array}$ \\
\hline
\end{tabular}

Sand and Gravel

$\begin{array}{rrrrrrrrrr}706 & \text { UP(1) } & <10 & <10 & 152 & <1 & <5 & \mathbf{6 9 4} & <50 & <25 \\ 706 & \text { UP(2) } & <10 & <10 & \mathbf{1 4 7} & <1 & <5 & \mathbf{6 0} & <50 & <25 \\ 706 & \text { UP(3) } & <10 & <10 & \mathbf{1 8 4} & <1 & <5 & 221 & <50 & <25 \\ 706 & \text { UP(4) } & <10 & <10 & 174 & <1 & <5 & 435 & <50 & <25 \\ & & & & & & & <5 \\ 1304 & \text { UP(1) } & <10 & <10 & 127 & <1 & <5 & 10 & <50 & <25 \\ 1304 & \text { UP(2) } & <10 & 11 & \mathbf{2 4 0} & <1 & <5 & 15 & <50 & \mathbf{2 7} \\ 1304 & \text { UP(3) } & <10 & \mathbf{1 3} & 224 & <1 & <5 & \mathbf{2 0} & <50 & <25 \\ 1304 & \text { UP(4) } & <10 & <10 & \mathbf{8 5} & <1 & <5 & <5 & <50 & <25 \\ 1302 & \text { DOWN(1) } & <10 & <10 & \mathbf{1 8 5} & <1 & <5 & <5 & <50 & <25 \\ 1302 & \text { DOWN(2) } & <10 & <10 & \mathbf{4 1 7} & <1 & <5 & \mathbf{1 3} & <50 & <25 \\ 1302 & \text { DOWN(3) } & <10 & <10 & 341 & <1 & <5 & <5 & <50 & <25 \\ 1302 & \text { DOWN(4) } & <10 & <10 & 308 & <1 & <5 & <5 & <50 & <25 \\ 111 & \text { DOWN(1) } & <3 & 4 & 98 & <0.1 & <0.3 & 1 & 2 \\ 502 & \text { DOWN(1) } & \text { NS } & 12 & 316 & \text { NS } & <0.3 & 1,580 & 2 \\ 502 & \text { DOWN(3) } & \text { NS } & <4 & 252 & \text { NS } & <0.3 & 775 & 2 \\ 8605 & \text { DOWN(1) } & <3 & 5 & 163 & <0.1 & <0.3 & <1 & 7\end{array}$

Weathered Till

\begin{tabular}{|c|c|c|c|c|c|c|c|c|c|}
\hline NDATR & $\operatorname{DOWN}(1)$ & $<10$ & $<10$ & 25 & $<1$ & $<5$ & $<5$ & $<50$ & $<25$ \\
\hline NDATR & DOWN (2) & $<10$ & $<10$ & 42 & $<1$ & $<5$ & $<5$ & $<50$ & $<25$ \\
\hline NDATR & DOWN (3) & $<10$ & $<10$ & 47 & $<1$ & $<5$ & $<5$ & $<50$ & $<25$ \\
\hline NDATR & DOWN(4) & $<10$ & $<10$ & 44 & $<1$ & $<5$ & $<5$ & $<50$ & $<25$ \\
\hline 909 & $\operatorname{DOWN}(1)$ & $<10$ & 16 & 179 & $<1$ & $<5$ & $<5$ & $<50$ & $<25$ \\
\hline
\end{tabular}

Unweathered Till

$\begin{array}{rrrrrrrrrr}405 & \mathrm{UP}(1) & <10 & <10 & \mathbf{2 3 3} & <1 & <5 & 397 & <50 & \mathbf{4 6} \\ 405 & \mathrm{UP}(2) & <10 & <10 & \mathbf{9 3} & <1 & <5 & \mathbf{1 7 1} & <50 & <25 \\ 405 & \mathrm{UP}(3) & <10 & <10 & 95 & <1 & <5 & 937 & <50 & <25 \\ 405 & \mathrm{UP}(4) & <10 & <10 & 159 & <1 & <5 & \mathbf{4 , 8 2 0} & <50 & 35 \\ & & & & & & & & \\ 1303 & \mathrm{UP}(1) & <10 & \mathbf{3 4} & \mathbf{4 6 1} & \mathbf{2} & <5 & \mathbf{6 0} & <50 & \mathbf{6 0} \\ 1303 & \mathrm{UP}(2) & <10 & 26 & 368 & \mathbf{2} & <5 & 44 & <50 & 39 \\ 1303 & \mathrm{UP}(3) & <10 & 17 & 269 & 1 & <5 & 28 & <50 & <25 \\ 1303 & \mathrm{UP}(4) & <10 & \mathbf{1 5} & \mathbf{2 5 6} & <1 & <5 & \mathbf{1 9} & <50 & <25\end{array}$

Note: Bolding convention applied to these data. (See p. E-2

NS - Not sampled.

Sample collection quarter is noted in parentheses next to hydraulic position. Hydraulic position is relative to other wells within the same hydrogeologic unit.

$$
E-15
$$




\section{Table E-10 (concluded) \\ 2005 Results for Metals in Groundwater}

Title 6 NYCRR Appendix 33 List

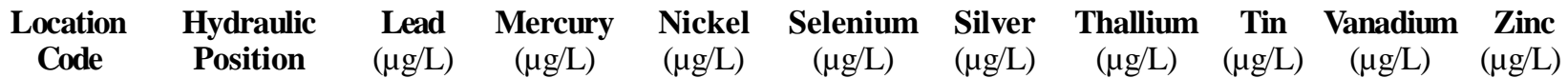

Sand and Gravel

\begin{tabular}{|c|c|c|c|c|c|c|c|c|c|c|}
\hline 706 & UP(1) & $<3$ & $<0.2$ & 1,055 & $<5$ & $<10$ & $<10$ & $<3,000$ & $<50$ & $<20$ \\
\hline 706 & $\mathrm{UP}(2)$ & $<3$ & $<0.2$ & 528 & $<5$ & $<10$ & $<10$ & $<3,000$ & $<50$ & $<20$ \\
\hline 706 & UP(3) & $<3$ & $<0.2$ & 690 & $<5$ & $<10$ & $<10$ & $<3,000$ & $<50$ & $<20$ \\
\hline 706 & $\mathrm{UP}(4)$ & $<3$ & $<0.2$ & 904 & $<5$ & $<10$ & $<10$ & $<3,000$ & $<50$ & $<20$ \\
\hline 1304 & UP(1) & 7 & $<0.2$ & $<40$ & $<5$ & $<10$ & $<10$ & $<3,000$ & $<50$ & 38 \\
\hline 1304 & $\mathrm{UP}(2)$ & 9 & $<0.2$ & $<40$ & $<5$ & $<10$ & $<10$ & $<3,000$ & $<50$ & 55 \\
\hline 1304 & $\mathrm{UP}(3)$ & 13 & $<0.2$ & $<40$ & $<5$ & $<10$ & $<10$ & $<3,000$ & $<50$ & 68 \\
\hline 1304 & $\mathrm{UP}(4)$ & $<3$ & $<0.2$ & $<40$ & $<5$ & $<10$ & $<10$ & $<3,000$ & $<50$ & $<20$ \\
\hline 1302 & $\operatorname{DOWN}(1)$ & 3 & $<0.2$ & $<40$ & $<5$ & $<10$ & $<10$ & $<3,000$ & $<50$ & $<20$ \\
\hline 1302 & DOWN(2) & 5 & $<0.2$ & $<40$ & $<5$ & $<10$ & $<10$ & $<3,000$ & $<50$ & 53 \\
\hline 1302 & DOWN(3) & $<3$ & $<0.2$ & $<40$ & $<5$ & $<10$ & $<10$ & $<3,000$ & $<50$ & $<20$ \\
\hline 1302 & DOWN(4) & $<3$ & $<0.2$ & $<40$ & $<5$ & $<10$ & $<10$ & $<3,000$ & $<50$ & $<20$ \\
\hline 111 & $\operatorname{DOWN}(1)$ & $<2$ & $<0.1$ & 2 & $<4$ & $<1$ & $<5$ & $<3$ & $<1$ & 7 \\
\hline 502 & DOWN(1) & $<2$ & $<0.1$ & 50 & $<4$ & $<1$ & NS & NS & 6 & 12 \\
\hline 502 & DOWN(3) & $<2$ & $<0.1$ & 29 & $<5$ & $<1$ & NS & NS & 2 & 44 \\
\hline 8605 & $\operatorname{DOWN}(1)$ & $<2$ & $<0.1$ & 2 & $<4$ & $<1$ & $<5$ & $<3$ & $<1$ & 7 \\
\hline
\end{tabular}

Weathered Till

\begin{tabular}{|c|c|c|c|c|c|c|c|c|c|c|}
\hline NDATR & DOWN(1) & $<3$ & $<0.2$ & $<40$ & $<5$ & $<10$ & $<10$ & $<3,000$ & $<50$ & $<20$ \\
\hline NDATR & $\operatorname{DOWN}(2)$ & $<3$ & $<0.2$ & $<40$ & $<5$ & $<10$ & $<10$ & $<3,000$ & $<50$ & $<20$ \\
\hline NDATR & DOWN(3) & $<3$ & $<0.2$ & $<40$ & $<5$ & $<10$ & $<10$ & $<3,000$ & $<50$ & $<20$ \\
\hline NDATR & DOWN(4) & $<3$ & $<0.2$ & $<40$ & $<5$ & $<10$ & $<10$ & $<3,000$ & $<50$ & $<20$ \\
\hline 909 & $\operatorname{DOWN}(1)$ & 6 & $<0.2$ & $<40$ & $<5$ & $<10$ & $<10$ & $<3,000$ & $<50$ & $<20$ \\
\hline
\end{tabular}

Unweathered Till

\begin{tabular}{|c|c|c|c|c|c|c|c|c|c|c|}
\hline 405 & UP(1) & 15 & $<0.2$ & 1,690 & $<5$ & $<10$ & $<10$ & $<3,000$ & $<50$ & 35 \\
\hline 405 & $\mathrm{UP}(2)$ & $<3$ & $<0.2$ & 1,620 & $<5$ & $<10$ & $<10$ & $<3,000$ & $<50$ & $<20$ \\
\hline 405 & UP(3) & $<3$ & $<0.2$ & 1,185 & $<5$ & $<10$ & $<10$ & $<3,000$ & $<50$ & $<20$ \\
\hline 405 & $\mathrm{UP}(4)$ & 4 & $<0.2$ & 1,420 & $<5$ & $<10$ & $<10$ & $<3,000$ & $<50$ & $<20$ \\
\hline 1303 & UP(1) & 32 & $<0.2$ & 94 & $<5$ & $<10$ & $<10$ & $<3,000$ & 75 & 196 \\
\hline 1303 & $\mathrm{UP}(2)$ & 13 & $<0.2$ & 66 & $<5$ & $<10$ & $<10$ & $<3,000$ & 53 & 136 \\
\hline 1303 & UP(3) & 16 & $<0.2$ & 41 & $<5$ & $<10$ & $<10$ & $<3,000$ & $<50$ & 82 \\
\hline 1303 & $\mathrm{UP}(4)$ & 12 & $<0.2$ & $<40$ & $<5$ & $<10$ & $<10$ & $<3,000$ & $<50$ & 60 \\
\hline
\end{tabular}

Note: Bolding convention applied to these data. (See p. E-2 2 (ㅁ)

NS - Not sampled.

Sample collection quarter is noted in parentheses next to hydraulic position. Hydraulic position is relative to other wells within the same hydrogeologic unit.

$E-16$

WVDP Annual Site Environmental Report

Calendar Year 2005 


\section{Table E-11 \\ 2005 Radioactivity in Groundwater From Selected Monitoring Locations}

\begin{tabular}{|c|c|c|c|c|}
\hline $\begin{array}{c}\text { Location } \\
\text { Code }\end{array}$ & $\begin{array}{c}\text { Hydraulic } \\
\text { Position }\end{array}$ & $\begin{array}{c}\text { C-14 } \\
(\mu \mathrm{Ci} / \mathrm{mL})\end{array}$ & $\begin{array}{c}\text { Sr-90 } \\
(\mu \mathrm{Ci} / \mathrm{mL})\end{array}$ & $\begin{array}{c}\text { Tc-99 } \\
(\mu \mathrm{Ci} / \mathrm{mL})\end{array}$ \\
\hline \multicolumn{5}{|c|}{ Sand and Gravel } \\
\hline 401 & UP(1) & $-1.04 \pm 2.44 \mathrm{E}-08$ & $2.55 \pm 1.73 \mathrm{E}-09$ & $-0.06 \pm 1.90 \mathrm{E}-09$ \\
\hline 706 & UP(1) & $0.34 \pm 2.57 \mathrm{E}-08$ & $5.09 \pm 1.81 \mathrm{E}-09$ & $0.79 \pm 1.96 \mathrm{E}-09$ \\
\hline 706 & UP(2) & $0.18 \pm 3.86 \mathrm{E}-08$ & $5.30 \pm 1.74 \mathrm{E}-09$ & $0.99 \pm 1.51 \mathrm{E}-09$ \\
\hline 706 & UP(3) & $0.54 \pm 3.11 \mathrm{E}-08$ & $6.40 \pm 2.08 \mathrm{E}-09$ & $0.94 \pm 1.45 \mathrm{E}-09$ \\
\hline 706 & $\mathrm{UP}(4)$ & $-0.76 \pm 3.10 \mathrm{E}-08$ & $2.18 \pm 0.61 \mathrm{E}-09$ & $-1.21 \pm 1.55 \mathrm{E}-09$ \\
\hline 1304 & UP(1) & $-1.87 \pm 2.59 \mathrm{E}-08$ & $2.50 \pm 1.68 \mathrm{E}-09$ & $1.66 \pm 1.90 \mathrm{E}-09$ \\
\hline 1304 & UP(2) & $-0.88 \pm 3.08 \mathrm{E}-08$ & $3.83 \pm 1.43 \mathrm{E}-09$ & $0.30 \pm 1.25 \mathrm{E}-09$ \\
\hline 1304 & UP(3) & $1.42 \pm 3.14 \mathrm{E}-08$ & $1.62 \pm 1.59 \mathrm{E}-09$ & $2.15 \pm 1.63 \mathrm{E}-09$ \\
\hline 1304 & $\mathrm{UP}(4)$ & $-1.34 \pm 2.97 \mathrm{E}-08$ & $9.89 \pm 5.70 \mathrm{E}-10$ & $-1.26 \pm 1.54 \mathrm{E}-09$ \\
\hline 1302 & DOWN(1) & $0.25 \pm 2.53 \mathrm{E}-08$ & $0.83 \pm 1.28 \mathrm{E}-09$ & $1.45 \pm 1.93 \mathrm{E}-09$ \\
\hline 1302 & DOWN(2) & $-3.33 \pm 3.03 \mathrm{E}-08$ & $1.23 \pm 0.89 \mathrm{E}-09$ & $1.10 \pm 1.32 \mathrm{E}-09$ \\
\hline 1302 & DOWN(3) & $0.66 \pm 3.12 \mathrm{E}-08$ & $1.33 \pm 1.56 \mathrm{E}-09$ & $0.70 \pm 1.96 \mathrm{E}-09$ \\
\hline 1302 & DOWN(4) & $1.51 \pm 3.04 \mathrm{E}-08$ & $5.13 \pm 4.03 \mathrm{E}-10$ & $-1.18 \pm 1.52 \mathrm{E}-09$ \\
\hline 111 & DOWN(1) & NS & $1.35 \pm 0.03 \mathrm{E}-06$ & NS \\
\hline 406 & DOWN(1) & $-0.56 \pm 2.71 \mathrm{E}-08$ & $1.61 \pm 1.42 \mathrm{E}-09$ & $-0.76 \pm 1.95 \mathrm{E}-09$ \\
\hline 408 & DOWN(1) & $-0.96 \pm 1.93 \mathrm{E}-08$ & $8.79 \pm 0.01 \mathrm{E}-05$ & $1.66 \pm 0.26 \mathrm{E}-08$ \\
\hline 501 & $\operatorname{DOWN}(1)$ & NS & $5.23 \pm 0.02 \mathrm{E}-05$ & NS \\
\hline 502 & $\operatorname{DOWN}(1)$ & NS & $5.21 \pm 0.02 \mathrm{E}-05$ & NS \\
\hline $602 \mathrm{~A}$ & $\operatorname{DOWN}(1)$ & NS & $4.12 \pm 1.73 \mathrm{E}-09$ & NS \\
\hline 8605 & DOWN(1) & NS & $5.28 \pm 0.06 \mathrm{E}-06$ & NS \\
\hline 8609 & DOWN(1) & NS & $1.12 \pm 0.03 \mathrm{E}-06$ & NS \\
\hline 8609 & DOWN(3) & NS & $9.27 \pm 0.25 \mathrm{E}-07$ & NS \\
\hline 116 & DOWN(1) & NS & $1.01 \pm 0.02 \mathrm{E}-06$ & NS \\
\hline 116 & DOWN(3) & NS & $1.56 \pm 0.03 \mathrm{E}-06$ & NS \\
\hline 605 & DOWN(1) & NS & $1.46 \pm 0.26 \mathrm{E}-08$ & NS \\
\hline
\end{tabular}

Note: Bolding convention applied to these data. (See p. E-2 $\mathbf{6 0}$ )

Note: Strontium-90 (Sr-90) analysis in water was performed by a non-NYSDOH ELAP-certified analytical method. See Chapter 5.

NS - Not sampled.

Sample collection quarter is noted in parentheses next to hydraulic position. Hydraulic position is relative to other wells within the same hydrogeologic unit.

$$
E-17
$$




\section{Table E-11 (continued) 2005 Radioactivity in Groundwater From Selected Monitoring Locations}

$\begin{array}{ccccc}\begin{array}{c}\text { Location } \\ \text { Code }\end{array} & \begin{array}{c}\text { Hydraulic } \\ \text { Position }\end{array} & \begin{array}{c}\text { C-14 } \\ (\mu \mathrm{Ci} / \mathrm{mL})\end{array} & \begin{array}{c}\text { Sr-90 } \\ (\mu \mathrm{Ci} / \mathrm{mL})\end{array} & \begin{array}{c}\text { Tc-99 } \\ (\mu \mathrm{Ci} / \mathrm{mL})\end{array}\end{array}$

Sand and Gravel (concluded)

$\begin{array}{ll}801 & \text { DOWN(1) } \\ 801 & \text { DOWN(2) } \\ 801 & \text { DOWN(3) } \\ 801 & \text { DOWN(4) } \\ 8603 & \text { DOWN(1) } \\ 8603 & \text { DOWN(3) }\end{array}$

$\begin{array}{ll}\text { NS } & \mathbf{2 . 4 2} \pm \mathbf{0 . 0 4 E - 0 6} \\ \text { NS } & 4.20 \pm 0.05 \mathrm{E}-06 \\ \text { NS } & \mathbf{4 . 2 6} \pm \mathbf{0 . 0 5 E - 0 6} \\ \text { NS } & 4.06 \pm 0.02 \mathrm{E}-06 \\ & \\ \text { NS } & 2.87 \pm 0.01 \mathrm{E}-05 \\ \text { NS } & 2.67 \pm 0.01 \mathrm{E}-05\end{array}$

NS
NS
NS
NS
NS
NS

Weathered Till

$\begin{array}{ccccr}\text { NDATR } & \text { DOWN(1) } & -2.50 \pm 2.27 \mathrm{E}-08 & 9.02 \pm 0.59 \mathrm{E}-08 & -1.71 \pm 1.88 \mathrm{E}-09 \\ \text { NDATR } & \text { DOWN(3) } & -0.73 \pm 3.49 \mathrm{E}-08 & 6.92 \pm 0.48 \mathrm{E}-08 & 5.12 \pm 2.84 \mathrm{E}-09 \\ 909 & & & & \\ & \text { DOWN(1) } & -1.41 \pm 2.48 \mathrm{E}-08 & 1.70 \pm 0.08 \mathrm{E}-07 & 2.08 \pm 1.99 \mathrm{E}-09\end{array}$

Unweathered Till

$\begin{array}{rrrrr}405 & \text { UP(1) } & -1.71 \pm 2.26 \mathrm{E}-08 & 2.21 \pm 1.52 \mathrm{E}-09 & 1.41 \pm 1.96 \mathrm{E}-09 \\ 405 & \text { UP(2) } & -1.57 \pm 3.78 \mathrm{E}-08 & 2.65 \pm 1.45 \mathrm{E}-09 & -1.79 \pm 1.26 \mathrm{E}-09 \\ 405 & \text { UP(3) } & 0.28 \pm 3.10 \mathrm{E}-08 & \mathbf{6 . 6 6} \pm \mathbf{2 . 0 9 E}-\mathbf{0 9} & 1.14 \pm 1.46 \mathrm{E}-09 \\ 405 & \text { UP(4) } & 2.80 \pm 3.17 \mathrm{E}-08 & \mathbf{1 . 7 8} \pm \mathbf{0 . 5 4 E - 0 9} & -1.07 \pm 1.50 \mathrm{E}-09 \\ & & & \\ 1303 & & -1.27 \pm 2.38 \mathrm{E}-08 & 5.28 \pm 9.13 \mathrm{E}-10 & \mathbf{2 . 2 1} \pm \mathbf{1 . 9 4 E}-\mathbf{0 9} \\ 1303 & \text { UP(1) } & -1.65 \pm 2.85 \mathrm{E}-08 & 0.46 \pm 1.37 \mathrm{E}-09 & -0.67 \pm 1.33 \mathrm{E}-09 \\ 1303 & \text { UP(2) } & 1.05 \pm 3.10 \mathrm{E}-08 & 0.29 \pm 1.45 \mathrm{E}-09 & 1.93 \pm 1.43 \mathrm{E}-09 \\ 1303 & \text { UP(3) } & -0.10 \pm 3.00 \mathrm{E}-08 & 0.04 \pm 3.32 \mathrm{E}-10 & 0.14 \pm 1.59 \mathrm{E}-09\end{array}$

Note: Bolding convention applied to these data. (See p. E-2 2 (ब्)

Note: Strontium-90 (Sr-90) analysis in water was performed by a non-NYSDOH ELAP-certified analytical method. See Chapter 5.

NS - Not sampled.

Sample collection quarter is noted in parentheses next to hydraulic position. Hydraulic position is relative to other wells within the same hydrogeologic unit. 


\section{Table E-11 (continued) 2005 Radioactivity in Groundwater From Selected Monitoring Locations}

\section{Location Hydraulic Code Position}

Sand and Gravel

$\begin{array}{lccc}401 & \text { UP(1) } & 6.49 \pm 7.51 \mathrm{E}-10 & 0.64 \pm 6.44 \mathrm{E}-09 \\ 706 & \mathrm{UP}(1) & 0.38 \pm 5.29 \mathrm{E}-10 & 1.04 \pm 6.92 \mathrm{E}-09 \\ 706 & \mathrm{UP}(2) & \mathbf{1 . 5 7} \pm \mathbf{1 . 2 2 E}-09 & 2.58 \pm 7.25 \mathrm{E}-09 \\ 706 & \mathrm{UP}(3) & 0.84 \pm 5.52 \mathrm{E}-10 & -1.24 \pm 6.37 \mathrm{E}-09 \\ 706 & \mathrm{UP}(4) & 5.57 \pm 5.51 \mathrm{E}-10 & \mathbf{2 . 2 9} \pm \mathbf{2 . 1 0 E}-09 \\ & & & \\ 1304 & \mathrm{UP}(1) & -0.68 \pm 9.82 \mathrm{E}-10 & 1.31 \pm 6.37 \mathrm{E}-09 \\ 1304 & \mathrm{UP}(2) & 0.36 \pm 1.37 \mathrm{E}-09 & 5.10 \pm 6.15 \mathrm{E}-09 \\ 1304 & \mathrm{UP}(3) & -2.43 \pm 4.03 \mathrm{E}-10 & 5.42 \pm 7.35 \mathrm{E}-09 \\ 1304 & \mathrm{UP}(4) & -3.34 \pm 6.75 \mathrm{E}-10 & 1.92 \pm 1.94 \mathrm{E}-09 \\ & & & \\ 1302 & \text { DOWN(1) } & 2.05 \pm 9.33 \mathrm{E}-10 & -1.43 \pm 6.96 \mathrm{E}-09 \\ 1302 & \text { DOWN(2) } & 0.87 \pm 2.14 \mathrm{E}-09 & -3.10 \pm 5.95 \mathrm{E}-09 \\ 1302 & \text { DOWN(3) } & -3.46 \pm 7.89 \mathrm{E}-10 & -1.74 \pm 4.64 \mathrm{E}-09 \\ 1302 & \text { DOWN(4) } & 0.14 \pm 8.87 \mathrm{E}-10 & \mathbf{3 . 6 9} \pm \mathbf{3 . 4 2 E}-09 \\ & & & \\ 406 & \text { DOWN(1) } & -2.25 \pm 7.93 \mathrm{E}-10 & 1.99 \pm 6.70 \mathrm{E}-09 \\ & & & \\ 408 & \text { DOWN(1) } & 0.23 \pm 1.03 \mathrm{E}-09 & 0.74 \pm 1.74 \mathrm{E}-09 \\ 408 & \text { DOWN(2) } & \text { NS } & \text { NS }\end{array}$

\section{Weathered Till}

$\begin{array}{ll}\text { NDATR } & \text { DOWN(1) } \\ \text { NDATR } & \text { DOWN(3) }\end{array}$

$0.00 \pm 4.58 \mathrm{E}-10$ $8.28 \pm 7.37 \mathrm{E}-10$

$-0.75 \pm 6.82 \mathrm{E}-09$ $1.69 \pm 5.40 \mathrm{E}-09$

$3.18 \pm 6.44 \mathrm{E}-09$

909

$\operatorname{DOWN}(1)$

$6.77 \pm 1.27 \mathrm{E}-09$

\author{
Ra-226 \\ $(\mu \mathrm{Ci} / \mathrm{mL})$
}

\section{Ra-228}

$(\mu \mathrm{Ci} / \mathrm{mL})$
U-232

$(\mu \mathrm{Ci} / \mathrm{mL})$

$8.23 \pm 3.26 \mathrm{E}-10$

$9.07 \pm 5.77 \mathrm{E}-10$

$3.75 \pm 3.15 \mathrm{E}-10$

$-1.11 \pm 3.52 \mathrm{E}-11$

$1.88 \pm 1.00 \mathrm{E}-10$

$1.93 \pm 1.78 \mathrm{E}-10$

$2.18 \pm 3.80 \mathrm{E}-10$

$-3.95 \pm 3.11 \mathrm{E}-11$

\section{Unweathered Till}

$\begin{array}{lrrrrrr}405 & \text { UP(1) } & -1.38 \pm 4.06 \mathrm{E}-10 & 3.17 \pm 5.90 \mathrm{E}-09 & 4.11 \pm 2.61 \mathrm{E}-10 & 0.21 \pm 4.74 \mathrm{E}-10 & -4.06 \pm 2.95 \mathrm{E}-11 \\ 405 & \text { UP(2) } & -0.31 \pm 6.89 \mathrm{E}-10 & -3.89 \pm 5.75 \mathrm{E}-09 & 1.36 \pm 1.93 \mathrm{E}-10 & -0.90 \pm 5.14 \mathrm{E}-10 & -1.09 \pm 3.90 \mathrm{E}-11 \\ 405 & \text { UP(3) } & 2.62 \pm 6.09 \mathrm{E}-10 & 3.28 \pm 8.77 \mathrm{E}-09 & 0.68 \pm 2.22 \mathrm{E}-10 & \mathbf{1 . 5 2} \pm \mathbf{0 . 7 6 E}-\mathbf{0 9} & -1.13 \pm 4.70 \mathrm{E}-11 \\ 405 & \text { UP(4) } & -7.51 \pm 8.58 \mathrm{E}-10 & 0.44 \pm 2.16 \mathrm{E}-09 & \mathbf{6 . 8 6} \pm \mathbf{3 . 9 5 E}-10 & 4.14 \pm 3.23 \mathrm{E}-10 & 2.35 \pm 3.72 \mathrm{E}-11 \\ & & & & & & \\ 1303 & \text { UP(1) } & 2.45 \pm 6.23 \mathrm{E}-10 & -3.07 \pm 5.64 \mathrm{E}-09 & 1.63 \pm 1.87 \mathrm{E}-10 & 2.12 \pm 3.98 \mathrm{E}-10 & 6.41 \pm 7.14 \mathrm{E}-11 \\ 1303 & \text { UP(2) } & 0.40 \pm 1.08 \mathrm{E}-09 & 2.88 \pm 7.14 \mathrm{E}-09 & -0.27 \pm 2.04 \mathrm{E}-10 & 6.35 \pm 3.57 \mathrm{E}-10 & -7.81 \pm 6.78 \mathrm{E}-11 \\ 1303 & \text { UP(3) } & 2.00 \pm 3.57 \mathrm{E}-10 & -0.75 \pm 4.54 \mathrm{E}-09 & 1.52 \pm 2.14 \mathrm{E}-10 & \mathbf{1 . 4 1} \pm \mathbf{0 . 7 6 E}-\mathbf{0 9} & 1.34 \pm 4.93 \mathrm{E}-11 \\ 1303 & \text { UP(4) } & \mathbf{7 . 6 0} \pm \mathbf{4 . 7 2 E}-10 & 0.51 \pm 1.51 \mathrm{E}-09 & \mathbf{6 . 6 0} \pm \mathbf{4 . 4 3 E}-10 & 3.27 \pm 3.47 \mathrm{E}-10 & 2.10 \pm 4.00 \mathrm{E}-11\end{array}$

Note: Bolding convention applied to these data. (See p. E-2 NS - Not sampled.

Sample collection quarter is noted in parentheses next to hydraulic position. Hydraulic position is relative to other wells within the same hydrogeologic unit. 


\section{Table E-11 (concluded) 2005 Radioactivity in Groundwater From Selected Monitoring Locations}

$\begin{array}{cccccc}\begin{array}{c}\text { Location } \\ \text { Code }\end{array} & \begin{array}{c}\text { Hydraulic } \\ \text { Position }\end{array} & \begin{array}{c}\text { U-233/234 } \\ (\mu \mathrm{Ci} / \mathrm{mL})\end{array} & \begin{array}{c}\mathbf{U}-235 / 236 \\ (\mu \mathrm{Ci} / \mathrm{mL})\end{array} & \begin{array}{c}\mathbf{U}-238 \\ (\mu \mathrm{Ci} / \mathrm{mL})\end{array} & \begin{array}{c}\text { Total U } \\ (\mu \mathrm{g} / \mathrm{mL})\end{array}\end{array}$

Sand and Gravel

\begin{tabular}{|c|c|c|c|c|c|}
\hline 401 & $\mathrm{UP}(1)$ & $9.96 \pm 8.33 \mathrm{E}-11$ & $1.39 \pm 0.94 \mathrm{E}-10$ & $1.03 \pm 0.83 \mathrm{E}-10$ & $-1.67 \pm 0.30 \mathrm{E}-05$ \\
\hline 706 & $\mathrm{UP}(1)$ & $9.18 \pm 9.41 \mathrm{E}-11$ & $9.47 \pm 7.93 E-11$ & $7.41 \pm 7.27 E-11$ & $4.75 \pm 0.77 E-05$ \\
\hline 706 & $\mathrm{UP}(2)$ & $1.10 \pm 1.13 \mathrm{E}-10$ & $-1.66 \pm 1.88 \mathrm{E}-11$ & $0.64 \pm 4.89 \mathrm{E}-11$ & $2.70 \pm 0.09 \mathrm{E}-04$ \\
\hline 706 & UP(3) & $2.85 \pm 5.63 \mathrm{E}-11$ & $3.18 \pm 4.41 \mathrm{E}-11$ & $4.37 \pm 5.43 \mathrm{E}-11$ & $4.09 \pm 0.37 \mathrm{E}-04$ \\
\hline 706 & $\mathrm{UP}(4)$ & $9.88 \pm 5.38 \mathrm{E}-11$ & $2.48 \pm 2.81 \mathrm{E}-11$ & $7.40 \pm 4.60 \mathrm{E}-11$ & $1.77 \pm 0.08 \mathrm{E}-04$ \\
\hline 1304 & $\mathrm{UP}(1)$ & $3.80 \pm 1.54 \mathrm{E}-10$ & $1.77 \pm 1.02 \mathrm{E}-10$ & $1.96 \pm 1.11 \mathrm{E}-10$ & $1.33 \pm 0.04 E-03$ \\
\hline 1304 & $\mathrm{UP}(2)$ & $2.81 \pm 1.61 \mathrm{E}-10$ & $8.36 \pm 8.85 \mathrm{E}-11$ & $1.90 \pm 1.32 \mathrm{E}-10$ & $4.56 \pm 0.13 \mathrm{E}-04$ \\
\hline 1304 & $\mathrm{UP}(3)$ & $1.67 \pm 1.03 E-10$ & $4.17 \pm 4.72 \mathrm{E}-11$ & $9.70 \pm 7.19 \mathrm{E}-11$ & $7.11 \pm 0.46 \mathrm{E}-04$ \\
\hline 1304 & $\mathrm{UP}(4)$ & $2.41 \pm 1.00 \mathrm{E}-10$ & $2.81 \pm 3.49 \mathrm{E}-11$ & $2.79 \pm 1.05 E-10$ & $4.80 \pm 0.14 \mathrm{E}-04$ \\
\hline 1302 & $\operatorname{DOWN}(1)$ & $2.23 \pm 1.24 \mathrm{E}-10$ & $1.35 \pm 1.00 \mathrm{E}-10$ & $1.22 \pm 0.94 \mathrm{E}-10$ & $7.27 \pm 0.23 E-04$ \\
\hline 1302 & DOWN(2) & $2.90 \pm 1.61 \mathrm{E}-10$ & $4.48 \pm 7.73 \mathrm{E}-11$ & $1.54 \pm 1.23 \mathrm{E}-10$ & $1.85 \pm 0.11 \mathrm{E}-04$ \\
\hline 1302 & DOWN(3) & $1.99 \pm 1.13 \mathrm{E}-10$ & $4.06 \pm 5.04 \mathrm{E}-11$ & $1.43 \pm 0.91 \mathrm{E}-10$ & $4.53 \pm 0.31 \mathrm{E}-04$ \\
\hline 1302 & DOWN(4) & $2.91 \pm 0.97 \mathrm{E}-10$ & $3.88 \pm 3.59 \mathrm{E}-11$ & $1.22 \pm 0.64 \mathrm{E}-10$ & $4.55 \pm 0.14 \mathrm{E}-04$ \\
\hline 406 & DOWN(1) & $1.50 \pm 1.01 \mathrm{E}-10$ & $6.92 \pm 6.79 \mathrm{E}-11$ & $2.69 \pm 4.29 \mathrm{E}-11$ & $1.28 \pm 0.04 \mathrm{E}-04$ \\
\hline 408 & DOWN(1) & $2.78 \pm 1.38 \mathrm{E}-10$ & $1.90 \pm 1.15 \mathrm{E}-10$ & $1.94 \pm 1.14 \mathrm{E}-10$ & $5.27 \pm 0.07 \mathrm{E}-04$ \\
\hline \multicolumn{6}{|c|}{ Weathered Till } \\
\hline NDATR & $\operatorname{DOWN}(1)$ & $4.98 \pm 1.69 \mathrm{E}-10$ & $2.37 \pm 1.16 \mathrm{E}-10$ & $4.54 \pm 1.61 \mathrm{E}-10$ & $1.25 \pm 0.12 \mathrm{E}-03$ \\
\hline NDATR & DOWN(3) & $2.11 \pm 0.28 \mathrm{E}-09$ & $2.80 \pm 1.08 \mathrm{E}-10$ & $1.73 \pm 0.25 \mathrm{E}-09$ & $4.76 \pm 0.14 \mathrm{E}-03$ \\
\hline 909 & $\operatorname{DOWN}(1)$ & $7.37 \pm 2.29 \mathrm{E}-10$ & $2.48 \pm 1.32 \mathrm{E}-10$ & $5.89 \pm 2.06 \mathrm{E}-10$ & $9.00 \pm 0.22 \mathrm{E}-04$ \\
\hline
\end{tabular}

Unweathered Till

$\begin{array}{llllll}405 & \text { UP(1) } & \mathbf{5 . 0 7} \pm \mathbf{1 . 7 7 E}-\mathbf{1 0} & \mathbf{1 . 9 3} \pm \mathbf{1 . 1 2 E}-\mathbf{1 0} & \mathbf{4 . 9 5} \pm \mathbf{1 . 7 4 E}-\mathbf{1 0} & 7.97 \pm 0.16 \mathrm{E}-04 \\ 405 & \text { UP(2) } & \mathbf{1 . 5 9} \pm \mathbf{1 . 1 0 E}-\mathbf{1 0} & 4.03 \pm 6.17 \mathrm{E}-11 & 2.52 \pm 1.35 \mathrm{E}-10 & \mathbf{4 . 9 9} \pm \mathbf{0 . 0 7 E}-\mathbf{0 4} \\ 405 & \text { UP(3) } & 2.18 \pm 1.25 \mathrm{E}-10 & 1.38 \pm 4.93 \mathrm{E}-11 & \mathbf{1 . 7 8} \pm \mathbf{1 . 1 2 E}-\mathbf{1 0} & \mathbf{1 . 0 8} \pm \mathbf{0 . 0 6 E - 0 3} \\ 405 & \text { UP(4) } & 3.51 \pm 1.16 \mathrm{E}-10 & 6.65 \pm 5.31 \mathrm{E}-11 & 2.00 \pm 0.87 \mathrm{E}-10 & 6.47 \pm 0.17 \mathrm{E}-04 \\ & & & & & \\ 1303 & \mathrm{UP}(1) & \mathbf{5 . 9 8} \pm \mathbf{2 . 0 1 E}-10 & \mathbf{1 . 4 8} \pm \mathbf{1 . 0 3 E}-10 & 2.86 \pm 1.36 \mathrm{E}-10 & 7.00 \pm 0.12 \mathrm{E}-04 \\ 1303 & \text { UP(2) } & 3.89 \pm 1.69 \mathrm{E}-10 & 6.29 \pm 7.11 \mathrm{E}-11 & \mathbf{2 . 3 2} \pm \mathbf{1 . 2 6 E}-\mathbf{1 0} & \mathbf{3 . 7 3} \pm \mathbf{0 . 1 5 E}-\mathbf{0 4} \\ 1303 & \mathrm{UP}(3) & \mathbf{3 . 2 1} \pm \mathbf{1 . 4 9 E}-10 & 2.57 \pm 4.82 \mathrm{E}-11 & \mathbf{3 . 1 6} \pm \mathbf{1 . 4 4 E}-\mathbf{1 0} & \mathbf{9 . 5 0} \pm \mathbf{0 . 3 8 E}-\mathbf{0 4} \\ 1303 & \text { UP(4) } & 3.89 \pm 1.18 \mathrm{E}-10 & 3.79 \pm 3.94 \mathrm{E}-11 & 2.74 \pm 0.98 \mathrm{E}-10 & 5.70 \pm 0.17 \mathrm{E}-04\end{array}$

Note: Bolding convention applied to these data. (See p. E-2 $\mathbf{\text { cod } )}$

Sample collection quarter is noted in parentheses next to hydraulic position. Hydraulic position is relative to other wells within the same hydrogeologic unit.

$E-20$ 


\section{Table E-12 \\ Practical Quantitation Limits (PQLs)}

COMPOUND

PQL

$(\mu g / L)$

6 NYCRR $^{a}$ Appendix 33 Volatiles

$\begin{array}{lc}\text { Acetone } & 10 \\ \text { Acetonitrile } & 100 \\ \text { Acrolein } & 11 \\ \text { Acrylonitrile } & 7.2 \\ \text { Allyl chloride } & 5 \\ \text { Benzene } & 5 \\ \text { Bromodichloromethane } & 5 \\ \text { Bromoform } & 5 \\ \text { Bromomethane } & 10 \\ \text { Carbon disulfide } & 10 \\ \text { Carbon tetrachloride } & 5 \\ \text { Chlorobenzene } & 5 \\ \text { Chloroethane } & 10 \\ \text { Chloroform } & 5 \\ \text { Chloromethane } & 10 \\ \text { Chloroprene } & 5 \\ \text { 1,2-Dibromo-3-chloropropane } & 5 \\ \text { Dibromochloromethane } & 5 \\ \text { 1,2-Dibromoethane } & 5 \\ \text { Dichlorodifluoromethane (DCDFMeth) } & 5 \\ \text { 1,1-Dichloroethane(1,1-DCA) } & 5 \\ \text { 1,2-Dichloroethane(1,2-DCA) } & 5 \\ \text { 1,1-Dichloroethylene(1,1-DCE) } & 5 \\ \text { 1,2-Dichloropropane } & 5 \\ \text { Ethyl benzene } & 5 \\ \text { Ethyl methacrylate } & 5 \\ \text { 2-Hexanone } & 10\end{array}$

6 NYCRR $^{a}$ Appendix 33 Metals

$\begin{array}{lc}\text { Aluminum }^{b} & 200 \\ \text { Antimony } & 10 \\ \text { Arsenic } & 10 \\ \text { Barium } & 200 \\ \text { Beryllium } & 1 \\ \text { Cadmium } & 5 \\ \text { Chromium } & 10 \\ \text { Cobalt } & 50\end{array}$

COMPOUND PQL

$(\mu g / L)$

6 NYCRR $^{a}$ Appendix 33 Volatiles

Isobutyl alcohol $\quad 100$

Methacrylonitrile 5

Methyl ethyl ketone $\quad 10$

Methyl iodide 5

Methyl methacrylate 5

4-Methyl-2-pentanone 10

Methylene bromide 10

Methylene chloride 5

Pentachloroethane 5

Propionitrile 50

Styrene 5

1,1,1,2-Tetrachloroethane 5

1,1,2,2-Tetrachloroethane 5

Tetrachloroethylene 5

Toluene 5

1,1,1-Trichloroethane (1,1,1-TCA) 5

1,1,2-Trichloroethane 5

1,2,3-Trichloropropane 5

Vinyl acetate 10

Vinyl chloride $\quad 10$

Xylene (total) 5

cis-1,3-Dichloropropene 5

trans-1,2-Dichloroethylene (1,2-DCE[trans]) 5

trans-1,3-Dichloropropene 5

trans-1,4-Dichloro-2-butene 5

Trichloroethylene (TCE) 5

Trichlorofluoromethane 5

6 NYCRR a Appendix 33 Metals

Lead 3

Manganese $^{b} \quad 15$

Mercury $\quad 0.2$

Nickel 40

Selenium 5

Silver 10

Thallium $\quad 10$

Tin $\quad 3,000$

Note: Specific quantitation limits are highly matrix dependent and may not always be achievable.

${ }^{a}$ Title 6 of the Official Compilation of Codes, Rules, and Regulations of the State of New York.

${ }^{b}$ Not a 6 NYCRR Appendix 33 parameter; sampled for the north plateau early warning program.

$$
E-21
$$




\section{Table E-12 (continued) Practical Quantitation Limits (PQLs) \\ PQL \\ $(\mu g / L)$ \\ COMPOUND PQL \\ $(\mu g / L)$}

COMPOUND

6 NYCRR $^{a}$ Appendix 33 Semivolatiles

Acenaphthene 10

Acenaphthylene 10

Acetophenone 10

2-Acetylaminofluorene $\quad 10$

4-Aminobiphenyl 10

Aniline 10

Anthracene 10

Aramite 10

Benzo[a]anthracene 10

Benzo[a]pyrene 10

Benzo[b]fluoranthene $\quad 10$

Benzo[ghi]perylene $\quad 10$

Benzo[k]fluoranthene 10

Benzyl alcohol 10

Bis(2-chlorethyl)ether 10

Bis(2-chloroethoxy)methane $\quad 10$

Bis(2-chloroisopropyl)ether $\quad 10$

Bis(2-ethylhexyl)phthalate $\quad 10$

4-Bromophenyl phenyl ether $\quad 10$

Butyl benzyl phthalate $\quad 10$

Chlorobenzilate 10

2-Chloronaphthalene $\quad 10$

2-Chlorophenol 10

4-Chlorophenyl phenyl ether $\quad 10$

Chrysene 10

Di-n-butyl phthalate $\quad 10$

Di-n-octyl phthalate $\quad 10$

Diallate 10

Dibenz[a,h]anthracene 10

Dibenzofuran 10

3,3-Dichlorobenzidine 10

2,4-Dichlorophenol 25

2,6-Dichlorophenol 10

Diethyl phthalate $\quad 10$

Dimethoate 10

7,12-Dimethylbenz[a]anthracene $\quad 10$

3,3-Dimethylbenzidine 20

2,4-Dimethylphenol 10

Dimethyl phthalate $\quad 10$

4,6-Dinitro-o-cresol 25

2,4-Dinitrophenol 25
6 NYCRR $^{a}$ Appendix 33 Semivolatiles

2,4-Dinitrotoluene 10

2,6-Dinitrotoluene 10

Diphenylamine 10

Ethyl methanesulfonate $\quad 10$

Famphur 15

Fluoranthene 10

Fluorene 10

Hexachlorobenzene 10

Hexachlorobutadiene 10

Hexachlorocyclopentadiene 24

Hexachloroethane 10

Hexachlorophene 50

Hexachloropropene 10

Indeno(1,2,3,-cd)pyrene $\quad 10$

Isodrin 10

Isophorone 10

Isosafrole 10

Kepone $\quad 50$

Methapyrilene 40

Methyl methanesulfonate $\quad 10$

3-Methylcholanthrene 10

2-Methylnaphthalene $\quad 10$

1,4-Naphthoquinone 10

1-Naphthylamine 10

2-Naphthylamine 10

Nitrobenzene 10

5-Nitro-o-toluidine 10

4-Nitroquinoline 1-oxide 40

N-Nitrosodi-n-butylamine 10

N-Nitrosodiethylamine 10

N-Nitrosodimethylamine $\quad 10$

N-Nitrosodipropylamine 10

N-Nitrosodiphenylamine $\quad 10$

N-Nitrosomethylethylamine $\quad 10$

N-Nitrosomorpholine 10

N-Nitrosopiperidine $\quad 10$

N-Nitrosopyrrolidine 10

Naphthalene 10

0,0,0-Triethyl phosphorothioate $\quad 10$

0,0-Diethyl 0-2-pyrazinyl- phosphorothioate 10

Note: Specific quantitation limits are highly matrix dependent and may not always be achievable.

${ }^{a}$ Title 6 of the Official Compilation of Codes, Rules, and Regulations of the State of New York.

$E-22$ 


\section{Table E-12 (concluded) \\ Practical Quantitation Limits (PQLs)}

COMPOUND

PQL

$(\mu g / L)$

6 NYCRR ${ }^{a}$ Appendix 33 Semivolatiles

p-(Dimethylamino)azobenzene $\quad 10$

p-Chloroaniline 10

p-Chloro-m-cresol 10

p-Cresol 10

p-Dichlorobenzene 10

p-Nitroaniline 25

p-Nitrophenol 25

p-Phenylenediamine 35

Parathion 10

Pentachlorobenzene 10

Pentachloronitrobenzene $\quad 10$

Pentachlorophenol 25

Phenacetin 10

Phenanthrene 10

Phenol 10

Pronamide 10

Pyrene 10

Safrole 10

1,2,4,5-Tetrachlorobenzene $\quad 10$

Other Organic Compounds

1,2-Dichloroethelyne (Total)

Tributyl phosphate
COMPOUND

PQL

$(\mu g / L)$

6 NYCRR ${ }^{a}$ Appendix 33 Semivolatiles

2,3,4,6-Tetrachlorophenol $\quad 10$

Tetraethyl dithiopyrophosphate $\quad 10$

1,2,4-Trichlorobenzene $\quad 10$

2,4,5-Trichlorophenol 25

2,4,6-Trichlorophenol $\quad 10$

alpha,alpha-Dimethylphenethylamine $\quad 50$

m-Cresol 10

m-Dichlorobenzene 10

m-Dinitrobenzene 10

m-Nitroaniline 25

o-Cresol 10

o-Dichlorobenzene 10

o-Nitroaniline 25

o-Nitrophenol 10

o-Toluidine 10

sym-Trinitrobenzene $\quad 10$

2-Picoline 10

Pyridine 10

1,4-Dioxane 10

Note: Specific quantitation limits are highly matrix dependent and may not always be achievable.

${ }^{a}$ Title 6 of the Official Compilation of Codes, Rules, and Regulations of the State of New York.

E- 23 
This page intentionally left blank

E- 24 


\section{Appendix $F$ Summary of Biological Data}

$$
F-1
$$


The following tables contain a bolding convention devised to help the reader, when viewing the data, to quickly see the range of detectable measurements within a data series. A data series is a set of chemical or radionuclide measurements (e.g., gross alpha, gross beta, tritium) from a single location or from similar locations. Note that some tables contain data that should not be technically evaluated under this convention.

\section{Key to bolding convention:}

Results for each constituent constitute a single data series. If a radiological result is larger than the uncertainty term, the measurement is considered positive. Otherwise, a result is considered nondetectable.

If all results in a data series are positive, the lowest and highest values are bolded.

If a data series contains some positive results, the highest value is bolded.

If all values in a data series are nondetectable, no values are bolded.

$$
F-2
$$




\section{Table F-1 \\ 2005 Radioactivity Concentrations in Milk}

\begin{tabular}{|c|c|c|c|c|c|}
\hline Location & $\begin{array}{c}\mathbf{H - 3} \\
(\mu \mathrm{Ci} / \mathrm{mL})\end{array}$ & $\begin{array}{c}\mathbf{K}-\mathbf{4 0} \\
(\mu \mathrm{Ci} / \mathrm{mL})\end{array}$ & $\begin{array}{c}\text { Sr-90 } \\
(\mu \mathrm{Ci} / \mathrm{mL})\end{array}$ & $\begin{array}{c}\mathbf{I - 1 2 9} \\
(\mu \mathrm{Ci} / \mathrm{mL})\end{array}$ & $\begin{array}{r}\text { Cs-137 } \\
(\mu \mathrm{Ci} / \mathrm{mL})\end{array}$ \\
\hline \multicolumn{6}{|l|}{$\begin{array}{l}\text { BFMREED }^{a} \\
\text { (NNW Farm) }\end{array}$} \\
\hline 1st Quarter & $0.54 \pm 1.09 \mathrm{E}-07$ & $1.38 \pm 0.12 \mathrm{E}-06$ & $1.93 \pm 0.94 \mathrm{E}-09$ & $-0.77 \pm 3.33 \mathrm{E}-10$ & $0.72 \pm 2.47 \mathrm{E}-09$ \\
\hline 2nd Quarter & NA & $1.34 \pm 0.22 \mathrm{E}-06$ & $8.84 \pm 6.35 \mathrm{E}-10$ & $-1.50 \pm 2.81 \mathrm{E}-10$ & $0.79 \pm 5.35 \mathrm{E}-09$ \\
\hline \multicolumn{6}{|l|}{$\begin{array}{l}\text { BFMWIDR }^{b} \\
\text { (SE Farm) }\end{array}$} \\
\hline 4th Quarter & NA & $1.46 \pm 0.17 \mathrm{E}-06$ & $7.32 \pm 5.68 \mathrm{E}-10$ & $-0.92 \pm 1.56 \mathrm{E}-10$ & $3.57 \pm 3.34 \mathrm{E}-09$ \\
\hline \multicolumn{6}{|l|}{$\begin{array}{l}\text { BFMCTLS } \\
\text { (Control) }\end{array}$} \\
\hline Annual & NA & $1.40 \pm 0.12 \mathrm{E}-06$ & $1.02 \pm 0.82 \mathrm{E}-09$ & $1.81 \pm 4.01 \mathrm{E}-10$ & $0.05 \pm 1.56 \mathrm{E}-09$ \\
\hline \multicolumn{6}{|l|}{$\begin{array}{l}\text { BFMSCHT } \\
\text { (S Farm) }\end{array}$} \\
\hline Annual & NA & $1.33 \pm 0.16 \mathrm{E}-06$ & $1.16 \pm 0.78 \mathrm{E}-09$ & $-0.68 \pm 3.45 \mathrm{E}-10$ & $-0.81 \pm 3.15 \mathrm{E}-09$ \\
\hline \multicolumn{6}{|l|}{$\begin{array}{l}\text { BFMBLSY }^{c} \\
\text { (WNW Farm) }\end{array}$} \\
\hline Annual & NA & $1.63 \pm 0.15 \mathrm{E}-06$ & $3.30 \pm 2.49 \mathrm{E}-10$ & $1.10 \pm 2.19 \mathrm{E}-10$ & $0.83 \pm 3.12 \mathrm{E}-09$ \\
\hline
\end{tabular}

Note: Bolding convention not applicable to these data.

Note: Tritium analysis on all milk samples was discontinued in April 2005

${ }^{a}$ The BFMREED dairy discontinued production during the second quarter of 2005.

${ }^{b}$ The frequency of collection at the BFMWIDR farm was increased from annual to quarterly in late 2005.

${ }^{c}$ Milk sample collection at the BFMBLSY dairy was initiated in the fall of 2005.

$$
F-3
$$


Table F-2

2005 Radioactivity Concentrations in Venison

Location

$\%$ Moisture

H-3

$(\mu \mathrm{Ci} / \mathrm{mL})$

K-40

Sr-90

Cs-137

(ack

Deer Background

(BFDCTRL 11/05)

75.0

1.55 $+1.11 E-07$

$1.09 \pm 0.10 \mathrm{E}-05$

$2.57 \pm 2.41 \mathrm{E}-09$

$6.89 \pm 5.45 E-08$

Deer Background

(BFDCTRL 11/05)

63.6

1.49+1.07E-07

$1.23 \pm 0.05 E-05$

$-0.32 \pm 2.03 \mathrm{E}-09$

$1.31 \pm 0.28 \mathrm{E}-07$

Deer Background

(BFDCTRL 11/05)

65.0

$0.52 \pm 1.08 \mathrm{E}-07$

8.93 $\pm 0.74 E-06$

3.07 $\pm 2.77 E-09$

1.35 $\pm 0.28 E-07$

Deer Near-Site

(BFDNEAR 09/05)

72.0

$1.03 \pm 1.09 \mathrm{E}-07$

$1.28 \pm 0.11 \mathrm{E}-05$

2.37 $\pm 2.12 E-09$

3.15 $\pm 2.27 E-08$

Deer Near-Site

(BFDNEAR 10/05)

74.6

$1.00 \pm 1.07 \mathrm{E}-07$

$1.36 \pm 0.05 E-05$

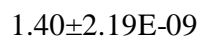

8.11+2.42E-08

Deer Near-Site

(BFDNEAR 11/05)

73.2

1.53 $\pm 1.10 E-07$

$1.10 \pm 0.08 E-05$

$1.31 \pm 2.42 \mathrm{E}-09$

1.12+0.28E-07

Note: Bolding convention applied to these data. See page F-2 $\mathbf{c 0}$

$$
F-4
$$




\section{Table F-3 \\ 2005 Radioactivity Concentrations in Food Crops}

Location

\% Moisture

$\underset{(\mu \mathrm{Ci} / \mathrm{mL})}{\mathbf{H}-3}$

K-40

Co-60

$(\mu \mathrm{Ci} / \mathrm{g}$ - dry $)$

Sr-90
$(\mu \mathrm{Ci} / \mathrm{g}-\mathrm{dry})$

Cs-137

$(\mu \mathrm{Ci} / \mathrm{mL}) \quad(\mu \mathrm{Ci} / \mathrm{g}-\mathrm{dry})$

$(\mu \mathrm{Ci} / \mathrm{g}-\mathrm{dry})$

( $\mu \mathrm{Ci} / \mathrm{g}$ - dry)

APPLES

Background

(BFVCTRA)

86.0

$0.43 \pm 1.44 \mathrm{E}-07$

$1.04 \pm 0.11 \mathrm{E}-05$

$1.52 \pm 2.69 \mathrm{E}-08$

$3.12 \pm 1.88 \mathrm{E}-09$

$1.52 \pm 6.65 \mathrm{E}-08$

Near-Site

(BFVNEAAF)

85.9

$1.68 \pm 1.46 \mathrm{E}-07 \quad 7.11 \pm 1.04 \mathrm{E}-06$

$1.33 \pm 2.72 \mathrm{E}-08$

$3.34 \pm 9.96 \mathrm{E}-10$

$2.66 \pm 2.93 \mathrm{E}-08$

BEANS

Background

(BFVCTRB)

92.0

$1.29 \pm 1.25 \mathrm{E}-07 \quad 3.72 \pm 0.24 \mathrm{E}-05$

$1.32 \pm 2.17 \mathrm{E}-08$

$5.02 \pm 0.46 \mathrm{E}-08$

$1.29 \pm 1.85 \mathrm{E}-08$

Near-Site

(BFVNEAB)

91.4

$1.48 \pm 1.29 \mathrm{E}-07$

$3.72 \pm 0.19 \mathrm{E}-05$

$1.24 \pm 2.52 \mathrm{E}-08$

$6.52 \pm 0.45 \mathrm{E}-08$

$0.78 \pm 2.21 \mathrm{E}-08$

\section{CORN}

Background

(BFVCTRC)

85.5

$1.57 \pm 1.30 \mathrm{E}-07 \quad 1.57 \pm 0.13 \mathrm{E}-05$

$0.78 \pm 2.70 \mathrm{E}-08$

$0.82 \pm 2.79 \mathrm{E}-09$

$1.17 \pm 2.56 \mathrm{E}-08$

Near-Site

(BFVNEAC)

86.4

$2.10 \pm 1.29 \mathrm{E}-07 \quad 1.99 \pm 0.15 \mathrm{E}-05$

$2.59 \pm 2.49 \mathrm{E}-08$

$6.13 \pm 3.93 \mathrm{E}-09$

$0.49 \pm 1.97 \mathrm{E}-08$

Note: Bolding convention not applicable to these data.

$$
F-5
$$




\title{
Table F-4 \\ 2005 Radioactivity Concentrations in Edible Portions of Fish From Cattaraugus Creek
}

\author{
Cattaraugus Creek above the Springville Dam (BFFCATC)
}

\begin{tabular}{|c|c|c|c|}
\hline \multirow[b]{2}{*}{ Species } & \multirow[b]{2}{*}{$\%$ Moisture } & \multicolumn{2}{|c|}{ Annual 2005} \\
\hline & & $\begin{array}{c}\text { Sr-90 } \\
(\mu \mathrm{Ci} / \mathrm{g}-\text { dry })\end{array}$ & $\begin{array}{c}\text { Cs-137 } \\
(\mu \mathrm{Ci} / \mathrm{g}-\mathrm{dry})\end{array}$ \\
\hline Hog-nosed Sucker & 77.1 & $6.01 \pm 0.85 \mathrm{E}-08$ & $4.41 \pm 4.06 \mathrm{E}-08$ \\
\hline Hog-nosed Sucker & 73.8 & $5.84 \pm 0.52 \mathrm{E}-08$ & $0.85 \pm 5.02 \mathrm{E}-08$ \\
\hline Hog-nosed Sucker & 72.9 & $7.64 \pm 0.56 \mathrm{E}-08$ & $-0.13 \pm 3.65 \mathrm{E}-08$ \\
\hline Hog-nosed Sucker & 72.1 & $4.19 \pm 0.37 \mathrm{E}-08$ & $2.93 \pm 3.99 \mathrm{E}-08$ \\
\hline Hog-nosed Sucker & 73.3 & $5.49 \pm 0.58 \mathrm{E}-08$ & $2.19 \pm 3.91 \mathrm{E}-08$ \\
\hline Hog-nosed Sucker & 71.6 & $2.05 \pm 0.08 E-07$ & $1.47 \pm 3.05 \mathrm{E}-08$ \\
\hline Hog-nosed Sucker & 74.2 & $5.23 \pm 0.61 \mathrm{E}-08$ & $3.81 \pm 3.97 \mathrm{E}-08$ \\
\hline Hog-nosed Sucker & 72.4 & $3.46 \pm 2.33 \mathrm{E}-09$ & $1.24 \pm 3.21 \mathrm{E}-08$ \\
\hline Hog-nosed Sucker & 73.2 & $5.90 \pm 0.51 \mathrm{E}-08$ & $2.20 \pm 2.86 \mathrm{E}-08$ \\
\hline Hog-nosed Sucker & 74.0 & $5.72 \pm 0.47 \mathrm{E}-08$ & $2.27 \pm 3.12 \mathrm{E}-08$ \\
\hline Average $\%$ Moisture & 73.5 & & \\
\hline Median & & $5.78 \mathrm{E}-08$ & $<3.78 \mathrm{E}-08$ \\
\hline Maximum & & $2.05 \mathrm{E}-07$ & 4.41E-08 \\
\hline Minimum & & $3.46 \mathrm{E}-09$ & $<2.86 \mathrm{E}-08$ \\
\hline
\end{tabular}

\section{Cattaraugus Creek below the Springville Dam (BFFCATD)}

\begin{tabular}{|c|c|c|c|}
\hline \multirow[b]{2}{*}{ Species } & \multirow[b]{2}{*}{$\%$ Moisture } & \multicolumn{2}{|c|}{$\underline{\text { Annual } 2005}$} \\
\hline & & $\begin{array}{c}\text { Sr-90 } \\
(\mu \mathrm{Ci} / \mathrm{g}-\mathrm{dry})\end{array}$ & $\begin{array}{c}\text { Cs-137 } \\
(\mu \mathrm{Ci} / \mathrm{g}-\text { dry })\end{array}$ \\
\hline Steelhead Trout & 74.6 & $8.78 \pm 1.75 \mathrm{E}-09$ & 7.67 $\pm 3.27 E-08$ \\
\hline Steelhead Trout & 67.2 & $5.61 \pm 1.62 \mathrm{E}-09$ & $1.32 \pm 1.45 \mathrm{E}-08$ \\
\hline Steelhead Trout & 71.5 & $5.01 \pm 1.64 \mathrm{E}-09$ & $6.16 \pm 4.29 \mathrm{E}-08$ \\
\hline Steelhead Trout & 71.7 & $6.07 \pm 1.77 \mathrm{E}-09$ & $1.70 \pm 1.74 \mathrm{E}-08$ \\
\hline Steelhead Trout & 73.7 & $2.30 \pm 1.22 \mathrm{E}-09$ & $4.18 \pm 2.69 \mathrm{E}-08$ \\
\hline Steelhead Trout & 67.6 & $2.64 \pm 1.85 \mathrm{E}-09$ & $0.00 \pm 2.48 \mathrm{E}-08$ \\
\hline Steelhead Trout & 68.9 & $6.16 \pm 2.03 \mathrm{E}-09$ & $-0.80 \pm 2.40 \mathrm{E}-08$ \\
\hline Steelhead Trout & 65.4 & $3.76 \pm 1.76 \mathrm{E}-09$ & $1.46 \pm 2.12 \mathrm{E}-08$ \\
\hline Steelhead Trout & 72.9 & $1.01 \pm 0.26 \mathrm{E}-08$ & $1.75 \pm 2.58 \mathrm{E}-08$ \\
\hline Steelhead Trout & 74.3 & $5.77 \pm 1.97 \mathrm{E}-09$ & $0.00 \pm 1.83 \mathrm{E}-08$ \\
\hline Average $\%$ Moisture & 70.8 & & \\
\hline Median & & 5.69E-09 & $<2.44 \mathrm{E}-08$ \\
\hline Maximum & & $1.01 \mathrm{E}-08$ & 7.67E-08 \\
\hline Minimum & & $2.30 \mathrm{E}-09$ & $<1.45 \mathrm{E}-08$ \\
\hline
\end{tabular}

Note: Bolding convention applied to these data. See page F-2 $\mathbf{c 0}$

$$
F-6
$$




\section{Table F-4 (concluded) \\ 2005 Radioactivity Concentrations in Edible Portions of Fish From Cattaraugus Creek}

\section{Cattaraugus Creek Background (BFFCTRL)}

\begin{tabular}{|c|c|c|c|}
\hline \multirow[b]{2}{*}{ Species } & \multirow[b]{2}{*}{$\%$ Moisture } & \multicolumn{2}{|c|}{$\underline{\text { Annual } 2005}$} \\
\hline & & $\begin{array}{c}\text { Sr-90 } \\
(\mu \mathrm{Ci} / \mathrm{g}-\text { dry })\end{array}$ & $\begin{array}{c}\text { Cs-137 } \\
(\mu \mathrm{Ci} / \mathrm{g} \text { - dry })\end{array}$ \\
\hline Brown Trout & 72.7 & $3.81 \pm 1.67 \mathrm{E}-09$ & $3.36 \pm 3.75 \mathrm{E}-08$ \\
\hline Brown Trout & 72.0 & $2.99 \pm 1.98 \mathrm{E}-09$ & $-0.92 \pm 3.51 E-08$ \\
\hline Brown Trout & 73.6 & $1.36 \pm 0.25 \mathrm{E}-08$ & $-0.39 \pm 4.51 \mathrm{E}-08$ \\
\hline White Sucker & 79.0 & $6.13 \pm 1.77 \mathrm{E}-09$ & $0.37 \pm 3.07 \mathrm{E}-08$ \\
\hline Hog-nosed Sucker & 74.9 & $7.96 \pm 2.67 \mathrm{E}-09$ & $-3.41 \pm 3.60 \mathrm{E}-08$ \\
\hline White Sucker & 78.4 & $7.14 \pm 2.17 \mathrm{E}-09$ & $0.25 \pm 4.44 \mathrm{E}-08$ \\
\hline White Sucker & 79.7 & $1.60 \pm 0.20 \mathrm{E}-08$ & $0.23 \pm 2.61 \mathrm{E}-08$ \\
\hline Hog-nosed Sucker & 75.1 & $7.92 \pm 1.57 \mathrm{E}-09$ & $-1.36 \pm 2.75 \mathrm{E}-08$ \\
\hline White Sucker & 79.5 & $1.43 \pm 2.33 \mathrm{E}-09$ & $-0.03 \pm 2.55 \mathrm{E}-08$ \\
\hline White Sucker & 77.1 & $4.08 \pm 1.94 \mathrm{E}-09$ & $9.67 \pm 9.62 E-09$ \\
\hline Average $\%$ Moisture & 76.2 & & \\
\hline Median & & $6.64 \mathrm{E}-09$ & $<3.29 \mathrm{E}-08$ \\
\hline Maximum & & $1.60 \mathrm{E}-08$ & $9.67 \mathrm{E}-09$ \\
\hline Minimum & & $<2.33 \mathrm{E}-09$ & 9.67E-09 \\
\hline
\end{tabular}

Note: Bolding convention applied to these data. See page F-2 $\mathbf{m}$

$$
F-7
$$


This page intentionally left blank

$$
F-8
$$




\section{Appendix G-1 \\ Summary of Soil and Aquatic Sediment \\ Guidelines and Standards}

$G-1$ 
This page intentionally left blank

$G-2$ 
Table G-1A

Eastern U.S. Background Concentrations for Elements in Soils ${ }^{a}$

\begin{tabular}{|l|c|c|}
\hline \multicolumn{1}{|c|}{ Analyte } & Units & $\begin{array}{c}\text { Eastern U.S. Background } \\
\text { Concentrations for Soil }\end{array}$ \\
\hline Aluminum & $\mathrm{mg} / \mathrm{kg}(\mathrm{ppm})$ & 33,000 \\
\hline Antimony & $\mathrm{mg} / \mathrm{kg}(\mathrm{ppm})$ & -- \\
\hline Arsenic & $\mathrm{mg} / \mathrm{kg}(\mathrm{ppm})$ & $3-12^{b}$ \\
\hline Barium & $\mathrm{mg} / \mathrm{kg}(\mathrm{ppm})$ & $15-600$ \\
\hline Beryllium & $\mathrm{mg} / \mathrm{kg}(\mathrm{ppm})$ & $0-1.75$ \\
\hline Cadmium & $\mathrm{mg} / \mathrm{kg}(\mathrm{ppm})$ & $0.1-1$ \\
\hline Calcium & $\mathrm{mg} / \mathrm{kg}(\mathrm{ppm})$ & $130-35,000$ \\
\hline Chromium & $\mathrm{mg} / \mathrm{kg}(\mathrm{ppm})$ & $1.5-40^{b}$ \\
\hline Cobalt & $\mathrm{mg} / \mathrm{kg}(\mathrm{ppm})$ & $2.5-60^{b}$ \\
\hline Copper & $\mathrm{mg} / \mathrm{kg}(\mathrm{ppm})$ & $1-50$ \\
\hline Iron & $\mathrm{mg} / \mathrm{kg}(\mathrm{ppm})$ & $2,000-550,000$ \\
\hline Lead & $\mathrm{mg} / \mathrm{kg}(\mathrm{ppm})$ & $4-61^{c}$ \\
\hline Magnesium & $\mathrm{mg} / \mathrm{kg}(\mathrm{ppm})$ & $100-5,000$ \\
\hline Manganese & $\mathrm{mg} / \mathrm{kg}(\mathrm{ppm})$ & $50-5,000$ \\
\hline Mercury & $\mathrm{mg} / \mathrm{kg}(\mathrm{ppm})$ & $0.001-0.2$ \\
\hline Nickel & $\mathrm{mg} / \mathrm{kg}(\mathrm{ppm})$ & $0.5-25$ \\
\hline Potassium & $\mathrm{mg} / \mathrm{kg}(\mathrm{ppm})$ & $8,500-43,000^{b}$ \\
\hline Selenium & $\mathrm{mg} / \mathrm{kg}(\mathrm{ppm})$ & $0.1-3.9$ \\
\hline Silver & $\mathrm{mg} / \mathrm{kg}(\mathrm{ppm})$ & -- \\
\hline Sodium & $\mathrm{mg} / \mathrm{kg}(\mathrm{ppm})$ & $6,000-8,000$ \\
\hline Thallium & $\mathrm{mg} / \mathrm{kg}(\mathrm{ppm})$ & -- \\
\hline Vanadium & $\mathrm{mg} / \mathrm{kg}(\mathrm{ppm})$ & $1-300$ \\
\hline Zinc & $\mathrm{mg} / \mathrm{kg}(\mathrm{ppm})$ & $9-50$ \\
\hline
\end{tabular}

-- No reference level available for these analytes

${ }^{a}$ Source: New York State Department of Environmental Conservation "Technical and Administrative Guidance Memorandum (TAGM) \#4046"

${ }^{b}$ New York State background

${ }^{c}$ Background levels for lead vary widely. Average levels in undeveloped, rural areas may range from 4-61 ppm. Average background levels in metropolitan or suburban areas or near highways are much higher and typically range from $200-500 \mathrm{ppm}$.

$G-3$ 


\section{Table G-1B}

\section{Screening Concentrations for Elements in Contaminated Sediments ${ }^{a}$}

\begin{tabular}{|c|c|c|c|}
\hline Analyte & Units & Lowest Effect Level $^{b}$ & Severe Effect Level ${ }^{c}$ \\
\hline Aluminum & $\mathrm{mg} / \mathrm{kg}(\mathrm{ppm})$ & -- & -- \\
\hline Antimony & $\mathrm{mg} / \mathrm{kg}(\mathrm{ppm})$ & $2.0(\mathrm{~L})$ & $25.0(\mathrm{~L})$ \\
\hline Arsenic & $\mathrm{mg} / \mathrm{kg}(\mathrm{ppm})$ & $6.0(\mathrm{P})$ & $33.0(\mathrm{P})$ \\
\hline Barium & $\mathrm{mg} / \mathrm{kg}(\mathrm{ppm})$ & -- & -- \\
\hline B eryllium & $\mathrm{mg} / \mathrm{kg}(\mathrm{ppm})$ & -- & -- \\
\hline Cadmium & $\mathrm{mg} / \mathrm{kg}(\mathrm{ppm})$ & $0.6(\mathrm{P})$ & $9.0(\mathrm{~L})$ \\
\hline Calcium & $\mathrm{mg} / \mathrm{kg}(\mathrm{ppm})$ & -- & -- \\
\hline Chromium & $\mathrm{mg} / \mathrm{kg}(\mathrm{ppm})$ & $26.0(\mathrm{P})$ & $110.0(\mathrm{P})$ \\
\hline Cobalt & $\mathrm{mg} / \mathrm{kg}(\mathrm{ppm})$ & -- & -- \\
\hline Copper & $\mathrm{mg} / \mathrm{kg}(\mathrm{ppm})$ & $16.0(\mathrm{P})$ & $110.0(\mathrm{P})$ \\
\hline Iron & $\%$ & $2.0(\mathrm{P})$ & $4.0(\mathrm{P})$ \\
\hline Lead & $\mathrm{mg} / \mathrm{kg}(\mathrm{ppm})$ & $31.0(\mathrm{P})$ & $110.0(\mathrm{~L})$ \\
\hline Magnesium & $\mathrm{mg} / \mathrm{kg}(\mathrm{ppm})$ & -- & -- \\
\hline Manganese & $\mathrm{mg} / \mathrm{kg}(\mathrm{ppm})$ & $460.0(\mathrm{P})$ & $1,100.0(\mathrm{~L})$ \\
\hline Mercury & $\mathrm{mg} / \mathrm{kg}(\mathrm{ppm})$ & $0.15(\mathrm{~L})$ & $1.3(\mathrm{~L})$ \\
\hline Nickel & $\mathrm{mg} / \mathrm{kg}(\mathrm{ppm})$ & $16.0(\mathrm{P})$ & $50.0(\mathrm{~L})$ \\
\hline Potassium & $\mathrm{mg} / \mathrm{kg}(\mathrm{ppm})$ & -- & -- \\
\hline Selenium & $\mathrm{mg} / \mathrm{kg}(\mathrm{ppm})$ & -- & -- \\
\hline Silver & $\mathrm{mg} / \mathrm{kg}(\mathrm{ppm})$ & $1.0(\mathrm{~L})$ & $2.2(\mathrm{~L})$ \\
\hline Sodium & $\mathrm{mg} / \mathrm{kg}(\mathrm{ppm})$ & -- & -- \\
\hline Thallium & $\mathrm{mg} / \mathrm{kg}(\mathrm{ppm})$ & -- & -- \\
\hline Vanadium & $\mathrm{mg} / \mathrm{kg}(\mathrm{ppm})$ & -- & -- \\
\hline Zinc & $\mathrm{mg} / \mathrm{kg}(\mathrm{ppm})$ & $120.0(\mathrm{P} / \mathrm{L})$ & $270.0(\mathrm{~L})$ \\
\hline
\end{tabular}

-- No reference value available for these analytes

${ }^{a}$ Source: New York State Department of Environmental Conservation "Technical Guidance for Screening Contaminated Sediments," January 1999

${ }^{b}$ The Lowest Effect Level for each metal is the lowest of the either the Persaud et al. (1992) Lowest Effect Level or the Long and Morgan (1990) Effect Range-Low

${ }^{c}$ The Severe Effect Level for each metal is the lowest of either the Persaud et al. (1992) Severe Effect Level or the Long and Morgan (1990) Effect Range-Moderate

$L$ - An " $L$ " following a criterion indicates that it was taken from Long and Morgan (1990).

$P$ - A "P" following a criterion indicates that it was taken from Persaud et al. (1992). 
Table G-1C

\section{Consultation Triggers for Residential and Commercial/Industrial Soil Contamination ${ }^{a}$}

\begin{tabular}{|c|c|c|c|}
\hline Radionuclide & Units & Residential Soil Concentration & $\begin{array}{c}\text { Industrial/Commercial Soil } \\
\text { Concentration }\end{array}$ \\
\hline Co-60 & $\mu \mathrm{Ci} / \mathrm{g}$ & $4.0 \mathrm{E}-06$ & $6.0 \mathrm{E}-06$ \\
\hline Sr-90 ${ }^{b}$ & $\mu \mathrm{Ci} / \mathrm{g}$ & $2.3 \mathrm{E}-05$ & $1.1 \mathrm{E}-03$ \\
\hline Cs-137 & $\mu \mathrm{Ci} / \mathrm{g}$ & $6.0 \mathrm{E}-06$ & $1.1 \mathrm{E}-05$ \\
\hline U-234 & $\mu \mathrm{Ci} / \mathrm{g}$ & $4.0 \mathrm{E}-04$ & $3.3 \mathrm{E}-03$ \\
\hline $\mathrm{U}-\mathbf{2 3 5}^{b}$ & $\mu \mathrm{Ci} / \mathrm{g}$ & $2.0 \mathrm{E}-05$ & 3.9E-05 \\
\hline $\mathrm{U}^{-238}{ }^{b}$ & $\mu \mathrm{Ci} / \mathrm{g}$ & 7.4E-05 & $1.8 \mathrm{E}-04$ \\
\hline Total U & $\mu \mathrm{g} / \mathrm{g}$ & $4.7 \mathrm{E}+01$ & $1.2 \mathrm{E}+03$ \\
\hline Pu-238 & $\mu \mathrm{Ci} / \mathrm{g}$ & $3.0 \mathrm{E}-04$ & $1.6 \mathrm{E}-03$ \\
\hline Pu-239 & $\mu \mathrm{Ci} / \mathrm{g}$ & 2.6E-04 & $1.4 \mathrm{E}-03$ \\
\hline Am-241 & $\mu \mathrm{Ci} / \mathrm{g}$ & $1.9 \mathrm{E}-04$ & $5.7 \mathrm{E}-04$ \\
\hline
\end{tabular}

${ }^{a}$ Memorandum of Understanding between the Environmental Protection Agency and the Nuclear Regulatory Commission "Consultation and Finality on Decommissioning and Decontamination of Contaminated Sites"

${ }^{b}$ Although concentrations triggers for these radionuclides were set taking the daughter products into consideration, values in this table are based on single contaminant concentrations. These concentrations may be directly compared with analytical results from the data tables.

$G-5$ 
This page intentionally left blank

$G-6$ 


\section{Appendix G-2}

Soil and Sediment Data

$G-7$ 
This page intentionally left blank

$G-8$ 
Table G-2A

2005 Contaminants in On-Site Soils Downstream of the WVDP at Frank's Creek (SNSP006)

RADIOACTIVE CONSTITUENTS

\begin{tabular}{|c|c|c|c|c|c|}
\hline \multirow[t]{2}{*}{ Isotope } & \multirow[t]{2}{*}{ Units } & \multirow[t]{2}{*}{$\mathbf{N}$} & \multirow[t]{2}{*}{ SNSP006 } & \multicolumn{2}{|c|}{$\begin{array}{l}\text { Consultation Triggers }{ }^{a} \\
\text { For Soil Contamination }\end{array}$} \\
\hline & & & & Residential & Industrial/Commercial \\
\hline Gross Alpha & $\mu \mathrm{Ci} / g$ & 1 & $1.12 \pm 0.14 \mathrm{E}-05$ & - & -- \\
\hline Gross Beta & $\mu \mathrm{Ci} / \mathrm{g}$ & 1 & $3.02 \pm 0.20 \mathrm{E}-05$ & -- & -- \\
\hline K-40 & $\mu \mathrm{Ci} / \mathrm{g}$ & 1 & $1.65 \pm 0.12 \mathrm{E}-05$ & -- & -- \\
\hline Co-60 & $\mu \mathrm{Ci} / \mathrm{g}$ & 1 & $0.41 \pm 1.38 \mathrm{E}-08$ & $4.0 \mathrm{E}-06$ & $6.0 \mathrm{E}-06$ \\
\hline Sr-90 & $\mu \mathrm{Ci} / \mathrm{g}$ & 1 & $4.14 \pm 0.54 \mathrm{E}-07$ & $2.3 \mathrm{E}-05$ & $1.1 \mathrm{E}-03$ \\
\hline Cs-137 & $\mu \mathrm{Ci} / \mathrm{g}$ & 1 & $1.30 \pm 0.09 \mathrm{E}-05$ & $6.0 \mathrm{E}-06$ & $1.1 \mathrm{E}-05$ \\
\hline U-232 & $\mu \mathrm{Ci} / \mathrm{g}$ & 1 & $6.77 \pm 4.99 \mathrm{E}-08$ & -- & -- \\
\hline U-233/234 & $\mu \mathrm{Ci} / \mathrm{g}$ & 1 & $7.12 \pm 1.07 \mathrm{E}-07$ & 4.0E-04 & 3.3E-03 \\
\hline $\mathrm{U}-235 / 236$ & $\mu \mathrm{Ci} / \mathrm{g}$ & 1 & $7.31 \pm 3.86 \mathrm{E}-08$ & $2.0 \mathrm{E}-05$ & 3.9E-05 \\
\hline U-238 & $\mu \mathrm{Ci} / \mathrm{g}$ & 1 & $7.40 \pm 1.07 \mathrm{E}-07$ & 7.4E-05 & $1.8 \mathrm{E}-04$ \\
\hline Total U & $\mu \mathrm{g} / \mathrm{g}$ & 1 & $2.04 \pm 0.12 \mathrm{E}+00$ & $4.7 \mathrm{E}+01$ & $1.2 \mathrm{E}+03$ \\
\hline Pu-238 & $\mu \mathrm{Ci} / \mathrm{g}$ & 1 & $2.80 \pm 2.19 \mathrm{E}-08$ & $3.0 \mathrm{E}-04$ & $1.6 \mathrm{E}-03$ \\
\hline Pu-239/240 & $\mu \mathrm{Ci} / \mathrm{g}$ & 1 & $2.83 \pm 2.29 \mathrm{E}-08$ & 2.6E-04 & $1.4 \mathrm{E}-03$ \\
\hline Am-241 & $\mu \mathrm{Ci} / \mathrm{g}$ & 1 & $4.10 \pm 2.40 \mathrm{E}-08$ & 1.9E-04 & 5.7E-04 \\
\hline
\end{tabular}

Note: Effects of radiological soils and sediments are addressed with the evaluation of radiological dose to biota in Chapter 2.

$N$ - Number of samples

-- No reference standard available

a Source: Memorandum of Understanding between the Environmental Protection Agency and the Nuclear Regulatory Commission "Consultation and Finality on Decommissioning and Decontamination of Contaminated Sites" 


\section{Table G-2A (concluded)}

\section{Contaminants in On-Site Soils Downstream of the WVDP at Frank's Creek (SNSP006)}

\section{METALS}

\begin{tabular}{|c|c|c|c|c|c|c|}
\hline \multirow[b]{2}{*}{ Analyte } & \multirow[b]{2}{*}{ Units } & \multirow[b]{2}{*}{$\mathbf{N}$} & \multirow[b]{2}{*}{ SNSP006 } & \multicolumn{3}{|c|}{ Guidance Values } \\
\hline & & & & $\begin{array}{c}\text { Lowest Effect } \\
\text { Level }^{a}\end{array}$ & $\begin{array}{c}\text { Severe Effect } \\
\text { Level }^{a}\end{array}$ & $\begin{array}{c}\text { No Appreciable } \\
\text { Contamination } \\
\text { Level }^{b}\end{array}$ \\
\hline Aluminum & $\mathrm{mg} / \mathrm{kg}$ & 1 & 7,755 & -- & -- & -- \\
\hline Antimony & $\mathrm{mg} / \mathrm{kg}$ & 1 & $<0.42$ & 2.0 & 25.0 & -- \\
\hline Arsenic & $\mathrm{mg} / \mathrm{kg}$ & 1 & 8.8 & 6.0 & 33.0 & 14 \\
\hline Barium & $\mathrm{mg} / \mathrm{kg}$ & 1 & 65.6 & -- & -- & -- \\
\hline Beryllium & $\mathrm{mg} / \mathrm{kg}$ & 1 & 0.42 & -- & -- & -- \\
\hline Cadmium & $\mathrm{mg} / \mathrm{kg}$ & 1 & 0.16 & 0.6 & 9.0 & $<1.2$ \\
\hline Calcium & $\mathrm{mg} / \mathrm{kg}$ & 1 & 13,700 & -- & -- & -- \\
\hline Chromium & $\mathrm{mg} / \mathrm{kg}$ & 1 & 11.2 & 26.0 & 110.0 & -- \\
\hline Cobalt & $\mathrm{mg} / \mathrm{kg}$ & 1 & 10.1 & -- & -- & -- \\
\hline Copper & $\mathrm{mg} / \mathrm{kg}$ & 1 & 18.8 & 16.0 & 110.0 & $<33$ \\
\hline Iron & $\%$ & 1 & 1.8 & 2.0 & 4.0 & -- \\
\hline Lead & $\mathrm{mg} / \mathrm{kg}$ & 1 & 12.4 & 31.0 & 110.0 & $<33$ \\
\hline Magnesium & $\mathrm{mg} / \mathrm{kg}$ & 1 & 5,625 & -- & -- & -- \\
\hline Manganese & $\mathrm{mg} / \mathrm{kg}$ & 1 & 628 & 460.0 & $1,100.0$ & -- \\
\hline Mercury & $\mathrm{mg} / \mathrm{kg}$ & 1 & 0.04 & 0.15 & 1.3 & 0.17 \\
\hline Nickel & $\mathrm{mg} / \mathrm{kg}$ & 1 & 21.6 & 16.0 & 50.0 & -- \\
\hline Potassium & $\mathrm{mg} / \mathrm{kg}$ & 1 & 1,150 & -- & -- & -- \\
\hline Selenium & $\mathrm{mg} / \mathrm{kg}$ & 1 & $<1.48$ & -- & -- & -- \\
\hline Silver & $\mathrm{mg} / \mathrm{kg}$ & 1 & $<0.10$ & 1.0 & 2.2 & -- \\
\hline Sodium & $\mathrm{mg} / \mathrm{kg}$ & 1 & 111 & -- & -- & -- \\
\hline Thallium & $\mathrm{mg} / \mathrm{kg}$ & 1 & $<2.07$ & -- & -- & -- \\
\hline Vanadium & $\mathrm{mg} / \mathrm{kg}$ & 1 & 14.6 & -- & -- & -- \\
\hline Zinc & $\mathrm{mg} / \mathrm{kg}$ & 1 & 73.2 & 120.0 & 270.0 & -- \\
\hline
\end{tabular}

$N$ - Number of samples

-- No reference standard available

${ }^{a}$ Screening guidelines for chemical constituents obtained from NYSDEC "Technical Guidance for Screening Contaminated Sediments."

${ }^{b}$ NYSDEC: Draft Technical and Operational Guidance Series 5.1.9, "In-Water Riparian Management of Sediment and Dredge Material," January 2003. 


\section{Table G-2B}

\section{Contaminants in On-Site Soils From North Swamp (SNSW74A)}

\section{RADIOACTIVE CONSTITUENTS}

\begin{tabular}{|c|c|c|c|c|c|}
\hline \multirow[t]{2}{*}{ Isotope } & \multirow[t]{2}{*}{ Units } & \multirow[t]{2}{*}{$\mathbf{N}$} & \multirow[t]{2}{*}{ SNSW74A } & \multicolumn{2}{|c|}{$\begin{array}{l}\text { Consultation Triggers }^{a} \\
\text { For Soil Contamination }\end{array}$} \\
\hline & & & & Residential & Industrial/Commercial \\
\hline Gross Alpha & $\mu \mathrm{Ci} / \mathrm{g}$ & 1 & $1.10 \pm 0.13 \mathrm{E}-05$ & -- & -- \\
\hline Gross Beta & $\mu \mathrm{Ci} / \mathrm{g}$ & 1 & $2.38 \pm 0.18 \mathrm{E}-05$ & -- & -- \\
\hline K-40 & $\mu \mathrm{Ci} / \mathrm{g}$ & 1 & $1.55 \pm 0.05 \mathrm{E}-05$ & -- & -- \\
\hline Co-60 & $\mu \mathrm{Ci} / \mathrm{g}$ & 1 & $0.31 \pm 1.32 \mathrm{E}-08$ & 4.0E-06 & $6.0 \mathrm{E}-06$ \\
\hline Sr-90 & $\mu \mathrm{Ci} / \mathrm{g}$ & 1 & $6.93 \pm 2.23 \mathrm{E}-08$ & $2.3 \mathrm{E}-05$ & $1.1 \mathrm{E}-03$ \\
\hline Cs-137 & $\mu \mathrm{Ci} / \mathrm{g}$ & 1 & $2.70 \pm 0.05 \mathrm{E}-06$ & $6.0 \mathrm{E}-06$ & $1.1 \mathrm{E}-05$ \\
\hline U-232 & $\mu \mathrm{Ci} / \mathrm{g}$ & 1 & $-0.68 \pm 4.44 \mathrm{E}-08$ & -- & -- \\
\hline U-233/234 & $\mu \mathrm{Ci} / \mathrm{g}$ & 1 & $7.50 \pm 1.00 \mathrm{E}-07$ & 4.0E-04 & $3.3 \mathrm{E}-03$ \\
\hline U-235/236 & $\mu \mathrm{Ci} / \mathrm{g}$ & 1 & $1.26 \pm 0.43 \mathrm{E}-07$ & $2.0 \mathrm{E}-05$ & 3.9E-05 \\
\hline U-238 & $\mu \mathrm{Ci} / \mathrm{g}$ & 1 & $7.12 \pm 0.98 \mathrm{E}-07$ & 7.4E-05 & $1.8 \mathrm{E}-04$ \\
\hline Total U & $\mu \mathrm{g} / \mathrm{g}$ & 1 & $1.74 \pm 0.06 \mathrm{E}+00$ & $4.7 \mathrm{E}+01$ & $1.2 \mathrm{E}+03$ \\
\hline Pu-238 & $\mu \mathrm{Ci} / \mathrm{g}$ & 1 & $2.04 \pm 1.51 \mathrm{E}-08$ & $3.0 \mathrm{E}-04$ & $1.6 \mathrm{E}-03$ \\
\hline $\mathrm{Pu}-239 / 240$ & $\mu \mathrm{Ci} / \mathrm{g}$ & 1 & $5.24 \pm 2.55 \mathrm{E}-08$ & $2.6 \mathrm{E}-04$ & $1.4 \mathrm{E}-03$ \\
\hline Am-241 & $\mu \mathrm{Ci} / \mathrm{g}$ & 1 & $6.10 \pm 2.66 \mathrm{E}-08$ & $1.9 \mathrm{E}-04$ & 5.7E-04 \\
\hline
\end{tabular}

Note: Effects of radiological soils and sediments are addressed with the evaluation of radiological dose to biota in Chapter 2.

$N$ - Number of samples

-- No reference standard available

${ }^{a}$ Source: Memorandum of Understanding between the Environmental Protection Agency and the Nuclear Regulatory Commission "Consultation and Finality on Decommissioning and Decontamination of Contaminated Sites" 


\section{Table G-2B (concluded) \\ 2005 Contaminants in On-Site Soils From North Swamp (SNSW74A)}

METALS

\begin{tabular}{|c|c|c|c|c|}
\hline Analyte & Units & $\mathbf{N}$ & SNSW74A & Reference Value $^{a}$ \\
\hline Aluminum & $\mathrm{mg} / \mathrm{kg}$ & 1 & 4,910 & 33,000 \\
\hline Antimony & $\mathrm{mg} / \mathrm{kg}$ & 1 & $<0.36$ & -- \\
\hline Arsenic & $\mathrm{mg} / \mathrm{kg}$ & 1 & 6.5 & $3-12^{b}$ \\
\hline Barium & $\mathrm{mg} / \mathrm{kg}$ & 1 & 41.6 & $15-600$ \\
\hline Beryllium & $\mathrm{mg} / \mathrm{kg}$ & 1 & 0.39 & $0-1.75$ \\
\hline Cadmium & $\mathrm{mg} / \mathrm{kg}$ & 1 & 0.32 & $0.1-1$ \\
\hline Calcium & $\mathrm{mg} / \mathrm{kg}$ & 1 & 119,000 & $130-35,000$ \\
\hline Chromium & $\mathrm{mg} / \mathrm{kg}$ & 1 & 10.2 & $1.5-40^{b}$ \\
\hline Cobalt & $\mathrm{mg} / \mathrm{kg}$ & 1 & 4.3 & $2.5-60^{b}$ \\
\hline Copper & $\mathrm{mg} / \mathrm{kg}$ & 1 & 16.0 & $1-50$ \\
\hline Iron & $\mathrm{mg} / \mathrm{kg}$ & 1 & 11,800 & $2,000-550,000$ \\
\hline Lead & $\mathrm{mg} / \mathrm{kg}$ & 1 & 12.0 & $4-61^{c}$ \\
\hline Magnesium & $\mathrm{mg} / \mathrm{kg}$ & 1 & 8,440 & $100-5,000$ \\
\hline Manganese & $\mathrm{mg} / \mathrm{kg}$ & 1 & 524 & $50-5,000$ \\
\hline Mercury & $\mathrm{mg} / \mathrm{kg}$ & 1 & 0.02 & $0.001-0.2$ \\
\hline Nickel & $\mathrm{mg} / \mathrm{kg}$ & 1 & 13.5 & $0.5-25$ \\
\hline Potassium & $\mathrm{mg} / \mathrm{kg}$ & 1 & 1,060 & $8,500-43,000^{b}$ \\
\hline Selenium & $\mathrm{mg} / \mathrm{kg}$ & 1 & $<0.52$ & $0.1-3.9$ \\
\hline Silver & $\mathrm{mg} / \mathrm{kg}$ & 1 & $<0.10$ & -- \\
\hline Sodium & $\mathrm{mg} / \mathrm{kg}$ & 1 & 121.0 & $6,000-8,000$ \\
\hline Thallium & $\mathrm{mg} / \mathrm{kg}$ & 1 & $<0.89$ & -- \\
\hline Vanadium & $\mathrm{mg} / \mathrm{kg}$ & 1 & 9.7 & $1-300$ \\
\hline Zinc & $\mathrm{mg} / \mathrm{kg}$ & 1 & 114.0 & $9-50$ \\
\hline
\end{tabular}

$N$ - Number of samples

-- No reference standard available

${ }^{a}$ NYSDEC: Technical and Administrative Guidance Memorandum (TAGM) \#4046.

${ }^{b}$ New York State background

${ }^{c}$ Background levels vary widely. Average levels in undeveloped rural areas may range from 4-61 ppm (reported here). Average background levels in metropolitain or suburban areas, or near highways are much higher and typically range from 200-500 ppm. 
Table G-2C

2005 Contaminants in On-Site Soils From Northeast Swamp (SNSWAMP)

RADIOACTIVE CONSTITUENTS

\begin{tabular}{|l|c|c|c|c|c|}
\hline \multicolumn{1}{|c|}{ Isotope } & Units & N & SNSWAMP & \multicolumn{2}{c|}{$\begin{array}{c}\text { Consultation Triggers } \\
\text { For Soil Contamination }\end{array}$} \\
\hline & & & & Residential & Industrial/Commercial \\
\hline Gross Alpha & $\mu \mathrm{Ci} / \mathrm{g}$ & 1 & $1.73 \pm 0.17 \mathrm{E}-05$ & -- & -- \\
\hline Gross Beta & $\mu \mathrm{Ci} / \mathrm{g}$ & 1 & $5.99 \pm 0.28 \mathrm{E}-05$ & -- & -- \\
\hline K-40 & $\mu \mathrm{Ci} / \mathrm{g}$ & 1 & $1.39 \pm 0.07 \mathrm{E}-05$ & -- & $6.0 \mathrm{E}-06$ \\
\hline Co-60 & $\mu \mathrm{Ci} / \mathrm{g}$ & 1 & $1.65 \pm 1.66 \mathrm{E}-08$ & $4.0 \mathrm{E}-06$ & $1.1 \mathrm{E}-03$ \\
\hline Sr-90 & $\mu \mathrm{Ci} / \mathrm{g}$ & 1 & $2.96 \pm 0.13 \mathrm{E}-06$ & $2.3 \mathrm{E}-05$ & $1.1 \mathrm{E}-05$ \\
\hline Cs-137 & $\mu \mathrm{Ci} / \mathrm{g}$ & 1 & $5.22 \pm 0.09 \mathrm{E}-06$ & $6.0 \mathrm{E}-06$ & -- \\
\hline U-232 & $\mu \mathrm{Ci} / \mathrm{g}$ & 1 & $4.53 \pm 3.74 \mathrm{E}-08$ & -- & $3.3 \mathrm{E}-03$ \\
\hline U-233/234 & $\mu \mathrm{Ci} / \mathrm{g}$ & 1 & $8.37 \pm 1.05 \mathrm{E}-07$ & $4.0 \mathrm{E}-04$ & $3.9 \mathrm{E}-05$ \\
\hline U-235/236 & $\mu \mathrm{Ci} / \mathrm{g}$ & 1 & $1.19 \pm 0.41 \mathrm{E}-07$ & $2.0 \mathrm{E}-05$ & $1.8 \mathrm{E}-04$ \\
\hline U-238 & $\mu \mathrm{Ci} / \mathrm{g}$ & 1 & $7.87 \pm 0.99 \mathrm{E}-07$ & $7.4 \mathrm{E}-05$ & $1.2 \mathrm{E}+03$ \\
\hline Total U & $\mu \mathrm{g} / \mathrm{g}$ & 1 & $1.88 \pm 0.15 \mathrm{E}+00$ & $4.7 \mathrm{E}+01$ & $1.6 \mathrm{E}-03$ \\
\hline Pu-238 & $\mu \mathrm{Ci} / \mathrm{g}$ & 1 & $2.97 \pm 0.59 \mathrm{E}-07$ & $3.0 \mathrm{E}-04$ & $1.4 \mathrm{E}-03$ \\
\hline Pu-239/240 & $\mu \mathrm{Ci} / \mathrm{g}$ & 1 & $3.59 \pm 0.64 \mathrm{E}-07$ & $2.6 \mathrm{E}-04$ & $5.7 \mathrm{E}-04$ \\
\hline Am-241 & $\mu \mathrm{Ci} / \mathrm{g}$ & 1 & $6.06 \pm 0.88 \mathrm{E}-07$ & $1.9 \mathrm{E}-04$ & 1 \\
\hline
\end{tabular}

Note: Effects of radiological soils and sediments are addressed with the evaluation of radiological dose to biota in Chapter 2.

$N$ - Number of samples

-- No reference standard available

${ }^{a}$ Source: Memorandum of Understanding between the Environmental Protection Agency and the Nuclear Regulatory Commission "Consultation and Finality on Decommissioning and Decontamination of Contaminated Sites" 


\section{Table G-2C (concluded)}

\section{Contaminants in On-Site Soils From Northeast Swamp (SNSWAMP)}

METALS

\begin{tabular}{|c|c|c|c|c|}
\hline Analyte & Units & $\mathbf{N}$ & SNSWAMP & Reference Value ${ }^{a}$ \\
\hline Aluminum & $\mathrm{mg} / \mathrm{kg}$ & 1 & 10,900 & 33,000 \\
\hline Antimony & $\mathrm{mg} / \mathrm{kg}$ & 1 & 0.43 & -- \\
\hline Arsenic & $\mathrm{mg} / \mathrm{kg}$ & 1 & 10.7 & $3-12^{b}$ \\
\hline Barium & $\mathrm{mg} / \mathrm{kg}$ & 1 & 74.1 & $15-600$ \\
\hline Beryllium & $\mathrm{mg} / \mathrm{kg}$ & 1 & 0.67 & $0-1.75$ \\
\hline Cadmium & $\mathrm{mg} / \mathrm{kg}$ & 1 & $<0.05$ & $0.1-1$ \\
\hline Calcium & $\mathrm{mg} / \mathrm{kg}$ & 1 & 3,090 & $130-35,000$ \\
\hline Chromium & $\mathrm{mg} / \mathrm{kg}$ & 1 & 14.2 & $1.5-40^{b}$ \\
\hline Cobalt & $\mathrm{mg} / \mathrm{kg}$ & 1 & 8.5 & $2.5-60^{b}$ \\
\hline Copper & $\mathrm{mg} / \mathrm{kg}$ & 1 & 27.9 & $1-50$ \\
\hline Iron & $\mathrm{mg} / \mathrm{kg}$ & 1 & 24,200 & $2,000-550,000$ \\
\hline Lead & $\mathrm{mg} / \mathrm{kg}$ & 1 & 20 & $4-61^{c}$ \\
\hline Magnesium & $\mathrm{mg} / \mathrm{kg}$ & 1 & 3,720 & $100-5,000$ \\
\hline Manganese & $\mathrm{mg} / \mathrm{kg}$ & 1 & 648 & $50-5,000$ \\
\hline Mercury & $\mathrm{mg} / \mathrm{kg}$ & 1 & 0.04 & $0.001-0.2$ \\
\hline Nickel & $\mathrm{mg} / \mathrm{kg}$ & 1 & 21.5 & $0.5-25$ \\
\hline Potassium & $\mathrm{mg} / \mathrm{kg}$ & 1 & 1,280 & $8,500-43,000^{b}$ \\
\hline Selenium & $\mathrm{mg} / \mathrm{kg}$ & 1 & $<0.52$ & $0.1-3.9$ \\
\hline Silver & $\mathrm{mg} / \mathrm{kg}$ & 1 & $<0.10$ & -- \\
\hline Sodium & $\mathrm{mg} / \mathrm{kg}$ & 1 & 159 & $6,000-8,000$ \\
\hline Thallium & $\mathrm{mg} / \mathrm{kg}$ & 1 & $<0.88$ & -- \\
\hline Vanadium & $\mathrm{mg} / \mathrm{kg}$ & 1 & 16.3 & $1-300$ \\
\hline Zinc & $\mathrm{mg} / \mathrm{kg}$ & 1 & 92.1 & $9-50$ \\
\hline
\end{tabular}

$N$ - Number of samples

-- No reference standard available

${ }^{a}$ NYSDEC: Technical and Administrative Guidance Memorandum (TAGM) \#4046.

${ }^{b}$ New York State background

${ }^{c}$ Background levels vary widely. Average levels in undeveloped rural areas may range from 4-61 ppm (reported here). Average background levels in metropolitain or suburban areas, or near highways are much higher and typically range from 200-500 ppm.

Table G-2D

2005 Radioactivity in Surface Soils Collected at Air Stations Around the WVDP

In 2005, collection frequency was reduced to once every three years at these locations. The samples will next be collected in CY 2007. 


\section{Table G-2E}

\section{Radioactivity in Stream Sediments Around the WVDP}

\begin{tabular}{|c|c|c|c|c|c|c|}
\hline Analyte & Units & $\mathbf{N}$ & SFCCSED & SFSDSED & $\mathbf{N}$ & $\begin{array}{c}\text { Background Location } \\
\text { SFBISED }^{a}\end{array}$ \\
\hline Gross Alpha & $\mu \mathrm{Ci} / \mathrm{g}$ & 1 & $8.35 \pm 3.87 \mathrm{E}-06$ & $1.34 \pm 0.50 \mathrm{E}-05$ & 10 & $1.16 \pm 0.35 \mathrm{E}-05$ \\
\hline Gross Beta & $\mu \mathrm{Ci} / \mathrm{g}$ & 1 & $1.57 \pm 0.50 \mathrm{E}-05$ & $2.68 \pm 0.56 \mathrm{E}-05$ & 10 & $1.69 \pm 0.29 \mathrm{E}-05$ \\
\hline K-40 & $\mu \mathrm{Ci} / \mathrm{g}$ & 1 & $1.30 \pm 0.11 \mathrm{E}-05$ & $1.63 \pm 0.08 \mathrm{E}-05$ & 10 & $1.37 \pm 0.15 \mathrm{E}-05$ \\
\hline Co-60 & $\mu \mathrm{Ci} / \mathrm{g}$ & 1 & $1.34 \pm 2.37 \mathrm{E}-08$ & $-0.80 \pm 1.92 \mathrm{E}-08$ & 10 & $0.02 \pm 1.62 \mathrm{E}-08$ \\
\hline Sr-90 & $\mu \mathrm{Ci} / \mathrm{g}$ & 1 & $1.35 \pm 2.76 \mathrm{E}-08$ & $0.41 \pm 2.44 \mathrm{E}-08$ & 10 & $0.04 \pm 4.97 \mathrm{E}-08$ \\
\hline Cs-137 & $\mu \mathrm{Ci} / \mathrm{g}$ & 1 & $1.41 \pm 0.37 \mathrm{E}-07$ & $-1.27 \pm 1.74 \mathrm{E}-08$ & 10 & $3.73 \pm 2.27 \mathrm{E}-08$ \\
\hline U-232 & $\mu \mathrm{Ci} / \mathrm{g}$ & 1 & $1.10 \pm 3.01 \mathrm{E}-08$ & $1.41 \pm 2.93 \mathrm{E}-08$ & 10 & $0.00 \pm 3.25 \mathrm{E}-08$ \\
\hline U-233/234 & $\mu \mathrm{Ci} / \mathrm{g}$ & 1 & $6.38 \pm 1.39 \mathrm{E}-07$ & $6.49 \pm 1.26 \mathrm{E}-07$ & 10 & $5.42 \pm 1.19 \mathrm{E}-07$ \\
\hline U-235/236 & $\mu \mathrm{Ci} / \mathrm{g}$ & 1 & $5.84 \pm 4.47 \mathrm{E}-08$ & $1.21 \pm 0.56 \mathrm{E}-07$ & 10 & $5.73 \pm 3.88 \mathrm{E}-08$ \\
\hline U-238 & $\mu \mathrm{Ci} / \mathrm{g}$ & 1 & $6.70 \pm 1.43 \mathrm{E}-07$ & $8.01 \pm 1.40 \mathrm{E}-07$ & 10 & $5.30 \pm 1.14 \mathrm{E}-07$ \\
\hline Total U & $\mu \mathrm{g} / \mathrm{g}$ & 1 & $1.76 \pm 0.05 \mathrm{E}+00$ & $2.28 \pm 0.06 \mathrm{E}+00$ & 10 & $1.91 \pm 0.04 \mathrm{E}+00$ \\
\hline Pu-238 & $\mu \mathrm{Ci} / \mathrm{g}$ & 1 & $0.25 \pm 1.23 \mathrm{E}-08$ & $0.00 \pm 1.11 \mathrm{E}-08$ & 10 & $1.11 \pm 1.86 \mathrm{E}-08$ \\
\hline Pu-239/240 & $\mu \mathrm{Ci} / \mathrm{g}$ & 1 & $-0.29 \pm 1.27 \mathrm{E}-08$ & $1.43 \pm 1.96 \mathrm{E}-08$ & 10 & $1.44 \pm 1.44 \mathrm{E}-08$ \\
\hline Am-241 & $\mu \mathrm{Ci} / \mathrm{g}$ & 1 & $-0.09 \pm 1.35 \mathrm{E}-08$ & $-0.60 \pm 1.28 \mathrm{E}-08$ & 10 & $1.70 \pm 2.24 \mathrm{E}-08$ \\
\hline Analyte & Units & $\mathbf{N}$ & SFTCSED & & $\mathbf{N}$ & $\begin{array}{c}\text { Background Location } \\
\text { SFBCSED }^{b}\end{array}$ \\
\hline Gross Alpha & $\mu \mathrm{Ci} / \mathrm{g}$ & 1 & $6.52 \pm 3.81 \mathrm{E}-06$ & -- & 10 & $9.18 \pm 3.16 \mathrm{E}-06$ \\
\hline Gross Beta & $\mu \mathrm{Ci} / \mathrm{g}$ & 1 & $1.86 \pm 0.50 \mathrm{E}-05$ & -- & 10 & $1.80 \pm 0.30 \mathrm{E}-05$ \\
\hline K-40 & $\mu \mathrm{Ci} / \mathrm{g}$ & 1 & $1.30 \pm 0.10 \mathrm{E}-05$ & -- & 10 & $1.40 \pm 0.15 \mathrm{E}-05$ \\
\hline Co-60 & $\mu \mathrm{Ci} / \mathrm{g}$ & 1 & $0.42 \pm 1.56 \mathrm{E}-08$ & -- & 10 & $-0.09 \pm 1.94 \mathrm{E}-08$ \\
\hline Sr-90 & $\mu \mathrm{Ci} / \mathrm{g}$ & 1 & $1.62 \pm 2.28 \mathrm{E}-08$ & -- & 10 & $3.11 \pm 5.32 \mathrm{E}-08$ \\
\hline Cs-137 & $\mu \mathrm{Ci} / \mathrm{g}$ & 1 & $7.16 \pm 0.80 \mathrm{E}-07$ & -- & 10 & $3.41 \pm 2.77 \mathrm{E}-08$ \\
\hline U-232 & $\mu \mathrm{Ci} / \mathrm{g}$ & 1 & $0.73 \pm 2.52 \mathrm{E}-08$ & -- & 10 & $2.16 \pm 6.13 \mathrm{E}-08$ \\
\hline U-233/234 & $\mu \mathrm{Ci} / \mathrm{g}$ & 1 & $5.49 \pm 1.23 \mathrm{E}-07$ & -- & 10 & $6.35 \pm 1.19 \mathrm{E}-07$ \\
\hline U-235/236 & $\mu \mathrm{Ci} / \mathrm{g}$ & 1 & $7.32 \pm 4.55 \mathrm{E}-08$ & -- & 10 & $5.03 \pm 3.52 \mathrm{E}-08$ \\
\hline U-238 & $\mu \mathrm{Ci} / \mathrm{g}$ & 1 & $4.86 \pm 1.15 \mathrm{E}-07$ & -- & 10 & $6.79 \pm 1.24 \mathrm{E}-07$ \\
\hline Total U & $\mu \mathrm{g} / \mathrm{g}$ & 1 & $1.65 \pm 0.04 \mathrm{E}+00$ & -- & 10 & $2.19 \pm 0.05 \mathrm{E}+00$ \\
\hline Pu-238 & $\mu \mathrm{Ci} / \mathrm{g}$ & 1 & $0.15 \pm 1.11 \mathrm{E}-08$ & -- & 10 & $2.69 \pm 1.90 \mathrm{E}-08$ \\
\hline Pu-239/240 & $\mu \mathrm{Ci} / \mathrm{g}$ & 1 & $0.14 \pm 1.10 \mathrm{E}-08$ & -- & 10 & $0.91 \pm 1.24 \mathrm{E}-08$ \\
\hline Am-241 & $\mu \mathrm{Ci} / \mathrm{g}$ & 1 & $0.62 \pm 1.12 \mathrm{E}-08$ & -- & 10 & $0.61 \pm 1.23 \mathrm{E}-08$ \\
\hline
\end{tabular}

$N$ - Number of samples

-- Not applicable; no additional sampling location

${ }^{a}$ Sediment sampling at Bigelow Bridge (SFBISED), the upstream Cattaraugus Creek background, was discontinued in 2005. The ten-year historical average is used as the comparative reference for the Cattaraugus Creek locations.

${ }^{b}$ Sampling data at the location upstream in Buttermilk Creek (SFBCSED) is presented as a ten-year rolling average and is used as a comparative reference for Thomas Corners in Buttermilk Creek (SFTCSED), immediately downstream of facility effluents. 


\section{Table G-2F}

\section{Metals and Organics From the Lag Storage Area (LSA) \#2 Truck Staging Area Shallow Soil Characterization}

\begin{tabular}{|c|c|c|c|c|c|}
\hline Analyte & Soil Depth & $\mathbf{N}$ & $\begin{array}{l}\text { LSA \#2 Soil } \\
\text { (mg/kg) }\end{array}$ & $\begin{array}{c}\text { TAGM } 4046 \\
\text { Action Level } \\
(\mathrm{mg} / \mathrm{kg})\end{array}$ & $\begin{array}{c}\text { Proposed Site-Specific } \\
\text { TAGM 4046 Soil } \\
\text { Cleanup Action Level } \\
(\mathrm{mg} / \mathrm{kg})\end{array}$ \\
\hline Barium & 6-12 inches & 2 & $\begin{array}{c}32.9 \\
22\end{array}$ & 300 or $\mathrm{SB}^{a}$ & 300 \\
\hline Cadmium & 6-12 inches & 2 & $\begin{array}{l}0.31 \\
0.17\end{array}$ & 1 or $\mathrm{SB}^{a}$ & 1 \\
\hline Chromium & $6-12$ inches & 2 & $\begin{array}{l}7.7 \\
9.2\end{array}$ & 10 or $\mathrm{SB}^{a}$ & $19.7^{b}$ \\
\hline Lead & $6-12$ inches & 2 & $\begin{array}{c}(\mathrm{J})^{c} 22.5 \text { replicate } 7.5 \\
4.1 \text { replicate } 8.6\end{array}$ & $\mathrm{SB}^{a}$ & $16.7^{b}$ \\
\hline Mercury & 6-12 inches & 2 & $\begin{array}{l}<0.02 \\
<0.02\end{array}$ & 0.1 & 0.1 \\
\hline Selenium & $6-12$ inches & 2 & $\begin{array}{l}<0.36 \\
<0.36\end{array}$ & 2 or $\mathrm{SB}^{a}$ & 2 \\
\hline Silver & $6-12$ inches & 2 & $\begin{array}{l}<0.14 \\
<0.14\end{array}$ & $\mathrm{SB}^{a}$ & $0.37^{b}$ \\
\hline Benzene & $6-12$ inches & 2 & $\begin{array}{l}<0.008 \\
<0.005 \\
<0.004\end{array}$ & 0.06 & 0.06 \\
\hline $\begin{array}{l}\text { PCBs: } \\
\text { pcb } 1016\end{array}$ & $0-2$ inches & 2 & $\begin{array}{l}<0.14 \\
<0.15\end{array}$ & \multirow{7}{*}{1.0} & \multirow{7}{*}{$\begin{array}{c}1.0(\text { Surface }) \\
10.0 \text { (Subsurface) }\end{array}$} \\
\hline pcb 1221 & $0-2$ inches & 2 & $\begin{array}{l}<0.14 \\
<0.15\end{array}$ & & \\
\hline pcb 1232 & $0-2$ inches & 2 & $\begin{array}{l}<0.14 \\
<0.15\end{array}$ & & \\
\hline pcb 1242 & $0-2$ inches & 2 & $\begin{array}{l}<0.14 \\
<0.15\end{array}$ & & \\
\hline pcb 1248 & $0-2$ inches & 2 & $\begin{array}{l}<0.14 \\
<0.15\end{array}$ & & \\
\hline pcb 1254 & $0-2$ inches & 2 & $\begin{array}{l}<0.14 \\
<0.15\end{array}$ & & \\
\hline pcb 1260 & $0-2$ inches & 2 & $\begin{array}{l}(\mathrm{J})^{d} 0.071 \\
(\mathrm{~J})^{d} 0.10\end{array}$ & & \\
\hline
\end{tabular}

$N$ - Number of samples

${ }^{a}$ SB - Site background; WVDP site backgrounds values were taken from the "Draft Corrective Measures Study Work Plan for the West Valley Demonstration Project (WVNSCO, January 2006).

${ }^{b}$ Data validation "J" flag indicates analyte was identified but the associated numerical value is an estimated quantity. The results were flagged because of imprecision between the two values.

"Data validation " J" flag indicates analyte was identified but the associated numerical value is an estimated quantity because the analyte was identified below the detection limit.

${ }^{d}$ The proposed cleanup action level is presented as the site-specific background level.

$$
G-16
$$




\section{Appendix $\mathrm{H}$ \\ Summary of Direct Radiation Monitoring Data}

$H-1$ 
This page intentionally left blank

$H-2$ 
Table $\mathrm{H}-1$

Summary of 2005 Quarterly Averages of Off-Site TLD Measurements (mR \pm 2 SD/quarter)

$\begin{array}{lccccc}\begin{array}{l}\text { Location } \\ \text { Number }\end{array} & \text { 1st Quarter } & \text { 2nd Quarter } & \text { 3rd Quarter } & \text { 4th Quarter } & \begin{array}{c}\text { Location } \\ \text { Average }\end{array} \\ \text { DFTLD01 } & & & & & \\ \text { DFTLD02 } & 17 \pm 4 & 23 \pm 5 & 22 \pm 5 & 17 \pm 6 & 20 \pm 5 \\ \text { DFTLD03 } & 17 \pm 4 & 22 \pm 5 & 24 \pm 5 & 17 \pm 6 & 20 \pm 5 \\ \text { DFTLD04 } & 15 \pm 3 & 19 \pm 4 & 20 \pm 5 & 15 \pm 6 & 17 \pm 5 \\ \text { DFTLD05 } & 16 \pm 4 & 23 \pm 5 & 22 \pm 5 & 18 \pm 6 & 20 \pm 5 \\ \text { DFTLD06 } & 17 \pm 4 & 23 \pm 5 & 24 \pm 5 & 19 \pm 7 & 21 \pm 5 \\ \text { DFTLD07 } & 16 \pm 4 & 24 \pm 5 & 21 \pm 5 & 18 \pm 6 & 20 \pm 5 \\ \text { DFTLD08 } & 14 \pm 3 & 17 \pm 4 & 18 \pm 4 & 15 \pm 6 & 16 \pm 4 \\ \text { DFTLD09 } & 17 \pm 4 & 21 \pm 4 & 22 \pm 5 & 18 \pm 6 & 19 \pm 5 \\ \text { DFTLD10 } & 17 \pm 4 & 20 \pm 4 & 23 \pm 5 & 16 \pm 6 & 19 \pm 5 \\ \text { DFTLD11 } & 15 \pm 3 & 18 \pm 4 & 23 \pm 5 & 15 \pm 6 & 18 \pm 5 \\ \text { DFTLD12 } & 15 \pm 3 & 17 \pm 4 & 20 \pm 5 & 14 \pm 6 & 17 \pm 5 \\ \text { DFTLD13 } & 18 \pm 4 & 20 \pm 4 & 21 \pm 5 & 16 \pm 6 & 19 \pm 5 \\ \text { DFTLD14 } & 16 \pm 4 & 21 \pm 5 & 25 \pm 6 & 18 \pm 6 & 20 \pm 5 \\ \text { DFTLD15 } & 15 \pm 3 & 19 \pm 4 & 22 \pm 5 & \text { NA } & 19 \pm 4 \\ \text { DFTLD16 } & 16 \pm 4 & 18 \pm 4 & 23 \pm 5 & 15 \pm 6 & 18 \pm 5 \\ \text { DFTLD20 } & 14 \pm 3 & 20 \pm 4 & 23 \pm 5 & 16 \pm 6 & 19 \pm 5 \\ \text { DFTLD21 } & 17 \pm 4 & 17 \pm 4 & 18 \pm 4 & 13 \pm 6 & 15 \pm 4 \\ \text { DFTLD22 } & 17 \pm 4 & 21 \pm 4 & 26 \pm 6 & 17 \pm 6 & 20 \pm 5 \\ \text { DFTLD23 } & 17 \pm 4 & 21 \pm 5 & 25 \pm 5 & 17 \pm 6 & 20 \pm 5 \\ & & 20 \pm 4 & 23 \pm 5 & 16 \pm 6 & 19 \pm 5\end{array}$

NA - 4th-quarter 2005 result unreliable.

${ }^{a}$ Off-site locations are shown on Figures A-13, A-14, and A-15.

Conversion factor: Milliroentgen $(m R)$ units are used to report exposure rates in air. To convert mR to $m r e m(d o s e$ to humans), a conversion factor of 1.03 must be applied. For example, a reported exposure rate of 18.1 mR/quarter would be equivalent to 18.6 mrem/quarter (based upon dose-equivalent phantom calibration using cesium-137).

$H-3$ 
Table $\mathrm{H}-2$

Summary of 2005 Quarterly Averages of On-Site TLD Measurements

$\begin{array}{lccccc}\begin{array}{l}\text { Location } \\ \text { Number }^{a}\end{array} & \begin{array}{c}\text { 1st Quarter } \\ \text { (mR/quarter) }\end{array} & \begin{array}{c}\text { 2nd Quarter } \\ \text { (mR/quarter) }\end{array} & \begin{array}{c}\text { 3rd Quarter } \\ (\mathbf{m R / q u a r t e r})\end{array} & \begin{array}{c}\text { 4th Quarter } \\ \text { (mR/quarter) }\end{array} & \begin{array}{c}\text { Location Ave } \\ \text { (mR/quarter) }\end{array} \\ \text { DNTLD18 } & 28 \pm 6 & 32 \pm 7 & \mathrm{NA} & \mathrm{NA} & 30 \pm 4 \\ \text { DNTLD19 } & 21 \pm 4 & 22 \pm 5 & 24 \pm 5 & 19 \pm 7 & 22 \pm 5 \\ \text { DNTLD24 } & 454 \pm 89 & 452 \pm 89 & 486 \pm 95 & 447 \pm 88 & 460 \pm 90 \\ \text { DNTLD25 } & 20 \pm 4 & 24 \pm 5 & 27 \pm 6 & 20 \pm 7 & 23 \pm 6 \\ \text { DNTLD26 } & 20 \pm 4 & 25 \pm 5 & 27 \pm 6 & 20 \pm 7 & 23 \pm 6 \\ \text { DNTLD27 } & 17 \pm 4 & 22 \pm 5 & 23 \pm 5 & 18 \pm 6 & 20 \pm 5 \\ \text { DNTLD28 } & 19 \pm 4 & 24 \pm 5 & 25 \pm 5 & 20 \pm 7 & 22 \pm 5 \\ \text { DNTLD29 } & 19 \pm 4 & 23 \pm 5 & 28 \pm 6 & 19 \pm 7 & 22 \pm 5 \\ \text { DNTLD30 } & 20 \pm 4 & 24 \pm 5 & 27 \pm 6 & 21 \pm 7 & 23 \pm 6 \\ \text { DNTLD31 } & 18 \pm 4 & 20 \pm 4 & \mathrm{NA} & \mathrm{NA} & 19 \pm 3 \\ \text { DNTLD32 } & 26 \pm 5 & 30 \pm 6 & \mathrm{NA} & \mathrm{NA} & 28 \pm 4 \\ \text { DNTLD33 } & 27 \pm 6 & 31 \pm 6 & 33 \pm 7 & 28 \pm 8 & 30 \pm 7 \\ \text { DNTLD34 } & 45 \pm 9 & 48 \pm 10 & \mathrm{NA} & \mathrm{NA} & 47 \pm 7 \\ \text { DNTLD35 } & 76 \pm 15 & 78 \pm 15 & 86 \pm 17 & 77 \pm 16 & 79 \pm 16 \\ \text { DNTLD36 } & 56 \pm 11 & 58 \pm 12 & 68 \pm 14 & 88 \pm 18 & 68 \pm 14 \\ \text { DNTLD38 } & 32 \pm 7 & 36 \pm 7 & 44 \pm 9 & 36 \pm 9 & 37 \pm 8 \\ \text { DNTLD39 } & 45 \pm 9 & 51 \pm 10 & 57 \pm 11 & 47 \pm 11 & 50 \pm 10 \\ \text { DNTLD40 } & 108 \pm 21 & 111 \pm 22 & 115 \pm 23 & 110 \pm 22 & 111 \pm 22 \\ \text { DNTLD42 } & 70 \pm 14 & 73 \pm 14 & 72 \pm 14 & 71 \pm 15 & 72 \pm 14 \\ \text { DNTLD43 } & 27 \pm 6 & 30 \pm 6 & 33 \pm 7 & 27 \pm 8 & 29 \pm 7\end{array}$

NA - Sampling was discontinued at these on-site TLD locations.

${ }^{a}$ On-site locations are shown on Figure A-12.

Conversion factor: Milliroentgen $(m R)$ units are used to report exposure rates in air. To convert $m R$ to mrem (dose to humans), a conversion factor of 1.03 must be applied. For example, a reported exposure rate of $18.1 \mathrm{mR/}$ quarter would be equivalent to $18.6 \mathrm{mrem} / q u a r t e r$ (based upon dose-equivalent phantom calibration using cesium-137).

$H-4$ 
Table $\mathrm{H}-3$

Third-Quarter 2005 TLD Results and Instantaneous Exposure Rate Readings With a High-Pressure Ion Chamber (HPIC) at Each Monitoring Location

\begin{tabular}{|c|c|c|c|c|c|}
\hline $\begin{array}{l}\text { Off-Site } \\
\text { Location } \\
\text { Number }\end{array}$ & $\begin{array}{c}\text { 3rd-Quarter } \\
\text { TLD Result } \\
(\mu \mathrm{R} / \mathrm{hr})\end{array}$ & $\begin{array}{c}\text { 3rd-Quarter } \\
\text { HPIC Result } \\
\quad(\mu \mathrm{R} / \mathrm{hr})\end{array}$ & $\begin{array}{l}\text { On-Site } \\
\text { Location } \\
\text { Number }\end{array}$ & $\begin{array}{c}\text { 3rd-Quarter } \\
\text { TLD Result } \\
(\mu \mathrm{R} / \mathrm{hr})\end{array}$ & $\begin{array}{c}\text { 3rd-Quarte } \\
\text { HPIC Resu } \\
\qquad(\mu \mathrm{R} / \mathrm{hr})\end{array}$ \\
\hline DFTLD01 & 9.9 & 9.2 & DNTLD19 & 10.9 & 9.7 \\
\hline DFTLD02 & 10.8 & 9.0 & DNTLD24 & 220.1 & 313.7 \\
\hline DFTLD03 & 9.0 & 9.0 & DNTLD25 & 12.1 & 11.5 \\
\hline DFTLD04 & 10.0 & 8.8 & DNTLD26 & 12.1 & 10.7 \\
\hline DFTLD05 & 11.0 & 9.2 & DNTLD27 & 10.6 & 9.4 \\
\hline DFTLD06 & 9.5 & 9.1 & DNTLD28 & 11.1 & 10.1 \\
\hline DFTLD07 & 8.1 & 8.4 & DNTLD29 & 12.9 & 10.7 \\
\hline DFTLD08 & 10.0 & 7.5 & DNTLD30 & 12.2 & 11.9 \\
\hline DFTLD09 & 10.2 & 9.7 & DNTLD33 & 14.8 & 14.3 \\
\hline DFTLD10 & 10.3 & 8.6 & DNTLD35 & 38.9 & 42.1 \\
\hline DFTLD11 & 9.1 & 7.9 & DNTLD36 & 30.8 & 37.8 \\
\hline DFTLD12 & 9.6 & 9.1 & DNTLD38 & 19.9 & 24.6 \\
\hline DFTLD13 & 11.5 & 9.2 & DNTLD39 & 25.8 & 25.0 \\
\hline DFTLD14 & 9.9 & 9.1 & DNTLD40 & 51.9 & 57.1 \\
\hline DFTLD15 & 10.6 & 8.6 & DNTLD42 & 32.7 & 27.3 \\
\hline DFTLD16 & 10.3 & 9.1 & DNTLD43 & 14.9 & 12.9 \\
\hline DFTLD20 & 8.0 & 8.5 & & & \\
\hline DFTLD21 & 11.6 & 9.0 & & & \\
\hline DFTLD22 & 11.1 & 9.2 & & & \\
\hline DFTLD23 & 10.4 & 8.5 & & & \\
\hline
\end{tabular}

$H-5$ 


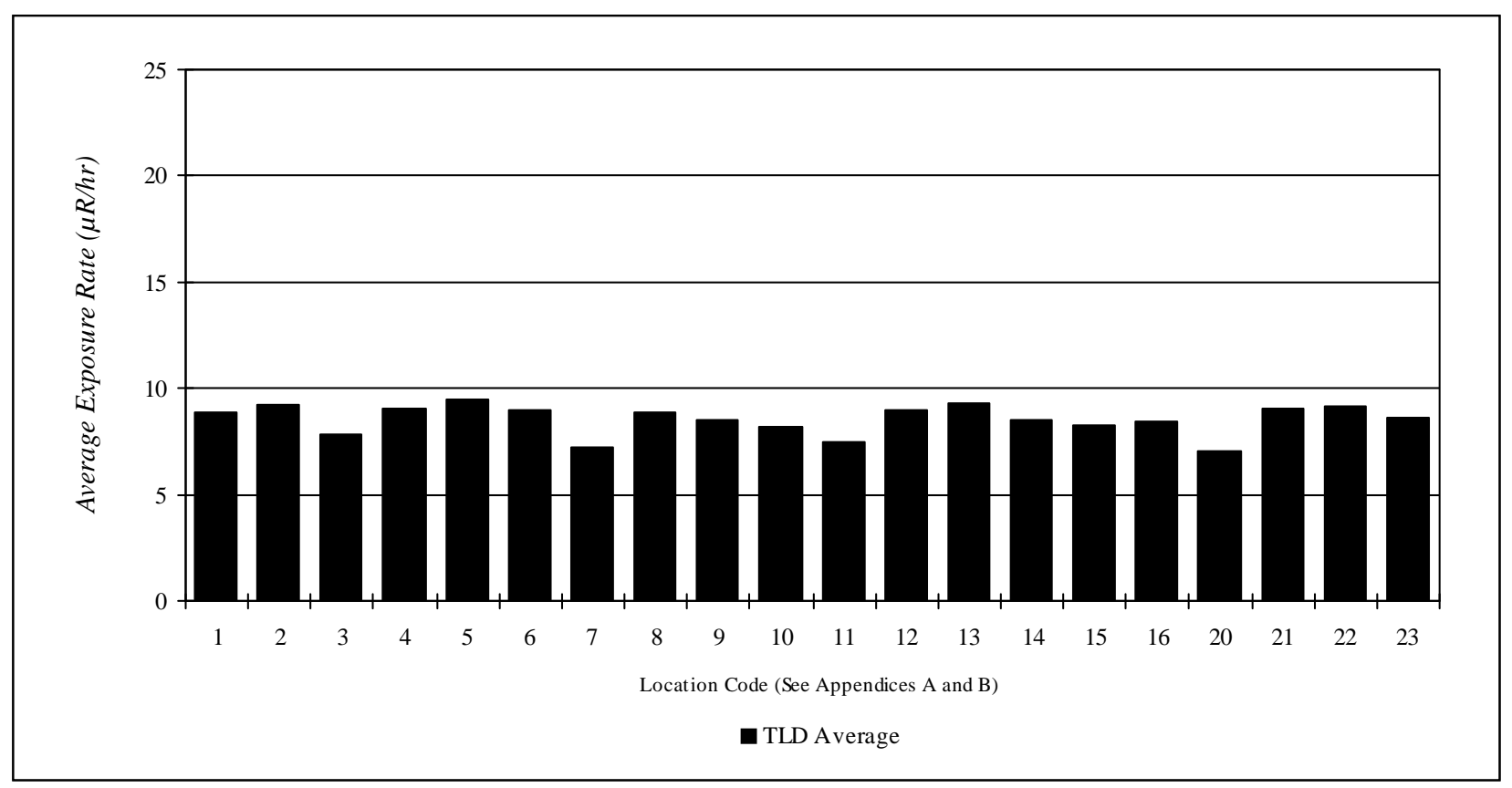

Figure H-1. 2005 Average Annual Gamma Exposure Rates Around the WVDP

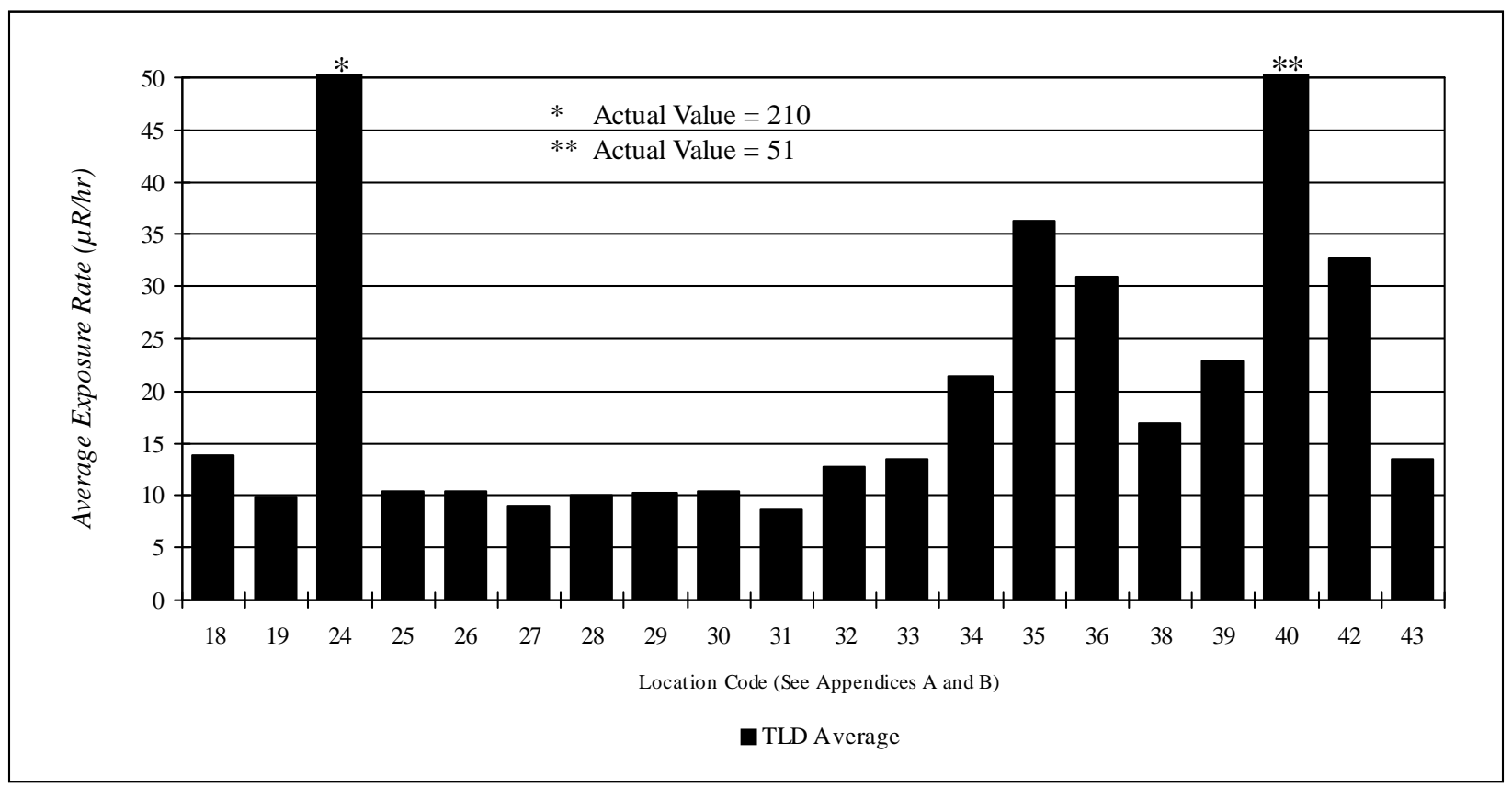

Figure H-2. 2005 Average Annual Gamma Exposure Rates on the WVDP

$$
H-6
$$




\section{Appendix I Summary of Meteorological Data}

$I-1$ 
This page intentionally left blank

$$
I-2
$$




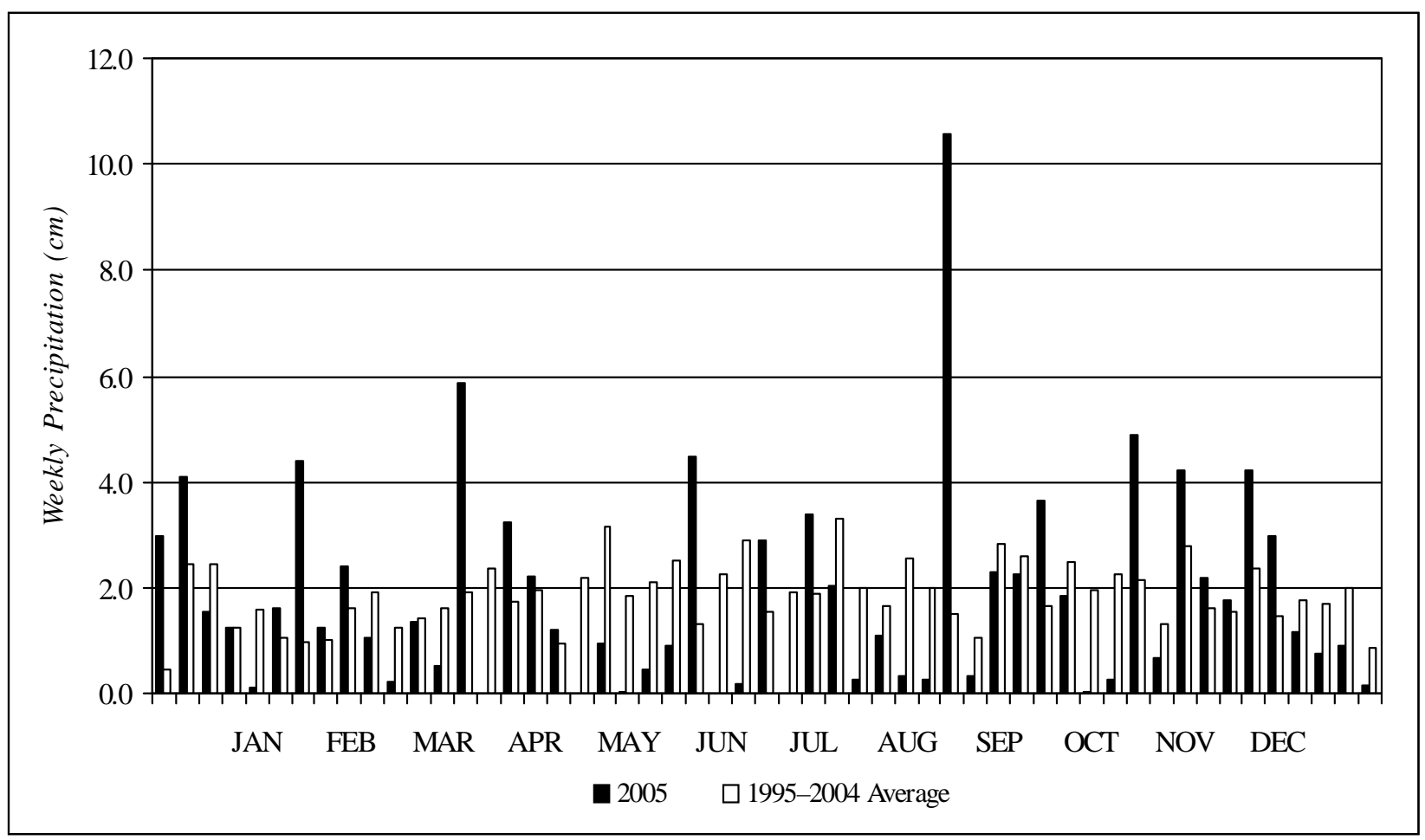

Figure I-1. Calendar Year 2005 Weekly Precipitation

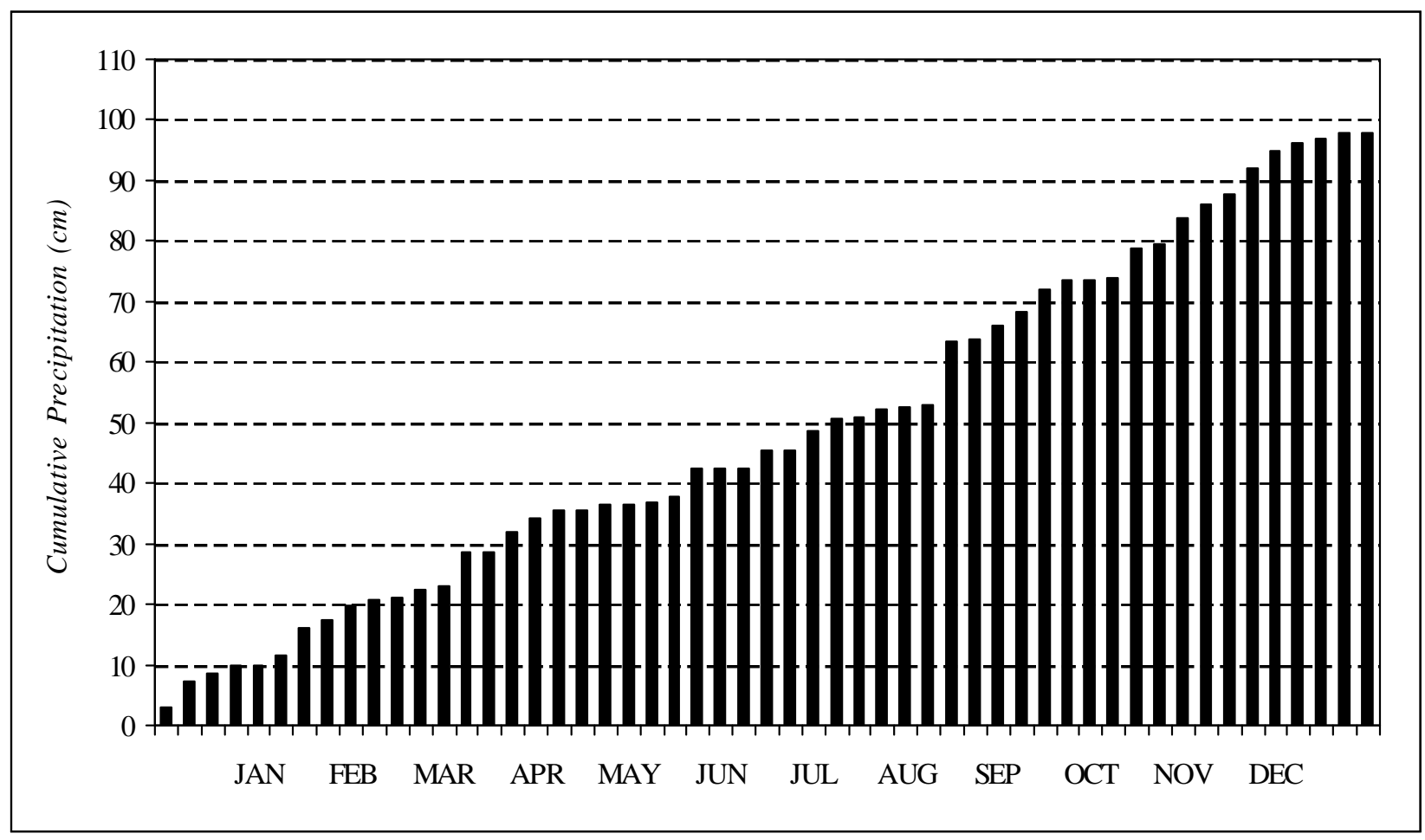

Figure I-2. Calendar Year 2005 Cumulative Precipitation

$$
I-3
$$


Table I-1

2005 Site Precipitation Collection Data

\begin{tabular}{|c|c|c|c|c|c|c|c|c|c|}
\hline \multirow{2}{*}{$\begin{array}{l}\text { Week } \\
\text { Ending: }\end{array}$} & \multicolumn{2}{|c|}{ Weekly } & \multicolumn{2}{|c|}{ Cumulative } & \multirow{2}{*}{$\begin{array}{l}\text { Week } \\
\text { Ending: }\end{array}$} & \multicolumn{2}{|c|}{ Weekly } & \multicolumn{2}{|c|}{ Cumulative } \\
\hline & $(\mathrm{cm})$ & (inches) & $(\mathrm{cm})$ & (inches) & & $(\mathrm{cm})$ & (inches) & $(\mathrm{cm})$ & (inches) \\
\hline Jan 07 & 2.97 & 1.17 & 2.97 & 1.17 & Jul 08 & 2.90 & 1.14 & 45.31 & 17.84 \\
\hline Jan 14 & 4.11 & 1.62 & 7.09 & 2.79 & Jul 15 & 0.00 & 0.00 & 45.31 & 17.84 \\
\hline Jan 21 & 1.55 & 0.61 & 8.64 & 3.40 & Jul 22 & 3.38 & 1.33 & 48.69 & 19.17 \\
\hline Jan 28 & 1.24 & 0.49 & 9.88 & 3.89 & Jul 29 & 2.03 & 0.80 & 50.72 & 19.97 \\
\hline Feb 04 & 0.13 & 0.05 & 10.01 & 3.94 & Aug 05 & 0.25 & 0.10 & 50.98 & 20.07 \\
\hline Feb 11 & 1.60 & 0.63 & 11.61 & 4.57 & Aug 12 & 1.09 & 0.43 & 52.07 & 20.50 \\
\hline Feb 18 & 4.42 & 1.74 & 16.03 & 6.31 & Aug 19 & 0.36 & 0.14 & 52.43 & 20.64 \\
\hline Feb 25 & 1.24 & 0.49 & 17.27 & 6.80 & Aug 26 & 0.28 & 0.11 & 52.71 & 20.75 \\
\hline Mar 04 & 2.41 & 0.95 & 19.69 & 7.75 & Sep 02 & 10.57 & 4.16 & 63.27 & 24.91 \\
\hline Mar 11 & 1.07 & 0.42 & 20.75 & 8.17 & Sep 09 & 0.36 & 0.14 & 63.63 & 25.05 \\
\hline Mar 18 & 0.23 & 0.09 & 20.98 & 8.26 & Sep 16 & 2.29 & 0.90 & 65.91 & 25.95 \\
\hline Mar 25 & 1.35 & 0.53 & 22.33 & 8.79 & Sep 23 & 2.26 & 0.89 & 68.17 & 26.84 \\
\hline Apr 01 & 0.51 & 0.20 & 22.83 & 8.99 & Sep 30 & 3.66 & 1.44 & 71.83 & 28.28 \\
\hline Apr 08 & 5.87 & 2.31 & 28.70 & 11.30 & Oct 07 & 1.83 & 0.72 & 73.66 & 29.00 \\
\hline Apr 15 & 0.00 & 0.00 & 28.70 & 11.30 & Oct 14 & 0.05 & 0.02 & 73.71 & 29.02 \\
\hline Apr 22 & 3.25 & 1.28 & 31.95 & 12.58 & Oct 21 & 0.25 & 0.10 & 73.96 & 29.12 \\
\hline Apr 29 & 2.24 & 0.88 & 34.19 & 13.46 & Oct 28 & 4.90 & 1.93 & 78.87 & 31.05 \\
\hline May 06 & 1.22 & 0.48 & 35.41 & 13.94 & Nov 04 & 0.69 & 0.27 & 79.55 & 31.32 \\
\hline May 13 & 0.00 & 0.00 & 35.41 & 13.94 & Nov 11 & 4.22 & 1.66 & 83.77 & 32.98 \\
\hline May 20 & 0.94 & 0.37 & 36.35 & 14.31 & Nov 18 & 2.18 & 0.86 & 85.95 & 33.84 \\
\hline May 27 & 0.03 & 0.01 & 36.37 & 14.32 & Nov 25 & 1.75 & 0.69 & 87.71 & 34.53 \\
\hline Jun 03 & 0.46 & 0.18 & 36.83 & 14.50 & Dec 02 & 4.22 & 1.66 & 91.92 & 36.19 \\
\hline Jun 10 & 0.91 & 0.36 & 37.74 & 14.86 & Dec 09 & 2.97 & 1.17 & 94.89 & 37.36 \\
\hline Jun 17 & 4.47 & 1.76 & 42.21 & 16.62 & Dec 16 & 1.17 & 0.46 & 96.06 & 37.82 \\
\hline Jun 24 & 0.00 & 0.00 & 42.21 & 16.62 & Dec 23 & 0.74 & 0.29 & 96.80 & 38.11 \\
\hline Jul 01 & 0.20 & 0.08 & 42.42 & 16.70 & Dec 30 & 0.89 & 0.35 & 97.69 & 38.46 \\
\hline & & & & & Dec 31 & 0.15 & 0.06 & 97.84 & 38.52 \\
\hline
\end{tabular}

$$
I-4
$$




\section{Appendix $J$ \\ Summary of Quality Assurance Crosscheck Analyses}

$$
J-1
$$


This page intentionally left blank

$$
J-2
$$


Table J-1

Crosscheck Sample Comparisons From the DOE Mixed Analyte Performance Evaluation Program (MAPEP) ; Study 13; May 2005

\begin{tabular}{|c|c|c|c|c|c|c|c|}
\hline Analyte & Matrix & Units & Actual & Reported & $\begin{array}{c}\text { Acceptance } \\
\text { Range }\end{array}$ & Accept? & $\begin{array}{c}\text { Analyzed } \\
\text { by: }\end{array}$ \\
\hline \multicolumn{8}{|c|}{ MAPEP - 05 - GrF13 Gross Alpha/Beta Air Filter } \\
\hline Gross Alpha & Air Filter & $\mathrm{Bq} / \mathrm{sample}$ & 0.232 & 0.0730 & $0.000-0.464$ & Yes & ELAB \\
\hline Gross Beta & Air Filter & Bq/sample & 0.297 & 0.369 & $0.148-0.446$ & Yes & ELAB \\
\hline \multicolumn{8}{|c|}{ MAPEP - 05 - RdF13 Radiological Air Filter } \\
\hline Cs-137 & Air Filter & $\mathrm{Bq} / \mathrm{sample}$ & 2.26 & 2.24 & $1.58-2.94$ & Yes & ELAB \\
\hline Co-60 & Air Filter & Bq/sample & 3.03 & 3.04 & $2.12-3.94$ & Yes & ELAB \\
\hline Am-241 & Air Filter & Bq/sample & 0.102 & 0.102 & $0.07-0.13$ & Yes & GEL \\
\hline Cs-137 & Air Filter & Bq/sample & 2.26 & 2.277 & $1.58-2.94$ & Yes & GEL \\
\hline Co-60 & Air Filter & $\mathrm{Bq} / \mathrm{sample}$ & 3.03 & 3.190 & $2.12-3.94$ & Yes & GEL \\
\hline $\mathrm{Pu}-238$ & Air Filter & $\mathrm{Bq} /$ sample & 0.195 & 0.173 & $0.14-0.25$ & Yes & GEL \\
\hline $\mathrm{Pu}-239 / 240$ & Air Filter & $\mathrm{Bq} / \mathrm{sample}$ & 0.165 & 0.165 & $0.12-0.21$ & Yes & GEL \\
\hline Sr-90 & Air Filter & Bq/sample & 1.35 & 1.453 & $0.94-1.75$ & Yes & GEL \\
\hline $\mathrm{U}-233 / 234$ & Air Filter & Bq/sample & 0.34 & 0.336 & $0.24-0.44$ & Yes & GEL \\
\hline $\mathrm{U}-238$ & Air Filter & Bq/sample & 0.352 & 0.356 & $0.25-0.46$ & Yes & GEL \\
\hline \multicolumn{8}{|c|}{ MAPEP - 05 - GrW13 Gross Alpha/Beta Water Standard } \\
\hline Gross Alpha & Water & $\mathrm{Bq} / \mathrm{L}$ & 0.525 & 0.265 & $0.000-1.050$ & Yes & ELAB \\
\hline Gross Beta & Water & $\mathrm{Bq} / \mathrm{L}$ & 1.67 & 1.80 & $0.835-2.505$ & Yes & ELAB \\
\hline Gross Alpha & Water & $\mathrm{Bq} / \mathrm{L}$ & 0.525 & 0.291 & $0.000-1.050$ & Yes & GEL \\
\hline Gross Beta & Water & $\mathrm{Bq} / \mathrm{L}$ & 1.67 & 1.645 & $0.835-2.505$ & Yes & GEL \\
\hline \multicolumn{8}{|c|}{ MAPEP - 05 - MaW13 Water Standard - Radionuclides } \\
\hline Cs-137 & Water & $\mathrm{Bq} / \mathrm{L}$ & 332 & 319 & $232.40-431.60$ & Yes & ELAB \\
\hline Co-60 & Water & $\mathrm{Bq} / \mathrm{L}$ & 251 & 241 & $175.70-326.30$ & Yes & ELAB \\
\hline H-3 & Water & $\mathrm{Bq} / \mathrm{L}$ & 280 & 280 & $196.00-364.00$ & Yes & ELAB \\
\hline Sr-90 & Water & $\mathrm{Bq} / \mathrm{L}$ & $b$ & 0.132 & $b$ & Yes & ELAB \\
\hline Am-241 & Water & $\mathrm{Bq} / \mathrm{L}$ & 1.72 & 1.803 & $1.20-2.24$ & Yes & GEL \\
\hline Cs-137 & Water & $\mathrm{Bq} / \mathrm{L}$ & 332 & 318.0 & $232.40-431.60$ & Yes & GEL \\
\hline Co-60 & Water & $\mathrm{Bq} / \mathrm{L}$ & 251 & 247.3 & $175.70-326.30$ & Yes & GEL \\
\hline $\mathrm{H}-3$ & Water & $\mathrm{Bq} / \mathrm{L}$ & 280 & 279.7 & $196.00-364.00$ & Yes & GEL \\
\hline $\mathrm{Pu}-238$ & Water & $\mathrm{Bq} / \mathrm{L}$ & 0.018 & 0.016 & $b$ & Yes & GEL \\
\hline $\mathrm{Pu}-239 / 240$ & Water & $\mathrm{Bq} / \mathrm{L}$ & 2.4 & 2.400 & $1.68-3.12$ & Yes & GEL \\
\hline Sr-90 & Water & $\mathrm{Bq} / \mathrm{L}$ & $b$ & 0.14 & $b$ & Yes & GEL \\
\hline Tc-99 & Water & $\mathrm{Bq} / \mathrm{L}$ & 42.9 & 37.5 & $30.03-55.77$ & Yes & GEL \\
\hline U-233/234 & Water & $\mathrm{Bq} / \mathrm{L}$ & 3.24 & 3.273 & $2.27-4.21$ & Yes & GEL \\
\hline $\mathrm{U}-238$ & Water & $\mathrm{Bq} / \mathrm{L}$ & 3.33 & 3.400 & $2.33-4.33$ & Yes & GEL \\
\hline
\end{tabular}

ELAB - Environmental Laboratory

GEL - General Engineering Laboratory

Note: This report has been excerpted to include only those matrix/analyte combinations performed in support of the analyses of samples collected at the WVDP and which are presented in this Annual Site Environmental Report.

${ }^{a}$ MAPEP monitors performance and requests corrective action as required.

${ }^{b}$ Although no actual values or acceptable range was provided, the results were assessed by MAPEP as acceptable. 
Table J-1 (continued)

Crosscheck Sample Comparisons From the DOE Mixed Analyte Performance Evaluation Program (MAPEP) ; Study 13; May 2005

\begin{tabular}{|c|c|c|c|c|c|c|c|}
\hline Analyte & Matrix & Units & Actual & Reported & $\begin{array}{c}\text { Acceptance } \\
\text { Range }\end{array}$ & Accept? & $\begin{array}{c}\text { Analyzed } \\
\text { by: }\end{array}$ \\
\hline \multicolumn{8}{|c|}{ MAPEP - 05 - RdV13 Vegetation Standard } \\
\hline Cs-137 & Veg & Bq/sample & 4.11 & 3.45 & $2.88-5.34$ & Yes & GEL \\
\hline Sr-90 & Veg & Bq/sample & 1.65 & 1.89 & $1.15-2.14$ & Yes & GEL \\
\hline \multicolumn{8}{|c|}{ MAPEP - 05 - MaW13 Water Standard - Metals } \\
\hline Arsenic & Water & $\mathrm{mg} / \mathrm{L}$ & $b$ & 0.003 & $b$ & Yes & LVLI \\
\hline Barium & Water & $\mathrm{mg} / \mathrm{L}$ & 2.63 & 2.68 & $1.84-3.42$ & Yes & LVLI \\
\hline Beryllium & Water & $\mathrm{mg} / \mathrm{L}$ & 0.417 & 0.408 & $0.29-0.54$ & Yes & LVLI \\
\hline Cadmium & Water & $\mathrm{mg} / \mathrm{L}$ & 0.303 & 0.297 & $0.21-0.39$ & Yes & LVLI \\
\hline Chromium & Water & $\mathrm{mg} / \mathrm{L}$ & 1.67 & 1.83 & $1.17-2.17$ & Yes & LVLI \\
\hline Copper & Water & $\mathrm{mg} / \mathrm{L}$ & 1.92 & 1.95 & $1.34-2.50$ & Yes & LVLI \\
\hline Lead & Water & $\mathrm{mg} / \mathrm{L}$ & 1.21 & 1.2 & $0.85-1.57$ & Yes & LVLI \\
\hline Mercury & Water & $\mathrm{mg} / \mathrm{L}$ & 0.102 & 0.103 & $0.07-0.13$ & Yes & LVLI \\
\hline Nickel & Water & $\mathrm{mg} / \mathrm{L}$ & 0.968 & 0.963 & $0.68-1.26$ & Yes & LVLI \\
\hline Selenium & Water & $\mathrm{mg} / \mathrm{L}$ & 0.362 & 0.343 & $0.25-0.47$ & Yes & LVLI \\
\hline Vanadium & Water & $\mathrm{mg} / \mathrm{L}$ & 3.67 & 3.65 & $2.57-4.77$ & Yes & LVLI \\
\hline Zinc & Water & $\mathrm{mg} / \mathrm{L}$ & 1.33 & 1.3 & $0.93-1.73$ & Yes & LVLI \\
\hline \multicolumn{8}{|c|}{ MAPEP - 05 - OrW13 Water Standard - Organic Compounds } \\
\hline 1,3-Dichlorobenzene & Water & $\mu \mathrm{g} / \mathrm{L}$ & 30.7 & 37 & $6.94-54.53$ & Yes & LVLI \\
\hline 1,4-Dichlorobenzene & Water & $\mu \mathrm{g} / \mathrm{L}$ & 27.2 & 32 & $6.25-48.11$ & Yes & LVLI \\
\hline 2,4-Dimethylphenol & Water & $\mu \mathrm{g} / \mathrm{L}$ & 49.9 & 60 & $20.10-79.70$ & Yes & LVLI \\
\hline 1,2,4-Trichlorobenzene & Water & $\mu \mathrm{g} / \mathrm{L}$ & 31.5 & 35 & $9.07-53.95$ & Yes & LVLI \\
\hline Napthalene & Water & $\mu \mathrm{g} / \mathrm{L}$ & 37 & 42 & $13.02-61.02$ & Yes & LVLI \\
\hline Hexachlorobutadiene & Water & $\mu \mathrm{g} / \mathrm{L}$ & 28.8 & 34 & $2.31-55.20$ & Yes & LVLI \\
\hline 2-Methylphenol & Water & $\mu \mathrm{g} / \mathrm{L}$ & 41.5 & 59 & QL-110.80 & Yes & LVLI \\
\hline 2,6-Dichlorophenol & Water & $\mu \mathrm{g} / \mathrm{L}$ & 44.8 & 46 & $12.60-77.04$ & Yes & LVLI \\
\hline 2,6-Dinitrotoluene & Water & $\mu \mathrm{g} / \mathrm{L}$ & 55.9 & 58 & $19.02-92.73$ & Yes & LVLI \\
\hline 2,4-Dinitrotoluene & Water & $\mu \mathrm{g} / \mathrm{L}$ & 57.6 & 69 & $3.76-111.35$ & Yes & LVLI \\
\hline 4-Nitrophenol & Water & $\mu \mathrm{g} / \mathrm{L}$ & 50.8 & 74 & QL-133.57 & Yes & LVLI \\
\hline Diethylphthalate & Water & $\mu \mathrm{g} / \mathrm{L}$ & 53.4 & 57 & $23.70-83.14$ & Yes & LVLI \\
\hline Hexachlorobenzene & Water & $\mu \mathrm{g} / \mathrm{L}$ & 31.9 & 38 & QL-77.09 & Yes & LVLI \\
\hline Anthracene & Water & $\mu \mathrm{g} / \mathrm{L}$ & 41.3 & 54 & QL-106.29 & Yes & LVLI \\
\hline 1,3-Dinitrobenzene & Water & $\mu \mathrm{g} / \mathrm{L}$ & 50.5 & 58 & QL-109.67 & Yes & LVLI \\
\hline Pyrene & Water & $\mu \mathrm{g} / \mathrm{L}$ & 42.1 & 56 & QL-109.11 & Yes & LVLI \\
\hline Benzo(a)anthracene & Water & $\mu \mathrm{g} / \mathrm{L}$ & 27.3 & 34 & QL-67.32 & Yes & LVLI \\
\hline
\end{tabular}

GEL - General Engineering Laboratories

LVLI - Lionville Laboratories, Inc.

QL - Quantitation Limit

Note: This report has been excerpted to include only those matrix/analyte combinations performed in support of the analyses of samples collected at the WVDP and which are presented in this Annual Site Environmental Report.

${ }^{a}$ MAPEP monitors performance and requests corrective action as required.

${ }^{b}$ Although no actual values or acceptable range was provided, the results were assessed by MAPEP as acceptable. 
Table J-1 (concluded)

Crosscheck Sample Comparisons From the DOE Mixed Analyte Performance Evaluation Program (MAPEP) ; Study 13; May 2005

\begin{tabular}{|c|c|c|c|c|c|c|c|}
\hline Analyte & Matrix & Units & Actual & Reported & $\begin{array}{c}\text { Acceptance } \\
\text { Range }\end{array}$ & Accept? & $\begin{array}{c}\text { Analyzed } \\
\text { by: }\end{array}$ \\
\hline \multicolumn{8}{|c|}{ MAPEP - 05 - MaS13 Soil Standard - Metals } \\
\hline Antimony & Soil & $\mathrm{mg} / \mathrm{kg}$ & 30.9 & 13.5 & $21.63-40.17$ & No & LVLI \\
\hline Arsenic & Soil & $\mathrm{mg} / \mathrm{kg}$ & 51.9 & 47.9 & $36.33-67.47$ & Yes & LVLI \\
\hline Barium & Soil & $\mathrm{mg} / \mathrm{kg}$ & 792 & 785 & $554.40-1,029.60$ & Yes & LVLI \\
\hline Beryllium & Soil & $\mathrm{mg} / \mathrm{kg}$ & 10.3 & 10.5 & 7.21-13.39 & Yes & LVLI \\
\hline Cadmium & Soil & $\mathrm{mg} / \mathrm{kg}$ & 13.2 & 11.7 & $9.24-17.16$ & Yes & LVLI \\
\hline Chromium & Soil & $\mathrm{mg} / \mathrm{kg}$ & 57.2 & 64.8 & $40.04-74.36$ & Yes & LVLI \\
\hline Lead & Soil & $\mathrm{mg} / \mathrm{kg}$ & 69.0 & 65.1 & $48.30-89.70$ & Yes & LVLI \\
\hline Mercury & Soil & $\mathrm{mg} / \mathrm{kg}$ & 0.437 & 0.45 & $0.31-0.57$ & Yes & LVLI \\
\hline Nickel & Soil & $\mathrm{mg} / \mathrm{kg}$ & 144 & 141 & $100.80-187.20$ & Yes & LVLI \\
\hline Silver & Soil & $\mathrm{mg} / \mathrm{kg}$ & 43.1 & 42.4 & $30.17-56.03$ & Yes & LVLI \\
\hline Thallium & Soil & $\mathrm{mg} / \mathrm{kg}$ & 61.8 & 52.7 & $43.26-80.34$ & Yes & LVLI \\
\hline Vanadium & Soil & $\mathrm{mg} / \mathrm{kg}$ & 92.7 & 84.1 & $64.89-120.51$ & Yes & LVLI \\
\hline Zinc & Soil & $\mathrm{mg} / \mathrm{kg}$ & 200 & 193 & $140.00-260.00$ & Yes & LVLI \\
\hline
\end{tabular}

LVLI - Lionville Laboratories, Inc.

Note: This report has been excerpted to include only those matrix/analyte combinations performed in support of the analyses of samples collected at the WVDP and which are presented in this Annual Site Environmental Report.

${ }^{a}$ MAPEP monitors performance and requests corrective action as required.

$$
J-5
$$


Table J-2

\section{Crosscheck Sample Comparisons From the DOE Mixed Analyte Performance Evaluation Program (MAPEP); Study 14; November 2005}

\begin{tabular}{|c|c|c|c|c|c|c|c|}
\hline Analyte & Matrix & Units & Actual & Reported & $\begin{array}{c}\text { Acceptance } \\
\text { Range }\end{array}$ & Accept? & $\begin{array}{c}\text { Analyzed } \\
\text { by: }\end{array}$ \\
\hline \multicolumn{8}{|c|}{ MAPEP - 05 - GrF14 Gross AIpha/Beta Air Filter } \\
\hline Gross Alpha & Air Filter & $\mathrm{Bq} / \mathrm{sample}$ & 0.482 & 0.204 & $-0.17-0.80$ & Yes & ELAB \\
\hline Gross Beta & Air Filter & $\mathrm{Bq} / \mathrm{sample}$ & 0.827 & 0.899 & $0.55-1.22$ & Yes & ELAB \\
\hline \multicolumn{8}{|c|}{ MAPEP - 05 - RdF14 Radiological Air Filter } \\
\hline Cs-137 & Air Filter & $\mathrm{Bq} / \mathrm{sample}$ & 3.23 & 3.03 & $2.26-4.20$ & Yes & ELAB \\
\hline Co-60 & Air Filter & $\mathrm{Bq} / \mathrm{sample}$ & 2.85 & 2.66 & $1.99-3.70$ & Yes & ELAB \\
\hline Am-241 & Air Filter & $\mathrm{Bq} / \mathrm{sample}$ & 0.158 & 0.164 & $0.11-0.21$ & Yes & GEL \\
\hline Cs-137 & Air Filter & $\mathrm{Bq} / \mathrm{sample}$ & 3.23 & 3.113 & $2.26-4.20$ & Yes & GEL \\
\hline Co-60 & Air Filter & $\mathrm{Bq} / \mathrm{sample}$ & 2.85 & 2.867 & $1.99-3.70$ & Yes & GEL \\
\hline $\mathrm{Pu}-238$ & Air Filter & $\mathrm{Bq} / \mathrm{sample}$ & 0.0969 & 0.093 & $0.07-0.13$ & Yes & GEL \\
\hline $\mathrm{Pu}-239 / 240$ & Air Filter & Bq/sample & 0.0898 & 0.079 & $0.06-0.12$ & Yes & GEL \\
\hline Sr-90 & Air Filter & Bq/sample & 2.25 & 2.465 & $1.58-2.92$ & Yes & GEL \\
\hline U-233/234 & Air Filter & $\mathrm{Bq} / \mathrm{sample}$ & 0.273 & 0.280 & $0.19-0.35$ & Yes & GEL \\
\hline $\mathrm{U}-238$ & Air Filter & Bq/sample & 0.283 & 0.281 & $0.20-0.37$ & Yes & GEL \\
\hline \multicolumn{8}{|c|}{ MAPEP - 05 - GrW14 Gross Alpha/Beta Water Standard } \\
\hline Gross Alpha & Water & $\mathrm{Bq} / \mathrm{L}$ & 0.790 & 0.845 & $0.21-1.38$ & Yes & ELAB \\
\hline Gross Beta & Water & $\mathrm{Bq} / \mathrm{L}$ & 1.350 & 1.50 & $0.85-1.92$ & Yes & ELAB \\
\hline Gross Alpha & Water & $\mathrm{Bq} / \mathrm{L}$ & 0.790 & 0.673 & $0.21-1.38$ & Yes & GEL \\
\hline Gross Beta & Water & $\mathrm{Bq} / \mathrm{L}$ & 1.350 & 1.343 & $0.85-1.92$ & Yes & GEL \\
\hline \multicolumn{8}{|c|}{ MAPEP - 05 - MaW14 Water Standard } \\
\hline Cs-137 & Water & $\mathrm{Bq} / \mathrm{L}$ & 333 & 316 & $233.10-432.90$ & Yes & ELAB \\
\hline Co-60 & Water & $\mathrm{Bq} / \mathrm{L}$ & 261 & 254 & $182.70-339.30$ & Yes & ELAB \\
\hline $\mathrm{H}-3$ & Water & $\mathrm{Bq} / \mathrm{L}$ & 527 & 530 & $368.90-685.10$ & Yes & ELAB \\
\hline Sr-90 & Water & $\mathrm{Bq} / \mathrm{L}$ & 8.98 & 8.39 & $6.29-11.67$ & Yes & ELAB \\
\hline Am-241 & Water & $\mathrm{Bq} / \mathrm{L}$ & 2.23 & 1.987 & $1.56-2.90$ & Yes & GEL \\
\hline Cs-137 & Water & $\mathrm{Bq} / \mathrm{L}$ & 333 & 315.0 & $233.10-432.90$ & Yes & GEL \\
\hline Co-60 & Water & $\mathrm{Bq} / \mathrm{L}$ & 261 & 257.0 & $182.70-339.30$ & Yes & GEL \\
\hline $\mathrm{H}-3$ & Water & $\mathrm{Bq} / \mathrm{L}$ & 527 & 512.7 & $368.90-685.10$ & Yes & GEL \\
\hline $\mathrm{Pu}-238$ & Water & $\mathrm{Bq} / \mathrm{L}$ & 1.67 & 1.523 & $1.34-2.48$ & Yes & GEL \\
\hline $\mathrm{Pu}-239 / 240$ & Water & $\mathrm{Bq} / \mathrm{L}$ & 2.45 & 2.273 & $1.92-3.58$ & Yes & GEL \\
\hline Sr-90 & Water & $\mathrm{Bq} / \mathrm{L}$ & 8.98 & 7.42 & $6.29-11.67$ & Yes & GEL \\
\hline Tc-99 & Water & $\mathrm{Bq} / \mathrm{L}$ & 66.5 & 65.1 & $46.55-86.45$ & Yes & GEL \\
\hline $\mathrm{U}-233 / 234$ & Water & $\mathrm{Bq} / \mathrm{L}$ & 4.1 & 4.033 & $2.87-5.33$ & Yes & GEL \\
\hline $\mathrm{U}-238$ & Water & $\mathrm{Bq} / \mathrm{L}$ & 4.26 & 4.197 & $2.98-5.54$ & Yes & GEL \\
\hline \multicolumn{8}{|c|}{ MAPEP - 05 - RdV14 Vegetation Standard } \\
\hline Cs-137 & Veg & $\mathrm{Bq} /$ sample & 5.43 & 2.853 & $3.80-7.06$ & No & GEL \\
\hline Sr-90 & Veg & $\mathrm{Bq} / \mathrm{sample}$ & 2.42 & 2.030 & $1.69-3.15$ & Yes & GEL \\
\hline
\end{tabular}

ELAB - Environmental Laboratory

GEL - General Engineering Laboratories

Note: This report has been excerpted to include only those matrix/analyte combinations performed in support of the analyses of samples collected at the WVDP and which are presented in this Annual Site Environmental Report.

${ }^{a}$ MAPEP monitors performance and requests corrective action as required. 
Table J-2 (continued)

\section{Crosscheck Sample Comparisons From the DOE Mixed Analyte Performance Evaluation Program (MAPEP); Study 14; November 2005}

\begin{tabular}{|c|c|c|c|c|c|c|c|}
\hline Analyte & Matrix & Units & Actual & Reported & $\begin{array}{l}\text { Acceptance } \\
\text { Range }\end{array}$ & Accept? & $\begin{array}{l}\text { Analyzed } \\
\text { by: }\end{array}$ \\
\hline \multicolumn{8}{|c|}{ MAPEP - 05 - MaW14 Water Standard - Metals } \\
\hline Antimony & Water & $\mathrm{mg} / \mathrm{L}$ & 1.77 & 1.8 & $1.24-2.30$ & Yes & LVLI \\
\hline Arsenic & Water & $\mathrm{mg} / \mathrm{L}$ & 2.04 & 2.1 & $1.43-2.65$ & Yes & LVLI \\
\hline Barium & Water & $\mathrm{mg} / \mathrm{L}$ & 16.34 & 16.4 & $11.44-21.24$ & Yes & LVLI \\
\hline Beryllium & Water & $\mathrm{mg} / \mathrm{L}$ & 1.276 & 1.3 & $0.89-1.66$ & Yes & LVLI \\
\hline Cadmium & Water & $\mathrm{mg} / \mathrm{L}$ & ${ }^{b}$ & $<0.00030$ & $b$ & Yes & LVLI \\
\hline Chromium & Water & $\mathrm{mg} / \mathrm{L}$ & 1.27 & 1.3 & $0.89-1.65$ & Yes & LVLI \\
\hline Copper & Water & $\mathrm{mg} / \mathrm{L}$ & 3.80 & 3.8 & $2.66-4.94$ & Yes & LVLI \\
\hline Lead & Water & $\mathrm{mg} / \mathrm{L}$ & $b$ & $<0.0025$ & $b$ & Yes & LVLI \\
\hline Mercury & Water & $\mathrm{mg} / \mathrm{L}$ & 0.00885 & 0.0080 & $0.01-0.01$ & Yes & LVLI \\
\hline Nickel & Water & $\mathrm{mg} / \mathrm{L}$ & 1.457 & 1.5 & $1.02-1.89$ & Yes & LVLI \\
\hline Selenium & Water & $\mathrm{mg} / \mathrm{L}$ & 0.443 & 0.45 & $0.31-0.58$ & Yes & LVLI \\
\hline Silver & Water & $\mathrm{mg} / \mathrm{L}$ & $b$ & 0.0023 & $b$ & Yes & LVLI \\
\hline Thallium & Water & $\mathrm{mg} / \mathrm{L}$ & 4.97 & 5.1 & $3.48-6.46$ & Yes & LVLI \\
\hline Vanadium & Water & $\mathrm{mg} / \mathrm{L}$ & 0.876 & 0.89 & $0.61-1.14$ & Yes & LVLI \\
\hline Zinc & Water & $\mathrm{mg} / \mathrm{L}$ & 4.57 & 4.5 & $3.20-5.94$ & Yes & LVLI \\
\hline \multicolumn{8}{|c|}{ MAPEP - 05 - OrW14 Water Standard - Organic Compounds } \\
\hline 2-Chlorophenol & Water & $\mu \mathrm{g} / \mathrm{L}$ & 81.4 & 85 & $17.50-145.33$ & Yes & LVLI \\
\hline 1,3-Dichlorobenzene & Water & $\mu \mathrm{g} / \mathrm{L}$ & 34.2 & 39 & $7.93-60.51$ & Yes & LVLI \\
\hline Hexachloroethane & Water & $\mu \mathrm{g} / \mathrm{L}$ & 39.5 & 43 & $8.78-70.19$ & Yes & LVLI \\
\hline Nitrobenzene & Water & $\mu \mathrm{g} / \mathrm{L}$ & 52.2 & 51 & $17.19-87.18$ & Yes & LVLI \\
\hline 2,4-Dimethylphenol & Water & $\mu \mathrm{g} / \mathrm{L}$ & 70.8 & 74 & $25.44-116.24$ & Yes & LVLI \\
\hline 1,2,4-Trichlorobenzene & Water & $\mu \mathrm{g} / \mathrm{L}$ & 38.5 & 41 & $9.57-67.39$ & Yes & LVLI \\
\hline Napthalene & Water & $\mu \mathrm{g} / \mathrm{L}$ & 41.9 & 43 & $15.60-68.28$ & Yes & LVLI \\
\hline Hexachlorobutadiene & Water & $\mu \mathrm{g} / \mathrm{L}$ & 41.2 & 49 & $2.66-80.89$ & Yes & LVLI \\
\hline 2-Methylphenol & Water & $\mu \mathrm{g} / \mathrm{L}$ & 63.2 & 68 & $6.47-119.98$ & Yes & LVLI \\
\hline 2,6-Dichlorophenol & Water & $\mu \mathrm{g} / \mathrm{L}$ & 50.5 & 50 & $15.21-85.75$ & Yes & LVLI \\
\hline 2,6-Dinitrotoluene & Water & $\mu \mathrm{g} / \mathrm{L}$ & 48.3 & 50 & $20.16-76.44$ & Yes & LVLI \\
\hline 2,4-Dinitrotoluene & Water & $\mu \mathrm{g} / \mathrm{L}$ & 94.1 & 100 & $34.65-153.47$ & Yes & LVLI \\
\hline Diethylphthalate & Water & $\mu \mathrm{g} / \mathrm{L}$ & 53.5 & 55 & $27.29-79.77$ & Yes & LVLI \\
\hline Hexachlorobenzene & Water & $\mu \mathrm{g} / \mathrm{L}$ & 35.7 & 43 & QL-110.16 & Yes & LVLI \\
\hline Anthracene & Water & $\mu \mathrm{g} / \mathrm{L}$ & 34.9 & 42 & QL-110.34 & Yes & LVLI \\
\hline 1,3-Dinitrobenzene & Water & $\mu \mathrm{g} / \mathrm{L}$ & 39.1 & 41 & $2.53-75.62$ & Yes & LVLI \\
\hline Fluoranthene & Water & $\mu \mathrm{g} / \mathrm{L}$ & 37.6 & 49 & QL-95.13 & Yes & LVLI \\
\hline Pyrene & Water & $\mu \mathrm{g} / \mathrm{L}$ & 31.1 & 36 & QL-89.40 & Yes & LVLI \\
\hline Benzo(a)anthracene & Water & $\mu \mathrm{g} / \mathrm{L}$ & 28.9 & 32 & QL-79.44 & Yes & LVLI \\
\hline
\end{tabular}

LVLI - Lionville Laboratories, Inc.

QL - Quantitation limit

Note: This report has been excerpted to include only those matrix/analyte combinations performed in support of the analyses of samples collected at the WVDP and which are presented in this Annual Site Environmental Report.

${ }^{a}$ MAPEP monitors performance and requests corrective action as required.

${ }^{b}$ Although no actual value or acceptance range was provided, the results were assessed by MAPEP as acceptable. 
Table J-2 (concluded)

\section{Crosscheck Sample Comparisons From the DOE Mixed Analyte Performance Evaluation Program (MAPEP); Study 14; November 2005}

\begin{tabular}{|c|c|c|c|c|c|c|c|}
\hline Analyte & Matrix & Units & Actual & Reported & $\begin{array}{c}\text { Acceptance } \\
\text { Range }\end{array}$ & Accept? & $\begin{array}{l}\text { Analyzed } \\
\text { by: }\end{array}$ \\
\hline \multicolumn{8}{|c|}{ MAPEP - 05 - MaS14 Soil Standard } \\
\hline Antimony & Soil & $\mathrm{mg} / \mathrm{kg}$ & 51 & 49.8 & $35.70-66.30$ & No & LVLI \\
\hline Arsenic & Soil & $\mathrm{mg} / \mathrm{kg}$ & 38.7 & 42.0 & $27.09-50.31$ & Yes & LVLI \\
\hline Barium & Soil & $\mathrm{mg} / \mathrm{kg}$ & 400 & 445 & $280.00-520.00$ & Yes & LVLI \\
\hline Beryllium & Soil & $\mathrm{mg} / \mathrm{kg}$ & 29.1 & 31.8 & $20.37-37.83$ & Yes & LVLI \\
\hline Cadmium & Soil & $\mathrm{mg} / \mathrm{kg}$ & 6.8 & 7.1 & $4.76-8.84$ & Yes & LVLI \\
\hline Chromium & Soil & $\mathrm{mg} / \mathrm{kg}$ & 34.1 & 40.9 & $23.87-44.33$ & Yes & LVLI \\
\hline Copper & Soil & $\mathrm{mg} / \mathrm{kg}$ & 22 & 20.5 & $b$ & Yes & LVLI \\
\hline Lead & Soil & $\mathrm{mg} / \mathrm{kg}$ & 41 & 42.9 & $28.70-53.30$ & Yes & LVLI \\
\hline Mercury & Soil & $\mathrm{mg} / \mathrm{kg}$ & 1.53 & 1.5 & $1.07-1.99$ & Yes & LVLI \\
\hline Nickel & Soil & $\mathrm{mg} / \mathrm{kg}$ & 71 & 76.4 & $49.70-92.30$ & Yes & LVLI \\
\hline Selenium & Soil & $\mathrm{mg} / \mathrm{kg}$ & 15.01 & 16.5 & $10.51-19.51$ & Yes & LVLI \\
\hline Silver & Soil & $\mathrm{mg} / \mathrm{kg}$ & $b$ & 0.13 & $b$ & Yes & LVLI \\
\hline Thallium & Soil & $\mathrm{mg} / \mathrm{kg}$ & $b$ & $<0.75$ & $b$ & Yes & LVLI \\
\hline Vanadium & Soil & $\mathrm{mg} / \mathrm{kg}$ & 127.1 & 128 & $88.97-165.23$ & Yes & LVLI \\
\hline Zinc & Soil & $\mathrm{mg} / \mathrm{kg}$ & 158 & 167 & $110.60-205.40$ & Yes & LVLI \\
\hline Am-241 & Soil & $\mathrm{Bq} / \mathrm{kg}$ & 81.1 & 74.13 & $56.77-105.43$ & Yes & GEL \\
\hline Cs-137 & Soil & $\mathrm{Bq} / \mathrm{kg}$ & 439 & 451.7 & $307.30-570.70$ & Yes & GEL \\
\hline Co-60 & Soil & $\mathrm{Bq} / \mathrm{kg}$ & 287 & 299.0 & $200.90-373.10$ & Yes & GEL \\
\hline $\mathrm{Pu}-238$ & Soil & $\mathrm{Bq} / \mathrm{kg}$ & 60.8 & 62.90 & $42.56-79.04$ & Yes & GEL \\
\hline $\mathrm{Pu}-239 / 240$ & Soil & $\mathrm{Bq} / \mathrm{kg}$ & $b$ & 0.86 & $b$ & Yes & GEL \\
\hline $\mathrm{K}-40$ & Soil & $\mathrm{Bq} / \mathrm{kg}$ & 604 & 671.3 & $422.80-785.20$ & Yes & GEL \\
\hline Sr-90 & Soil & $\mathrm{Bq} / \mathrm{kg}$ & 757 & 810.0 & $529.90-984.10$ & Yes & GEL \\
\hline U-233/234 & Soil & $\mathrm{Bq} / \mathrm{kg}$ & 52.5 & 48.47 & $36.75-68.25$ & Yes & GEL \\
\hline U-238 & Soil & $\mathrm{Bq} / \mathrm{kg}$ & 168 & 167.33 & $117.60-218.40$ & Yes & GEL \\
\hline
\end{tabular}

LVLI - Lionville Laboratories, Inc.

GEL - General Engineering Laboratories

Note: This report has been excerpted to include only those matrix/analyte combinations performed in support of the analyses of samples collected at the WVDP and which are presented in this Annual Site Environmental Report.

${ }^{a}$ MAPEP monitors performance and requests corrective action as required.

${ }^{b}$ Although no actual value or acceptance range was provided, the results were assessed by MAPEP as acceptable. 
Table J-3

Comparisons of Results From Crosscheck Samples Analyzed for Water Quality Parameters as Part of the EPA's 2005 Discharge Monitoring Report - Quality Assurance (DMR-QA) Study 25 for the National Pollutant Discharge Elimination System (NPDES)

\begin{tabular}{|l|c|c|c|c|c|c|}
\hline \multicolumn{1}{|c|}{ Analyte } & Units & Actual & Reported & $\begin{array}{c}\text { Acceptance } \\
\text { Range }^{a}\end{array}$ & Accept? & Analyzed by \\
\hline Aluminum & $\mu \mathrm{g} / \mathrm{L}$ & 818 & 912 & $653-978$ & Yes & STL \\
\hline Ammonia (as Nitrogen) & $\mathrm{mg} / \mathrm{L}$ & 9.58 & 9.63 & $7.08-12.0$ & Yes & STL \\
\hline Arsenic & $\mu \mathrm{g} / \mathrm{L}$ & 407 & 407 & $340-478$ & Yes & STL \\
\hline Biochemical oxygen demand & $\mathrm{mg} / \mathrm{L}$ & 110 & 108 & $55.6-164$ & Yes & STL \\
\hline Cadmium & $\mu \mathrm{g} / \mathrm{L}$ & 341 & 336 & $291-388$ & Yes & STL \\
\hline Chlorine, total residual & $\mathrm{mg} / \mathrm{L}$ & 0.880 & 0.890 & $0.635-1.10$ & Yes & WVNSCO - OTS \\
\hline Chromium & $\mu \mathrm{g} / \mathrm{L}$ & 675 & 695 & $588-763$ & Yes & STL \\
\hline Cobalt & $\mu \mathrm{g} / \mathrm{L}$ & 730 & 743 & $642-818$ & Yes & STL \\
\hline Copper & $\mu \mathrm{g} / \mathrm{L}$ & 445 & 471 & $403-490$ & Yes & STL \\
\hline Cyanide, total & $\mathrm{mg} / \mathrm{L}$ & 0.703 & 0.496 & $0.439-0.968$ & Pass & STL \\
\hline Grease and Oil (Gravimetric) & $\mathrm{mg} / \mathrm{L}$ & 42.0 & 40.1 & $26.0-52.2$ & Yes & STL \\
\hline Iron & $\mu \mathrm{g} / \mathrm{L}$ & 310 & 374 & $271-355$ & No & STL \\
\hline Lead & $\mu \mathrm{g} / \mathrm{L}$ & 468 & 471 & $407-528$ & Yes & STL \\
\hline Manganese & $\mu \mathrm{g} / \mathrm{L}$ & 552 & 581 & $495-613$ & Yes & STL \\
\hline Mercury & $\mu \mathrm{g} / \mathrm{L}$ & 2.96 & 3.43 & $1.84-4.15$ & Yes & STL \\
\hline Nickel & $\mu \mathrm{g} / \mathrm{L}$ & 321 & 331 & $285-362$ & Yes & STL \\
\hline Nitrate (as Nitrogen) & $\mathrm{mg} / \mathrm{L}$ & 7.72 & 8.06 & $8.01-9.32$ & Yes & STL \\
\hline Nitrogen (total Kjeldahl) & $\mathrm{mg} / \mathrm{L}$ & 24.5 & 25.7 & $16.1-31.5$ & Yes & STL \\
\hline pH & $\mathrm{SU}$ & 6.48 & 6.50 & $6.28-6.68$ & Yes & ELAB \\
\hline Phosphorus (total, as $\mathrm{P})$ & $\mathrm{mg} / \mathrm{L}$ & 2.98 & 1.07 & $2.42-3.80$ & No & STL \\
\hline Selenium & $\mu \mathrm{g} / \mathrm{L}$ & 716 & 706 & $568-829$ & Yes & STL \\
\hline Suspended solids, total & $\mathrm{mg} / \mathrm{L}$ & 57.6 & 56.0 & $45.5-65.3$ & Yes & STL \\
\hline Vanadium & $\mu \mathrm{g} / \mathrm{L}$ & 597 & 613 & $523-668$ & Yes & STL \\
\hline Zinc & $\mu \mathrm{g} / \mathrm{L}$ & 871 & 886 & $748-1,000$ & Yes & STL \\
\hline
\end{tabular}

STL - Severn Trent Laboratories

WVNSCO - OTS - WVDP Wastewater Treatment Facility Laboratory

ELAB - WVDP Environmental Laboratory

Note: Samples provided by Environmental Research Associates (ERA)

${ }^{a}$ Acceptance limits are determined by ERA or the New York State Department of Health (NYSDOH), as applicable. 
This page intentionally left blank

$$
J-10
$$




\section{Appendix $\mathrm{K}$ \\ Environmental Laws, Regulations, Standards, and Orders}

$K-1$ 
This page intentionally left blank

$$
K-2
$$




\section{Table K-1}

\section{U.S. Department of Energy Radiation Protection Standards and Derived Concentration Guides ${ }^{a}$}

\begin{tabular}{|c|c|c|c|c|c|c|c|}
\hline \multicolumn{8}{|c|}{$\begin{array}{l}\text { Effective Dose Equivalent Radiation Standard for Protection of the Public } \\
\text { Continuous exposure of any member of the public from routine activities: } \\
\text { All exposure pathways }=100 \text { mrem/year ( } 1 \mathrm{mSv} / y \text { r) effective dose equivalent }\end{array}$} \\
\hline \multicolumn{8}{|c|}{$\begin{array}{c}\text { U.S. Department of Energy Derived Concentration Guides (DCGs) } \\
\text { for Inhaled Air or Ingested Water }(\mu \mathrm{Ci} / \mathrm{mL})\end{array}$} \\
\hline Radionuclide & $\begin{array}{c}\text { Half-life }^{b} \\
\text { (years) }\end{array}$ & In Air & In Water & Radionuclide & $\begin{array}{l}\text { Half-life }^{b} \\
\text { (years) }\end{array}$ & In Air & In Water \\
\hline $\mathbf{H}-3^{c}$ & $1.23 \mathrm{E}+01$ & $1 \mathrm{E}-07$ & $2 \mathrm{E}-03$ & Eu-152 & $1.35 \mathrm{E}+01$ & $5 \mathrm{E}-11$ & $2 \mathrm{E}-05$ \\
\hline$C-14^{c}$ & $5.70 \mathrm{E}+03$ & $6 \mathrm{E}-09$ & $7 \mathrm{E}-05$ & Eu-154 & $8.59 \mathrm{E}+00$ & $5 \mathrm{E}-11$ & $2 \mathrm{E}-05$ \\
\hline K-40 & $1.25 \mathrm{E}+09$ & $9 \mathrm{E}-10$ & $7 \mathrm{E}-06$ & Eu-155 & $4.75 \mathrm{E}+00$ & $3 \mathrm{E}-10$ & $1 \mathrm{E}-04$ \\
\hline Fe-55 & $2.74 \mathrm{E}+00$ & $5 \mathrm{E}-09$ & 2E-04 & Th-232 & $1.40 \mathrm{E}+10$ & $7 \mathrm{E}-15$ & $5 \mathrm{E}-08$ \\
\hline $\mathrm{Co}-60^{c}$ & $5.27 \mathrm{E}+00$ & $8 \mathrm{E}-11$ & $5 \mathrm{E}-06$ & $\mathrm{U}-232^{c}$ & $6.89 \mathrm{E}+01$ & $2 \mathrm{E}-14$ & $1 \mathrm{E}-07$ \\
\hline Ni-59 & $7.60 \mathrm{E}+04$ & 4E-09 & 7E-04 & $\mathrm{U}-\mathbf{2 3 3}^{c}$ & $1.59 \mathrm{E}+05$ & $9 \mathrm{E}-14$ & $5 \mathrm{E}-07$ \\
\hline Ni-63 & $1.00 \mathrm{E}+02$ & $2 \mathrm{E}-09$ & $3 \mathrm{E}-04$ & $\mathrm{U}-234^{c}$ & $2.46 \mathrm{E}+05$ & $9 \mathrm{E}-14$ & $5 \mathrm{E}-07$ \\
\hline Sr-90 ${ }^{c}$ & $2.89 \mathrm{E}+01$ & 9E-12 & $1 \mathrm{E}-06$ & $\mathrm{U}-\mathbf{2 3 5}^{c}$ & $7.04 \mathrm{E}+08$ & $1 \mathrm{E}-13$ & $6 \mathrm{E}-07$ \\
\hline Y-90 & 7.31E-03 & $1 \mathrm{E}-09$ & 1E-05 & $\mathbf{U}-\mathbf{2 3 6}^{c}$ & $2.34 \mathrm{E}+07$ & $1 \mathrm{E}-13$ & $5 \mathrm{E}-07$ \\
\hline Zr-93 & $1.53 \mathrm{E}+06$ & $4 \mathrm{E}-11$ & 9E-05 & $\mathrm{U}-\mathbf{2 3 8}^{c}$ & 4.47E+09 & $1 \mathrm{E}-13$ & $6 \mathrm{E}-07$ \\
\hline Nb-93m & $1.61 \mathrm{E}+01$ & $4 \mathrm{E}-10$ & $3 \mathrm{E}-04$ & Np-239 & $6.45 \mathrm{E}-03$ & $5 \mathrm{E}-09$ & $5 \mathrm{E}-05$ \\
\hline Tc-99 ${ }^{c}$ & $2.11 \mathrm{E}+05$ & $2 \mathrm{E}-09$ & $1 \mathrm{E}-04$ & $\mathbf{P u}-238^{c}$ & $8.77 \mathrm{E}+01$ & $3 \mathrm{E}-14$ & 4E-08 \\
\hline Ru-106 & $1.02 \mathrm{E}+00$ & $3 \mathrm{E}-11$ & $6 \mathrm{E}-06$ & $\mathbf{P u}-239^{c}$ & $2.41 \mathrm{E}+04$ & $2 \mathrm{E}-14$ & $3 \mathrm{E}-08$ \\
\hline Cd-113m & $1.41 \mathrm{E}+01$ & $8 \mathrm{E}-12$ & 9E-07 & $\mathrm{Pu}-240^{c}$ & $6.56 \mathrm{E}+03$ & $2 \mathrm{E}-14$ & 3E-08 \\
\hline Sn-126 & $2.30 \mathrm{E}+05$ & $1 \mathrm{E}-10$ & $8 \mathrm{E}-06$ & Pu-241 & $1.43 \mathrm{E}+01$ & $1 \mathrm{E}-12$ & $2 \mathrm{E}-06$ \\
\hline Sb-125 & $2.76 \mathrm{E}+00$ & $1 \mathrm{E}-09$ & $5 \mathrm{E}-05$ & Am-241 ${ }^{c}$ & $4.32 \mathrm{E}+02$ & $2 \mathrm{E}-14$ & 3E-08 \\
\hline Te-125m & $1.57 \mathrm{E}-01$ & $2 \mathrm{E}-09$ & $4 \mathrm{E}-05$ & Am-242m & $1.41 \mathrm{E}+02$ & $2 \mathrm{E}-14$ & 3E-08 \\
\hline I-129 $c$ & $1.57 \mathrm{E}+07$ & 7E-11 & $5 \mathrm{E}-07$ & Am-243 & $7.37 \mathrm{E}+03$ & $2 \mathrm{E}-14$ & 3E-08 \\
\hline Cs-134 & $2.07 \mathrm{E}+00$ & $2 \mathrm{E}-10$ & $2 \mathrm{E}-06$ & Cm-243 & $2.91 \mathrm{E}+01$ & $3 \mathrm{E}-14$ & $5 \mathrm{E}-08$ \\
\hline Cs-135 & $2.30 \mathrm{E}+06$ & 3E-09 & $2 \mathrm{E}-05$ & Cm-244 & $1.81 \mathrm{E}+01$ & $4 \mathrm{E}-14$ & $6 \mathrm{E}-08$ \\
\hline Cs-137 ${ }^{c}$ & $3.00 \mathrm{E}+01$ & $4 \mathrm{E}-10$ & $3 \mathrm{E}-06$ & Gross Alpha & NA & $2 \mathrm{E}-14$ & $3 \mathrm{E}-08$ \\
\hline Pm-147 & $2.62 \mathrm{E}+00$ & $3 \mathrm{E}-10$ & $1 \mathrm{E}-04$ & (as Am-241) & & & \\
\hline Sm-151 & $9.00 \mathrm{E}+01$ & $4 \mathrm{E}-10$ & $4 \mathrm{E}-04$ & $\begin{array}{l}\text { Gross Beta } \\
\text { (as Sr-90) }\end{array}$ & NA & $9 \mathrm{E}-12$ & $1 \mathrm{E}-06$ \\
\hline
\end{tabular}

NA - Not applicable.

${ }^{a}$ DOE Order 5400.5 (February 8, 1990). Effective May 8, 1990. (See Derived Concentration Guides in Chapter 1, Environmental Program Information.)

${ }^{b}$ Nuclear Wallet Cards. April 2005. National Nuclear Data Center. Brookhaven National Laboratory. Upton, New York.

${ }^{c}$ Radionuclides measured in WVDP effluent.

K - 3 


\section{Table $\mathrm{K}-2$ \\ Environmental Laws, Regulations, Standards, and Orders}

The following environmental standards and laws are applicable, in whole or in part, to the West Valley Demonstration Project. Although the list covers the major activities at the West Valley Demonstration Project, it does not constitute a complete enumeration.

Atomic Energy Act of 1954, 42 United States Code (USC) §2011 et seq., as amended, and federal implementing regulations.

Clean Air Act (CAA) of 1970. Pub. L. No. 84-159. 42 USC $\$ 7401$ et seq., as amended, and federal and state implementing regulations.

Comprehensive Environmental Response, Compensation, and Liability Act (CERCLA) of 1980. Pub. L. No. 96-510.42 USC $\$ 9601$ et seq. (including Superfund Amendments and Reauthorization Act [SARA] of 1986), and federal implementing regulations.

DOE Order 231.1A. August 19, 2003. Environment, Safety, and Health Reporting, including Change 1 (June 3, 2004).

DOE Order 414.1A. April 29, 1999. Quality Assurance, including Change 1 (July 12, 2001). (Although DOE Order 414.1A was still in the WVNSCO contact through 2005, it has been superceded by DOE Orders 414.1B [April 29, 2004] and 414.1C [June 17, 2005].)

DOE Order 435.1. July 9, 1999. Radioactive Waste Management, including Change 1 (August 28, 2001).

DOE Order 440.1A. March 27, 1998. Worker Protection Management for DOE Federal and Contractor Employees.

DOE Order 450.1. January 15, 2003. Environmental Protection Program, including Change 1 (January 15, 2005) and Change 2 (December 7, 2005). [DOE Order 450.1 canceled DOE Order 5400.1.]

DOE Order 451.1B. October 26, 2000. National Environmental Policy Act Compliance Program, including Change 1 (September 28, 2001).

DOE Order 5400.5. February 8, 1990. Radiation Protection of the Public and the Environment, including Change 2 (January 7, 1993).

DOE Order 5480.4. May 15, 1984. Environmental Protection, Safety, and Health Protection Standards, including Change 4 (January 7, 1993).

DOE Policy 141.1. May 2, 2001. Department of Energy Management of Cultural Resources.

$$
K-4
$$




\section{Table K-2 (continued) Environmental Laws, Regulations, Standards, and Orders}

DOE Policy 141.2. May 2, 2003. Public Participation and Community Relations.

DOE Regulatory Guide DOE/EH-0173T. January 1991. Environmental Regulatory Guide for

Radiological Effluent Monitoring and Environmental Surveillance.

DOE Standard DOE-STD-1153-2002. July 2002. A Graded Approach for Evaluating Radiation Doses to Aquatic and Terrestrial Biota.

Emergency Planning and Community Right-to-Know Act (EPCRA) of 1986. Pub. L. No. 99-499. 42 USC $\$ 11001$ et seq., and federal implementing regulations.

Endangered Species Act of 1973. Pub. L. No. 93-205. 16 USC $\$ 1531$ et seq., and federal and state implementing regulations.

Environmental Conservation Law of the New York State Consolidated Laws and state implementing regulations (NYCRR).

Executive Order 11988. May 25, 1977. Floodplain Management.

Executive Order 11990. May 25, 1977. Protection of Wetlands.

Executive Order 13101. September 16, 1998. Greening the Government Through Waste Prevention, Recycling, and Federal Acquisition.

Executive Order 13148. April 26, 2000. Greening the Government Through Leadership in Environmental Management.

Federal Insecticide, Fungicide, and Rodenticide Act (FIFRA) of 1996. 7 USC $\$ 136$ et seq.

Federal Water Pollution Control Act (Clean Water Act [CWA]) of 1977. Pub. L. No. 95-217. 33 USC $\S 1251$ et seq., as amended, and federal and state implementing regulations.

Migratory Bird Treaty Act of 1918. 16 USC \$703-712 as amended, and federal and state implementing regulations.

National Environmental Policy Act (NEPA) of 1969. Pub. L. No.91-190. 42 USC §4321 et seq., as amended, and federal implementing regulations.

National Historic Preservation Act of 1966. Pub. L. No. 102-575. 16 USC $\$ 470$ et seq., and federal implementing regulations. 


\section{Table K-2 (concluded) Environmental Laws, Regulations, Standards, and Orders}

Resource Conservation and Recovery Act (RCRA) of 1976. Pub. L. No. 94-580. 42 USC §6901 et seq., as amended, and federal and state implementing regulations.

Safe Drinking Water Act (SDWA) of 1974. Pub. L. No. 93-523. 42 USC $3300 f$ et seq., as amended, and federal and state implementing regulations.

Toxic Substances Control Act (TSCA) of 1976. Pub. L. No. 94-469. 15 USC §2601 et seq., as amended, and federal implementing regulations.

U.S. Environmental Protection Agency. 1992. Region II Administrative Order on Consent. Docket No. II RCRA 3008(h)-92-0202. In the Matter of: Western New York Nuclear Service Center.

U.S. Environmental Protection Agency. 1996. West Valley Demonstration Project Federal Facilities Compliance Act Order on Consent.

Water quality standards contained in the New York State Pollutant Discharge Elimination System (SPDES) permit issued for the facility are listed in Table C-1A. Airborne emissions are regulated by the Environmental Protection Agency under the National Emission Standards for Hazardous Air Pollutants (NESHAP), 40 CFR §61 Subpart H (December 15, 1989, including amendments effective September 9, 2002).

$K-6$ 


\section{Table $\mathrm{K}-3$ \\ West Valley Demonstration Project Act \\ (Public Law 96-368 [S. 2443]; October 1, 1980)}

(As presented in Exhibit G of the Cooperative Agreement between United States Department of Energy and New York State Energy Research and Development Authority on the Western New York Nuclear Service Center at West Valley, New York; Effective October 1, 1980 as amended September 18, 1981.)

EXHIBIT G

\section{WEST VALLEY PROJECT DEMONSTRATION ACT}

PUBLIC LAW 96-368 [S. 2443]; October 1, 1980

\section{WEST VALLEY DEMONSTRATION PROJECT ACT}

For Legislative History of this and other Laws, see Table 1, Public

Laws and Legislative History, at end of final volume

An Act to authorize the Department of Energy to carry out a high-level liquid

nuclear waste management demonstratlon project

Be it enacted by the Senate and House of Representatives of the United States of America in Congress assembled,

SECTION 1. This Act may be cited as the "West Valley Demonstration Project Act".

SEc. 2. (a) The Secretary shall carry out, in accordance with this Act, a high level radioactive waste management demonstration project at the Western New York Service Center in West Valley, New York, for the purpose of demonstrating solidification techniques which can be used for preparing high level radioactive waste for disposal. Under the project the Secretary shall carry out the following activities:

(1) The Secretary shall solidify, in a form suitable for transportation and disposal, the high level radioactive waste at the Center by vitrification or by such other technology which the Secretary determines to be the most effective for solidification.

(2) The Secretary shall develop containers suitable for the permanent disposal of the high level radioactive waste solidified at the Center.

(3) The Secretary shall, as soon as feasible, transport, in accordance with applicable provisions of law, the waste solidified at the Center to an appropriate Federal repository for permanent disposal.

(4) The Secretary shall, in accordance with applicable licensing requirements, dispose of low level radioactive waste and transuranic waste produced by the solidification of the high level radioactive waste under the project.

(5) The Secretary shall decontaminate and decommission(A) the tanks and other facilities of the Center in which the high level radioactive waste solidified under the project was stored,

(B) the facilities used in the solidification of the waste, and

(C) any material and hardware used in connection with the project,

in accordance with such requirements as the Commission may prescribe.

(b) Before undertaking the project and during the fiscal year ending September 30,1981 , the Secretary shall carry out the following: (1) The Secretary shall hold in the vicinity of the Center public
hearings to inform the residents of the area in which the Center is located of the activities proposed to be undertaken under the project and to receive their comments on the project.

(2) The Secretary shall consider the various technologies available for the solidification and handling of high level radioactive waste taking into account the unique characteristics of such waste at the Center.

94 STAT. 1347

\section{G-1}

$K-7$
West Valley Demonstration Project Act. 42 USC 2021a

note.

42 USC 2021a

note.

Activities. 


\begin{abstract}
(3) The Secretary shall-
(A) undertake detailed engineering and cost estimates for the project.

(B) prepare a plan for the safe removal of the high level radioactive waste at the Center for the purposes of solidification and include in the plan provisions respecting the safe breaching of the tanks in which the waste is stored, operating equipment to accomplish the removal, and sluicing techniques,

(C) conduct appropriate safety analyses of the project, and

(D) prepare required environmental impact analyses of the project.

(4) The Secretary shall enter into a cooperative agreement

42 USC 501 note.

State costs, percentage.

Licensing amendment application.

42 USC 2011 note. 42 USC 5801 note.

Publications in Federal Register. with the State in accordance with the Federal Grant and Cooperative Agreement Act of 1977 under which the State will carry out the following:

(A) The State will make available to the Secretary the facilities of the Center and the high level radioactive waste at the Center which are necessary for the completion of the project. The facilities and the waste shall be made available without the transfer of title and for such period as may be required for completion of the project.

(B) The Secretary shall provide technical assistance in securing required license amendments.

(C) The State shall pay 10 per centum of the costs of the project, as determined by the Secretary. In determining the costs of the project, the Secretary shall consider the value of the use of the Center for the project. The State may not use Federal funds to pay its share of the cost of the project, but may use the perpetual care fund to pay such share.

(D) Submission jointly by the Department of Energy and the State of New York of an application for a licensing amendment as soon as possible with the Nuclear Regulatory Commission providing for the demonstration.

(c) Within one year from the date of the enactment of this Act, the Secretary shall enter into an agreement with the Commission to establish arrangements for review and consultation by the Commission with respect to the project: Provided, That review and consultation by the Commission pursuant to this subsection shall be conducted informally by the Commission and shall not include nor require formal procedures or actions by the Commission pursuant to the Atomic Energy Act of 1954, as amended, the Energy Reorganization Act of 1974 , as amended, or any other law. The agreement shall provide for the following:

(1) The Secretary shall submit to the Commission, for its review and comment, a plan for the solidification of the high level radioactive waste at the Center, the removal of the waste for purposes of its solidification, the preparation of the waste for disposal, and the decontamination of the facilities to be used in solidifying the waste. In preparing its comments on the plan, the Commission shall specify with precision its objections to any provision of the plan. Upon submission of a plan to the Commission, the Secretary shall publish a notice in the Federal Register of the submission of the plan and of its availability for public inspection, and, upon receipt of the comments of the Commission respecting a plan, the Secretary shall publish a notice in the Federal Register of the receipt of the comments and of the availability of the comments for public inspection. If the Secre-
\end{abstract}

94 STAT. 1348

$K-8$ 
tary does not revise the plan to meet objections specified in the comments of the Commission, the Secretary shall publish in the Federal Register a detailed statement for not so revising the plan.

(2) The Secretary shall consult with the Commission with respect to the form in which the high level radioactive waste at the Center shall be solidified and the containers to be used in the permanent disposal of such waste.

(3) The Secretary shall submit to the Commission safety analysis reports and such other information as the Commission may require to identify any danger to the public health and safety which may be presented by the project.

(4) The Secretary shall afford the Commission access to the Center to enable the Commission to monitor the activities under the project for the purpose of assuring the public health and safety.

(d) In carrying out the project, the Secretary shall consult with the Administrator of the Environmental Protection Agency, the Secretary of Transportation, the Director of the Geological Survey, and the commercial operator of the Center.

SEC. 3. (a) There are authorized to be appropriated to the Secretary for the project not more than $\$ 5,000,000$ for the fiscal year ending September 30, 1981.

(b) The total amount obligated for the project by the Secretary shall be 90 per centum of the costs of the project.

(c) The authority of the Secretary to enter into contracts under this Act shall be effective for any fiscal year only to such extent or in such amounts as are provided in advance by appropriation Acts.

SEC. 4. Not later than February 1, 1981, and on February 1 of each calendar year thereafter during the term of the project, the Secretary shall transmit to the Speaker of the House of Representatives and the President pro tempore of the Senate an up-to-date report containing a detailed description of the activities of the Secretary in carrying out the project, including agreements entered into and the costs incurred during the period reported on and the activities to be undertaken in the next fiscal year and the estimated costs thereof.

SEC. 5. (a) Other than the costs and responsibilities established by this Act for the project, nothing in this Act shall be construed as affecting any rights, obligations, or liabilities of the commercial operator of the Center, the State, or any person, as is appropriate, arising under the Atomic Energy Act of 1954 or under any other law, contract, or agreement for the operation, maintenance, or decontamination of any facility or property at the Center or for any wastes at the Center. Nothing in this Act shall be construed as affecting any applicable licensing requirement of the Atomic Energy Act of 1954 or the Energy Reorganization Act of 1974. This Act shall not apply or be extended to any facility or property at the Center which is not used in conducting the project. This Act may not be construed to expand or diminish the rights of the Federal Government.

(b) This Act does not authorize the Federal Government to acquire title to any high level radioactive waste at the Center or to the Center or any portion thereof.

SEC. 6. For the purposes of this Act:

(1) The term "Secretary" means the Secretary of Energy.

(2) The term "Commission" means the Nuclear Regulatory

Reports and other information to Commission.

Consultation with

EPA and others.

Appropriation authorization. 42 USC 2021a note.

Commission.

(3) The term "State" means the State of New York.

94 STAT. 1349

$K-9$ 
(4) The term "high level radioactive waste" means the high level radioactive waste which was produced by the reprocessing at the Center of spent nuclear fuel. Such term includes both liquid wastes which are produced directly in reprocessing, dry solid material derived from such liquid waste, and such other material as the Commission designates as high level radioactive waste for purposes of protecting the public health and safety.

(5) The term "transuranic waste" means material contaminated with elements which have an atomic number greater than 92, including neptunium, plutonium, americium, and curium, and which are in concentrations greater than 10 nanocuries per gram, or in such other concentrations as the Commission may prescribe to protect the public health and safety.

(6) The term "low level radioactive waste" means radioactive waste not classified as high level radioactive waste, transuranic waste, or byproduct material as defined in section $11 \mathrm{e}$. (2) of the Atomic Energy Act of 1954.

(7) The term "project" means the project prescribed by section 42 USC 2014.

(8) The term "Center" means the Western New York Service Center in West Valley, New York.

Approved October 1, 1980. 